UNIVERSIDADE DE SÃO PAULO

FACULDADE DE FILOSOFIA, LETRAS E CIÊNCIAS HUMANAS

DEPARTAMENTO DE LINGUÍSTICA

CAROLINA TOMASI

Semiótica da Agudeza: da negação da euforia barroca ao objeto poético fluido do final do século $X X$ 
CAROLINA TOMASI

tomasicarol@usp.br

\title{
Semiótica da Agudeza: da negação da euforia barroca ao objeto poético fluido do final do século $X X$
}

\author{
Tese apresentada ao Programa de Pós- \\ Graduação em Semiótica e Linguística Geral \\ do Departamento de Linguística da Faculdade \\ de Filosofia, Letras e Ciências Humanas da \\ Universidade de São Paulo, para obtenção do \\ título de Doutor em Letras. \\ Área de concentração: Semiótica e Linguística \\ Geral. \\ Orientador: Prof. Dr. Antonio Vicente \\ Pietroforte
}


Nome: TOMASI, Carolina

Título: Semiótica da Agudeza: da negação da euforia barroca ao objeto poético fluido do final do século $X X$

\begin{abstract}
Tese apresentada ao Programa de PósGraduação em Semiótica e Linguística Geral do Departamento de Linguística da Faculdade de Filosofia, Letras e Ciências Humanas da Universidade de São Paulo, para obtenção do título de Doutor em Letras.
\end{abstract}

Área de concentração: Semiótica e Linguística Geral.

Aprovada em: /2014
Julgamento: Assinatura:

Julgamento: Assinatura:

Julgamento: Assinatura:

Julgamento: Assinatura:

Julgamento: Assinatura: 
Para o estudo.

Para a disciplina, libertadora do homem.

Para Vicente Pietroforte e João Bosco, dois "corocos" do coração.

Para mamma Luigina e mio fratello Stefano.

Para mãe, para pai, para irmão; Sueli, Domingos e Felipe, meu-tudo.

$\sim \sim \sim$

Para Saulo, a paz do amor colossal. 


\section{Agradecimentos}

Meus agradecimentos a todas as pessoas que colaboraram comigo para a confecção desta tese, especialmente a:

Antonio Vicente Pietroforte, grande amigo e orientador, pelos divãs-momentos e pela generosidade. Waldir Beividas, pelo ensinamento generoso, sempre do meu lado.

lara Rosa Farias, pela ternura e amizade, uma luz para o cotidiano.

Ivã Carlos Lopes e Marcos Lopes, pelo apoio e amizade.

Elizabeth Harkot-de-la-Taille, pelas conversas carinhosas.

Luiz Tatit pela prontidão nos diálogos semióticos.

Diana Luz Pessoa de Barros e José Luiz Fiorin, meus primeiros mestres.

João Adolfo Hansen, agudo e engenhosamente discreto, com quem muito aprendi.

Alcir Pécora pela lucidez.

Cris Altman, exemplo de sabedoria, cujos ensinamentos vão me deixar muita saudade.

Ivan Darrault, sempre presente, mesmo de longe.

Francesco Marsciani, pelas lições com humildade.

Norma Discini, pela prontidão amorosa.

Cocó e Adriana; Vó Lourdes, minha nova família.

Paolo Demuru e Julia Codo, minha família paulistana.

Mariana e Danilo, pelos goles felizes.

Dayane e Ricardo, irmãozinhos queridos.

Conrado Mendes, Pergolino amado.

Odair, pelo toca-terror às sextas-feiras.

Camila Ribeiro, sempre comigo.

Kiko Merçon, caríssimo amigo.

Lu e Paulinho, companheiros do pão e do vinho.

Eliane Soares de Lima, querida amiga-conselheira.

Loredana e Ana Paula, doces companhias.

Alexandre Marcelo Bueno, amigo colossal.

Cleyton, Akira, Thiago, Baulé, Débora, Carol Santana, vicentinos amados!

Jean Portela e Matheus, doces mosquitinhos do coração.

Felipe Tomasi, meu irmão gêmeo, minha metade.

Dani Souza Pinto, querida irmã vintenária.

Natália Guirado, pela longa amizade e pelo amor fraterno. 
João Bosco, mil vezes "grazie" pela amizade, fraternidade e sobretudo pelo diálogo semio-literário.

Sueli-Domingos, pais, obrigada pelos livros desde sempre. Sem vocês, nada.

Aos avós e avôs e tios Man’Antonios.

Saulo, pelo amor-companheiro, pelos desenhos desta tese, pela dedicação. Sem você, nulla.

Os a(MIM)gos:

Alexandre Felipe Ana Paula Scher Claudio Daniel Dani Bracchi Edite Alde Indaiá Bassani Ilka

Suzana Lopes José Roberto do Carmo Júnior Julia Lourenço Juliana Di Fiori Pondian Juliana

Prado Vita Lucas Shimoda Luís Fernando de Souza Pinto Marcello Modesto Marcus Lunguinho

$\sim$ Paula Martins $\sim$ Ricardo Monteiro $\sim$ Sueli Ramos $\sim$ Tata de Oliveira $\sim$ Thami $\sim$ Thiago Del Bel $\sim$ Vitor Augusto Nóbrega e todos os companheiros do GES-USP.

Os amigos semióticos do Ceará: Ricardo, José Américo, Luann, Susy Anne; de Araraquara: Ude, Cris Guzzi, Marcela, Marisa Giannecchini; de Londrina: Loredana e Ana Paula; de Niterói: Renata Mancini, Lucia Teixeira e Tainá Teixeira; de São Carlos: Mônica; do Mato Grosso: caríssimo Geraldo.

Erica Flávia, pela paciência, pelas risadas e amizade.

Nilton, da seção de alunos da graduação, pela paciência e tranquilidade.

Robson e Benhur, pela eficiência.

Aos professores do DL.

À Faculdade de Filosofia, Letras e Ciências Humanas da Universidade de São Paulo, pela oportunidade de realização da Pós-Graduação.

Ao Conselho Nacional de Desenvolvimento Científico e Tecnológico (CNPq), pela bolsa concedida para a realização deste trabalho.

A Haroldo de Campos. 
TOMASI, Carolina. Semiótica da Agudeza: da negação da euforia barroca ao objeto poético fluido do final do século XX. 2014. 518 f. Tese (Doutorado) - Faculdade de Filosofia, Letras e Ciências Humanas, Universidade de São Paulo, 2014.

Esta tese ocupa-se da investigação da semiótica da agudeza, utilizando como corpus poemas do final do século XX, chamados "neobarrocos", e fragmentos de Galáxias, de Haroldo de Campos, e Finnegans Wake, de James Joyce. As recepções contemporâneas aos séculos XVI e XVII não entendem as produções literárias como barrocas, mas como clássicas, diferentemente, portanto, do valor atribuído ao "estado de barroco" constante dos textos da crítica do século XX. Da investigação das obras de Peregrini, Gracián, Hansen e Pécora, depreende-se a agudeza como sistematizadora das produções barrocas dos seiscentos. Além disso, esta pesquisa constata não a presença eufórica de barroco sincrônico ou a existência de um possível neobarroco, mas gradações da agudeza como um operador formal da poesia dita barroquista. Com base nessa agudeza, propõe-se, dentro do quadro teóricometodológico da semiótica tensiva, demonstrar como essa poesia, vista por muitos críticos como "neobarroca", é regida segundo uma oscilação que a regula, reconhecendo nela uma dominância de agudeza do plano da expressão (PE) e/ou uma dominância de agudeza do plano do conteúdo (PC). Observadas as propriedades da agudeza, os objetos poéticos apresentam diferenças tensivas que os encaminham para uma poesia que conhece a graduação entre mais fluida e mais nítida, manifestando diferenças de acentuação no obscurecimento formal do enunciado. O enunciador, ao privilegiar a vivificação das agudezas, promove uma tensão estetizante: um jogo entre o rápido prazer da conservação sensível e o demorado prazer do reconhecimento inteligível do objeto estético, dois tipos diferentes de fruição. Dividida em cinco capítulos, a tese aborda inicialmente a ausência e a presença do recorte de barroco nos estudos literários, bem como a dominância do sobrevir nos semas de barroco e a sincronia e diacronia dos estados de barroco em direção a uma agudeza idiossincrônica. Em seguida, examina o jogo tensivo entre agudeza da expressão e agudeza do conteúdo, focalizando sobretudo os tratadistas seiscentistas e as propriedades da agudeza. Ocupa-se também da negação da euforia barroquista em direção à visualidade na poesia da agudeza. Como o conceito de "neobarroco" varia de autor para autor, examinase o ponto de vista de Umberto Eco, Omar Calabrese, Severo Sarduy, Lezama Lima, Alejo Carpentier, Haroldo de Campos, Affonso Ávila, Affonso Romano Sant'Anna, Horácio Costa, Ana Hatherly, Ivan Teixeira, para estabelecer um modelo mais conforme à semiótica tensiva. A tese trata ainda dos limites entre sensível e inteligível na poesia aguda do século XX, realizando uma recapitulação da fenomenologia em diálogo com a semiótica tensiva, da qual sobressai o conceito de fé perceptiva e de perobjeto zilberberguiano. Finalmente, entra em cena a agudeza do final do século XX na direção do objeto fluido.

Palavras-chave: Semiótica tensiva. Agudeza seiscentista. Literatura brasileira. Estética. Barroco. Neobarroco. 


\section{ABSTRACT}

TOMASI, Carolina. Semiotics of Sharpness: from denial of baroque euphoria to the fluid poetic object of the late 20th century. 2014. $518 \mathrm{f}$. Thesis (Doctorate) - Faculdade de Filosofia, Letras e Ciências Humanas, Universidade de São Paulo, 2014.

This thesis is concerned with the investigation of semiotics of sharpness. Its corpus consists of poems from the late 20th century which are called "neo-baroque", and fragments of Haroldo de Campos' Galáxias and James Joyce's Finnegans Wake. Contemporary receptions to the sixteenth and seventeenth centuries do not understand the literary productions as baroque, but as classical, therefore unlike the value assigned to the "state of baroque" in critical texts of the 20th century. Sharpness is inferred from the research of the works of Peregrini, Gracián, Hansen and Pécora as systematizing baroque productions of the 1600 s. Furthermore, this research finds not the euphoric presence of synchronous baroque or the existence of a possible neo-baroque but gradations of sharpness as a formal operator of the so-called baroqueist poetry. Based on this sharpness, and within the theoretical and methodological framework of tensive semiotics, it is proposed to demonstrate how this poetry, regarded by many critics as "neo-baroque", is governed according to an oscillation that regulates it, recognizing in it a sharpness dominance of the level of expression (PE plano da expressão) and / or a sharpness dominance of the level of content (PC - plano do conteúdo). Once observed the properties of sharpness, poetic objects show tensive differences that forward them for a poetry that knows the graduation from more fluent to more clear, manifesting differences of emphasis in the formal obscuration of the enunciation. The enunciator, while privileging the enlivenment of sharpness, promotes aesthetic tension: a game between the quick pleasure of sensitive conservation and delayed enjoyment of intelligible recognition of the aesthetic object - two different types of enjoyment. Divided into five chapters, the thesis first addresses the absence and the presence of baroque slice in literary studies as well as the dominance of occurrence in baroque units of meaning and the synchrony and diachrony of baroque states towards an idiosynchronic sharpness. Then it examines the tensive game between sharpness of expression and sharpness of content, particularly focusing on the seventeenth-century treatise writers and the properties of sharpness. It also deals with the denial of baroqueist euphoria towards the visuality in the poetry of sharpness. As the concept of "neo-baroque" varies from author to author, the thesis examines the viewpoint of Umberto Eco, Omar Calabrese, Severo Sarduy, Lezama Lima, Alejo Carpentier, Haroldo de Campos, Alfonso Ávila, Affonso Romano Sant'Anna, Horácio Costa, Ana Hatherly, Ivan Teixeira, in order to establish a model more consistent with tensive semiotics. It also addresses the boundaries between sensible and intelligible in the sharp poetry of the 20th century, making a recapitulation of phenomenology in a dialogue with tensive semiotics, from which the concepts of perceptual faith and zilberbergian perobject stand out. Finally, the sharpness of the late 20th century comes into play towards the fluid object.

Keywords: tensive semiotics. Seventeenth century sharpness. Brazilian literature. Aesthetics. Baroque. Neo-baroque 


\section{RÉSUMÉ}

TOMASI, Carolina. Sémiotique de l'acuité: de la négation de l'euphorie baroque à l'objet poétique fluide de la fin du XXe siècle. 2014. 518 f. Thèse de Doctotat - Faculdade de Filosofia, Letras e Ciências Humanas, Universidade de São Paulo, 2014.

Cette thèse s'occupe de la recherche de la sémiotique de l'acuité, en utilisant comme corpus des poèmes de la fin du XXe siècle appelés "néo-baroques" et des fragments de Galáxias d'Haroldo de Campos et Finnegans Wake de James Joyce. Réceptions contemporaines aux $\mathrm{XVle}$ et XVIle siècles ne comprennent pas les productions littéraires comme baroques, mais comme classiques, contrairement donc à la valeur attribuée à l' "état de baroque" figurant dans les textes critiques du XXe siècle. De la recherche des oeuvres de Peregrini, Gracián, Hansen et Pécora l'acuité ressort comme systematisatrice des productions baroques du XVIle siècle. En outre, ce que cette recherche constate n'est pas la présence euphorique du baroque synchrone ou l'existence d'un possible néo-baroque, mais gradations de l'acuité comme un opérateur formel de la poésie dite baroquiste. Sur la base de cette acuité, il est proposé, dans le cadre théorique et méthodologique de la sémiotique tensive, de démontrer comment cette poésie, considéré par de nombreux critiques comme «néo-baroque», est régie selon une oscillation qui la régule, en reconnaissant en elle une dominace d'acuité du plan de l'expression (PE) et/ou une dominace d'acuité du plan du contenu (PC). Une fois observées les propriétés de l'acuité, les objets poétiques présentent des différences tensives qui les conduisent vers une poésie qui connaît la graduation entre plus fluide et plus nette, manifestant des différences d'accentuation dans l'obscurcissement formel de l'énoncé. L'énonciateur, tout en privilégiant la vivificarion des acuités, promeut une tension esthétisante: un jeu entre le plaisir rapide de la conservation sensible et le plaisir prolongé de la reconnaissance intelligible de l'objet esthétique, c'est-à-dire deux types différents de plaisir. Divisée en cinq chapitres, la thèse traite d'abord de l'absence et la présence du découpage de baroque dans les études littéraires, ainsi que la dominance du survenir dans les sèmes du baroque et la synchronie et diachronie des états de baroque vers une acuité idiosynchronique. Ensuite, elle examine le jeu tensive entre acuité de l'expression et acuité du contenu, en se concentrant particulièrement sur les érudits du XVIle siècle et les propriétés de l'acuité. Elle s'occupe également de la négation de l'euphorie baroquiste vers la visualité dans la poésie de l'acuité. Comme le concept de «néo-baroque» varie d'un auteur à l'autre, les points de vue d'Umberto Eco, Omar Calabrese, Severo Sarduy, Lezama Lima, Alejo Carpentier, Haroldo de Campos, Affonso Ávila, Affonso Romano de Sant'Anna, Horácio Costa, Ana Hatherly, Ivan Teixeira sont examinés pour s'établir un modèle plus conforme à la sémiotique tensive. La thèse aborde en outre les frontières entre le sensible et l'intelligible dans la poésie aiguë du XXe siècle, faisant une récapitulation de la phénoménologie dans en dialoguant avec la sémiotique tensive, de laquelle ressort le concept de foi perceptive et de perobjet zilberberguien. Enfin, entre en jeu la acuité de la fin du XXe siècle vers l'objet fluide.

Mots-clés: Sémiotique tensive. Acuité du XVIle siècle. Littérature brésilienne. Esthétique. Baroque. Néo-baroque 


\section{SUMÁRIO}

\section{Introdução, 13}

1 RECORTE DE BARROCO NA CONTINUIDADE CLÁSSICA: A DISFORIA BARROCA, 24

1 Multiplicidade semântica inicial do conceito de barroco, 25

2 Recorte de barroco, 28

2.1 Na Alemanha, 28

2.2 Reflexos em outros países da Europa, 30

3 Barroco como continuidade clássica, 33

4 Ausência e presença do recorte de barroco nos estudiosos da literatura, 40

4.1 Sobre a divisão do quadro, 44

4.2 Balanço dos estudos realizados, 45

5 Pérola irregular, a metáfora da intensidade, 51

6 Semema barroco e seus semas, a dominância do sobrevir, 57

7 Sincronia e diacronia: em direção à agudeza idiossincrônica, 66

2 JOGO TENSIVO ENTRE AGUDEZA DA EXPRESSÃO E AGUDEZA DO CONTEÚDO, 71

$1 \quad$ Agudeza: preliminares, 72

2 Conceitos de agudeza entre tratadistas, 81

3 Agudeza e triângulo isósceles: a contribuição inicial de Sarbiewski, 91

3.1 Paradigmas do PE e do PC na agudeza, 94

3.2 Formas agudas em Augusto de Campos e John Donne, 109

4 Propriedades estruturais da agudeza dos seiscentos e do final do século XX, 125

3 VISUALIDADE NA POESIA DA AGUDEZA: NEGAÇÃO DA EUFORIA BARROCA, 154

1 Jogo especular e mudança de perspectiva nos objetos seiscentistas, 155

2 Neobarroco: diversidade de pontos de vista, 161

2.1 Umberto Eco: barroco como obra aberta, 161

2.2 Omar Calabrese: idade neobarroca, 164

2.3 Severo Sarduy: neobarroco do desperdício em função do prazer, 165

2.4 Lezama Lima: neobarroco e a arte da contraconquista, 173

2.5 Alejo Carpentier: real maravilhoso do neobarroco americanizado, 176 
3.1 Barroquismo sincrônico em Haroldo de Campos, 180

3.2 O cânone barroquista de Haroldo de Campos, 190

3.3 Cenário da euforização barroquista, 210

3.4 Barroquismo para Ávila, Sant'Anna, Costa, Hatherly, Teixeira, 214

3.4.1 Tradição criativa do barroco em Affonso Ávila, 214

3.4.2 Barroquismo enigmático de Affonso Romano de Sant'Anna, 218

3.4.3 Tradição visual no neobarroco português na obra crítica de Ana Hatherly, 222

3.4.4 Visualidade barroca em Horácio Costa e contemporaneidade barroquista em Ivan Teixeira, 228

4 Tradição ou ruptura? Continuidade ou parada?, 243

1 A questão do sensível: a semiótica greimasiana e o diálogo com a filosofia, 249

2 Atração ou repulsão: entrada do sensível na semiótica, 250

3 Da estaticidade ao movimento: diálogo da fenomenologia com a semiótica tensiva de Zilberberg, 255

$4 \quad$ Fé perceptiva no objeto estético agudo: "Retrato de Dom Luís de Góngora", de Horácio Costa, 261

5 Semiocepção de Beividas: o sensível e o inteligível em ")lacraias", de Haroldo de Campos, 277

6 Intensidade/concentração e extensidade/difusão em Affonso Ávila e Horácio Costa: o jogo de fluidez e nitidez, 282

7 A poesia aguda de Horácio Costa como perobjeto, 292

8 Agudeza e fluidez: labirinto tensivo, combinações anagramáticas e as dobras, 308

8.1 Labirinto tensivo, 316

8.2 Combinações anagramáticas, 329

8.3 Tensividade das dobras agudas, 333

1 Teatralização da crise de verso: o discurso da poesia fluida e a potencialização da poesia nítida, 339

2 Intensificação da agudeza visual no cenário da crise de verso, 348

2.1 Condensação aguda: a fluidez em "Metade", de Arnaldo Antunes, 349

2.2 Acentuação da fluidez aguda em "Caminho novo", de Affonso Ávila, 355 
2.3 Constelação aguda em "Por Gertrude Stein", de Affonso Ávila, 364

2.4 Agudeza visual e sonora em "Pilar", de Affonso Ávila, 371

2.5 Ut pictura poesis na construção da poesia do século XX, 381

2.5.1 "Klimt: tentativa de pintura", de Haroldo de Campos, 391

2.5.2 "Anatomia do gol”, de Haroldo de Campos, 402

2.6 A acentuação da re-forma e o simulacro de materialização em Galáxias, de Haroldo de Campos, 419

2.6.1 Entre prosa e poesia, 419

2.6.2 Agudeza do PE em Galáxias: ritornello sonoro e expansão da linha no branco da página, 426

2.6.3 O recrudescimento da fluidez em Galáxias, 443

2.6.4 Paroxismo em Finnegans Wake, de James Joyce, 446

3 Para não concluir..., 465

Conclusão, 474

Referências, 483

Índice remissivo, 507 
INTRODUÇÃO 
Os rótulos identificadores de estéticas constituem um entrave para qualquer investigação científica no campo das artes. Por essa razão, de saída realizei quase uma desconstrução do que seria o neobarroco, sugerindo uma semiótica da agudeza, objeto de minha pesquisa. Como o prefixo neo ecoa um passado que se presentifica, revisitei o percurso do chamado barroco.

O termo barroco vem ganhando através dos tempos muitos significados, não sendo raro quem o desconsidere, nem mesmo raro quem o euforize; neste último caso, sobressai a tendência de encontrar barroquismo em objetos de variadas épocas, como em Sousândrade, Oswald de Andrade, Augusto de Campos, Haroldo de Campos, Guimarães Rosa, Affonso Ávila, Horácio Costa, Claudio Daniel entre outros. A esse rótulo associa-se ainda latinoamericanos, como Lezama Lima, Severo Sarduy, Alejo Carpentier, Nestor Perlongher.

Após a exclusão do barroco do livro Formação da literatura brasileira ([1959] 1993b), Antonio Candido ([1969] 1989, p. 163-198), no ensaio "Literatura de dois gumes", encara a literatura do Brasil "mais como fato histórico do que como fato estético", identificando uma literatura que "traz como condição necessária uma carga de liberdade que a torna independente sob muitos aspectos, de tal maneira que a explicação de seus produtos é encontrada sobretudo neles mesmo" (p. 163, destaques nossos) e outra literatura que "possui tantas ligações com a vida social, que vale a pena estudar a correspondência e a interação entre ambas" (p. 163). Afirma ainda que "herdamos relativamente pouco do que havia de popular, mágico-religioso e espontâneo na literatura da Idade Média; e muito, ao contrário, de uma literatura erudita, cheia de exigências formais, aberta para uma visão realista e ao mesmo tempo alegórica da vida" (p. 164, destaque nosso). E, à página 169, faz referência aos séculos XVII e XVIII, afirmando que para muitos escritores desse período "a linguagem metafórica e os jogos de argúcia do espírito barroco eram maneiras normais de comunicar a sua impressão a respeito do mundo e da alma" (destaque nosso).

E, em seguida, comentando as condições do ambiente, "formado de contrastes entre a inteligência do homem culto e o primitivismo reinante, entre a grandeza das tarefas e a pequenez dos recursos" (p. 169), conclui que "a desproporção gera o senso dos extremos e 
das oposições" (p. 169) e que esses escritores se ajustaram à moda literária de então que Ihes possibilitava "empregar ousadamente a antítese, a hipérbole, as distorções mais violentas da forma e do conceito. Para eles, o estilo barroco foi uma linguagem providencial" (p. 169). Não obstante a passagem das modas literárias, "muito delas permaneceu como algo congenial ao País" (p. 169, destaque nosso). Ao final do ensaio, à página 180, declara: "mesmo dentro dos quadros que estabeleci fui limitado e talvez injusto. Teria sido preciso mostrar como algumas tendências, vistas aqui sob o aspecto positivo foram também negativas. Mostrar, por exemplo, como a transfiguração barroca inaugurou nos hábitos mentais do brasileiro um amor irracional pela grandiloquência pura e simples". Muito embora o reconhecimento de ter sido injusto com o barroco, parece que seu texto não se coaduna com as pesquisas mais recentes sobre as letras seiscentistas, como a de Hansen (2000, 2001, 2006a, 2011, 2013) e Pécora e Hansen (2006).

Em outro ensaio, "Dialética da malandragem" ([1970] 1993a), Antonio Candido no lugar da história literária organizada segundo a sucessividade de autores e obras, opta pelo estudo de um tema constitutivo, o picaresco. Assim, vai buscar em Lazarillo de Tormes (1554), no Renascimento, e em Apuleio e Petrônio traços constituidores de obras como as de Manuel Antônio de Almeida (Memórias de um Sargento de Milícias), Mário de Andrade (Macunaíma), Oswald de Andrade (Serafim Ponte Grande). Vê ainda influência do picaresco na sátira de Gregório de Matos. Ao ligar o picaresco a Gregório de Matos, passava o autor de Formação a considerar em certa medida a existência do barroco na Literatura Brasileira.

Em termos internacionais, a partir de Wölfflin é que se dá, de certa forma, a valorização do chamado barroco, uma espécie de euforia do fazer artístico; a "nova" estética passa a ser vista como liberdade criadora em relação ao classicismo, ofuscando a relação do "barroco" com um conjunto de preceitos tratadísticos rigorosamente definidos (cf. GOMES JÚNIOR, 1998, p. 20; SNYDER, 2007; GRACIÁN, 1986). O barroco propriamente não rompia com os rigores da estética clássica. Algumas acepções de barroco recorrentes trazem à tona, por sua vez, um barroco do excesso, do scuro, da sensualidade extrema, enfim um barroco que se caracteriza por um conjunto de elementos que o conduziram ao caminho da valorização do subversivo nas artes. E são esses valores de revolução, de liberdade, de subversão, que se imbricam com os valores do experimentalismo poético e vanguardístico do século XX, acabando por desembocar no chamado neobarroco ou no barroquismo. 
Parece-nos então que o "barroco" deságua em duas correntes principais: uma fundamentalmente histórica, algo a ser pesquisado por historiadores da arte, e uma corrente teórico-operacional, de base formalista, atuante na área da interpretação dos textos de arte (pintura e poesia), objeto de pesquisa de literatos, críticos e linguistas.

Boa quantidade de textos que trata das letras seiscentistas inicia-se pelo estudo da reconstituição histórica do termo barroco $^{1}$. O simples fato de traçar essa história, no entanto, não nos permite um entendimento adequado desse termo nem seria suficiente para examinar com profundidade os textos produzidos nos séculos XVI-XVII (cf. WELLEK, 197-, p. 69). No final do século XIX e início do século XX, em quase toda a Europa, alguns estudiosos concentraram seus esforços para estabelecer a noção de barroco com base na imersão em textos seiscentistas. Barroco passa então a ganhar a inicial em "caixa alta", definindo-se como período literário ou artístico. Paralelamente, notamos que os estudos de Wölfflin, quando explicita a não pertinência dos rótulos de bizarro e de ridículo, demonstrando a natureza da arte do século XVII formalmente organizada em um sistema, salvaguardam o chamado barroco dessas avaliações disfóricas recebidas a partir do século XIX (cf. GOMES JÚNIOR, 1998, p. 22).

O século $X X$, apropriando-se do clima intelectual de insatisfação em relação aos estudos do "barroco" com base em elementos externos ao texto e em rotulações vazias, contempla um recrudescimento de pontos de vista que investigam os objetos de arte e das letras a partir do estudo do próprio texto e de sua estrutura interna. Para Gomes Júnior (1998, p. 23),

essa tendência geral não deixou de se reproduzir no Brasil, onde se viu barroco e nova crítica como bandeiras simultâneas do incansável publicismo de Afrânio Coutinho, ou depois de Haroldo de Campos apelar pelo barroco a partir de uma perspectiva que teve na origem, de um lado, a semiótica americana e, de outro, o formalismo do Leste europeu.

O ponto de vista de um barroquismo cíclico não é exclusividade de Haroldo de Campos; pode-se até mesmo afirmar que, de um lado, há autores que defendem a continuidade do barroco (Ernst Curtius, Eugênio D’Ors, Gustav Hocke, Haroldo de Campos, Severo Sarduy e outros) e, de outro lado, os que rejeitam esse ponto de vista (Hansen,

\footnotetext{
${ }^{1}$ Há autores, como Hansen (2001) e Snyder (2007), que preferem a expressão "obras produzidas nos seiscentos" ou "obras seiscentistas".
} 
Pécora, Gomes Jr.). Entender a problemática do barroco que conjuga em si um viés formalista e um viés historicista, talvez seja um grande desafio.

Saussure (2004, p. 286), em seus Escritos de linguística geral, coloca em pauta a ciência dos valores. Segundo ele, para tal ciência seria improdutivo tratar ao mesmo tempo de dois estados. Por isso, optamos nesta tese por separar o estado de barroco nos seiscentos (momento inicial) de outros estados subsequentes, como:

1. Estado em que há a ausência de recorte, ou seja, as obras seiscentistas não são denominadas barrocas.

2. Estado em que há presença do recorte, ou seja, o barroco é sinônimo dos objetos artísticos da égide do bizarro, do ridículo, do excesso.

3. Estado em que há, a partir dos estudos de Wölfflin, a presença do recorte da categoria formal barroco em oposição ao classicismo; nesse momento, o valor de barroco conta então com a oposição clássica.

4. Estado em que há a sugestão de um neobarroco, ou seja, formas "barrocas" se atualizariam ao longo da história das artes.

Consideremos agora o uso de barroco em certo estado, localizado em $\mathrm{X}$ tempo, em que cada estado de barroco estaria determinado pelos valores contemporâneos em jogo. Assim, o valor de qualquer termo, por exemplo, é estabelecido por aquilo que o rodeia (cf. SAUSSURE, 1996, p. 135; LOPES, 1997, p. 114). Para discutir a questão, retomemos o paralelo saussuriano entre "estado de língua" e "jogo de xadrez": "uma posição de jogo corresponde de perto a um estado de língua" e o valor de cada peça depende de sua posição no tabuleiro (cf. SAUSSURE, 1996, p. 104); desse modo, na língua cada termo tem seu valor segundo a posição que ocupa em oposição a outros termos.

Afirma ainda Saussure que o sistema é estático, "momentâneo" e, nesse caso, varia de um estado para outro. Aplicando esse princípio ao estudo do barroco, seria pertinente considerar seu valor nas diversas sincronias e verificar as variadas oposições que estabelece. A teoria de Saussure, segundo Claudine Normand (2009, p. 64), não pode, sem prejuízo, ser apartada da teoria do valor, estando esta última vinculada à noção de arbitrariedade do signo. O signo barroco só ganha importância, pois, se definido em determinado sistema de valores. Mais importante do que sua existência seria a descrição de seu funcionamento em $X$ ou Y estado. 
Arrivé (2010, p. 137) discute a reflexão de Godel sobre o tempo na perspectiva sincrônica ser o espaço do discurso. Simplifiquemos a descrição em dois estados sincrônicos; $\mathrm{X}$ e $\mathrm{Y}$ constituem dois tempos discursivos:

- $\mathrm{X}$ : séculos XVI e XVII - tempo discursivo de ausência de recorte de barroco; não há a categoria de barroco para período literário/artístico; só se conhecem nos seiscentos poéticas e retóricas clássicas, como as de Aristóteles, Horácio, Quintiliano e os tratados que difundem o pensamento aristotélico e a agudeza (acutezza, concetto, conceito) como estrutura regente do fazer poético seiscentista.

- Y: final do século XIX (pós-Wölfflin) - tempo discursivo em que o barroco serve de recorte para o período de produção literária/artística dos séculos XVI-XVII.

Trata-se de dois momentos de observação, de dois períodos de tempo: cada época estabelece, portanto, um valor de uso (cf. BOUISSAC, 2012, p. 167).

- Por desconhecerem discursivamente o recorte do signo barroco como categoria de um tempo literário/artístico, os séculos XVI-XVII não carregam as mesmas disforias e preconceitos do século XIX em relação a seus objetos estéticos;

- Por recortar discursivamente o barroco como tempo literário/artístico, o século XIX convive com as expressões pérola irregular, bizarro, excessivo, verrugoso, tumoral para descrever as produções seiscentistas. A partir da obra de Wölfflin (1888), o barroco erige-se como categoria formal. E, nesse caso, há uma discretização antitética entre clássico e barroco.

Se abandonássemos o ponto de vista sincrônico, contaminaríamos nossa pesquisa com possíveis visões disfóricas trazidas de um tempo para outro. Assim, foi-nos possível optar por uma epistemologia que adota os valores em jogo:

- De um tempo estático $X$, com a ausência de recorte, sem oposição entre clássico e barroco, em que há a valorização eufórica da estrutura da agudeza nos fazeres poéticos. 
- De um tempo estático Y: conjuga a ausência de recorte de barroco (presente em alguns manuais e dicionários que escolhem valores disfóricos, como irregular, bizarro, excêntrico, verrugoso etc., para caracterização dos objetos poéticos dos seiscentos) com a presença do recorte wolffliniano da categoria barroco em oposição à categoria clássico.

Erigiu-se, pois, em interesse maior desta pesquisa investigar as propriedades da agudeza. Recorri para isso a um conjunto expressivo de textos de João Adolfo Hansen (1978, 1989, 1995, 1997, 2000, 2001, 2004, 2006a, 2006b, 2006c, 2006d, 2011, 2013), de Pécora e Hansen (2006), Pécora (2013) e Snyder (2007), que tratam do conceito de agudeza vigente nos séculos XVI-XVII. Esse conceito é constante de tratadistas seiscentistas, como Matteo Peregrini, Baltazar Gracián, Emanuele Tesauro e outros, que reciclam Aristóteles, Cícero, Horácio, Quintiliano, Longino.

As agudezas, escolhas que erigem a acentuação como valor a ser perseguido no enunciado poético, regulam a constituição de metáforas, formadoras de condensações agudas, bem como dos artifícios formais de efeitos visuais e sonoros. Ao longo desta tese, espero demonstrar que as agudezas, por apresentarem semelhanças com a semiótica tensiva de Zilberberg, operam com a gradação de objetos ora mais fluidos, ora mais nítidos, ora mais fantásticos, ora mais icásticos, ora mais acentuados na expressão, ora mais acentuados no conteúdo. A agudeza conjuga-se perfeitamente com a semiótica tensiva, visto pertencer a um nível tensivo e a produzir no nível discursivo os efeitos mencionados.

Em “Estrutura e história”, Greimas (1975, p. 98 e 105) salienta que a significação não é percebida como uma "extensão no tempo", mas como uma "iteração de certo número de permanências". Com base nisso, questionamos:

- Será mesmo que a repetição de certo número de permanências de formas seiscentistas, observando seu uso, sua estrutura imanente e sua iteração, nos possibilitaria depreender uma espécie de traço estrutural, que ultrapassa seu tempo seiscentista, perpassando a história da arte, como nos sugere principalmente Haroldo de Campos com o resgate do barroco, o neobarroco ou o barroquismo? 
- Será que a agudeza seiscentista, que se identifica com o trabalho com a linguagem poética, pode ser considerada uma destinadora dos objetos estéticos do final do século XX?

- Não seria a poesia do final do século XX regida por uma agudeza diferente da agudeza seiscentista? Com outros destinadores? Outro contrato enunciativo?

A fim de discutir essas questões investigaremos a semiótica da agudeza com base na semiótica tensiva de Zilberberg (2006a, 2006b, 2011a). Antes de arriscar uma resposta pronta para tais questões, discutiremos inicialmente no capítulo 1 a multiplicidade semântica do conceito de barroco. Nesse capítulo, examinamos o recorte do chamado barroco na continuidade clássica, bem como a ausência e presença desse recorte nos estudos literários. Finalmente, focalizamos a sincronia e a diacronia que vai nos dirigir para a agudeza idiossincrônica.

No capítulo 2, a tese concentrou-se no jogo tensivo entre agudeza da expressão (PE) e agudeza do conteúdo (PC). Por isso, detivemo-nos nas obras de tratadistas seiscentistas como Mateo Sarbiewski, Matteo Peregrini, Emanuele Tesauro, Baltazar Gracián, Francisco Leitão Ferreira entre outros, introdutores dos princípios de concetto, agudeza, arguzia. É então que termos como maravilha, inventividade, novidade, engenho, surpresa passam a constituir-se em pilares da chamada arte poética aguda. Examinamos, apoiados em Zilberberg (2011a, p. 183), a metáfora aguda como uma analogia composta de termos sobrecontrários. Seriam eles os responsáveis pela acentuação dos enunciados. Ainda nesse capítulo focalizamos as propriedades estruturais da agudeza dos seiscentos e do final do século XX.

No capítulo 3, sondamos a negação da euforia barroquista em direção à visualidade na poesia da agudeza. Constituem então objeto da pesquisa variados autores que tratam do neobarroco de diversos pontos de vista. Entre eles, destacam-se Umberto Eco, com seu conceito de barroco como obra aberta; Omar Calabrese, que sustenta uma idade neobarroca; Severo Sarduy, que trata o neobarroco como uma estética do desperdício em função do prazer; Lezama Lima, que vê o neobarroco como uma arte da contraconquista; Alejo Carpentier, que estuda o neobarroco como um real maravilhoso da América Latina. Também foi objeto de nossa pesquisa o barroquismo sincrônico de Haroldo de Campos, com 
sua sugestão de um cânone barroquista, bem como o barroquismo de Affonso Ávila, Affonso Romano Sant'Anna, Horácio Costa, Ana Hatherly e Ivan Teixeira. Com base nesses três últimos autores, deduzimos o conceito de poesia visual, expressão que, no lugar de neobarroco, parece-nos mais apropriada para o estudo de objetos estéticos que comungam da operação da agudeza visual.

No capítulo 4, focalizamos o sensível e o inteligível na semiótica da agudeza. Ocupamo-nos então do diálogo da fenomenologia com a semiótica tensiva, bem como do conceito de fé perceptiva no objeto estético. A fé perceptiva constitui-se numa porta de entrada por meio da qual o sujeito modaliza-se mais pelo crer do que pelo saber, ou seja, o acesso ao mundo natural não se faz com a certeza objetiva do saber, mas pela dúvida do crer: o sujeito jamais poderá ter certeza de que sua percepção exaure o reconhecimento dos objetos. Sem a segurança intelectiva, a fé perceptiva revela-se mais pelo invisível do que pelo visível. Com apoio em um exemplo de Bertrand (2008, p. 128), em que compara a "Estação de Zola" com a "Estação de Simon", depreendemos dois modos distintos de percepção: enquanto Zola manifesta uma "certeza" no que observa, Simon admite que o sujeito se abala diante de seu objeto e, por isso, apresenta uma estação mais fluida, sem contornos propriamente nítidos. A partir de então, à semiótica da agudeza adicionamos os conceitos de fluidez e nitidez como parâmetros para a observação dos objetos estéticos que compõem o corpus desta tese. Discutindo ainda a introdução da fenomenologia na semiótica, avaliamos ser relevante o conceito de semiocepção de Beividas (In: MARCHEZAN; CORTINA; BAQUIÃO, 2011, p. 13-33). Finalmente, verificamos tratar-se a poesia aguda de um perobjeto nos termos de Zilberberg (2006b, p. 143-144); suas considerações nos levarão a focalizar aspectos como a estetização e a etização.

No capítulo 5, a agudeza do final do século XX direciona-se para o objeto fluido. Tratamos da teatralização da crise de verso, quanto do discurso da poesia fluida e da potencialização da poesia nítida. São examinadas então as consequências dos entravamentos formais na poesia: no conteúdo, na expressão, na percepção sensível, no reconhecimento inteligível, no andamento e na duplicidade da fruição. No exame da acentuação da agudeza fluida, discutimos a condensação aguda, a acentuação da fluidez, a constelação semântica, a agudeza sonoro-visual. Uma linha de poesia do final do século XX, a visual, é porta de entrada para o estudo da écfrase e da hipotipose, conceitos que se imbricam com o ut pictura poesis, que nos permitirá homologar a fluidez com o fantástico, 
com o ver mais de perto, e a nitidez com o icástico, com o ver mais de longe. Ainda nesse capítulo final analisamos a acentuação da inovação das formas e o simulacro de materialização para atingir o delongamento do reconhecimento inteligível. Nesse momento, discutimos os conceitos de prosa e poesia, agudeza fluida e seu recrudescimento em Galáxias, bem como o paroxismo agudo em Finnegans Wake.

Estabelecemos um corpus de poemas de Arnaldo Antunes, Affonso Ávila, Haroldo de Campos, Horácio Costa e fragmentos de Finnegans Wake, de James Joyce, com o objetivo de explicitar as operações da semiótica da agudeza na constituição de objetos estéticos que se encaminham para a fluidez. Valemo-nos ainda para efeito de argumentação de poemas atribuídos a Gregório de Matos, fragmentos de textos de Vieira, de poemas de John Donne, de Augusto de Campos, João Cabral de Melo Neto entre outros.

No percurso de realização desta tese sofri o paradoxo da alta satisfação, porque se tratava de um objeto literário de alta complexidade e beleza estética, bem como de momentos de intensa atribulação, quer em virtude das extensas análises que o objeto solicitava, quer em razão dos antissujeitos da ciência.

Ao término da pesquisa percebi que, embora tenha me concentrado na investigação semiótica de um objeto literário, este, ao longo do trabalho, se mostrou tão forte que parecia querer tomar o lugar da ciência que escolhi, a semiótica. Por um lado, o objeto recusava-se, muitas vezes, a submeter-se ao frio olhar analítico, que destruía, a cada tentativa de "anatomia", as belezas estéticas da silhueta dos poemas. Por outro lado, sentia também que a teoria, boa parte do tempo, é que me permitia fruir o objeto. Oscilação tensiva que me perseguiu até colocar ponto final no trabalho.

A propósito, cito Jakobson (2005, p. 161-162) em seu texto "Linguística e poética"

Esta minha tentativa de reivindicar para a Linguística o direito e o dever de empreender a investigação da arte verbal em toda a sua amplitude e em todos os seus aspectos conclui com a mesma máxima que resumia meu informe à conferência que se realizou em 1953 aqui na Universidade de Indiana: Linguista sum; linguistici nihil me alienum puto. Se o poeta Ransom estiver certo (e o está) em dizer que "a poesia é uma espécie de linguagem", o linguista, cujo campo abrange qualquer espécie de linguagem, pode e deve incluir a poesia no âmbito de seus estudos. A presente conferência demonstrou claramente que o tempo em que os linguistas, tanto quanto os historiadores literários, eludiam as questões referentes à estrutura poética ficou, felizmente, para trás. Em verdade, conforme escreveu Hollander, "parece não haver razão para a tentativa de apartar os problemas literários da Linguística geral". Se existem alguns críticos que ainda duvidam da competência da Linguística para abarcar o 
campo da Poética, tenho para mim que a incompetência poética de alguns linguistas intolerantes tenha sido tomada por uma incapacidade da própria ciência linguística. Todos nós que aqui estamos, todavia, compreendemos definitivamente que um linguística surdo à função poética da linguagem e um especialista de literatura indiferente aos problemas linguísticos e ignorante dos métodos linguísticos são, um e outro, flagrantes anacronismos.

Com base nas palavras de Jakobson e na experiência vivida nesses quase quatro anos de reflexão, verifico que de fato ao linguista cabe observar a língua em sua totalidade, não excluindo nenhum de seus objetos, particularmente os estéticos.

Finalmente, esclareço que as dicotomias terminológicas que aparecem ao longo desta tese devem ser consideradas apenas para efeito de demonstração. Se separamos plano de expressão e plano de conteúdo, significante e significado, diacronia e sincronia, intensidade e extensidade entre outras, foi porque o momento argumentativo da análise pedia uma discretização. Quando seccionamos sensível e inteligível, também fiz consciente de que se tratava apenas de teatralização científica: são duas dimensões que se distinguem, mas são necessariamente articuladas entre si. 


\section{RECORTE DE BARROCO NA CONTINUIDADE CLÁSSICA:}

A DISFORIA BARROCA

Escrever um livro sobre a estética do Barroco provoca uma sensação [...]; é preciso navegar num tempestuoso mare magnum de textos teóricos inclassificáveis, estranhos, singulares e inquietantes [...], na esperança de alcançar finalmente uma margem que nos seja familiar a nós, viajantes do século XXI. Jon R. Snyder

A categoria "barroco", coisa que hoje acho totalmente desnecessária, [...] só produz equívocos de interpretação. João Adolfo Hansen

[...] O século XVI é, na história do mundo moderno, um século de transição e de gestação. Se se pretender que, por causa disso, seja necessário colocá-lo sob uma etiqueta que o diferencie do Renascimento, pergunta-se se convém chamá-lo de barroco. 


\section{MULTIPLICIDADE SEMÂNTICA INICIAL DO CONCEITO dE BARROCO}

Como nosso objeto de estudo é a poesia do final do século $X X$, conhecida também como neobarroca, pareceu-nos pertinente investigar primeiramente o que caracteriza a arte dos seiscentos, conhecida como barroca. Que pontos de contato haveria entre uma arte e outra?

A visão disfórica e negativa do chamado barroco que prevaleceu em todo o século XX derivou do nome que se dava ao quarto modo da segunda figura dos silogismos, segundo o qual baroco seria um termo mnemônico. Tomemos o silogismo apresentado por Croce, citado por Wellek (197-, p. 69 ss): "todo doido é teimoso; algumas pessoas não são teimosas, logo algumas pessoas não são doidas". Já no século XVI esse tipo de argumento era considerado sofístico e artificial. Daí Luís Vives, também citado por Wellek, ter ridicularizado os professores de Paris como "sofistas em baroco e baralipton". O conceito negativo também advém do termo espanhol barrueco, utilizado para identificar uma pérola de forma irregular.

No século XVIII, a peregrinação do termo continua sua jornada disfórica e é visto como "extravagante", "esquisito", "decorativo", "jocosamente livre", ponto de vista adotado pela estética classicista. Curtius (1996, p. 342) entende que a palavra barroco tem "suscitado tanta confusão que é melhor excluí-la". Afirma também que o que se designa como períodos "clássicos" "são píncaros isolados que só para fins práticos podemos agrupar sob a rubrica de classicismo ideal".

Desde sua origem, tem havido, portanto, nos estudos das letras seiscentistas, uma multiplicidade semântica que, antes que elucidar o fenômeno, contribui para obscurecê-lo; daí denominações como "pérola irregular", "período lacunar", "densidade aglutinada de pedra", "bizarrice" entre outras expressões.

Em Escrito sobre um corpo, Sarduy (1979, p. 57-58) salienta a ambiguidade do barroco desde o seu nascimento, bem como sua difusão semântica (cf. também MILTON In: FIGUEIREDO, 2010, p. 73). Entre outros termos, elenca "excrescência", "quisto", "o que prolifera, ao mesmo tempo livre e lítico, tumoral, verrugoso". Sarduy faz ainda uma 
avaliação dos verbetes de dicionários, que incluem "amontoados de banalidade codificada" e que neles o barroco equivale a "bizarria chocante", a "estrambótico", a "extravagância" e a "mau gosto".

Historiadores literários e críticos de arte, na época, rejeitavam as obras produzidas no período seiscentista, hoje chamadas de barroco, alegando sua "irregularidade e inconstância" em relação às obras tidas como modelares clássicas. Hauser (2003, p. 444) comenta que "não só a atitude de Winckelmann, Lessing e Goethe, mas também a de Burckhardt ${ }^{1}$ ainda é guiada fundamentalmente pelo ponto de vista da teoria classicista".

O que se vê aí é que determinadas obras foram avaliadas do ponto de vista de um destinador julgador rigoroso que não admitia alterações na forma estética fechada do Renascimento. Utilizamos aqui destinador no sentido que Greimas e Courtés (1983, p. 115) dão ao termo: "aquele que comunica ao Destinatário-sujeito (do âmbito do universo imanente) não só os elementos da competência modal, mas também o conjunto dos valores em jogo".

Ao final do século XIX, Wölfflin ([1888] 1989, p. 16) enfatizará que os valores clássicos, regidos pelo respeito ao parecer verdadeiro, pela razão, pela obediência aos preceitos da antiguidade clássica greco-romana, pela imitação da natureza, são:

1. Linearidade.

2. Valorização da superfície.

3. Multiplicidade: partes coordenadas de igual valor.

4. Forma fechada: arte tectônica que se revela na superfície, deixando de fora o observador ${ }^{2}$.

5. Claridade absoluta (clareza).

Esses valores clássicos estão em jogo de oposição às seguintes categorias dedutivas barrocas:

\section{Picturalidade.}

2. Valorização da profundidade.

\footnotetext{
${ }^{1}$ Burckhardt, historiador da cultura, e, posteriormente, Croce, ainda não libertos do racionalismo do século XVIII, percebem no barroco apenas os sinais de ausência de lógica e de estrutura (HAUSER, 2003, p. 444).

${ }^{2} O$ texto de Wölfflin, como sabemos, não leva em conta que a enunciação é um complexo de enunciador e enunciatário, sendo este último chamado por Wölfflin de "observador". O enunciatário é sempre pressuposto, bem como o enunciador (coenunciação). Talvez o que ocorra nas artes renascentistas e clássicas é uma participação do enunciatário menos acentuada, enquanto nas obras seiscentistas teríamos um enunciatário mais acentuadamente aproximado.
} 
3. Unidade: subordinação das partes em relação ao todo.

4. Forma aberta: arte atectônica.

5. Claridade relativa (obscuridade).

Como sabemos, as categorias dedutivas de Wölfflin são estabelecidas a posteriori e não levam em conta certa competência regente do fazer artístico dos seiscentos. Depreendemos, portanto, dois destinadores diferentes:

- Destinador do final do século XIX, apoiado nas categorias dedutivas originárias da observação de Wölfflin, posterior, pois, aos eventos estéticos seiscentistas.

- Destinador dos séculos XVI-XVII, constituído pelos enunciadores dos tratados poéticos da agudeza.

Ao afirmar que a arte clássica era guiada pela razão, comentaristas posteriores a Wölfflin entenderam que, pelo princípio da diferença e da oposição, havia desvalorização das obras que não seguiam os princípios clássicos. Todavia, Wölfflin euforiza a liberdade do artista que não se submete aos rigores e limitações do código classicista vigente. Portanto, não disforiza a razão, mas euforiza a liberdade presente nas obras de artistas que considera mais evoluídos do que aqueles que simplesmente seguiam a estreiteza do cânone renascentista.

Nossa pesquisa propõe-se investigar que os artistas dos seiscentos eram guiados por uma razão poética; talvez se enganem os que consideram as letras seiscentistas como arte orientada pela irracionalidade. Se consultados os tratadistas da época, verifica-se quão rigorosos eram os enunciadores poéticos dos séculos XVI-XVII, que seguiam a racionalidade estrutural da agudeza, a ser vista no capítulo 2, bem como a engenhosidade de sua liberdade criativa.

A prática da doutrina aristotélica é comum no século XVII, que recicla a Retórica, sobretudo o livro III, que trata da elocução (ARISTÓTELES, 2007, p. 147-191). Os tratados poéticos da agudeza, italianos ou ibéricos, de interpretação neoescolástica aristotélica e de autores latinos, como Horácio, Longino (In: ARISTÓTELES, HORÁCIO, LONGINO, 2008, p. 5568; p. 71-114), Cícero ([86-82 a.C.] 2005) e Quintiliano (2001), tiveram ampla circulação nas colônias espanholas e portuguesas da América (o Brasil, por exemplo) pelas mãos 
principalmente dos jesuítas (cf. HANSEN, 2001, p. 22-23). Para Hansen (2000, p. 321-322), as obras seiscentistas se inserem na racionalidade e propõem a agudeza como elemento formal a ser explorado pelo fazer artístico da época. As avaliações disfóricas sobre as letras seiscentistas introduzem ambiguidade e não pertinência, visto que as obras produzidas nos séculos XVI-XVII não excluem, portanto, a razão.

Ademais, antes que fosse aplicado às artes, o termo barroco era visto como sinônimo de bizarro, extravagante, monstruoso; posteriormente, passou a rotular a arte seiscentista como um período de decadência das artes renascentistas ou clássicas. Esse conceito, utilizado pela crítica neoclássica e iluminista, difundiu-se pelo século XIX. Barroco entrou disforicamente ${ }^{3}$ no vocabulário da filosofia (pensamento barroco, argumentação barroca); no das artes (tela barroca, arquitetura barroca, música barroca, literatura barroca); no da moda (roupa barroca, cabelo barroco) etc.

A seguir, discutimos o recorte de barroco, cujo início se deu na Alemanha, com reflexos por toda a Europa.

\section{RECORTE DE BARROCO}

\subsection{Na Alemanha}

Jakob Burckhardt, historiador suíço, deu início à revisão do fenômeno barroco, relacionando-o "ao que considerava a decadência da Alta Renascença na florida arquitetura da Contrarreforma na Itália, na Alemanha e na Espanha" (WELLEK, 197-, p. 70), mas é a Wölfflin que se deve a reviravolta de seu conceito.

Em 1888, na obra Renascença e barroco, Wölfflin (1989, edição brasileira) realiza uma análise técnica do desenvolvimento do estilo em Roma. É a ele também que se deve a aplicação pela primeira vez do conceito de barroco à literatura e à música, pois nesse estudo compara a literatura clássica de Ariosto (Orlando Furioso, 1516) com a literatura de Tasso (Jerusalém libertada, 1584), denominada por ele de barroca. As mesmas avaliações de Wölfflin encontramos nas obras de historiadores e críticos literários do século XX. Vejamos os versos de Jerusalém libertada comentados por ele:

\footnotetext{
${ }^{3}$ Até hoje, ouvimos expressões, como: "A fala de fulano é barroca"; "Essa calça é barroca"; "Seu argumento é barroco" etc.
} 
Canto l'armi pietosi, e il Capitano

Che il gran sepolcro liberò di Cristo:

Molto egli oprò col senno e con la mano;

Molto soffrì nel glorioso acquisto:

E invan l'Inferno a lui s'oppose, e invano

S'armò d'Asia e di Libia il popolo misto;

Che il Ciel gli die favore (TASSO In: WÖLFFLIN, 1989, p. 98).

Com base nesses versos, Wölfflin (1989, p. 98) afirma: "notem-se em toda parte os adjetivos de reforço, as terminações sonoras, as pesadas repetições (molto..., molto..., $e$ invan... e invano...), a construção afetada da frase [...]" (destaques nossos). Além disso, logo à "Introdução" de Renascença e barroco, à página 28, já afirmara que o barroco iniciou-se "pesado, maciço, contraído, severo", tornou-se "mais leve e mais alegre" para chegar afinal "à dissolução brincalhona de todas as formas tectônicas, a que chamamos de Rococó".

A sanção ${ }^{4}$ no enunciado de Wölfflin $(1989$, p. 48) encaminha-se, em alguns momentos, da euforia à disforia: "o barroco exerce momentaneamente um efeito poderoso, mas em breve nos abandona, deixando-nos uma espécie de náusea" (destaques nossos). Nesse caso, a avaliação é feita com base em um sistema axiológico estético que Wölfflin elege como valores de um destinador transcendental: o pensamento positivista do final do século XIX.

Antes de 1914, a referência à arte barroca era muito rara. Benedetto Croce, em sua obra Saggi sulla letteratura italiana del seicento, publicada em 1910, não denomina barroca a literatura da época, considerando-a apenas exagerada. Em 1914, o dinamarquês Valdemar Vedel publica um estudo sobre o barroco "Den digteriske Barokstil omkring aar 1600", comparando o estilo de Rubens com o estilo poético francês e inglês dos anos de 1550 e 1650 (cf. WELLEK, 197-, p. 73 ss). Ele via na literatura tanto quanto na arte de Rubens efeitos de decoração, coloração e ênfase. Todavia, muito provavelmente por ser escrito em língua dinamarquesa, ficou na obscuridade.

\footnotetext{
${ }^{4}$ A sanção proferida por um destinador transcendental à performance do sujeito está relacionada ao sistema axiológico de "justiça”, "de boas maneiras", "de estética” (GREIMAS; COURTÉS, 1983, p. 389).
} 
A partir de $1915^{5}$, no entanto, com a publicação de Conceitos fundamentais da história da arte, de Wölfflin, o termo barroco irradia-se. Ainda contribuíram para a entrada do termo na literatura (cf. WELLEK, 197-, p. 73 ss):

1. Fritz Strich, que realizou análise estilística da poesia lírica alemã do século XVII, denominada por ele de barroca.

2. Oskar Walzel, em artigo de 1916, que considerou Shakespeare barroco (cf. também HATZFELD, 2002, p. 17).

3. Josef Nadler, que, em 1918, utilizou o termo barroco para tratar da literatura da Contrarreforma.

Rudolf Von Delius, em 1921, publica uma antologia de poesia barroca alemã. Em 1923, Spengler considera a poesia barroca semelhante ao expressionismo alemão, que era turbulento, tenso, torturado e apresentava uma visão trágica do mundo. Então, a arte seiscentista, que antes era desprezada por causa de seus "exageros", passa a despertar interesse e compreensão.

\subsection{Reflexos em outros países da Europa}

O pensamento de Wölfflin foi paulatinamente absorvido pelos críticos e historiadores de arte. Na Espanha, o termo barroco passou a englobar os termos locais gongorismo e conceitismo; Wilhelm Michels, em 1929, vê na obra de Shakespeare as mesmas tendências estilísticas de Calderón, considerado barroco; segundo Hatzfeld (2002, p. 19), a Espanha seria eterna e basicamente barroca, tendo sido "historicamente centro de irradiação do espírito barroco pela Europa" (cf. também WELLEK, 197-, p. 75).

A visão de Hatzfeld altera completamente a compreensão que o homem moderno tem do barroco: em vez de vê-lo como posterior ao Renascimento, vê o Renascimento como um período que encobriu os objetos barrocos, que pertenciam à cultura artística da Espanha (HATZFELD, 2002, p. 13-37). Nesse caso, não há no enunciado de Hatzfeld a noção de arte disfórica, degenerescente, ou seja, a de barroco como clássico corrompido. Ao contrário, ele nos revela que a arte renascentista de gosto clássico seria apenas um período que conviveu com as formas barrocas. É com base nesse ponto de vista mais euforizado que muitos objetos literários podem ser entendidos como barrocos. Nesse sentido, Wellek (197-, p. 76),

\footnotetext{
${ }^{5}$ A questão foi cogitada por Wölfflin pela primeira vez em 1888 (cf. também COUTINHO, 2001b, p. 12; RAMOS, 1979, capítulo "Poesia barroca", p. 1-30).
} 
apoiado em Schürr, classifica Rabelais de barroco. O mesmo o faz Erich Auerbach ([1929] 2012, p. 223-226), em relação a Molière, La Fontaine, Nicolas Boileau e Racine. Para ele, os quatro são barrocos.

Ao considerar Rabelais barroco, Wellek (197-, p. 76) mostra a força dessa forma que se espalha por toda a história da literatura. Bakhtin (1987, p. 32-33), em A cultura popular na Idade Média e no Renascimento: o contexto da obra de François Rabelais, viu na obra do autor de Pantagruel laços entre a cultura popular e a carnavalização.

Fiorin (2006, p. 90) entende que a literatura carnavalizada

não se apoia na tradição, mas critica-a e opta pela experiência e pela livre invenção; constrói uma pluralidade intencional de estilos e vozes (mistura o sublime e o vulgar; usa gêneros intercalares, como cartas, manuscritos encontrados, paródias de gêneros elevados, citações caricaturadas, etc.). Nela, a palavra não representa; é representada e, por isso, é sempre bivocal. Mesclam-se dialetos, jargões, vozes, estilos...

Nesse sentido, pode-se estabelecer um paralelo entre a obra de Rabelais e o barroco, visto que a estrutura das obras do chamado barroco comporta a dessacralização e a relativização das coisas sérias e a subversão de estruturas consagradas como clássicas. Os exageros seiscentistas da metáfora são semelhantes aos excessos em Pantagruel. Além disso, assim como o carnaval não é a negação nem a afirmação absoluta, podemos dizer que, nos termos de Zilberberg (2011a, p. 44), na arte do século XVII ocorre uma mistura paradoxal da afirmação com a negação, fugindo dos valores absolutos. Essa livre invenção, que fundamenta a carnavalização literária, é uma característica, pois, do período. Leo Spitzer, por sua vez, vê em Racine característica de um barroco suavizado (cf. DELEUZE, 2011a, p. 208-213). Na visão de Hatzfeld (2002, p. 72), o classicismo francês seria uma variação de barroco: a mesma tensão, a mesma sensualidade.

Examinando a literatura inglesa, Paul Meissner, citado também por Wellek (197-, p. 78), viu barroco em Paraíso perdido, de Milton. A propósito, Hatzfeld já o havia considerado o mais espanholado e barroco poeta da época.

Schnüner, assim como muitos de seus colegas estudiosos alemães, vê no barroco um movimento unificado: Espanha, Portugal, Itália, França, Alemanha, Áustria, Polônia, Hungria e ex-lugoslávia são todos considerados barrocos (cf. WELLEK, 197-, p. 78). Daí se cogita a possibilidade de existência de países "barrocos". Se pertinente ou não tal afirmativa, não o sabemos; Sarduy (1991), no século XX, afirma ser o barroco um traço do fazer poético dos 
países latino-americanos, opinião muito debatida desde então. Nesse sentido, ao traçar uma trajetória do "transbarroco" no Brasil, Haroldo de Campos (2001, p. 372-379; In: DANIEL, 2004a, p. 13-16) sugere que nossa identidade teria a matriz barroca, algo a ser discutido demoradamente no capítulo 3.

Como vimos, a iniciativa de investigação do barroco deve-se aos alemães, mas já em 1919 o termo ultrapassa os limites da Alemanha, atingindo outros países. Nesse sentido, Wellek (197-, p. 80), ao estudar a história da penetração do termo barroco na Espanha, afirma ser fantasiosa a aplicação que Eugenio D'Ors $(2002,2011)$ faz do barroco, ao vê-lo em toda a história: em Góngora, Vagner, Pope, Vico, Rousseau, El Greco; em Portugal do século XV e do século XX. Eugenio D’Ors (2011, p. 27-28; 89-98) propõe um pan-barroco, neutralizando, portanto, as outras estéticas.

Essa euforia em relação ao chamado barroco contaminou entusiasticamente não apenas Eugenio D’Ors na Espanha, mas também Jean Cassou na França e Sacheverell Sitwell na Inglaterra. Na França, o termo barroco encontrou, porém, mais resistência. Gonzague de Reynold, com sua obra Le XVII siècle: le classique et le baroque (1944), seria uma exceção. Ele entende que até o espírito da época lhe parecia barroquista. Trata-se de um conceito que vai além dos textos literários e das obras artísticas. Nesse estudo, ele reconhece uma disputa entre o clássico e o barroco na França do século XVII, mas os historiadores de arte francesa na sua maioria, como Lebègue e Henri Peyre, opõem-se ao uso do termo nos estudos de literatura (cf. WELLEK, 197-, p. 80-81).

Paralelamente ao preconceito na avaliação das obras hoje consideradas barrocas, há estudiosos que o rejeitam in totum. E, quando alguns deles se dedicaram ao seu estudo, como Marcel Raymond, que distinguiu elementos renascentistas e barrocos em Ronsard, o resultado, segundo Wellek (197-, p. 81), foi insatisfatório.

Estabelecendo um balanço da difusão do termo pela Europa e América, verificamos que o percurso do designado barroco não conheceu a mesma receptividade nos mais variados países:

- Na Alemanha, recebeu completa aceitação.

- Na Itália, as expressões marinismo e seiscentismo, já usadas há muito tempo, foram sincretizadas no termo barroco, evitando assim a referência a Marino e à etiqueta histórica seiscentista. 
- Na Espanha, o barroco englobou o recorte das categorias "culteranismo", "gongorismo", "conceptismo".

- Na Inglaterra, sua adoção deu-se de forma lenta.

- Na América do Norte e Latina, ele foi concebido como literatura colonial.

- Na França, o termo foi recusado pelos estudiosos de literatura, visto que o classicismo francês, destinador imperante, antagonizava-se fortemente com os valores barrocos.

Por isso, afirma Curtius (1996, p. 368) que

quem observa as coisas do ponto de vista francês vê no cultismo e no conceptismo duas "perigosas" doenças do espírito espanhol e, a título de explicação, alega a circunstância de que a Espanha, para a sua infelicidade, nunca teve "mestres-escolas tão rigorosos como Malherbe, Vaugelas e a Academia". É evidente que tais censuras preceptoriais falham ante a tarefa do conhecimento histórico, bem como da apreciação estética.

Examinemos agora o chamado barroco como continuidade clássica.

\section{3}

\section{BARROCO COMO CONTINUIDADE CLÁSSICA}

Os comentadores do barroco, bem como seus "inventores", questionaram seu conceito devido à sua extensão arbitrária (DELEUZE, 2011a, p. 64). Muitas expressões utilizadas para identificar o objeto barroco produzem ambiguidade, confusão, impropriedade. No afã de caracterizá-lo, muitos estudiosos lançaram mão de designações às vezes disfóricas. Por outro lado, para evitar o efeito de amplitude desse conceito, verificamos também uma restrição do barroco à arquitetura, ou a períodos ou lugares, quando não uma negação radical de sua existência.

Em Crátilo de Platão, deparamos com uma discussão sobre a origem do nome das pessoas ou das coisas. Crátilo afirma que "todas as coisas possuem um nome correto, que Ihe é inerente por força da natureza e que o nome de uma coisa não é algo pelo qual é chamada devido a um acordo das pessoas" (PLATÃO, 2010, p. 35). Nega, portanto, a arbitrariedade saussuriana. O que legitimaria um nome? Hermógenes, por sua vez, afirma que "não importa qual o nome" que damos a uma coisa; o "nome correto" seria aquele que se deve "à convenção e ao costume" daqueles que o empregam e estabeleceram seu uso (PLATÃO, 2010, p. 37; cf. também COSERIU; LAMAS, 2010, p. 25-44). Afirma, portanto, a arbitrariedade saussuriana. 
Essas observações nos permitem afirmar que o rótulo barroco, por mais diversas que sejam suas propriedades conceituais, é um signo estabelecido por convenção. Não se pode querer ver debaixo do rótulo uma correspondência com a realidade extralinguística. O que se nota nos mais diversos autores de história literária é uma preocupação com a "verdade", posição que se pode discutir, pois que a linguagem é que configura o mundo; ela não é espelho da realidade. E, dessa forma, não haveria necessidade de multiplicar os signos identificadores do barroco (pérola irregular, bizarrice, lacuna etc.), como se com sua abundância fosse possível retratar uma "realidade barroca", algo "fora do texto".

Esse elenco de designações utilizadas pelos manuais de literatura manifesta uma concepção de submissão da linguagem em relação ao mundo, em que as palavras funcionariam como rótulos. Não é o mundo extralinguístico que é anterior à linguagem, mas a língua natural é que recorta o modo como compreendemos o mundo.

O denominado barroco literário configura-se discurso e, portanto, seria conveniente investigá-lo como texto no entendimento hjelmsleviano, uma entidade de autonomia interna, sem necessidade de buscar correspondência entre o signo e a realidade (HJELMSLEV, 1975, p. 28). Sobejam exemplos de estabelecimento de rótulos nos manuais históricos, quando tentam descrever, diacronicamente, com precisão positivista, a natureza dos objetos poéticos: "isto é barroco", "isto é maneirista", "isto é clássico", "isto é parnasiano", e assim por diante ${ }^{6}$. Beividas e Lopes (2009, p. 444), a esse propósito, afirmam que

a ciência não descobre ou explora alguma 'verdade', verdade intrínseca ao mundo real, algo de efetivamente 'verdadeiro' no mundo. Verdade e verdadeiro estão excluídos dessa epistemologia saussuriana. Ao invés disso, a ciência cria 'pontos de vista' sobre a massa bruta desse real e, com isso, cria os 'objetos' que constituirão sua arena exploratória. Sua tarefa, então, não é mais aquela, positivista, de encontrar 'verdades parciais' aqui e acolá, mas de 'constituir' uma 'veridiç̧ão' interna na composição de seus conceitos descritivos.

\footnotetext{
${ }^{6}$ Essa concepção de rotular milimetricamente os objetos poéticos é satirizada no filme Sociedade dos poetas mortos (direção de Peter Weir, 1990), em que um professor, diante de seus alunos, recomenda-lhes que rasguem seus manuais de literatura. Pede-Ihes que atentem para a estrutura linguística da poesia. Transpondo para o nosso caso, poderíamos dizer que os sucessivos rótulos identificadores de estéticas literárias colocados no eixo da ordenada $Y$, bem como a descrição de suas propriedades no eixo da abscissa $X$, teríamos como resultado um estudo que parece de literatura, mas não é (e, portanto, é um pseudoestudo) e que, veridictoriamente, Greimas e Courtés (1983, p. 488), no quadrado semiótico, denominam "mentira". Tatit (2001, p. 165) utiliza o termo ilusão no lugar do termo mentira.
} 
Duas questões brotam do texto de Beividas e Lopes:

a) O que é a verdade?

b) O que é a veridicção?

No verbete verdade, Greimas e Courtés (1983, p. 485) afirmam que a verdade "subsume os termos ser e parecer situados no eixo dos contrários no interior do quadrado semiótico das modalidades veridictórias". O "verdadeiro" estaria no interior do discurso, "pois ele é o fruto das operações de veridiç̧ão", o que exclui a relação com o referente. No caso das etiquetas, "é barroco", "é clássico", elas funcionam como se houvesse uma relação direta com a verdade (em termo lógicos, correspondência entre a realidade e o discurso); no entanto, trata-se de uma construção discursiva. O caráter imanente do texto, como base epistemológica, não se vale de referente externo. Nesse sentido, historiadores de literatura, quando classificam os objetos estéticos por períodos literários ou históricos, o fazem assumindo de certa forma correspondência externa ao texto. Em geral, tais divisões e épocas são admitidas sem maiores discussões.

A semiótica de base saussuriana, em virtude de sua epistemologia imanentista, não recorre a um referente externo para explicar seus objetos, ocupando-se não da verdade, mas do dizer verdadeiro. Por isso, Greimas e Courtés (1983, p. 486) afirmam que "um crer verdadeiro deve ser instalado nas duas extremidades do canal da comunicação", e seria esse entendimento tácito entre dois sujeitos que eles denominam "contrato de veridicção (ou contrato enuncivo)".

Além disso, Greimas (1981, p. 16) afirma que "o discurso científico é um fazer que constrói seu próprio objeto". O discurso científico sobre o usualmente chamado barroco recorta os objetos estéticos que considera barroquistas. Esses objetos são discursivos e passíveis, portanto, de discussão. Diferentemente, as etiquetas postulam a existência de objetos não discursivos, rotulados e sem possibilidade de embate. Se se diz na tradição dos estudos literários: "é barroco", "é clássico", erigem-se assertivas incontestáveis. Para Barbosa (1980, p. 28), a etiquetagem levou à incompreensão marcada na atividade literária francesa, desenvolvida a partir de Montaigne, na constituição de um estilo que hoje é chamado de barroco, mas que durante muito tempo foi visto apenas como "época de transformações literárias paralelas às transformações político-sociais de Richelieu, sem maiores precisões dentro da Historiografia Literária Francesa". 
Barthes (1970, p. 214), depois de afirmar que "a literatura é a exploração do nome", alerta-nos para o fato de que, "no fundo, o escritor tem sempre em si a crença de que os signos não são arbitrários e que o nome é uma propriedade natural da coisa: os escritores estão ao lado de Crátilo, não de Hermógenes". Eis a diferença entre o lugar do escritor e o lugar do pesquisador: enquanto um se ocupa de produzir objetos estéticos, o outro se ocupa de recortá-los, categorizando-os, muitas vezes introduzindo sanções negativas. E aqui voltamos a Saussure (1996, p. 15): "é o ponto de vista que cria o objeto". Por isso, Hansen (2001, p. 12) afirma que "barroco é Heinrich Wölfflin" e que só passou a existir depois de 1888 , ponto de vista com o qual concordo.

Em A dobra: Leibniz e o barroco, Deleuze (2011a, p. 64) entende que "é estranho negar a existência do barroco como se nega a dos unicórnios ou a dos elefantes rosas, pois, em tais casos, o conceito está dado, ao passo que no caso do barroco trata-se de saber se se pode inventar um conceito capaz (ou não) de lhe dar existência".

Parece que a afirmativa de Deleuze pode ser compreendida em termos discursivos; sempre que há um recorte, passamos a ter desse recorte um conhecimento pela linguagem. Por exemplo, pérolas irregulares recortam determinado objeto, que passa a ter existência na linguagem. Se barroco é pérola irregular, essa metáfora produz a existência desse recorte na linguagem. Desse modo, ele não teria razão de existir sem um conceito que the dê suporte. Se, pela linguagem, não tivesse sido proposto um recorte formal de categoria de barroco, ele simplesmente deixaria de existir, porque é a língua natural que estabelece nosso conhecimento enciclopédico do mundo.

A inexistência do recorte de barroco pode ser vista na História da literatura clássica (edição original, 1917-1922), de Fidelino de Figueiredo (1946). O autor chama o período correspondente à arte produzida nos seiscentos de "2a época". Na introdução do livro, descreve o nome das correntes dominantes da literatura portuguesa de 1580 a 1756 -misticismo religioso, profetismo sebastianista, culteranismo, academias --, mas não categoriza nenhuma estética com a denominação de barroco. A obra é de perspectiva histórica, justificando avaliar os objetos poéticos como "obras de arte, que a exprimir beleza e emoção visaram sempre" (FIGUEIREDO, 1946, p. 7).

Em uma nota posterior, do ano de 1946, Figueiredo assinala que alguns dos pontos de vista estavam ultrapassados, podendo alterar as "interpretações e os juízos". Na nota à edição de 1917, não constava o nome barroco, que também não foi incorporado na edição 
de 1946. A obra de Figueiredo continuou, portanto, sem o recorte do nome barroco nos estudos literários portugueses da época, mesmo após os estudos de Wölfflin, que são de 1888 (Renascença e barroco; a edição brasileira consultada é de 1989). Para o autor português, do Renascimento ao neoclássico, há um continuum sem recortes: "O rápido bosquejo sobre a literatura medieval, o humanismo e o renascimento [...] organizámo-lo para opôr a estética literária medieva à neo-clássica, principal assunto do livro" (FIGUEIREDO, 1946, p. 7, destaques nossos).

As línguas naturais, cada uma a sua maneira, apresentam articulações sêmicas diversas. Tais articulações consistem em categorizações diferentes do mundo, "que definem, em sua especificidade, culturas e civilizações" (GREIMAS, 1976, p. 37). Trata-se de mais ou menos recorte ou categoria, a depender das conquistas científicas de cada época e do ponto de vista do analista, caso de Wölfflin, que introduz a categoria barroco. A título de esclarecimento, suponhamos um leigo em oftalmologia que utilizasse a categoria genérica "insuficiência visual" em oposição a um oftalmologista, que por possuir mais formas, mais categorias (mais recortes para substância do conteúdo), usaria termos como miopia, astigmatismo, hipermetropia, entre outros, para designar determinada "insuficiência visual".

Para muitos analistas do século XIX-XX, o barroco talvez tivesse a função de rótulo, como se fosse propriedade natural de um período artístico. $\mathrm{O}$ excesso de propriedades do barroco, como irregularidade, pérola irregular, bizarrice, verrugosidade etc., teria como justificativa a preocupação da "correspondência entre o rótulo e a coisa". Ora, a arbitrariedade do signo desmistifica essas posições. No Curso de linguística geral, Saussure (1996, p. 81), utilizando as expressões "arbitrariedade do signo", bem como "o signo linguístico é arbitrário", afirma que até mesmo as onomatopeias são convencionadas:

quanto às onomatopeias autênticas (aquelas do tipo glu-glu, tic-tac etc.), não apenas são pouco numerosas, mas sua escolha é já, em certa medida, arbitrária, pois que não passam de imitação aproximativa e já meio convencional de certos ruídos (compare-se o francês ouaoua e o alemão wauwau) (SAUSSURE, 1996, p. 83).

É assim que só viemos a conhecer o recorte barroco, posteriormente, pois antes, não havendo esse nome, os objetos eram englobado pelo nome clássico, que abrangia os séculos XVI ao XIX (até ao que hoje se chama neoclassicismo). As obras que não se conformavam com o padrão "clássico" eram vistas disforicamente. Nome tardio, o barroco teria como 
programa querer romper com a estrutura e com as regras do classicismo, em prol da liberdade das formas.

Os estudos modernos do classicismo, dos seiscentos e do neoclassicismo revelam sucessivos recortes utilizados para a compreensão dos objetos artísticos ao longo da história de sua produção. A obra de Fidelino de Figueiredo, que chegou ao Brasil nos anos de 1946, como dissemos, é uma dessas obras em que o recorte do barroco está ausente.

Outros manuais de história da literatura portuguesa e brasileira ora apresentam a classificação de barroco, ora não. A ausência de recorte, porém, não significa que os autores da época não tenham sido mencionados, mas somente que foram englobados pelo classicismo; simplesmente, não existia a denominação da categoria barroco. Havia, no entanto, objetos poéticos seiscentistas, que só não conheciam o rótulo barroco. E, por extensão, o classicismo era visto como um grande período em que o barroco inexistia como recorte, sendo apenas lacunar; as obras conhecidas hoje como barrocas eram vistas como imperfeitas, porque não seguiam os valores do destinador clássico vigente. O barroco estava configurado por ser o que o clássico não era.

Teóricos e historiadores literários da Alemanha, preocupados com novos caminhos para a teoria literária e seduzidos pelo positivismo, encantaram-se pela proposta do suíço Wölfflin, que lecionava na Alemanha. Sua teoria propunha o recorte de mais uma categoria na arte compreendida pelos séculos XVI ao XVIII. Tratava-se de um critério formal de diferenciação dos estilos clássico e barroco (cf. COUTINHO, 2001b, p. 13 ss; cf. WELLEK, 197-, p. 85). Nesse sentido, para Wölfflin o barroco, o estilo do século XVII, era um estilo tardio, que só poderia se formar necessariamente após o Renascimento, em razão da lógica da evolução das formas imanentes. Além disso, Hanna Levy (1941, p. 261) afirma que "as características estilísticas da Renascença e do Barroco representam igualmente, segundo Wölfflin, os conceitos fundamentais de toda a história da arte". Desse modo, segundo o pensamento wölffliniano, haveria uma lei lógica regendo as formas: o barroco seria uma forma evolutiva:

Barroco

\section{$\uparrow$}

Renascimento (latência do Barroco) 
Levy (1941, p. 264) contesta a teoria wolffliniana: como explicar que "ao estilo pictórico do barroco sucedeu o classicismo [posterior] dos séculos XVIII e XIX, à fase 'barroca' do gótico sucedeu o estilo linear da Renascença, etc."? A teoria de Wölfflin "destrói, no fundo, a sua própria tese sobre o caráter absolutamente imanente do desenvolvimento da história dos estilos" (LEVY, 1941, p. 264). Levy conclui, à página 265, que o esquema de Wölfflin "não oferece nenhuma explicação nem da Renascença nem do barroco e não explica tampouco a transição daquela para este".

Seguindo o pensamento de Wölfflin -- embora ele mesmo reconheça que o barroco possui traços próprios -- de que não apenas o barroco histórico do século XVII (a arte antiga e o gótico também) é tão somente um estilo tardio, todos os estilos desembocariam em suas últimas etapas em barroco.

Questiono:

Ora, se todos os estilos evoluem para o barroco, então teríamos um estilo em que o barroco, em vez de ser pressuponente, seria ele mesmo pressuposto? Em tempos contemporâneos, a categoria /neobarroco/ teria como pressuposto o barroco? Mas de qual barroco? De Wölfflin? De Balet? (cf. LEVY, 1941, p. 274 ss). De Eugenio D’Ors? De Afrânio Coutinho? De Wellek? De Hauser? Ao tratar do problema do reinício, focalizando a evolução que retrocede, Wölfflin (2006, p. 325) afirma que a arte não retorna ao ponto inicial e que o movimento espiral "poderia descrever aproximadamente a realidade dos fatos".

Doravante, com o novo recorte wölffliniano, em vez de um período clássico de 300 anos, a história das artes passou a contar com três períodos: arte renascentista (clássica), barroco e neoclássico. $O$ universo seria um aglomerado de massa amorfa (uma nebulosa) se não fossem os recortes da língua natural (cf. SAUSSURE, 1996, p. 131; HJELMSLEV, 1975, p. 57). E se não fosse a língua natural, com sua forma, o chamado barroco estaria perdido em meio à continuidade clássica?

A característica de ilusionista, de efeito de sentido de trompe-l'oiel, de deformação, traços de barroco recolhidos por Leo Balet (cf. LEVY, 1941, p. 274-284), estudioso holandês, ganha amplitude e chega ao século XX e se revela como aquilo que se denomina neobarroco. Se fôssemos levar ao pé da letra a teoria das formas de Wölfflin, as formas do barroco brasileiro de onde viriam? Onde estariam as formas brasileiras do Renascimento? Levy (1941, p. 283), contrapondo-se ao ponto de vista de que as formas barrocas brasileiras teriam sido originadas pela arte portuguesa, pergunta: 
“Mas como explicar, então, o aspecto diferente que oferece, muitas vezes, o barroco português europeu comparado com o barroco brasileiro?"

E como explicar o barroco como um traço transbarroco que alcançaria o final do século XX? De um ponto de vista semiótico, talvez seja mais pertinente procurar uma estrutura comum a variados objetos estéticos distribuídos pela tradição que se presentifica.

A seguir, verificaremos com mais detalhes a ausência ou a presença do recorte de barroco nas obras de alguns críticos e historiadores da literatura, para assim traçar seu percurso.

\section{AUSÊNCIA E PRESENÇA DO RECORTE DE BARROCO NOS ESTUDIOSOS DA LITERATURA}

Nesta seção, selecionamos um conjunto de obras (brasileiras e portuguesas), divididas em duas categorias históricas:

a) Ausência de recorte de barroco: apresenta historicamente o classicismo como um período englobante (século XVI ao XVIII). Nessa classificação, o chamado barroco ainda não é uma categoria definidora de período literário.

b) Presença de recorte de barroco: contempla a categoria barroco como identificadora de um período e estabelece-Ihe um conjunto de propriedades semânticas.

O objetivo dessa análise é examinar como a ausência de recorte influiu na valoração disfórica dos objetos ditos barrocos na literatura brasileira e como a presença de recorte assume também valores disfóricos, o que nos faz observar que o percurso do conhecido barroco tem em seu nível narrativo a presença de um antissujeito vívido que, tensivamente, impulsiona sua trajetória.

Como os estudos literários portugueses serviram de matrizes para os estudos brasileiros, não distinguimos obras portuguesas das brasileiras, pois nosso interesse é verificar tão somente como o "barroco" entrou nos estudos de literatura. Para o desenvolvimento desta tese, não seria pertinente partir da compreensão tradicional, porque, ao selecionar valores disfóricos ao chamado barroco, ela vela nosso olhar em relação à presença da propriedade estrutural da agudeza que destinou o fazer dos seiscentos. 
No quadro 1.1, observaremos que o estudo do que comumente se chama barroco se faz a partir de escolhas de valores em jogo, com base em pontos de vista estabelecidos segundo determinado conhecimento enciclopédico, cultural etc. Não se trata, pois, de uma relação entre a palavra e a coisa barroca.

Quadro 1.1 Ausência e presença de recorte de barroco (as datas entre colchetes são da primeira edição).

\begin{tabular}{l} 
Coluna A - Ausência de recorte de barroco \\
\hline 1. Silvio Romero ([1888] 2001): prevalece a \\
visão do desinteresse pelas obras dos \\
séculos XVI e XVII (hoje chamadas \\
"barrocas"), porque não constituíam \\
literatura autônoma em relação a \\
Portugal. Utiliza critério político para \\
recortar a literatura brasileira, nomeando \\
o primeiro período de "1. Período de \\
formação, 1500-1750" (ROMERO, 2001, p. \\
155-214). Não estabelece, portanto, o \\
recorte da categoria barroco.
\end{tabular}

2. Araripe Júnior ([1894] 1978): prevalecem notas bibliográficas na análise de Gregório de Matos. Daí afirmações impressionistas: "pessimista objetivo, alma maligna, caráter rancoroso". Não há referência ao período estético que depois veio a ser recortado como barroco.
Coluna B - Presença de recorte de barroco

1. Otto Maria Carpeaux ([1942-1945] 2011, v. 2, p. 553-585): tenta desconstruir a visão disfórica do barroco. Para ele, essa categoria seria mais do que um estilo, compreenderia uma escolha de valores da vida social e cultural da Europa do século XVII.

2. Afrânio Coutinho ([1950] 2001a; 2001b): a obra de 1950 admite o genus humile que seria a forma adotada pela literatura barroca, apropriada ao discurso filosófico ou moralista; na poesia, a linguagem deveria ser engenhosa e Góngora, o modelo; na obra de 1955 (a edição consultada é de 2001b), o autor estabelece um lugar para o barroco na historiografia literária brasileira; antes, a divisão era feita por critérios histórico-políticos; na obra de 1959 (a edição consultada é de 2001a), apoiado em Wölfflin, estabelece princípios que regem a transição do Renascimento ao barroco.

3. Domício Proença Filho ([1967] 1989): propõe extensa lista de traços do barroco. Apresenta as categorias dedutivas wölfflinianas, bem como um quadroresumo das estéticas dos séculos XVI-XVIII, com precisão positivista de início e fim dos movimentos Renascimento, maneirismo, barroco, barroquismo na Itália, Espanha, França (PROENÇA FILHO, 1989, p. 167189). Com rara exceção, faz menção às relações de semiose entre PE e PC, quando trata do choque de cores, prevalecendo 


\begin{tabular}{|c|c|}
\hline & $\begin{array}{l}\text { em suas análises a metodologia tradicional } \\
\text { que focaliza apenas o plano de conteúdo. }\end{array}$ \\
\hline $\begin{array}{l}\text { 4. Fidelino de Figueiredo ([1917-1922] } \\
\text { 1946): não obstante a visão disfórica das } \\
\text { produções dos séculos XVI, XVII, é de } \\
\text { notar que, embora tenha percebido uma } \\
\text { continuidade clássica, ele já notava } \\
\text { diferenças formais entre as obras, que } \\
\text { apontavam para uma nova direção. No } \\
\text { entanto, categoriza as produções } \\
\text { seiscentistas como pertencentes à } \\
\text { "segunda época (1580-1756)". }\end{array}$ & $\begin{array}{l}\text { 4. Péricles Eugênio da Silva Ramos (1967): } \\
\text { entende que o barroco é um fenômeno } \\
\text { geral europeu. Ressalta a importância da } \\
\text { doutrina de Gracián, relativamente à } \\
\text { poesia engenhosa nas produções literárias } \\
\text { do século XVII. Como podemos observar, } \\
\text { não passou despercebido a Ramos o } \\
\text { princípio da agudeza como regedor das } \\
\text { produções seiscentistas. }\end{array}$ \\
\hline $\begin{array}{l}\text { 5. Ronald de Carvalho ([1919] 1955): seu } \\
\text { "fazer história literária" é destinado por } \\
\text { valores naturalistas (visão determinista). } \\
\text { Como se trata de um autor que participou } \\
\text { da Semana de Arte Moderna, é de } \\
\text { estranhar, quando considera o que hoje } \\
\text { chamamos textos barrocos, sua escolha de } \\
\text { valores tradicionais, dividindo a história } \\
\text { literária segundo critérios políticos } \\
\text { ("período de formação, 1500-1750; } \\
\text { período de transformação, 1750-1830 e } \\
\text { período autonômico, 1830-1925"). Ainda } \\
\text { aqui, nada de recorte da categoria barroco } \\
\text { como divisora de período. }\end{array}$ & $\begin{array}{l}\text { 5. Alfredo Bosi ([1970] 1995): menciona que } \\
\text { o barroco brasileiro seria um "eco" do } \\
\text { barroco europeu. Ao selecionar o léxico } \\
\text { "eco", o enunciador parece convidar o } \\
\text { enunciatário a atualizar uma direção de } \\
\text { repetição, ou seja, o barroco do colonizado } \\
\text { seria uma réplica do barroco do } \\
\text { colonizador. O Dicionário Houaiss (2001) } \\
\text { traz o sentido de eco: "ruído, distinto do } \\
\text { transmitido originalmente, uma imitação". } \\
\text { Nesse sentido, o barroco brasileiro seria } \\
\text { uma ressonância do barroco europeu. }\end{array}$ \\
\hline $\begin{array}{l}\text { 6. Hernani Cidade ([1933] 1968): esse autor } \\
\text { português é relevante, porque teve } \\
\text { influência sobre a crítica e a historiografia } \\
\text { brasileira, tendo o papel de destinador de } \\
\text { nossos estudiosos, que deram } \\
\text { continuidade ao pensamento de Cidade, } \\
\text { aos recortes, às escolhas. A ausência de } \\
\text { recorte em um autor português mostra } \\
\text { que também na Europa (Portugal), não } \\
\text { obstante os avanços de Wölfflin, houve } \\
\text { uma demora na assimilação do recorte de } \\
\text { barroco (a publicação Wölfflin é do fim do } \\
\text { século XIX e começo do XX). O "fazer" dos } \\
\text { produtores da época seiscentista foi } \\
\text { considerado por Cidade como "fazer } \\
\text { clássico deformado", ou que apresentava } \\
\text { subversão de forma. }\end{array}$ & $\begin{array}{l}\text { 6. José Guilherme Merquior (1977): embora } \\
\text { contasse com a difusão do estruturalismo } \\
\text { no Brasil, apoia-se, ao analisar um texto } \\
\text { dito barroco, em conceitos retórico- } \\
\text { estilísticos. Para ele (cf. MERQUIOR, 1977, } \\
\text { p. } 10 \text { ss), antecipando Haroldo de Campos, } \\
\text { o barroco já seria uma estética } \\
\text { identificadora da cultura ocidental } \\
\text { moderna (a obra O sequestro do barroco } \\
\text { na formação da literatura brasileira só será } \\
\text { publicada em 1989). }\end{array}$ \\
\hline $\begin{array}{l}\text { 7. Nelson Wernek Sodré ([1938] 1964): o } \\
\text { enunciador assume valores marxistas em } \\
\text { que a literatura tem ligação estreita com o } \\
\text { momento histórico. Daí prevalecer em } \\
\text { suas menções às obras seiscentistas }\end{array}$ & $\begin{array}{l}\text { 7. Sérgio Buarque de Holanda (1979, 1991): } \\
\text { critica a aplicação do New Criticism aos } \\
\text { textos do século XVI e XVII. É de notar que } \\
\text { Holanda (1979, p. 145) era historiador e } \\
\text { entendia "que a história não se repete, a }\end{array}$ \\
\hline
\end{tabular}


(Gregório de Matos) considerações sobre o meio e o tempo. Esse ponto de vista adotado por Sodré direciona o período barroco, não recortado com esse nome pelo autor, à marginalidade. não ser como caricatura". Critica também os paralelos erigidos modernamente "entre manifestações típicas de nosso século e outras". Essa visão, posteriormente, é discutida por Haroldo de Campos nos estudos que fez sobre barroco na modernidade.

8. Massaud Moisés ([1983] 2000): entende que o barroco é uma mistura de valores medievais cristãos e do paganismo de espírito greco-latino. Ocupa-se do que seria a fonte do barroco e quais seriam seus destinadores: um medieval e outro renascentista. e gongorismo $n$ Espanha, enquanto no Brasil prevaleceu a influência espanhola de culto ao exagero e ao gosto pela pompa.

9. Soares Amora ([1954] 1960): considera que no seiscentismo o classicismo se dividiu em duas tendências antagônicas: o cultismo e o conceptismo. Essa cisão é classificada disforicamente como um desequilíbrio que apenas será neutralizado, na visão do autor, pelo arcadismo (neoclassicismo).

\section{Saraiva e Lopes ([1954] 1966): considera} as produções literárias do século XVII e XVIII como poesia "cultista e conceptista". Reconhecem os autores a existência de um conjunto de características estéticas formais, que aparecem em variadas épocas e estéticas ("helenismo, gótico flamejante, século XVII, romantismo, impressionismo"). Essa visão não é isenta de disforia, visto que sanciona negativamente as produções que hoje chamamos de barroco: "desequilíbrio, exagero patético, bizarria fidalga, obsessão do irracional".

Nota: Antonio Candido ( $1^{\text {a }}$ edição, 1957; 1993b, v. 1), em Formação da literatura brasileira, entende que a literatura brasileira começou com os árcades. Para usar uma expressão de Haroldo de Campos (1989), Candido "sequestra", portanto, o chamado barroco de sua obra.
9. Francisco Maciel Silveira (1987): ao estabelecer limites temporais para o barroco, critica a visão de Eugenio D'Ors (pan-barroco). Também se vale das referências às categorias wölfflinianas e do conceito de engenho dos tratadistas seiscentistas. Afirma a hipertrofia (o exagero) do sentido da visão no barroco. Silveira não vê euforicamente o uso dos sentidos no barroco.

10. Fábio Lucas (1989): entende que o estilo brasileiro dos séculos XVII e XVIII tinha feições mais maneiristas do que barrocas. Era um maneirismo mesclado com moldes renascentistas, isto é, petrarquismo e camonismo. A afirmação de ausência de barroco no Brasil faz eco com o Formação de Antonio Candido.

11. Luiz Roncari (2002): ressaltamos sua afirmação de que "a poesia de cada época literária e artística tem uma linguagem própria" (p. 134). Obra isenta de considerações disfóricas em relação às obras seiscentistas. 


\subsection{SOBRE A DIVISÃO DO QUADRO}

Até aqui nossa intenção limita-se a expor um panorama de discussões sobre o barroco, não sendo de interesse, nesta tese, precisar em que obra de crítica literária brasileira o recorte do nome barroco surgiu pela primeira vez, mas mostrar que esse recorte era desconhecido não só ao tempo das produções artísticas brasileiras dos séculos XVI e XVII, como também da crítica até fins do século XIX.

É com Jacob Burckhardt, em 1855, e com Renascença e barroco, de Wölfflin, em 1888, que a discussão da categoria barroco ganha cena. Este último apresenta uma visão eufórica da estética, enquanto aquele propõe disforicamente que Barockstyl seria um dialeto selvagem da linguagem renascentista. Ainda em 1915, Wölfflin retoma a noção de barroco em Conceitos fundamentais da história da arte (cf. HANSEN, 2001, p. 12) ${ }^{7}$.

No quadro 1.1, seguimos a cronologia de publicação de algumas obras de história e crítica literária para verificar a ausência e a presença do recorte do nome barroco nos estudos de literatura. Com base nessa divisão, pretendemos mostrar que a categoria barroco é do final do século XIX; nesse sentido apenas obras do século XX, principalmente depois dos estudos de Wölfflin, contemplam o recorte daquilo que hoje se compreende por barroco.

O projeto de integrar a literatura à história nacional constitui a tônica das histórias literárias que predominaram no Brasil desde o século XIX. Com os românticos, o critério formal de beleza clássica foi substituído pelo critério histórico do valor representativo dos autores nacionais e de suas obras. Assim, maior apreço teria o texto nacional que valorizasse as características próprias do Brasil. Bosi (2000, p. 12) afirma que o historicismo nacionalista "é uma criação romântica, e no seu cerne já se contém o historicismo sociológico que o século XX herdou do positivismo e do evolucionismo". Essas categorias muitas vezes não pertinentes de tal historiografia literária baseavam-se em construções ideológicas, como o são o nacionalismo e o evolucionismo.

\footnotetext{
${ }^{7}$ Os dois livros de Wölfflin aqui citados, às vezes, aparecem nos manuais de literatura com os nomes: Renascimento e barroco e Princípios fundamentais da história da arte. Os livros que consultamos, no entanto, trocam Renascimento por Renascença (Editora Perspectiva, 1989) e princípios por conceitos (editora Martins Fontes, 2006).
} 


\subsection{BALANÇO dOS ESTUdos REALIzAdOS}

Iniciemos nossos comentários por Saraiva e Lopes (1966), que dividem sua obra em seis épocas. O nome barroco não aparece na divisão dos períodos estéticos, como acontece nas obras dos críticos e historiadores literários da coluna B do quadro 1.1. Embora não haja o recorte, no capítulo 12 de História da literatura portuguesa, encontramos um estudo sobre a transição para o barroco literário, que está englobado na terceira época, "Renascimento": "Francisco Rodrigues Lobo, o pastoralismo e a transição para o barroco literário". A quarta época da mesma obra recebe a denominação histórica "Restauração e época joanina". Nossos primeiros historiadores literários, Romero e Veríssimo, por exemplo, também utilizaram conceitos sócio-históricos para avaliar os objetos literários e depois dividi-los em períodos. Hoje, dividir a história literária pelo critério político-histórico é considerado não pertinente (COUTINHO, 2008, p. 18 ss).

O Renascimento, por exemplo, ganha na obra de Saraiva e Lopes a menção de nome de uma época, continuando o barroco um período lacunar, transitório, englobado pelo classicismo, sem recorte, portanto. As obras desse período são vistas sob o olhar do destinador clássico, que avalia disforicamente os valores do novo fazer artístico.

Ainda no capítulo 3 (quarta época), Saraiva e Lopes elegem o nome "poesia cultista e conceptista" para obras hoje conhecidas como barrocas. Se nossa visão de mundo dada pela língua natural não nos permite um recorte $X$, percebemos apenas uma continuidade. $\mathrm{Na}$ época, os produtores e críticos de arte não conheciam o recorte de mais uma categoria nesse contínuo, entendendo apenas como produções que seguiam a lição de Aristóteles, Horácio e Longino, orientadora dos valores clássicos. Hansen (2001, p. 22-23) afirma ainda que os grandes tratados, citados anteriormente, de retórica poética do século XVII chegaram ao Brasil pelas mãos dos jesuítas. Esses tratados, apoiados na retórica de Aristóteles, como já dissemos, assumem os valores do classicismo.

Dessa forma, não se tratava de período lacunar, de transição e tampouco de irregularidades, visto que as obras seiscentistas seguiam códigos clássicos rigorosos. Os enunciadores dos manuais elencados na coluna de "ausência de recorte", no quadro 1.1, talvez por desconhecerem os destinadores em jogo, perceberam os objetos literários do período como lacuna, irregularidade, mau gosto, que só posteriormente foram recortados como barrocos. 
O desconhecimento dos valores artísticos em voga talvez tenha gerado certo preconceito com relação aos objetos que viriam a ser chamados de barrocos. Além disso, os simpatizantes da ideologia protestante, entre eles alguns historiadores e estudiosos de arte, não viam com bons olhos a arte da Contrarreforma. Ora, como as produções artísticas, na maioria encomendadas pela Igreja, tinham em vista contrapor-se aos valores da Reforma Protestante de Lutero, é possível que os enunciadores da arte tenham recebido da crítica de então algumas sanções negativas.

Os estudos críticos de literatura dos manuais do quadro 1.1, em geral, valorizavam sobretudo aspectos extratextuais, como elementos do contexto histórico e gênese da obra, preocupando-se pouco com o texto. Daí a difusão e a proliferação de um manual para outro de adjetivos disfóricos e avaliativos com relação à produção seiscentista: irregularidade, bizarrice, tumoral, excêntrico etc.

A visão dos críticos do barroco como obra "imperfeita", "irregular", "tumoral", "verrugosa", que não se conformava rigorosamente aos cânones clássicos, é uma constante tanto nas obras em que ele não é recortado, quanto naquelas em que o é. A divisão que estabelecemos de ausência e presença de recorte serve-nos apenas para mostrar que esse fenômeno (o barroco como é entendido hoje) é do final do século XIX.

Os historiadores literários do fim do século XIX até hoje, mesmo contando com os estudos wölfflinianos, mantém o ponto de vista do barroco como irregular, excessivo, bizarro, salvo exceções, como a de Roncari (2002, p. 136).

A crítica de Rorty (2005, p. 305-338) às imperfeições dos cânones, que, muitas vezes, se caracterizam por escolhas arbitrárias e ausências indesejáveis, pode ser estendida às histórias literárias que excluem determinadas obras e autores de seus cânones, bem como camuflam a existência de estéticas, cuja influência não se pode negar mesmo nos objetos artísticos modernos. Esse é o caso do chamado barroco, como estamos vendo. A designação barroco se tornou ambígua, porque se refere a um conjunto de tendências artísticas e culturais predominantes do século XVII condicionadas pela estrutura do absolutismo da Casa da Áustria e por sua ligação com a Contrarreforma tridentina, ou compreende tendências artísticas e culturais de toda a Europa Ocidental.

Os mesmos estudiosos portugueses aqui citados, no entanto, já vislumbram o barroco como um conjunto de características estéticas formais "que, aparentemente, ressurgem em certas épocas, como no helenismo, no gótico flamejante, no séc. XVII, no 
romantismo e no impressionismo" (SARAIVA; LOPES, 1966, p. 442). Esse posicionamento sobre o barroco como forma que retorna ciclicamente nas estéticas é mencionado pontualmente pelos autores citados, sem grande ênfase.

Se Saraiva e Lopes (1966, p. 442) afirmam que o barroco compreende um conjunto de formas ("barroco designa um certo número de estruturas formais"), que ressurgem em variadas épocas, passam ao largo, no entanto, do exame dessas formas nas obras produzidas aquém e além do século XVII. Quando aventam en passant a possibilidade do barroco como forma, é possível que Saraiva e Lopes dialoguem com as obras de Henrich Wölfflin (Conceitos fundamentais da história da arte, [1915] 2006), de Henri Focillon (A vida das formas, [1943] 2001), de Eugenio D’Ors (Del barocco, [1945] 2011), de Gillo Dorfles (Barocco nell'architettura moderna, 1951) entre outros. Esse diálogo não quer dizer que os autores portugueses tenham consultado os autores citados; apenas indica que, no momento em que a obra História da literatura portuguesa foi publicada (1a edição em 1955), já havia na atmosfera intelectual da época a mudança do paradigma dos estudos clássicos e passava-se, então, a vislumbrar o barroco como categoria formal.

Ademais, as letras seiscentistas são sancionadas negativamente no livro de Saraiva e Lopes (1966, p. 443-444), com as seguintes figuras no enunciado: "a expressão artística e literária de um sentimento de desequilíbrio, de frustração e instabilidade" (destaques nossos). Os autores continuam atribuindo às letras do período outras propriedades: "exagero patético", "ascetismo macerado", "exaltado misticismo", "bizarria fidalga", "pitoresco folclórico", "obsessão do irracional", "evasão para o inefável", "sugestão do inapreensível, do subtil e fugidio" (destaques nossos). Embora, como já afirmamos, o barroco apareça na obra de Saraiva e Lopes (1966) englobado na época "O Renascimento" e não haja a categoria barroco como definidor de época, os autores afirmam que o desenvolvimento da burguesia portuguesa durante o século XVII sob o estímulo da colonização brasileira e do feudalismo decadente, juntamente com o revigoramento do absolutismo,

justificariam que reservássemos a designação de Época Barroca para o período de intensa crise política, social e cultural que se processa entre a Restauração e as reformas de Pombal (SARAIVA; LOPES, 1966, p. 445, destaques nossos). 
A modalização "justificariam" no trecho em destaque mostra certa ambiguidade no enunciado dos autores. Não há propriamente uma adesão ao barroco como "estética" (época barroca), mas tão somente referência a um período de crise política, social e cultural. O chamado barroco teve seu percurso permeado por antissujeitos; quando houve menção a ele, era para uni-lo a valores disfóricos, como crises políticas e históricas.

Na coluna B do quadro 1.1, descrevemos os manuais que consideram o recorte de barroco como divisor da continuidade clássica vigente, observando que se deve "renunciar às noções da sucessão cronológica e das fronteiras precisas entre os movimentos. Os períodos são antes manchas estilísticas, sistemas de normas que não têm limites precisos, mas ao contrário se imbricam, interpenetram, superpõem" (COUTINHO, 2008, p. 31). Já a coluna A do quadro 1.1 contempla alguns autores que consideravam clássicos os objetos que hoje são chamados de barroco. Em tais textos literários, eles viam pequenos desvios, entendidos como "falta de competência para o fazer artístico clássico". Não utilizavam, porém, o recorte da categoria barroco para designar esses objetos. Talvez, o processo do saber seja muito doloroso, porque, ao introduzir novos recortes, surgem antissujeitos, que querem preservar valores anteriores, valores de continuidade do programa que vinham seguindo. Evocamos aqui o caso do "saber ser barroco". Quando foi recortado e passou a ser conhecido, iniciou-se a polêmica. Aqui, o novo saber torna-se uma arena de conflitos, um campo de batalha, uma disputa de valores em jogo.

Dessa forma, valores clássicos e barrocos, hoje, estabilizados em seus programas narrativos, podem, segundo nosso ponto de vista, conviver solidariamente. No texto "Notas sobre o barroco", constante de Tentativas de mitologia, Sérgio Buarque de Holanda (1979, p. 143-145) discute as posições de Croce, Dámaso Alonso e Curtius em relação ao barroco. As objeções de Croce teriam sido determinadas por motivos diferentes dos de Alonso e Curtius. Estes dois últimos veem o barroco euforicamente, "um fenômeno histórico e literário digno de apreço", enquanto Croce se opõe a essa visão eufórica; para ele, o fenômeno barroco é um caso de depressão, de atenuação da capacidade criadora. Para o filósofo italiano, o barroco foi uma fase de transição entre o renascimento e a reforma, de um lado, e a ilustração, de outro (cf. CROCE, 1993). Além disso, os enunciados de Croce pertencem a um campo semântico histórico-político e não ao estético.

Em meio à amplitude conceitual e a certas impropriedades, Sergio Buarque de Holanda (1979, p. 145), em "Notas sobre o Barroco", reconhece a importância do 
redescobrimento do barroco ocorrido no século $\mathrm{XIX}$ e $\mathrm{XX}$, admitindo que seria preciso delimitar seu conceito "para evitar confusões perniciosas", sendo necessário o empreendimento do estudo do barroco brasileiro por meio de uma análise dos textos seiscentistas. Na obra Capítulos de literatura colonial (1991), Holanda detecta o traço barroco nos objetos dos séculos XVII e XVIII, mas não deixa de levar em conta a raiz do traço renascentista nessas mesmas obras; reconhece ainda o recorte de barroco e o encaixa no capítulo "As epopeias sacras". Suas escolhas em relação ao barroco não nos pareceram disfóricas, como normalmente temos visto em outros estudos. Sua restrição, porém, de que o barroco estaria confinado aos séculos XVII e XVIII é um valor claramente de um destinador histórico.

Já mencionamos que a inversão de valores em relação ao barroco só se iniciou na Europa, em 1888, com os estudos de Wölfflin, que passou a euforizá-lo; no Brasil, no entanto, como estamos vendo neste capítulo, só com os estudos de Afrânio Coutinho ([1955, 1959] 2001b) é que os ventos começaram a mudar de direção (ver coluna B do quadro 1.1). Todavia, incorporou-se nos manuais de literatura uma visão distorcida das obras dos séculos XVI-XVII, ainda vistas como exageradas e bizarras.

No final do século XX, Haroldo de Campos (1989), em diálogo com o Formação da literatura brasileira, de Antonio Candido, rompe a continuidade da disforia dos manuais de literatura brasileira e passa a vê-lo de forma eufórica, como regulador de uma linha inventiva de linguagem. Talvez se possa falar em uma paixão de alma de compensação, em que o autor de Sequestro do barroco, para neutralizar a ausência e a desconsideração das letras seiscentistas, encaminha-se a uma vivificação afetiva da euforização barroca.

Finalmente, nos autores relacionados no quadro 1.1 em que não há o recorte de barroco, as obras de apoio utilizadas referem-se apenas ao classicismo. Quando o recorte de barroco surge nos nossos primeiros historiadores e críticos literários, verificamos a existência de uma bibliografia relativa ao barroco europeu e, consequentemente, seus reflexos no Brasil. De modo geral, a referência aos estudos europeus do barroco nos livros analisados não oferece grandes dificuldades teóricas. Normalmente, prevalece a escolha de valores negativos na descrição da literatura seiscentista.

Ao introduzirem, porém, as ideias de Wölfflin, o que se nota é um esforço para conformar as obras nacionais às categorias dedutivas wolfflinianas. No que diz respeito à aplicação teórica aos objetos poéticos, alguns autores relacionam as categorias de Wölfflin 
em suas argumentações para criar um efeito de modernidade. $\mathrm{O}$ autor de Renascença $e$ barroco (1989) e Conceitos fundamentais da história da arte (2006) tornou-se um grande destinador do fazer crítico dos autores da coluna B do quadro 1.1 e da crítica brasileira em geral, não importando seu aproveitamento estrutural nos textos literários analisados.

Também nas obras em que prevalece a divisão histórica, segundo critérios políticos (Brasil Colônia e Brasil independente), as produções literárias brasileiras dos séculos XVI e XVII receberam, quando não um olhar disfórico (preconceituoso), um interesse menor. $A$ concepção de tempo judaico-cristã, linear e teleológica, vislumbra uma sucessão de acontecimentos, conduzindo a um "fim glorioso". Assim sendo, o barroco seria melhoramento do classicismo, o arcadismo melhoramento do barroco, o romantismo melhoramento do arcadismo, e assim por diante.

As obras de história literária que recortam o barroco, aqui analisadas, ao fazerem suceder o barroco ao classicismo e ao fazerem o barroco anteceder o neoclassicismo, são guiadas por esse valor positivista de sucessões melhorativas. Ora, em arte, um período subsequente não é superior esteticamente ao anterior, pois cada objeto pode suscitar semioses específicas e conter cifras tensivas de um período que lhe é anterior. E daí ruptura e vanguarda seriam apenas encenação discursiva. Esse tipo de história literária positivista concebe o tempo linearmente sem acidentes, prevalecendo causas e finalidades (da ordem da implicação, cf. ZILBERBERG, 2011a, p. 242-243). Daí, as histórias oficiais apresentarem uma listagem de estéticas em sequência cronológica.

Haroldo de Campos (1977a, p. 205), em "Poética sincrônica", sugere porém outra forma de visada, que seria a sincrônica. Nesse caso, prevalece o critério o estético-criativo:

\footnotetext{
A poética diacrônica procura reconhecer, ao longo de um dado período, cujas características são extraídas da história - o Classicismo ou o Romantismo, por exemplo -, as várias manifestações coincidentes do mesmo fenômeno, estabelecendo-lhes as concordâncias e discordâncias, sem a preocupação de hierarquizá-las de um ponto de vista estético atual.
}

Como pudemos ver nas análises dos autores historicistas da literatura, há uma infinidade de adjetivos, que tentam descrever o estado de barroco seiscentista. Essa descrição, no entanto, delineia-se pelo olhar do século XIX-XX. Com o passar do tempo, as definições de barroco acumularam-se, compondo uma multiplicidade semântica complexa, destinadora das sanções negativas das produções hoje conhecidas como barrocas. 
A seguir, examinaremos o barroco como metáfora da ordem da intensidade para, em seguida, tratar de algumas de suas definições vistas do ponto de vista tensivo, com o auxílio de textos de estudiosos da literatura e de dicionaristas.

\section{Pérola irRegular, A Metáfora da INTENSIDADE}

Em Portugal, desde 1563 em Colóquios do simples e drogas da índia, de Garcia da Orta, pérola irregular é metáfora de barroco: "pérola irregular: huns barrocos mal afeiçoados e não redondos, e com águas mortas" (TAPIÉ, 1983, p. 3).

$\mathrm{Na}$ Espanha, a palavra berrueco, ainda com sentido de joalheria, aparece no Tesoro de la lengua castelhana (1611). O primeiro registro da palavra barroco na França, segundo Tapié (1983, p. 3-4), data de 1694, ano da publicação do Dictionnaire de l'Académie Françoise: é um "termo de joalheria, designativo de pérolas de esfericidade imperfeita". Esse dicionário registrava o termo como adjetivo. Sua edição de 1740 é que passou a admitir o sentido figurado disfórico de irregular, bizarro, desigual.

Só mais tarde é que a palavra baroco se relacionou com uma figura do silogismo. Afirma ainda Tapié (1983, p. 3-4) que "baroco não traduz nenhuma irregularidade, imperfeição ou extravagância no modo de pensar". O sentido disfórico surgiu para ridicularizar as concepções muito formais das universidades francesas. Assim, doutores eram chamados de baroco. Nas Mémoires (1711), de Saint Simon, o termo barroco aparece para definir uma "ideia estranha e chocante".

Quatremère de Quincy, em 1788, na Enciclopédia metódica, utilizou o termo em arquitetura como adjetivo; ele seria uma gradação de bizarro, ou seja, barroco seria o superlativo de bizarro, muito bizarro. O barroco teria o sentido de excesso de artifício, estando, portanto, no mais mais, um processo de recrudescimento a caminho do demais. Zilberberg (2011a, p. 115), em sua análise do demais, já salienta que, "do ponto de vista diacrônico, o estilo posterior denuncia habitualmente o precedente como excessivo ou deficiente". Não é estranho, pois, que neoclássicos e estéticas posteriores considerem o barroco como excessivo.

Francesco Borromini e Camillo Guarini, por exemplo, teriam proporcionado os maiores modelos de bizarrice e de excesso na arquitetura (cf. TAPIÉ, 1983, p. 5-6). Talvez se possa dizer que alguns artistas, ao atingir a cifra demais, interrompem o curso "ascendente dos mais que se sucedem" (ZILBERBERG, 2011a, p. 114), chegando a um basta! A partir daí, 
caminha-se para o demasiadamente mais. Se o enunciado chegar ao basta, portanto, qualquer acréscimo de mais leva o enunciado a um demasiadamente mais (ZILBERBERG, 2011a, 115). O basta interrompe o curso do demais em ascensão. É assim que algumas obras seiscentistas, recortadas como objetos da ordem do excesso, encaminham-se à adjetivação da saturação, como veremos no exame das acepções de dicionários.

A França artística do século XVII, que censurava os excessos de inventividade poética, veste a função actancial de antissujeito do barroco. Eram censores de formas que incluíam o recrudescimento da agudeza seiscentista e não recorriam à palavra barroco para categorizar os objetos que não lhes agradavam. Por isso, os termos bizarro e bizarrice, como sinônimo de barroco, assentaram-se no francês para designar as letras seiscentistas. Bizarro, "da ordem do irregular", foge ao "padrão convencional", "artificioso". Embora barroco fosse, na época, superlativo (mais mais) de bizarro, ele passou a ser usado no lugar de bizarro e bizarrice.

Como se vê, o uso não consagrou as nuanças (bizarro, bizarrice e outras, como pérola irregular), prevalecendo assim o termo barroco. Tapié $(1983$, p. 6) informa que o sucesso desse nome foi assegurado pela língua alemã, como já dissemos, a partir da metade do século XIX, com Burckhardt, em o Cicerone ([1860] cf. TAPIÉ, 1983, p. 6 ss) e, no final desse mesmo século, com Wölfflin (Renascença e barroco, 1888 e Conceitos fundamentais da história da arte, 1915). Burckhardt, em 1860, embora considere o barroco um estilo inferior ao do Renascimento, entendia que ele não era desprovido de interesse; dá-se, então, o começo da valorização eufórica dos objetos barrocos. A conexão simples e direta de renascimento e barroco, a derivação do segundo em relação ao primeiro, a noção, portanto, de causa e efeito é contestada.

Alguns autores, como Hatzfeld (2002, p. 51), introduzem o maneirismo como uma fase intermediária entre o barroco e o Renascimento. Para Tapié (1983, p. 7-9), a importância de Burckhardt está em ter despertado interesse por um estilo condenado pelo classicismo e ter contribuído para o sucesso da adesão ao termo barroco. Ainda segundo o estudioso citado, a paixão da França pelo classicismo teria contribuído negativamente para que a palavra barroco não fosse difundida no território francês.

Ora, como a cultura francesa sempre gozou de destaque no cenário literário mundial, o entendimento disfórico dos objetos artísticos seiscentistas prevaleceu. Então, como um 
efeito de onda, foram se juntando mais e mais adjetivos negativos para designar a arte seiscentista.

A maioria dos estudos literários retromencionados, como se pode ver no quadro 1.2, inicia-se pela definição do termo barroco, que tem como metáfora a difundidíssima expressão pérola irregular.

Quadro 1.2 Uso difundido da expressão "pérola irregular" nos textos dos estudiosos do chamado barroco.

“Na ourivesaria, 'barroca' é a designação de uma pedra irregular" (PROENÇA FILHO, 1989, p. 176).

“A palavra 'barroco', tomada de empréstimo ao vocábulo empregado para designar uma pérola de forma irregular, rotula um movimento literário" (SILVEIRA, 1987, p. 9).

"Foi a grossa pérola irregular - em espanhol barrueco ou berrueco, em português, barroco - a rocha, o nodoso, a densidade aglutinada da pedra - barrueco ou berrueco [...]" (SARDUY, 1979, p. 57).

“Essa origem deve ser procurada no termo 'barroco', usado na língua portuguesa do século XVI para designar uma pérola de forma irregular" (AGUIAR E SILVA, 1976, p. 364).

“Acreditam uns na origem ibérica, espanhola - 'barrueco', ou portuguesa - 'barroco', designando uma pérola de superfície irregular" (COUTINHO, 2001b, p. 12).

"A etimologia do termo barroco [...] significando uma pérola irregular" (COUTINHO, 1950).

"A estética barroca, cuja complexidade se evidencia desde o problema posto pela origem do vocábulo 'barroco': designaria uma pérola de forma irregular" (MOISÉS, 2000, p. 65-66).

"Barroco, pérola de forma irregular" (MOISÉS, 2011, p. 52).

"Fruto do mar nunca dantes navegado e do comércio no Oriente, barroco era uma pérola irregular, mal conformada pela madre-natura, de água impura, abundantemente comerciada em Barokia, cidade (próxima à fortaleza de Dio)" (SILVEIRA; MONGELLI; CUNHA, 1993, p. 87).

"Assim o Barroco, termo que originalmente se empregava para as pérolas defeituosas e irregulares, passou a ser utilizado para designar a arte seiscentista europeia" (RONCARI, 2002, p. 135).

As escolhas do enunciador não são neutras: a seleção da expressão pérola irregular denuncia uma visão do barroco marcada pela disforia. A palavra pérola isoladamente tem o sentido de joalheira nobre, em que se ressalta a beleza e harmonia das formas, produzindo ainda o efeito de sentido de produto lapidado, cuja confecção é esmerada.

Ocorre que o significado primeiro de barroco é de pérola irregular e é essa irregularidade que ganhou preeminência na designação dos objetos seiscentistas; se 
prevalecesse o sentido de pérola, teríamos uma valorização eufórica desses objetos, mas, como prevaleceu o adjetivo disfórico, podemos reconhecer paradoxalmente uma direção que vai da cifra tensiva de andamento lento, observável na regularidade da composição do objeto pérola, que se forma paulatinamente sem interrupções, para uma direção que vai em sentido contrário, de uma cifra tensiva de andamento rápido, produzido pela fluidez da irregularidade e pela ruptura da descontinuidade, engendradora de uma mudança no andamento. Assim, à regularidade dos objetos clássicos, de andamento mais lento, porque persegue a nitidez do acabamento, sucede uma irregularidade dos objetos seiscentistas, de andamento mais rápido, que persegue a fluidez do acabamento.

A metáfora pérola irregular concentra semanticamente um traço comum aos objetos seiscentistas denominados posteriormente de barroco: a irregularidade, que, todavia, se traduz em inventividade regulada, em liberdade criativa, produtora de maravilhamento. Ao concentrar, vivifica-se o sentido de barroco de não conformidade. No entanto, a avaliação disfórica não é pertinente por duas razões principais:

1. As obras seiscentistas só são reconhecidas como irregulares em oposição ao classicismo no final do século XIX com as categorias dedutivas wölfflinianas. Ironicamente, porém, visto que Wölfflin euforiza a liberdade criativa, não se referindo às características de deformidade. Para Hannah Levy (1941, p. 264), "Wölfflin considerava o nascimento do estilo barroco como sendo a consequência lógica da evolução imanente da visão humana e das formas artísticas que conduzem necessariamente do clássico ao barroco".

2. Os artistas seiscentistas seguiam, por sua vez, os destinadores tratadistas dos séculos XVI-XVII: Matteo Peregrini, Baltasar Gracián, Emanuele Tesauro, Francisco Leitão Ferreira entre outros, que advogam as poéticas e retóricas clássicas, como as de Aristóteles, Horácio, Quintiliano.

No item 1, verificamos que o chamado barroco seria uma evolução e não uma deformação. Parece ter havido um desvio na leitura dos textos de Wölfflin. No item 2, a existência de obediência aos destinadores tratadistas citados impede um juízo negativo de que o chamado barroco seria desleixado, não conforme a regras. 
É o conhecimento pós-Wölfflin que temos hoje do dito barroco que o distancia dos objetos clássicos; eles eram tidos como pertencentes à continuidade clássica, ainda que pudessem ser chamados de "exagerados", "excessivos", "artificiosos".

Embora a expressão pérola irregular nos dicionaristas e nas obras dos críticos de barroco tenha orientação negativa, o sentido de irregularidade no barroco, de um ponto de vista semiótico, pode ser visto euforicamente, porque se afasta do contrato puramente mimético vigente; as obras dos seiscentos buscam um novo efeito, o estético do maravilhamento. É a agudeza, ainda com suas regras discretas, aristotélicas, que liberta o enunciado da mimesis rigorosa, promovendo um efeito de êxtase; e é esse efeito que os sujeitos destinados e orientados pelo classicismo refutavam e chamavam de irregular. $\mathrm{O}$ demais, fórmula do "barroco", em virtude de seu uso, conheceu em alguns casos o demasiadamente mais, recebendo inúmeras adjetivações que passaram a identificar também aquilo que não era demasiadamente mais, como é caso do uso da estratégia da agudeza nos enunciados poéticos.

Como veremos na seção 6, nos enunciados dicionarizados de barroco, a metáfora pérola irregular lexicalizou-se, dessensibilizando-se; se em um primeiro momento a metáfora focalizava o aspecto visual, da ordem do sensível, o uso contínuo promovido pelos estudiosos da literatura e pelos dicionaristas transformou-a em catacrese, agora utilizamos "barroco" sem que se pense em primeiro momento em pérola irregular e os sentidos que foram difundidos igualam barroco a bizarrice, excessivo, exagero.

Essa repetição discursiva de que o barroco é "bizarro", é "excêntrico", é "carregado", é "enigmático", é "irregular" desgastou o valor de uso de uma forma seiscentista, que acabou por ser chamada de barroca. A forma discursiva potencializada, segundo Fontanille (2007, p. 276), dá-se quando sua difusão ou seu reconhecimento são tais que podem figurar como topos do discurso. Nesse sentido, as expressões pérola irregular, extravagante, bizarro e outras tornam o discurso cristalizado e essas formas cristalizadas podem obnubilar a apreensão do objeto.

A circulação dos objetos chamados barrocos e de discursos sobre ele é que promove a difusão ou rejeição de seus usos inovadores ou cristalizados, provocando em certos casos mudanças nesses discursos. O que se vê nos manuais e nos dicionários é um discurso estereotipado sobre o "barroco". Há neles a recorrência, segundo o viés positivista, da assunção de uma forma que se dessemantizou, perdendo seu conteúdo seiscentista. 
Em termos de presença, ou seja, em relação aos aspectos espaço-temporais, tem prevalecido nas variadas abordagens das letras seiscentistas, em sua práxis enunciativa, o modo de existência potencializado. Herdamos sentidos acumulados na memória e, na maioria das vezes que os atualizamos, o fazemos com base no sensível, mas não o sensível da relação entre sujeito da enunciação -- enunciador e enunciatário -- e objeto literário, o das produções dos séculos XVI-XVII, e sim o da relação desse sujeito da enunciação com o discurso da crítica literária sobre o entendimento de barroco.

O aparecimento de uma forma pode estar correlacionado ao desaparecimento de outra forma, o que configura uma mudança semiótica (cf. FONTANILLE, 2007, p. 281). Substituiu-se o que pertencia a um nível tensivo, a agudeza estruturante, por figuras discursivas de um nível de superfície, como as figuras bizarro, verrugoso, irregular, tumoral etc. Hansen (In: MOREIRA; ROCHA, 2005, p. 11-25) salienta que é a partir do século XIX que passamos a avaliar as produções dos séculos XVI e XVII como artificiosas, como monstruosas, como exageradas etc. Para ele, essas sanções "eliminaram o específico dessas letras". O "específico" a que o autor se refere seria a agudeza, cujo engenho e trabalho poético apoiavam-se na Retórica de Aristóteles. O conceito de agudeza a ser visto no capítulo 2 nos permitirá retomar o ponto de vista que regia o fazer artístico dos objetos poéticos seiscentistas.

Essa multiplicidade semântica disfórica que encontramos nos estudiosos do chamado barroco afeta "gravemente a constituição de uma rigorosa terminologia crítica" e dificulta particularmente a compreensão dos objetos estéticos. Talvez por isso Hansen (In: MOREIRA; ROCHA, 2005, p. 11) tenha afirmado que eliminou o termo barroco de seus estudos e o substituiu por formulações analíticas: no lugar de "a sátira barroca" passou a utilizar "a sátira inventada com os procedimentos retóricos do conceito engenhoso". Nesta tese, utilizaremos os termos "barroco" e "neobarroco" apenas quando da necessidade de discussão teórica.

A seguir, investigaremos mais detalhadamente os semas e sememas de barroco, bem como a configuração de um acontecimento, produzido pelo sobrevir, resultado do maravilhamento introduzido pela engenhosidade das metáforas agudas. 
Como afirma Tapié (1983, p. 3), o termo barroco é registrado na língua portuguesa por Garcia da Orta em 1563. Inicialmente, a palavra era empregada apenas em outros sentidos que não o de estética. Sincronicamente, a descrição atual do estado de barroco é de cunho estético e é uma herança do recorte categorial de Wölfflin (cf. HANSEN In: MOREIRA; ROCHA, 2005, p. 11-12).

As definições de barroco posteriores ao século XIX mantiveram os traços de "irregularidade", de "artifício", de "inesperado" entre outros. Os mais diversos estudiosos de barroco, posteriores a Wölfflin, foram acrescendo adjetivos que ampliaram seu campo temático-figurativo: irregularidade, artificialidade (pérola irregular, exagerado, bizarro, excessivo entre outros). Ladear as sincronias de estados de barroco possibilita verificar que os artistas dos séculos XVI e XVII não tinham a visão do recorte de barroco de hoje e muito menos as escolhas tensivas de valores disfóricos dos dicionaristas de nosso tempo. Essas definições de dicionário destinaram, de certa forma, os rumos das letras seiscentistas, como observamos no quadro 1.1. Os estudiosos que estabeleceram o recorte de barroco para as produções dos séculos XVI-XVII fizeram-no assumindo valores negativos.

A seguir, vejamos como as acepções dos dicionários revelam um enunciado dessemantizado pela repetição discursiva dos adjetivos cristalizados nos discursos sobre o barroco. Nota-se também um enunciador peremptório que assume aplicar sanções negativas às obras seiscentistas.

Quadro 1.3 Ponto de vista dos dicionaristas nas definições de barroco.

\begin{tabular}{|l|l|l|}
\hline $\begin{array}{l}\text { Definições } \\
\text { de barroco } \\
\text { (língua } \\
\text { portuguesa) }\end{array}$ & {$\left[1865^{8}\right]$} & $\begin{array}{l}\text { (VITERBO, 1962) "penhasco ou penedo alto e sobranceiro ao vale ou à } \\
\text { terra plana e assente. Daqui, barrocal, lugar cheio de penedos altos e } \\
\text { fragosos. Desta palavra, ainda usam em Pinhel e Riba Côa"; "Os } \\
\text { lapidários chamam barroco a uma pérola tosca e desigual, que nem é } \\
\text { comprida, nem é redonda". }\end{array}$ \\
\hline 1936 & $\begin{array}{l}\text { (FIGUEIREDO) "o mesmo que barroca"; "penedo insulado e de forma } \\
\text { irregular"; "pérola de superfície irregular"; "diz-se do trabalho } \\
\text { artístico que é irregular e extravagante". }\end{array}$ \\
\hline 1939 & $\begin{array}{l}\text { (FREIRE) "barroca"; "penedo pequeno insulado e irregular"; "penedo } \\
\text { escabroso"; "extravagante, irregular e exagerado"; "que não se } \\
\text { sujeita às regras ou normas seguidas"; "gênero de arte irregular ou } \\
\text { extravagante"; "pérola de superfície irregular"; "nome de várias } \\
\text { pedras preciosas". }\end{array}$ \\
\hline
\end{tabular}

\footnotetext{
${ }^{8}$ Data da primeira edição.
} 


\begin{tabular}{|c|c|}
\hline 1946 & $\begin{array}{l}\text { (TORRINHA) "barroca"; "penedo irregular e pequeno"; pérola tosca } \\
\text { de superfície irregular"; "estilo barroco"; "diz-se do estilo } \\
\text { arquitetônico que se aproxima do gótico flamenjante, sem deixar de } \\
\text { manter os elementos primitivos da renascença"; "extravagante"; } \\
\text { "irregular"; "estapafúrdio". }\end{array}$ \\
\hline 1950 & $\begin{array}{l}\text { (LELLO; LELLO) "diz-se do, ou o estilo extravagante, irregular, } \\
\text { exagerado, estapafúrdio"; "o estilo barroco, criado no século XVII pelo } \\
\text { arquiteto Borromini, procurava a novidade na irregularidade (colunas } \\
\text { torcidas, volutas invertidas, saliências imprevistas nas fachadas etc.)"; } \\
\text { "penedo isolado e de forma irregular e finalmente pérola tosca de } \\
\text { forma irregular, barroca". }\end{array}$ \\
\hline$\left[1958^{9}\right]$ & $\begin{array}{l}\text { (AULETE, 1970) "penedo pequeno e irregular"; "cova, barranco"; } \\
\text { "pérola irregular"; "diz-se do, ou estilo arquitetônico nascido no fim } \\
\text { do séc. XVI, de uma livre interpretação das formas clássicas do } \\
\text { Renascimento, e que encarnava o espírito da Contrarreforma, com } \\
\text { um caráter essencialmente dinâmico, em que a forma, o equilíbrio e } \\
\text { a cor uniforme eram substituídos pelas massas, pelo movimento e } \\
\text { pela policromia"; "do sentido inicialmente depreciativo, veio o } \\
\text { figurado de extravagante, irregular, exagerado, que não se sujeita às } \\
\text { normas e regras seguidas"; "formação problemática": "foi o } \\
\text { português barroco que deu o italiano barocco e o francês baroque". }\end{array}$ \\
\hline 1961 & $\begin{array}{l}\text { (BUENO) "gênero de arquitetura, escultura, em que há exageros de } \\
\text { adorno"; "terreno desigual, sem simetria"; "aplicado à pérola } \\
\text { barroca, i. e., assimétrica". }\end{array}$ \\
\hline 1963 & $\begin{array}{l}\text { (AURÉLIO, ver FERREIRA) "barroca"; "penedo irregular e pequeno"; } \\
\text { "pérola de superfície irregular"; "estilo criado por Borromini no século } \\
\text { XVII na Itália, e que marcou com a sua influência a arquitetura das } \\
\text { igrejas coloniais no Brasil"; "estilo literário artístico e musical, e estilo } \\
\text { do pensar filosófico, religioso e político, que dominou na Europa e na } \\
\text { América Latina desde a segunda metade do século XVII até o começo } \\
\text { do século XVIII"; "irregular, extravagante". }\end{array}$ \\
\hline 1964 & $\begin{array}{l}\text { (CARVALHO; PEIXOTO) "penedo isolado e de forma irregular"; "pérola } \\
\text { de forma irregular"; "estilo caprichoso e bizarro"; "extravagante, } \\
\text { irregular, exagerado". }\end{array}$ \\
\hline 1972 & $\begin{array}{l}\text { (AURÉLIO, v. FERREIRA) "estilo criado por Borromini no século XVII na } \\
\text { Itália, e que marcou com a sua influência a arquitetura das igrejas } \\
\text { coloniais no Brasil: estilo literário, artístico e musical e estilo do } \\
\text { pensar filosófico, religioso e político, que dominou na Europa e na } \\
\text { América Latina desde a segunda metade do século XVII até o começo } \\
\text { do século XVIII"; "diz-se desses estilos; que apresentam a } \\
\text { características desses estilos; irregular, extravagante"; "penedo } \\
\text { irregular e pequeno"; "pérola de superfície irregular". }\end{array}$ \\
\hline
\end{tabular}

${ }^{9}$ Data da primeira edição. 


\begin{tabular}{|c|c|c|}
\hline & 1989 & $\begin{array}{l}\text { (FERNANDES) "barroca"; "extravagante"; "esquisito"; "irregular"; } \\
\text { "exagerado"; "estapafúrdio". }\end{array}$ \\
\hline & 1999 & $\begin{array}{l}\text { (AURÉLIO, v. FERREIRA) "barroca"; "penedo irregular e pequeno" [de } \\
\text { origem pré-romana possivelmente]; "diz-se de pérola de superfície } \\
\text { irregular"; "muito ornamentado, sobrecarregado, exuberante"; } \\
\text { "barroquismo". }\end{array}$ \\
\hline & 2001 & $\begin{array}{l}\text { (HOUAISS; VILLAR) "pérola de formato anômalo"; "caprichoso"; } \\
\text { "estilo com elementos da Alta Renascença e do Maneirismo, ligado à } \\
\text { estética da Contrarreforma, nascido em Roma c. } 1600 \text { e cujas } \\
\text { características básicas são o dinamismo do movimento com o triunfo } \\
\text { da linha curva e (esp. na escultura e pintura) a busca da captação das } \\
\text { reações emocionais humanas"; "modo empolado, bombástico, } \\
\text { extravagante de escrever, compor, pintar, decorar etc."; "o que é } \\
\text { complicado, extravagante, incomum"; "irregular", "tem algo de } \\
\text { surpreendente, extravagante, por vezes ridículo"; "excessivo"; } \\
\text { "excêntrico, afetado, ridículo"; "rebuscado". }\end{array}$ \\
\hline & 2002 & $\begin{array}{l}\text { (BORBA) [abstrato de estado] "estilo arquitetônico, literário e musical, } \\
\text { que predominou no século XVII, caracterizado pela irregularidade e o } \\
\text { exagero, e que se manifestou no Brasil no século XVIII"; } \\
\text { [quantificador] "exuberante", "sofisticado"; "irregular, } \\
\text { extravagante"; "marcado pela visão de mundo barroca"; "irregular, } \\
\text { confuso, estrambótico"; "extravagante, extraordinário"; "de mau } \\
\text { gosto". }\end{array}$ \\
\hline & 2008 & $\begin{array}{l}\text { (ACADEMIA BRASILEIRA DE LETRAS) "diz-se do estilo predominante } \\
\text { desde meados do século XVI até o século XVIII, na arquitetura, nas } \\
\text { artes plásticas, na literatura e na música"; "extravagante"; } \\
\text { "exuberante"; "bizarro"; "estilo barroco". }\end{array}$ \\
\hline \multirow[t]{3}{*}{$\begin{array}{l}\text { Definições } \\
\text { de barroco } \\
\text { (língua } \\
\text { italiana - } \\
\text { tradução } \\
\text { nossa) }\end{array}$} & $\begin{array}{l}2001 ; \\
2003\end{array}$ & $\begin{array}{l}\text { (ZINGARELLI) "gosto e estilo que se afirma na arte e na literatura dos } \\
\text { seiscentos"; "tendente aos efeitos bizarros, cenográficos, inusitados"; } \\
\text { "exagerado"; "carregado"; "vistoso"; "falso"; "ornamentado"; } \\
\text { "enfático"; "pesado"; "caracterizado pelas riquezas de ornamentos"; } \\
\text { "gosto pelo fingimento". }\end{array}$ \\
\hline & 2002 & $\begin{array}{l}\text { (GARZANTI) "gosto que se firma nos seiscentos caracterizado em } \\
\text { literatura pelo uso de metáforas inusitadas, na arquitetura e nas artes } \\
\text { plásticas dirigida para o cenográfico e do monumental"; "bizarro"; } \\
\text { "extravagante"; "de mau gosto". }\end{array}$ \\
\hline & 2005 & $\begin{array}{l}\text { (DEVOTO; OLI) "literatura, arte, arquitetura: movimento histórico- } \\
\text { cultural que se desenvolveu particularmente no século XVII, } \\
\text { caracterizado por uma arte voltada para efeitos de grandiosidade"; } \\
\text { "próprio do barroco: pintura, escultura"; "que denota uma riqueza } \\
\text { incomum"; "exagerado"; "de mau gosto"; "redundante"; "enfático"; } \\
\text { "pesado"; "afetado"; "visivelmente de mau gosto". }\end{array}$ \\
\hline
\end{tabular}




\begin{tabular}{|l|l|l|}
\hline & 2006 & $\begin{array}{l}\text { (CINTI) "grotesco"; "grandioso"; "retórico"; "bizarro"; } \\
\text { "extravagante"; "inflado"; "redundante". }\end{array}$ \\
\hline $\begin{array}{l}\text { Definições } \\
\text { de barroco } \\
\text { (língua } \\
\text { espanhola - } \\
\text { tradução } \\
\text { nossa) }\end{array}$ & 2005 & $\begin{array}{l}\text { (DICCIONARIO ESENCIAL DE LA LENGUA ESPAÑOLA) "estilo de } \\
\text { ornamentação arquitetônica, caracterizado pela profusão de volutas } \\
\text { e outros adornos em que predomina a linha curva". }\end{array}$ \\
\hline $\begin{array}{l}\text { Definições } \\
\text { de barroco } \\
\text { (língua } \\
\text { francesa } \\
\text { tradução } \\
\text { nossa) }\end{array}$ & 2008 & $\begin{array}{l}\text { (PETIT ROBERT) "pérola de forma irregular"; "de irregularidade } \\
\text { bizarra"; "inesperado"; "bizarro"; "chocante"; "excêntrico"; } \\
\text { "irregular"; "estranho"; "disforme"; "esquisito"; "estrambólico"; } \\
\text { "esquisito"; "diz-se de um estilo que se desenvolveu nos séculos XVI, } \\
\text { XVII e XVIII"; "de início na Itália, depois nos demais países católicos, } \\
\text { caracterizado pela liberdade das formas e profusão de ornamentos"; } \\
\text { "diz-se da literatura francesa sob Henrique IV e Luís XIII, caracterizada } \\
\text { por uma grande liberdade de expressão". }\end{array}$ \\
\hline $\begin{array}{l}\text { Definições } \\
\text { be barroco } \\
\text { (língua } \\
\text { inglesa } \\
\text { tradução } \\
\text { nossa) }\end{array}$ & 2010 & $\begin{array}{l}\text { (OXFORD) "usado para descrever a arquitetura, a arte e a música } \\
\text { europeia do século XVII e começo do XVIII; "que tem um estilo } \\
\text { altamente decorativo". } \\
\text { Nota: O Oxford não apresentou nenhuma definição de valor disfórico; } \\
\text { apenas o descreve como arte do século XVII. }\end{array}$ \\
\hline
\end{tabular}

O elenco de definições mencionado é resultado de uma enunciação movida pela escolha de valores que partem de um ponto de vista positivista -- os dicionários e os livros de literatura datam em sua maioria do final do século XIX em diante -- e são guiados por um destinador que incorpora valores de seu tempo, como, por exemplo, a necessidade de diferenciar uma estética de outra pelo exercício da adjetivação.

Além disso, a enumeração de adjetivos pelos dicionaristas faz pensar ainda numa operação de amplificação da intensidade pela extensidade: um objeto que é por natureza intenso intensifica-se ainda mais com a pletora de adjetivos. E nessa operação de estender a intensidade introduziram-se distorções, que fazem o chamado barroco ser o que ele estruturalmente não é. Os verbetes relacionados não revelam que as letras seiscentistas eram orientadas por tratadistas que se apoiavam na retórica aristotélica, nem revelam que faziam uso da agudeza.

O uso de substantivos ou adjetivos disfóricos para a definição de barroco advém da forte influência da escolha enunciativa de enunciados do classicismo francês, como vimos anteriormente, que tendia a ver as obras do século XVI e XVII como decadentes, ao 
compará-las com as obras do Renascimento. As letras francesas foram grandes destinadoras das produções europeias de então.

No campo da literatura, a rigidez do classicismo francês levou à exclusão das obras que seguiam outros códigos retóricos (cf. WELLEK, 197-, p. 80-81; TAPIÉ, 1983, p. 7-8). Enfim, os franceses consideravam determinadas obras seiscentistas excessivamente herméticas. Na Espanha (Gracián), na Itália (Matteo Peregrini e Sforza Pallavicino) e em Portugal (Francisco Leitão Ferreira), onde prevaleceram valores regidos pelos tratados poéticos, que se ocupavam do Livro III da Retórica de Aristóteles, outros destinadores, portanto, o recorte foi diverso e predominaram termos, como engenho, engenhosidade, agudeza, accutezza, concetto, conceito, estimuladores da liberdade criativa do fazer dito barroco. Curioso, no entanto, é que, mesmo nos dicionários espanhóis, italianos e portugueses, a agudeza não aparece nas definições de barroco.

As artes dos séculos XVI-XVII foram muitas vezes mal vistas justamente porque não se soube posteriormente avaliar sua capacidade inventiva de criação. Como foi possível verificar, mesmo depois de Wölfflin, os dicionários e as histórias da literatura continuaram a etiquetar o barroco com adjetivos negativos. Raros são os manuais que conseguiram identificar a capacidade de artifício das formas agudas (cf. RAMOS, 1967, 1979). E é esse artifício do fazer poético que introduz dinamismo, movimento e "desequilíbrio", por nós visto como eufóricos, nas obras dos seiscentos.

Para a semiótica, as definições de dicionário constituem efeitos de sentido e não reproduzem a realidade. A cada época, e podemos notar isso pelas datas de publicação dos dicionários, temos uma produção de sentido do barroco que vai inicialmente de simples "pérola irregular", "penedo pequeno insulado e irregular", passando por "extravagante, irregular, exagerado" a considerações sobre a arte: "diz-se do estilo arquitetônico que se aproxima do gótico flamejante, sem deixar de manter os elementos primitivos da renascença" (TORRINHA, 1946, verbete barroco).

Embora os estudos de Wölfflin sejam datados do final do século XIX e início do século $X X$, nenhum dicionário de língua portuguesa, italiana, francesa e espanhola consultado faz menção às categorias barrocas de Wölfflin. Caudas Aulete, embora não mencione o estudo wolffliniano, identifica o "caráter essencialmente dinâmico, em que a forma, o equilíbrio e a cor uniforme eram substituídos pelas massas, pelo movimento e pela policromia" (quadro 1.3 , destaques nossos). 
O Dicionário Oxford, em sua $7^{a}$ edição, não contempla as acepções disfóricas mencionadas pelos outros dicionaristas. Se, como sabemos, os dicionários registram o ponto de vista dominante em determinada cultura, podemos inferir que os enunciados negativos de barroco são ainda predominantes, porque os dicionários, em sua maioria, não deixam de assumir os valores de "irregularidade", "exagero", "mau gosto", "excesso", "extravagante". Além disso, também se depreende que se trata de uma arte da ordem da intensidade pela carga tensiva de todos esses valores, visto que apresentam cifras que caminham para uma acentuação da tonicidade, como verificaremos por meio dos semas que envolvem a arte dita barroca $^{10}$.

Das várias definições vistas no quadro 1.3, selecionamos alguns semas que são mais comuns na definição de barroco e que participam solidariamente da categoria sêmica /artístico/: burlesco, falso, ornamentado, bizarro, esquisito, extraordinário, extravagante, grotesco.

O cálculo semântico, porém, não obedece às mesmas leis da matemática e, portanto, é passível de releitura (GREIMAS, 1976, p. 48; POTTIER, 1992, p. 33-46; POTTIER In: LOBATO, 1977, p. 23-31). Em "Os atuantes, os atores e as figuras", Greimas (In: CHABROL, 1977, p. 188-189) afirma que o exame semântico de um lexema apresenta-se dotado de uma figura nuclear com base na qual são desenvolvidas certas virtualidades, certos percursos semêmicos que permitem sua realização em discurso. Recorrendo ao nosso exemplo, a figura /arte barroca/ organiza-se em torno de um campo figurativo amplo que engloba artifício, irregularidade, acontecimento (sobrevir, surpresa), simulação/fingimento etc.

Nas definições de dicionário do quadro 1.3, bem como nos enunciados sobre o barroco do quadro 1.1, verificamos que o campo figurativo do barroco estende seus percursos semêmicos, englobando outras figuras semelhantes constituidoras de constelações figurativas, que possuem organização própria. Trata-se, portanto, no caso da figura /arte barroca/, da formação de uma rede figurativa relacional, como veremos no quadro 1.5 (cf. também GREIMAS, 1976, p. 57-74).

$E$, por nos orientarmos pela semiótica tensiva, cujos confins são extremamente tênues, os limites dos semas são muitas vezes imprecisos. O preenchimento do quadro 1.5 deu-se por meio da seleção de definições retiradas dos dicionários Aulete (1970), Houaiss e Villar (2001), Borba (2002), como vemos no quadro 1.4:

\footnotetext{
${ }^{10}$ Seguimos a terminologia de Pottier.
} 
Burlesco: que burla, que provoca o riso por suas ideias extravagantes, iludir, farsesco.

Falso: fictício, enganoso, iludido, falsidade, aparente, simulado, fingido, que parece ser mas não é, postiço, artificial, dissimulado, duvidoso, difícil.

Ornamentado: ornado, enfeitado, guarnecido, adornar, que se adornou, artificioso, tornar algo mais atraente, que contrasta com o funcional e prático, realçar, florear.

Bizarro: que foge ao padrão convencional, de aspecto estranho, esquisito, extravagante, singular, raro.

Esquisito: estranho, diferente, exótico, desconhecido, que não é igual à maioria, anormal, diferente, excêntrico.

Extraordinário: que foge ao previsto, fora do comum, não regular, raro, que é excessivo em quantidade ou em intensidade, acontecimento imprevisto.

Extravagante: estranho, excêntrico, excessivo, inesperado, se afasta do comum, diferente.

Grotesco: extravagante, disforme, excêntrico, monstruoso.

Com base então nessas definições, temos o quadro 1.5:

Quadro 1.5 Semas e lexemas pertinentes à arte barroca.

\begin{tabular}{|l|c|c|c|c|}
\hline Semas $\rightarrow$ & $\begin{array}{c}\text { Artifício (ou } \\
\text { engenho) }\end{array}$ & Irregularidade & $\begin{array}{c}\text { Acontecimento } \\
\text { (sobrevir) }\end{array}$ & $\begin{array}{c}\text { Simulação } \\
\text { (dissimulação } \\
\text { /fingimento) }\end{array}$ \\
\hline Burlesco & + & - & + & + \\
\hline Falso & + & - & + & + \\
\hline Ornamentado & + & - & + & + \\
\hline Bizarro & - & + & + & + \\
\hline Esquisito & - & + & + & + \\
\hline Extraordinário & - & + & + & + \\
\hline Extravagante & - & + & + & + \\
\hline Grotesco & + & & + & + \\
\hline
\end{tabular}

Verificamos no quadro 1.5 que os adjetivos atributivos dos objetos ditos barrocos organizam-se, como vimos, segundo os semas de /artifício/ (ou /engenho/), /irregularidade/, /acontecimento/ (ou /sobrevir/), /simulação/.

O termo sobrevir, constante da semiótica tensiva de Zilberberg (2011a, p. 277), tem o mesmo significado de "acontecimento imprevisto" que encontramos na definição de extraordinário, umas das propriedades das letras seiscentistas: "Extraordinário: ‘que foge ao 
previsto', 'fora do comum', 'não regular', 'raro', 'que é excessivo em quantidade ou em intensidade', 'acontecimento imprevisto'" (AULETE [1970], HOUAISS; VILLAR [2001], BORBA [2002], destaques nossos). Como podemos ver no quadro 1.5, o sema /acontecimento/ ou /sobrevir/ consta dos lexemas burlesco, falso, ornamentado, bizarro, esquisito, extraordinário, extravagante, grotesco, próprios da definição de barroco.

Tomando, por exemplo, burlesco, notamos o traço sêmico de /acontecimento/ no "ato de burlar", "iludir"; em falso, o acontecimento está em ser "enganoso", "dissimulado"; em ornamentado, está em "artificioso"; em bizarro, está em "estranho", "extravagante" e "singular", enquanto em esquisito, novamente, em "estranho", "exótico", "diferente"; em extraordinário, vemos acontecimento em "que foge ao previsto", "fora do comum", "não regular", "raro" e até mesmo, pleonasticamente, em "acontecimento imprevisto"; já em extravagante, o acontecimento está no "estranho", no "inesperado" e, finalmente, em grotesco, o acontecimento está em "extravagante", "excêntrico".

Acontecimento, do latim evenire, significa vir para fora, sair de, chegar, acabar, acontecer, suceder, ocasionar-se, sobrevir. Para Cícero, evenire significa ter resultado (SARAIVA, 2000, p. 440). A identificação do barroco com "acontecimento", "sobrevir", proposta por Zilberberg (2011a, p. 44), que dispensaria a lista de lexemas muitas vezes disfóricos que o acompanham até hoje nos dicionários e na crítica literária, será alvo de discussão no final do capítulo 5. O quadro apresentado objetiva apenas mostrar que os vários adjetivos disfóricos contemplam o valor de sobrevir; não afirmamos, porém, que somente barroco identifica-se com acontecimento.

A dimensão perturbadora de qualquer acontecimento suscita desejo de retorno ao estado anterior. Como o chamado barroco provoca a sensação de acontecimento, maravilhamento, desarranjador do continuum clássico dos seiscentos, ele introduz certo desequilíbrio no curso regular do tempo discursivo clássico, levando à reação de seu controle. Entendendo-o como caos, o homem clássico deseja o retorno do equilíbrio, da ordem. A novidade da agudeza poética seiscentista provoca no ambiente clássico o desejo de frear o que the parecia perturbador.

O teatro shakespeariano, constituído por uma estratégia de descontinuidade do tempo em suas tragédias, é um exemplo de "incômodo barroco". Em Hamlet, os acontecimentos são atualizados pelas rupturas na narrativa, introduzindo a presentificação de um tempo passado e, portanto, descontínuo. As paradas na progressão narrativa chocava 
a plateia acostumada com a linearidade da continuidade: na narrativa clássica, comumente, o tempo segue adiante, em progressão. O destinador clássico entendia como dissonante a reiteração das rupturas ou sua intensificação, como ocorria na obra de Shakespeare.

A distinção realizada pelo clássico entre restabelecimento e recrudescimento constitui-se em processo da ordem da espera, do pervir. Ser acontecimento ou não ser dependerá do ponto de vista, ou seja, para o clássico o neoclássico constitui-se em pervir, em espera; para o barroco, o neoclássico configura-se um sobrevir, uma tentativa de parada no fazer do chamado barroco. O esforço para conter a força de ruptura do acontecimento, para reordená-lo dentro do estabelecido pelas regras clássicas, deu às artes seiscentistas um destino negativo, como vimos nos manuais e dicionários. Nesse sentido, embora as categorias wölfflinianas sejam neokantianas e positivistas, desconhecidas nos seiscentos, elas têm o mérito de examinar as obras de então livres das sanções negativas.

Além disso, o acontecimento, o maravilhamento, nos textos seiscentistas carrega forte carga de emoção, o que não quer dizer ausência de racionalidade, porque para a constituição do enunciado o enunciador se vale de regras rígidas. As letras dos séculos XVIXVII conviviam, portanto, com a tensão entre o restabelecimento das formas clássicas e o recrudescimento das formas agudas. O clássico, ao desejar coibir a ascendência da agudeza, já antecipava o que sobreviria àquele período, o neoclassicismo. O restabelecimento é um contraprograma que se estabelece sempre que uma novidade avança. Assim é que um presente artístico convoca um futuro que o aquiete. Enquanto o restabelecimento destinase a excluir ou "subtrair um a um os menos, o recrudescimento se inscreve como a operação destinada a acrescentar um a um os mais" (ZILBERBERG, 2011a, p. 272).

A teoria de Zilberberg (2006a, 2011a), ao propor o acontecimento como da ordem do sobrevir e da concessão, apresenta afinidade com o maravilhamento suscitado pela agudeza, visto que os semas identificadores das obras seiscentistas têm em comum traços de inesperado, imprevisibilidade, todos eles componentes da cifra tensiva da agudeza. Todavia, esclareça-se, o acontecimento não é exclusivo de uma estética, pois que todas elas podem engendrá-lo. Ele ocorre sempre que o artista alcança maior vivificação na intensidade, superando às expectativas do enunciatário. Em geral, seus enunciados são orientados por concessão $o^{11}$.

\footnotetext{
${ }^{11}$ A concessão, segundo Zilberberg (2011a, p. 242), da égide da semiótica do acontecimento e do sobrevir, engendra no enunciador uma consequência contrária ao sentido esperado da oração regente. Por exemplo:
} 
No que toca à oposição entre clássico e o barroco, defendemos o ponto de vista de um continuum tensivo em que a agudeza seiscentista, entendida como sobrevir/acontecimento/maravilhamento, é também produto da continuidade renascentista, não havendo, portanto, nem descontinuidade nem ruptura entre os objetos artísticos produzidos nos séculos XVI-XVII; o que ocorre apenas é uma oscilação tensiva na semiótica da agudeza.

Como vimos, o aparecimento de uma nova forma pode estar correlacionado ao desaparecimento de outra, o que configuraria uma mudança semiótica. No caso das letras seiscentistas, não temos propriamente uma forma nova, mas uma agudização de formas em uso. Essas formas continuavam seguindo a orientação clássica, proveniente de Aristóteles, Horácio, Quintiliano, como temos discutido. Ocorre que o desconhecimento do princípio orientador, a agudeza, bem como a crítica psicológica apoiada em gosto pessoal, introduziu observações negativas sobre os objetos agudos que se difundiram. A propósito, lembre-se da querela entre Quevedo e Góngora. Acusado este último de ser obscuro, teria respondido que sua arte era para poucos (cf. HANSEN, 2011, p. 35). As avaliações discursivas disfóricas, à custa de repetições, difundidas por manuais de literatura e verbetes de dicionários, desgastaram a imagem das obras agudas.

A seguir, retomaremos a agudeza idiossincrônica como orientadora das produções seiscentistas.

\section{SINCRONIA E DIACRONIA: EM DIREÇÃO À AGUDEZA IDIOSSINCRÔNICA}

Não seria impertinente aplicar à cultura seiscentista as coordenadas de um sistema filosófico positivista? Nos séculos XVI e XVII, como vimos, não se falava de estética barroca; não havia nenhum vestígio dos conceitos que depois de Wölfflin vieram a se firmar na esfera das artes e da literatura; não havia, segundo Snyder (2007, p. 18-19), nenhum rastro enunciativo do debate sobre o conceito de arte barroca.

Se barroco não existia como barroco, como pôde ser entendido como anticlássico? Enquanto o historiador literário diacrônico auspicia a neutralidade estética, porque lhe interessa a coleção de fatos, seus desdobramentos no eixo do tempo, como pudemos

\footnotetext{
"Embora Messi estivesse com um febrão, jogou muito bem a partida." A conjunção subordinativa concessiva embora coloca em crise o esperado implicativo do porque (cf. CASTILHO, 2010, p. 377-380): "ele não jogou muito bem a partida, porque estava com um febrão". O que se afirma no exemplo de lógica concessiva, no entanto, é que ele jogou muito bem, mesmo com febrão. Diante de um enunciado, o enunciatário espera uma consequência $X$, mas, no caso dos objetos concessivos, ocorre uma consequência $Y$.
} 
verificar pelas análises dos livros de história da literatura aqui empreendidas, o estudioso sincrônico tem função crítica e retificadora "sobre as coisas julgadas da poética histórica [diacrônica]" (CAMPOS, 1977a, p. 207). Em um estudo diacrônico, destaca-se o acúmulo dos fatos em uma sequência cronológica linear, como se os fatos precedentes fossem a causa dos posteriores e como se houvesse uma evolução ou aperfeiçoamentos das formas literárias anteriores.

Jakobson, por sua vez, defende que a descrição sincrônica compreende não só a produção literária do estado inicial, "mas também aquela parte da tradição literária que, para o período em questão, permaneceu viva ou foi revivida" (JAKOBSON, 2005, p. 121). Quando abordamos a agudeza seiscentista, não estamos defendendo a diacronia, nem a evolução das formas literárias até a modernidade, como pretendem os barroquistas. Estamos apenas descrevendo que, nos seiscentos, a agudeza erigia os objetos seiscentistas.

Em "Os problemas dos estudos literários e linguísticos", Jakobson e Tynianov (In: EIKHENBAUM et al., 1978, p. 96) reconhecem que a oposição entre o aspecto sincrônico e diacrônico, para a linguística e a história literária, era "uma hipótese de trabalho fecundo". Essa dicotomia permitia verificar o caráter sistemático da língua ou literatura de cada período histórico. No entanto, admitem que as conclusões da concepção sincrônica levam a reexaminar a diacronia. Esta última teria reformulado "a seu modo a noção de aglomeração mecânica dos fenômenos, que a ciência sincrônica substituiu pela noção de sistema, de estrutura" (p. 96).

Uma vez que cada sistema sincrônico engloba seu passado e futuro, o sincronismo puro parece ser algo inatingível. Para explicar os elementos estruturais "passado" e "futuro", admitamos as obras seiscentistas, conhecidas como barrocas, e o polêmico "neobarroco", que se quer ressurgido das cinzas barroquistas. Nesse caso, ingenuamente, poderíamos pensar que a agudeza seiscentista do passado revive no futuro, inovando o sistema literário e ressurgindo no final do século $X X$.

Não se trata, pois, de ressurgimento, nem de mudança de sistema, mas de objetos estruturados e erigidos segundo a tutela de novos destinadores. Objetos seiscentistas suscitam maravilhamento estranho à época renascentista, e os objetos de consenso neobarroco retrabalham alguns valores poéticos de uma tradição que se assume como viva. A inventividade é similar nos dois tempos discursivos, mas o valores escolhidos são diferentes. Em cada um desses tempos, a inventividade com o sistema é invariável, mas as 
funções são diferentes. Assim, uma aliteração seiscentista criativa, aguda, tem uma função própria no enunciado que é diferente da função que se encontra em uma aliteração de um enunciado do final do século XX. Da mesma forma, em termos de manifestação discursiva, uma mesma figura utilizada no século XVI e no XX não apresenta os mesmos valores.

Um sistema literário, para Jakobson e Tynianov, não é constituído apenas por "obras de arte próximas no tempo" (p. 96), mas também por obras atraídas para o sistema e provenientes de literaturas estrangeiras ou de épocas anteriores ou diversas. Talvez por isso Haroldo de Campos (1977c, p. 13) tenha afirmado que se poderia pensar, com base em Roman Jakobson, em uma história estrutural da literatura,

erigida como uma superestrutura sobre uma série de descrições sincrônicas sucessivas, que levem em conta não apenas a produção de um determinado período, mas também a parte da tradição literária que permaneceu válida ou foi revivescida no período em questão.

O estudo do barroco, para Haroldo de Campos, numa revisão diacrônica, dá-se de um ponto de vista que vê nele um valor que não se esgota nos seiscentos, mas que se atualiza em todos os momentos da história da arte. Com base no pensamento de Haroldo, questiono:

- Como apostar na sincronia barroca e na transposição de seus traços estéticos na história da literatura se as obras seiscentistas são erigidas sob o contrato da agudeza de uma época determinada (só foi recortada posteriormente como barroca)?

- Num primeiro momento, não seria mais pertinente observar a estrutura da agudeza seiscentista com suas propriedades? Num segundo momento, não seria mais pertinente estudar a estrutura dos objetos catalogados como neobarrocos? E, num terceiro momento, não caberia verificar se é possível observar algum tipo específico de agudeza nas obras do final do século XX?

Essas questões serão objeto de discussão ao longo da tese.

Inicialmente, para empreender uma reflexão mais detalhada, retomemos os conceitos de diacronia e sincronia de Saussure (1996, p. 107-116). Embora reconheça que essa antinomia tenha exercido influência decisiva na constituição da linguística moderna, Maurice Leroy (1966, p. 111; 1982, p. 142) afirma que é "seguramente hoje um dos pontos 
mais fracos do ensino saussuriano" ["assurément aujourd'hui un des points les plus faibles de l'enseignement saussurien"].

Tenha-se em conta que, na época de Saussure, a pesquisa linguística (gramática comparada) centrava-se no aspecto histórico. Os conceitos saussurianos visavam instaurar uma polêmica, ou seja, era preciso complementar a pesquisa historicista com o ponto de vista da pesquisa sincrônica. W. Von Wartburg, romanista suíço, citado por Leroy, teria se insurgido contra a divisão de sincronia e diacronia; segundo ele, a linguística deveria dissolver o abismo entre ciência descritiva e histórica, fazendo sobressair a interdependência do sistema e do movimento. Nesse sentido, Edward Lopes (1997, p. 272) afirma que "sincronia e diacronia constituem uma unidade dinâmica indivisível".

Parafraseando Leroy, podemos afirmar que um "certo estado de barroco" não é em si mesmo sincrônico ou diacrônico, mas pode ser encarado tanto de um ponto de vista como de outro, de modo suplementar, visto que mantém nexo entre, de um lado, um estado de barroco supostamente sincrônico e, de outro, todos os estados sincrônicos anteriores e posteriores ao "certo estado de barroco seiscentista", ou seja, por hipótese, um "estado de barroco" funcionaria sincronicamente, mas seria também constituído diacronicamente.

Para entender a linha do pensamento barroquista de Haroldo de Campos, porém, cito a concepção idiossincrônica de Saussure dos Escritos de linguística geral (2004, p. 196). Pensar o barroco idiossincronicamente não seria admitir um barroquismo generalizado, mas particularizado por cada artista, cada texto. Essa é a razão, acreditamos, pela qual Haroldo de Campos (1976b, 1989, 2001, 2006; In: DANIEL, 2004a) sugere um cânone constituído não de autores propriamente, mas de textos que ele identifica como novo barroco. Assim é que, em um autor romântico como Bernardo Guimarães, ele identifica no poema "A orgia dos duendes" características barroquistas e vê os mesmos traços barroquistas em Macunaíma, de Mário de Andrade. Não afirma, por exemplo, que Sousândrade é barroco, mas que determinados enunciados de $O$ Guesa o são, como os enunciados de "O inferno de Wall Street" (canto X) e de "Tatuturema" (canto II), nem que Luís Gama é barroco, mas que seu poema "A bodarrada" o é.

Ainda em relação à poética idiossincrônica, Haroldo de Campos (1977a, p. 209) propõe uma nova forma de estudo do passado literário até os tempos modernos, em que os autores seriam selecionados pela contribuição à renovação das formas poéticas, bem como pela ampliação e diversificação do repertório estético. Não se trata, pois, de descrever as 
obras de um autor in totum como fazem alguns dos manuais descritos anteriormente. Desse modo, cada autor, idiossincronicamente, atualizaria, segundo Haroldo, o barroco a seu modo. Essa visão é diferente, pois, do ponto de vista de um barroco pancrônico, como sugere euforicamente Eugenio D’Ors, que vê o barroco como um espírito do tempo, ou mesmo Maravall ([1975] 2009, p. 24) que o considera um "fenômeno europeu", identificando o barroco com "novidade", "liberdade".

Organizando até aqui nosso pensamento, temos:

1. Um período seiscentista, desconhecido como barroco.

2. Um período categorizado como barroco segundo Wölfflin.

3. Um período transbarroco: euforia barroquista, ou seja, traço barroco presentificado na literatura (visão de Haroldo de Campos).

4. Um período discursivo erigido pela agudeza, cujos destinadores eram a escolástica aristotélico-tomista e os valores da contrarreforma, não havendo possibilidade de repetição discursiva no final do século XX nem em nenhum outro período, posição de Hansen e desta tese. A título de esclarecimento, a agudeza sugerida do século XX é outra, pois que seus destinadores não são nem Gracián, nem Tesauro, nem Peregrini, mas Mallarmé, Joyce, Pound, E. E. Cumminngs.

No capítulo 2, veremos detidamente as propriedades da agudeza. 
JOGO TENSIVO ENTRE AGUDEZA DA EXPRESSÃO

E AGUDEZA DO CONTEÚDO

A agudeza depende de uma espécie de claro-escuro estrutural em que o jogo de luz e de sombra ilumina e ofusca alternadamente o objeto, para surpreender e deleitar o leitor ou o ouvinte. Jon R. Snyder

Para a compreensão da poesia usualmente nomeada de "barroca" [...], nenhuma noção é mais central do que a de "agudeza".

Alcir Pécora

Conforme a poética seiscentista, somente o engenho consegue perceber a relação entre coisas aparentemente desconexas.

Ivan Teixeira 


\section{Agudeza: Preliminares}

A crítica literária moderna distingue a hermenêutica romântica da hermenêutica retórico-poética (cf. TEIXEIRA, 2003, p. 138-159). Enquanto a primeira neutraliza o passado para conformá-lo ao presente, apoiando-se no princípio melhorativo, em que o presente literário é um melhoramento do passado, a segunda recusa a ideia de valores progressistas, buscando as estratégias segundo as quais se constrói o sentido do texto poético. É com base, pois, nas estratégias dos tratados poéticos seiscentistas e na semiótica tensiva que focalizaremos o que vem a ser a forma da agudeza.

O percurso do chamado barroco, se pensando do ponto de vista da hermenêutica teleológica melhorativa, tem latente o classicismo, na medida em que é visto como tentativa de superação de um antissujeito: as normas rígidas do Renascimento. Todavia, nem o classicista mais rígido entende que só de regras estreitas se faz uma obra de arte. Jon R. Snyder (2007, p. 25), utilizando as palavras de Tesauro, um tratadista seiscentista, afirma que "tudo é lícito" para a nova arte aguda barroca, mas "é menos subversiva do que parece". O uso do termo barroco, em estética, como vimos no capítulo 1, só entra em circulação no final do século XIX e muitas vezes com valoração negativa.

De Platão ao final do século XVII, na filosofia ocidental, a maior parte dos sujeitos da enunciação segue uma estrutura conceitual e uma lógica argumentativa, previstas nos tratados de retórica, que a poética renascentista imitava. Nesta tese, adotamos em alguns momentos o termo sujeito da enunciação, que, para Greimas e Courtés (1983, p. 150), "cobre de fato as duas posições actanciais de enunciador e enunciatário".

Os teóricos do conceptismo -- Peregrini, Gracián, Tesauro entre outros --, segundo Snyder (2007, p. 27), "quase nunca se contentam em tomar ou defender uma única posição no interior de um determinado texto ou em dar uma definição precisa dos termos que empregam". As obras desses tratadistas, quando colocadas em relação, "contradizem-se e anulam-se, desafiando quem queira apresentar uma síntese delas". Os tratados de Peregrini, Gracián, Tesauro têm como objetivo argumentar sobre a escrita criativa e, para utilizar uma expressão proposta por eles, a escrita poética engenhosa. 
Tesauro, por exemplo, inventa exemplos "maravilhosos" para demonstrar sua teoria. Ele procura "impressionar o leitor, transportá-lo por meio de efeitos irresistíveis da escrita num turbilhão de imagens e de metáforas sedutoras: em suma, trata-se de uma performance textual, uma espécie de metaliteratura que replica e amplia as qualidades das obras" que ele analisa (SNYDER, 2007, p. 27).

Ambientado nesse mesmo clima intelectual, Francesco Patrizi escreve Della poetica em 1586, obra antecipadora do futuro desenrolar da chamada poética barroca, que valoriza a criatividade do poeta: "a premissa fundamental da obra é a de que 'as poesias não são imitações' para que o poeta 'possa exprimir aquelas ideias que muitas vezes concebeu e sem qualquer correspondência com as coisas artificiais, naturais ou divinas'" (SNYDER, 2007, p. 33). O tratado de Francesco Patrizi defende que a poesia depende do "maravilhoso" e assim ganha em "cor", "calor" e "vida" (cf. SNYDER, 2007, p. 33 ss). A arte encaminha-se do programa de ensinamento moral ou filosófico para o programa estético do encanto deleitoso por meio do "efeito especial de 'assombro' produzido por qualquer coisa 'nova, súbita e imprevista'” (p. 34). Dava-se então um pequeno distanciamento do destinador clássico e o estabelecimento de um novo contrato enunciativo, cuja preocupação era encantar pela agudeza.

Aos poucos, os conceitos de maravilha, inventividade, novidade, engenho, surpresa serão os pilares comuns da vindoura chamada arte poética aguda, conhecida hoje como barroco. Para os tratadistas seiscentistas, o poema, construído pela fantasia e engenhosidade do poeta, transitava pela agudeza. Há, portanto, aí uma tensividade, em que a direção de mais mais delectare e mais mais docere ampliava e intensificava o prazer e o ensinamento: a emoção e a razão imbricam-se, portanto. Segundo Snyder (2007, p. 35), Torquato Tasso amplia a noção de maravilhamento poético: "o maravilhoso não é imaginação pura e muito menos razão pura, mas uma mistura das duas, composta de qualidades opostas ou contraditórias". A natureza complexa do maravilhoso coloca em evidência um poeta capaz de produzir imagens engenhosamente novas, aumentando o prazer e a admiração do enunciatário:

A poesia maravilhosa requer um tipo de escrita figurada muito particular, afirma Tasso, para juntar elementos opostos: deve ser "clara", mas ao mesmo tempo quase uma "linguagem estranha" composta de palavras que "são como forasteiros na cidade". Em particular, a figura conhecida dos eruditos antigos como enargeia (ou evidentia), cujo significado é "clareza" ou "esplendor", é "aquela virtude que nos faz quase ver as coisas que se 
narram". Ligada à teoria humanista da ut pictura poesis, ou seja, a relação entre a poesia e a pintura, mas dotada de uma intensidade maior relativamente a este lugar comum literário, a enargeia possui a força necessária para invadir o leitor "de assombro" e encantá-lo "com a maravilha" [...] (SNYDER, 2007, p. 35).

A agudeza, estratégia por excelência do maravilhamento, recebe no século XVII diversos nomes: concetto, argutezza, acutezza, vivezza, argúcia, conceito, conceito engenhoso, concepto ingenioso, wit, witz, pointe, entimema, silogismo retórico, ornato dialético, ornato dialético enigmático (cf. HANSEN, 2006a, p. 86). Esses termos perpassaram as obras de Tesauro, Pallavicino, Gracián, Peregrini, Ferreira.

Embora haja diversidade de nomenclatura, são procedimentos linguísticos que consideram a poesia como artifício produzido pela palavra. A agudeza é uma experiência de liberdade poética, em que o engenho rompe com os laços rigorosamente miméticos, encaminhando-se para relações desconhecidas e raras. Platão (1983, p. 153 ss), no Sofista, apresenta um diálogo entre Estrangeiro e Teeteto, em que distingue duas formas de arte:

[Estrangeiro] -- A primeira arte que distingo na mimética é a arte de copiar. Ora, copia-se mais fielmente quando, para melhorar a imitação, transportam-se do modelo as suas relações exatas de largura, comprimento e profundidade, revestindo cada uma das partes das cores que lhe convêm. [...]

[Estrangeiro] - Mas à arte que, em lugar de uma cópia, produz um simulacro, não caberia, perfeitamente, o nome de arte do simulacro? [Teeteto] - Sim, perfeitamente.

[Estrangeiro] - Aí estão as duas formas que te anunciei da arte que produz imagens: a arte da cópia e a arte do simulacro.

Segundo Hansen (1997, p. 182), Tesauro, um dos tratadista da agudeza, teria se apoiado na Retórica de Aristóteles, bem como incluído alguns dados da discussão posta no Sofista, sobretudo nos momentos em que o Estrangeiro analisa a mimesis, distinguindo duas espécies de imagens: a icástica e a fantástica. Vejamos o que vem a ser icástico em correlação com o fantástico:

Icástico: 1. que representa ou reproduz com exatidão e fidelidade (uma ideia, um objeto); 2. sem artifícios; natural; simples. Etim. grego, eikastikós, relativo à apresentação de objetos (HOUAISS; VILLAR, 2001). // que representa nitidamente uma ideia ou um objeto (BORBA, 2002).

Icastico: che rappresenta la realtà con immagini realistiche; incisivo, efficace [que representa a realidade com imagem realista; preciso, nítido] (GARZANTI, 2002, tradução nossa). 
Fantástico: 1. que ou aquilo que só existe na imaginação, na fantasia; 2 . que tem caráter caprichoso, extravagante; 3. que é fora do comum, extraordinário, prodigioso; 4. [...] inventado; Etim. latim, phantasticus, fantástico, que tem origem na imaginação ou na fantasia. Do grego, phantastikós, relativo à imaginação (HOUAISS; VILLAR, 2001). // extraordinário; muito grande, fantasioso (BORBA, 2002).

Fantastico: 1. che suscita ammirazione; straordinario, bellissimo, uno spettacolo; [...] ciò che è straordinario [que suscita admiração; extraordinário, belíssimo, um espetáculo] (GARZANTI, 2002, tradução nossa).

A desproporção fantástica teria sido reciclada no século XVII com o nome de agudeza (cf. HANSEN, 1997, p. 183). O que se nota pelas definições é que icástico relaciona-se com precisão, nitidez, enquanto fantástico com maravilhamento, extraordinário.

Pela definição, a desproporção fantástica possui uma cifra de acentuação, de vivificação, suscitando nos enunciados um efeito de prodígio, de surpresa, "de extraordinário". Desde o início, a agudeza constitui-se em artifício de linguagem, engendrando nos poemas dos séculos XVI-XVII esse efeito de êxtase e de desproporção fantástica, distanciando-se do eixo icástico.

Os preceptistas seiscentistas reconheciam, portanto, na poética da agudeza o efeito inesperado de maravilhamento que persuade, agrada e espanta o enunciatário (HANSEN, 2000, p. 317). Baltazar Gracián (1987, p. 56-63), ao tratar das variedades de agudezas poéticas, identifica três tipos:

- Agudeza de conceito -- pressupõe a sutileza do pensar. Esse tipo de agudeza engendra correspondências semânticas inesperadas entre conteúdos (cf. GRACIÁN, 1987, p. 58). Conhecida também como ornato dialético, relacionase mais com o inteligível, posto que a metáfora aguda é "uma formulação mental que condensa conceitos extremos analisados dialeticamente" (HANSEN, 1995, p. 172). Essa vertente chamo de agudeza de ênfase no conteúdo (em toda a tese, agudeza do $P C$ ).

- Agudeza de palavra - caracteriza-se pela relação inesperada entre representações gráficas, sonoras (cf. GRACIÁN, 1987, p. 58); essa vertente chamo de agudeza de ênfase na expressão (em toda tese, agudeza do PE); ela erige um enunciado poético de inovações formais. No final do século XX, conforme veremos, essa agudeza tem mais lastro com o sensível, embora, 
como já afirmamos na introdução, a separação entre sensível e inteligível é puramente conceitual e de finalidade argumentativa.

- Agudeza de ação -- relativa às formas de vida aguda (cf. GRACIÁN, 1987, p. 59); não trataremos da agudeza de ação nesta tese.

O sujeito, na percepção do objeto estético, ou é tocado pela substância do conteúdo ou pelas formas do conteúdo e da expressão. Quando tocado pela substância do conteúdo, prevalece o eixo icástico, o simulacro da realidade; os objetos da agudeza de ênfase no conteúdo, nesse caso, estão próximos de uma estética da substância. Prevalece, porém, o eixo fantástico ou poiético, quando tocado pelas formas do conteúdo e da expressão. Temos, nesse caso, um simulacro de reconstrução de formas da expressão e do conteúdo, uma arquitextura formal, o que não deve levar à conclusão de que os objetos do eixo icástico sejam destituídos de formas poiéticas, pois tanto o objeto icástico quanto o fantástico são criações discursivas que criam efeito de realidade (nitidez) ou de fantasia (fluidez). Por isso, optamos por organizar os objetos estéticos segundo um continuum, em que a agudeza de ênfase no conteúdo se aproxima mais do eixo icástico, mimético, e a agudeza de ênfase na expressão mais do eixo poiético, da re-forma.

Para elucidar a escolha dos termos agudeza do PE/agudeza do PC, cito um esquema adaptado de Marsciani (2012b, v. 2, p. 39):

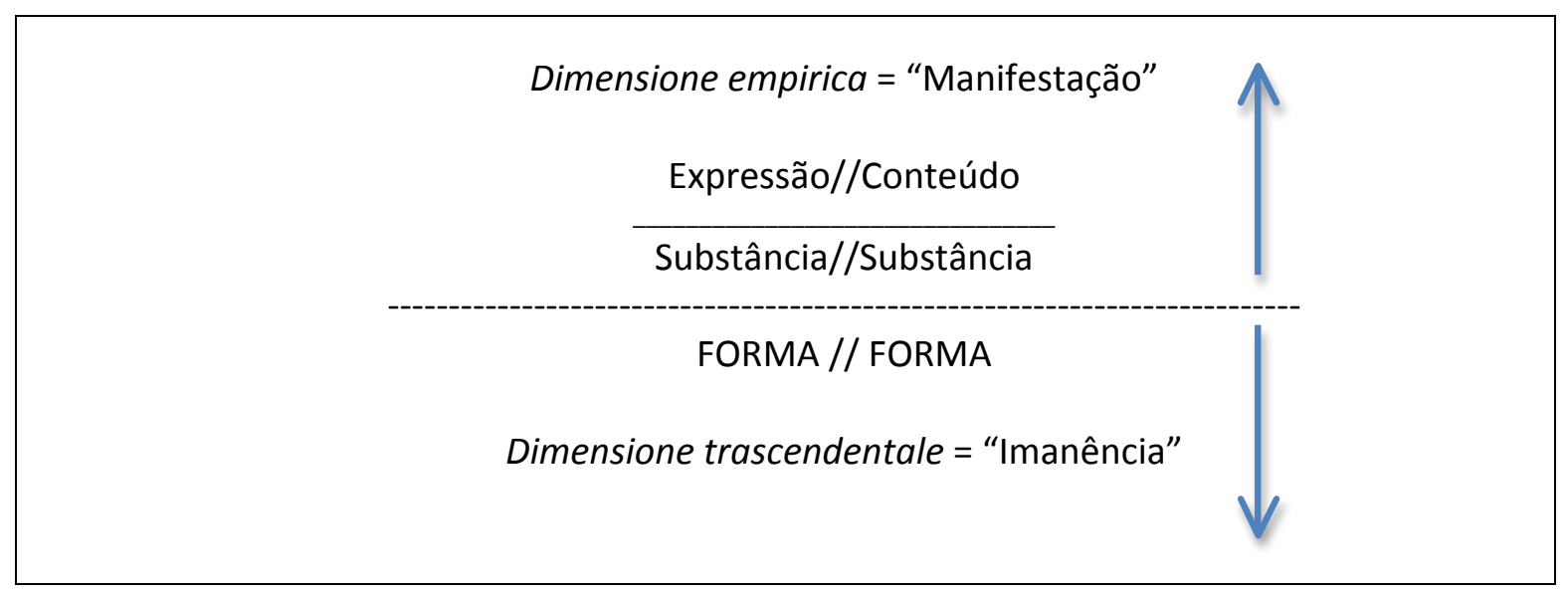


Pelo gráfico proposto, a agudeza do PE e a agudeza do PC englobam duas dimensões, a da manifestação e a da imanência ${ }^{1}$. Noutros termos, pela manifestação, temos enunciados que pendem ora para os simulacros que enfatizam o PC, ora para os simulacros que enfatizam o PE; pela imanência, temos uma forma subjacente, que se "arranja" e se "organiza" na enunciação, para a criação de efeitos visuais, sonoros (PE) ou de ênfase no conteúdo (PC) e que se manifesta no enunciado. Trata-se, assim, de um enunciador que escolhe tensivamente os arranjos formais (mais ou menos vívidos; mais ou menos lentos) subjacentes aos enunciados poéticos. Resumindo, agudeza do PE e agudeza do PC é um complexo articulado (indivisível) regido por oscilações tensivas de escolhas da enunciação, anteriores à manifestação, mais profundas, portanto.

Ademais, as poesias agudas não são concebidas como uma forma de expressão ou de conteúdo, mas como uma linguagem, dotada da relação de um plano de expressão (PE) com um plano de conteúdo (PC). Sugerimos, como consequência, a agudeza como uma semiótica, cujo jogo tensivo vivifica ora mais a expressão, ora mais o conteúdo. E em casos de excesso de agudeza, ambos. Floch (In: LANDOWSKI; FIORIN, 1997, p. 213), em “Diário de um bebedor de cerveja", define "a visão barroca como uma linguagem cuja forma do plano de expressão daria ênfase à negação da descontinuidade e a forma do conteúdo, à negação da continuidade". No capítulo 3 de Forme dell'impronta (Les formes de l'empreinte), Floch (2005, p. 65) volta a insistir que "do ponto de vista sintagmático, a forma semiótica do barroco e do clássico podem ser, portanto, representadas:

$\begin{array}{llll} & \text { clássico } & & \text { barroco } \\ \text { expressão } & \text { descontínuo } & \text { vs. } & \text { contínuo } \\ \text { conteúdo } & \text { contínuo } & \text { vs. } & \text { descontínuo }\end{array}$

Nossa posição não é propriamente binarista, porque entendemos tratar-se de relação de dependência e não de oposição (vs.), ou seja, entendemos a descontinuidade de

\footnotetext{
${ }^{1}$ A concepção de signo seiscentista desconhece, no entanto, o entendimento saussuriano, que o divide em significante e significado, bem como a divisão hjelmsleviana, que o refina em PE e PC. Nos séculos XVI-XVII, entendia-se que a substância sonora das línguas era um efeito de uma causa primeira, a divina. Dominado pelo pensamento cristão, o discurso não era visto como uma produção humana, mas como manifestação da vontade de Deus. Os autores passíveis de imitação (destinadores), aqueles em cujas obras era patente essa posição, eram considerados auctoritas (cf. HANSEN, 2011, p. 25-62).
} 
Floch em termos de fluidez, bem como a continuidade em termos de nitidez. Não há antitetismo nos objetos, mas uma gradação tensiva provocada por uma operação de agudeza que manifesta no enunciado poético os efeitos de mais nitidez ou de mais fluidez ou, ainda, uma concomitância de ambos os efeitos; também não fazemos separação entre clássico e barroco por entendermos, juntamente com Hansen (1997, 2000, 2001, 2006a, 2006c), que não havia esse recorte no século XVI.

A agudeza do PC produz, assim, uma poesia que se encaminha ao maravilhamento inteligível e a do PE produz uma poesia que se encaminha ao maravilhamento sensível. Haveria, pois, um duplo movimento no sistema das agudezas: quando o inteligível é atualizado, virtualiza-se o sensível; quando o sensível é atualizado, virtualiza-se o inteligível. A divisão dessas duas formas engenhosas é puramente didática; consideramos ora a dominância de uma ou de outra, ora a coexistência de ambas.

Das definições de agudeza dicionarizadas, depreendemos uma cifra tensiva:

Qualidade do que é agudo, afilado, pontiagudo [...]; Inteligência penetrante; compreensão exata; perspicácia, argúcia, sagacidade; dito engenhoso, espirituoso (HOUAISS; VILLAR, 2001, verbete agudeza).

Qualidade do que é agudo, agudeza de espírito, perspicácia, sagacidade; gravidade, intensidade [...] (AULETE, 1970, verbete agudeza).

Perspicácia; percuciência; argúcia. Agudizar: estimular. Agudo: intenso; penetrante (BORBA, 2002, verbete agudeza).

Que termina em ponta; penetrante, intenso; muito forte; referente aos sentidos e à mente; eficácia na percepção; muito intenso no plano das emoções; capacidade de percepção, vivacidade (acutezza d'ingegno); mais intenso; acentuado (DEVOTO; OLI, 2005, verbete acuto, acutezza, tradução nossa).

Origem latina acutus; caráter agudo; intenso; grau de sensibilidade (de um sentido), finesse de sensibilidade, discriminativa; finesse e penetração intelectual; perspicácia; de uma frequência elevada; intenso e penetrante; particularmente vívido e penetrante no domínio do espírito [...] (PETIT ROBERT, 2008, verbete acuité; aigu, uë, tradução nossa).

A cifra tensiva de acentuada tonicidade na intensidade pode ser verificada em:

Agudo

Engenhoso

Gravidade

Intensidade

Estimular 
Que termina em ponta

Intenso

Penetrante

Muito forte

Muito intenso no plano das emoções

Acentuado

Grau de sensibilidade

Frequência elevada

Essa tonicidade acentuada é verificável nos objetos poéticos de apelo sensível, que utilizam a agudeza como estratégia de sensibilização do enunciado. A agudeza do PC vivifica o conteúdo, explorando combinações de entimemas, metáforas, antíteses, parodoxos, oxímoros etc.). A agudeza do PE enfatiza o plano visual e/ou sonoro: quebra e amálgama de palavras, fluidez do verso, exploração do branco da página como significante etc.

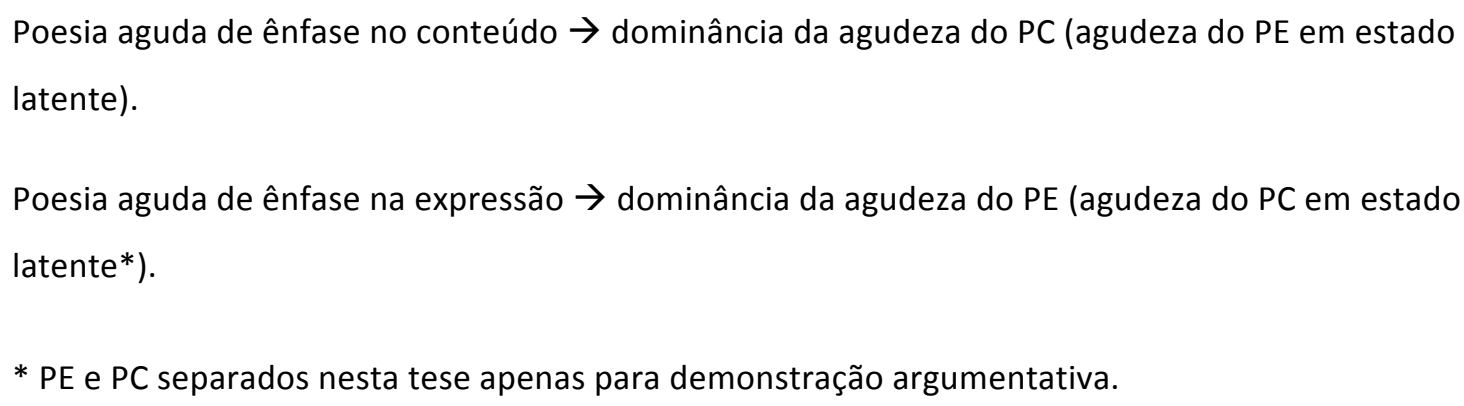

Em ensaio literário, Teixeira (1997-1998, p. 102) discute o conceito de agudeza seiscentista, questionando se haveria constantes dessa agudeza na poesia contemporânea brasileira. Salienta ainda que Baltasar Gracián (1986, 1987), em Agudeza y arte de ingenio, teria lamentado que os antigos não tivessem definido a agudeza, embora a tivessem praticado com frequência, mencionando que o próprio Gracián não a definira com tanta clareza.

- E o que seria então a agudeza?

- Ela seria uma forma revivida? E, por isso, o ressurgimento e a canonização de um <neo $>$ barroco, novo barroco? 
Esse questionamento leva-nos a outra questão: a agudeza seiscentista teria sido aproveitada ou aprimorada nas produções do século XX? Ivan Teixeira (1997-1998, p. 101), em "Rosa e depois: o curso da agudeza na literatura contemporânea", defende que "boa parte dos efeitos literários obtidos por Guimarães Rosa e por João Cabral decorre da apropriação de certos elementos da agudeza seiscentista, muito bem aclimatada em diversos aspectos da construção da arte no século XX". Essa posição de Teixeira vai de acordo com a de Haroldo de Campos na construção de um cânone estabelecido com base numa tradição barroca, o cânone do neobarroco, chamado de transbarroco por estar livre das amarras do tempo. Mais recentemente, no entanto, em artigo publicado na Revista USP, "Hermenêutica, retórica e poética nas letras da América Portuguesa", afirma criticamente Teixeira (2003, p. 152) que "a vanguarda concretista de São Paulo vem promovendo operações retroativas da mesma natureza epistemológica [recortes seletivos e mutilações programáticas do passado], isto é, tem efetuado incisões seletivas com o propósito de instaurar uma genealogia nobilitante para os próprios experimentos".

Para nós, a agudeza seiscentista não é uma forma revivida ou aprimorada no tempo. Ela pertenceria à estrutura do fazer poético do século XVII, caracterizado por um contrato enunciativo próprio, ou seja, convenções poéticas das letras seiscentistas, com um destinador específico, os tratadistas da agudeza. Enquanto esse contrato seiscentista apoiava-se no prodesse (docere) cum delectare, o contrato do final do século XX apoia-se mais no delectare.

Além disso, os poemas agudos seiscentistas estão divididos segundo um contrato de gênero: poesia lírica, satírica nas variações aristotélicas cômicas, ridículas e maledicente etc. Trata-se ainda de uma hierarquia que a estrutura: gênero, forma -- soneto, medida nova, formas mais populares --, a depender da prescrição do contrato. Segundo Hansen (2001, p. 32-33), não se pode ignorar completamente o plano da expressão no século XVII: as poesias atribuídas a Gregório de Matos, por exemplo, publicadas na atualidade, alteram a pontuação original que simulava atos de fala; elas eram declamadas oralmente. Ignorar esse fato das letras seiscentistas e assumir a pontuação moderna na tentativa de organizá-las sintaticamente conduz o objeto a um juízo fora de seu tempo discursivo. Consideramos, portanto, a agudeza dos seiscentos um tempo discursivo diverso do tempo discursivo do final do século XX, que é orientado por outro contrato enunciativo, outro destinador, outras escolhas tensivas. Por isso, a agudeza não ser propriamente uma forma revivida, mas 
participar de tempos discursivos singulares, que distanciam tensivamente a arte dos seiscentos da arte do final do século XX.

A agudeza estaria liberta dos rótulos de barroco ou de neobarroco, podendo tensivamente contar com escolhas que evidenciam, na manifestação poética, mais vivacidade no PE ou no PC (ou em ambos), independentemente da "marca estética", e que se funda em um contrato enunciativo próprio ao século seiscentista e ao final do século XX.

Vejamos a seguir, mais detidamente, como o conceito de agudeza aparece em vários tratadistas do século conhecido como barroco.

\section{Conceitos DE AGUDEZA ENTRE tRATADISTAS}

Entre as obras dos tratadistas da agudeza, destacam-se:

1. Delle acutezze, che altrimenti spiriti, vivezze, e concetti volgarmente si appellano, de Matteo Peregrini ([1639] obra consultada de 1997) - Itália.

2. Del bene (1644) e Trattato dello stile e del dialogo, ove nel cercarsi l'idea dello scrivere insegnativo discorresi partitamente de'vari pregi dello stile, si latino come italiano e della natura dell'imitazione e dell'utilità del dialogo ([1646] 1828), de Pietro Sforza Pallavicino (cf. SNYDER, 2007, p. 55-68) - Itália.

3. Agudeza y arte de ingenio, de Baltasar Gracián ([1644] obras consultadas de 1986 e 1987) - Espanha.

4. Il cannocchiale aristotelico, de Emanuele Tesauro ([1654] obra consultada de 2000) - Itália.

5. Nova arte de conceitos, de Francisco Leitão Ferreira (1718-1721; cf. CASTRO, 2008, p. 143-227) - Portugal.

A seguir, vejamos um quadro-resumo do cenário intelectual do discurso sobre a agudeza.

Quadro $2.1 \quad$ Síntese dos conceitos de agudeza.

\begin{tabular}{|l|l|}
\hline $\begin{array}{l}\text { Matteo Sarbiewski (1595-1640) - jesuíta } \\
\text { polaco; buscou dar uma primeira ordem } \\
\text { conceitual ao novo pensamento artístico da }\end{array}$ & \\
época, atualmente conhecido como \\
barroco.
\end{tabular}




\begin{tabular}{|c|c|}
\hline $\begin{array}{l}\text { concordância discordante, ou uma } \\
\text { discordância concordante do mesmo" } \\
\text { (SNYDER, 2007, p. 41-42) }\end{array}$ & mão em mão, em cópias manuscritas. \\
\hline $\begin{array}{l}\text { Matteo Peregrini (1595-1652) - nos anos } \\
\text { em que o clima intelectual do marinismo } \\
\text { surge e a discussão sobre a nova tendência } \\
\text { estética ganha corpo, o jesuíta Peregrini } \\
\text { publica um tratado intitulado Delle acutezze, } \\
\text { o primeiro a ser publicado na Itália sobre o } \\
\text { assunto. } \\
\text { Para Peregrini, "a agudeza pertence ao } \\
\text { 'gênero do belo e do deleitoso' e não ao } \\
\text { 'raciocínio filosófico'” (SNYDER, 2007, p. 46) } \\
\text { e "todas as agudezas 'plausíveis' ensinam } \\
\text { alguma coisa, comovem os afectos ou } \\
\text { deleitam o espírito, sendo três os efeitos } \\
\text { (docere, movere, delectare) que a retórica } \\
\text { pode provocar em quem escuta ou em } \\
\text { quem lê" (SNYDER, 2007, p. 47). }\end{array}$ & $\begin{array}{l}\rightarrow \text { Matteo Peregrini (1639), Delle acutezze, } \\
\text { che altrimenti spiriti, vivezze, e concetti } \\
\text { volgarmente si apellano (1997). Confira } \\
\text { também Snyder (2007, p. 44-55). }\end{array}$ \\
\hline $\begin{array}{l}\text { Segundo Peregrini, "o artifício da agudeza } \\
\text { deleita o ouvinte, fazendo com que se } \\
\text { maravilhe com a genialidade inata do } \\
\text { escritor" (SNYDER, 2007, p. 47). }\end{array}$ & $\begin{array}{l}\rightarrow \text { Peregrini se interessa pelas agudezas } \\
\text { admiráveis, "que exprimem o engenho do } \\
\text { seu próprio criador" (SNYDER, 2007, p. 47). }\end{array}$ \\
\hline $\begin{array}{l}\text { Peregrini menciona que "a agudeza é } \\
\text { necessariamente regida pela ligação." "A } \\
\text { agudeza é sempre um artifício 'muito raro', } \\
{[\ldots] \text {, "visando simplesmente 'uma }} \\
\text { determinada simetria de duas partes } \\
\text { concorrentes uma diante da outra" } \\
\text { (SNYDER, 2007, p. 47, destaques nossos). }\end{array}$ & $\begin{array}{l}\rightarrow \text { Ao falar de simetria, Peregrini se } \\
\text { aproxima ainda do pensamento } \\
\text { renascentista que fazia fundo às obras dos } \\
\text { séculos XVI-XVII. }\end{array}$ \\
\hline $\begin{array}{l}\text { Agudeza, para Peregrini, é “'ligação } \\
\text { entimemática' que 'liga duas coisas } \\
\text { diferentes mediante uma terceira” (SNYDER, } \\
\text { 2007, p. 48). }\end{array}$ & $\begin{array}{l}\rightarrow \text { A agudeza condensa duas grandezas } \\
\text { diversas e gera uma terceira. }\end{array}$ \\
\hline $\begin{array}{l}\text { Na visão de Peregrini, “a agudeza é uma } \\
\text { figura de elipses em que a omissão de um } \\
\text { elemento obriga o receptor a subentendê- } \\
\text { lo" (SNYDER, 2007, p. 48). }\end{array}$ & $\begin{array}{l}\rightarrow \text { A agudeza, que procede por } \\
\text { condensação, pode ser apreendida } \\
\text { intelectivamente por catálise. Utilizamos } \\
\text { aqui o sentido de catálise de Hjelmslev } \\
\text { (1975, p. 99-100; 140): catálise é condição } \\
\text { necessária à efetuação da análise, "registro } \\
\text { de coesões através do câmbio de uma } \\
\text { grandeza por outra com respeito à qual há } \\
\text { uma substituição". Pela catálise, explicitam- } \\
\text { se os "elementos elípticos ausentes na } \\
\text { estrutura de superfície" (GREIMAS; }\end{array}$ \\
\hline
\end{tabular}




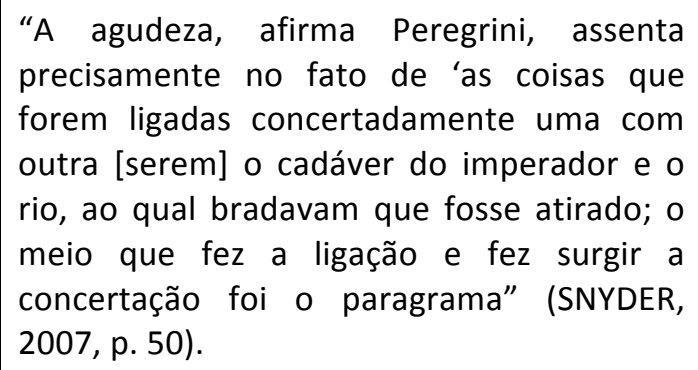
precisamente no fato de 'as coisas que forem ligadas concertadamente uma com outra [serem] o cadáver do imperador e o rio, ao qual bradavam que fosse atirado; o meio que fez a ligação e fez surgir a concertação foi o paragrama" (SNYDER, 2007, p. 50).

Conforme Peregrini, "a agudeza não é tida como devendo refletir o real de modo mimético ou reiterar o sentido comum das coisas: pelo contrário, é uma experiência de liberdade em que o engenho se desvincula de todos os laços com a ordem préconstituída de mundo" (SNYDER, 2007, p. 51).

Mas quem seria capaz de compreender uma relação discursiva aguda? "Não 'o povo ignorante de letras', argumenta Peregrini, que 'nem costuma nem pode deleitar-se'. [...] Nem a 'turba popular' nem 'os letrados de fachada' podem entender a agudeza admirável. [...] Só 'pessoas dotadas de engenho nobre e culto' são capazes de ler um texto engenhoso e ao mesmo tempo admirá-lo: afinal de contas, Peregrini escreve o Delle acutezze para o restrito e aristocrático ambiente acadêmico de Gênova" (SNYDER, 2007, p. 51-52).
COURTÉS, 1983, p. 43, verbete catálise).

$\rightarrow$ Após a morte de Tibério em Roma, o enunciado proferido era: "Tiberium in Tiberim". O jesuíta Peregrini explica em seu tratado a agudeza dessa construção: "Está aqui subentendido o fato de ser costume na Roma antiga deitar o cadáver dos celerados célebres ao Tibre" (SNYDER, 2007, p. 50). A agudeza está no efeito engenhoso do paragrama, em que rio e cadáver, partes ligantes e ligadas, ganham corpo no enunciado agudo. Cria-se então uma nova e surpreende relação entre "rio" e "cadáver" ("Tiberium in Tiberim"). Relação de conteúdos estranhos condensados e relação de expressão por meio da aliteração do fonema / $t$ /, que os aproxima sonoramente. Nesse sentido, Snyder (2007, p. 50) afirma que estética significa inventar agudezas por meio de criatividade e engenho.

$\rightarrow$ A agudeza busca relações desconhecidas e raras, surpreendentes. Ela é deleitosa, quer para o engenho do enunciador, quer para o engenho do enunciatário, inscritos ambos no conceito greimasiano de sujeito da enunciação.

$\rightarrow$ Na teoria de Peregrini, o que surpreende na agudeza não são tanto os enunciados em si, mas a capacidade criativa do engenho. Hansen (2004, p. 93) afirma que o discreto apresenta as virtudes do cortesão e do perfeito cavaleiro cristão, singularizando-se "pelo engenho e pela prudência, que fazem dele um tipo agudo e racional, capacitado sempre para distinguir o melhor em todas as ocasiões". E, à página 335, afirma que "ser discreto consiste em saber que às vezes é preciso não o ser". Contrapõe-se ao conceito de discreto o de vulgaridade. Ainda para Hansen (2006a, p. 97), "Matteo Peregrini [...] critica os que a exercitam 'senz arte quasi del tutto, senza prudenza e senza giudicio', classificando-os como vulgares". A vulgaridade, categoria intelectual indiscriminada do uso da agudeza, é uma afetação discursiva. A indiscrição vulgar pode ser ridícula pelo exagero. 
"O engenho [segundo Peregrini] permanece sempre completamente em poder da retórica, cujo objetivo é a produção do belo". Para Peregrini, a metáfora é uma figura aguda importante, mas não crucial (SNYDER, 2007, p. 52 e 64).

Pietro Sforza Pallavicino (1607-1667) Marquês, de nobre família de Parma, é um dos mentores intelectuais de Roma. Tornase jesuíta em 1637; é também professor de filosofia e de teologia. Escreve Del bene (1644) e Trattato dello stile e del dialogo (1646).

Não trata de conceptismo (conceito) nem de agudeza de maneira direta. Aborda a questão da poesia segundo novo viés, a poesia posteriormente considerada barroca: "se o campo da poesia é o das imagens e das metáforas [...] os poetas não podem ser criticados pelas falsidades que contam, porque estas não são erros nem mentiras, mas simplesmente um modo de deleitar os leitores com a beleza das fábulas poéticas" (SNYDER, 2007, p. 57). $\rightarrow$ A metáfora não é crucial, visto que a agudeza pode ser resultado de agudos entimemas, bem como de agudos refreamentos do PE, como os anagramas. Além disso, a agudeza é de propriedade do complexo <enunciador-enunciatário>. O belo está ao alcance de quem o produz e de quem o apreende (primeiro deleite sensível + segundo deleite inteligível).

A agudeza é de ordem contratual, convencionada entre enunciador e enunciatário. Comumente, "o contrato fiduciário, que assim se instaura, pode repousar numa evidência (isto é, numa certeza imediata) ou então ser precedido de um fazer persuasivo (de um fazer crer) do enunciador, ao qual corresponde um fazer interpretativo (um crer) da parte do enunciatário" (GREIMAS; COURTÉS, 1983, p. 86). Na agudeza, não haveria propriamente evidência; ao contrário, por parte do enunciador, há, no lugar de um "fazer crer", um "fazer deleitar" ao qual corresponde, por parte do enunciatário, não um "crer", mas um "deleitar". E esse fazer deleitar e o próprio deleitar situam-se em uma instância bipartida entre instância de deleite sensível rápido + instância de deleite inteligível demorado. Lentidão e demora seguem-se engrenadas tensivamente, possibilitando o desfrute da agudeza.

$\rightarrow$ Pallavicino menciona que o único objetivo da poesia é adornar o intelecto de imagens, "ou seja, apreensões suntuosas, novas, admiráveis, esplêndidas" (cf. SNYDER, 2007, p. 57). 
Pallavicino propõe "separar claramente os dois gêneros de escrita - a poesia e a filosofia - que têm a ver respectivamente com o prazer e o ensinamento: o primeiro é puro deleite e pura fantasia, enquanto o segundo é rigorosamente didático" (SNYDER, 2007, p. 61).

Pallavicino considera a metáfora a rainha das figuras, a essência do conceito de agudeza (cf. SNYDER, 2007, p. 64).

A metáfora deve ser breve, concisa e, por isso, aguda = unidade na multiplicidade, produzindo a surpresa com a cifra acelerada do sobrevir (ZILBERBERG, 2011a, p. 277). $\rightarrow$ Nesse sentido, as obras seiscentistas vão se afastando do docere clássico.

$\rightarrow$ A metáfora aguda de Pallavicino é semelhante à de Peregrini: a cifra tensiva desse tipo de metáfora é constituída pela acentuação da intensidade, devido à relação que estabelece entre elementos semanticamente distantes (sobrecontrários na teoria tensiva), nesse caso, o sujeito da enunciação engendra "unidade entre coisas que antes não lhe pareciam de forma alguma conformes", criando uma uniformidade inesperada entre elas (cf. SNYDER, 2007, p. 65). Duas unidades semelhantes estabelecem uma relação de entendimento rápido, enquanto duas unidades distantes, ao serem aproximadas, causam surpresa, estabelecendo uma relação de entendimento lento, mas de apelo sensível repentino. Nesse sentido, a condensação "estranha" dos elementos suscita o maravilhamento, um tipo de êxtase repentino do enunciado poético.

O prazer inicial cede lugar ao prazer intelectual quando da apreensão da agudeza. Há, portanto, um deleite promovido pelo PE (sonoro e/ou visual) e um deleite promovido pela intelecção da engenharia do PC.

$\rightarrow$ O pensamento de Zilberberg (2011a, p. 277) ecoa o de Pallavicino, ainda que o semioticista possa não ter visitado a obra do tratadista: as metáforas contêm "aquele maravilhoso conjunto e aquele imprevisto onde se forma breve e aguda ponta para docemente ferir o intelecto de quem escuta, e assim para merecer o título de conceito" (cf. SNYDER, 2007, p. 65). Nesse caso, temos uma cifra de agudeza vívida. Em outros termos, "ferir o intelecto", pois que a confusão do estranhamento agudo é acelerada no sensível, ferindo o inteligível em um primeiro momento; depois de o objeto invadir o sujeito, dá-se a caminhada 
Vê-se em Pallavicino o que propõe o pensamento estético de Leibniz (DELEUZE, 2011a). Para este último, há uma infinidade de percepções de figuras e imagens aglomeradas em nossa mente, provocando em nós uma sensibilidade acelerada. A cifra da aceleração ocorre pelas imagens condensadas e o jogo de claro-escuro, em que o claro está para o todo e o escuro para as partes (DELEUZE, 2011a, p. 135). Essa desordem de sentidos distancia-se do pensamento classicista.

Baltazar Gracián - Jesuíta espanhol, professor, pregador, crítico e filósofo. Nascido no reino de Aragão, nunca sairá da Espanha; antes de morrer, será conhecido por toda a Europa pelas obras filosóficas, morais, religiosas e pelo tratado sobre a agudeza que escreveu.

Baltazar Gracián define a agudeza:

Cet artífice conceptuex consiste donc en une élégante concordance, en une harmonieuse corrélation entre deux ou trois extremes connaissables, exprimée par un acte de l'entendement (GRACIÁN, 1983, p. 97, destaques no original).

[Esse artifício conceptuoso consiste, pois, numa primorosa concordância (elegante), em uma harmônica correlação entre dois ou três cognoscíveis extremos, expressos por um ato do entendimento] (tradução nossa cotejada com o exemplar original espanhol, cf. GRACIÁN, 1987, p. 55).

Para Gracián: "a arte do engenho implica uma estética de ruptura". "Para o teórico espanhol a única prática concebível para exprimir 'os primados' das agudezas do engenho é, paradoxalmente, o uso da linguagem figurada" (SNYDER, 2007, p. 74). prazerosa para o reconhecimento inteligível da elaboração aguda.

$\rightarrow$ O chamado barroco é da ordem da sedução linguística: a arte se faz com palavras e suas combinações sonoras, visuais e metafóricas (as agudezas de ênfase no PC e/ou no PE). Respinga nas obras seiscentistas a herança horaciana do docere cum delectare.

$\rightarrow$ Numa época de escritores de peso Cervantes, Lope de Vega, Calderón, Góngora, Quevedo - que marcaram a literatura europeia, Gracián não fica para trás, fazendo circular seu pensamento original e seu incomparável estilo literário agudo (cf. SNYDER, 2007, p. 69). O preconceito moderno em relação ao chamado barroco nutre o desinteresse pela tradução do texto de Gracián. Ele discursa em torno das noções de agudeza e de engenho, que estavam relacionadas ao difundido "mau gosto" das obras seiscentistas, mais um motivo para ser valorizado euforicamente muito depois de seu tempo.

$\rightarrow$ Defensor do conceptismo, escreve um romance singular, El criticón (1651-1657). Trata-se de uma "estranha história barroca que será lida por Defoe, Voltaire e Schopenhauer", o que confirma a importância literária de Gracián (SNYDER, 2007, p. 70).

Nota-se a erudição de Gracián ao citar textos bíblicos, greco-romanos, o que dificultou sua tradução. Além disso, produziu mais de um texto sobre agudeza e o definitivo é extenso, 
A fórmula de Gracián é de invenção no lugar de imitação mimética: "homo faber barroco" (cf. SNYDER, 2007, p. 77). Tal invenção encontra-se em aproximar dois sobrecontrários; tensivamente, eis o maravilhamento.

O conceptismo, para Gracián, é "o triunfo da imagem" (SNYDER, 2007, p. 92), conferindo estética à poesia.

O pensamento estético de Gracián "não abandonou por certo nem o aristotelismo nem a poética horaciana, o velho cavalo de batalha de tantas poéticas renascentistas" (SNYDER, 2007, p. 95). Obtém-se a invenção poética aguda por meio de um entimema ou de um silogismo retórico: deduz-se uma semelhança "inesperada" de dois termos com um terceiro desconhecido. Trata-se de uma condensação rápida, metáfora aguda, operada por analogia $[A: B: C]$, ou por proporção (homologação) [A:B::C:D] (cf. Hansen, 2006a, p. 92).

Gracián tem apreço pela poesia de Quevedo, expoente do conceptismo e pela poesia de Góngora, expoente máximo do cultismo poético. fruto de longa revisão por parte do autor. Para Snyder (2007, p. 71), "o pensamento de Gracián não é facilmente comparável às teorias que precedem o conceptismo. A terminologia empregue no tratado parece a mesma - o conceito, o engenho, a agudeza", mas não é. Continua Snyder (p. 71): "Gracián conhece certamente o livro de Matteo Peregrini sobre as agudezas (para nomear uma das fontes mais conhecidas), mas não o plagiou".

$\rightarrow$ Gracián aponta para a superação da tradição de um classicismo rígido, sendo a favor da invenção poética aguda, de cunho aristotélico.

$\rightarrow$ A arte poética se dá por meio de uma estrutura de inteligência, invenção e engenho. Não há um gênero específico para as agudezas e os conceitos; eles encontramse em prosa ou em verso.

$\rightarrow$ O conceito (ou agudeza) é da ordem da inventio, pois engendra correspondência entre dois termos semanticamente dissonantes, que não se encontram em relação ordinária um com o outro. Trata-se de uma condensação engenhosa, de relações inesperadas. Há uma força tensiva que opera no inteligível: um campo de força engenhoso (agudo), que vai de um termo 1 a um termo 2, são ao mesmo tempo divergentes entre si e correlacionados. Passada a aceleração do maravilhamento sensível (o primeiro deleite), dá-se o reconhecimento inteligível: a instância da enunciação deleita-se pela segunda vez com o desvelamento da agudeza.

$\rightarrow$ Idealiza na obra poética o casamento entre cultismo e conceptismo; para Gracián, a noção do belo em poesia dá-se pela harmonia entre os engenhos dos planos de expressão e do conteúdo: "aquilo que é beleza para os olhos e a harmonia para os ouvidos, é-o, para a inteligência, o conceito [lo que es para los ojos la hermosura, y para los oídos la consonancia, eso es para el entendimiento el concepto]" (GRACIÁN, 
Snyder (2007, p. 98), ao fazer um balanço da obra de Gracián, aponta que "o mérito de Agudeza e Arte de Engenho é enorme, porque pela primeira vez na cultura barroca tenta-se formular um princípio estético universal e unitário para todas as artes, desde a poesia à pintura, que recusa um papel operativo ou normativo, mas abrindose às possibilidades infinitas da fantasia e da sensibilidade".

Emanuele Tesauro (1592-1675) - nasce em Torino, entra precocemente para a Companhia de Jesus em 1611 e sai dela em 1634, mas mantém-se como sacerdote secular; aos 50 anos de idade, inicia-se como autor de inúmeros estudos sobre retórica. Em sua obra, Tesauro trata do conceptismo; o nome de Gracián, teórico contemporâneo à época, não é citado, nem o de Matteo Peregrini ou mesmo de Pallavicino (cf. SNYDER, 2007, p. 109-110).

A metáfora aguda, segundo Tesauro, "produz uma compreensão do espaço juntamente com uma aceleração temporal" (destaque nosso); a agudeza exprime-se "'rapidamente' ou 'num relâmpago'", de modo que o enunciatário "'veja' mais do que um objeto nessa figura comprimida, rápida, inesperada" (SNYDER, 2007, p. 121).

Francisco Leitão Ferreira (1667-1735) Presbítero e membro da Academia Real de História, da Arcádia Romana. Além de poeta, é prosador. Todavia, é como tratadista
1987, p. 51; SNYDER, 2007, p. 97). Nesse sentido, o cultismo, da ordem do ofício do $P E$, e o conceptismo, da ordem do ofício do $P C$, funcionam harmonicamente como uma engrenagem na poesia da agudeza.

$\rightarrow$ O pensamento de Gracián enfrenta com originalidade a complexidade das letras seiscentistas, que polemiza a questão do fazer poético pautado em estratégias agudas, que eram divididas em duas, as cultistas e as conceptistas; nesta tese, ora vivifica-se o PE, ora o PC. A agudeza suscita no objeto um lado maravilhosamente sensível e surpreendentemente inteligível, dois momentos de deleite.

$\rightarrow$ Sua obra II cannocchiale aristotelico, conhecida na Itália por sua contribuição originalíssima às artes seiscentistas, foi publicada no mínimo 14 vezes. Foi traduzida para o latim no final do século XVII. Com quase 80 anos, viu seu livro, de mais de 700 páginas, na versão definitiva de 1670, reimpresso em Veneza em 1674. Vívido no mundo cultural lombardo e piemontês durante o século XVII (morreu em 1675), não era desconhecido dos outros tratadistas de então. A leitura de seus textos, devido ao elevado grau de dificuldade, faz-se possível graças à fortuna crítica e a seus leitores. Além disso, Tesauro nunca revela em seu enunciado qual é a edição da tradução da Retórica de Aristóteles, citada em seu texto cerca de 400 vezes. Embora sua obra eleve o nome de Aristóteles, o nome do filósofo grego aparece uma só vez no texto (cf. SNYDER, 2007, p. 102 ss).

$\rightarrow$ A agudeza é propriedade, na visão de Tesauro, do objeto estético. A associação aguda segundo o pensamento de Tesauro produz um efeito de surpresa. No texto do tratadista italiano, há linhas paralelas ao pensamento de Zilberberg (2011a, p. 44), quanto ao andamento rápido da estética barroca. 
literário que se destaca (cf. MOISÉS, 1997, p. 201-288; CASTRO, 2008, p. 143-227).

Leitão Ferreira entende a agudeza como destreza de conceito e destreza de palavra (CASTRO, 2008, p. 164-165).

Para Leitão Ferreira (cf. CASTRO, 2008, p. 198), há uma forma de expressão ornada que suscita um efeito de surpresa na poesia.

Leitão Ferreira concebe a metáfora como palavra peregrina, "que velozmente significa, \& demonstra hum objecto por meyo de outro" (cf. CASTRO, 2008, p. 200).

Em Leitão Ferreira, "a causa material da metáfora é o vocábulo translato, enquanto mantém a sua significação; a sua causa formal é a significação imprópria; a causa final é a procura da novidade engenhosa, fonte de admiração e de prazer estético" (cf. CASTRO, 2008, p. 206).

Francisco Leitão Ferreira "fundiu numa teoria única as duas tendências conceptista e cultista - que têm vindo a caracterizar, com separação demasiado estanque, a literatura barroca. [...] Foi anticulteranista ou anti-conceptista sempre que sentiu necessidade" (cf. CASTRO, 2008, p. 226).

O que está no foco do pensamento de Leitão Ferreira é a imagem sensível $\rightarrow$ Ao propormos o PE e O PC como categorias de análise, consideramos dois tipos de agudeza (a de ênfase no PE e a de ênfase no PC), como o faz Francisco Leitão Ferreira quando distingue conceito de palavra. No século XVII-XVIII, palavra referiase à grafia e ao som (em termos saussurianos, significante), enquanto $\mathrm{o}$ conceito referia-se ao significado.

$\rightarrow$ Valoriza o tratadista português o caráter formal do $\mathrm{PE}$, que, trabalhado, torna-se agudo.

$\rightarrow$ A agudeza (a metáfora peregrina nas palavras de Francisco L. Ferreira) carrega a cifra da acentuação da tonicidade ao surpreender o enunciatário: "pelo facto de significar velozmente e demonstrar um objecto por outro, não se confunde com as palavras e figuras gramaticais, que apenas significam, sem novidade, sem energia" (cf. CASTRO, 2008, p. 200). A logicidade implicativa das figuras gramaticais não atribui ao enunciado novidade; ao contrário da agudeza, que suscita, pela condensação de termos distantes e pela coesão concessiva, o maravilhamento no enunciado poético.

$\rightarrow$ A agudeza do PE ("vocábulo translato") e agudeza do PC ("significação imprópria") funcionam como uma engrenagem do prazer estético.

$\rightarrow$ Era a favor da agudeza estética, mas contra o empolado ou o afetado, contra o mais da saturação, do basta de que fala Zilberberg (2011a, p. 60). Ele condena a separação entre cultismo e conceptismo, algo com o que estamos de acordo, pois a poesia aguda faz-se por meio dos artifícios formais do PE e do PC.

$\rightarrow$ Moisés (1997, p. 262) comenta que a poesia "barroca" é sensível na medida em 


\begin{tabular}{|l|l|}
\hline engenhosa que a poesia aguda suscita (cf. & $\begin{array}{l}\text { que usa do experimentalismo formal, e aqui } \\
\text { temos o vínculo forte com a poesia visual } \\
\text { MOISÉS, 1997, p. 251). }\end{array}$ \\
$\begin{array}{l}\text { seiscentista e a do século XX: labirintos, } \\
\text { anagramas, acrósticos, enigmas, } \\
\text { paronomásias etc. Trata-se de uma poesia } \\
\text { pictórico-verbal. }\end{array}$
\end{tabular}

Ao tratar da poesia seiscentista, Pécora (2013, p. 1-2) salienta que "para a compreensão da poesia usualmente nomeada de 'barroca' [...], nenhuma noção é mais central do que a de "agudeza'". Como vimos no quadro 2.1, a agudeza é um artifício linguístico que suscita maravilhamento pela vivificação das formas do PE e do PC. Portanto, entende-se por aguda a poesia cujo programa é evidenciar em seu percurso manipulativo uma inteligibilidade oculta da ordem do maravilhamento e da surpresa.

Esse elo inteligível obscurecido proporciona ao enunciatário enorme prazer quando é descoberto. Essa inteligibilidade obnubilada conhece limites, dependendo do gênero: nem sempre o poeta agudo opta pelos "cultos modos", pois há ocasiões em que a agudeza consiste no uso de "frase corriqueira", que é mais adequada para generalidades que requerem clareza, como é o caso, por exemplo, da sátira cuja didascália é "Em tempo que governava esta cidade da Bahia o Marquez das Minas ajuiza o poeta com subtileza de homem sagaz, e entendido o fogo selvagem, que por meyo da urbanidade se introduzio em certa casa", atribuída a Gregório de Matos (cf. HANSEN, 2004, p. 334):

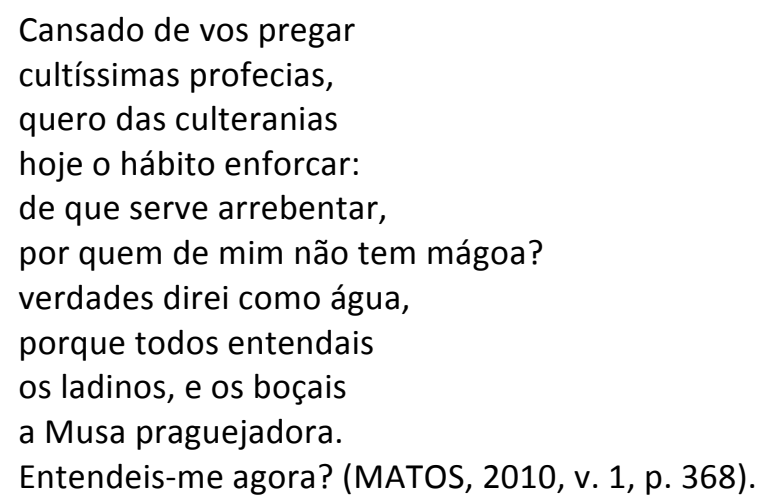

Hansen (2004, p. 334) entende que "a censura da agudeza hermética se faz em termos horacianos de ut pictura poesis: [...] falar em 'cultos modos' é asneira". Atento a essas normas do artifício poético agudo, o enunciador do poema, cuja didascália é "Torna o poeta a dar outra volta ao mundo com esta segunda crisi", satiriza:

Mas que eu fizesse hoje estudo

para cousas importantes,

por estéreis consoantes, 
que não podem dizer tudo:

que algum diga carrancudo, quando escrevo para todos, que não falo em cultos modos, mas em frase corriqueira!

Boa asneira (MATOS, 2010, v. 1. p. 396).

A sátira evidencia que ser discreto "consiste em saber que às vezes é preciso não o ser" (HANSEN, 2004, p. 335; cf. PÉCORA, 2008, p. 180). A agudeza leva em conta o decoro, ou seja, o contrato fiduciário, que é precedido de fazer persuasivo e de fazer interpretativo dos sujeitos da enunciação. É esse contrato o regulador das proporções analógicas agudas. Se o sujeito da enunciação desrespeita o contrato (o decoro), corre o risco de produzir uma poesia disforme (cf. HANSEN, 2004, p. 318).

A seguir, examinamos a contribuição do polonês Sarbiewski com relação à agudeza.

\section{AgUdeZA E TRIÂNGULo ISÓSCELES: A CONTRIBUIÇÃo INICIAL DE SARBIEWSKI}

Um dos mais antigos tratadistas é o jesuíta polonês Matteo Sarbiewski. No ano de 1626 redigiu De acuto et arguto, que circulou pela Europa na forma de manuscrito (cf. SNYDER, 2007, p. 40-47) $)^{2}$.

Matteo Sarbiewski (cf. SNYDER, 2007, p. 41-44) revela ser a agudeza um discurso que contém a convergência de acordos e de desacordos lógicos, ou seja, ou uma concordância discordante ou uma discordância concordante. Como se vê, em termos zilberberguianos, a agudeza não é da ordem da implicação, do pervir (se... então), mas da concessão, do sobrevir (embora... mesmo assim). Para explicá-la, o tratadista polonês lança mão da analogia com um triângulo isósceles, no qual o vértice é formado pelo encontro e pela convergência de duas linhas que se juntam em um único ponto.

O vértice (acúmen - agudo) da figura 2.1 configura a mistura de dois lados que se opõem como se fossem contrários e separados; partem da mesma base e encaminham-se para uma fusão completa no vértice. Retoricamente, temos uma linha, cuja narrativa está em acordo e uma que está em desacordo com a lógica proposta pelo enunciado.

\footnotetext{
${ }^{2}$ Para Sarbiewski (cf. SNYDER, 2007, p. 40-47), argúcia (argutia) é um artifício de ordem ornamental, ou seja, constitui-se em artimanha da ordem dos significantes (paronomásia, aliteração, anagramas) para vivificar e sensibilizar o enunciado poético. Agudo (acuto), para ele, seria o ornamento dialético pelo qual se intensifica o PC, tendo em vista o obscurecimento e o delongamento do reconhecimento inteligível. Nos seiscentos, não havia, como estamos vendo, um consenso terminológico.
} 


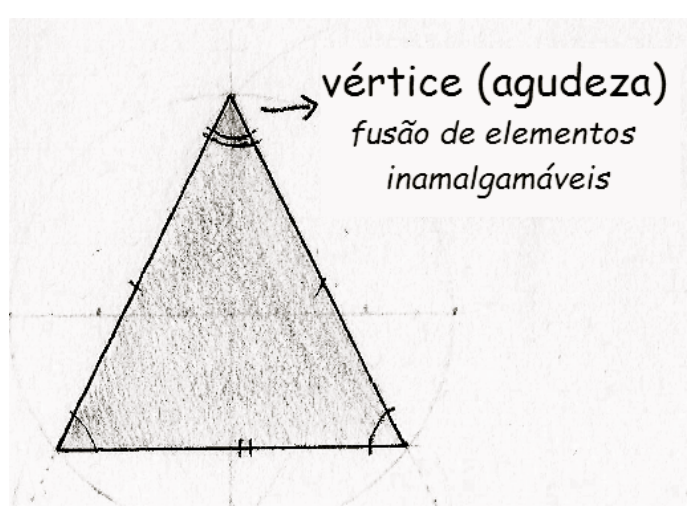

Figura 2.1 Triângulo de Sarbiewski.

Analogamente à figura geométrica do triângulo isósceles, podemos afirmar que, para a constituição da agudeza do $P C$, é preciso que ambas as linhas, duas figuras discursivas distantes semanticamente, juntem-se no vértice; nesse caso, acordo e desacordo coincidem, configurando-se em fusão (condensação ${ }^{3}$ ) de um só elemento da ordem da concessividade: embora em desacordo, mesmo assim coincidem.

A tensão originária entre dois lados que se opõem, mas acabam convergindo, produz o efeito de agudeza que vivifica e acentua o PC, surpreendendo o sujeito da enunciação, ao provocar admiração sensível e prazer intelectual. No caso do objeto agudo (o usualmente nomeado barroco), são comuns os paradoxos e os oxímoros, que são formados pela convergência de duas figuras que se opõem para formar um novo sentido, figurativizado pela ponta do triângulo. Esse é o caso da metáfora aguda de Ovídio (GRACIÁN, 1986, p. 37; 1987, p. 55):

O, nix, flamma mea! [Ó, neve, chama minha!]

$\rightarrow$ Aqui, temos um processo de agudeza que associa no poema figuras afastadas semanticamente: neve e chama, que produzem um oxímoro, porque neve é gelo e chama é fogo. Ao amalgamar no mesmo verso neve e chama, engendra-se um efeito intenso e surpreendente, pontiagudo representado pela ponta do triângulo, que conjuga duas retas que tendem a andar paralelamente.

Baltazar Gracián (1987, p. 55), em “O, nix, flamma mea! [...] [Oh, nieve, llama mia!]”, mostra-nos que a agudeza do PC consiste em uma surpreendente concordância entre elementos distantes. Tais extremos interseccionam-se, e o maravilhamento se dá na fruição sensível e na fruição do reconhecimento da associação. Os objetos agudos conjugam, além do sensível, a surpresa no nível da inteligibilidade.

\footnotetext{
${ }^{3}$ Essa propriedade será tratada ainda neste capítulo.
} 
Outro exemplo de agudeza do PC, na operação de oxímoros e paradoxos, notamos na metáfora aguda apresentada por Baldassare Castiglione em Il libro del cortegiano sobre um fidalgo castelhano que, ao ver um casal da corte vestido com roupas de damasco branco, cujo marido era muito feio e a mulher belíssima, teria dito para a rainha Isabel, a Católica (cf. HANSEN, 2000, p. 318):

Esta é a dama, aquele o asco. $\rightarrow$ dama (s1) + asco (s2) = o casal damasco (s3).

Nesse caso, a estratégia é de junção de dois elementos distantes dama e asco (os lados do triângulo), que, unidos pontiagudamente, formam um elemento inesperado damasco (a ponta do triângulo) ${ }^{4}$.

No poema cuja didascália é "Casado, e rico se embarcou para Portugal a comprar nobreza; e o poeta lhe faz as despedidas profetizando, o que realmente succedeo", atribuído a Gregório de Matos, a divisão da palavra, trocando de lugar o começo com o fim dela, produz uma agudeza que se acentua mais no PE sonoro e visual. Vejamos:

Em verdade vos afirmo, que então vos supus, e cri surrada tapeçaria, tisnado guadamecim. O que direis de mentiras, quando tornares aqui! amizades de um Visconde, favores de um Conde vis, Valido de um tal Ministro, Cabido de um Juiz, e até do mesmo Cabido leiguíssimo Mandarim (MATOS, 2010, v. 2, p. 682, destaques nossos).

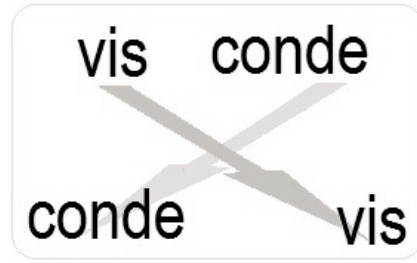

O enunciador explora a estratégia anagramática do $\mathrm{PE}$, bem como a do $\mathrm{PC}$, por meio da ambiguidade de VIS, que é plural de vil, e do hipérbato e, nesse caso, teríamos "favores vis de um Conde".

\footnotetext{
${ }^{4}$ Damasco é tecido de seda ornado, em alto-relevo, com fios para cetim ou tafetá, originário da cidade de Damasco (HOUAISS; VILLAR, 2001).
} 
No classicismo, contrapondo ao triângulo isósceles agudo do chamado barroco, em vez da comparação com a figura geométrica do triângulo isósceles, talvez se possa fazer analogia com duas linhas que nunca se encontram, ou seja, figuras discursivas que se aproximam, mas que não se chocam semanticamente:

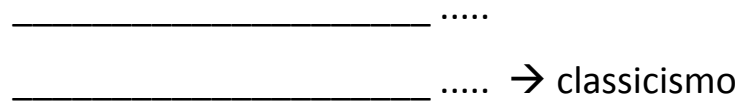

Já na agudeza, a percepção inicialmente acentuada no sensível alcança a difusão inteligível de modo lento; quando o alcança, temos o êxtase intelectivo. Resumindo, a estratégia aguda funcionaria como uma espécie de escuro/claro estrutural, brotando o objeto poético do jogo de sombra e luz: uma obscuridade rápida sensível e um clarão lento inteligível, que apreende e deleita o sujeito da enunciação.

\footnotetext{
Elementos preliminares da agudeza = provocar êxtase no sujeito da enunciação + produção de enunciado configurado pela fusão de elementos normalmente inamalgamáveis (perda do contorno semântico, cf. ZILBERBERG, 2011a, p. 44.)
}

Estabelecendo um paralelo da agudeza com a semiótica tensiva, verificamos que os conceitos de "maravilhamento", "inesperado", "surpresa", "acontecimento" (sobrevir) entre outros, constituintes das propriedades da agudeza, vistas no quadro 2.1, são os mesmos que vamos encontrar nos estudos de Zilberberg, em Eléments de grammaire tensive (2006a, p. 233; 2011a, p. 277). É de admirar que Sarbiewski ([1626] In: SNYDER, 2007, p. 40-47), precursor dos tratadistas dos seiscentos, já saliente o caráter de maravilhamento das obras seiscentistas.

A seguir, examinamos como a agudeza, engendradora dos efeitos de maravilhamento na poesia, funda-se nas artimanhas paradigmáticas do PE e do PC.

\subsection{Paradigmas do PE E do PC na agudeza}

A similaridade mobiliza as correlações paradigmáticas entre os componentes de determinada classe. Por semelhança, escolhemos um elemento entre uma alternativa de pelo menos dois elementos em ausência, a conhecida fórmula hjelmsleviana "ou... ou..." (HJELMSLEV, 1975, p. 43). Selecionado, o elemento na condição de paradigmático passa à 
condição de sintagmático no eixo horizontal do texto. Nessa posição, combina-se com outros elementos aí dispostos, formando o processo.

Paradigmaticamente, a seleção produz fenômenos de similaridade sonora, o chamado paradigma do PE (cf. LOPES, 1981, p. 92), que compreende:

- Rima: caso particular de homeoteleuto; semelhanças de sons no interior do mesmo verso (rima interna); a rima também pode ser externa, combinando, nesse caso, sons em versos diferentes. A rima toante caracteriza-se como rima apenas de vogais tônicas (GOLDSTEIN, 2011, p. 108).

- Igualdade sonora: segundo Lausberg (2004, p. 214), a igualdade sonora de partes das palavras em um verso ou em uma oração pode se dar no começo ou no final delas. São de vários tipos:

- Aliteração - consiste na repetição do mesmo som ou sílaba em duas palavras ou mais, dentro do mesmo verso ou estrofe. Geralmente, a reiteração sonora ocorre entre fonemas ou sílabas iniciais, podendo também dar-se no meio ou no final das palavras. É comum ser constituída por um fonema consonantal, não excluindo a formação por fonema vocálico. A escolha ocorre por similaridade entre sons (fonemas) e não grafemas, operando-se no plano de expressão sonora e não visual. Como vimos, trata-se de um artifício paragramático, um procedimento do PE. Segundo Moisés (2011, p. 17), trata-se de forma de ornato bárbara, "proscrita no tempo de Cícero, retomada, sob nome de vers lettrisés, versos letrizados, pelos poetas franceses dos séculos XV e XVI". A seguir, um exemplo de aliteração em Os lusíadas, de Camões, canto décimo, estrofe 29:

"O mar todo com fogo e ferro ferve" (CAMÕES, 2003, p. 238)

- Eco - aliteração no final das palavras:

“Um estilo tão empeçado, um estilo tão dificultoso, um estilo tão afetado, um estilo tão encontrado a toda a arte e a toda natureza?" (VIEIRA, 2000, v. 1, p. 39). Nas duas décimas do trecho de um poema atribuído a Gregório (ver no item seguinte, paronomásia), verifica-se exemplos de eco. 
- Paronomásia ou antanáclase - consiste na escolha de elementos que engendram semelhança sonora (ou de prosódia), isto é, há semelhança no som, mas distância no PC. Exemplos:

- Treme e teme.

- Paço (palácio) e passo (andar): “Ah Pregadores! Os de cá, acharvos-eis com mais Paço; os de lá, com mais passos." (VIEIRA, 2001, v. 1, p. 29). Nesse caso, há uma jogo entre pregadores que saem para evangelizar (passos) e pregadores que vivem na corte (Paço).

- Cura (tratamento, remédio, medicação) e cura (vigário, pároco), em "Ao cura da Sé que era naquele tempo, introduzido ali por dinheyro, e com presunções de namorado satyriza o poeta como creatura do prelado", atribuído a Gregório de Matos (2010, v. 1, p. 208):

O Cura, a quem toca a cura de curar esta cidade, cheia a tem de enfermidade tão mortal, que não tem cura: dizem, que a si só se cura de uma natural sezão, que lhe dá na ocasião de ver as moças no eirado, com que o Cura é o curado, e as Moças seu cura são

Desta meizinha se argúi, que o tal Cura assezoado mais the rende o ser curado, que o Curado, que possui, grande virtude the influi o curado exterior: mas o vício interior Amor curá-lo procura, porque Amor todo loucura, ser a cura é de louco amor.

O que se observa nesse trecho do poema é que, paralelamente à paronomásia e aos ecos, o enunciador explora as ambiguidades eróticas. A sátira, composta de diversas homonímias, inverte a ação espiritual do Cura (pároco), que, em vez de curar espiritualmente seus fiéis, é curado pela conjunção carnal com seu 
objeto de valor: sua excitação (natural sezão [febre]), seu furor sexual, é aplacado pela relação sodomita.

Em todo poema, há uma relação constante de englobante e englobado, em que o vocábulo $\mathrm{CU}$, escolha constante em Gregório, é a base de onde derivam novas escolhas paradigmáticas, que vão, sintagmaticamente, proporcionando o progresso textual: cura $(8 x)$, curar $(2 x)$, curado $(3 x)$, proCURA (1x), IOUCURA (1x):

\section{CU \\ Cura \\ Curar \\ Curá-lo \\ Curado \\ Procura \\ Loucura}

Há no exemplo um jogo mútuo de som e sentido, de caráter latente e virtual do ponto de vista sintático e morfológico, visto que, partindo da sílaba cu, derivam-se e flexionam-se outras palavras. A patente correspondência entre PC e PE estabelece uma relação necessária e interdependente, engendrando um poema, que seduz inicialmente pelo som - um lampejo estético sensível -- e, posteriormente, pela descoberta do sentido, sua faceta inteligível.

A semelhança de sons, fruto da paronomásia, é tanto quanto a metáfora uma operação paradigmática. A metáfora trabalha na linha de semelhança de significado; a paronomásia na de semelhança de significante. Inumeráveis ocorrências de sons similares criam condições para o surgimento de fenômenos como paronomásia, rima, assonância. 
- Assonância - do latim assonare, produzir repetição sonora, ressoar. Consiste na repetição sonora de uma ou mais vogais no interior do verso em forma de aliteração (MOISÉS, 2011, p. 43):

toura

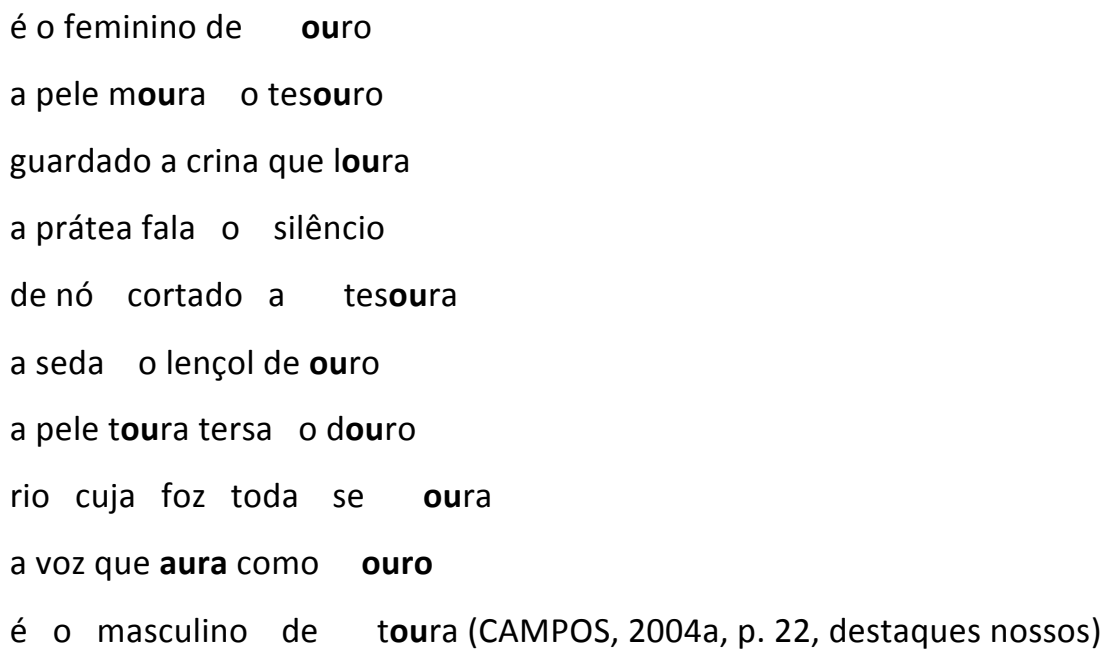

Basicamente, há uma oposição entre o som da vogais abertas /a/, / $\varepsilon /$ e os sons fechados de /i/, /e/, /o/, /u/:

/e//o//i//i//e//o//u//o/

/a/ /e/ /e/ /o/ /u/ /a/ /o//e/ /o/ /u/ /o/

/u/ /a/ a/ /o/ /a/ /i/ /a/ /u/ /e//o//u/ a/

/a/ /a/ /e/ /a/ /a//a//o/ /i/ /e/ /i/ /o/

/e/ /o/ /o//a//o//a//e//o//u//a/

/a/ /e/ /a/ /o/ /e/ /o/ /e/ /o/ /u/ /o/

/a/ /e/ /e/ /o/ /u/ /a/ /e/ /a/ /o/ /o/ /u/ /o/

/i/ /o/ /u/ /a/ /o/ /o//a/ /e//o//u//a/

/a/ /o/ /u/ /e/ /a/ /u/ /a/ /o/ /o/ /o/ /u/ /o/

/e/ /o/ /a/ /u/ /i/ /o/ /e/ /o/ /u/ /a/

À semelhança da oposição dos sons, no primeiro e no último verso, há uma oposição morfológica: "é o feminino de ouro" e "é o masculino de toura". O poema engendra um jogo em que as 
palavras se assemelham na sonoridade: ouro, moura, tesouro, loura, tesoura, ouro, toura, douro, oura, aura, ouro, toura. Como no poema atribuído a Gregório, visto anteriormente, é o paradigma que permite as associações e o progresso do processo (sintagma). De cada palavra, o enunciador processa um novo verso. Assim é que ouro puxa o trabalho escravo do negro ("pele moura") em busca de tesouro. O cavaleiro (o capataz que toma conta dos escravos), sobre um cavalo de crina alourada ("loura"), quando fala, produz o silêncio dos escravos. Como se vê, as metáforas agudamente condensadas vão brotando do texto, produzindo uma figura que a retórica chama de hipotipose (pintura com palavras, a ser vista no capítulo 5, cf. LAUSBERG, 2004, p. 218). O enunciador reduz, assim, a distância da cena narrada, fazendo com que o enunciatário seja seu cúmplice ou testemunha visual, em virtude do acúmulo de pormenores constituídos pela agudeza.

Em "nó cortado a tesoura", o enunciador orienta-nos para uma dificuldade insolúvel (nó górdio), que só se minimiza se cortada com a tesoura. Toda a acumulação de riquezas, promovida pelo trabalho escravo na escavação do ouro, resulta em roupas de seda, lençol de ouro para os que nunca se enrugaram por trabalhar ao sol ("pele tersa" - pele lustrosa, íntegra, sem mancha de sol).

A metáfora condensada de "douro", rio de Portugal, encaminha o sentido para o português, explorador das riquezas do Brasil.

Em a "foz toda se oura", temos o final do percurso narrativo, em que o trabalho do oprimido resulta em benefício na foz do opressor. Em "oura", o poeta inverte a posição do /a/ com /o/; assim, em vez de "auro" [áureo], temos "oura", um jogo sonoro que sugere a violência semântica em homologação com a violência do colonizador em busca do ouro.

Em "aura como ouro", novamente o enunciador troca o /o/ inicial e final de /ouro/ por /a/, configurando o poder trazido pela riqueza. Retomando o título do poema "toura", verificamos que, 
ironicamente, o enunciador sugere que, com a riqueza, tudo se pode subverter: feminino de ouro (oura no antepenúltimo verso) e de touro ("toura" no último verso). O que notamos no poema é que, por meio das associações sonoras produzidas no eixo do paradigma, dá-se a constituição do processo poético. De certa forma, o enunciador mostra na estrutura do enunciado a arquitextura do poema agudo do final do século XX.

○ Homeoteleuto -- seleção por terminação semelhante; consiste na identidade fonética das terminações das palavras finais de um verso ou de uma oração. Registrada primeiramente por Aristóteles, é considerada a matriz da rima; esta se constitui um caso particular de homeoteleuto (LAUSBERG, 2004, p. 226; MOISÉS, 2011, p. 224; HOUAISS; VILLAR, 2001):

o elogio da xilo

a xilo
o isso
da xilo
o aquilo
a eira
a beira
da madeira
a xilo
a arte da
xilo
-
a feira
o cordel
a bandeira
o corte
a parte da
madeira
o ferro
o norte
o recorte
do ferro
na madeira

a xilo 


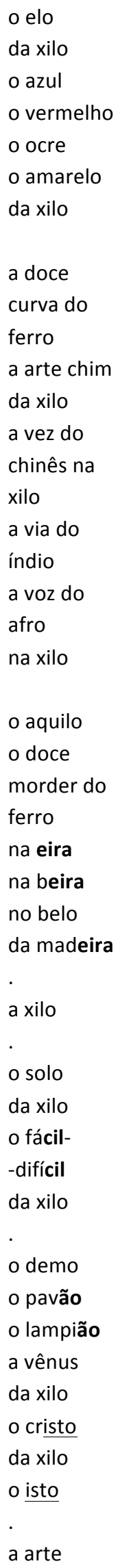




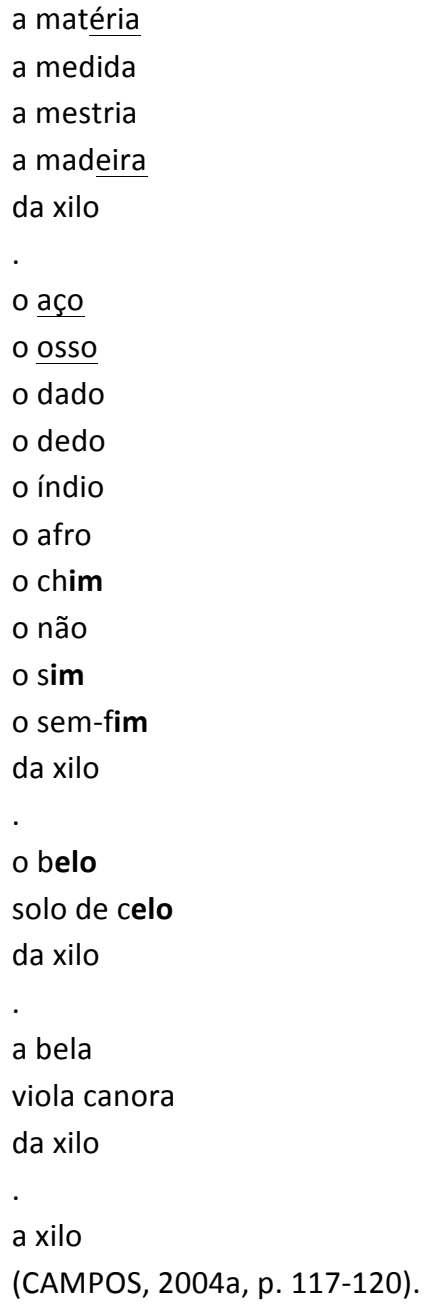

Para Lopes (1981, p. 92, destaque no original), "essas figuras todas, de grande importância na criação poética, derivam dos automatismos presentes no processo da seleção paradigmática referente ao plano da expressão". São da ordem, portanto, do paradigma do $\mathrm{PE}$, que, nesta tese, designamos agudeza do $P E$.

Ao lado das figuras do paradigma do $P E$, há as do paradigma do $P C$, que é o caso das metáforas. Tomando como exemplo uma metáfora comum:

\section{Maria é uma flor.}

o termo flor aplicado a um ser humano pode ter o sentido de que Maria é perfumada, delicada, bonita, semas intersectores, que constituem o fundamento da metáfora; pelo fato de flor e Maria possuírem qualidades semelhantes que se imbricam, estas funcionam como conectores de isotopia, possibilitando abertura para vários planos do conteúdo (cf. LOPES, 
1987, p. 29). Aqui, o caso é de semelhança e não de identidade. A metáfora flor é uma figura paradigmática do PC, pois Maria poderia ser:

\author{
uma flor \\ um doce \\ um pão \\ um avião \\ uma lesma etc.
}

Com base na retórica antiga, Lopes (1987, p. 24, destaques no original) define metáfora:

\begin{abstract}
como uma comparação abreviada, elíptica, concebida nos termos de uma figura do plano de conteúdo (um metassemema) resultante de uma comparação entre dois termos $\mathrm{A}$ e $\mathrm{B}$, tomados como impropriamente semelhantes entre si; $A$ seria, então, o termo a definir - o comparado - e $B$ o comparante que o define a partir de um fundamento (sema comum a $\mathrm{A}$ e B) impróprio, com supressão da partícula comparativa (como, qual, tal, tal como...).
\end{abstract}

Enquanto a comparação tem um caráter mais prosaico, que se relaciona com algum tipo de grau zero da linguagem, a metáfora é gradualmente mais obscura e enigmática e, portanto, "mais apta a exprimir a intuição poética, com toda sua carga de estranhamento" (LOPES, 1987, p. 25).

Comparações e metáforas exprimem valores que resultam da associação de duas ideias que se comparam. Na comparação, "a definição do termo comparado A traduz um saber ao modo do parecer" (LOPES, 1987, p. 27, destaques no original); nesse sentido, o termo comparado parece, "mas não é" é uma "figura construída como um análogo simulado" (LOPES, 1993, p. 150). Temos, portanto, uma simulação. Na metáfora, "a definição do termo comparado A traduz um saber ao modo do ser" (LOPES, 1987, p. 27, destaques no original); nesse sentido, o termo comparado "é, mas não parece" é uma "figura construída como um análogo dissimulado" (LOPES, 1993, p. 151).

As paráfrases científicas do tipo $\mathrm{H}_{2} \mathrm{O}=$ água exprimem "uma relação unívoca entre os vocábulos de uma língua" (LOPES, 1987, p. 29). Já as paráfrases não científicas ocorrem na poesia, na prosa literária, nas conversações do dia-a-dia: moro com uma flor, minha mulher 
(minha mulher é delicada, perfumada, bonita etc.). Enquanto no discurso científico, as paráfrases estabelecem identidade absoluta da ordem da univocidade e produzem o efeito de sentido de "verdade", nas metáforas não científicas ou literárias, como é o caso das metáforas poéticas, a equivalência é por similaridade, não por identidade absoluta.

Assim, no discurso poético, as metáforas, segundo Lopes (1987, p. 30, destaques no original), se fazem por meio de escolhas paradigmáticas incompatíveis no nível do sistema. Elas produzem um saber dissimulado, que "é saber, ainda que o não pareça - um conhecimento da ordem do segredo e do mistério, pois, que por isso mesmo tem de ser postulado e em razão disso vem sobremodalizado pelo crer: os mistérios só são verdades quando cremos neles" (p. 30). A comparação, que se utiliza de como, tal, tal como, não manifesta um mistério, apenas um parecer e aqui se distancia da metáfora, pois que esta última articula o "ser com não parecer". Nesse caso, Maria é flor, mas não parece. E, por ser e não parecer, a metáfora é da ordem do mistério, enquanto a comparação, parece, mas não é, é da ordem da simulação. Graficamente, temos:

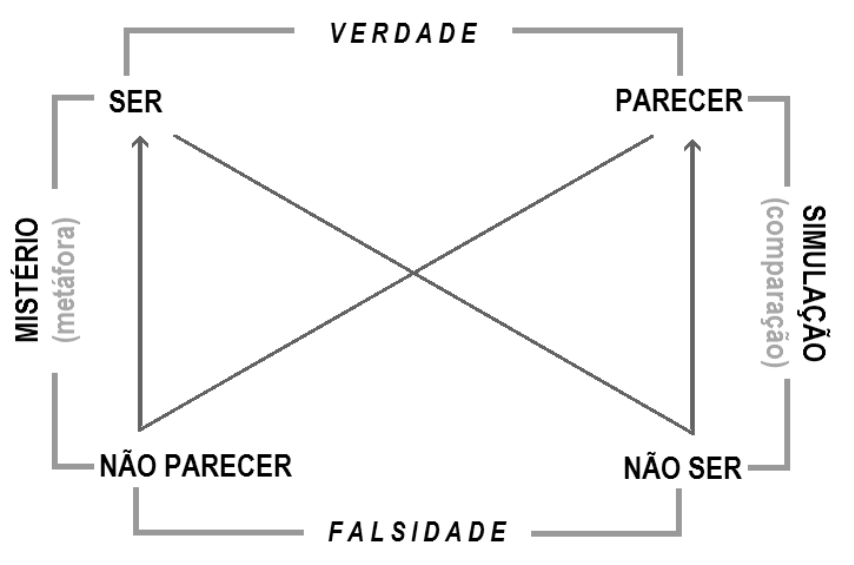

Fonte: Lopes (1987, p. 32).

Na metáfora poética, a preocupação não é revelar "verdade" ou "falsidade", mas erigir um mistério, um enigma. Por aproximar inesperadamente termos distantes, a metáfora aguda tem um potencial de engendrar no poema o efeito de estranhamento, de maravilhamento. Com base em Jakobson, Lopes $(1987$, p. 25) frisa não se poder confundir metaforicidade com poeticidade "num paralelismo absoluto". Como sabemos, a metáfora é utilizada em qualquer tipo de discurso: poético, ensaístico, científico. Considerando que é da essência das línguas naturais serem metafóricas, e que a metáfora é uma criação discursiva, 
não seria pertinente afirmá-la como desvio, pois nesse caso estaríamos nos apoiando em uma referência extratextual. Como tudo se constrói por associações e combinações, paradigmas e sintagmas, como manter o conceito de desvio e impropriedade?

Cada metáfora constitui-se em substituição de um termo em ausência (paradigma) por um termo em presença (sintagma), que, conforme a distância entre os termos, menos agudos ou mais agudos, promove menor ou maior efeito de estranhamento. A arte, para Hansen (2006b, p. 157), é "um jogo de signos analógicos que estabelecem relações entre coisas próximas e distantes, entre uma qualidade dada e uma qualidade oculta". Nesse sentido, dois planos do conteúdo se chocam, duas retas desembocam no cume do já apresentado triângulo de Sarbiewski (figura 2.1).

Em seu estudo "Em direção à imagem-acontecimento?", Zilberberg (2011a, p. 182) afirma que "a competência, até então confiada a um poeta que dominava as figuras e os poemas de formas fixas, foi transferida por Bachelard à linguagem, e por Breton à imaginação". Em seguida, revela adotar um ajuste da distância a ser estabelecida entre a metáfora e a comparação, citando Fontanier e Dumarsais.

Para Fontanier (1977, p. 100), a metáfora deveria ser verdadeira e justa, luminosa, nobre, natural e coerente e seria "natural" se não contemplasse semelhança entre termos muito distantes, mais do que o pensamento possa reconhecer. Zilberberg (2011a, p. 182), por sua vez, ressalta que "diante disso é claro que ela se inscreve sem dificuldade nessa semiótica da desigualdade dos intervalos que [...] marca, do ponto de vista paradigmático, sua predileção pela moderação dos subcontrários, $\mathrm{S} 2 \leftrightarrow \rightarrow \mathrm{S} 3$, e sua recusa de veemência dos sobrecontrários, $\mathrm{S} 1 \leftarrow \rightarrow \mathrm{S} 4$ ":

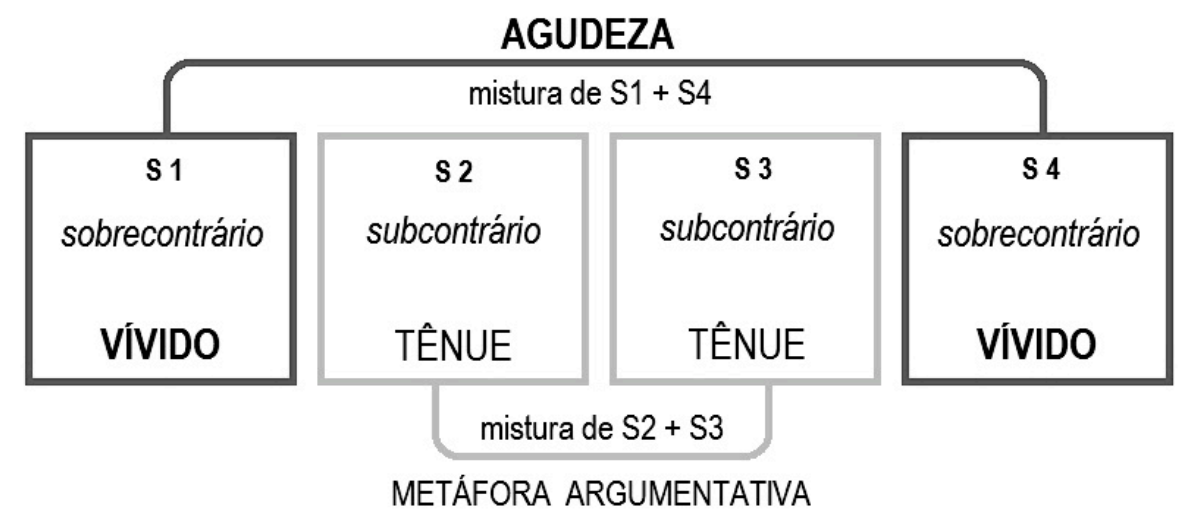

Nota: Com apoio na Dialética da duração de Bachelard (2010), Zilberberg admite que entre os contrários há uma gradação, pois há contrários que são mais hostis e outros que apresentam contrariedades mínimas, ou seja, temos os mais hostis e os menos distantes (subcontrários); daí Zilberberg estabelecer duas ordens de contrários, os tônicos, mais distantes/sobrecontrários, e os átonos, próximos/subcontrários. 
As metáforas de Aristóteles, de Dumarsais, de Fontanier subordinam-se à analogia; Zilberberg (2011a, p. 183) propõe chamá-la de metáfora-argumento e contrapõe a ela a metáfora-acontecimento, que chamamos aqui de metáfora aguda. Nos três primeiros autores citados, a metáfora alia-se à semelhança, que a endossa. Por isso, entende que a metáfora é implicativa, entimêmica, motivada.

Já a metáfora-acontecimento é concessiva, porque requisita o inesperado, a novidade. Nesse sentido, enquanto a primeira é resultativa, preservando a doxa, a segunda é ocasional, rompendo com ela.

Em seguida, Zilberberg cita Reverdy (p. 184), para quem "quanto mais distantes e justas as relações entre as duas realidades, mais a imagem será forte - mais terá potência emotiva e realidade poética". E nesse ponto Zilberberg aproxima-se muito daquilo que nesta tese tratamos como agudeza.

Tomando como exemplo trecho do poema "Antiode", de João Cabral de Melo Neto (1999, p. 98), verificamos logo no primeiro e segundo versos uma metáfora menos tônica, mais tênue, a que Zilberberg chama metáfora argumentativa:

Poesia, te escrevia:

flor! conhecendo que és fezes. Fezes como qualquer,

Na primeira metáfora $(A)$, flor aproxima-se de poesia, pois temos uma intersecção sêmica cujos traços /beleza/, /sensibilidade/, /delicadeza/ são comuns tanto à poesia quanto à flor. Notamos uma impertinência semântica de grau menor do que a metáfora aguda. A distância que separa um e outro termo (poesia $\rightarrow$ flor) é pequena, não causando maior impacto para o enunciatário. Já no terceiro verso (B), ao aproximar poesia de fezes, a distância semântica entre os termos aumenta, causando vívido impacto; e nesse caso temos o que Zilberberg chama de metáfora-acontecimento e nós chamamos de metáfora aguda ${ }^{5}$.

Intensifica-se, pois, na metáfora aguda um traço e não todos, ou seja, no caso a grandeza /bizarra/, por triagem, cria um novo sentido para poesia ("poesia $\rightarrow$ fezes"). Como a distância percorrida entre um termo e outro dá-se de forma impactante, maravilhante,

\footnotetext{
${ }^{5}$ Talvez Zilberberg não tenha entrado diretamente com a obra dos tratadistas seiscentistas, mas sua teoria tem muitos pontos de contato com o conceito de agudeza.
} 
temos uma aceleração de ordem sensível e uma desaceleração do reconhecimento inteligível.

No caso de "poesia $\rightarrow$ flor", como o impacto é menor, temos uma graduação menor em aceleração se comparada com a metáfora aguda ("poesia $\rightarrow$ fezes"). Nesta última, o enunciador rejeita a poesia "perfumada", largamente conhecida pela doxa, para assumir outros valores, o de poesia do feio, do mau cheiro, das mazelas da vida, do bizarro de Baudelaire. Desse modo, a agudeza dá-se pelas cifras de acentuação da tonicidade, de aceleração, cujas descontinuidades provocam omissões de etapas do discurso; abreviam-se as durações, havendo um corte de elevada vivificação. Na metáfora argumentativa, ocorre um corte que deixa ver as implicações - poesia, logo flor; na metáfora aguda, ocorre um corte concessivo - embora fezes, poesia. A metáfora aguda nada mais é do que precipitação, encaminhando-se a um processo de condensação.

A metonímia, por sua vez, faz-se por uma relação de causa e consequência e a sinédoque por uma relação de parte e todo; com base nisso, depreendemos uma cifra de desaceleração se comparada à da metáfora (cf. TATIT, 1997, p. 22). Por ser mais desacelerada, o andamento metonímico retoma as continuidades e, com as continuidades, se restabelece a duração, permitindo a reconstrução, uma forma de recuperação, uma costura na descontinuidade. Por exemplo: "Enquanto almoça, Marina ouve Bach". Ouvir Bach é ouvir uma obra musical que Bach produziu. Esse restabelecimento da continuidade carrega uma cifra tensiva de menor aceleração se comparada à da metáfora.

É então a falta de relação direta entre os termos da metáfora que produz a aceleração. Fiorin (2008a, p. 118) afirma que tanto a metáfora como a metonímia são procedimentos discursivos de constituição do sentido: "nelas, o narrador rompe de maneira calculada as regras de combinatória das figuras, criando uma impertinência semântica que produz novos sentidos". A metáfora e a metonímia não são propriamente a substituição de uma palavra por outra, mas nova possibilidade de leitura criada pelo discurso.

Assim é que a distância entre os termos aumenta na metáfora aguda, vivificando-se pelo estranhamento entre a extrema separação semântica entre eles:

Y é Z.

Y é simultaneamente $\mathrm{Y}$ e não $\mathrm{Y}$. 
No enunciado seiscentista já citado, "o casal é damasco", simultaneamente temos casal e não casal. A agudeza constitui-se pela reunião de dois sentidos opostos: casal é casal e casal é damasco. Quando se diz que "um casal é damasco", o casal continua tendo as qualidades de casal e adquire também a qualidade de ser damasco, o que configura um estranhamento, pois damasco não é propriedade humana e, portanto, não se amalgama com casal. Nesse caso, quando se diz que o "casal é damasco", referindo-se a ela como dama e a ele como asqueroso (asco), juntam-se duas qualidades incompatíveis, mas que se atualizam sintagmaticamente no nível do não esperado.

Nos poemas seiscentistas e nos poemas do final do século $X X$, essa operação de agudeza manifesta-se, muitas vezes, em grau acentuado e acelerado, provocando maravilhamento no enunciatário:

$\rightarrow$ em um primeiro momento, êxtase sensível pelo impacto sonoro e/ou visual:

a. "pela toura terza o douro" $\rightarrow$ sensibilidade dada pelo som, que produz um maravilhamento ou estranhamento no primeiro contato;

b. em "amizades de um Visconde, / favores de um Conde vis" $\rightarrow$ sensibilidade sonora e visual. O maravilhamento é dado pela alternância do som VISCONDE -> CONDE VIS e pela posição quiasmática dos grafemas:

vis conde

conde vis

$\rightarrow$ em um segundo momento, maravilhamento dado pela resolução do cálculo do reconhecimento inteligível da agudeza do PC. Assim é que a operação poética não se dá exclusivamente como procedimento sensível; é também da ordem do inteligível. O objeto agudo proporciona, pois, dupla fruição ou duplo êxtase.

Ademais, a metáfora aguda do PC caminha da justaposição para a posição absoluta. Vejamos as possibilidades de posição metafórica no enunciado, segundo Lopes (1987, p. 37):

a. aposição pospositiva $(X, Y)$ : $O$ menino $(X)$, aquele vendaval $(Y) \ldots$

b. aposição prepositiva $(\mathrm{Y}, \mathrm{X})$ : Aquele vendaval $(\mathrm{Y})$, o menino $(\mathrm{X}) \ldots$

c. justaposição pospositiva (XY): Aquele menino-vendaval (XY)...

d. justaposição prepositiva (YX): Aquele vendaval-menino (YX)...

e. assimilação pospositiva ( $\mathrm{X}$ de $\mathrm{Y}$ ): Aquele menino de vendaval $(\mathrm{X}$ de $\mathrm{Y}) \ldots$ 
f. assimilação prepositiva ( $\mathrm{Y}$ de $\mathrm{X})$ : Aquele vendaval de menino $(\mathrm{Y}$ de $\mathrm{X}) \ldots$

g. posição absoluta: há uma condensação aguda de $\mathrm{X}+\mathrm{Y}$ : $\mathbf{O}$ vendaval... Retomando o poema "toura" de Haroldo de Campos, "douro" está no lugar de português ou colonizador. O poema não diz que o português é douro, simplesmente diz condensadamente "douro", rio de Portugal.

Neste último caso, já não temos a figura do menino nem do português, mas apenas a condensação aguda de menino + vendaval e, por isso, ele passa a ser chamado de vendaval, bem como o português passa a ser condensado em douro.

Algumas posições metafóricas identificam-se mais com o classicismo: as letras (a) e (b); na poesia da agudeza, temos o encaminhamento para a metáfora na posição absoluta.

Em suma, o trabalho do poeta agudo talvez seja mais intensamente paradigmático e menos intensamente sintagmático. Quando o trabalho é dominantemente da ordem do paradigma do $P C$, temos um poeta voltado para a agudeza do $P C$; quando o trabalho é de dominância da ordem do paradigma do $P E$, temos um poeta voltado para a agudeza do $P E$.

Como sabemos, a poesia sempre se atribuiu como tarefa os refreamentos formais; a performance do poeta é evidenciar os significantes. E por que então a agudeza em foco? A agudeza seria fundadora de um fazer que se afasta pouco a pouco do icástico e encaminhase ao fantástico, simulando objetos estéticos mais fluidos que nítidos, como veremos ao longo desta tese.

A seguir, antes de considerar as propriedades da agudeza, verificaremos como exemplo de poeta agudo, John Donne. Em sua poesia, é patente não apenas a agudeza do PC, mas também a do PE. Nesse sentido, a poética do final do século XX encontra em Donne, por meio de Augusto de Campos, uma amostra de poeta que mescla as estratégias do significante e do significado.

\subsection{Formas agudas em Augusto de Campos e John Donne}

A agudeza é um ofício engenhoso que opera no enunciado poético articulações formais tanto com o PE quanto com o PC. Na poesia de Augusto de Campos, "John Donne: o dom e a danação", temos uma amostra do fazer poético agudo do final do século XX: estratégias de condensação no conteúdo; vivificação da expressão: aliteração, anagrama, paronomásia, exploração do espaço branco da página como significante etc. 
Ao mesmo tempo que explicita a engenhosidade do poeta seiscentista inglês, o poema de Augusto de Campos constitui-se também em um enunciado de dominância da agudeza do PE.

Vejamos inicialmente o poema (A. CAMPOS, 1986, p. 39-43):

\section{John Donne: o dom e a danação}

é. john donne (1572-1631) não teve $\rightarrow$ Augusto de Campos um $4^{\circ}$ centenário como o de shakespeare, john donne, primo pobre de shkspr, como sá de miranda, primo pobre de camões, melhor que camões.

mirabilis miranda, "poeta até o umbigo os baixos prosa":

não vejo o rosto a ninguém cuidais que são e não são homens que não vão nem vêm parece que avante vão entre o doente e o são mente a cada hora a espia na meta do meio dia andais entre o lobo e o cão

contra a "tradição de tagarelas" (perto disso até camões é palavroso) sá(de miranda)carneiro:

comigo me desavim fui posto em todo perigo não posso viver comigo não posso fugir de mim

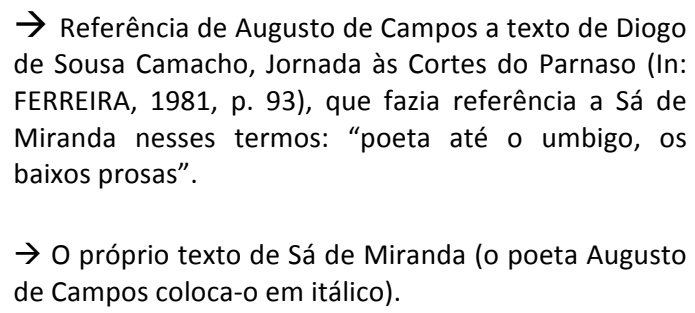
de Sousa Camacho, Jornada às Cortes do Parnaso (In: FERREIRA, 1981, p. 93), que fazia referência a Sá de Miranda nesses termos: "poeta até o umbigo, os baixos prosas".

$\rightarrow$ O próprio texto de Sá de Miranda (o poeta Augusto de Campos coloca-o em itálico).

$\rightarrow$ (condensação entre Sá de Miranda e Sá Carneiro)

$\rightarrow$ Sá de Miranda

$\rightarrow$ Trecho do poema “Dispersão" de Sá Carneiro porque eu era labirinto e agora quando me sinto é com saudades de mim)

que meio espero ou que fim $\rightarrow$ Sá de Miranda do vão trabalho que sigo pois que trago a mim comigo tamanho imigo de mim? 
imigo, sim, i-migo

(imago)

inimigo de mim, anti-migo,

imigo, onde a paronomásia com comigo

reetimologiza a palavra

"pronome em lugar do nome"

imigo, o inimigo em mim

assim john donne, primo pobre

de jacquespère, melhor do que

ele, poeta por poeta,

embora shkspr seja maior,

se é q me entendem

john donne

"antes muerto que mudado"

SCIENS, NESCIS

disse vieira

(tinha 25 anos quando o deão donne

morreu)

no "sermão do mandato" (1645)

SCIENS JESUS

TU NESCIS

"só cristo amou finamente

porque amou sabendo:

SCIENS

só os homens foram finamente amados

porque foram amados ignorando:

NESCIS

unindo-se porém

e trocando-se de tal sorte

o SCIENS com o NESCIS

e o NESCIS com o SCIENS

que estando a ignorância

da parte dos homens

e a ciência

da parte de cristo,

cristo amou, sabendo,

como se amara, ignorando;

e os homens foram amados,

ignorando,

como se fossem amados sabendo.

vá agora o amor

distorcendo estes fios

e espero que todos vejam

a fineza deles."

SCIENS

(mas ninguém viu o anagrama)

NESCIS

eles são cegos aos significantes $\rightarrow$ Augusto de Campos

$\rightarrow$ Augusto de Campos

$\rightarrow$ citação direta a Vieira

$\rightarrow$ Vieira é citado entre aspas por Augusto de Campos $\rightarrow$ Augusto de Campos - texto entre parêntesis. 
só veem significados

donne, undone

pois é: donne, ele sabia

das coisas.

que outro foi capaz

de fazer um poema diáfano tão sólido

como o êxtase

maravilhosa fusão de concreto e abstrato?

nossas mãos claramente cimentadas

$\rightarrow$ John Donne

no firme bálsamo que delas vem,

nossas vistas trançadas e tecendo

os olhos em um duplo filamento

ou como em despedida: proibindo o pranto

$\rightarrow$ Augusto de Campos cita trecho de Donne

que (diria joão cabral)

"a atenção lenta desenrola":

$\rightarrow$ De João Cabral de Melo Neto

assim serás para mim que pareço

$\rightarrow$ John Donne

como a outra perna obliquamente andar.

tua firmeza faz-me, circular,

encontrar meu final em meu começo.

ou como a corajosa elegia: indo para o leito, strip-tease meta-físico, q o pun

d'onor da época vetou na $1^{a}$ edição:

a coberta de um homem te é bastante

donne arriscou-se

a "danação provinciana"

para ensinar que a poesia

é sempre o contrário

do que dizem as regras que ela é

"a verdadeira regra - disse marino -

é saber romper as regras"

(eu sei q já disse isso antes

mas o estou dizendo outra vez

e isto é poesia)

vejam

em a relíquia

a surpreendente montagem túmulo-mulher

e a pedra-de-toque

de um dos seus versos condenados

("jaw-breaking" - quebra-queixo - diziam):

"a bracelete of bright hair about the bone"

que encantou eliot

e desespera os tradutores

$\rightarrow$ Augusto de Campos cita trecho de Donne

$\rightarrow$ John Donne

$\rightarrow$ Augusto de Campos

$\rightarrow$ Citação direta de Giambattista Marino (Marinismo)

$\rightarrow$ De Augusto de Campos

$\rightarrow$ Augusto cita poema de Donne

$\rightarrow$ Verso de Donne 


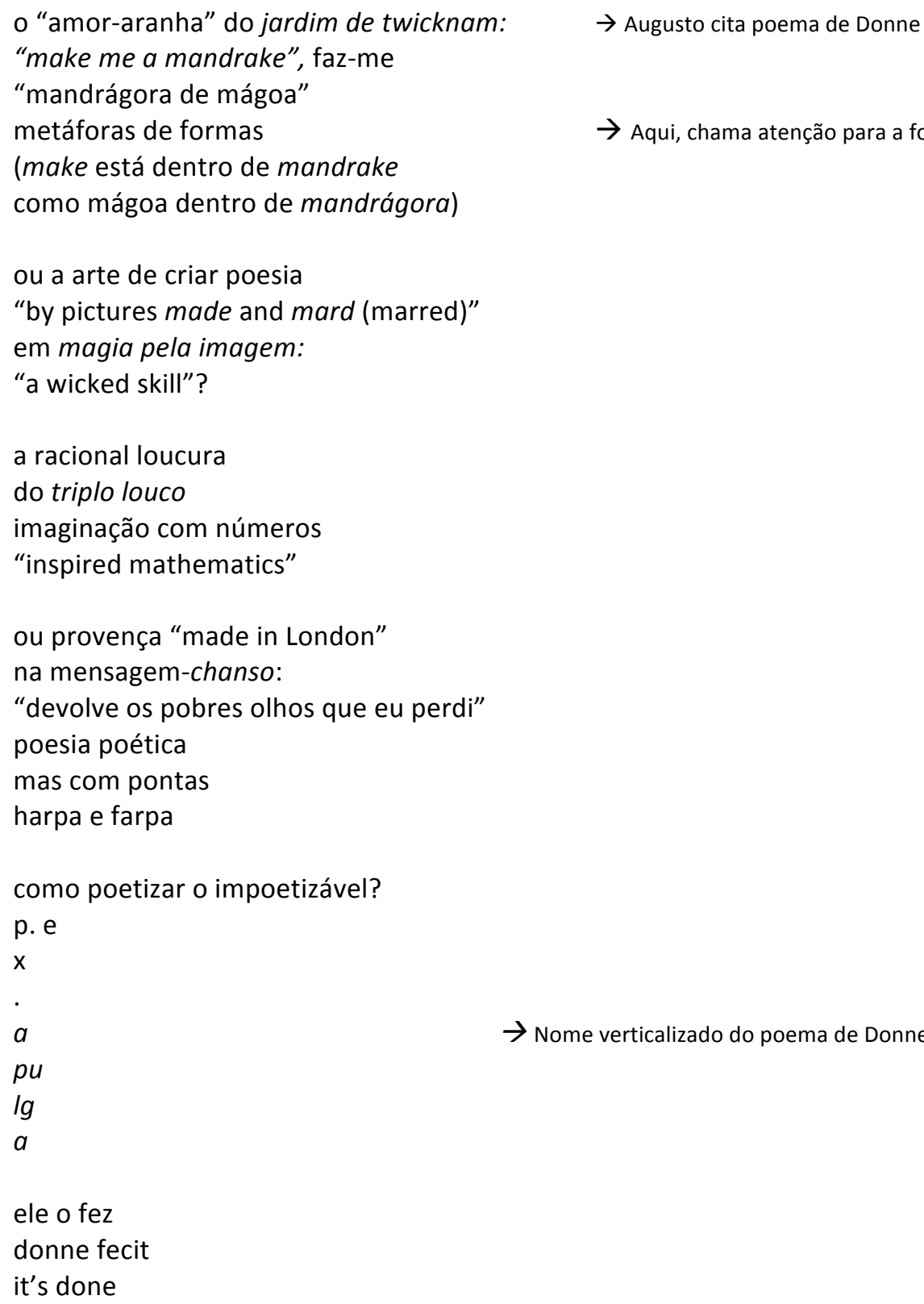

No título "dom e danação", há um jogo linguístico produzido pelo nome próprio Donne e o substantivo português dom. Dom e donne homologam-se pelas categorias de identidade no $P E$ e de diferença no $P C$ : no $P E$, há identidade sonora, possibilitando diferença e duplo sentido no PC. Assim, o enunciador aproxima "donne" de duas palavras que se distanciam semanticamente, dois sobrecontrários: afinal, "dom" afasta-se totalmente de "danação". Ocorre que o poeta inglês, na visão do enunciador cuja pele discursiva é Augusto de Campos, teria granjeado adversários contrários à agudeza de seu fazer poético. Nesse caso, dom corresponde à valorização eufórica de Campos e danação, à valorização disfórica do poeta inglês por seus contemporâneos. No poema de Campos, "DONNE" condensa 
acentuadamente duas figuras, dom e danação. Essa economia linguística é outra característica da poesia do final do século XX.

O efeito de sentido de "dom" é ambivalente, pois é ao mesmo tempo um título honorífico de nobreza, digno de respeito, e predicador de talento. Nesse sentido, o fazer poético de John Donne acumula uma virtude e uma ruína. Daí Augusto de Campos afirmar em seu poema que "donne arriscou-se / a 'danação provinciana' / para ensinar que a poesia / é sempre o contrário / do que dizem as regras que ela é" (destaques nossos). No clima intelectual seiscentista, essas regras, constituídas por um destinador do fazer poético, determinavam convenções literárias rígidas, bem como um código moral provinciano.

Como John Donne não se sujeitava a repetir o código moral, seu fazer leva-o à condenação (danação). Seus pares, em choque com suas ideias (PC), recusavam aceitar também suas agudezas do PE, como ocorre com a aliteração "a bracelet of bright hair about the bonne". Essa confluência de consoantes, um tipo de entravamento sonoro, era denominada por seus críticos e avaliadores de "jaw-breaking" [quebra-queixo]. Diferentemente dos julgadores de Donne, os tratadistas seiscentistas consideram os refreamentos sonoros, as agudezas de palavras, qualidades sensíveis do objeto estético.

A ambiguidade em dom (talento e título honorífico) é a mesma que faz oscilar o poema de Augusto de Campos sobre os dois eixos: o do PE e o do PC, ora chamando a atenção para o significante, ora para o significado. Nesse aspecto, a título de ilustração, verificamos uma variedade no número de versos das estrofes: 6-4-8-4-4-4-4-7-5-2-30-3-2-16-4-3-4-4-5-2-3-9-6-4-4-6-1-7-3. Além de manifestar o rompimento com qualquer expectativa de regularidade estrófica, o enunciador faz do seu poema um exemplo de poesia aguda do final do século XX:

- Constantes citações de textos de outros autores.

- Citações de poemas do próprio poeta John Donne, o homenageado.

- Mistura de línguas.

- Comentário críticos sobre o fazer poético.

E, por fim, mostra no final do poema a performance da agudeza do PE, quando distribui a palavra "pulga" na vertical, num exemplo de semissimbolismo, homolongando: 
PE: categoria verticalizada [letras salteadas na vertical] :: PC: categoria verticalizada [comportamento verticalizado do pulo da pulga, que pula e salta continuamente]

Para mostrar a superioridade de Donne em relação a Shakespeare, Augusto de Campos (1986, p. 43) reduz este último às suas consoantes; esvazia o enunciado das vogais "a e e a e", restando apenas "shkspr". Além de chocar o enunciatário com tal procedimento, o PC do signo "Shakespeare" é também esvaziado; nesse caso, homologa-se o novo PE "shkspr" a um novo PC. Enquanto Shakespeare é diminuído ("shkspr") tanto no PC quanto no $P E$, John Donne não se reduz, o que configura uma nova possibilidade de leitura de ambos os poetas ingleses. O maior agora é John Donne, o que ironicamente ressoa em "john donne, primo pobre de shkspr". Da mesma forma, ambiguamente, sugere que Sá de Miranda é primo pobre de Camões, mas melhor que Camões. Os arranjos poéticos de Augusto de Campos apoiam-se sobretudo na agudeza do PE; se um poeta se vale menos do ofício com os significantes, para Augusto tal poeta se vincularia à "tradição de tagarelas" (A. CAMPOS, 1986, p. 39).

Como estão divididos no poema, pode-se ler também, isoladamente no verso, "pobre de Camões", que Camões, no confronto com Sá de Miranda, revela-se um desaventurado; todavia, lendo todo o enunciado como um bloco único, notamos que John Donne, para Augusto de Campos, seria maior que Shakespeare e maior que Camões. O enunciador indica a razão do seu ponto de vista: esses poetas seriam de "tradição de tagarelas". Contra essa tradição, haveria poetas como Sá de Miranda e Sá Carneiro, que se ocupam de um fazer poético mais condensado, mais voltado, em alguns casos, para o artifício do PE:

contra a "tradição de tagarelas"

(perto disso até camões é palavroso) $\rightarrow$

sá(de miranda)carneiro (destaques nossos)
Saltando o verso entre parênteses, temos: contra a “tradição de tagarelas" sá(de miranda)carneiro.

Para mostrar a intertextualidade do texto de Sá Carneiro com o texto de Sá de Miranda, o enunciador evidencia no enunciado a condensação de um no outro:

\section{sá(de miranda)carneiro}

Nesse exemplo, Sá de Miranda foi englobado por Sá Carneiro. Vejamos os trechos dos dois poemas, lado a lado: 


\begin{tabular}{|c|c|}
\hline $\begin{array}{l}\text { Sá de Miranda, citado em parte por Augusto } \\
\text { de } \text { Campos }^{6}\end{array}$ & $\begin{array}{l}\text { Trecho do poema "Dispersão", de Sá } \\
\text { Carneiro, citado por Augusto de Campos } \\
(1986, \text { p. 40) }\end{array}$ \\
\hline $\begin{array}{l}\text { Comigo me desavim } \\
\text { Sou posto em todo perigo; } \\
\text { Não posso viver comigo } \\
\text { Nem posso fugir de mim. } \\
\text { Com dor, da gente fugia, } \\
\text { Antes que esta assi crescesse; } \\
\text { Agora já fugiria } \\
\text { De mim, se de mim pudesse. } \\
\text { Que meio espero ou que fim } \\
\text { Do vão trabalho que sigo, } \\
\text { Pois que trago a mim comigo, } \\
\text { Tamanho imigo de mim? } \\
\text { Fonte: MOISÉS (1988, p. 93-94). }\end{array}$ & $\begin{array}{l}\text { (perdi-me dentro de mim } \\
\text { porque eu era labirinto } \\
\text { e agora quando me sinto } \\
\text { é com saudades de mim) }\end{array}$ \\
\hline
\end{tabular}

A. Campos (1986, p. 40) elucida a focalização paronomásica de Sá de Miranda, mostrando o jogo anagramático entre comigo, mim, inimigo, imigo, imago, anti-migo. A palavra inimigo [anagramaticamente, temos INimigo, inIMIGO e iNIMigo; esta última formação de trás para a frente] compreende "in-imigo-min", indicando que o grande inimigo do homem está em si mesmo.

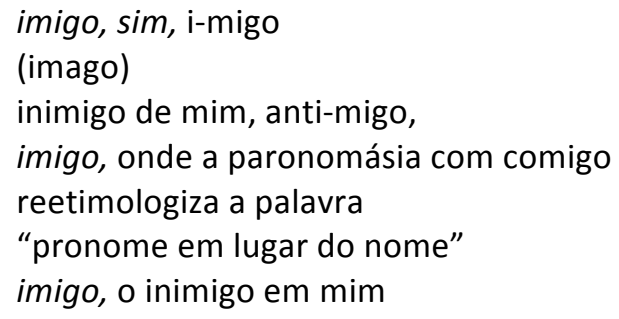

Ainda no poema de Augusto de Campos, notamos esse mesmo ludismo quando ele cita diretamente Padre Antonio Vieira; o pregador vê em SCIENS um anagrama de NESCIS:

\footnotetext{
${ }^{6}$ Augusto de Campos troca, na transcrição de versos de Sá de Miranda, "sou posto" por "fui posto".

${ }^{7}$ O poema de Sá Carneiro não traz os parênteses de Augusto de Campos, mas nos é perfeitamente compreensível o efeito de sentido produzido por eles, visto que a estrofe de Carneiro está compreendida pelas estrofes de Sá de Miranda, ou seja, apresenta uma estrofe de Sá de Miranda, uma estrofe de Sá Carneiro e, novamente, uma estrofe de Sá de Miranda. Portanto, no plano da expressão visual, os parênteses indicam não só uma intermediação gráfica, como também mostram que há uma relação intertextual dos poemas, estando um dentro do outro.
} 
SCIENS JESUS

TU NESCIS

"só cristo amou finamente

porque amou sabendo:

SCIENS

só os homens foram finamente amados

porque foram amados ignorando:

NESCIS

unindo-se porém

e trocando-se de tal sorte

o SCIENS com o NESCIS

e o NESCIS COM o SCIENS

que estando a ignorância

Além do quiasmo, observa-se o uso de letras maiúsculas, que chamam a atenção para o próprio significante.

da parte dos homens

e a ciência

da parte de cristo,

cristo amou, sabendo,

como se amara, ignorando;

e os homens foram amados,

ignorando,

como se fossem amados sabendo.

vá agora o amor

distorcendo estes fios

e espero que todos vejam

a fineza deles."

SCIENS

(mas ninguém viu o anagrama)

NESCIS

eles são cegos aos significantes

só veem os significados

O que se vê nessa agudeza linguística não é jogo estéril, mas uma tensão entre significante e significado: os significantes contribuem para acentuar e desacelerar o reconhecimento do significado. Nesse caso, pelo enunciado notamos conteúdos tão distantes (SCIENS / NESCIS) e tão próximos quando não englobados um no outro. John 
Donne igualmente se vale de anagramas e de paronomásias na construção de seus poemas, como vai ocorrer em "make me a madrake; so I may grow here", verso do poema "Twicknam Garden", ou seja, faz ver em madrake um anagrama de make. Assistimos nos poemas de Donne a um contraste fonemático, a uma produção de palavras que brotam de outras palavras, enfim uma urdidura poética que se faz particularmente com as agudezas.

Na poesia "John Donne: o dom e a danação", A. Campos estabelece uma linha de poetas agudos, que, assim como Donne, ocupam-se das agudezas do PE e do PC. Daí dizer: "pois é: donne, ele sabia / das coisas". Os poetas e prosadores intertextualizados no enunciado de A. Campos são:

- Sá de Miranda (In: MOISÉS, 1988, p. 93-94) $\rightarrow$ Poema "Comigo me desavim".

- $\quad$ Sá Carneiro (In: MOISÉS, 1988, p. 410-412) $\rightarrow$ Poema “Dispersão".

- Padre Antônio Vieira (2000, v. 1, p. 344) $\rightarrow$ "Sermão do mandato".

- João Cabral de Melo Neto (1999, p. 95) $\rightarrow$ sexto poema de Psicologia da composição.

O próprio A. de Campos (1986, p. 73), em "Donne em dobro", vê em "The expiration" um Donne mais secreto e propício às artimanhas da linguagem ("crioptologopeia") e se interroga, depois de mostrar a densidade fônica e gráfica do original, sobre se valeria a pena ao analista mostrar a espinha dorsal do poema. Depois de afirmar que vale, nos interroga:

- "mas como experienciar / a fundo a criação de um poema / sem desvendar o véu da sua oculta / urdidura subjacente?"

Afinal, perder o prazer que o desvendamento das artimanhas formais proporciona é perder o prazer das agudezas engendradas pelos sujeitos da enunciação: eis uma poesia "com pontas / harpa e farpa". Harpa no sentido de melódico e farpa no sentido de poesia aguda, de espetar a sensibilidade e a inteligibilidade do enunciatário.

O texto poético de A. de Campos extrai dos próprios poemas de Donne "a urdidura subjacente". Sinteticamente, em primeiro lugar, chama a atenção para a oposição "poesia palavrosa" e "poesia condensada" (a do novo fazer poético agudo); em segundo lugar, caracteriza a agudeza como operação estética de valorização de anagramas, aliterações, paronomásias, ecos, homeoteleutos, bem como do jogo contrastante de fonemas. Outro procedimento agudo relaciona-se com o artifício engenhoso que se extrai, às vezes, até 
mesmo da justaposição de prefixos e sufixos (donne/undone). Nesse caso, como dissemos, do[n]ne condensa dom com John DONNE, aptidão inata do poeta para fazer poesia, um doador de poesia, mas também criador reverenciado honorificamente. Ao prefixar negativamente undone (A. CAMPOS, 1986, p. 41), revela o percurso do poeta John Donne repleto de antissujeitos: críticos literários e críticos de sua moral. Undone, em inglês, é danado, arruinado. Ao fazer esse jogo de donne (dom) e undone (danação), Augusto de Campos condensa em undone dois planos de conteúdo: dom e ruína. 0 primeiro com o sentido de abençoado pelo presente da doação poética e o segundo, de depreciado pela crítica seiscentista contemporânea a ele.

Ao comentar o poema "A pulga", de Donne, outra vez Augusto de Campos mostra a agudeza do poeta inglês por meio dos fonemas e grafemas que saltam, mudam de lugar, fazendo a vista do enunciatário pular como pulga. Vejamos o poema de Donne:

The flea (John Donne In: A. CAMPOS, 1986, p. 70)

Mark but this flea, and mark in this, How little that which thou deny'st me is;

Me it suck'd first, and now sucks thee, And in this flea, our two bloods mingled be;

Confess it, this cannot be said A sin, or shame, or loss of maidenhead, Yet this enjoys before it woe, And pamper'd swells with one blood made of two,

And this, alas, is more than we would do.

Oh stay, three lives in one flea spare, Where we almost, nay more than married are:

This flea is you and $I$, and this Our marriage bed, and marriage temple is; Though parents grudge, and you, we're met,

And cloisterd in these living walls of Jet.

Though use make thee apt to kill me, Let not to this, self murder added be, And sacrilege, three sins in killing three.

Cruel and sudden, hast thou since Purpled thy nail, in blood of innocence?

In what could this flea guilty be, Except in that drop which it sucked from the? Yet thou triumph'st, and say'st that thou
A pulga (tradução de Augusto de Campos, 1986, p. 71)

Repara nesta pulga e apreende bem Quão pouco é o que me negas com desdém. Ela sugou-me a mim e a ti depois, Mesclando assim o sangue de nós dois. E é certo que ninguém a isto alude Como pecado ou perda de virtude. Mas ela goza sem ter cortejado E incha de um sangue em dois revigorado: É mais do que teríamos logrado.

Poupa três vidas nesta que é capaz De nos fazer casados, quase ou mais. A pulga somos nós e este é o teu Leito de núpcias. Ela nos prendeu, Queiras ou não, e os outros contra nós, Nos muros vivos deste Breu a sós.

E embora possas dar-me fim, não dês:

É suicídio e sacrilégio, três

Pecados em três mortes de uma vez.

Mas tinges de vermelho, indiferente, A tua unha em sangue de inocente. Que falta cometeu a pulga incauta Salvo a mínima gota que te falta? $E$ te alegras e dizes que não sentes Nem a ti nem a mim menos potentes. Então, tua cautela é desmedida. 
Find's not thy self, nor me the weaker now;

'Tis true, then learn how false, fears be; Just so much honor, when thou yield'st to me, Will waste, as this flea's death took life from thee.
Tanta honra hei de tomar, se concedida, Quanto a morte da pulga à tua vida.

A disposição gráfica dos versos de Donne também é sui generis: os avanços e os recuos dos grafemas nos versos sobre o branco da página desenham o vaivém contínuo das investidas da pulga e do cortejar dos amantes no "leito de núpcias". A essa primeira isotopia das picadas do inseto soma-se a isotopia erótica dos amantes na tentativa de conjunção, introduzindo assim nova direção de sentido.

Além da organização de grafemas e de fonemas, o poema é marcado por repetições ou reduplicações, também indicativas da reiteração da performance da pulga:

Mark but this flea, and mark in this,

[...]

Me it suck'd first, and now sucks thee

[...]

And in this flea, our two bloods mingled be;

[...]

And pamper'd swells with one blood made of two,

Oh stay, three lives in one flea spare,

[...]

This flea is you and I, and this

Where we almost, nay more than married are:

Our marriage bed, and marriage temple is [...]

Essa mesma operação iterativa do PC ocorre no PE por meio das aliterações. Assim é que, sem exaurir a busca de aliterações sem-fim, podemos verificar: "me it suck'd first, and now sucks thee, / and in this flea, our two bloods mingled be; / confess it, this cannot be said / A sin, or shame, or loss of maidenhead".

Considerando os fonemas no poema, constata-se uma tensão entre constritivas fricativas surdas, não vozeadas /f/-/s/ (flea [sete vezes], first, finds, false, fears, life, from, confess, suck'd, sucks, said, sin, self [duas vezes], sacrilege, sins, sudden, since, innocence, except, sucked, say'st, self) e constritivas fricativas sonoras, vozeadas /z/ (this [dez vezes], is 
[quatro vezes], bloods, alas, lives, almost, parents, these, use, hast, waste, as, flea's). Essas escolhas por parte do enunciador produzem a tensão entre o não vozeado da performance da pulga e o vozeado do som produzido pelo desacordo do casal no leito. Nesse sentido, dáse uma tensão no PE entre os fonemas não vozeados e vozeados, bem como uma oscilação tensiva entre a ruptura causada pela recusa da amada -- marcada por valores cristãos de uma sociedade conservadora, que impedem que ela vá para o leito antes do casamento, pois que vê o sexo apenas com fim utilitário de reprodução - e o pedido do amado para que ela ceda.

No enunciado, a agudeza está na vivificação em condensar o percurso da pulga no percurso dos amados: enquanto a pulga pica os amados, fundindo-lhes o sangue, o amado sugere que a conjunção de seus corpos fora feita "sem maldade" pela pulga que os picara, unindo-os pelo sangue, ou seja, os sangues já foram misturados no interior da pulga; daí a conjunção já ter sido efetivada. A metáfora aguda associa pulga a sacramento ${ }^{8}$. 0 "pecado ou perda de virtude" antes do casamento configura uma sanção negativa do destinador julgador, ator discursivo "os outros", a sociedade moralizante: "queiras ou não, e os outros contra nós".

O amado manipula a amada para a realização do enlace carnal: "repara nesta pulga e apreende bem / quão pouco é o que me negas com desdém". A pulga é seu coadjuvante quando diz para ela que não adianta negar, pois que a pulga já os enlaçara: "ela sugou-me a mim e a ti depois, / mesclando assim o sangue de nós dois"; "a pulga somos nós e este é o teu / Leito de núpcias. Ela nos prendeu".

Na pele do ator discursivo homem, um dos sujeitos admite a sanção negativa; no entanto, quer convencer sua amada a superar a avaliação social, caindo em seus braços: "que falta cometeu a pulga incauta / salvo a mínima gota que te falta?". Assim, como é natural a pulga picar para sugar sangue quente, a amada deveria ver como natural o ato de cópula entre os dois: "então tua cautela é desmedida. / Tanta honra hei de tomar, se concedida, / quanto a morte da pulga à tua vida". Como para a moça a morte da pulga não representa nenhum mal, o rapaz tenta dissuadi-la dos valores que ela traz para a cena: a cópula não se configuraria assim perda de virtude.

\footnotetext{
${ }^{8}$ Hansen (2006a, p. 108) comenta que os gêneros satíricos admitem "despropósitos propositais". Para nós, há contrato entre um fazer persuasivo e um fazer interpretativo (entre enunciador e enunciatário), que admite tais "despropósitos propositais", como o fato de condensar em "pulga" um "sacramento". Assim como a pulga junta sangues diferentes, o sacramento do matrimônio também o faz.
} 
No entanto, a amada mata a pulga e nega a cópula, acentuando hiperbolicamente a intensidade da resposta negativa. O amado sente essa ação como uma morte, que por metonímia é a morte de seu desejo. Diz a ela: "e te alegras e dizes que não sentes / Nem a ti nem a mim menos potentes". Seria um anacronismo ver na cena uma manipulação por imposição e intimidação do rapaz em relação à moça. Não se trata aqui de valor machista, mesmo porque o século seiscentista não conhecia esse recorte. Além disso, o rapaz não se configura no nível narrativo um antissujeito em relação ao sujeito, ator moça no nível discursivo; o antissujeito aqui são os valores morais da época, que impedem de os sujeitos realizarem a conjunção erótica.

Ainda no poema, há uma agudeza que condensa pulga+casal: "a pulga somos nós". Essa intensidade figurativa recebe o nome de alegoria, figura retórica central nos seiscentos. Segundo Lopes (1993, p. 155), a alegoria utiliza paralelamente no nível discursivo atores humanos e ator animal, que convivem no mesmo enunciado; temos, assim, a naturalidade do picar da pulga e a naturalidade do copular humano. O percurso narrativo da pulga figurativiza a tensão e a investida -- manipulação por tentação, visto que o objeto de valor cópula sexual é positivo na visão do rapaz --, configurando uma metáfora aguda, em que a história da pulga serve de contraponto para a história dos amantes:

\begin{tabular}{|l|l|l|l|}
\hline Estado inicial & Estado medial & Estado final & Resultado \\
\hline $\begin{array}{l}\text { Percurso do inseto: a } \\
\text { pulga pica os amados }\end{array}$ & $\begin{array}{l}\text { A pulga mescla o } \\
\text { sangue dos amados. }\end{array}$ & $\begin{array}{l}\text { A amada mata a } \\
\text { pulga ("a tua unha } \\
\text { em sangue de } \\
\text { inocente”). }\end{array}$ & $\begin{array}{l}\text { Sanção desmedida } \\
\text { por parte da moça } \\
\text { em relação à pulga } \\
\text { ("e te alegras e dizes } \\
\text { que não sentes”). A } \\
\text { pulga morre. }\end{array}$ \\
\hline $\begin{array}{l}\text { Percurso do casal: o } \\
\text { amado pede à } \\
\text { amada que ceda à } \\
\text { conjunção carnal. }\end{array}$ & A amada resiste. & $\begin{array}{l}\text { A amada continua } \\
\text { resistindo, apesar da } \\
\text { manipulação do há conjunção } \\
\text { amado. }\end{array}$ & $\begin{array}{l}\text { Naro hal, visto ser a } \\
\text { cautela da amada } \\
\text { desmedida. }\end{array}$ \\
\hline
\end{tabular}

A amada atenua a conjunção, porque incorpora os valores sociais de punição, enquanto o amado acentua a conjunção, porque, valorizando seu desejo, desconsidera os valores sociais. Trata-se de uma tensão entre os valores humanos e os valores morais sociais: 
Ele $\rightarrow$ acentua valores humanos (desejo)

Ela $\rightarrow$ acentua valores morais sociais ("boa conduta", segundo a moral vigente)

Ele + ela $\rightarrow$ incompatibilidade entre os eixos tensivos:

Da ordem da intensidade: o desejo, a ruptura dos valores sociais;

Da ordem da extensidade: a boa conduta vigente, a continuidade dos valores sociais.

Enfim, no poema, o amado manipula a amada nos seguintes termos: se me negas amor, matas-me como mataste a pulga. O exagero aqui é compreensível dentro do contrato enunciativo seiscentista. Ademais, a hipérbole vivifica o argumento na tentativa de fazer a moça ceder ao desejo. Ela sofre a mesma tensão, que brota do conflito de seu desejo -- ela já está com ele na cena -- com o controle moral e social; no entanto, ela permanece na extensidade da boa conduta. Notamos no poema uma operação silogística:

Silogismo 1: A picada da pulga é um ato natural.

A pulga picou o casal.

Logo, procedeu a um ato natural.

Silogismo 2: A cópula humana é um ato natural.

Dois sujeitos querem copular.

Logo, copular entre dois sujeitos seria um ato natural.

Como a figura da pulga alegoriza agudamente a figura do casal, podemos estabelecer uma síntese conclusiva: "a união sexual do casal não alteraria a virtude moral dos amantes". No entanto, no poema, a presença de valores morais estabelece um jogo tensivo entre o querer do casal e o dever social (costume) e ainda a negação desses valores morais por parte do enunciador.

\section{$A: B:: C: D$}

Picada da pulga $\rightarrow$ isenta de danos morais: o casal é condensado agudamente na figura discursiva da pulga.

Se a picada da pulga não afeta a entidade física do casal, logo o ato sexual não alteraria a virtude dos amantes. E se a picada da pulga é algo natural, logo o ato sexual deveria ser natural, não afetando a moral do casal. 
O sujeito da enunciação valoriza tanto os ornatos do PE quanto os ornatos dialéticos do PC. Há uma tensão entre dois planos de conteúdo: o desejo natural e o controle moral. Feitas essas considerações, esclarece-se em certa medida o título agudo e condensado do poema de Augusto de Campos, quando atribui a John Donne o "dom e a danação"; a contestação de valores sociais, bem como suas escolhas estratégicas agudas, resultou em avaliação negativa da obra de John Donne, que só foi recuperado gerações e gerações depois.

Donne era um poeta da agudeza; seu ofício astuto impediu que seus pares reconhecessem nele valor pelas artimanhas com os significantes, como ocorre na poesia "Twicknam garden", no penúltimo verso da segunda estrofe: "Some senseless piece of this place be; / make me a mandrake; so I may grow here", em que há uma agudeza anagramática, como vimos, da forma "make" englobada por "mandrake". Esse verso é traduzido por Augusto de Campos (1986, p. 62-63) com a mesma intensidade aguda formal: "Que eu me transforme em coisa que não sente, / MAndráGOrA de mágoa" (mágoa está dentro de mandrágora).

A crítica da época recepcionou os textos seiscentistas como excessivos, bizarros. Uma das razões resume-se em não valorizar o ofício do poeta com os significantes: "eles são cegos aos significantes / só veem significados/ donne, undone" (A. CAMPOS, 1986, p. 41). Talvez, a poesia do final do século XX sofra, assim como a seiscentista, o mesmo juízo negativo, sendo até acusada de poesia vazia no PC. Seria por se revelar intensamente artificiosa no PE?

Quase ao final de "John Donne: o dom e a danação", Augusto de Campos (1986, p. 43) mostra no PE as qualidades do poetar donniano, que "poetiza o impoetizável", fazendo uma pulga pular graficamente:
p. e
$\mathrm{X}$
$\cdot$
pu
$\lg$
a
ele o fez
donne fecit
it's done 
Finalmente, num processo aliterante, fez/fecit - done/donne, retoma o Gênesis (cap. 1, versículos 1-3): "In principio creavit Deus caelum et terram terra autem erat inanis et vacua et tenebrae super faciem abyssi et spiritus Dei ferebatur super aquas dixitque Deus fiat lux et facta est lux. [No princípio, Deus criou o céu e a terra. Mas a terra era deserta e caótica e havia trevas na superfície do abismo e o espírito de Deus encontrava-se na superfície das águas. Deus então ordenou: 'Faça-se a luz'. E a luz foi feita. Tradução nossa]”. Observemos a peremptoriedade do pretérito perfeito, cuja aspectualidade pontual não admite réplica. Daí o presente gnômico e o particípio, indicativos de obra acabada: "It's done". Enfim, as duplicações (/f/, /n/, /d/, /t/, /e/ e /o/), as paronomásias (done/donne), a mistura de latim e português, assim como a elevação do fazer de Donne à categoria de "palavra sagrada" dão ao texto qualidade tão vívidas que não permitem sequer o retorno à racionalidade gramatical. Por isso também a ausência de ponto final do sujeito em êxtase.

Depois de explorar o ofício agudo em Augusto de Campos e em John Donne, vejamos a seguir as propriedades estruturais da agudeza.

\section{Propriedades estruturais da Agudeza dos SeIsCENTOS E do Final do SÉCULO XX}

No ensaio "Os poetas metafísicos", T. S. Eliot (1989, p. 123), depois de afirmar que os poetas "devem ser difíceis", estabelece que "o poeta deve tornar-se cada vez mais abrangente, mais alusivo, mais indireto, no sentido de violentar - de deslocar, se necessário - a linguagem em seu significado". Frederico Barbosa (In: COSTA, 1992, p. 137), em "A tradição do rigor e depois", reforça que o texto, em que não se percebesse o trabalho com a linguagem por meio de "condensações linguísticas", "articulações formais", "descobertas originais", não seria poesia e sim prosa.

Com base na valorização dos entraves linguísticos, examinemos a seguir como a agudeza se estrutura nos preceptistas seiscentistas, em termos de PE e de PC. As produções artísticas seiscentistas configuradas pela agudeza apoiavam-se em versões neoescolásticas do livro III da Retórica de Aristóteles e em novos conceitos de dialética e retórica produzidos, no século XVI, em Roma, em Florença, na França, em Castela, em Portugal. À dialética cabia a tarefa de definir e contradefinir tópicas exclusivas até então da retórica, que foi modificada como doutrina renovada da elocução ou do ornato. Anteriormente, ela ocupavase em particular da argumentação (invenção e disposição). 
Os preceptistas seiscentistas recorreram ao Organon e ao De anima (Aristóteles) para propor dez categorias e especificações sobre o juízo silogístico como esquema de definição e organização dialética dos temas e dos argumentos (cf. CARVALHO, 2007, p. 44). Em seguida, recuperam também a doutrina sobre a metáfora de Aristóteles, bem como as leituras que dele fizeram Quintiliano e Cícero.

A agudeza poética era rigorosa quanto aos procedimentos retóricos dos poetas, cuja causa eficiente era o engenho das escolhas enunciativas e cuja consequência seria provocar êxtase no enunciatário. Escolhido um tema ("tópica", topos), o artista aplicava as categorias aristotélicas de substância, quantidade, qualidade, relação, ação, paixão, situação, tempo, espaço, hábito. Suponhamos que, tomado um tema qualquer, o enunciador aplicasse a categoria de quantidade: deveria, então, considerar a quantidade do tamanho (pequeno, grande, longo, curto, curtíssimo); a quantidade numérica (nenhum, um, dois, poucos, pouquíssimo); a quantidade de peso (leve, pesado, pesadíssimo); a quantidade de apreço (precioso, vil, preciosíssimo); a quantidade geral (medida, parte, todo, perfeito, perfeitíssimo, infinito, maior, menor etc.).

Em Hansen (2000, p. 328), vemos um exemplo de aplicação de agudeza poética à figura de um anão para caracterizá-lo como um ator de tipo ridículo nos enunciados da poesia seiscentista joco-satírica:

\footnotetext{
Quando examinamos o termo repassando-o pelas categorias - por exemplo, a categoria quantidade, que é a primeira das acidentais podemos achar inúmeras metáforas de coisas pequenas em coisas elementares, como "átomo" e "grão de areia"; em coisas humanas, como "pigmeu" e "unha"; em animais, como "formiga", "pulga", "mosca", "ácaro", "escama de peixe" etc.; em plantas, como "grão de trigo", e, ainda, em objetos; entre eles, os militares, como "umbigo do escudo" etc. Por meio da categoria quantidade, podemos dizer, por exemplo, "Esse umbigo do escudo" para significar "Esse anão".
}

Assim, as categorias aristotélicas possibilitam que o processo de invenção seja levado à exaustão e desse processo exaustivo surge a agudeza do PC nos seiscentos. Trata-se de um trabalho com a linguagem em que a intensidade, preocupação do poeta, resvala no hermetismo da metáfora aguda. Por exemplo: a alegoria de umbigo de escudo para dizer anão obscurece de tal forma o enunciado que o enunciatário se maravilha pela aproximação distante de "umbigo de escudo" e de "anão". Ao aproximar semanticamente duas unidades 
afastadas, suscita-se prazer intelectivo, aproximando e convidando o enunciatário à busca de uma solução para o efeito de sentido produzido.

Outras possibilidades de vivificar anão seriam as figuras:

- átomo

- grão de areia

- pigmeu

- unha

- formiga

- pulga

- mosca

- ácaro

- escama de peixe

- grão de trigo

Essas opções encaminham o enunciado poético para uma acentuação da tonicidade de excessivamente pequeno: muito pequeno, pequeníssimo, demasiadamente pequeno. Fundamentalmente, a técnica consiste na exploração das virtualidades discursivas da analogia. São virtuais, porque estão em ausência paradigmática, havendo mil combinações possíveis; todavia, em presença (no sintagma), o enunciador combina (o que chamamos aqui de condensação) termos sobrecontrários (as figuras) e, portanto, semanticamente distantes. Essa combinação inesperada provoca, em termos zilberberguianos, maravilhamento, êxtase, surpresa estética.

Consideramos a possibilidade de dois momentos de maravilhamentos:

$\rightarrow$ o sensível do primeiro contato sonoro e visual com a agudeza do PE;

$\rightarrow$ o inteligível do segundo momento dado pelo reconhecimento da agudeza do PC.

Não se trata aqui de projetar a teoria de Zilberberg nos séculos XVI e XVII, mas de verificar que o jogo tensivo se dá em qualquer tempo, é anacrônico. Ademais, os preceptistas seiscentistas já reconheciam na poética da agudeza dos seiscentos, avant la lettre, o efeito de inesperado, de surpreendente, que agrada, maravilha e persuade o enunciatário (HANSEN, 2000, p. 317).

As agudezas, segundo Hansen (2001, p. 32), "evidenciavam o engenho e a perícia técnica dos autores, sendo aplaudidas como signo de discrição". Trata-se de um simulacro de erudição entre seus pares. O poeta dissimula, produz efeitos de sentido para promover o deleite do enunciatário, finalidade máxima do intento poético agudo. Muito antes do século 
$\mathrm{XX}$, os artistas seiscentistas teriam percebido que o fazer poético é antes de tudo fazer linguístico, ou seja, com a poesia criavam-se mundos de palavras, o mundo dos vulgares, dos eruditos, dos fidalgos etc.

No poema que se inicia com "Que néscio, que era então" -- na edição organizada por James Amado, consta a seguinte didascália "Expoem esta doutrina com miudeza, e entendimento claro, e se resolve a seguir seu antigo dictame" --, o enunciador, na pele discursiva de Gregório de Matos (2010, v. 1, p. 352), trata do tema do simulacro discursivo, primeira propriedade da agudeza:

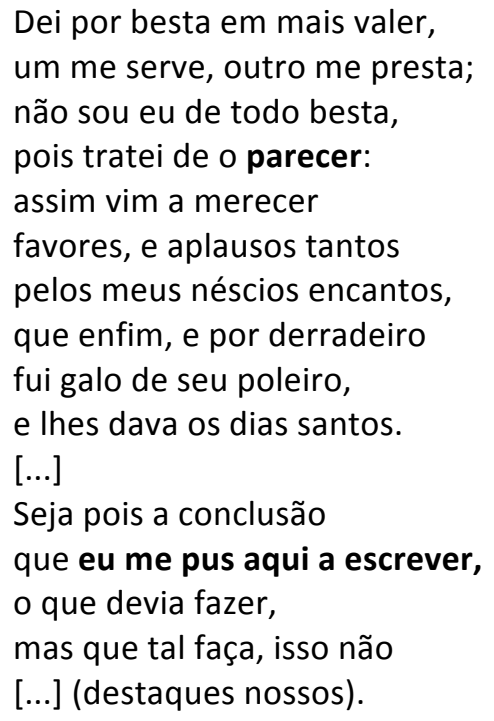

Dei por besta em mais valer, um me serve, outro me presta; não sou eu de todo besta, pois tratei de o parecer: assim vim a merecer favores, e aplausos tantos pelos meus néscios encantos, que enfim, e por derradeiro fui galo de seu poleiro, e lhes dava os dias santos. [...]

Seja pois a conclusão que eu me pus aqui a escrever, o que devia fazer, mas que tal faça, isso não [...] (destaques nossos).

Primeira propriedade: simulacro discursivo (o fazer poético é um contrato enunciativo; é competência do sujeito da enunciação [enunciador e enunciatário])

Por essa razão, enganam-se os que atualmente interpretam as sátiras atribuídas a Gregório de Matos como se fossem a representação de seu "eu psicológico". O enunciador do poema projeta-se no enunciado como um ator discursivo que participa de uma cena enunciativa singular.

O sujeito da enunciação competente engloba enunciador e enunciatário pressupostos ao contrato enunciativo em questão. Trata-se de um contrato fiduciário que revela, então, um fazer persuasivo e um fazer interpretativo em jogo (GREIMAS; COURTÉS, 1983, p. 86). Assim, a agudeza seiscentista leva em conta os destinadores retóricos, que estabelecem uma convenção poética como conhecimento socialmente partilhado por poetas e público contemporâneos à época (cf. HANSEN, 2004, p. 374). Nesse sentido, a 
recepção da poesia seiscentista por seus contemporâneos era regida por um simulacro discursivo de letras específicas. Por isso, não seria apropriado o conceito de neobarroco como ressurgimento do barroco, mas como outro tipo de contrato, que se propõe euforizar o barroquismo como categoria que pudesse transpassar o tempo, algo que refutamos, como já dissemos, pelo fato de distinguirmos dois tempos discursivos singulares, cada um movido por um destinador diferente.

Com base no simulacro discursivo, depreendemos também um artifício de verossimilhança (GREIMAS; COURTÉS, 1983, p. 489). Segundo os tratadistas seiscentistas, um pintor que faz um nariz deformado não peca contra a arte; essa deformação é uma exigência do contrato fiduciário que implica igualmente uma cena enunciativa convencionada e uma escolha do enunciador em sua arte de dissimular.

A título de esclarecimento, os enunciadores pressupostos, constantes da poesia atribuída a Gregório, assumem papéis diferentes na sátira, na poesia religiosa e na líricoamorosa: se na sátira, o enunciador é mais despudorado, na religiosa é mais comedido. Trata-se de dissimulação.

A propriedade discursiva da agudeza de dissimular está diretamente relacionada ao artifício, técnica aplicada ao fazer poético seiscentista. Tal artifício indica qualquer espécie de ficção ou fingimento produzida pela competência do enunciador para a obtenção de determinado efeito. Por exemplo:

- O enunciador/enunciatário discreto, simulacro do engenhoso: caracteriza-se pela prudência, pelo engenho, "que fazem dele um tipo agudo e racional" (HANSEN, 2004, p. 93), competente para distinguir o que é melhor.

- O enunciador/enunciatário néscio, simulacro do rústico, do desprovido de saber: "caracteriza-se pela falta de juízo" (HANSEN, 2004, p. 93); do latim, néscio acumula "ne" (não) + "scio, scire" (saber). Modalizado pelo não saber, néscio era, pois, o sujeito vulgar; do latim, vulgaris, "conhecimento ralo, comum". Não equivale ao antitetismo pobreza/riqueza. Conceito aristotélico por excelência, o "vulgo" "pode significar aqueles que, embora pertencentes aos 'melhores' pela propriedade e posição, são caracterizados como rústicos, falhos de discernimento e, portanto, como 'néscios'” (p. 93). 
Desse modo, o poeta constrói um simulacro, a depender do contrato fiduciário, do néscio ou do discreto. Se não incorporado ao texto os destinadores justos e seus valores, a leitura dos poemas atribuídos a Gregório terá um resultado enviesado. Como vimos em alguns manuais de literatura, houve durante muito tempo (e ainda há) equivalência do ator, simulacro do néscio, com a pessoa de Gregório, o de carne e osso, considerado como rústico, grosso, canalha. Mais ainda, alguns deles reconhecem no enunciado poético gregoriano uma euforização da língua indígena. Ao contrário, nessas poesias, há um simulacro do néscio que utiliza uma variante não valorizada do português colonial, mesclando-a com a língua tupi. Em vez da euforia, a ironia. Essa é uma confusão inapropriada: onde o poeta foi sarcástico, conservador nos moldes da atualidade, a crítica atual vê-o como antecipador de tendências modernas, vê-o como revolucionário em termos de usos de linguagem.

Pécora e Hansen (2006, p. 90) afirmam que "o artifício deve ser entendido como uma operação técnica ou como o efeito de uma técnica [...] como o resultado controlado da aplicação de um conjunto de preceitos". Por isso, reconhecem não ser correto contrapor artificioso a natural, em que artificial seria visto disforicamente. Nesse sentido, no século XVII, o termo artificial nada tinha de valor negativo, pois se acreditava que "uma construção artificiosa" não contradizia o natural nem o verdadeiro, mas ajustava um e outro "aos conceitos de 'belo' ou 'artístico'". O artifício era regulado por preceptivas poéticas, como as de Gracián e de Tesauro.

Esse conceito de artifício como simulacro discursivo seria o lugar por excelência do engenho agudo, gerando outras propriedades, conforme veremos adiante. Uma delas, ainda concernente ao fingimento discursivo, diz respeito à adequação. A agudeza poderia ser adequada em um poema lírico, mas não adequada, por exemplo, em um sermão. Trata-se, portanto, de coerções de gênero a que o enunciador competente estaria submetido. Nesse sentido, a crítica de Vieira (2000, p. 40-41) aos dominicanos diz respeito à não adequação linguística de procedimentos que poderiam ser conformes a outros lugares, mas não ao púlpito:

Não fez Deus o Céu em xadrez de estrelas, como os Pregadores fazem o sermão em xadrez de palavras. Se de uma parte está Branco, da outra há de estar Negro; se de uma parte está Dia, da outra há de estar Noite; se de uma parte dizem Luz, da outra hão de dizer Sombra; se de uma parte dizem Desceu, da outra hão de dizer Subiu. Basta que não havemos de ver num sermão duas palavras em paz? [...] 
Este desventurado estilo que hoje se usa, os que o querem honrar chamamIhe culto, os que o condenam chama-lhe escuro [...] É possível que somos Portugueses, e havemos de ouvir um pregador em Português, e não havemos de entender o que diz? [...] Se houvesse um homem que assim falasse na conversação, não o havíeis de ter por néscio? Pois o que na conversação seria necessidade, como há de ser discrição no púlpito? [...] Se o lavrador semeara o primeiro trigo, e sobre o trigo semeara centeio, e sobre o centeio semeara milho grosso e miúdo, e sobre o milho semeara cevada, que havia de nascer? Uma mata brava, uma confusão verde. Eis o que acontece aos sermões deste gênero. Como semeiam tanta variedade, não podem colher coisa certa.

Da mesma forma, o Gregório lírico, enunciador de papel, como sabemos, não pode ser confundido com o Gregório pessoa física. A ele cabia fingir, criar um ator discursivo competente que enunciasse enunciativamente, em primeira pessoa, um discurso capaz de levar o enunciatário a crer na verdade discursiva de seus enunciados em jogo (verossimilhança). Ainda, a poesia atribuída a Gregório de Matos, por meio de figuras, utilizava os motivos petrarquistas que eram comuns no mediterrâneo (séculos XV a XVIII).

O fingimento discursivo desse fazer poético seguia, como dissemos, os destinadores tratadistas e preceptistas, influenciadores dos seiscentos. Ao enunciador cabia, se fizesse poesia lírica, por exemplo, saber compor enunciados cujo nível discursivo contemplasse atores de papel, simulações da criação do discurso poético, que se apoiassem nas convenções do gênero. Não se trata, portanto, do derramamento de emoções do poeta romântico em que as paixões do "eu", ator do enunciado, identifica-se com as paixões mundanas desse eu, pessoa de carne e osso, extralinguística. Ora, todas essas formas poéticas são produtos da invenção discursiva, sejam as seiscentistas, sejam as novecentistas.

Como verificamos, trata-se de uma questão de procedimentos enunciativos. A enunciação é apresentada por Benveniste como a instância do ego, hic et nunc. O eu instaura-se no ato de enunciar: "eu é que[m] diz eu". A pessoa a quem o eu se dirige é o tu: “Eu designa aquele que fala e implica ao mesmo tempo um enunciado sobre o 'eu' [...]. Na segunda pessoa, 'tu' é necessariamente designado por eu e não pode ser pensado fora de uma situação proposta a partir do 'eu'; [...]”' (BENVENISTE, 2005, v. I, p. 250 e 286).

Assim, eu e tu, compositores da ação enunciativa, constituem o sujeito da enunciação, porque o "eu" produz o enunciado e o "tu" é levado em consideração pelo "eu" na construção desse mesmo enunciado (FIORIN, 2008b, p. 137). O espaço e o tempo linguísticos do "eu" são organizados com base no "aqui" e "agora". As debreagens enunciativa e enunciva são mecanismos da enunciação que tornam possível a instauração de 
pessoa, tempo e espaço nos textos. Na debreagem enunciva, por exemplo, temos um efeito de objetividade, de distanciamento, de neutralidade e de clareza e na debreagem enunciativa, temos um efeito de subjetividade, aproximação, parcialidade e obscuridade. Todos apenas efeitos de sentido, visto que tudo emana de um enunciador que parte de um fazer persuasivo.

Podemos, então, inferir dos estudos de Benveniste que sempre há efeito de objetividade e subjetividade, respaldados por uma enunciação pressuposta em qualquer enunciado. A subjetividade pode advir de um advérbio, de um adjetivo, de uma reiteração, de uma ênfase etc. Daí se conclui que a subjetividade não é produto tão somente de pessoas verbais; um discurso pode estar em terceira pessoa, mas provocar o efeito de aproximação, dependendo de outros elementos linguísticos presentes no enunciado.

A debreagem enunciativa simula no enunciado um "eu-aqui-agora" da enunciação. Ao simular um "eu", está implicado um "tu". A debreagem enunciva é erigida com um "elealhures-então"; nesse caso, ocultam-se os actantes, os espaços e os tempos da enunciação. Na debreagem enunciva, o enunciado constrói-se com os actantes, os espaços e os tempos do enunciado e não da enunciação. É um jogo, uma dissimulação, em que a enunciação estrategicamente se revela ou se esconde. Como sabemos, a enunciação é uma instância pressuposta em ambas as debreagens.

Com as marcas deixadas pela enunciação no enunciado poético, podemos, por exemplo, reconstituir o ato enunciativo, que nada mais é do que competência discursiva (GREIMAS; COURTÉS, 1983, p. 147-148; FIORIN, 2008b, p. 138), uma das propriedades da agudeza.

O enunciador e o enunciatário são o "autor" e o "leitor", não de carne e osso, mas os que estão implícitos; em outras palavras, temos a imagem do autor e de seu leitor construída pelo próprio texto dentro da cena enunciativa. Em diferentes poemas, por exemplo, essas posições se concretizam, e os actantes tornam-se atores da enunciação. 0 ator, do nível discursivo, é um caso de concretude temático-figurativa do actante, que é mais abstrato, pertencente ao nível narrativo. Por exemplo, a simulação do enunciador no enunciado é sempre o ator eu, como no soneto "Admiravel expressão que faz o poeta de seu atiencioso silencio", atribuído a Gregório de Matos; nesse poema, o EU é concretizado no ator poeta "de papel", discursivo, que a crítica impressionista identifica com o próprio Gregório de Matos (2010, v. 1, p. 415): 


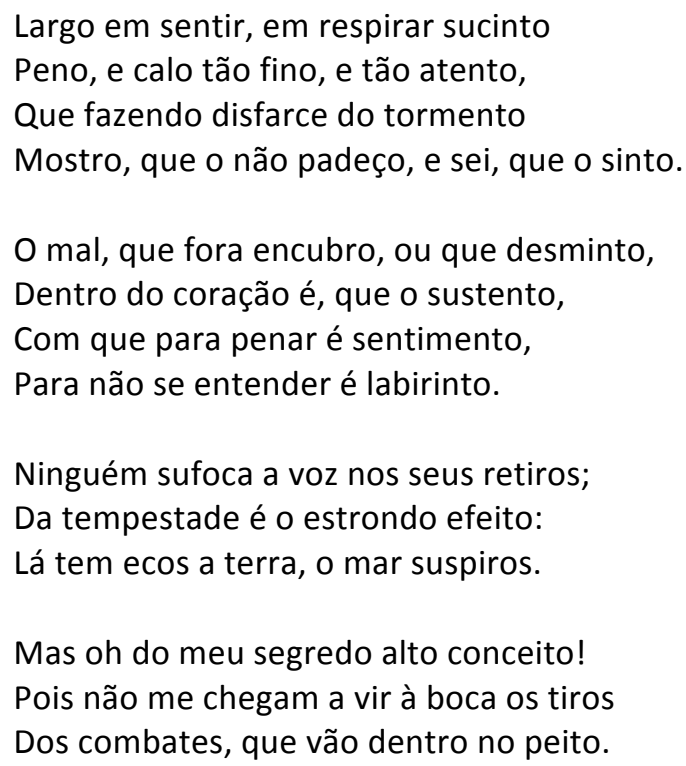

Não se trata, pois, do poeta Gregório de Matos em tamanho real, mas de um ator discursivo. Os verbos em primeira pessoa (peno, calo, mostro, encubro, desminto, sustento...) configuram uma debreagem enunciativa aproximadora, como convém nos poemas em que o pathos é figura central do discurso. Um distanciamento maior poderia produzir descrença no enunciatário. O eu fingido revela as paixões e a tensão entre o que sente e o que exterioriza.

A escolha é pela dissimulação dos sentimentos, pela a arte de fingir, pelo labirinto de palavras. Assim, a tensividade antitética de "largo em sentir, em respirar sucinto" e entre as categorias "interior-exterior [simulação]", em "o mal, que fora encubro, ou que desminto,/ dentro do coração é que sustento"; "pois não me chegam a vir à boca os tiros/ dos combates, que vão dentro do peito", funciona como escolha de valores pelo enunciador. A simulação das paixões da alma no enunciado poético, em geral, são traduzidas pela metáfora aguda de "fogo". Nosso enunciador, por sua vez, opta por traduzir suas revoluções de alma por "tiros do combate que vão dentro no peito". A metáfora agora aguda encampa o fogo e o estampido do tiro; estampido, porém, que fica abafado no peito.

O objeto seiscentista, com sua agudeza de dissimulação, é uma máquina de truques, em que o texto progride na direção metalinguística; o fazer poético é um disfarçar e um mostrar, ambos produtos da linguagem: "que fazendo disfarce do tormento / mostro, que o não padeço, e sei, que o sinto". Não trataremos nesta tese da questão da autoria de Gregório de Matos, discutida a posteriori por Pécora e Hansen (2006, p. 96; cf. também 
HANSEN, 2004), que afirmam que sua poesia é apógrafa, ou seja, trata-se de poemas cuja autoria é atribuída a Gregório de Matos.

Outro tipo de simulacro discursivo evidencia-se no jogo enunciativo dos poemas do final do século XX. Essa primeira propriedade da agudeza tem como pressuposto um jogo enunciativo entre um enunciador, que suscita maravilhamento por meio de fingimento discursivo, de condensações (fusões) de elementos inamalgamáveis etc., e um enunciatário cujo fim é deleitar duplamente: (1) após o impacto sensível do êxtase; (2) após o reconhecimento dos emaranhados da agudeza do PC, quando a fruição se dá também inteligivelmente.

Em "São Francisco de Assis", poema de Affonso Ávila (2008a, p. 296), fazer poético conduzido por outro tipo de destinador, o do final do século $X X$, dá-se uma amostra da propriedade aguda do simulacro discursivo:

\section{São Francisco de Assis}

$\&$

pelo partido se conhece a arquitetura

$\&$

pela portada se conhece $\mathrm{o}$ arquiteto

$\&$

Embora o verso "pela portada se conhece o arquiteto" pareça comportar um enunciador ausente devido ao verbo na terceira pessoa do singular, a enunciação está sempre pressuposta. Ademais, a escolha desse verbo instaura um distanciamento; todavia, pela tonalidade coloquial do enunciado, o da máxima popular, o enunciatário reconhece "eu afirmo que "pela portada se conhece o arquiteto'". O verso evidencia ainda a enunciação reger qualquer enunciado, seja de terceira, seja de primeira pessoa, visto que, se "pela portada se conhece o arquiteto", é esse rastro (portada) do enunciador no enunciado que marca a presença da enunciação.

O "\&" reiterativo funciona no poema "São Francisco" como um caminho meândrico que enreda o enunciatário. O poema não mostra marca aparente da enunciação no enunciado, mas se trata de um truque. Ao afastar-se do enunciado, constrói-se um simulacro de objetividade, que engendra um efeito de sapiência, estabelecido pela figura do 
verbo conhecer. As declarações funcionam como máximas do campo semântico da arquitetura erguidas à semelhança de outras: "pelo filho se conhece o pai". Esse jogo linguístico-poético erige no enunciado a imagem da frente da Igreja de São Francisco de Assis de Ouro Preto, título do poema, imagem que é formada pelas figuras discursivas "partido", "arquitetura", "portada", "arquiteto".

No poema, dá-se ainda a construção de um destinador que sabe e quer fazer seu destinatário saber; noutros termos, é quase um guia turístico que acompanha o enunciatário pelas ladeiras de Ouro Preto, transmitindo-Ihe um saber reconhecer o arquiteto pela portada; pelo conhecimento enciclopédico, o projeto da Igreja de São Francisco é de Aleijadinho. A enunciação condensada revela, por meio dos dois enunciados lapidares, confiança no próprio saber. Não há possibilidade de ouvirmos a voz do enunciatário, pois ele não está projetado como "tu". Desse modo, temos um jogo de um enunciador que se distancia, porque tem a posse do saber (no verso: "se conhece"), mas, ao mesmo tempo, se aproxima, transmitindo seu conhecimento ao enunciatário, valendo-se, para isso, de um tipo de discurso encontrável no cotidiano: as máximas populares. Enfim, temos uma enunciação marcada pelo "fazer saber", que estabelece um diálogo implícito entre um eu e um tu.

Augusto Campos (In: CAMPOS; CAMPOS, 1968, p. 104-105), no texto "Atualidade dos 'metafísicos'”, contesta a crítica que acusa determinados poetas de produzirem poesias marcadas pela desumanização -- o caso dos concretistas, que se estende ao usualmente nomeado neobarroco de Affonso Ávila -- e, em seguida, afirma que tal desumanização nada mais seria do que

a tomada de consciência, por parte do poeta, em plena lucidez de sua verdadeira função ética e social. Não há, de fato, uma recusa ao "humano", mas, ao contrário, uma recusa a se deixar transformar em objeto, a permitir - o poeta - que dele façam uma "juke-box" de titilações sentimentais. E, ao mesmo tempo, a busca do verdadeiramente humano na linguagem, tomada em si, como fonte de conhecimento e de apreensão da realidade. 0 poeta, cada vez mais, utiliza a linguagem, ao invés de ser utilizado por ela.

Como notamos no poema de Ávila, ali também há forte preocupação com a linguagem e não com o derramamento de emoções. Daí a simulação de uma enunciação enunciva - nesse caso, o enunciador distancia-se, criando efeito de objetividade --, marcada pelo tempo verbal no presente, terceira pessoa, do indicativo para que a verdade do 
enunciador soe como máxima, dando origem à voz de um destinador, superior e que tudo sabe. O poema parece perder em subjetividade para ganhar em racionalidade.

Todavia, ao conter as emoções e os sentimentos -- observar a repetição nos dois versos do poema do verbo pronominal "se conhece" -- e estabelecer a já dita construção poética pela arquitetura linguística, o enunciador mostra uma linguagem que deixa de ser apenas substância do conteúdo como grande mensagem sentimental para se transformar ela própria em fim e forma; nesse caso, a linguagem poética é operação que estrutura as relações entre formas do PE e do PC, característica semelhante à da poesia aguda seiscentista.

A agudeza da enunciação (primeira propriedade do simulacro discursivo) revela-se no poema "São Francisco", de Affonso Ávila, pela seleção de figuras que levam o enunciatário a aproximar-se do cotidiano: tomar conhecimento sobre como identificar uma obra de Aleijadinho in loco, ou seja, observando a "portada".

Ao ocupar-se do fazer arquitetural, o enunciador volta-se para a própria linguagem. Trata-se de um poema metalinguístico, tônica dos destinadores do século XX, que leva a pensar sobre o próprio fazer poético como poiesis, criação, afastando-se do contrato de fazer mimético, próprio do destinador das obras seiscentistas. Mais uma razão para se descartar o rótulo "neobarrocas" para as poesias de Affonso Ávila ou de Haroldo de Campos, visto seguirem outros destinadores.

Em "São Francisco", o trabalho com a linguagem pode também ser observado no jogo linguístico em que feminino (portada e arquitetura) e masculino (partido e arquiteto) vão sucessivamente trocando de lugar, como numa combinatória. Trata-se de um quiasmo morfológico: as figuras do poema são distribuídas em forma de X; nesse sentido, feminino e masculino cruzam-se diagonalmente. Quiasmo ${ }^{9}$ é uma figura retórica que se caracteriza pela disposição entrecruzada e simétrica das figuras de dois enunciados (LAUSBERG, 2004, p. 233):

\footnotetext{
${ }^{9}$ O termo quiasmo deriva da letra grega $\chi$ (qui), em latim chiasmus. Em português, sofreu alteração por causa da influência da língua italiana cuja pronuncia de ch é /k/.
} 


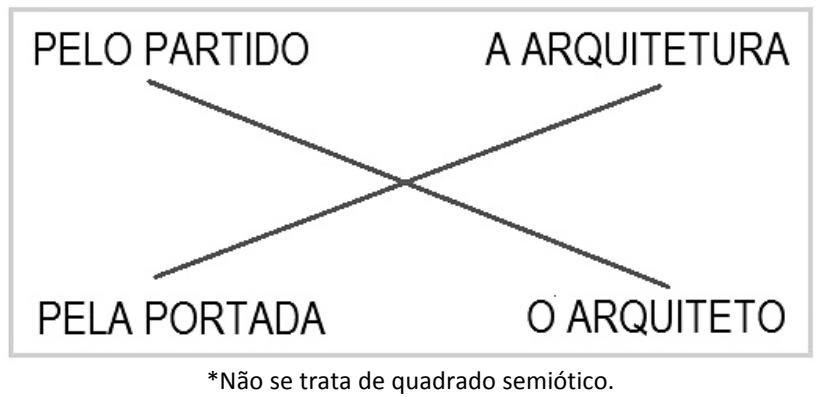

Com base em Baltasar Gracián, para Pécora e Hansen (2006, p. 92), o sujeito da enunciação é discreto e possui competência semiótica para dissimular enunciados, dando a cada um deles a exata medida que lhes é devida. Essa competência de enunciador e de enunciatário pode ser percebida no verso "pela portada se conhece o arquiteto", isto é, só conhece o "arquiteto" e a "arquitetura" quem tem competência para tal. Enunciadores não se confundem, pois que deixam rastros no enunciado.

Em suma, tanto os sujeitos da enunciação do século XVI e XVII quanto os do final do século XX são instituições pressupostamente competentes ${ }^{10}$, que contam com um contrato, regido por uma agudeza de um fazer persuasivo e de um fazer interpretativo implícitos. Com base nesse argumento, temos uma coenunciação, conceito de sujeito da enunciação já citado, que concentra e difunde o enunciado, quando é preciso fazê-lo, mantendo-se o jogo da poética tensiva entre o maravilhamento sensível e o posterior prazer do reconhecimento inteligível.

Corolário da primeira propriedade da agudeza seria a solidariedade do complexo sujeito da enunciação:

Agudeza: (1) Enunciador compositor e decompositor; (2) Enunciatário decompositor e compositor

Temos, portanto, um movimento, cujo sentido se dá numa sintaxe solidária $e$ reflexiva, em que tanto enunciador quanto enunciatário têm papel ativo na construção do sentido do enunciado poético. Desse modo, quando o enunciador compõe o poema, amalgamando fonemas, morfemas, ressignificando-os, toca ao enunciatário decompô-lo para reconhecê-lo inteligivelmente, visto que esteve refreado sensivelmente por algumas

\footnotetext{
${ }^{10}$ Teixeira (1997-1998) afirma: "Sabe-se que, no século XVII, os intelectuais reuniam-se em seções acadêmicas para exibir os frutos dos respectivos engenhos sobre um tema previamente apresentado. Nessas disputas, a sutileza das composições funcionava como elemento diferenciador entre os concorrentes."
} 
estratégias da agudeza. E, quando o mesmo enunciador decompõe, desmantela uma sílaba, um morfema, por exemplo, cabe ao enunciatário recompor e reorganizar o enunciado. Ademais, a troca de posição de categorias gramaticais do gênero masculino e feminino, em "São Francisco de Assis" ("partido / arquitetura / portada / arquiteto"), sugere uma troca de posição entre objeto estético (arquitetura) e seu criador/contemplador (arquiteto) para que o sentido do texto se estruture.

Em “Casa de Gonzaga”, outro poema de Affonso Ávila (2008a, p. 295), a cooperação entre enunciador e enunciatário opera-se também na reorganização dos refreamentos formais da agudeza. Vejamos o poema:

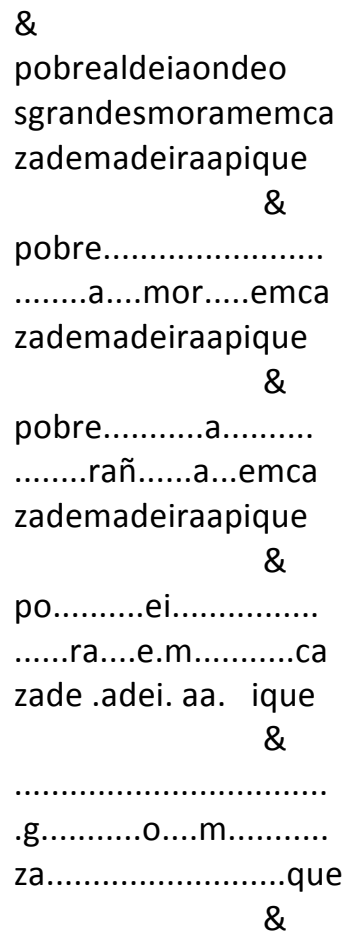

(1) Enunciador compositor de quebras inesperadas e enunciatário decompositor e reorganizador do enunciado poético

Inicialmente, o enunciador condensa as formas do PE e do PC num continuuum fonológico e morfológico em que os recortes usuais são desconsiderados. Trata-se de um artifício de agudeza, que convoca o enunciatário para executar uma operação no sentido inverso, o de descondensação (decomposição), que promova restabelecimento novamente dos recortes formais. Na descompactação, ao deleite sensível visual e sonoro segue-se um procedimento secundário: a prazerosa descoberta das tramas do inteligível. 
Em uma terceira etapa, verifica-se que o PE incide sobre o PC, constituindo um semissimbolismo:

PE : categoria da aglutinação -- fonemas aglutinados :: PC : categoria da aglutinação -- construção da "casa de Gonzaga" por meio da aglutinação de materiais

\section{(2) Enunciador decompositor e enunciatário preenchedor dos elos da linguagem}

Nesse caso, o enunciador refreador de formas convoca a participação do enunciatário para restabelecer $\mathrm{o}$ enunciado esmaecido em seus contornos. 0 maravilhamento inicial do sensível transforma-se na tentativa inteligível de buscar uma direção para o sentido. Os pontilhados dos versos configuram interrupções que ofuscam o enunciado. Temos, então, novamente outro semissimbolismo:

PE: categoria da descontinuidade [os pontilhados gráficos interrompem a continuidade dos fonemas nos versos] :: PC: categoria da descontinuidade [a poeira na casa de pau a pique impede a continuidade da visibilidade dos objetos]

Nos três primeiros versos, há uma aglutinação aguda no significante que erige no significado o conteúdo Casa de Gonzaga, cuja imagem surge no enunciado visual da última estrofe ".g.........o....m........./za..........................que". O PE vai perdendo paulatinamente alguns de seus fonemas, visualmente representado pelos pontilhados gráficos. As elipses, as faltas, no PE endossam o PC com a expressão ambígua a pique, que significa, além da técnica de construção casa de pau a pique, tonicidade elevada de "malogro", "fazer gorar" (HOUAISS; VILLAR, 2001). Aqui, notamos um cifra tensiva de acentuação da intensidade, que figurativiza o estágio de alta deterioração da Casa de Gonzaga. A essa cifra de vivificação junta-se o juízo avaliativo do enunciador, que escolhe isolar o termo "pobre" no primeiro verso da segunda estrofe e elimina "aldeiaondeo/sgrandemoram".

O jogo tensivo continua no segundo verso em que, ao separar "a" de "mor", figurativiza "amor" (amor vivido por Tomás Antônio Gonzaga e Marília de Dirceu), bem como a dor da "mor"(te), que pode ser lida também como morte da Casa de Gonzaga e morte do amor, visto que o casal "Tomás e Marília de Dirceu" se separa. "Mor" é ainda 
forma intensificada de grande (maior) e teríamos, assim, como possibilidade de direção a grandiosa Casa de Gonzaga.

$\mathrm{Na}$ terceira estrofe, o enunciador elege outros artifícios de agudeza: a sequência de fonemas /rãn/, que se inicia com a velar vozeada vibrante /R/, corrobora o PC de ruir.

Semissimbolicamente, temos:

PE: categoria vibrante [sequência de fonemas vibrantes] :: PC: categoria vibrante [movimento vibrante de ruir, de tombar, cair]

Nesse sentido, se na segunda estrofe o PE visual mostra o PC da casa em ruína; na terceira estrofe, é o PE sonoro que nos faz perceber o estágio de desmoronamento da casa.

$\mathrm{Na}$ quarta estrofe, novamente a escolha pela eliminação de determinados fonemas faz sobrar no PC do primeiro verso "po (pó)" e "ei" e no PC do segundo verso "ra". Somando os elementos, temos "poeira". Ao seccionar, ainda no segundo verso da quarta estrofe, por meio do recurso gráfico <pontilhado> junto com a preposição "e.m", constrói-se a imagem visual de partículas de pó (poeira) pela Casa de Gonzaga. E, no terceiro verso, subtraindo-se grafemas e fonemas, sobra, no PC, em meio à poeira, a estrutura de madeira, suporte para a construção de casa de pau a pique: "zade .adei. aa. ique" = "casa de aldeia cujo madeirame está a pique, desfazendo-se".

Finalmente na quinta estrofe, o objeto estético é reduzido no PE e no PC a quase nada:

$$
\text { "g.... o... m......za......que", }
$$

configurando o isolamento do amante de Marília de Dirceu, Tomás Antônio Gonzaga, também agonizante, e sugerindo um efeito de sentido de grito lamento de uma enunciação que vê um monumento histórico em decomposição. Nesse sentido, a disjunção fonemática também cria o efeito de sentido de alguém soluçando, gaguejando, construindo um enunciado de difícil identificação, posto que tomado por forte emoção, por um estado de alma de elevada intensidade.

Como vimos, no PE, a partir da segunda estrofe, as seguidas supressões e os esvaziamentos são indicados no visual pelo grafismo dos pontilhados, correlacionando-se, no PC, à perda de composição da casa. O grafema "\&" costura todo o poema, 
ornamentando-o como uma coluna da arquitetura seiscentista; se o considerarmos polissíndeto (repetições de \& [-e]), teríamos a somação da sequência das cenas de arruinamento, bem como inesgotamento da História de Ouro Preto. Há uma tensão fundamental entre o exaurimento da Casa física de Gonzaga e a permanência da imagem de Tomás Antônio Gonzaga e o que ele representa na História dos Inconfidentes e da Literatura da Colônia.

Até aqui pudemos notar que a primeira propriedade da agudeza funda-se no simulacro discursivo e na competência do sujeito da enunciação para a composição e decomposição do sentido, a depender do enunciado poético em questão, conforme observamos em 1 e 2 .

A segunda propriedade da agudeza funda-se na tensão de escuro-claro estrutural. Em que consiste tal propriedade? Trata-se de um jogo estético de distanciamento e de aproximação, de obscurecer pelo esmaecimento dos contornos e de evidenciar/clarear pela nitidez do restabelecimento dos contornos, uma oscilação própria da poética da agudeza.

A arquitetura poética do final do século XX teria, por exemplo, uma faceta experimental, dada pelo princípio de combinação não previsto pelas relações esperadas e facilmente reconhecíveis entre PE e PC. Nesse sentido, predomina a proximidade e a participação ativa do enunciatário:

- Quanto mais escuro o enunciado, mais elipses, mais faltas, mais fluidez que resulta do esmaecimento dos contornos; assim, quanto mais se requer a aproximação do enunciatário, maior a necessidade de restabelecimento dos contornos.

- Quanto mais claro o enunciado, menos elipses, mais nitidez que resulta da atualização dos contornos; assim, quanto mais distante se encontra o enunciatário, menor a necessidade de restabelecimento dos contornos.

Todavia, o movimento em alguns poemas agudos é o de composição complexa: ocorre ao mesmo tempo aproximação e distanciamento. Em "Casa de Gonzaga", por exemplo, menor aproximação permite o primeiro prazer sensível, que é estético e visual; maior aproximação possibilita o segundo prazer inteligível, o do reconhecimento cognitivo. A agudeza em Affonso Ávila propõe-se quebrar qualquer expectativa no processo sintagmático, linear, de lógica implicativa. As relações dão-se em dobra: infinitas 
possibilidades combinatórias devido às condensações de palavras, às quebras de morfemas, às subtrações de fonemas. O objeto poético invade, então, o sujeito que, chocado e desamparado, vai em busca do reconhecimento inteligível momentaneamente obnubilado pelo refreamento formal acentuado. Assim, a agudeza do PE revela a potência de o significante ressignificar o significado.

Segunda propriedade: jogo de escuro (sensível)-claro (inteligível) estrutural: fazer escurecer o sentido e fazer clarear o sentido. O esmaecimento dos contornos engendra uma poesia aguda cujo efeito é de maravilhamento, afastando-se do icástico e aproximando-se do fantástico.

Vejamos, a título ilustrativo, como se dá o jogo de escuro-claro estrutural na tela Vertumnus, retrato de Rodolfo II (1590), de Giuseppe Arcimboldo, pintor seiscentista (15271593), que se caracteriza pelo jogo visual e pelo jogo de sentidos ocultos. Hauser (2007, p. 277) vê nele um surrealismo avant la lettre.

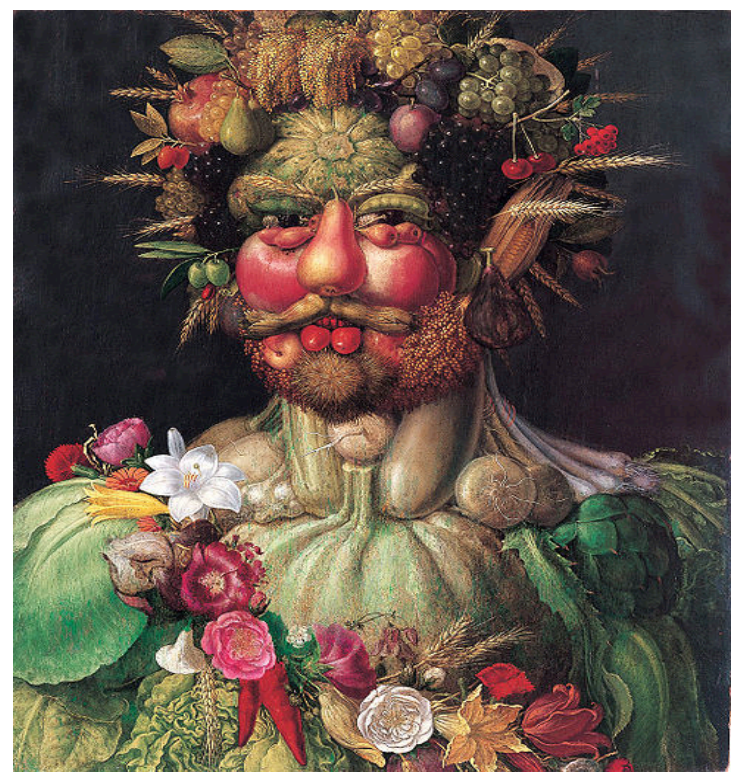

Vertumnus, retrato de Rodolfo II - 1590.

Observando a imagem de perto, veem-se frutos e legumes; afastando-se da tela, notam-se a cabeça e o tronco de um homem. Conforme o estágio de deleite, o enunciatário aproxima-se ou afasta-se do objeto. Pela aumento da distância, sobressai a figura humana; a redução da distância faz saltar à vista os detalhes dos frutos, dos legumes, das flores etc. Nesse sentido, na pintura de Arcimboldo, o enunciatário é surpreendido pela justaposição 
de duas figuras: a figura humana, englobadora, e a natural, de legumes, frutos e flores, a englobante.

O enunciador, ao misturar figuras discursivas distantes semanticamente, produz um efeito de maravilhamento, de sobrevir estrutural: face humana composta por frutos + legumes + flores.

frutas + legumes + flores $\rightarrow$ somadas formam um rosto $\rightarrow$ "surpresa/sobrevir estrutural".

Uma abóbora vale por uma testa; as uvas valem por cabelos. No lugar dos elementos esperados da face humana, encontram-se elementos da natureza. Em um primeiro impacto sensível (em um flash), temos:

- Uma operação de síntese: o enunciatário choca-se quanto percebe estranhamente o rosto de um homem.

- Uma operação de análise (segundo momento): o enunciatário vê no rosto do homem uma condensação de frutas, legumes e flores.

- Uma operação de reconhecimento inteligível: o prazeroso reconhecimento do rosto de Rodolfo II, título da obra de Arcimboldo.

Essas operações provocam deleite no sujeito da enunciação: enquanto o sensível compõe em um átimo a imagem humana, o inteligível decompõe essas partes. $\mathrm{O}$ sentido aqui não advém da face humana esperada pela semiótica do mundo natural, nem dos elementos naturais individualmente, mas desses elementos naturais aglutinados, formando a face de Rodolfo II. É nessa agudeza que o enunciatário encontra o sentido.

É assim que, nos objetos agudos, o enunciatário deleita-se com o êxtase de contemplar simultaneamente um objeto de duas perspectivas diferentes, aproximando-as, $\mathrm{o}$ que chamamos aqui de condensação, terceira propriedade da agudeza. O reconhecimento do objeto dá-se estruturalmente no vértice, na ponta, do triângulo agudo, já mencionado anteriormente. Há, portanto, uma oscilação entre figura humana e mistura de frutas, legumes e flores até o momento da percepção e da condensação da pintura integral no vértice agudo. A agudeza depende dessa tensão de escuro-claro estrutural, em que o artifício de obscurecimento e clareamento ofusca e ilumina o objeto com a finalidade de 
surpreender, no sentido zilberberguiano, e fazer regozijar o enunciatário (cf. ZILBERBERG, 2011a, p. 44; SNYDER, 2007, p. 43).

Para Barthes (1984, p. 113-114), Arcimboldo explora os recursos da língua em seu fazer plástico: "sua pintura tem um fundo de linguagem, a sua imaginação é propriamente poética: não cria os signos, combina-os, permuta-os, extravia-os - o que faz exatamente o operário da língua". A agudeza, como propriedade da linguagem poética, era, pois, comum também na pintura, como vimos em Arcimboldo.

Essa mesma agudeza encontramos em Max Ernst, nos anos de 1920, quando amalgama a figura chapéu com a figura de partes do corpo para formar silhuetas humanas. O que vemos aí é um tipo de condensação aguda:

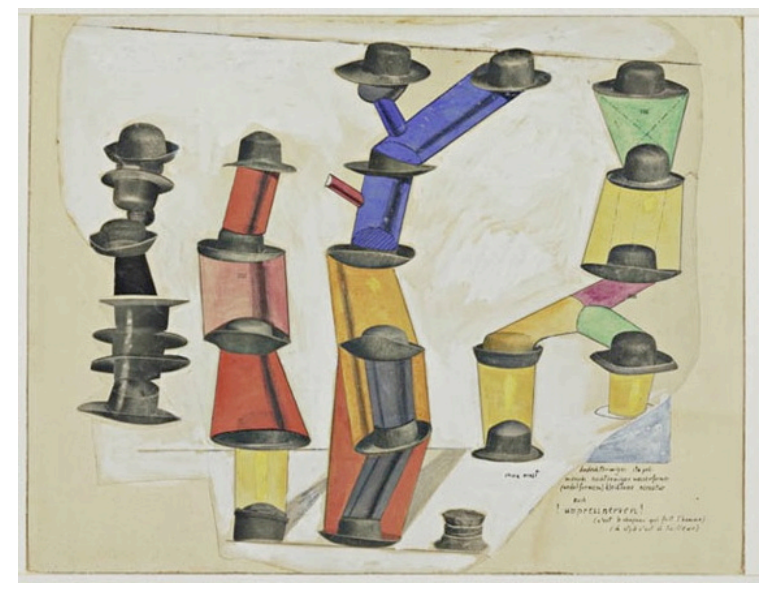

C'est le chapeau qui fait I'homme (É o chapéu que faz o homem) - 1920.

Nessa pintura, reconhecemos primeiramente, em um flash sensível, uma diversidade de chapéus empilhados. É apenas em um segundo momento, quando o sensível encaminhase para o reconhecimento inteligível, que vemos o sintagma homens feitos de chapéu. Na agudeza, como temos visto, há uma acentuação da tensão entre paradigma e sintagma, organizando-se nas seguintes etapas:

1. Sensibilização de figuras paradigmáticas que se projetam individualmente como sintagmas: as pilhas de vários chapéus isolados $\rightarrow$ não são apenas chapéus (acentuação da intensidade).

2. Sensibilização de figuras paradigmáticas no processo sintagmático: figuras humanas com chapéu na cabeça (atenuação da intensidade). 
3. Sensibilização e inteligibilização do processo sintagmático: percepção visual e reconhecimento de homens feitos de somatória de chapéus (acentuação da intensidade que se encaminha para sua atenuação e difusão na extensidade). Depois do reconhecimento inteligível de homens compostos de somatória de chapéus diversos empilhados, o objeto estético, se continuamente olhado, perde o maravilhamento inicial. A estesia não conhece, portanto, a duração (GREIMAS, 2002, p. 26), pois que se dá numa precipitação temporal, num átimo. De repente, ilumina-se a tela com a identificação de que, conforme o nível social, altera-se o modelo de chapéu. Nesse caso, identifica-se uma crítica ao ser que se individualiza por caracteres externos.

Para Octavio Paz (1983, p. 79), o poeta dos seiscentos "quiere asombrar e maravillar; exactamente lo mismo se propuso Apollinaire al exaltar a la sorpresa como uno de los elementos centrales de la poesia" ("quer assombrar e maravilhar; exatamente o mesmo propôs Apollinaire ao exaltar a surpresa como um dos elementos centrais da poesia" -tradução nossa). Como vimos, os efeitos de surpresa e de maravilhamento advêm não só da simulação discursiva (primeira propriedade), do jogo de escuro-claro estrutural (segunda propriedade), mas também da condensação (terceira propriedade da agudeza).

Terceira propriedade: condensação (fusão de elementos inamalgamáveis) e decomposição (separação de elementos que não se separariam normalmente). Na linguagem, a condensação reflete-se também na ultraconcentração de formas da expressão e do conteúdo.

A agudeza rege-se sintaticamente pela condensação, pela síntese de coisas inamalgamáveis, dessemelhantes. Daí depreendermos que a primeira propriedade (simulação discursiva - fazer poético como competência do sujeito da enunciação), que a segunda (jogo de escuro-claro estrutural) e que a terceira propriedades (condensação) são solidárias entre si. Tais propriedades separam-se apenas para fins de estudo; no fundo, pertencem todas à arquitextura linguística do poema.

De igual forma, Frei Antonio do Rosário, em sermões pregados em Salvador em 1699 ("Frutas do Brasil"), compara o amor de Nossa Senhora do Rosário a 25 frutas tropicais, retirando de cada analogia um aspecto religioso em que sobressai a doçura do amor de 
Cristo em forma de metáforas agudas (cf. HANSEN, 2000, p. 331; HANSEN, 2001, p. 57; BIRON, 2009, p. 47-57).

As analogias com frutas brasileiras aparecem em alguns discursos seiscentistas. Em um deles, explora-se a agudeza composta pela condensação entre "ananás" e "Annanascitur, Senhora do Rosário", duas figuras semânticas que normalmente não se misturariam. No sermão citado, a analogia é composta pelas propriedades do ananás e pelos atributos da realeza; em seguida, a analogia configura-se pelas virtudes do ananás em confronto com as da rosa, evidenciando a superioridade hierárquica das frutas sobre as flores:

Nasce o ananás com coroa como rei; na casca, que parece um brocado em pinhas, tem a opa real; nos espinhos como arqueiros a sua guarda; pelas insígnias reais com que a natureza o produziu tão singular, de grande, e fermosa estatura, tem a forma digna de império, entre as mais frutas do universo; mas pelas partes, e qualidades que tem para o bom governo, é Príncipe perfeito, porque é severo, e suave, sendo para o gosto a maior delícia; sendo tão gostoso, suave, e deleitável, é mui severo, áspero, e cruel para os criminosos, para os que têm chagas, e feridas: rigor, e brandura a seu tempo, é o axioma do melhor governo.

[...]

Por que há de ser o Ananás, e não outro fruto do Brasil, a metáfora do Rosário? Porque em todo o mundo não há fruta que mais tenha da Senhora do Rosário, do que o Ananás. O nome diz, Ananás vale o mesmo que Annanascitur: de Santa Ana nasceu a mãe de Deus. Ana quer dizer graça; cento e cinquenta vezes se nomeia no Rosário a filha de Ana cheia de graça; e se os nomes são sinais das naturezas que os têm, o Ananás é o fruto que melhor significa a Senhora do Rosário porque contém a origem da sua cheia de graça, de que está cheio o Rosário [...] logo também se pode dizer que Annanascitur, é Ananás, o mais sublime, e majestoso fruto desta terra, a metáfora, a significação, e o retrato do Rosário (ROSÁRIO, 2002, p. 1-2, 2021, destaques nossos).

Se em Arcimboldo a agudeza é configurada plasticamente na condensação de frutas, legumes e flores em face humana (mistura de elementos distantes semanticamente: frutas, legumes e flores = face humana, numa relação de englobante/englobado), em Frei Antonio do Rosário o ananás (abacaxi) aproxima-se de paixões religiosas. Como se vê no enunciado do sermão, amalgama-se ananás com o nome de Sant'Anna, mãe de Nossa Senhora. Por meio de uma etimologia engenhosa, temos a analogia entre figuras discursivas completamente distantes: "Ananás" e "Anna nascitur". Feita a aproximação, o enunciador continua a retirar metáforas agudas do fruto brasileiro: as folhas do ananás representam a coroa do rei; a casca, a opa real; os espinhos, a guarda do rei; a verticalidade do fruto, a 
forma digna do império. A analogia com o governo do rei revela-se na mistura de doçura e acidez (severidade) do fruto.

Todas essas agudezas são proporcionadas pelo artifício engenhoso da condensação que maravilha o enunciatário. Assim, quanto mais dessemelhantes os elementos aproximados, maior é a surpresa, maior a agudeza, mais arquitetural a linguagem, maior a competência poética do enunciador em escurecer o objeto e maior o prazer (saber, do latim "sapere", "ter sabor") do enunciatário em clareá-lo (coenunciação). Confrontando a agudeza de Arcimboldo com a de Frei Antonio do Rosário, observa-se no enunciado deste último menor acentuação da intensidade, pois que seus comentários metalinguísticos, regidos pela necessidade de clareza pragmático-religiosa de seu sermão, orientam o enunciatário na apreensão inteligível das agudezas. Reduz-se o maravilhamento em intensidade sensível (e aumenta-se o inteligível), quando explicita a agudeza do PC, aproximando ananás da mãe de Nossa Senhora.

Todavia, acentua-se a agudeza, quando o enunciatário depara-se com o som da paronomásia Ananás/Annanascitur. O inteligível nesse primeiro instante é mais lento e, devido à alta sensibilização sonora, temos um recrudescimento de intensidade. Ao ouvir a aproximação de sons semelhantes, mas de conteúdos distantes, o sujeito é invadido pelo êxtase breve e pouco durativo.

A terceira propriedade da agudeza (condensação), que estamos examinando, também pode ser observada em poema atribuído a Gregório de Matos (2010, v. 1, p. 507): 


\begin{abstract}
Lizongea outra vez impaciente a retenção de sua mesma desgraça, aconselhando a esposa neste regallado soneto ${ }^{11}$
\end{abstract}

Discreta, e formosíssima Maria,

Enquanto estamos vendo a qualquer hora

Em tuas faces a rosada Aurora,

Em teus olhos, e boca o Sol, e o dia:

Enquanto com gentil descortesia

$\mathrm{O}$ ar, que fresco Adônis te namora,

Te espalha a rica trança voadora,

Quando vem passear-te pela fria:

Goza, goza da flor da mocidade,

Que o tempo trota a toda ligeireza,

E imprime em toda a flor sua pisada.

Oh não aguardes, que a madura idade

Te converta em flor, essa beleza

Em terra, em cinza, em pó, em sombra, em nada.

Em algumas metáforas do poema, nota-se a propriedade aguda da condensação: "Em tuas faces a rosada Aurora," / "em teus olhos e boca o Sol, e o dia" e "Que o tempo trota em toda ligeireza," / "E imprime em toda flor sua pisada". Na primeira condensação, o fenômeno físico do amanhecer é aproximado agudamente da face humana feminina de Maria. A beleza de Maria é justaposta à beleza da "Aurora". No poema, a figura do amanhecer personifica a juventude da mulher, metáfora que faz sobressair a sensibilidade da cor rosada, da coloração do céu e da pele de Maria.

Na segunda condensação, a claridade do sol engloba o brilho dos dentes ("e boca o Sol") e dos olhos de Maria; o sentido orienta-se por categorias eufóricas: os olhos brilham como o Sol e os dentes são claros como o dia. Todos sugerem beleza jovial.

$\mathrm{Na}$ terceira condensação, orientada por um efeito de sentido disfórico do tempo que passa inexorável e rapidamente, a agudeza revela-se na sua inteireza: o tempo é associado ao trote de um cavalo; há o maravilhamento pela aproximação de figuras discursivas muito distantes, como o é tempo e cavalo. O enunciatário vê-se momentaneamente desorientado pelo sensível sonoro e pela imagem visual do galopar do tempo, porque não se espera o reconhecimento da prosopopeia do tempo que trota como cavalo.

\footnotetext{
${ }^{11}$ Nos poemas atribuídos a Gregório de Matos (2010, v. 1 e v. 2), o título [a didascália] é uma criação dos organizadores de sua obra. Esses títulos têm a função de direcionar o sentido do poema.
} 
E mais à frente, "imprime em toda flor sua pisada", ou seja, o tempo destrói a conjunção do sujeito com a beleza. Aqui, novamente, o enunciatário surpreende-se ao reconhecer e compor um sentido que junta "flor pisada" com "o efeito do passar do tempo no corpo". Essa inexorabilidade abstrata do tempo ganha no poema a concretude figurativa de um trotar de cavalo e de suas pisadas, metaforizando agudamente a rapidez do efeito do tempo no corpo dos sujeitos.

Enquanto a filosofia de Leibniz (DELEUZE, 2011a) era dominada pela procura de regras que governassem as indagações sobre a verdade e harmonia do mundo natural, os ensaístas seiscentistas, por sua vez, reconheciam a incontrolável desordem dos sentidos nos objetos poéticos. E são esses sentidos que escapavam às regras clássicas. Não obstante os esforços de Pallavicino (In: SNYDER, 2007, p. 58-68), em Trattato dello stile e del dialogo, para dar ordem às desordens sensoriais das letras seiscentistas, a linguagem artística da época seduzia justamente por suas características ligadas ao sensível.

A manipulação do sensível e a alta elaboração inteligível é a engrenagem que faz funcionar as propriedades da agudeza, desdobradas em expressão e conteúdo. Peregrini (1997, p. 42), ao mencionar a agudeza, reforça a condensação de duas figuras diferentes, sendo então essa propriedade necessariamente regida por uma relação de diferença. Embora figuras diferentes e distantes, elas são associadas em outro tipo de relação de intersecção e, nesse caso, passamos a ter uma relação de dependência, de englobante/englobado. O engenho agudo do sujeito da enunciação consistia, pois, em descobrir semelhança na diferença, bem como a hierarquia entre essas relações.

Para finalizar, vejamos na tabela 2.1 uma síntese com os trechos dos tratadistas seiscentistas a respeito das propriedades da agudeza:

Tabela 2.1 Síntese das propriedades da agudeza.

\begin{tabular}{|c|c|c|}
\hline $\begin{array}{l}\text { Simulação discursiva - } \\
\text { PRIMEIRA PROPRIEDADE }\end{array}$ & $\begin{array}{l}\text { Jogo de escuro(sensível)- } \\
\text { claro (inteligível) estrutural: } \\
\text { fazer escurecer e clarear o } \\
\text { sentido; a poesia e o efeito } \\
\text { de maravilhamento - } \\
\text { SEGUNDA PROPRIEDADE }\end{array}$ & $\begin{array}{l}\text { Condensação de elementos } \\
\text { inamalgamáveis - } \\
\text { TERCEIRA PROPRIEDADE }\end{array}$ \\
\hline $\begin{array}{l}1^{\circ} \text {. "a cagione di ciò si } \\
\text { tresanda tanto oggidi per } \\
\text { questa traccia che si viene a } \\
\text { sfacciatamente dare in }\end{array}$ & $\begin{array}{l}1^{\circ} \text {. “L'unico scopo delle } \\
\text { poetiche favole si è adornar } \\
\text { l'intelletto nostro d'immagini } \\
\text { o vogliam dire d'apreensioni }\end{array}$ & $\begin{array}{l}1^{\circ} . \quad \text { "I'acutezza si regge } \\
\text { necessariamente } \\
\text { legamento" } \\
\text { (PEREGRINI, } \\
\text { (997, p. } 30 \mathrm{ss).}\end{array}$ \\
\hline
\end{tabular}




\begin{tabular}{|c|c|c|}
\hline 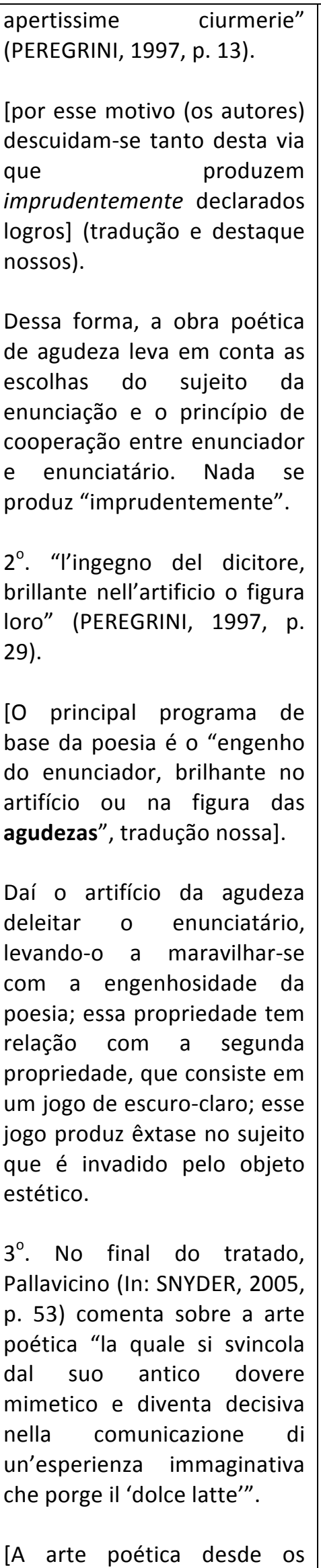 & 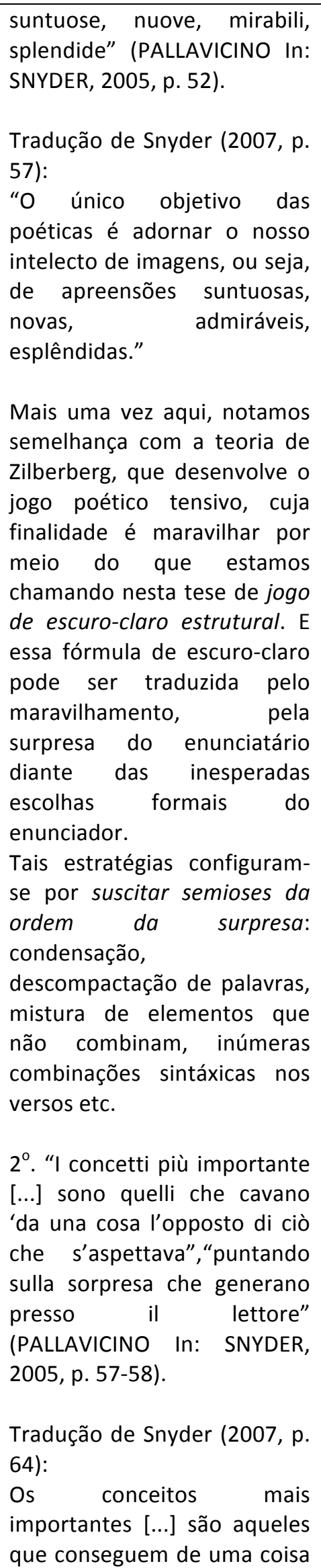 & 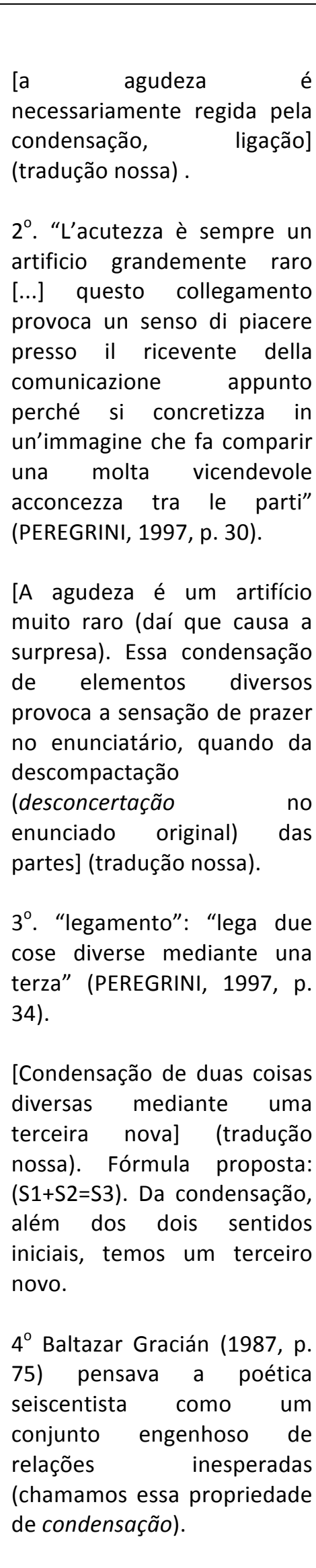 \\
\hline
\end{tabular}




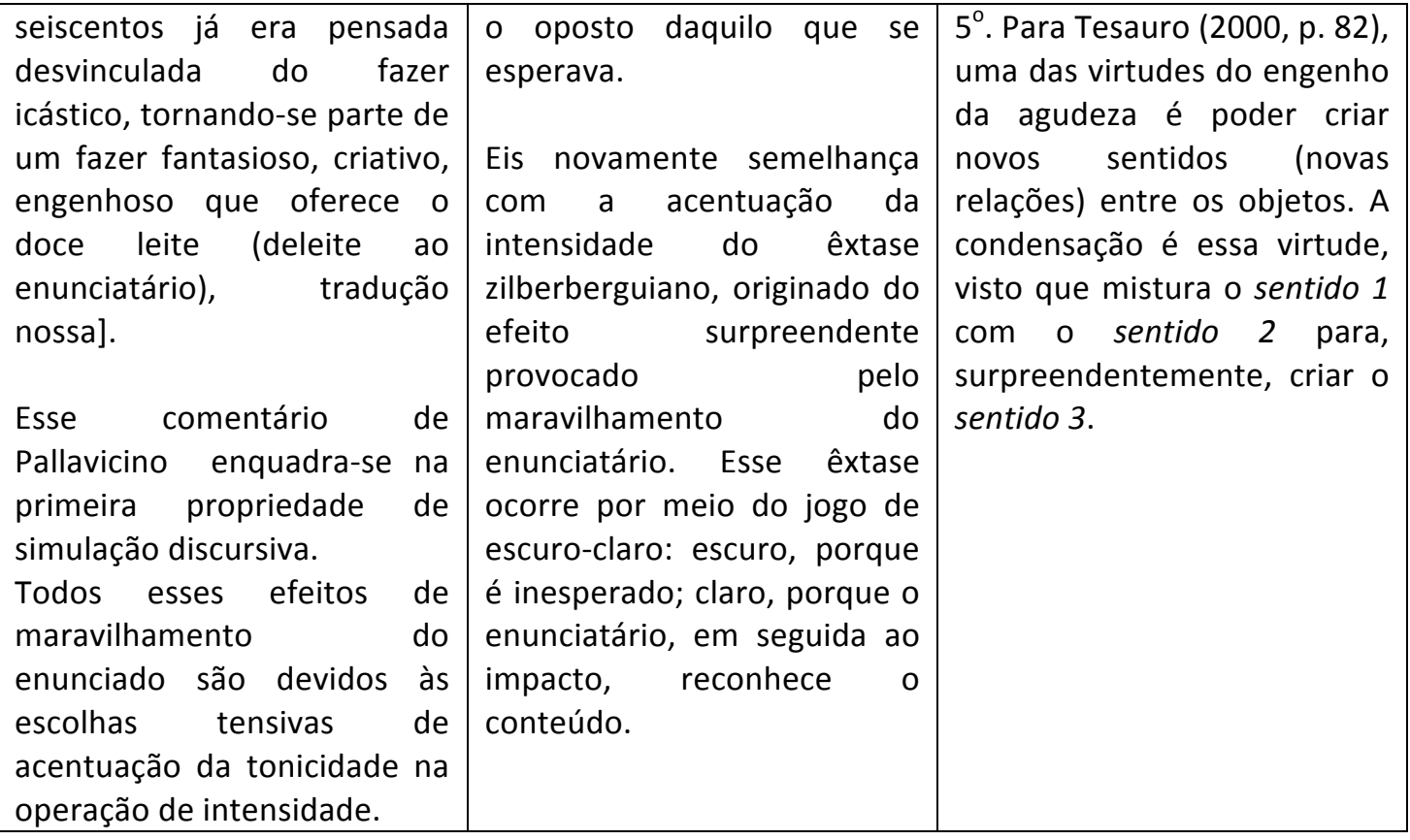

A seguir, resumidamente, esquematizamos as propriedades da agudeza mencionadas e o modo como são solidariamente articuladas entre si:

Terceira propriedade: condensação e decomposição
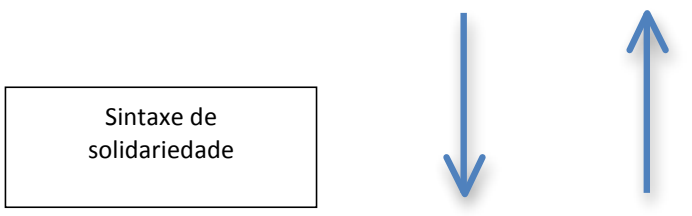

Segunda propriedade: jogo de escuro-claro estrutural

[o sobrevir do enunciado poético - efeito de maravilhamento]

Sintaxe de

solidariedade

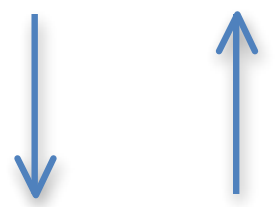

Primeira propriedade: simulação discursiva pelo sujeito da enunciação (fazer poético composto por enunciador e enunciatário [coenunciação]) 
Como vimos neste capítulo, optamos pelo desdobramento da agudeza em duas vertentes: a agudeza do PE e a agudeza do PC. Ambas pertencem a dois tempos discursivos muito diferentes: o das letras seiscentistas e o das letras do final do século XX. Observamos, porém, que há um jogo tensivo que rege as duas vertentes de agudeza. Desse modo, quanto mais entravamento formal, mais lento, em geral, é o reconhecimento inteligível do conteúdo; quanto menos entravamento, mais acelerado, pois, é o reconhecimento.

Embora haja a tradição de poesia visual nos seiscentos, ela se diferencia das poesias visuais de Affonso Ávila, por exemplo. Embora em "São Francisco de Assis" estejam em evidência as figuras discursivas da tradição dita "barroca", no nível figural (tensivo) não se assume no poema um novo barroco. E aqui volto a insistir na existência de destinadores e sujeitos da enunciação movidos por valores diferentes, não sendo pertinente afirmar o retorno do chamado barroco no final do século $X X$, pois, nos séculos $X V I-X V I I$, além de um contrato enunciativo divergente, diversos eram também os valores dos destinadores regulados pela sociedade de então.

Muitas vezes, o enunciador, ao privilegiar as agudezas do plano da expressão, busca a atenuação do conteúdo. Se há predominância das agudezas do conteúdo, por buscar relações "estranhas" e altamente elaboradas entre conteúdos diversos, o plano da expressão é atenuado em refreamento. Não se trata, porém, de uma regra, pois é possível a mistura das agudezas, como se observa em Galáxias, de Haroldo de Campos, a ser vista no capítulo 5.

O jogo entre a agudeza de expressão e de conteúdo faz-se sob a regência de diferentes cifras tensivas, conforme vimos na análise do objeto. A título de exemplo, em "Casa de Gonzaga", os entravamentos formais por si só produzem maravilhamento e um andamento inicialmente acelerado no sensível e lento no inteligível (há uma demora no reconhecimento); em um segundo momento, o sensível perde em duração e em aceleração, suscitando um segundo tipo de prazer. Nesse momento, o inteligível ganha em aceleração e dá-se a apreensão cognitiva do objeto. Agora, o sujeito é que apreende, pelo saber, o objeto estético.

Como a arte em geral, a poesia tem como programa a duração sensível e esta, como sabemos, é efêmera. Essa desejada duração sensível, que é passageira, está em tensão permanente com a demora do reconhecimento inteligível. Além disso, a poesia mostra-se ainda mais aguda, quando proporciona ao enunciatário o prazer demorado da descoberta 
dos laços cognoscíveis e engenhosos, segundo os quais ela foi erigida. Eis a tensão da semiótica da agudeza:

Rapidez sensível tensionada com a lenta descoberta do inteligível.

A seguir, vejamos no capítulo 3 a negação da euforia barroquista e a afirmação da visualidade e da fluidez na poesia da agudeza. 
VISUALIDADE NA POESIA DA AGUDEZA: NEGAÇÃO DA EUFORIA BARROCA

[...] os autores não são 'clássicos' ou 'medievais' ou 'renascentistas' ou 'maneiristas' ou 'barrocos', mas antes de tudo politécnicos ou pantécnicos, conhecedores das muitas medidas diferenciais dos muitos estilos dos muitos gêneros. João Adolfo Hansen

Este processo, reconhecível em muitos textos barrocos ou os chamados neobarrocos, não é exclusivo deles e pode ser percebido, por exemplo, em momentos como o alto-romantismo, o simbolismo e a vanguarda, em diferentes autores como Novalis, Mallarmé ou Pessoa. Horácio Costa Os Experimentalistas não queriam fazer revivalismo: o que queriam e conseguiram fazer foi explorar sistemas operatórios que se revelaram tão eficazes no passado como no presente.

Ana Hatherly

O barroco e o experimental, como nós o entendemos, são os modelos criativos da nossa específica criação poética. Ernesto M. de Melo e Castro 


\section{JOGO ESPECULAR E MUDANÇA DE PERSPECTIVA NOS OBJETOS SEISCENTISTAS}

Os objetos artísticos previsíveis e mais rapidamente inteligíveis talvez já não servissem como parâmetro estético desde os seiscentos. Já em 1523, Francesco Mazzola colocou-se na frente de um espelho e produziu um autorretrato, fato que marcou uma mudança de perspectiva nas artes (cf. HOCKE, 2005, p. 15). Serviu-Ihe de base para seu fazer artístico um espelho convexo, capaz de engendrar uma imagem distorcida, cujo primeiro plano da tela /l Parmigiano revela uma mão gigantesca e anatomicamente deformada: uma mudança de perspectiva, portanto, conforme podemos ver na Figura 3.1.

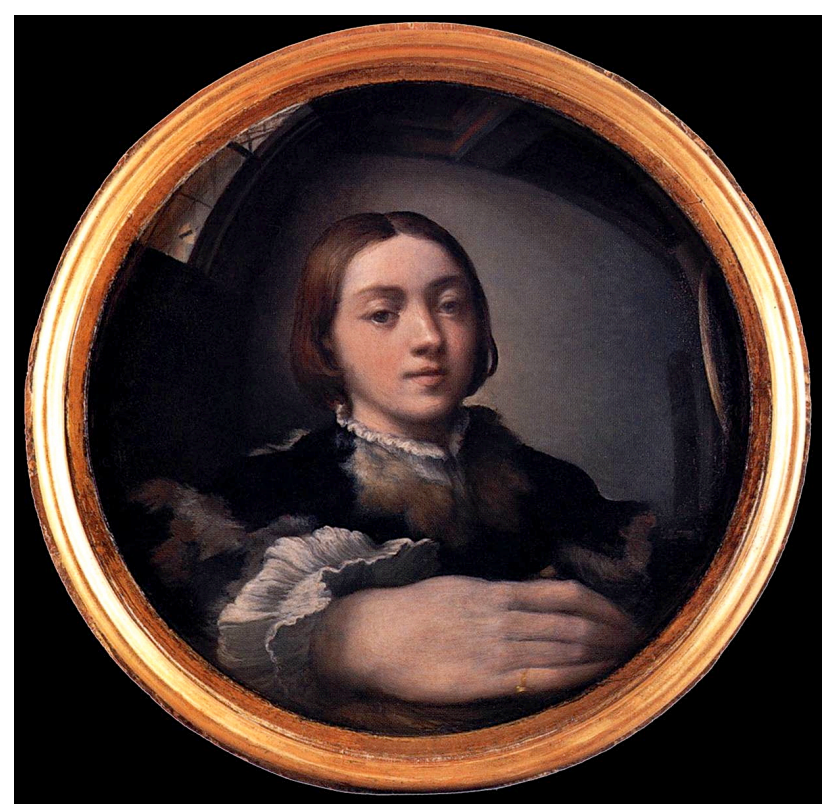

Figura $3.1 \quad$ II Parmigiano (Francesco Mazzola, 1523)

No período artístico seiscentista, observa-se um movimento tensivo entre as figuras do quadrado renascentista e as da elipse barroca. Segundo Affonso Romano de Sant'Anna (2000, p. 25), pensadores, cientistas e artistas captam o abstrato e o concretizam por meio de figuras discursivas: "há quem diga que o retângulo é para a Grécia o que o círculo é para Roma e a elipse para o barroco. [...] Isso equivale a dizer que certas figuras geométricas são o que a filosofia chama de autênticas metáforas epistemológicas". 
O chamado barroco surge como continuação do Renascimento no momento em que a teoria da perspectiva de Brunelleschi e Alberti, ilustrada na pintura por Dürer, está se alterando (cf. SANT'ANNA, 2000, p. 26). A mudança do quadrado classicista, deslocado em seu centro, é constituída por um vetor que vai da simetria em direção à deformação aguda. O sujeito da enunciação, atingido por esse deslocamento, opta por valores de dinamização, por valores visuais enigmático-deformadores.

Nas artes pictóricas dos seiscentos, a perspectiva e o ponto de fuga da frente (ou do fundo) deslocam-se para a lateralidade da tela; o quadrado vai ganhando forma elíptica; a linha reta atinge a curva; o ângulo delimitado, o afrouxamento; o percurso do quadrado, o da elipse, alterando a perspectiva.

A partir do ponto de fuga (linhas convergindo para o horizonte), houve uma redescoberta do espaço pictural e os objetos ganharam uma visão tridimensional. A perspectiva adquire abertura, um efeito de sentido de infinito labiríntico. Para Sant'anna (2000, p. 43), com a virada na perspectiva, "surge um aspecto curioso que pode ser tido como um limite na passagem do Renascimento para o Barroco, tomando-se a imagem do espelho como limiar e metáfora epistemológica". O cenário renascentista de simulação simétrica da realidade é diverso do cenário barroco, "porque o que se espelha aqui já não são necessariamente a simetria e a verossimilhança" (p. 43):
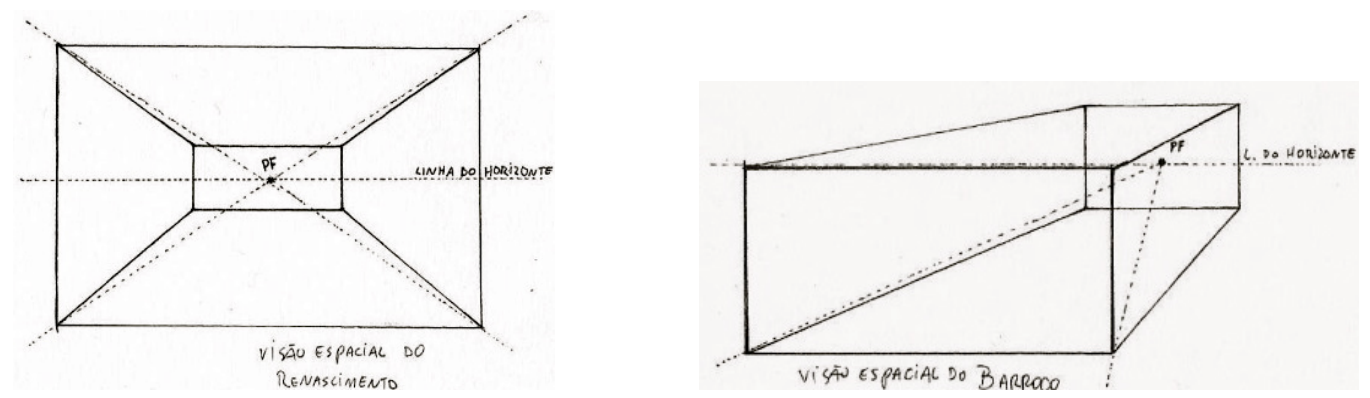

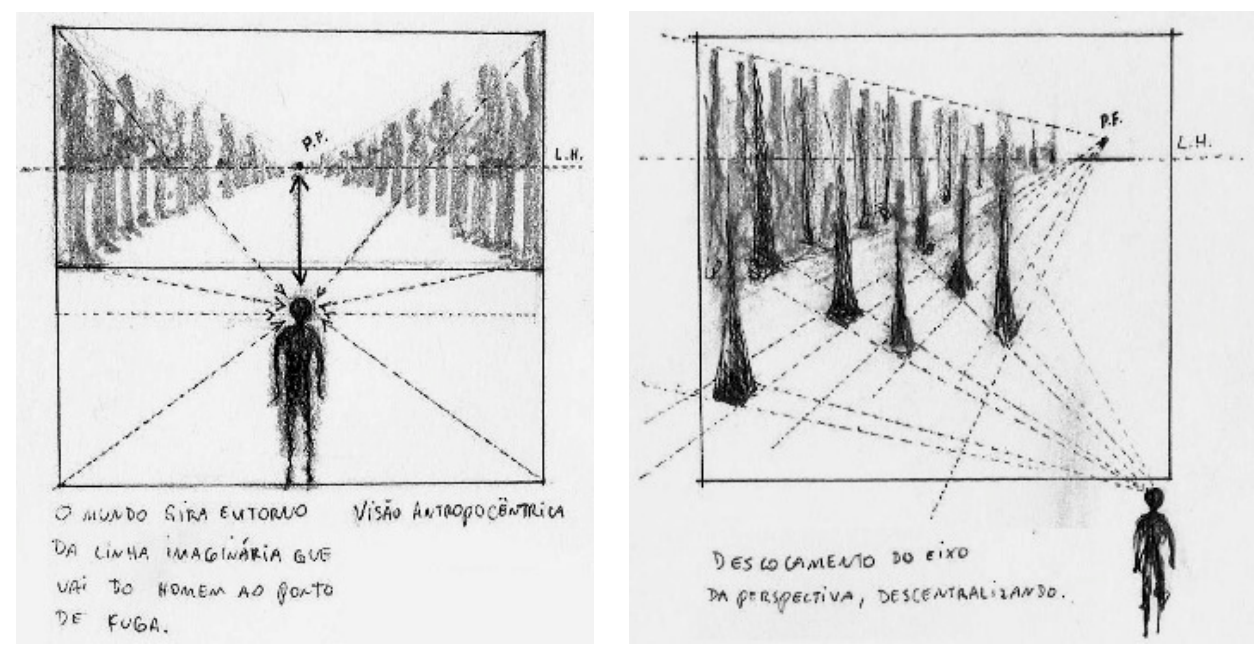

Quando se fala em classicismo, normalmente se pensa que ele seria um privilégio da arte antiga. Focillon (2001, p. 27), todavia, em $A$ vida das formas, menciona que o classicismo teria passado "por estádios diversos" e que deixa de ser clássico quando se torna barroco. O olhar do enunciador no barroco aproxima-se do olhar de um sujeito embriagado; já o enunciado apresenta-se como um espelho convexo, que deforma o objeto. $O$ espéculo barroco simula discursivamente subjetividade, abertura e labirinto. Com o passar do tempo, o espelho renascentista vai ganhando formas côncavas e convexas que desabrocham na arte seiscentista, proporcionando deformação daquilo que era seu objeto. Ao mesmo tempo que ocorrem transformações, algumas formas permanecem, ou seja, certos valores virtualizados atualizam-se pela potencialização de uma memória formal. Daí Focillon (2001, p. 28) admitir que o "estádio barroco permite igualmente reencontrar a permanência das mesmas características nos meios e épocas mais diversos".

Do nosso ponto de vista, a permanência dessas formas não é uma repetição delas, mas uma re-formatação (cf. também WÖLFFLIN, 2006, p. 324). Por exemplo, as formas utilizadas no século XVI são orientadas pela agudeza, que se apoia na memória da Retórica aristotélica, constituindo-se, portanto, introdução de novas perspectivas de observação do objeto. No final do século XX, ocorre outra atualização da agudeza. Diferentemente da agudeza seiscentista, de dominância do PC que se dá por meio de metáforas e alegorias, atualizou-se outro tipo de agudeza muito diverso, quando se acentuam os artifícios de obscurecimento formal. Nesse sentido, obnubila-se o conteúdo, havendo um recrudescimento na acentuação da intensidade; vivifica-se o sensível e delonga-se o 
reconhecimento inteligível. Em um segundo momento, reduz-se a aceleração sensual, aumentando em aceleração inteligível.

As formas agudas, abertas a muitas combinações, afastadas do ponto de fuga clássico do quadrado, aproximam-se da mudança de perspectiva, que conduz o enunciatário a vários pontos, figurativizados pela elipse e pelo labirinto. Dá-se, portanto, a agudeza, entre outros elementos, pela mudança de perspectiva.

Van Eyck, na tela Retrato do casal Arnolfini (figura 3.2), prenuncia um tipo de objeto que interessaria ao enunciador seiscentista. O quadro mostra um casal de mãos dadas em pé diante do enunciatário. Entre o casal, no fundo da tela, há um espelho convexo pregado à parede, que mostra elementos do cenário que estão à frente e atrás dos atores do enunciado, parte que o olhar do enunciatário não apreende, se ele recortar a imagem do casal apenas.

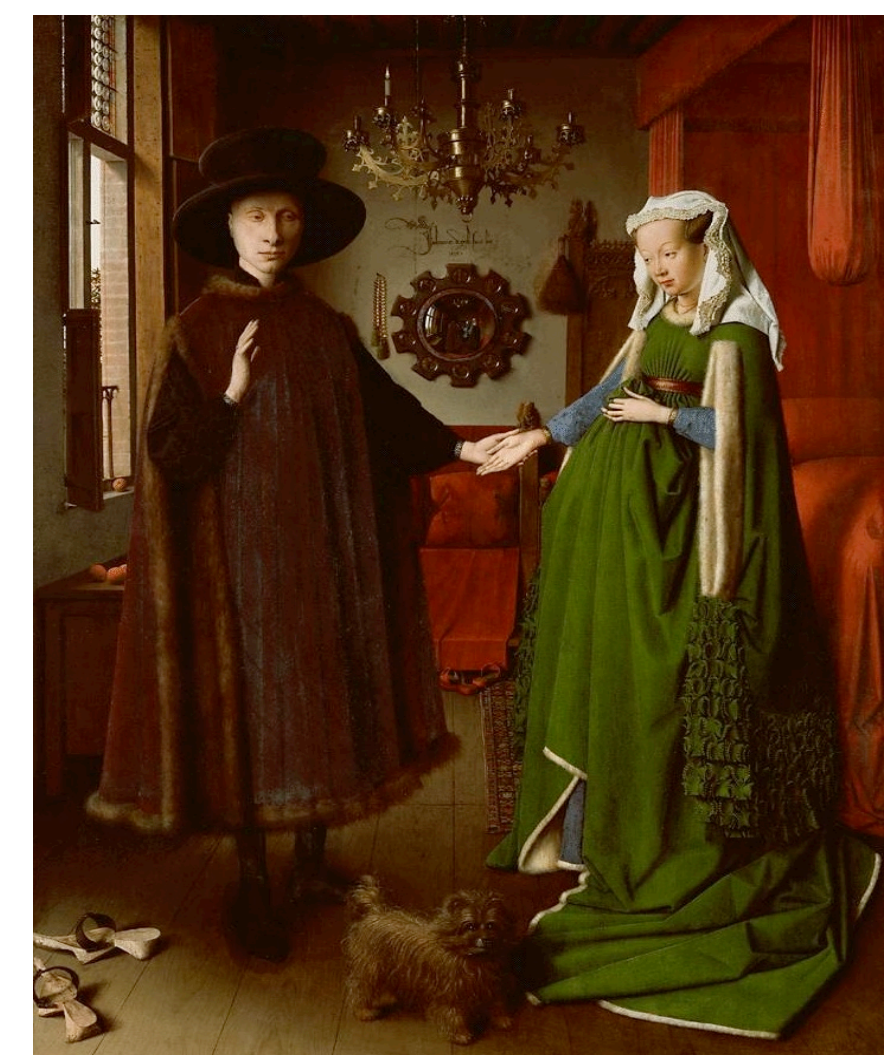

Figura 3.2 O casal Arnolfini (Van Eyck, 1434, óleo sobre tela).

Outro elemento inovador responsável por essa mudança de perspectiva é a projeção do enunciador no espelho ("Johannes de Eyck fuit hic" - "Johannes de Eyck esteve aqui"). 0 fato de o enunciador estar simulado na tela, como ocorre em As meninas de Velázquez 
(figura 3.3), gera o efeito de proximidade, na medida em que a colocação do EU no discurso dos seiscentos é diretamente responsável pelo efeito de aproximação de um TU. É o simulacro do EU que engendra imediatamente um simulacro discursivo do TU.

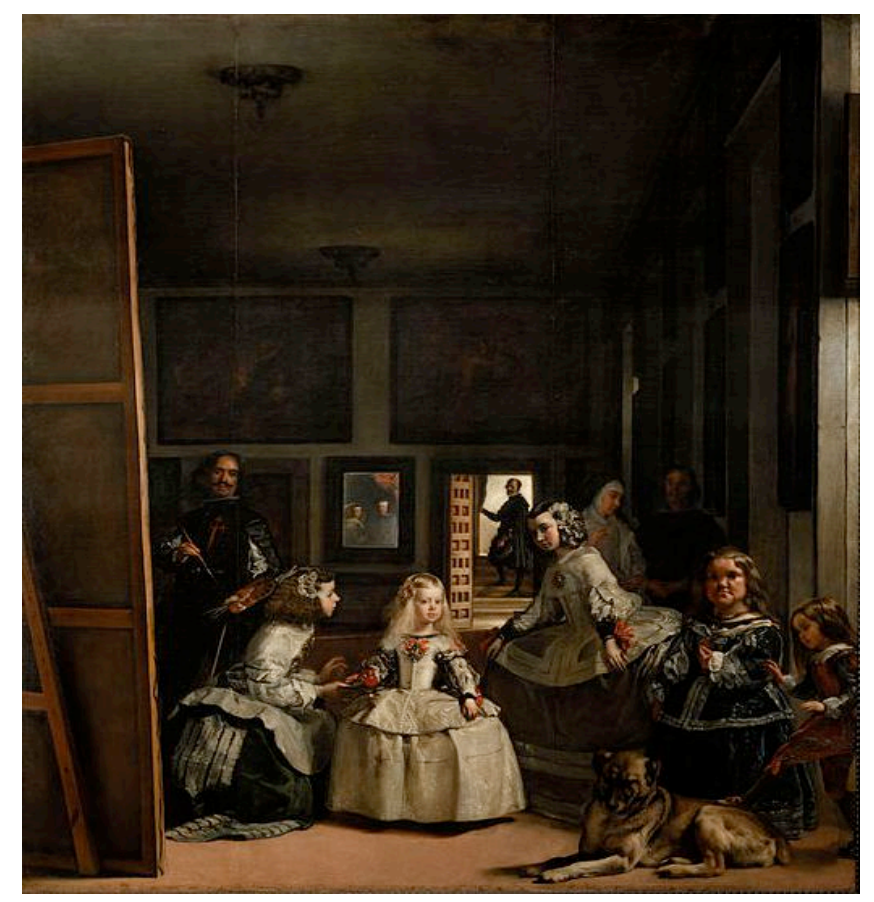

Figura 3.3

Las meninas (Diego Velázquez, 1656, óleo sobre tela).

A inscrição do sujeito da enunciação confirma a proximidade dessa instância. No classicismo, diferentemente, havia simulação de afastamento do enunciador e, consequentemente, afastamento do TU, aproximando-se do efeito de objetividade.

A arte seiscentista complexifica a perspectiva, diferentemente da pintura classicista, cujo fechamento e cuja precisão simétrica não possibilitam ao enunciador nem ao enunciatário a aproximação do enunciado: "no Renascimento, o mundo se reduz a um olhar, o olho do pintor é que ordena o universo, por isso ele geralmente está no centro do quadro; no Barroco, o olhar descentrou-se, a perspectiva é giratória e pode causar tonteira na alma" (SANT'ANNA, 2000, p. 46). E é essa "tonteira na alma" de que nos fala o ensaísta que encaminha a arte seiscentista para o efeito de "estranhamento no modo de ver" (p. 48).

Ao simular a presença do pintor no espelho, ocorre uma aproximação do enunciador projetado no enunciado, provocando no enunciatário o interesse em descobrir o enigma dessa presença. Afirmar que se está presente na cena pictórica, ou que foi testemunha dos fatos, produz efeito de realidade, mas isso não é tudo, porque há uma considerável 
alteração de perspectiva. Antes que ver os fatos de longe, como no classicismo, na arte seiscentista os fatos são vistos de perto e, portanto, o enunciador pode agora recortar elementos que passariam despercebidos a um enunciador projetado distantemente. Ver de perto parece atestar "ver melhor", ou ainda, ter a certeza de que os fatos se deram como estão estampados; ao mesmo tempo, porém, que quem está muito próximo pode deixar de ver muita coisa, pois que movido pelo simulacro de subjetividade. Essas técnicas dramáticas dos séculos XVI-XVII, influenciadas por Quintiliano, compõem o campo de visão do enunciatário, segundo a perspectiva do enunciador, que o convida a participar do aqui e agora da enunciação. Desse modo, enunciador e enunciatário tornam-se contemporâneos ao enunciado da tela (cf. HANSEN, 2006d, p. 93).

Assim é que Van Eyck (refletido no espelho) e Velázquez (de pé e defronte ao cavalete da pintura) introduzem no enunciado uma simulação discursiva do EU. E, ao fazê-lo, ativam o TU para também participar da cena. Estabelece-se, pois, solidariedade estrutural entre um e outro. Ao TU não se permite ver mais que o EU the revelou. No caso da perspectiva clássica, de simulacro de distanciamento do EU-TU, o enunciatário não conta com o ciceroneamento do enunciador. Revelar-se parte da cena também evidencia o fazer artístico como trabalho criativo, uma perspectiva diversa da do classicismo renascentista, visto que neste último a rigidez da perspectiva impede a abertura elíptica, a abertura em dobras e as variadas fugas.

Ao relacionar ciência e arte, Sarduy ([1975] 1991, p. 109-123) constata que o barroco é uma forma artística influenciada pela ciência. Assim, a descoberta kepleriana da órbita elíptica dos planetas teria incidido no fazer artístico de Caravaggio, de Borromini, de Góngora. Na opinião de Calabrese, diferentemente do posicionamento de Sarduy, não há determinismo entre ciência e arte. Para o semioticista italiano, a orientação ciência para arte não é mão obrigatória:

Pode muitíssimo bem dar-se o caso de uma grande descoberta científica ser capaz de revolucionar, como uma espécie de "origem", a mentalidade de um período. Mas também se pode dar o contrário, que um gosto artístico, literário ou proveniente das comunicações de massas incida sobre o próprio corpo das ideias científicas. Estabelecer o antes e o depois, a causa e o efeito, torna-se então ininteligível (CALABRESE [1987] 1999, p. 22-23) .

Não só a orientação "ciência $\rightarrow$ arte", ou seja, a matemática de Leibniz, de Pascal, da física de Kepler pode influenciar a arte, como também pode ocorrer o contrário: uma 
escolha enunciativa na literatura ou nas artes pode vetorializar um pensamento científico. Parece que em Sarduy, "não obstante a matriz claramente estruturalista (Barthes, por um lado, e Lacan, por outro)", pode-se colher "um vestígio de determinismo" (CALABRESE, 1999, p. 22).

O percurso do classicismo contempla a tensão entre a afirmação da ciência (Renascimento) e a afirmação da arte (uma virada seiscentista?). Assim é que as escolhas enunciativas de mudança de perspectiva, de configuração de enigmas, de propostas desafiadoras, que conjugam a capacidade inventiva de um enunciador e a argúcia da descoberta por parte do enunciatário, ambas capacidades cognitivas, constituem a contrapartida de uma arte renovada que quer entrar em competição com a ciência. A arte dos séculos XVI-XVII seria, então, arte do desafio da inteligência?

No final do século $X X$, ocorre nova atualização; retoma-se a memória da agudeza como ofício com as palavras, e a arte volta-se para o próprio fazer poético, com suas artimanhas de arte combinatória. Temos, de um lado, um percurso tensivo que compreende uma agudeza que participa de um continuum escalonado de recrudescimento da cifra da acentuação da intensidade e dos artifícios de esmaecimento dos contornos formais; de outro lado, temos a atenuação desses mesmos artifícios.

Apresentaremos a seguir variados pontos de vista sobre esse tipo de poesia aguda, usual e polemicamente conhecida como neobarroca, salientando desde já que não há um consenso entre os críticos sobre o que seja neobarroco.

\section{NEOBARROCO: DIVERSIDADE DE PONTOS DE VISTA}

\subsection{UMBERTO ECO: BARROCO COMO OBRA ABERTA}

Um dos conceitos fundamentais a qualquer estudo que se faça do neobarroco é, sem dúvida, o de obra aberta, constante da obra de Eco. Segundo o autor, Stockhausen teria proposto ao seu intérprete uma liberdade combinatória da peça musical (ECO, [1962] 1986, p. 38), cabendo-lhe montar a sucessão das frases musicais. Para o semioticista italiano, essa espécie de obra não estaria acabada e definida e o enunciado estaria estruturado de tal forma que possibilitaria inúmeras possibilidades de sentido. E, à página 41 , afirma que "a poética da obra 'aberta' tende, como diz Pouseur, a promover no intérprete 'atos de liberdade consciente', pô-lo como centro ativo de uma rede de relações inesgotáveis". 
Na obra aberta, o enunciatário sabe que "cada frase, cada figura se abre para uma multiformidade de significados que ele deverá descobrir" (ECO, 1986, p. 43), utilizando a chave de leitura que Ihe parecer adequada, "mas nesse caso 'abertura' não significa absolutamente 'indefinição' da comunicação, 'infinitas' possibilidades da forma, liberdade da fruição" (p. 43): trata-se de um feixe de resultados prefixados e condicionados, de modo que a "interpretação" do leitor não escape jamais ao controle do autor.

Assim, os limites de combinação são dados pela estrutura semiótica do texto enquanto elaborações formais, ou seja, sistema de relações em diversos níveis, fonológico, semântico, sintático. Há uma liberdade, mas vigiada pelo enunciado. Essa mobilidade estrutural está na base de textos dos século XIX e XX, como Lance de Dados, de Mallarmé, Finnegans Wake, de Jaimes Joyce, Galáxias, de Haroldo de Campos; os poemas de E. E. Cummings, as obras musicais de Boulez, de Shoenberg, de Stockhausen, de John Cage.

Conforme veremos a abertura nas poesias agudas mais fluidas, de contorno esmaecido ou aberto, erige-se por meio de um conjunto de estratégias refreadoras da forma. Um simples fonema, por exemplo, pode se desprender de um morfema, desmanchando surpreendentemente o objeto poético e requisitando maior participação do enunciatário para o seu restabelecimento. Ocorre então duplo movimento: fluidez, de um lado, por parte do enunciador, que desarticula e esmaece os contornos, e nitidez, de outro lado, por parte do enunciatário, que atualiza novamente tais contornos. Ao provar desse tipo de estesia, o enunciatário sente-se como que invadido pelo objeto, sente-se momentaneamente anestesiado pelas formas fluidas surpreendentes e fantasiosas; logo em seguida, porém, é movido pela intensidade de um estado de alma que o leva a querer saber o que se esconde por trás de formas estranhas e tão singulares. De passivo, em um primeiro momento de contato, passa então a ativo.

Enunciador e enunciatário permutam-se em papéis ativos ou passivos, conforme o ato semiótico em questão, o do fazer poético ou o do saber poético. Da mesma forma que o fazer poético engendra um enunciador pressupostamente competente, o saber poético engendra um enunciatário também pressupostamente competente para seguir as várias direções propostas pelo enunciado do objeto. Nesse sentido, as funções actanciais de enunciador e de enunciatário são cobertas por um mesmo actante: o sujeito da enunciação, simulador do fazer poético, realiza a performance da poesia, que necessita dessas duas 
funções actanciais para que se conserve na história da literatura, atualizando-se continuamente.

Ao tratarmos de competências de enunciador e enunciatário, se pensássemos em "leitores de fato", nenhum objeto estético se manteria semioticamente "em pé", porque paciência e impaciência são paixões que entravam de certo modo o estético. Como diz Zilberberg (2006b, p. 143), os museus sobrevivem, porque não dependem do saber e sim da crença. Cremos no objeto estético; o saber encontra-se num momento posterior ao crer. E a crença no objeto estético faz dele um objeto especial, empresta-lhe uma aura que desencadeia uma atitude de admiração e respeito. Enquanto a crença proporciona emoção, comoção sensível; o saber possibilita prazer intelectual, que é outro nível de prazer, o do reconhecimento cognitivo.

Umberto Eco, em resumo, contrapõe obra aberta à obra clássica renascentista, bem como não se revela um rígido estruturalista, afastando-se dos formalismos dogmáticos e definindo seu campo de investigação poética não como um sistema autoritário de regras, mas como um programa de criação a que um artista se predispõe. Ressalta ainda que a abertura seria uma qualidade de qualquer objeto estético de qualquer tempo discursivo (cf. SILVA In: WÖLFFLIN, 1989, p. 18). Além disso, parece-nos que Eco visita Wölfflin (2006, p. 168), para quem forma fechada é o "tipo de representação que, valendo-se de recursos mais ou menos tectônicos, apresenta a imagem como uma realidade limitada em si mesma, que em todos os pontos se volta para si mesma". O estilo de forma aberta, no entanto, "extrapola a si mesmo em todos os sentidos e pretende parecer ilimitado, ainda que subsista a uma limitação velada".

A obra seiscentista (aguda), que se caracteriza pela abertura, nega a estaticidade renascentista, bem como a centralização do espaço delimitado simetricamente, que converge para o centro, sugerindo a ideia de elipse (nesta tese, fluidez). O objeto estético é dinâmico, tende a uma indeterminação de efeito e convida o enunciatário "a deslocar-se continuamente para ver a obra sob aspectos sempre novos, como se ela estivesse em contínua mutação" (ECO, 1986, p. 44). A obra não impõe, assim, um sentido único; antes, as combinatórias do objeto fluido e aberto impregnam o enunciado de inúmeras possibilidades de sentido. 


\subsection{Omar Calabrese: IDADE neobarroca}

A questão das etiquetas na história da arte tem-se revelado uma solução que nem sempre conduz a resultados satisfatórios. Calabrese ([1987] 1999, p. 16) salienta a frequência "na história do gosto ou dos estilos" da denominação de períodos por meio de expressões "que os tornam extremamente simplificados e abstratos". Para ele, esse seria o caso do Renascimento, identificado pelo racionalismo e humanismo. Em relação ao final do século $X X$, entende ele que o gosto de nosso tempo pode ser denominado neobarroco, etiqueta que "não significa que tenhamos retornado ao barroco" (p. 10), nem que tal designação identifique a totalidade das manifestações artísticas atuais: "o 'neobarroco' é simplesmente um 'ar do tempo' que alastra a muitos fenômenos culturais de hoje” (p. 10). E adiante argumenta que

muitos importantes fenómenos de cultura do nosso tempo são marcas de uma "forma" interna específica que pode trazer à mente o barroco.

Só a evocação do termo pode fazer nascer mais do que uma objecção imediata. Quanto ao prefixo "neo". Assim como o "pós" de "pós-moderno" fazia pensar num "depois", ou num "contra" a modernidade, também "neo" poderá levar a crer na ideia de repetição, regresso, reciclagem de um período específico do passado, que seria então precisamente o barroco (CALABRESE, 1999, p. 27).

Para o autor, neobarroco seria concebido por analogia, não por "retomada" dos seiscentos. Nesta tese, também não pretendo fazer do neobarroco uma retomada do barroco, nem como história, nem como estrutura, pois pertencem a tempos discursivos muito diferentes, com destinadores díspares. Hansen (2001, p. 15) também discute a impropriedade da repetição histórica do barroco, que seria uma invenção neokantiana e positivista do século XIX, pois até o século XVIII não se falava em "barroco". Além disso, os séculos seiscentistas não foram barroco; esse recorte é póstumo.

Sarduy ([1975] 1991), por seu turno, define o barroco como especificidade formal dos objetos artísticos, podendo em sua visão haver barroco em qualquer época, aquém e além de seu tempo. Na argumentação de Calabrese, assim como na de Sarduy, vem à tona a preocupação com a forma. Nesse caso, barroco seria uma categoria formal diversa da categoria formal do classicismo. Haveria nos fenômenos culturais formas subjacentes, que possuem um andamento estrutural. Ao estudioso caberia "demonstrar que tais formas coexistem, conflitualmente, com outras de diferente natureza e estabilidade interna" (CALABRESE, 1999, p. 28). O termo barroco já fora pensado como categoria por Eugenio 
D’Ors (2011), Luciano Anceschi (In: D'ORS, 2011), Henri Focillon (2001), Wölfflin (1989, 2006), Gillo Dorfles (1951) e como estrutura histórica por Maravall ([1975] 2009, p. 65 e 120).

O barroco é, por exemplo, visto por Wölfflin $(1989,2006)$ como constante alternativa e por Focillon (2001) como degeneração formal: sucessão de geração clássica $\rightarrow$ acabamento $\rightarrow$ aperfeiçoamento $\rightarrow$ degeneração barroca. Embora ambos levem em conta a constante clássica, nem um nem outro, segundo Omar Calabrese (1999, p. 32), arrisca a formular um quadro formal mais articulado:

\begin{abstract}
Wölfflin, por exemplo, inventa os seus cinco pares formais a partir da ideia de obra de arte como aspecto, aparência, superfície sob a qual estão subjacentes formas mais abstractas. Mas não explica a pertinência recíproca de conceitos como "linearidade", "fecho formal", "superficialidade", "clareza" [...]. O resultado é, por isso, um formalismo pouco operativo, o qual poderá ser sempre contestado com a oposição de outros pares classificativos.
\end{abstract}

No artigo "Pour une définition sémiotique du maniérisme et du baroque", in Actes sémiotiques, James Sacré, citado por Calabrese (1999, p. 34), considera o barroco uma poética da suspensão das oposições, sendo uma estética da mistura, englobadora de outras. E, à página 56, afirma ser o neobarroco a construção de uma metrificação diversa, que engendra um ritmo frenético, inovando o ritmo do passado clássico. Seria o neobarroco, para ele, uma estética da repetição, uma variação organizada, de irregularidades reguladas, segundo a cifra tensiva do excesso e do gosto pelas formas elípticas.

Calabrese pauta sua reflexão no embate das formas que oscilam pela variação regulada (e aqui estamos novamente no eixo icástico) e pelo virtuosismo (e aqui a direção é do eixo fantástico). Outra vez, o Sofista de Platão. O excesso de um faz eclodir o outro.

A seguir, o neobarroco como desperdício.

\title{
2.3 SEVERo SARDUY: NEOBARROCO DO DESPERDÍCIO EM FUNÇÃo do PRAZER
}

Em sua obra crítica, Sarduy ([1969] 1979, p. 60) entende que "a extrema artificialização praticada em alguns textos, e sobretudo em alguns textos recentes da literatura latino-americana, já bastaria para assinalar neles a instância do barroco". Parece que Sarduy utilizou a terminologia extrema artificialização em seu sentido de "fazer com arte" e não de "artificial como falta de naturalidade". Ao afirmar a artificialização e associá- 
la ao barroco, o ensaísta euforiza esses objetos estéticos, porque seriam eles feitos com requintes formais. Como temos visto, esse tipo de artifício é uma operação de agudeza.

Diferentemente de todos os textos críticos que euforizam o barroco do final do século XX e são pouco precisos, o texto de Sarduy (1979, p. 57-79) apresenta algumas características linguísticas, numa tentativa de dar maior exatidão ao usualmente conhecido objeto neobarroco. Vejamos:

1. Extrema artificialização, particularmente na literatura latino-americana. Artificialização, no sentido de dissimulação, do fingir das artes, da ardilosidade discursiva, que leva ao mascaramento do sentido. O artifício é composto de substituição, proliferação, condensação:

a. Substituição de signos: muitas vezes, leva a um distanciamento máximo entre o significado inicial e o final. Essa característica aproxima-se da agudeza dos seiscentos. A título de ilustração, no quadro L'ortolano (e Ortaggi in una ciotola), de Arcimboldo (1590), vemos a substituição de nariz, boca, olhos, testa por frutas, legumes, verduras compondo a face de um homem:

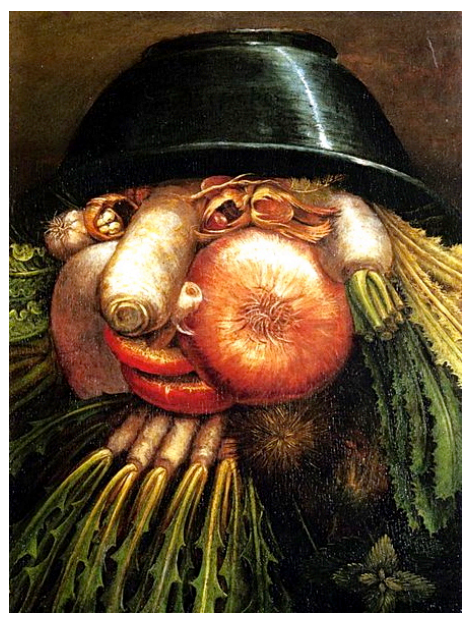

Figura 3.4

L'Ortolano (e Ortaggi in una ciotola)

Essa substituição não se atém a uma simples troca, pois, ao subverter a função semiótica, onde esperávamos (implicação) nariz, bochecha, barba, somos surpreendidos (concessão) por nabo, cebola, folhas do nabo etc. A analogia estabelecida entre face humana e leguminosas formando um rosto aproxima unidades semânticas distantes. Nessa equivalência, ocorre uma metáfora aguda, fortificando o sensível e promovendo o aparecimento de 
novos valores, como o da simplicidade e da vitalidade do homem do campo. Em uma simulação de um rosto humano representado icasticamente, teríamos um objeto atenuado no sensível, enquanto em um rosto humano representado por leguminosas, temos uma ressemantização, uma acentuação do estranhamento sensível. O uso rotineiro não nos permite sentir a face humana como participante da natureza, estando mais próxima da cultura. Desse modo, por meio da sensibilização estética, depreende-se um movimento fórico por inversão: a euforia percorre um caminho de retorno, da cultura em direção à natureza. A agudeza de Arcimboldo é semelhante àquela que vamos encontrar no conceito de substituição de Sarduy. É por meio da agudeza que os objetos de qualquer estética podem então ser examinados: não se estranhe, pois o "novo muitas vezes não é mais que um retorno a uma forma abandonada desde sempre, mas cuja virtualidade pelo menos está inscrita no sistema intemporal da linguagem" (GENETTE, 1972, p. 250). E com base em Valéry e Borges, Genette ainda afirma que "o verdadeiro criador não é aquele que inventa, mas o que descobre (isto é, inventa aquilo que quer ser inventado), e o critério de valor de uma criação não está em seu aspecto de novidade, mas, ao contrário, na sua antiguidade profunda: ou melhor dentro do novo está aquilo que corresponde a um desejo antigo" (p. 250). O maravilhamento, objeto dessa arte aguda, não advém propriamente do não esperado, mas de um estado latente que se atualiza, não obstante a expectativa do conhecido. Para nosso conforto inteligível, talvez preferíssemos ver na face do hortaliceiro nariz, bochechas, testa, construídos linguajeiramente com "nariz, bochechas, testa". Mas não é assim. Na tela, ocorre ainda metonímia e hipérbole, predominando o vívido e o exagero. Há uma relação erótica entre o sujeito, ator hortaliceiro, e os objetos que brotam de sua produção agrícola: o rosto reproduz as partes íntimas de um homem (pênis, o nabo; testículos, as cebolas; pelos pubianos, as folhas do nabo). A exuberância dos legumes por contiguidade metonímica atestam a exuberância sexual do sujeito. Também não parece que o enunciador atribua ao hortaliceiro um valor disfórico; ao contrário, ao aproximá-lo da natureza, vê as partes 
íntimas humanas e suas funções como algo natural. Além disso, enquanto o criador (hortaliceiro) é representado pela criatura (produções agrícolas), a relação metonímica estabelece uma intersecção que desbarata toda a hierarquia, ou seja, o homem é, antes que cultural, natural. A cabeça, sinédoque do homem, parte representando o todo, contribui para a tensão entre o inteligível (nariz representado por um nariz) e o sensível (nariz representado por um nabo). Nesse caso, o jogo tensivo dá-se pela oscilação entre sexo e cabeça; cultura e natureza; feio (no senso comum, partes íntimas descobertas) e o belo (a exuberância desses legumes = exuberância sexual); utilitário e estético; moralização e necessidade de prazer; alma e corpo. O fazer poético revela aqui uma tensão entre valores éticos e estéticos. Hansen (2004, p. 376) assume que a metáfora é simultaneamente representação e valor: no caso de Arcimboldo, ao substituir "nabo" por "nariz", não ocorre apenas a substituição pura e simples, mas uma troca de valores, uma mudança de isotopia. Um instrumento cortante, como uma enxada, que substituísse o nariz no lugar do nabo, desencadearia outras isotopias, como, por exemplo, a do trabalho pesado, a da agressividade do hortaliceiro etc. Da mesma forma, outros vegetais e legumes não são, na tela, apenas substituidores, eles carregam valores em tensão, como os da estetização e os da etização. Os valores éticos configuram um sujeito marcado pelo dever de produção de alimentos, deduzível do título da pintura Hortaliceiro (e hortaliças em uma gamela); a metáfora aguda figurativiza um trabalhador, cumpridor de seus deveres de produção de bons alimentos, em tensão com seus desejos carnais. Os valores estéticos, por sua vez, surpreendem por amalgamar sobrecontrários tão dissonantes: face não é cebola, nariz não é nabo; face humana associa-se a órgão sexual, ou seja, na tela, sexo é igual a rosto humano, uma tensão elíptica, sem fim. É pelo veio estético que depreendemos o modo operacional concessivo de que trata Zilberberg (2011a, p. 242-245): o estético permite revolver os sentidos, ver correspondência e analogias onde normalmente não as vislumbramos. Nesse sentido, a estética da agudeza, cujo nome convencionado é barroco e neobarroco, suscita, pelos refreamentos 
formais, conteúdos surpreendentes e concessivos. Ao obscurecer o PE, dificulta-se a apreensão imediata, levando o enunciatário a permanecer no prazer sensível por mais tempo, o que lhe permite encontrar um reconhecimento inteligível tão demorado e, por isso, prazeroso quanto foi o deleite inicial (mas passageiro) de visualizar a beleza de cebolas, nabo, folhas em forma de rosto.

b. Proliferação: esse desdobramento da artificialização leva ao obscurecimento formal. Um caso particular de proliferação na literatura brasileira ocorre em Grande sertão veredas, quando o ator Riobaldo nomeia o diabo com uma grande quantidade de nomes diversos: “Anhangão, Aquele, Barzabu, Berzebu, Belzebu, Bute, Capiroto, Ele, o Arrenegado, o Austero, o Azarape, o Bodepreto, o Cabrobó, o Canho, o Cão, o Careca, o Carocho, o Coisa-Má, o CoisaRuim, o Coxo, o Cramulhão, o Cujo, o Danador, o Das Trevas, Dê, o Debo, o Demo, o Demônio, o Diá, o Diogo, Dos Fins, o Drão, o Dubá, o Duba-Dubá, o Grão Tinhoso, o Homem, o Indivíduo, o Mafarro, o Mal-encarado, o Maligno, o Morcegão, o Não-sei-que-diga, o O, o Ocultador, o Outro, o Pé-de-Pato, o Pé-preto, o Que-Diga, O-que-não-existe, O-que-não-há, o Rapaz, o Satanão, o Sem-gracejos, o Severo-mor, o Solto, o Sujo, o Temba, o Tendeiro, o Tentador, o Tisnado, o Tristonho, o Tunes, O-que-nunca-se-ri, Xu" (cf. MARTINS, 2001, p. 169). Essa proliferação também pode dar-se em termos de justaposição de unidade grafemáticas, como podemos verificar no poema "Gradil-Poema em Casa de Mezanino", de Affonso Ávila (2008a, p. 287):

\section{$\&$}

$p^{a}$ eternamemóriadobene

ficioimmortalteunomefi

cagravadonestemetal

$\mathrm{dmpc}$

\&

$p^{a}$ eternamemoriadabema

madaidealseunomefica

gravadonestemeupeito

mdjs 
A proliferação de grafemas e de fonemas em bloco com desmanche de contornos obscurece as formas de expressão e de conteúdo, provocando o efeito de linguagem cifrada, garantindo o código secreto dos sujeitos amantes, identificados no enunciado pela inscrição do poema no gradil da casa de mezanino (presente do título). O enunciado poético é uma confissão de amor inscrita no metal (quinto verso: "dmpc") e no peito de um dos amantes (último verso: "mdjs") pela proliferação de fonemas amalgamados que não se separam nem para constituírem morfemas.

c. Condensação: fusão, permutação, espelhamento fonemas, grafemas, morfemas, lexemas em cadeia; o anagrama é, por exemplo, um tipo de condensação por associação. No primeiro formante de Galáxias (o primeiro e o último são fixos e vêm em itálico), de Haroldo de Campos, temos um exemplo de condensação por fusão, permutação, espelhamento. Em "começo", temos englobada a palavra "meço"; "recomeço" engloba "começo"; por homofonia "remeço" está dentro de "arremesso". Em "escrever", "sobrescrevo" e "sobrescravo", a permutação paronomásica confere ao enunciado a sugestão do escritor que é escravo de escrever. Tudo funciona como um espelhamento que advém das operações agudas de fusão sonora, que produz eco; da permutação, que produz anagramas. Todos esses procedimentos são espelhados e espiralados, produzindo um efeito de elipse, condição do objeto agudo constelar, um objeto fluido que não permite nitidez de contornos formais nem clareza absoluta. Um signo envolve-se no outro num processo ininterrupto de condensação imagética:

e começo aqui e meço aqui este começo e recomeço e remeço e arremesso/ e aqui me meço quando se vive sob a espécie da viagem o que importa/ não é mais a viagem mas o começo da por isso meço por isso começo escrever/ mil páginas escrever milumapáginas para acabar com a escritura para/ começar com a escritura para acabarcomeçar com a escritura por isso/ recomeço por isso arremeço por isso teço escrever sobre escrever é/ o futuro do escrever sobrescrevo sobrescravo em milumanoites miluma/páginas ou uma página em uma noite que é o mesmo noites e páginas/ mesmam ensimesmam onde o fim é o começo onde escrever sobre o escrever/ é não escrever sobre não escrever e por isso começo descomeço pelo/ descomeço desconheço e me 
teço um livro onde tudo seja fortuito e/ (CAMPOS, 2011a, formante fixo inicial)

2. Intertextualidade: processo que compreende a paródia e a citação (BAKHTIN, 1990, p. 234-249 e p. 275-281; BAKHTIN, 1997, p. 110-127; BAKHTIN, 2006, p. 186-192; KRISTEVA, 2005, p. 65-95; FARACO, 2009, p. 64-74; cf. BARROS; FIORIN, 1999; BRAIT, 2005). Sarduy nota que tanto uma quanto outra, procedimentos comuns na literatura e nas artes de modo geral, é mais intensa no (neo)barroco (para nós, vertente da agudeza do final do século XX). No trecho do formante inicial acima, já podemos verificar a intertextualidade com Mil e uma noites, cujo narrador, Sherazade, para livrar-se da morte, depois de uma noite de amor, conta histórias que aguçam a curiosidade do Rei e o levam sempre a esperar o desfecho na noite seguinte. Um processo que não conhece fim. Vejamos no formante fixo final de Galáxias outro exemplo de intertextualidade:

\begin{abstract}
fecho encerro reverbero aqui me fino aqui me zero não canto não conto/ não quero anoiteço desprimavero me libro enfim neste livro neste voo/ me revoo mosca e aranha mina e minério corda acorde psaltério musa nãomaisnãomais que destempero joguei limpo joguei a sério nesta sêde/ me desaltero me descomeço me encerro no fim do mundo o livro fina o/ (CAMPOS, 2011a, destaques nossos).
\end{abstract}

O enunciado destacado intertextualiza-se com Os lusíadas, de Camões (2003, canto X, p. 262):

\footnotetext{
Nô-mais, Musa, nô-mais, que a Lira tenho Destemperada e a voz enrouquecida, E não do canto, mas de ver que venho Cantar a gente surda e endurecida. $O$ favor com que mais se acende o engenho Não no dá a pátria, não, que está metida No gosto da cobiça e na rudeza Dua austera, apagada e vil tristeza.
}

Às vezes, a citação em Galáxias é tão obscura que o enunciatário se sente embaraçado diante do enigma, como no caso da referência ao Jogo da amarelinha, de Júlio Cortázar: "fundo o fim o livro a sina não fica traço nem sequela jogo de dama ou de amarela cabra-cega jogo da velha o livro acaba o mundo fina" (CAMPOS, 2011a, formante fixo final, destaques nossos). Esse mesmo trecho de Galáxias intertextualiza com o romance de José Régio, $O$ jogo 
da cabra cega. Ademais, no formante que inicia com "cheiro de urina de fécula [...]", até Chomsky aparece citado ipsis litteris: "aqui por acaso e que eu repito como veio sem pensar repito como o om da mandala refalo remoo repasso colorless green ideas sleep furiously dormem incolores ideias verdes dormem furiosamente verdes dormem furiosamente" (CAMPOS, 2011a, formante sem número, destaques nossos).

Na conclusão de suas considerações sobre o barroco, Sarduy $(1979$, p. 77) reafirma que o (neo)barroco é o espaço da superabundância, diferentemente, pois, da linguagem de comunicação, que é da ordem da economia, cuja função é utilitária. A linguagem neobarroca regozija-se, quando se afasta de seu objeto ou o perde. Seu propósito, segundo Sarduy, não é a veiculação de uma mensagem, "mas seu desperdício em função do prazer". Ocorre que toda poesia, seja de que estética for, afasta-se da pura veiculação da mensagem. Ela deixa de ser poesia quando passa a ter como finalidade algo que lhe é exterior. Daí seu caráter autotélico.

Devemos a Sarduy, segundo Chiampi (1998, p. 62), a consideração do barroco não como estilo epocal ou atemporal, "mas como o modo de dinamizar esteticamente o amontoado inútil dos saberes acumulados". Os latino-americanos, ao reciclarem objetos artísticos europeus para produzir objetos sensíveis, de beleza e prazer, valem-se de certa forma da cifra do desperdício pelo excesso, parafraseando redundantemente enunciados de textos clássicos (Camões, Homero, Virgílio, Dante), barrocos (Góngora, Shakespeare), românticos (Goethe), simbolistas (Mallarmé, Valéry), modernos (Ezra Pound, Borges, Cortázar, Maiakóvski, García Lorca), artistas plásticos modernos (Andy Warhol) etc. Entendemos o desperdício de que fala Sarduy como acentuação das agudezas de expressão e do conteúdo, produzidas por rearranjamentos de formas, condensações, paráfrases, citações, um emaranhado de estratégias que levam o enunciado, em um momento inicial, mais para a ordem da concessão, do sobrevir, do sensível, a fim de, em um momento posterior, como temos enfatizado, alcançar um segundo prazer, o do reconhecimento inteligível.

O enunciado poético agudo embaraça-se, prolifera-se, substitui-se, intertextualiza-se, envolvendo o enunciatário no prazer de descobrir que o sensível se dá por meio das astúcias engenhosas de formas inteligíveis de expressão e de conteúdo que querem dissimular-se em 
materialidade, ou seja, em continuidade fonemática e/ou grafemática com junções e recortes inesperados, como ocorre no poema "Gradil-poema em Casa de Mezanino", de Affonso Ávila, e em Galáxias, de Haroldo de Campos:

1. Exemplo em Affonso Ávila (2008a, p. 287):

$$
\begin{aligned}
& \& \\
& p^{a} \text { eternamemoriadabema } \\
& \text { madaidealseunomefica } \\
& \text { gravadonestemeupeito } \\
& \text { mdjs }
\end{aligned}
$$

2. Exemplo em Haroldo de Campos (2011a):

\begin{abstract}
aqui estátuassentado a banda latãochispante ataca o god sim save américa no tablado union square cadavezsim mais depressa o mundo gira o giralivro mundo gira ao ritmo do topless a-go-go a mulata de tretas tetas mais a ruiva pipilos mamilos encornam o templário tomate (CAMPOS, 2011a, formante do meio)
\end{abstract}

vai nessa foz do livro nessa voz e nesse vós do livro/que saltimboca e desemboca e pororoca nesse fim de rota (CAMPOS, 2011a, formante fixo final, destaques nossos).

Ocorre apenas um simulacro de ilusão de materialidade como massa sonora contínua que se resolve em si mesma. No entanto, as substâncias de expressão e de conteúdo não se descolam das formas de expressão e do conteúdo e, por mais estranho que seja o signo, ele é uma função semiótica de relação entre expressão e conteúdo (HJELMSLEV, 1975, 54).

\title{
2.4 LEZAMA LIMA: NEOBARROCO E A ARTE DA CONTRACONQUISTA
}

A estética barroca, para Lezama Lima (1988, p. 32), constitui "o legítimo eixo do nosso devir". Entende o autor cubano "ser o barroco um autêntico começo, e não uma origem, posto que é uma forma que re-nasce" (destaques nossos). Lezama jamais escreveu como um acadêmico; sua escritura ensaística, mais próxima da poesia, é obscura, repleta de metáforas. E ele, como poeta, mistura tropos, escolhe e associa conteúdos, formando uma imagem hiperbólica, sendo sua sintaxe repleta de dobras, de giros, uma legítima escritura labiríntica aguda. 
Diferentemente de Worringer, para quem o barroco é um gótico degenerado, entende Lezama Lima (1988, p. 79-80) que não se trata de um estilo em degeneração,

mas plenário, que na Espanha e na América Espanhola representa aquisições de linguagem, talvez únicas no mundo, móveis para a vivenda, formas de vida e curiosidade, misticismo que se prende a novos módulos para a prece, maneiras de saborear e de tratar os manjares, que exalam um viver completo, refinado e misterioso, teocrático e ensimesmado, errante na forma e arraigadíssimo nas suas essências (destaques nossos).

O livro Paradiso (1966b), de Lezama Lima, na visão de Haroldo de Campos (1977c, p. 34), seria, tanto quanto Grande sertão veredas, barroco: "neobarrocos, melhor dizendo". As características que identificam a obra de Lezama com a euforia barroquista seriam:

- Metaforização gongorina do cotidiano.

- Prodígio de linguagem.

- Misticismo sincrético.

- Fusão de sofisticação e ingenuidade.

Lezama Lima (1988, p. 80) entende que "o barroco foi uma arte da contraconquista". Para ele, os latino-americanos, ao apropriarem-se da estética barroca do colonizador, reformaram as formas poéticas, bem como lhes restituiu uma abertura que possibilita veicular valores diversos dos do colonizador: o latino-americano seria um

homem que vem ao terraço, que abana lentamente a arenisca diante do espelho devorador, para instalar-se perto da cascata lunar que se constrói no sonho de sua própria pertença. Trança e multiplica a linguagem ao desfrutá-la: o degustar do seu viver lhe cresce e fervoriza. Esse senhor americano começou por desfrutar e saborear, peça bem engastada que, se Ihe é extraída, protesta e desentoa (LIMA, 1988, p. 81).

A contraconquista de Lezama Lima toma a direção de "desforra" do colonizado em relação ao colonizador. E, nesse caso, os papéis actanciais invertem-se. Em um "primeiro barroco", o colonizador conquista o colonizado, impondo-lhe sua cultura, sua língua, ambas "antiobjetos" para o colonizado, que engole a seco tais valores; no entanto, no "segundo barroco", o que era para o colonizado "antiobjeto", língua e cultura, transforma-se em objeto de valor positivo de antropofagia cultural, quando reformula poeticamente os objetos estéticos europeus. Nessa esfera, o colonizado deglute, saboreando, o que lhe foi impingido no passado e o transforma em estética de contraconquista (cf. também ALMEIDA, 2002). 


\section{Percurso do chamado barroco}

$1^{\circ}$ momento: barroco tênue (agudeza seiscentista): barroco do colonizador (objeto mais nítido, implicativo, tendo sua narrativa fechada, com encadeamento lógico, com começo, meio e fim): jesuítico, dogmático, religioso, conservador [imposição de valores ao colonizado] $\rightarrow$ [antropofagia transformação dos objetos culturais].

$2^{\circ}$ momento: barroco vívido (recrudescimento da agudeza): barroco do colonizado (objeto mais fluido, concessivo); sua narrativa aberta, por se fazer, é permeada de rupturas e de sequências que não consideram a linearidade temporal; objetos espacializados.

\section{Movimento sintático: tênue (tradição passada) $\rightarrow$ vívido (tradição viva)}

Irlemar Chiampi $(1998$, p. 7) entende que, para Lezama Lima, o barroco é coisa dos latino-americanos e não caberia o conceito de constante artística de Eugenio D’Ors. Não seria um fenômeno transistórico, mas, mais do que isso, o barroco seria um paradigma modelizador e iniciador da arte americana da contracolonização.

Para nós, a agudeza do século XX é outra, visto se tratar de destinador diverso do destinador da agudeza seiscentista. Os artifícios dessa poesia que sente "novo barroco" promove estranhamento, surpresa e, ao mesmo tempo, busca rearranjar as dissonâncias para formar nova consonância cultural, uma nova identidade latino-americana, agora, a "neobarroca". No nível tensivo, temos acentuação da intensidade, com a cifra vívida de andamento, apresentando objetos estéticos acelerados; no nível discursivo, ainda que uma ou outra figura possam ser equivalentes, os valores, bem como as isotopias que o revestem, são completamente diferentes, pois nos seiscentos prevaleciam os valores da contrarreforma, enquanto no final do século XX dominam valores seculares de um capitalismo selvagem, sobretudo na América Latina.

Dessa forma, o colonizado teatraliza discursivamente um tipo de ruptura com o colonizador, em vista de presentificar uma tradição própria. O que temos, na verdade, é uma contraconquista da ordem do parecer: se quer tanto afirmar uma identidade latina, por que não se desvencilhar do nome "barroco" e assumir uma tradição de poesia visual, de ordem da fluidez? 


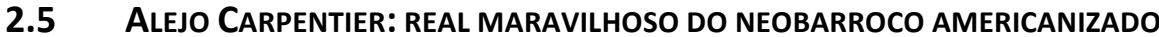

Lezama Lima, embora seja autor relevante na literatura latino-americana, ficou confinado em Cuba até os anos de 1970. Na revisão do barroco, segundo Irlemar Chiampi (1998, p. 9), sobressai o pensamento do cubano Alejo Carpentier, que vincula o real maravilhoso americano a uma reflexão linguística sobre o barroco. Desse modo, a proliferação de significantes seria uma marca discursiva que distingue a América Latina da cultura universal.

Na linha de Eugenio D'Ors, Carpentier considera falho ver o barroco como criação apenas do século XVII ou um estilo histórico determinado. Dessa forma, via o barroquismo como "uma constante humana" (CARPENTIER, 1987, p. 111). Em seu artigo "O barroco e o real maravilhoso", ele critica a postura comum de considerar a arte barroca decadente ( $p$. 110 ss). Parece que, na história das artes, os movimentos estéticos subsequentes quase sempre são vistos disforicamente: os impressionistas franceses, Cézanne, Manet e outros, foram classificados de decadentes; Beethoven também foi recebido como decadente pela crítica, assim como Wagner na sua época; Rimsky-Korsakov também não via com bons olhos a música de Debussy.

Entende Carpentier (1987, p. 111) que o barroco é uma força discursiva criadora e vê em Rebelais o príncipe dos barrocos franceses: era um "inventor de palavras, enriquecedor do idioma, que se permitia todos os luxos, pois quando Ihe faltavam os verbos os inventava, e quando não tinha advérbios também os inventava". Em seguida, critica as palavras identificadoras de estéticas: elas de modo geral não explicam nada. Assim, a palavra surrealismo não descreve o que é o surrealismo, assim como a palavra barroco não diz o que é a arte dos seiscentos.

A crítica de Carpentier sobre os rótulos é compreensível no sentido de que eles delimitam os objetos artísticos de forma pouco precisa; as descrições oferecidas pelos verbetes de dicionários ou pelos livros de arte, como vimos, são muitas vezes carregadas de valores disfóricos, ou mesmo de caracterizações que não condizem com o objeto. Nesse sentido, quando os críticos se referem ao classicismo, direcionam-se a um conjunto de semas que, ao recortarem o objeto estético, não dão conta de toda a semiótica dos objetos renascentistas. O dicionário Larousse, citado por ele, descreve o classicismo como "algo muito notável e digno de imitação. Diz-se do escritor ou da obra que é considerada como modelo em qualquer literatura" (CARPENTIER, 1987, p. 112). Seriam exemplos de autores 
clássicos Pedro Calderón de La Barca e Lope de Vega, que, por sua vez, pertencem às letras seiscentistas. A mesma questão Carpentier encontra no dicionário Real Academia: "sistema literário ou artístico que se baseia na imitação dos modelos gregos e romanos" (p. 112). Se compararmos a definição de Larousse com o da Real Academia, o analista pode perder-se nessas definições e não identificar os objetos que seriam clássicos ou identificar como clássico algo que não é.

Dessa forma, podemos fazer a mesma reflexão com relação ao neobarroco. Não se trata de adesão ao rótulo nem de sua recusa, mas de verificar o que compõe a estrutura tensiva dos objetos reunidos na categoria do chamado neobarroco. Nos vários autores que se ocuparam de estabelecer um cânone e de indicar seus traços formais, a questão central consiste no trabalho com a linguagem, ou seja, o foco central atém-se a um fazer com base na reelaboração das formas poéticas.

Na visão de Chiampi (1998, p. 26), Carpentier teria associado o "barroquismo verbal" de sua produção literária à sua própria interpretação da América Latina como mundo do "real maravilhoso". O termo neobarroco difundiu-se a partir da década de 60 do século XX em referência aos literatos Miguel Angel Asturias, o próprio Alejo Carpentier, José Lezama Lima, Guillermo Cabrera Infante, Severo Sarduy, Luis Rafael Sánchez, Carlos Fuentes, Fernando del Paso, além dos poetas Haroldo de Campos, Affonso Ávila, Carlos German Belli, José Kozer, Carlos Rodríguez Ortiz, Coral Bracho, Eduardo Espina, Eduardo Milán, Horácio Costa, Claudio Daniel, Josely Vianna Baptista, León Félix Batista, Mário Eduardo Arteca, Néstor Perlongher, Osvaldo Lamborghini, Paulo Leminski, Raúl Zurita, Reina María Rodriguez, Reynaldo Jiménez, Roberto Echavarren, Roberto Picciotto, Rodolfo Hinostroza, Tamara Kamenszain, Víctor Sosa, Wilson Bueno (cf. também DANIEL, 2004a).

Nos autores citados, são comuns: ornamentos, labirintos verbais, ambiguidades, elipses, sobreposição de recortes, que interrompem a narrativa, simulação de inconclusão, busca da forma aberta, da fluidez, da elipse e do labirinto. Entre todos os processos de vivificação sobressai a amplificação hiperbólica: citações de outros textos, paródia, profusão de formas reformadas (sobretudo as poéticas) entre outros.

Carpentier ainda trata da questão do maravilhoso, definindo-o como admirável e seria admirável, porque é belo, porque se projeta para o futuro, forjando uma língua para expressar a identidade latino-americana: 
Pois bem, eu falo em real maravilhoso quando me refiro a certos fatos que aconteceram na América, a certas características da paisagem, a certos elementos que têm alimentado a minha obra. No prólogo da primeira edição do meu livro $O$ reino deste mundo defino o que entendo por real maravilhoso. [...]

No que se refere ao surrealismo, não devemos esquecer que o surrealismo perseguiu o maravilhoso (e Breton o dizia no seu manifesto: "tudo o que é maravilhoso é belo, somente o maravilhoso é belo") através dos livros, através de coisas pré-fabricadas. [...]

Pois bem, se o surrealismo perseguiu o maravilhoso, é preciso dizer que raríssimas vezes o surrealismo ia buscá-lo na realidade. [...]

Nosso mundo [o da América] é barroco pela arquitetura - isso não precisa nem ser demonstrado - pelo arrevesamento e complexidade de sua natureza e vegetação, pela policromia de tudo quanto nos cerca, pela pulsação telúrica dos fenômenos aos quais ainda estamos submetidos. [...] Quanto ao real maravilhoso, precisamos apenas estender as mãos para alcançá-lo. A nossa história contemporânea apresenta todo dia insólitos acontecimentos. [...]. Hoje conhecemos os nomes das coisas, as formas das coisas, a texturas das nossas coisas; sabemos onde estão os nossos inimigos internos e externos; forjamos uma linguagem apta para expressar as nossas realidades, e o acontecimento que vier ao nosso encontro terá em nós, romancistas da América Latina, as testemunhas, os cronistas e intérpretes de nossa realidade Americana. Para isso, nos preparamos, para isso estudamos nossos clássicos, nossos autores, nossa história, e para expressar o nosso tempo Americano é que procuramos e encontramos nossa maturidade. Seremos os clássicos de um enorme mundo barroco que ainda nos reserva, e reserva ao mundo as mais extraordinárias surpresas (CARPENTIER, 1987, p. 122-129 passim, destaques nossos).

Como já temos reforçado neste tese, não haveria por que aproximar neobarroco latino-americano do barroco europeu seiscentista, uma vez que o barroco nunca existiu propriamente; foi uma criação posterior do século XIX. Nos seiscentos, o código poético era clássico regido pela destinação de tratadistas poéticos, que introduziram diferenças surpreendentes e significativas na produção de então. Qualquer análise de texto dos seiscentos que não leve em conta a agudeza, mas se apoie em clichês, como "poesia estrambótica, bizarra, excêntrica, visceral", corre o risco de produzir anacronismos.

Da mesma forma, em vez de nos apoiarmos em um número sem-fim de estilemas "neobarrocos", optamos por analisar poemas do final do século XX, segundo a semiótica de agudeza, que graduamos nas vertentes tensivas: poesia aguda de expressão e/ou poesia aguda de conteúdo (mais fluidas) e a mista (também fluida); as poesias que se afastam da agudeza são mais nítidas, mais icásticas, não fazendo parte de nosso corpus. Nas de agudeza, orientamo-nos pelas subdimensões da intensidade, como andamento rápido (vívido, de elevada tonicidade) e/ou lento (tênue, de atenuada tonicidade) do objeto 
poético. Essa poesia aguda do final do século XX tem uma característica semiótica peculiar, a do movimento dinâmico de fluidez de contornos.

O artista agudo do século XX acentua dos artifícios das formas de expressão e conteúdo, tria, extraindo uma grandeza semiótica "boa" de seu passado poético, da tradição dos seiscentos, "melhorando-a" por meio de novos procedimentos de seleção. Ocorre uma operação de melhoração. Em seguida, inclui uma "grandeza boa" na nova agudeza por meio do procedimento de mistura, que leva a um enriquecimento (ZILBERBERG In: CAÑIZAL; CAETANO, 2004, p. 89).

Considerando a axiologia da "pejoração", inicialmente ele elimina ou extrai uma grandeza má do "passado". Se o artista atingir o estágio de profanação, necessariamente incluirá "grandeza má" (do passado ou do presente) e nesse caso poderá saturar o objeto, que será avaliado como excessivo, labiríntico demais (ZILBERBERG In: CAÑIZAL; CAETANO, 2004 , p. 89). Em geral, isso ocorre com os epígonos. O problema da arte aguda do final do século XX, como de todas as outras, consistirá em sua postura diante do mais e do demais. É a passagem de uma cifra para outra que o denunciará como medíocre, átono, indigno ou bom, suficiente. Nesse sentido, se o enunciador escolhe mais melhoração e/ou mais pejoração, ou só um ou só outro, o objeto poderá pender para uma atenuação medíocre ou para uma acentuação extremamente vívida.

Em outras palavras, se escolher só valores da tradição, pode cair na repetição tediosa; se, por outro lado, prevalecer excesso nas operações de acréscimo de inovações e re-formas, que pode se constituir em pejoração, corre o risco de saturação por ininteligibilidade. A polêmica sobre se o barroco seiscentista seria uma decadência ou uma renovação da arte renascentista assemelha-se à seguinte questão: as formas do final do século XX são uma novidade ou apenas uma tentativa de resgate por continuidade?

Sem pretensão de dar uma resposta, a arte parece manter-se em tensão entre um discurso de ruptura atrelado a uma continuidade do passado, ou por melhoração ou por pejoração. A dúvida do fazer artístico concentra-se entre o quanto conservar da tradição e o quanto rompê-la. Afinal... tradição ou ruptura?

Na seção seguinte, examinamos o cânone de Haroldo de Campos que presentifica a tradição, que ele considera ora barroquismo, ora novo barroco, ora neobarroco, ora transbarroco. 


\section{BARROQUISMO: AQUÉM E ALÉM DO TEMPO HISTÓRICO}

\subsection{BarRoQuismo SINCRÔNICO EM HAROLdo de CAMPOS}

Haroldo de Campos (In: CAMPOS; CAMPOS, 2002, p. 32), na obra ensaística Re visão de Sousândrade, publicada em coautoria com seu irmão Augusto de Campos, convoca uma linhagem de literatura barroquista que euforiza o transbarroco. Ele não concebe o barroco como estilo histórico, limitado aos séculos XVI-XVII, preferindo o termo barroquismo, conceito pelo qual "se podem distinguir elementos tipológicos dessa natureza em obras de períodos que the são posteriores, inclusive modernas" (p. 32) (e, como veremos, anteriores também). Wölfflin (2006, p. 321), com base em Burckhardt e Dehio, já admitia que todo estilo possui seu estágio clássico e seu estágio barroco, constituindo-se este último em desenvolvimento do primeiro. O que se vê na proposta de Haroldo é um elenco de traços que teriam ultrapassado os limites dos séculos XVI e XVII.

Embora Haroldo e Augusto de Campos (2002, p. 33) identifiquem esses traços em Sousândrade, eles constituem o conceito que Haroldo, principalmente, utilizará para definir o neobarroco em sua obra ensaística. O mesmo critério lhe servirá para listar autores nacionais e internacionais, descritos ainda neste capítulo.

Para manter nossa terminologia, classificamos os traços de Haroldo como agudezas:

A. Agudezas léxicas:

- palavras raras;

- arcaísmos;

- neologismos (importação de elementos morfológicos de outras línguas);

- hibridismos (misturas de línguas).

B. Agudezas sintáticas:

- hipérbatos;

- elipses intensas;

- elusões (de elusivo, tornar enigmático);

- alusões;

- importação de recursos sintáticos de línguas estrangeiras;

- interpolação de sintagmas de línguas naturais diversas.

C. Agudezas semânticas:

- metáforas agudas (associação entre termos distantes);

- outros tropos retóricos. 
D. Agudezas melopeicas:

- requinte da tessitura sonora;

- onomatopeias;

- dissonâncias.

Além dessas características, o poeta de invenção - o chamado por ele de neobarroco - escolhe estratégias imagéticas, orientadas pelos "impactos olho-coisa, luz-movimento" (CAMPOS; CAMPOS, 2002, p. 33). Nesse sentido, são poetas que se valem do conceito poundiano de fanopeia: poesia como objeto visual. O neobarroco teria como princípio dificultar o reconhecimento do conteúdo poético enunciado. Na proposta de Haroldo de Campos, esse poeta de invenção, marcado pela arquitextura linguística, muitas vezes ocupase da agudeza do PE, de impacto visual (fanopeico) e sonoro (melopeico), e da agudeza do PC de tipo gongorino, valendo-se de escolhas enunciativas fanopeicas para atingir o efeito visual. Além da fanopeia, o poeta neobarroco utiliza ainda em suas estratégias agudas o conceito poundiano de logopeia (cf. CAMPOS, 1977b, p. 96), que se caracteriza pela dança do intelecto entre as palavras, um verdadeiro labirinto linguístico.

Em entrevista publicada no Jornal do Brasil, em 7 jul. 1995, Haroldo de Campos afirma que "o barroco é exatamente a poesia da proliferação metafórica do labirinto ocultista e também da miscigenação". A metáfora haroldiana da miscigenação identifica o barroco como categoria da mistura de variadas línguas naturais. Esse procedimento seria, segundo o ensaísta, comum em A música do parnaso, de Manuel Botelho de Oliveira, cujos enunciados contemplam a mistura de línguas: latim, espanhol e italiano.

Em Re visão de Sousândrade, Haroldo e Augusto de Campos (2002) voltam a insistir nessa característica da mistura de línguas como constituidora do novo barroco. Misturar línguas é, antes de tudo, vivificar o $\mathrm{PE}$, voltando-se para a sonoridade, para ritmos diversos, próprios das línguas naturais, para a melodia entoacional de cada uma delas. Também em Gregório de Matos é possível identificar o traço da mistura, mas não no sentido de que fala Haroldo de Campos.

Hansen (2004, p. 497-498) entende que tanto barbarismos e solecismos caracterizam discursivamente determinado tipo social, bem como sua condição, ou seja, configuram, por exemplo, um simulacro do índio e dos escravos africanos. Em geral, produzem efeitos cômico-burlescos e "constituem o tipo como inferior, propondo-o como objeto de ironia ou 
de maledicência da enunciação, por vezes indignada, por vezes jocosa, nunca empática" (p. 498). Gregório de Matos sincretiza, pois, a posição de um enunciador e de um destinador julgador, que sanciona negativamente, quando ironiza de modo jocoso a língua dos índios e dos africanos, diferentemente da leitura que faz Haroldo de Campos, quando entende que o poeta baiano valoriza a mistura de classes, de línguas. Essa euforia da igualdade de classes, da aceitação da alteridade, da afirmação da identidade nacional, pertence a uma escolha de valores dos tempos do século XX, não século XVII. Antes de valor eufórico, nos seiscentos dáse o sarcasmo, a ironia em relação ao tipo néscio, que não falava a língua considerada como padrão, como culta. Onde Haroldo de Campos vê liberalidade, euforização da quebra do decoro gramatical, Hansen vê como conservadorismo das letras seiscentistas.

Haroldo de Campos também vê na estratégia gregoriana de mistura a preocupação em criar "efeitos de contraste e de grotesco", produzidos por vocábulos tupis e africanos, "numa jocunda operação de caldeamento linguístico-satírico" (CAMPOS, 1977c, p. 35).

Vejamos um poema, atribuído a Gregório de Matos (2010, v. 1, p. 641), cuja didascália é "A Cosme Moura Rolim insigne mordaz contra os filhos de Portugal", em que é patente a mistura de línguas:

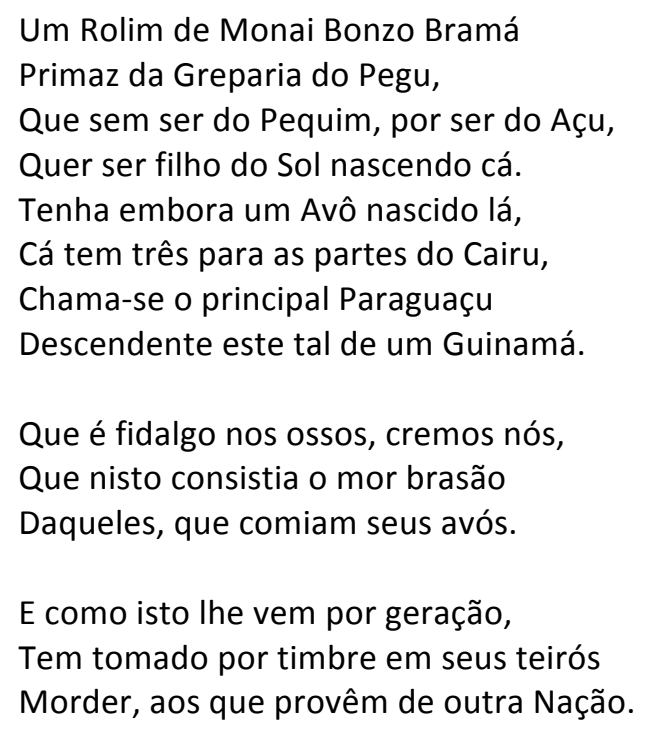

O enunciador faz no poema um trocadilho do nome próprio Rolim com o substantivo comum "rolim", que significa emissário ou embaixador entre os povos do Oriente. Bonzo Bramá é o sacerdote budista de Bramá (Birmânia) e greparia é coletivo de grepo, sacerdote de Pegu, cidade sagrada na baixa Birmânia. Hansen (2004, p. 494) acentua que os ouvidos 
lusitanos, mais afeitos à sonoridade do latim ou do Espanhol, rejeitavam a sonoridade dos vocábulos tupis no português do Brasil da época (Língua Geral).

Dimas (1981, p. 53), comentando uma décima de Gregório de Matos, "indo a caça de tatus / encontrei Quatimondé", salienta que "o significado isolado das palavras deste poema é menos importante do que o ritmo sincopado que sua acentuação propicia. A sonoridade dos versos acaba por se constituir em seu princípio norteador e o significado, ainda que existente, deixa de ser prioritário. A prioridade, parece, é do significante". No poema que estamos analisando, o PE também se faz sobressair ao PC. Do ponto de vista disfórico dos portugueses, a Língua Geral falada no Brasil era uma língua travada na sonoridade. Os tratadistas seiscentistas, por exemplo, recusavam a escolha dos versos oxítonos: no poema, "Bramá", "Pegu”, “Açu”, "cá”; "lá”, "Cairu”, "Paraguaçu”, "Guinamá”. O poema de Gregório “ironiza a pretensão de Cosme Moura Rolim à fidalguia” (HANSEN, 2004, p. 495).

A mistura de línguas, como vimos, não pode ser considerada uma característica neobarroca, visto que ela tem função diversa no barroco de Gregório e no neobarroco de Haroldo de Campos. Se essa fosse uma herança de um traço barroco, teríamos funções homogêneas. Na poesia de Gregório, ela tem efeito moral e hierarquizador de classes sociais.

Essa questão do barroco e do neobarroco é ainda objeto de "Da razão antropofágica: diálogo e diferença na cultura brasileira" (CAMPOS, 2006, p. 231-255). Nesse artigo, Haroldo de Campos transcreve texto de seu companheiro de geração Mário Faustino, que teria escrito no final dos anos de 1950:

O barroquismo do seicento, italiano ou espanhol, é, aliás, o primeiro grande impulso organizado, na poesia do Ocidente, no sentido de fazer uma poesia "orgânica", isto é, que cresce a partir das linhas de força dos próprios materiais de que se faz, poesia em que o poema reflete uma visão pormenorizada do mundo, à medida que constitui um outro mundo, microscópico e coisificado. [...] A verdadeira poesia do barroquismo seiscentista é evidentemente, antes de mais nada, uma poesia culta.

O que sempre fica patente no conceito de neobarroco haroldiano é que se trata de um fazer poético que se distancia da poesia de tradição lacrimejante, que engendra sensibilidades estereotipadas, de comunicação rápida, conquistando o enunciatário pelo pathos: poesia do amor sofrido, dor de alma, angústia etc. 
A manifestação barroquizante, a que Candido chama de preciosismo (Haroldo contesta Antonio Candido que teria alegado certo preciosismo em Sousândrade [In: CAMPOS; CAMPOS, 2002, p. 536]), não teria encontrado em Formação da literatura brasileira afinidade receptiva.

Em Sequestro do barroco na formação da literatura brasileira: o caso Gregório de Mattos, Haroldo de Campos questiona a ausência (o sequestro) do barroco na literatura brasileira. Coutinho (2008, p. 50) já em 1959 havia feito observações semelhantes a respeito da obra de Candido. Para ele, "o conceito de literatura que esposa Antonio Candido não é estético, mas histórico-sociológico". Irlemar Chiampi (1998, p. 21) entende que Haroldo de Campos "desconstrói o paradigma metafísico substancialista que ordenava a literatura brasileira como 'encarnação do espírito nacional'”.

O resgate de Gregório e do barroco mostra como o cânone estabelecido a partir do romantismo velou os objetos barroquistas como origem da nossa literatura. A hipótese de Haroldo de Campos é de que já no início de nossa colonização (século XVII) há um neobarroco como novo barroco americano do colonizado e não do colonizador. Para ele, as fantasias e a intensa exploração dos significantes servem para nos diferenciar dos portugueses no Brasil e dos espanhóis nos mais diversos países da América Latina.

Dessa forma, a linha evolutiva de nossa literatura, exposta no livro Formação da literatura brasileira, é marcada por uma visão da literatura desenvolvida no romantismo: a literatura seria, para Antonio Candido, expressão do espírito nacional em correlação com a autonomia política. Daí ter sequestrado (excluído) o barroco de sua obra. Trata-se de dois valores críticos diferentes:

1. Antonio Candido (1993b, v. 1, p. 23): apoia sua tese na comunicação de valores ideológicos, reunindo textos literários de mais rápida intelecção. E, nesse caso, prevalecem menos entraves nas formas do PE e do PC, acelerando o reconhecimento conteudístico.

2. Haroldo de Campos (1989, p. 62-63): apoia sua tese numa literatura de valorização de arquitetura da linguagem. E, nesse caso, prevalecem valores formais do PE e do PC. Propõe tratar esse tipo de literatura como barroquista; pensa a literatura menos como formação e mais como transformação, composta de momentos de ruptura e transgressão, em que a tradição é vista como renovação contínua da presentificação do passado. 
Antonio Candido (1993b, v. 1, p. 23) entende literatura como um "sistema de obras ligadas por denominadores comuns". A soma dos denominadores comuns produção + recepção + transmissão resulta na formação de uma literatura. Se não há sistema, há apenas manifestação literária. Por isso, Candido afirma ter a literatura brasileira começado por volta de 1750, o que o leva a excluir o chamado barroco de sua obra Formação. Coutinho (2008, p. 56) refuta os argumentos de Candido:

\begin{abstract}
Como aceitar a tese da "formação" da literatura brasileira depois de 1750, quando o espírito brasileiro já dava tais mostras de individualidade? E quando, mesmo na literatura, um Gregório de Matos já fala a mesma linguagem do Aleijadinho, a linguagem da civilização crioula, mestiça, que aqui se plasmava? [...] O defeito de sua visão crítica dessa literatura está em que ele transfere critérios atuais à sua compreensão, como se a vida literária na colônia fosse como hoje (aliás não era assim nem mesmo nos povos europeus). Por outro lado, ele repete e prolonga o critério crítico dos românticos "que localizaram na fase arcádica o início da nossa verdadeira literatura" [CANDIDO, 1993b, v. 1, p. 25. "Verdadeira" grifada por ele, como se a que se produziu antes não tivesse sido verdadeira.]
\end{abstract}

Contestando também a tese de Candido, Haroldo de Campos (2006, p. 239) entende que o barroco na literatura brasileira não seria a origem, porque nossa literatura já teria nascido adulta; ela não teria tido infância, porque nasceu falando "um código universal extremamente elaborado".

Nesse sentido, na história da literatura brasileira, dois modelos de leitura da tradição focalizaram diferentemente o chamado barroco:

- Inclusão: Afrânio Coutinho e Haroldo de Campos incluem euforicamente o barroco.

- Exclusão: Antonio Candido excluiu-o do Formação da literatura brasileira.

Segundo Haroldo de Campos (2006, p. 238), Candido teria economizado operacionalmente o barroco "por um argumento de ordem sociológica (ausência de produção impressa e de público)" e individualizado no arcadismo pré-romântico o momento inaugural de nossa formação literária. Com base em um arcabouço teórico, teria apoiado sua argumentação em um esquema de transmissão de mensagens referenciais, privilegiando a função de comunicação da linguagem literária. Coutinho, por sua vez, foi o primeiro a registrar o barroco brasileiro com base em uma crítica estilística e periódica, reconstruindo uma tradição afortunada: o barroco teria se integrado naturalmente à literatura brasileira. 
Tanto em Coutinho quanto em Candido, Haroldo de Campos (2006, p. 239) vê "a ultimação historiográfica [...] do projeto fundamental do romantismo brasileiro". Reconhece, porém, que Candido ([1970] 1993a, p. 19-54), no ensaio "Dialética da malandragem", apresenta uma "desleitura" do que afirmara em sua Formação da literatura brasileira em relação ao sequestro do barroco. Teria abandonado o traçado retilíneo e cronológico, em vista de uma "nova possibilidade de recorte inteligível do mesmo espaço, reorganizando [o cânone] agora em diferente constelação" (CAMPOS, 2006, p. 243). Distingue nessa "desleitura", então, o romance malandro do romance picaresco europeu, reconhecendo nele "elementos arquetípicos de matriz folclórica e um fermento vivo de um realismo popularesco" (p. 243).

Nesse sentido, Haroldo entende que o picaresco, que ultrapassa fronteiras históricas de séculos, seria para ele uma forma barroca sincrônica. Na origem do pícaro, teríamos $O$ asno de ouro, de Apuleio (125-180 d.C.); no século XVI, La vida de Lazarillo de Tormes (romance anônimo de 1554); no século XVII, El Buscón (1604), de Quevedo, Vida y hechos de Estebanillo Gonzáles (1645), do próprio Estebanillo Gonzáles; no século XVIII, Candide (1759), de Voltaire; no século XIX, História de Gil Braz de Santilhana (1885), de Le Sage.

Nesse novo esquema, não linear, constelar de Haroldo de Campos (1989, p. 72), Gregório de Matos, sequestrado no Formação da literatura brasileira, passa a ter voz e a ser visto como um dos precursores da comicidade malandra na literatura brasileira, "valorizado nessa óptica renovada, não pelo veio sério-estético da poesia lírica, amorosa e religiosa, mas pela sátira desabusada".

Hansen (2004, p. 329), no entanto, faz outra leitura da sátira gregoriana:

A sátira opera com uma desproporção programática entre disposição e elocução, produzindo discursos inverossímeis, segundo a preceptiva tradicional dos opináveis retóricos e verossímeis poéticos. Com uma dupla finalidade: atender ao gosto do público, interessado em fantasias e não em regras, e adequar o discurso à técnica da caricatura - seres moralmente monstruosos e baixos demandam discursos retoricamente baixos e monstruosos.

Antes de tudo o que se nota em Hansen é a conformidade da sátira de Gregório à preceptiva tradicional, ou seja, a arte gregoriana orientava-se por convenções rígidas. Onde Haroldo de Campos, muitas vezes, vê originalidade, invenção, comicidade malandra, Hansen verifica a existência de um poeta preocupado em seguir seus destinadores tratadistas. Além disso, seguia um contrato fiduciário regulador do gênero satírico. Nada havia de libertário, 
de desabusado; a sátira de Gregório segue o modelo da sátira romana, a de Juvenal, em que o programa estabelecido é o da moralização ${ }^{1}$. O enunciador nos poemas atribuídos a Gregório, como estamos vendo, escolhem valores que vão na direção da ética, da moral, visando aprimorar o comportamento individual. Daí seu ataque irônico e agressivo a pessoas de baixa condição social (índios, escravos, pobres), mas também a pessoas da administração pública e religiosa. A censura em seus poemas funciona como uma engrenagem neutralizadora dos males sociais.

Para Hansen (2004, p. 327), a "sátira pinta vícios e virtudes, em termos do ut pictura poesis. Pela simplificação esquemática das caricaturas, ela deforma como imagem incongruente a imagem verossímil do referencial discursivo contemporâneo dela". A deformação que apresenta é feita de modo que o enunciatário possa observar "a contradição existente entre o conhecimento prévio que tem do tema". A sátira de Gregório, portanto, é simulacro discursivo, em que o enunciador e o enunciatário têm conhecimento das regras desse jogo enunciativo. Se, por acaso, houve algum "ente do mundo" parecido com as figuras do poema é mero jogo, um jogo programado para cumprir um contrato poético.

Seguindo então a linha da sátira de Juvenal, orientada pela obscenidade e pela enunciação irada, os poemas de Gregório propõem a deformação programática de forma que divirta com exagero teatral e ensine com a correção moralizante:

Supondo-se que o homem chamado Gregório de Matos e Guerra tenha querido publicar poeticamente seu ponto de vista individual sobre um assunto qualquer da sociedade baiana do século XVII, ele não poderia fazêlo sem aplicar as convenções retóricas das paixões que modelam o "eu" poético como tipo não psicológico, ou seja, como tipo formalizado retoricamente. Em seu tempo, era impossível fazê-lo de outra maneira (HANSEN, 2004, p. 461).

Desse modo, Gregório só é Gregório de papel, cumprindo seu papel no jogo poético vigente. Se assim não fosse, a poesia deixaria de ser ficção e o ator discursivo se converteria em autor, e sua poesia seria uma expressão psicológica e não um texto. Além disso, discutese até hoje a autoria dos poemas de Gregório. Tudo que a ele se atribui é apócrifo.

Como se vê no confronto da leitura de Haroldo de Campos com a de Hansen, nota-se no primeiro maior paixão da euforia barroca como traço que perdura, enquanto o segundo é

\footnotetext{
${ }^{1}$ Diferentemente da sátira de Juvenal, a sátira menipeia não é moralizante, não visa neutralizar um "defeito" de caráter.
} 
marcado pela descrição dos fatos literários. Os argumentos de Hansen não permitem a identificação de Gregório de Matos com o topos da malandragem, ao passo que a identificação haroldiana do poeta baiano com o tipo malandro, e por isso barroco, parecenos menos convincente. Um Gregório malandro estaria distante da sátira de Juvenal, o que não se verifica no enunciado dos poemas; se malandro fosse, não seria moralista, não teria em vista punir, castigar para corrigir (ridendo castigat mores). Nesse sentido, o conceito de pícaro não se coaduna com o de sátira seiscentista.

A tradição "malandra" não seria, na visão de Haroldo, outra coisa que carnavalização, que retrocede ao barroco, entendido por Sarduy como fenômeno bakhtiniano: espaço do ludismo, da polifonia e da mistura de linguagens. Apoiado em Jauss, o qual recapitula uma tese de Adorno, Haroldo de Campos (2006, p. 237) entende como tradição o que ficou "à margem do caminho, desprezado, subjugado; aquilo que é coletado sob o nome de antiqualhas; é aí que busca refúgio o que há de vivo na tradição, não no conjunto daquelas obras que supostamente desafiam o tempo". Como o chamado barroco ficou à margem do livro Formação, ele tem em vista resgatá-lo e construir um cânone literário barroquista, uma crítica erigida segundo a paixão da neutralização da desconsideração do barroco.

A crítica de Haroldo de Campos (1977a, p. 114) em relação à incompreensão das formas barrocas não se atém apenas a Candido; alcança também Ezra Pound, cuja "má vontade" levou-a a excluir de seu paideuma o barroco de Góngora, bem como a vetar a linguagem engenhosa e suntuosa do grego Píndaro (518 a.C.-438 a.C.). Nessa mesma linha de raciocínio, Octavio Paz (2013, p. 141) comenta que "Pound condena Góngora exatamente quando os jovens poetas espanhóis o proclamam mestre".

Paideuma é "elenco de valores essenciais, culturalmente atuantes no momento histórico" [CAMPOS, 1977a, p. 48]; é "a ordenação do conhecimento de modo que o próximo homem [ou geração] possa achar, o mais rapidamente possível, a parte viva dele e gastar o mínimo de tempo com itens obsoletos" (POUND, 2008, p. 161). É esse conceito que permite a construção de um cânone literário. Daí a existência de um paideuma poundiano, um paideuma haroldiano, um paideuma de Auerbach entre outros. Haroldo de Campos (1976b, 1989, 2006), em seus mais diversos artigos e livros, defende um projeto de permanência de um traço barroco sincrônico, passível de ser detectado aquém e além do tempo demarcado dos seiscentos e, mais, afirma ser o barroco a marca característica da literatura das Américas. Para ele, como esse conceito atravessa tempo e espaço, é visto 
como um novo barroco, o qual se concentra sobretudo em uma arquitextura linguística, ou seja, no trabalho poético com a linguagem.

Essa visão eufórica de Haroldo de Campos, Eugenio D’Ors, Sarduy e outros é contestada por Hansen (2001, p. 15) em "Barroco, neobarroco e outras ruínas":

\begin{abstract}
Observou-se nos últimos 20 anos um interesse crescente e polêmico pelo "barroco", que retornou com alguma insistência em práticas artísticas e críticas contemporâneas identificadas muitas vezes como "neobarrocas", "pós-modernas" e "pós-utópicas". O retorno produziu e produz várias unilateralidades. O termo "neobarroco" significa "novo barroco" e implica a existência de um intervalo temporal entre o presente, que enuncia o "neo", e algo que seria um passado, "o barroco" entendido nos termos de Wölfflin, também chamado de barroco histórico, ou seja, as ruínas do século XVII.
\end{abstract}

Neobarroco, segundo o pensamento de Haroldo de Campos, leva a deduzir uma estrutura livre do tempo, entendido "intemporal" em conformidade com o pan-barroquismo de Eugenio D'Ors (2011). Ora, como barroco é um recorte de Wölfflin e o século XVII foi "agudo" e não "barroco", Hansen (2001, p. 17) afirma que "o termo 'neobarroco', como 'novo barroco', também significa - em todos os casos - o futuro de um pretérito que não houve".

A crítica de Hansen alcança Nestor Perlongher, que fala em "neobarroso", e Alejo Carpentier, que menciona "barroquismo". Com relação a Haroldo de Campos, entende que o poeta concretista vê o neobarroco como "a novidade contemporânea produzida por uma invenção artística que, apropriando-se sincronicamente de procedimentos técnicos e feitos das artes do século XVII, usa-os como matéria de transformações poéticas" (HANSEN, 2001, p. 15).

Entende ainda Hansen haver uma inversão na leitura que Haroldo faz de Góngora: não é Góngora que antecipa o estilhaçamento do Lance de Dados de Mallarmé, mas a leitura de Mallarmé feita pelo poeta paulistano no século XX que "permite constituir a poesia de Góngora como uma tradição do novo ou de determinado modo contemporâneo de compor poesia segundo um cânone poético de 'invenção"' (HANSEN, 2001, p. 15). Analisando ainda o conceito de neobarroco apoiado na antropofagia cultural oswaldiana, Hansen (2004, p. 15) critica a identificação da poesia atribuída a Gregório de Matos como antropofagia cultural.

Em "Letras coloniais e historiografia literária", Hansen (2006c, p. 18-19) rejeita não só o termo neobarroco como também o termo barroco: "quando fiz o trabalho [sobre Gregório em $A$ sátira e o engenho], ainda usei a categoria 'Barroco', coisa que hoje acho totalmente 
desnecessária, pois só produz equívocos de interpretação". É por isso que nesta tese, como já discutimos, optamos por observar se a estrutura do texto poético encaminha-se mais para os artifícios de expressão ou mais para os de conteúdo, engrenados tensivamente, sem nos ocuparmos em etiquetar os objetos com um nome muitas vezes polêmico. Interessou-nos verificar a linha de continuidade da poesia aguda.

Claudio Daniel (2009, p. 122), em sua dissertação de Mestrado A estética do labirinto: barroco e modernidade em Ana Hatherly, afirma que, após o neorrealismo português, a segunda metade do século XX viu surgir um novo momento de vanguarda de tendência experimentalista (década de 1950-1970). Teria então surgido a "Poesia Concreta" no Brasil e em Portugal, o "Neobarroco latino-americano", o "Oulipo francês" e o "Experimentalismo poético português". Para ele, a expressão "estética do labirinto", no lugar da expressão neobarroca, contemplaria uma tradição literária que desemboca na tendência experimentalista da poesia que chamamos de poesia aguda de ênfase no PE.

$\mathrm{Na}$ poesia de alta elaboração linguística, como as agudas, o ruído sintático e o morfológico são erigidos justamente para impedir a rapidez cognitiva, visto que, quanto mais se delongar a apreensão, mais prazerosas serão as possibilidades de descoberta. Acrescente-se, porém, que não se obscurece nem se reconhece, ou faz-se nítido, um objeto estético na totalidade, uma vez que é aberto a muitas combinatórias formais. É nesse sentido que Haroldo de Campos elege alguns objetos poéticos para participar de seu cânone barroquista a ser visto na seção 3.2 .

\subsection{O CÂnone barroquista de Haroldo de Campos}

Em sua trajetória de crítico e poeta, Haroldo de Campos triou alguns objetos, aquém ou além do tempo histórico barroco, denominando-os de neobarrocos. Para ele (CAMPOS, 1977c, p. 35), estaria no barroco o embrião, "essa atitude de não conformidade à partilha clássica dos gêneros e suas correlatas convenções literárias, de parte do escritor da América Latina". Em variados momentos de sua obra, Haroldo elenca um conjunto de textos e autores nacionais, que apresentariam barroquismo em seu fazer poético. Entre eles, podem ser citados os textos: (1) "Poética sincrônica" (1967); (2) "Uma arquitextura do barroco" (1971); (3) “Da razão antropofágica: diálogo e diferença na cultura brasileira" (1981); (4) O sequestro do barroco (1989). Este último reproduz um curso que o autor ministrou na Universidade de Yale em 1978; em 1981, o autor ofereceu esse mesmo curso na PUC de São 
Paulo e na Universidade do Texas em Austin. Informa ainda que uma primeira redação foi organizada em 1986 para uma conferência na Universidade Federal da Bahia, em simpósio comemorativo dos 350 anos de nascimento de Gregório de Matos. Em 1988, o texto voltou a ser exposto na Universidade Federal de Ouro Preto. Dois outros textos são ainda fundamentais para a compreensão do que seria esse novo barroco para Haroldo de Campos: (5) "Literary and artistic culture in modern Brazil" (2001); (6) Prefácio à obra Jardim de Camaleões "Barroco, neobarroco, transbarroco" (In: DANIEL, 2004a).

Os estudos de Haroldo de Campos (1977a, p. 207) apoiam-se no conceito de "poética sincrônica", cuja função ele afirma ter "um caráter eminentemente crítico e retificador sobre as coisas julgadas da poética histórica. Para o crítico de visada sincrônica, não interessa o horizonte abarcante e esteticamente indiferente da visão diacrônica". Considerando essa metodologia de abordagem sincrônica, afirma ainda Jakobson que são "presenças vivas no atual mundo poético da língua inglesa" os literatos: (1) Shakespeare, (2) John Donne; (3) Keats; (4) Emily Dickinson. Por outro lado, James Thomson (1700-1748) e Longfellow (18071882) não entraram no rol dessa tradição viva. E conclui que "a escolha de clássicos e sua reinterpretação à luz de uma tendência é um dos problemas essenciais dos estudos literários sincrônicos", que compreendem "fatores contínuos, duradouros, estáticos" (JAKOBSON, 2005 , p. 121). Trata-se de uma superestrutura a ser edificada com base em descrições sincrônicas sucessivas. Haroldo de Campos (1977a, p. 207) entende ser $A B C$ da literatura, de Ezra Pound (2008), o texto mais característico de uma poética sincrônica.

Haroldo de Campos (1977a, p. 208-209) utiliza o conceito de invenção (poesia criativa) e seleciona autores que apresentam "contribuição definida para a renovação de formas em nossa poesia, para a ampliação e diversificação de nosso repertório de informação estética", e é essa renovação de formas em nossa poesia que Haroldo euforicamente chama de barroquista.

O barroquismo da poesia e da prosa (proesia) da modernidade, na visão de Haroldo, não surgiu no final do século XX (entre 1960 e 1970) subitamente. Como veremos no quadro 3.1, ele seleciona obras e/ou autores "neobarrocos" ao longo de sua obra crítica; segundo H. Campos, essa tradição de trabalho com a linguagem perpassa as mais diversas épocas, aquém e além do período conhecido como barroco, considerando em seu cânone não apenas uma amostra de objetos estéticos que sucedem o século seiscentista, mas também uma seleta que $o$ antecede. 
As siglas das obras [entre colchetes], constantes do quadro, são indicativas dos artigos em que Haroldo cita objetos da tradição barroca, constituindo um cânone de euforia barroquista. Muitos deles foram mencionados em quase todos os textos, de 1967 até 2004: "Poética sincrônica" (1967) - [PS]; "Barroco em trânsito" (1971), posteriormente nomeado "Uma arquitextura do barroco" (1976b) - [BT]; “Da razão antropofágica: diálogo e diferença na cultura brasileira" (1981) - [RA]; O sequestro do barroco (1989) - [SB]; "Literary and artistic culture in modern Brazil" (2001) - [LACMBR]; "Prefácio" da Antologia poética neobarroca Jardim de Camaleões (2004a) - [PAJC].

Quadro 3.1 Objetos da tradição barroquista constantes da obra crítica de Haroldo de Campos.

\begin{tabular}{|c|c|c|}
\hline Autor & Justificativa de Haroldo de Campos para caracterizar seu cânone & Obra \\
\hline $\begin{array}{l}\text { Lícofron } \\
\text { Poeta do } \\
\text { século III } \\
\text { a.C. } \\
\text { (Alexandria) } \\
\text { (BT) }\end{array}$ & $\begin{array}{l}\text { Poema considerado obscuro; o ator Cassandra, uma vidente e } \\
\text { profeta, antevê a queda de Troia. Para Haroldo de Campos } \\
\text { ([1971] 1976b, p. 140), Lícofron é considerado precursor de } \\
\text { Góngora, de Mallarmé e de Joyce, devido à sintaxe "bizarra", } \\
\text { ao uso de palavras raras, dialetais, mistura de palavras } \\
\text { estrangeiras. No poema "Alexandra", o enunciador escolhe } \\
\text { processos metalinguísticos para a construção do enunciado: } \\
\text { "contarei sem torcer tudo o que me perguntas"; "perdoa-me } \\
\text { porém se o discurso delonga"; "aquilo que eu retenho na } \\
\text { alma e na memória"; "alço-me ao giro das palavras oblíquas". } \\
\text { O monólogo enigmático de Alexandra (Cassandra) é } \\
\text { construído por meio de um jogo de debreagens enuncivas e } \\
\text { enunciativas em ziguezague: (a) constituição da voz oracular } \\
\text { da pitonisa Alexandra (considerada como louca); (b) } \\
\text { transmissão dessa voz a um destinatário, o guarda do cárcere } \\
\text { em que ela, a destinadora, está presa. } \\
\text { O motivo barroquista é constituído por um discurso } \\
\text { fragmentado misterioso, estilhaçado dentro de um texto } \\
\text { estruturado misteriosamente. Há um enigma dentro de outro } \\
\text { enigma, um verdadeiro labirinto: } \\
\text { Fragmentos de "Alexandra" (CAMPos, 1976b, p. 145-146 - } \\
\text { tradução de Haroldo de Campos): } \\
\text { Do Prólogo } \\
\text { Contarei sem torcer tudo o que me perguntas, } \\
\text { tudo, desde o cume do começo. } \\
\text { Perdoa-me, porém, se o discurso delonga. } \\
\text { lançandandava a boca fluida dos oráculos, } \\
\text { clamor desmesurado; } \\
\text { flameava os vaticínios } \\
\text { repetindo fiel a voz da Esfinge escura. } \\
\text { Aquilo que eu retenho na alma e na memória } \\
\text { escuta, ó Rei, e repassando-o } \\
\text { no íntimo, sábio, }\end{array}$ & $\begin{array}{l}\text { Poema } \\
\text { "Alexandra" } \\
\text { (III a.C.) }\end{array}$ \\
\hline
\end{tabular}




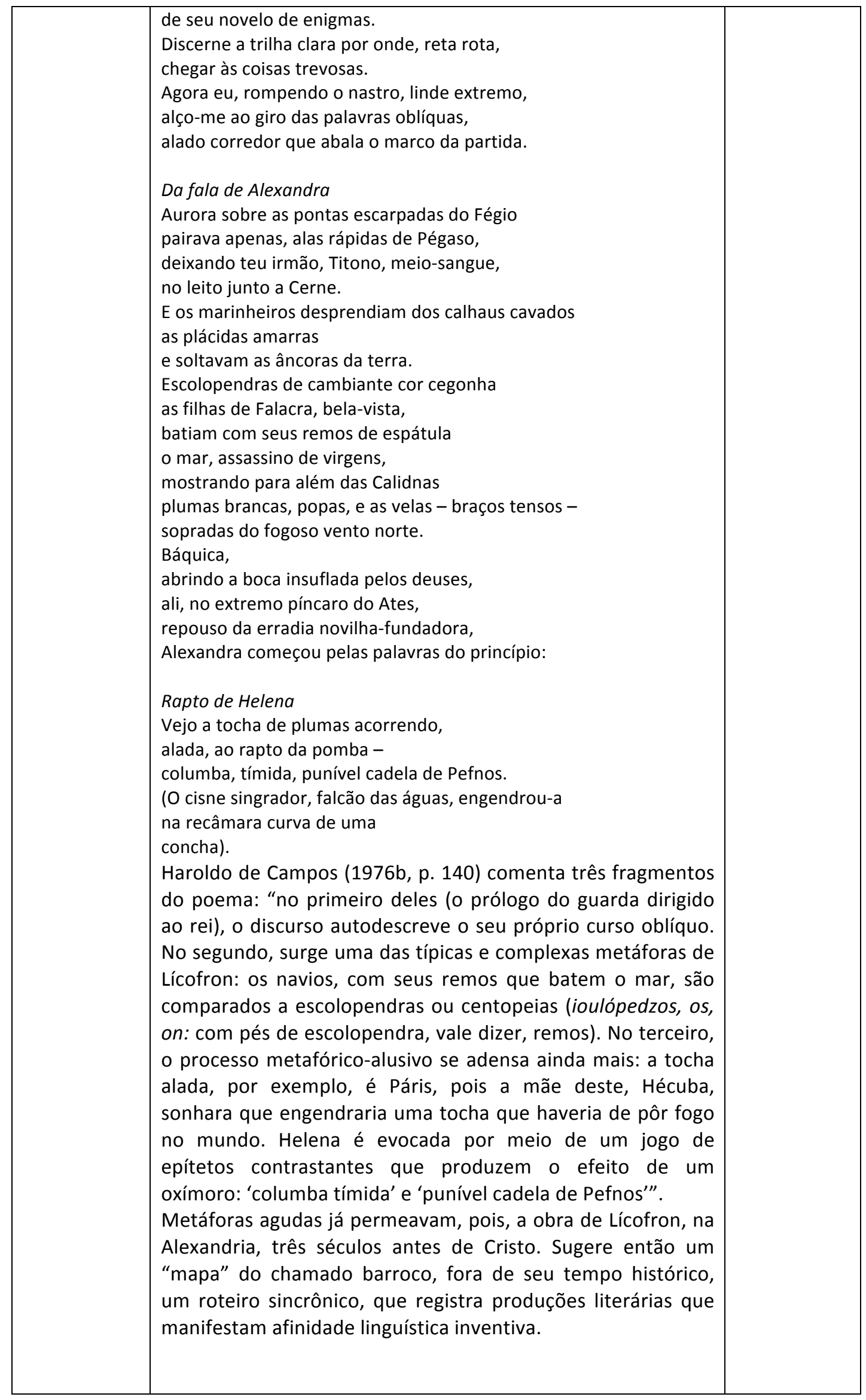




\begin{tabular}{|c|c|c|}
\hline $\begin{array}{l}\text { Li Shang-Yin } \\
\text { (812?-858) } \\
\text { Poeta da } \\
\text { Dinastia } \\
\text { T'ang } \\
\text { [BT] }\end{array}$ & 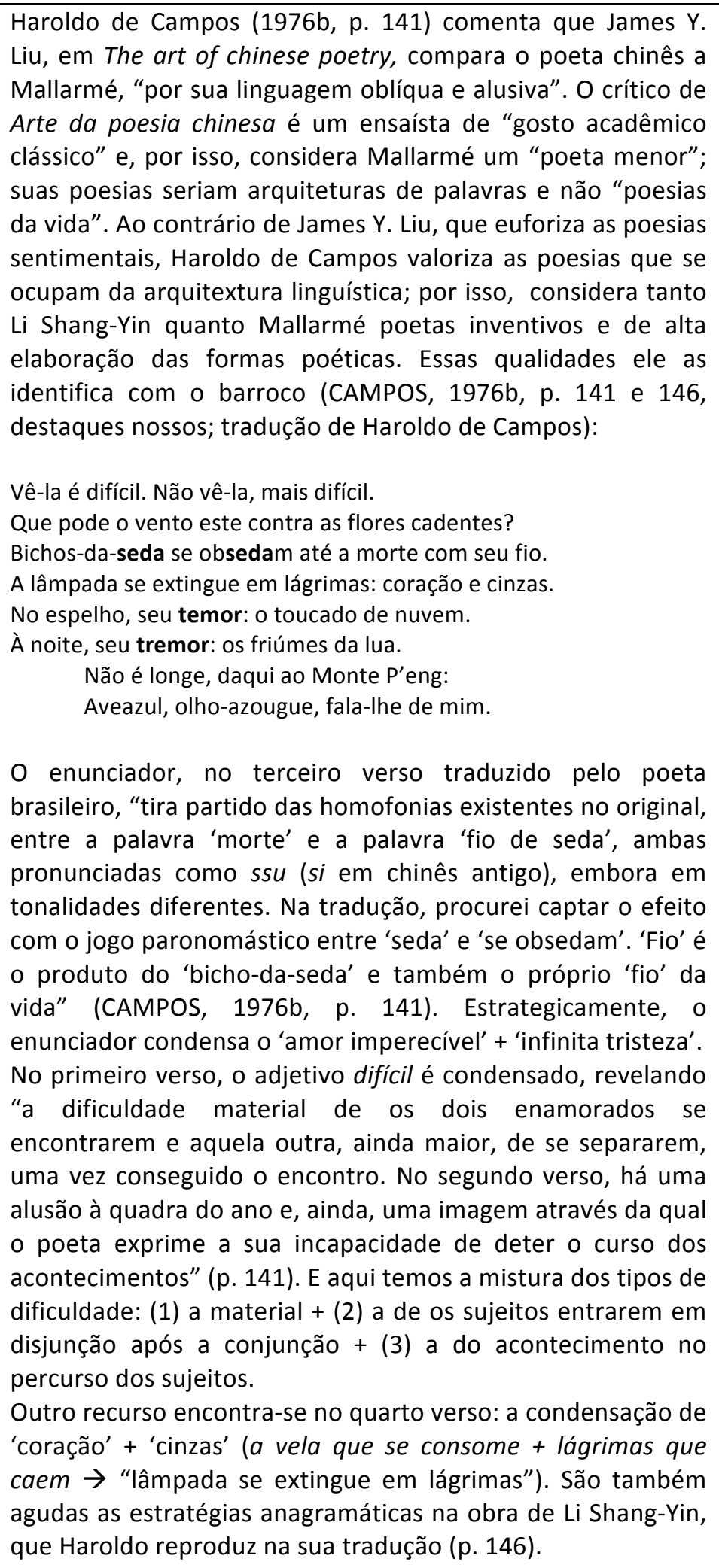 & $\begin{array}{l}\text { Sem título } \\
\text { (cf. } \\
\text { CAMPOS, } \\
{[1971]} \\
1976 b, \quad \text { p. } \\
146)\end{array}$ \\
\hline $\begin{array}{l}\text { Góngora } \\
\text { (1561-1627) } \\
\text { Religioso, } \\
\text { poeta e }\end{array}$ & $\begin{array}{l}\text { Segundo Haroldo de Campos (1976b, p. 143), o "mais } \\
\text { moderno, talvez, de todos os poetas de língua espanhola". No } \\
\text { artigo citado, ele traduz um excerto de "Polifemo y Galatea" } \\
\text { (há também versão de Ungaretti em italiano): }\end{array}$ & $\begin{array}{l}\text { Fábula } \\
\text { Polifemo } \\
\text { Galatea } \\
(1612)\end{array}$ \\
\hline
\end{tabular}




\begin{tabular}{|c|c|c|}
\hline $\begin{array}{l}\text { dramaturgo } \\
\text { castelhano } \\
{[\mathrm{BT}]}\end{array}$ & $\begin{array}{l}\text { Salamandra do Sol, vestido estrelas, } \\
\text { latindo o Cão celeste estava, quando } \\
\text {-- poeira o cabelo, úmidas centelhas, } \\
\text { se não ardentes pérolas suando- } \\
\text { chegou Ácis, e de ambas luzes belas } \\
\text { doce ocidente vendo ao sonho brando, } \\
\text { sua boca deu, e os olhos, deu-os, tudo } \\
\text { ao sonoro cristal, ao cristal mudo } \\
\text { (CAMPOS, 1976b, p. 147). } \\
\text { A salamandra, segundo a crença antiga, podia atravessar o } \\
\text { fogo sem se queimar, paradoxo tão ao gosto do chamado } \\
\text { barroco. Nas palavras de Haroldo (1976b, p. 143), “O 'Can del } \\
\text { cielo' é a constelação do Cão, vestida de suas estrelas (ou } \\
\text { melhor 'vestido estrellas', pois o poeta usa um acusativo } \\
\text { grego de coisa vestida, cultismo, sintático típico). Como a } \\
\text { salamandra, o 'Cão celeste' resiste ao abrasamento solar nos } \\
\text { 'dias caniculares'. Ácis, amado por Galateia, é o jovem pastor } \\
\text { que Polifemo, enciumado, acaba esmagando sob uma rocha. } \\
\text { A cena deste fragmento, descrita com recarga de tropos, } \\
\text { apresenta simplesmente Ácis que se dessedenta à beira do } \\
\text { arroio (o 'sonoro cristal'), enquanto espreita o corpo } \\
\text { luminosamente branco da ninfa adormecida (o 'cristal } \\
\text { mudo')". } \\
\text { Nessa obra de Góngora, há a escolha de procedimentos } \\
\text { agudos, engendradores de um enunciado enigmático, } \\
\text { obscuro, sintaticamente labiríntico, pronto a suscitar o prazer } \\
\text { sensível. Todavia, porque obscurecido no PE, obsta a } \\
\text { apreensão rápida, proporcionando um segundo prazer } \\
\text { inteligível decorrente da descoberta cognitiva pelo } \\
\text { enunciatário diante de variadas combinatórias de sentido. }\end{array}$ & \\
\hline $\begin{array}{l}\text { Sousândrade } \\
\text { (1832-1902) } \\
\text { Poeta } \\
\text { maranhense } \\
\text { [BT, RA, SB, } \\
\text { LACMBR, } \\
\text { PAJC] }\end{array}$ & $\begin{array}{l}\text { Destaca Haroldo de Campos, em "Uma arquitextura do } \\
\text { barroco", dois trechos de "Novo Éden", considerado poema } \\
\text { "labiríntico, perpassado por laivos barroquistas" (CAMPOS, } \\
\text { 1976b, p. } 143 \text { e 147-148 [parte da poesia de Sousândrade]): } \\
\text { Fragmentos de "Heleura" (do "Novo Éden") } \\
\qquad . . \text { Heleura } \\
\text { Mirou-se toda: uma áspide a mordera, } \\
\text { Ela o sentiu; fugiu para o aposento } \\
\text { Alcatifado de cravina e de ouro } \\
\text { E onde sonhos levianos não entravam, } \\
\text { Cheiro sentindo de jacintos, vendo } \\
\text { Lábios-luz, verdejantes laranjeiras } \\
\text { Flores-noivas grinaldas agitando } \\
\text { Sobre um abismo venturoso, em vagas } \\
\text { Como espelhos levando-a, combanidas, } \\
\text { À cristalina limpidez, reférvida } \\
\text { A epiderme num fósfor' luminoso - } \\
\text { Triângulos! triângulos! Semíramis! } \\
\text { A alvura e o sentimento! anéis da trança, } \\
\text { Quando as faces beijavam-Ihe, incendiam. }\end{array}$ & $\begin{array}{l}\text { O Guesa } \\
(1876 ; 2009) \\
\text { "Novo } \\
\text { Éden" } \\
(1893)\end{array}$ \\
\hline
\end{tabular}




\begin{tabular}{|c|}
\hline $\begin{array}{l}\text {... Porém, já prontinha } \\
\text { Co'as alvoradas estava Heleura, vendo: } \\
\text { Alta amarela estrela brilhantíssima; } \\
\text { Cadentes sul-meteoros luminosos } \\
\text { Do mais divino pó de luz; véus ópalos } \\
\text { Abrindo ao oriente a homérea rododáctila } \\
\text { Aurora! e ao cristalino firmamento } \\
\text { Cygni - esse par de sóis unidos sempre, } \\
\text { Invisiveis; e que ela via claros } \\
\text { Dadas mãos, em suas órbitas eternas } \\
\text { Qual num lago ideal as belas asas } \\
\text { Por essa imensidade... } \\
\text { Heleura, musa da República paradisíaca do sonho } \\
\text { sousandradino (“Novo Éden"), entra em delírio de febre. Em } \\
\text { homérea rododáctila, o enunciador recria a metáfora de } \\
\text { Homero para Aurora (dedos cor-de-rosa, rododáctila). } \\
\text { Rododáctila seria um neologismo construído com base em } \\
\text { dedirrósea do amigo e tradutor Odorico Mendes que o utiliza } \\
\text { em sua tradução de Homero. Sousândrade faz assim uma } \\
\text { homenagem ao conterrâneo maranhense. } \\
\text { Na obra de Sousândrade, o caráter barroquista, segundo } \\
\text { Haroldo de Campos (In: CAMPOS; CAMPOS, 2002, p. 33), "se } \\
\text { manifesta nos cultismos léxicos e sintáticos (palavras raras e } \\
\text { arcaizantes, neologismos, hibridismos; hipérbatos, elipses } \\
\text { violentas, elusões e alusões etc.); no arrojado processo } \\
\text { metafórico, que não hesita ante a metáfora pura e a } \\
\text { catacrese; na recarga de figuras de retórica; no requinte da } \\
\text { tessitura sonora, que incorpora os entrechoques } \\
\text { onomatopaicos e a dissonância, enfim, na opção por um } \\
\text { fraseado de torneio original e inusitado, que se lança à } \\
\text { importação constante de recursos sintáticos e morfológicos } \\
\text { de extração estrangeira (greco-latina, francesa, anglo- } \\
\text { germânica), além de eventuais interpolações idiomáticas (de } \\
\text { palavras ou sintagmas) que vão beber ainda em outras fontes, } \\
\text { como o tupi, o quíchua, o espanhol, o italiano, o holandês". } \\
\text { As arrojadas e rearranjadas formas de expressão e de } \\
\text { conteúdo lembram a "fanopeia poudiana" (poesia imagem, } \\
\text { poesia-pintura). Augusto e Haroldo de Campos (2002, p. } 33- \\
\text { tomadas visuais, verdadeiras cenas pictóricas (écfrases), }\end{array}$ \\
\hline
\end{tabular}




\begin{tabular}{|c|c|c|}
\hline & $\begin{array}{l}\text { como faz o poeta Pound. Além disso, a sintaxe sousandradina } \\
\text { adianta as características de uma obra fluida, com várias } \\
\text { combinatórias de sentido, visto ser de cunho labiríntico- } \\
\text { formal. Encontrar o fio do sentido suscita, além do prazer } \\
\text { inicialmente sensível, a fruição da descoberta da organização } \\
\text { sintagmática do poema. }\end{array}$ & \\
\hline $\begin{array}{l}\text { Mallarmé } \\
\text { (1842-1898) } \\
\text { Poeta e } \\
\text { crítico } \\
\text { literário } \\
\text { francês } \\
\text { [BT; RA; SB] }\end{array}$ & 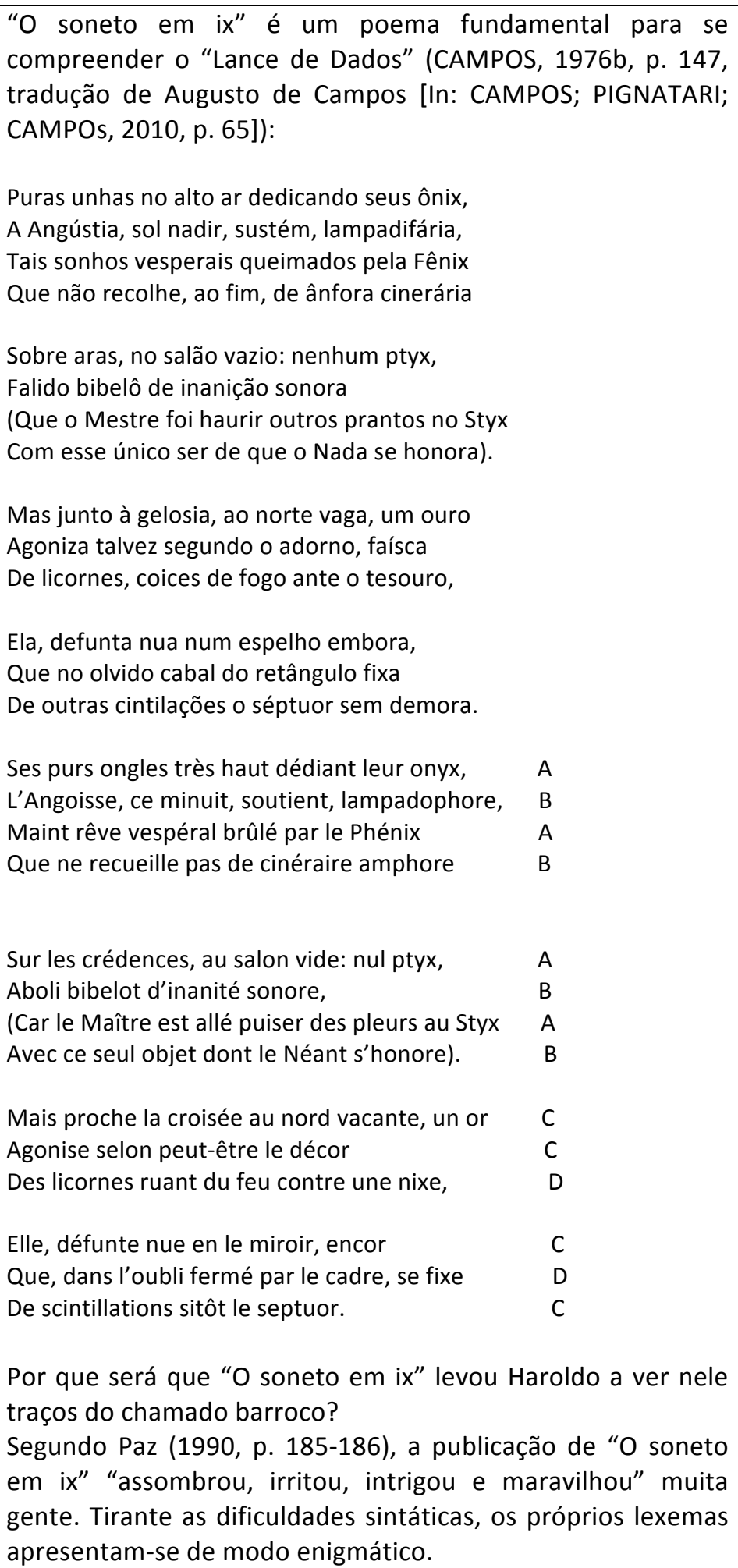 & $\begin{array}{l}\text { "O Soneto } \\
\text { em ix" } \\
\text { "Lance de } \\
\text { dados" }\end{array}$ \\
\hline
\end{tabular}




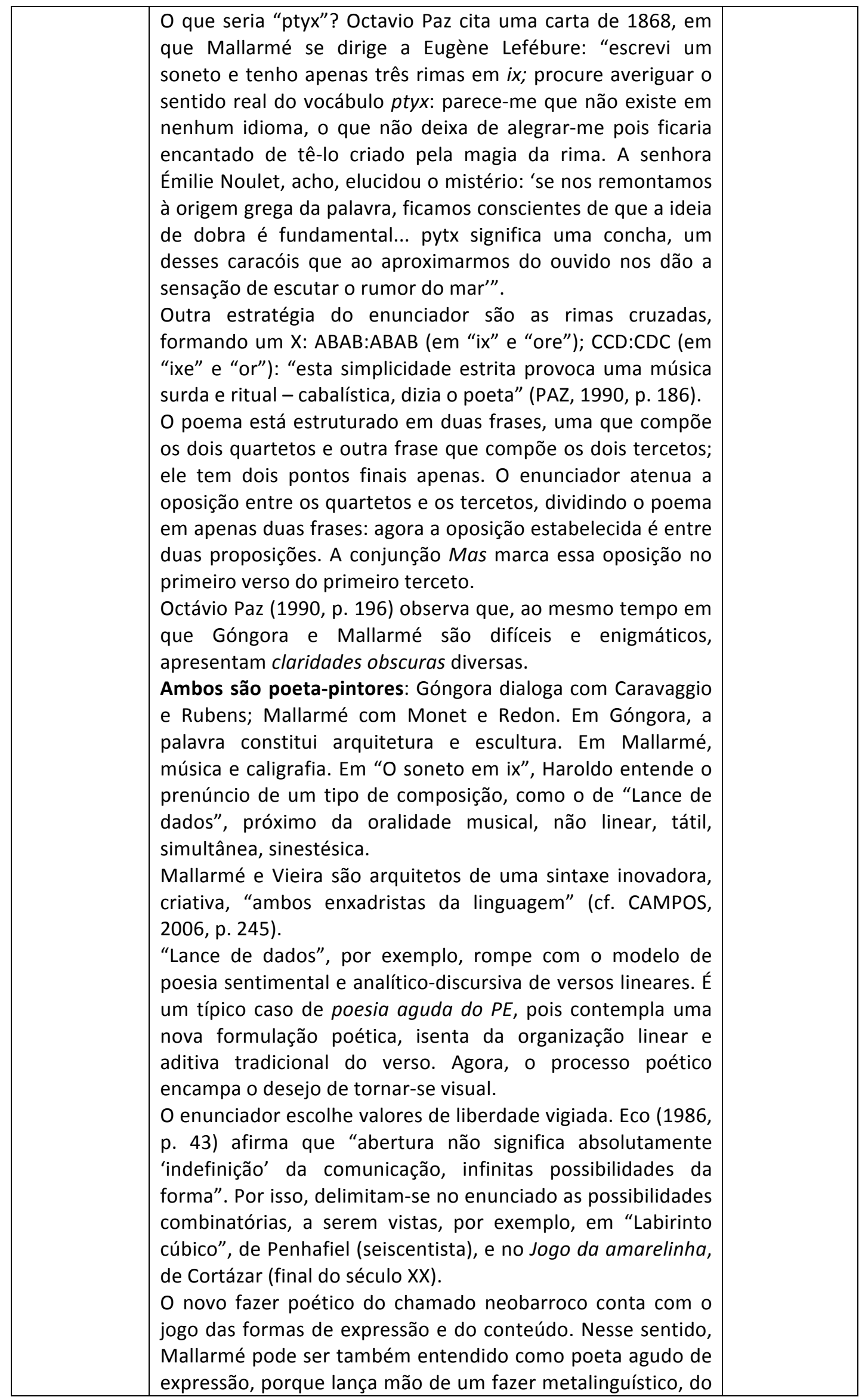




\begin{tabular}{|c|c|c|}
\hline & $\begin{array}{l}\text { exercício de trabalhar com a linguagem, um trabalho da } \\
\text { soberania paradigmática em relação ao eixo sintagmático. } \\
\text { Nesse sentido, Ávila é um pouco mallarmeamo, quando elege } \\
\text { a sintaxe visual, aproveitando o branco da página. Essa nova } \\
\text { poética, segundo Campos ( } 2006, \text { p. } 247) \text {, faz um uma reflexão } \\
\text { crítica sobre o conceito de barroco como obra aberta. }\end{array}$ & \\
\hline $\begin{array}{l}\text { Pedro } \\
\text { Kilkerry } \\
\text { (1885-1917) } \\
\text { Poeta } \\
\text { baiano. } \\
\text { [PS; RA] }\end{array}$ & $\begin{array}{l}\text { No artigo "Poética sincrônica" (CAMPOS, 1977a, p. 205-219), } \\
\text { Haroldo considera Kilkerry neobarroco: ele seria a face } \\
\text { mallarmaica da poesia brasileira. Mallarmé, Sousândrade, } \\
\text { Kilkerry teriam contribuído, na visão de Haroldo, } \\
\text { definitivamente para a renovação das formas em nossa } \\
\text { poesia. Poeta de grande inventividade, seria também } \\
\text { conhecido como Gregório de Matos da modernidade. }\end{array}$ & Poesias \\
\hline 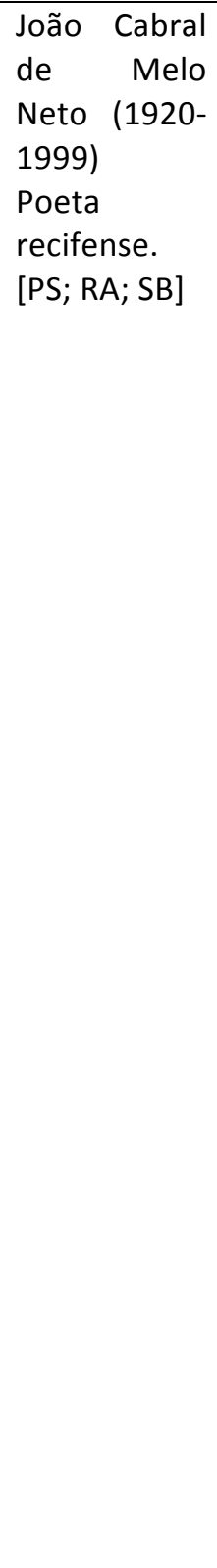 & $\begin{array}{l}\text { Poema construído como jogo lúdico e de estrutura } \\
\text { combinatória. João Cabral, segundo Haroldo de Campos } \\
\text { (2006, p. 245), é um "engenheiro de estruturas } \\
\text { mondrianescas", revelando um fazer geometrizado e } \\
\text { prolífero. } \\
\text { Sant'Anna (2000, p. 95) afirma que "na modernidade, João } \\
\text { Cabral de Melo Neto é um exemplar de poeta conceitista", } \\
\text { pois seus poemas seguem uma montagem lógico-racional. } \\
\text { Repetidas vezes, "ele mostra até mesmo repugnância por } \\
\text { uma poesia que não seja 'construída', levando a extremos } \\
\text { alguns preceitos de Paul Valéry. Intitula-se, por isso, um } \\
\text { 'engenheiro' do verso e fala da 'máquina' do poema, além de } \\
\text { privilegiar metáforas como 'relógio'. Curiosamente, há quem } \\
\text { diga que a palavra 'engenheiro' teve sua origem na época } \\
\text { barroca e sua utilização se deve ao matemático francês } \\
\text { Sebastian Caus". Sendo "engenho/engenheiro" termos de } \\
\text { Caus ou não o sendo, eles circulam no período seiscentista e } \\
\text { destinavam os fazeres poéticos de então. As poesias } \\
\text { cabralinas, por sua engenhosidade sintática e distribuição das } \\
\text { figuras semânticas, podem ser consideradas exemplos de } \\
\text { agudeza, visto que se trata da espiralização seiscentista do } \\
\text { quadrado clássico. } \\
\text { Assim, em Uma faca só lâminas, João Cabral de Melo Neto } \\
\text { escolhe estrofe de quatro versos regulares, organizando seu } \\
\text { enunciado poético como se demonstrasse um teorema } \\
\text { matemático. Comparando-o com a música, temos uma fuga, } \\
\text { que consiste na repetição de temas sucessivamente e de } \\
\text { modo entrelaçado. O poema de Cabral simula uma fuga e } \\
\text { perseguição de um tema, como em uma peça musical. } \\
\text { Uma faca só lâminas é estrategicamente composto como } \\
\text { uma fuga barroca: } \\
\text { Seja bala, relógio, } \\
\text { ou a lâmina colérica, } \\
\text { é contudo uma ausência } \\
\text { o que esse homem leva. }\end{array}$ & $\begin{array}{l}\text { Uma faca só } \\
\text { lâmina } \\
\text { (1955) } \\
\text { Educação } \\
\text { pela pedra } \\
\text { (1962-1965) }\end{array}$ \\
\hline
\end{tabular}




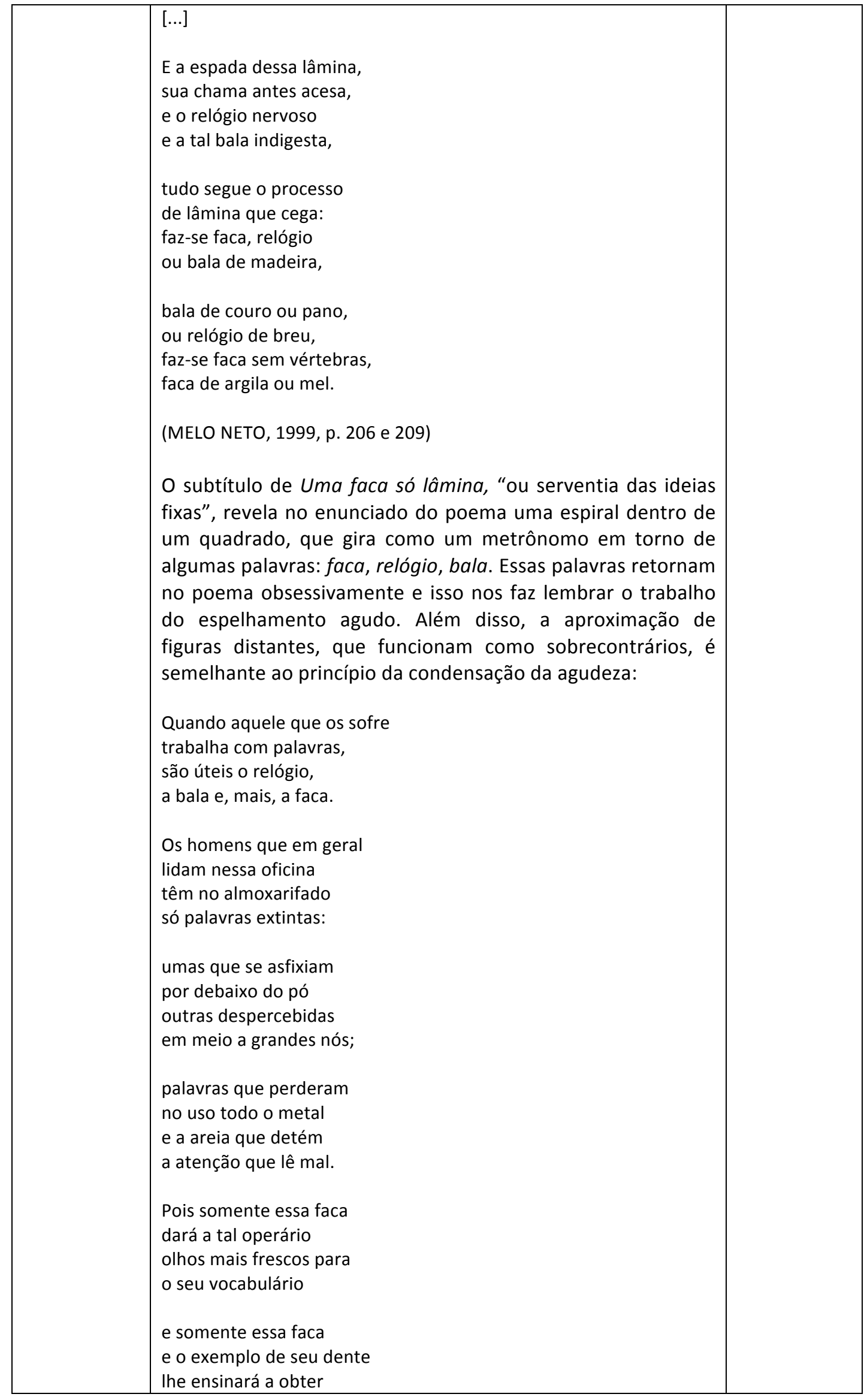




\begin{tabular}{|c|c|c|}
\hline & $\begin{array}{l}\text { de um material doente } \\
\text { o que em todas as facas } \\
\text { é a melhor qualidade: } \\
\text { a agudeza feroz, } \\
\text { certa eletricidade, } \\
\text { mas a violência limpa } \\
\text { que elas têm, tão exatas, } \\
\text { o gosto do deserto, } \\
\text { o estilo das facas. } \\
\text { Essa lâmina adversa, } \\
\text { como o relógio ou a bala, } \\
\text { se torna mais alerta } \\
\text { todo aquele que a guarda, } \\
\text { sabe acordar também } \\
\text { os objetos em torno } \\
\text { e até os próprios líquidos } \\
\text { podem adquirir ossos. } \\
\text { (MELO NETO, 1999, p. } 213-214) \text {. } \\
\text { Assim, palavra e faca são aproximadas de forma inesperada, } \\
\text { posto que são figuras semanticamente muito distantes. } \\
\text { Todavia, como a faca é cortante, há palavras que são como } \\
\text { lâminas de faca. } \\
\text { Outros dois exemplos de poemas cabralinos da linha da } \\
\text { agudeza engenhosa são “O sim contra o sim” e o ovo de } \\
\text { galinha", ambos de Serial (1959-1961). }\end{array}$ & \\
\hline $\begin{array}{l}\text { Jorge de } \\
\text { Lima (1893- } \\
\text { 1953) } \\
\text { Poeta } \\
\text { alagoano. } \\
\text { [PAJC] }\end{array}$ & $\begin{array}{l}\text { Em Jorge de Lima, também podemos encontrar no enunciado } \\
\text { um jogo probabilístico e matemático. O texto poético de mais } \\
\text { de } 200 \text { páginas, Invenção de Orfeu, é uma antiepopeia de dez } \\
\text { cantos, considerada por muitos críticos como texto obscuro e } \\
\text { hermético. Trata-se de um diálogo do enunciador com a } \\
\text { tradição lírica. Muitos críticos fazem alusão ao caráter } \\
\text { barroco de sua composição: labiríntico, enigmático, como o } \\
\text { texto de Góngora: "uma avalanche verbal da composição" } \\
\text { (SANT'ANNA, 2000, p. 97). Nesse poema, condensam-se e } \\
\text { complementam-se engenhosamente quadrado clássico e } \\
\text { elipse seiscentista. } \\
\text { Como o texto de Jorge de Lima é um diálogo de Orfeu com a } \\
\text { história das artes e da poesia, uma das saídas para encontrar } \\
\text { o fio labiríntico é: "o autor toma emprestado de Homero, } \\
\text { Dante, Camões, Virgílio, Milton e, às vezes, dele mesmo, } \\
\text { trechos de poemas, num jogo de espelhos textuais, } \\
\text { perfazendo um labirinto de significados. É uma arquitetura de } \\
\text { empréstimos e recriações textuais. A rigor, é uma estrutura } \\
\text { elíptica, no sentido de que virtualiza a manifestação } \\
\text { discursiva de outros autores. Faz a elipse/eclipse de um texto } \\
\text { originário e pratica o palimpsesto moderno. Ele não está } \\
\text { plagiando nem roubando obras, mas exercitando a técnica da } \\
\text { 'citação' e da 'apropriação', comum tanto nas artes clássica e }\end{array}$ & $\begin{array}{l}\text { Invenção de } \\
\text { Orfeu (1952) }\end{array}$ \\
\hline
\end{tabular}


seiscentista quanto nas modernas, como se observa no poeta americano Ezra Pound, ou como já era praticado por Camões, que também se apropriava de versos de Petrarca e Virgílio" (SANT'ANNA, 2000, p. 97-98).

\section{As expressões destacadas ilustram a intertextualidade entre Jorge de Lima e Camões:}

Em Jorge de Lima (1997, p. 509, destaques nossos)

Canto Primeiro: Fundação da ilha

I

Um barão assinalado

sem brasão, sem gume e fama

cumpre apenas o seu fado:

amar, louvar sua dama,

dia e noite navegar,

que é de aquém e de além-mar

a ilha que busca e amor que ama.

Canto Segundo (p. 561, destaques nossos):

IX

Ó Memória dos mares, Taprobana,

sou da raça de nautas submergida.

E este monstro! Que monstro tão antigo!

Tão puro Adamastor, tão reversivo,

tão grosso deus, tão pura geografia!

Em Camões (2003, p. 10, destaques nossos):

Canto Primeiro

As armas e os barões assinalados

Que, da Ocidental praia Lusitana,

Por mares nunca dantes navegados,

Passaram ainda além da Taprobana,

Em perigos e guerras esforçados

Mais do prometia a força humana,

E entre gente remota edificaram

Novo Reino, que tanto sublimaram;

Canto V (CAMÕES, 2003, p. 126, destaques nossos)

Canto quinto:

Fui dos filhos aspérrimo da Terra,

Qual Encélado, Egeu e o Centimano;

Chamei-me Adamastor, e fui na guerra

Contra o que vibra os raios de Vulcano;

Não que pusesse serra sobre serra,

Mas, conquistando as ondas do Oceano,

Fui capitão do mar, por onde andava

A armada de Neptuno, que eu buscava.

Em Jorge de Lima (1997, p. 763, destaques nossos).

Canto Nono

I

Inês da terra. Inês do céu. Inês.

Preferida dos anjos. Árdua rota,

conúbio consumado, anteviuvez. 


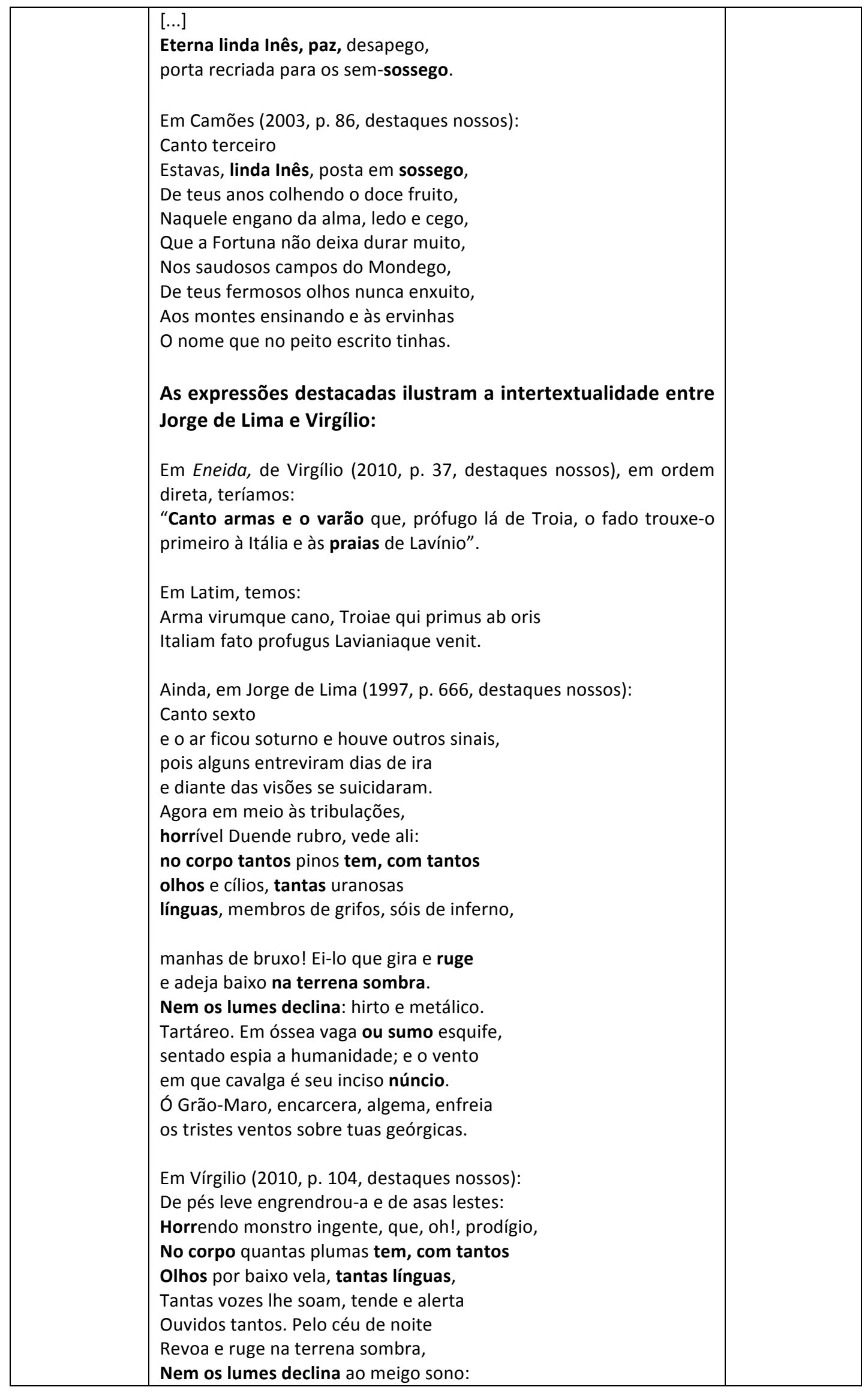




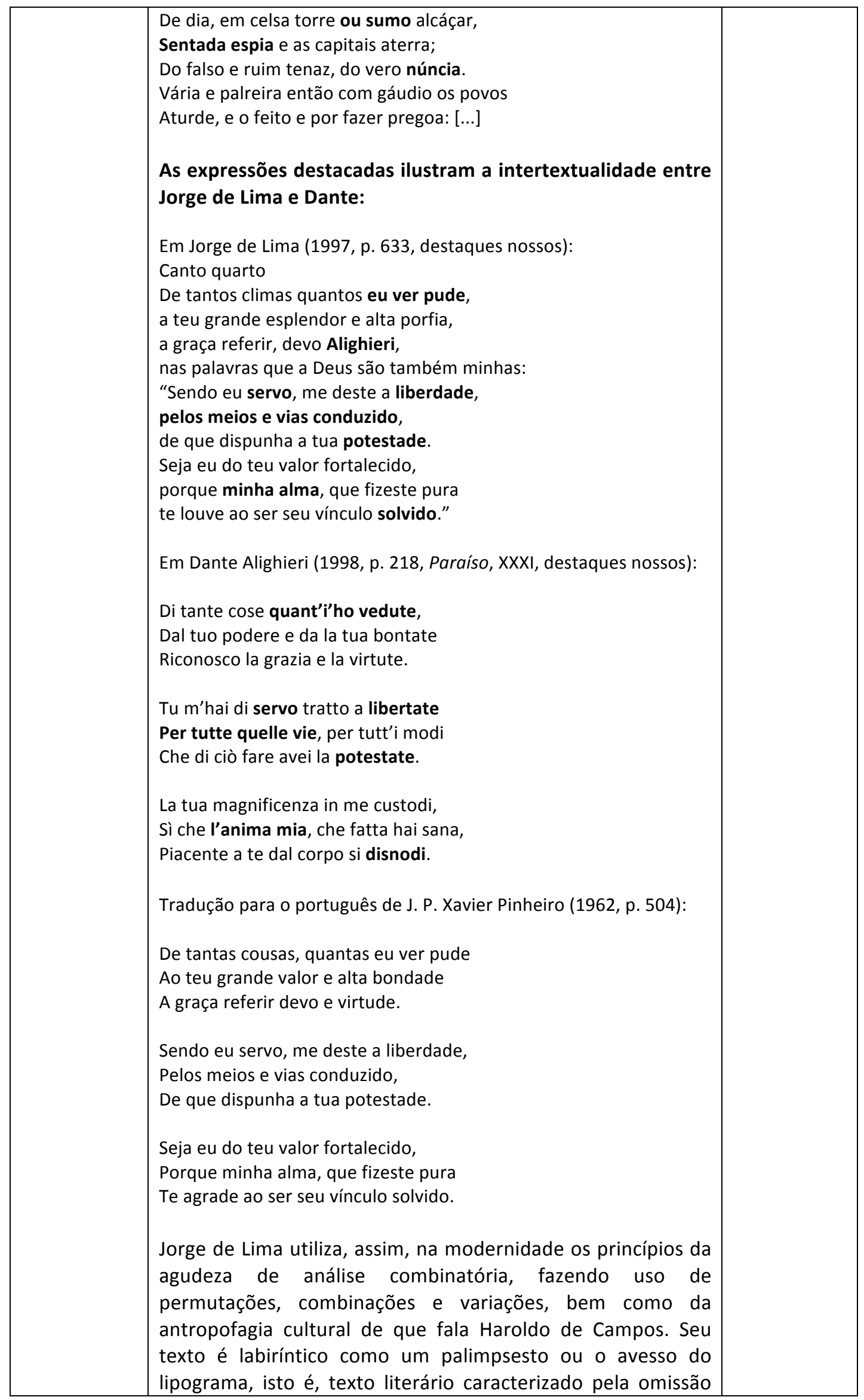




\begin{tabular}{|l|l|}
\hline $\begin{array}{l}\text { de determinada letra em seu texto. Por exemplo, a supressão } \\
\text { das vogais e ou i; em vez do processo de subtração de } \\
\text { elementos (letra, palavra), ele adiciona em seu enunciado } \\
\text { trechos de outros enunciados e enunciadores, como vimos } \\
\text { acima. } \\
\text { Sant'Anna (1985, p. 56), no livro Paródia, paráfrase \& cia., } \\
\text { com base em Luís Busato (Montagem: processo de } \\
\text { composição em Invenção de Orfeu), afirma que Jorge de Lima } \\
\text { não plagiou as obras clássicas no sentido comum do termo, } \\
\text { visto que ele próprio cita o nome de Dante, Virgílio, Camões } \\
\text { entre outros: “a Divina comédia é aí citada através da } \\
\text { tradução de J. P. Xavier Pinheiro; o Paraíso perdido, em } \\
\text { tradução de Antônio José Lima Leitão, e a Eneida em tradução } \\
\text { de Odorico Mendes". E ainda mostra que, ao valer-se das } \\
\text { Geórgicas de Virgílio, fê-lo com base na tradução de Antonio } \\
\text { Feliciano de Castilho. Sant'Anna (1985, p. 59) comenta que o } \\
\text { processo utilizado por Jorge de Lima é o da comutação, isto é, } \\
\text { troca de palavras e sintagmas "em busca de variações muito } \\
\text { mais fônicas e semânticas que propriamente ideológicas e } \\
\text { estéticas". É como se o poeta assumisse o processo } \\
\text { enunciativo de um jazzista que executa uma obra alheia, } \\
\text { retomando temas e improvisando. }\end{array}$ \\
\hline
\end{tabular}

Observando o quadro 3.1, nota-se que o paideuma haroldiano é formado por obras, fragmentos, poemas; o ensaísta privilegia apenas as obras que dão continuidade a uma literatura de inventividade linguística, que ele considera "barroca". Além disso, seu cânone é tributário do paideuma de Ezra Pound. Temos aqui um exemplo de contracrítica exercida por poetas e escritores insatisfeitos com a crítica e a historiografia tradicionais. Trata-se de uma crítica parcial. A crítica de H. Campos e seu cânone estão a serviço de sua própria prática. Para Perrone-Moisés (2009, p. 11), enquanto fala de

certos escritores do passado e não de outros, os escritores críticos efetuam um primeiro julgamento. Assim fazendo, cada um deles estabelece sua própria tradição e, de certa maneira, reescreve a história literária.

A posição de Haroldo constitui-se, pois, numa crítica que confirma e cria valores. Enquanto a crítica analítica (com pretensões de ciência) é cada vez menos judicativa, a crítica haroldiana "lida diretamente com os valores e exerce, sem pudores, a faculdade de julgar" (PERRONE-MOISÉS, 2009, p. 11).

A lista de obras apontadas por Haroldo de Campos como barroquistas não se limitam às apontadas no quadro 3.1. Para sintetizar, as características fundamentais nas quais ele se apoia são: (a) inventividade, (b) engenhosidade, (c) criatividade e (d) diálogo crítico com 
textos da tradição literária, parâmetros utilizados para denominar de neobarrocos autores e obras. No quadro 3.2, apresentamos uma relação de autores e de obras que Haroldo de Campos apenas cita, não nos oferecendo maiores elementos analíticos que comprovem a euforia barroquista. Muitas vezes, temos apenas o autor; outras vezes, autor e obra (as siglas entre colchetes indicam os textos em que o mapeamento neobarroco foi estabelecido). Segundo Haroldo, todas as obras mencionadas seguem uma linha de tradição de invenção criativa por meio do artifício que chamamos de agudezas do PE e/ou do PC.

Quadro 3.2 Obras e autores barroquistas* mencionados por Haroldo.

*Organizados segundo data de nascimento.

\begin{tabular}{|c|c|}
\hline Decimo Magno Ausonio (310-395) & $\begin{array}{l}\text { poeta romano - poema "Mosela"; Parentalia } \\
\text { (breves poemas construídos } \\
\text { engenhosamente) }[\mathrm{RA}] .\end{array}$ \\
\hline Petrarca (1304-1374) & Poeta humanista italiano [RA]. \\
\hline Sá de Miranda (1481-1558) & Poeta português [RA]. \\
\hline Camões (1481?-1558) & Poeta português [RA-SB-LACMBR]. \\
\hline Garcilaso de la Vega (1503-1536) & $\begin{array}{l}\text { Poeta espanhol, engenhoso e agudo, } \\
\text { influenciado por vários destinadores, como } \\
\text { Teócrito, Virgílio, Horácio e Petrarca [RA]. }\end{array}$ \\
\hline John Donne (1572-1631) & Poeta inglês [SB]. \\
\hline Hernando Domínguez Camargo (1606-1659) & Poeta colombiano [SB]. \\
\hline Pe. Antonio Vieira (1608-1697) & $\begin{array}{l}\text { Escritor português radicado no Brasil. } \\
\text { Sermões [RA-SB-LACMBR-PAJC]. }\end{array}$ \\
\hline Gregório de Matos (1636-1696) & $\begin{array}{l}\text { Poeta brasileiro [PS-BT-RA-SB-LACMBR- } \\
\text { PAJC]. }\end{array}$ \\
\hline Manuel Botelho de Oliveira (1636-1711) & $\begin{array}{l}\text { Poeta brasileiro. Música do parnaso (1705) } \\
\text { [SB-LACMBR-PAJC]. }\end{array}$ \\
\hline Sor Juana Inés de La Cruz (1651-1695) & Poeta mexicana [RA-SB]. \\
\hline Juan del Valle y Caviedes (1652-1698) & Poeta peruano de origem espanhola [RA-SB]. \\
\hline Claudio Manuel da Costa (1729-1789) & Poeta brasileiro [LACMBR-PAJC]. \\
\hline Alvarenga Peixoto (1742[44?]-1792) & Poeta brasileiro [PS]. \\
\hline Tomás Antonio Gonzaga (1744-1810) & $\begin{array}{l}\text { Poeta português radicado no Brasil. Cartas } \\
\text { chilenas (1863) [LACMBR-PAJC] }\end{array}$ \\
\hline
\end{tabular}




\begin{tabular}{|c|c|}
\hline Pe. Sousa Caldas (1762-1814) & $\begin{array}{l}\text { Poeta brasileiro. "Carta a João de Deus Pires } \\
\text { Ferreira". Para Haroldo de Campos (1977a, } \\
\text { p. 210), o trecho que o próprio padre-poeta } \\
\text { intitula "Diálogo com Tritão" será "peça } \\
\text { obrigatória" de uma "antologia de nossa } \\
\text { poesia criativa". Há no enunciado casos de } \\
\text { misturas de idiomas, sendo considerado um } \\
\text { precursor de Sousândrade [PS]. }\end{array}$ \\
\hline Bernardo Guimarães (1825-1884) & $\begin{array}{l}\text { Poeta brasileiro. O elixir do pajé (1840?): } \\
\text { poesias erótico-escatológicas [PS-LACMBR- } \\
\text { PAJC]. }\end{array}$ \\
\hline Luiz Gama (1830-1882) & $\begin{array}{l}\text { Poeta brasileiro. Poema "A bodarrada" (In: } \\
\text { Primeiras trovas burlescas de Getulino, 1859) } \\
\text { [SB-LACMBR-PAJC]. }\end{array}$ \\
\hline Manuel Antonio de Almeida (1831-1861) & $\begin{array}{l}\text { Escritor brasileiro. Memórias de um sargento } \\
\text { de milícias (1852-1853) [RA-LACMBR]. }\end{array}$ \\
\hline Cruz e Sousa (1861-1898) & $\begin{array}{l}\text { Poeta brasileiro. Haroldo de Campos (In: } \\
\text { DANIEL, 2004a, p. 14) cita trecho de "O cisne } \\
\text { negro" como barroquista: "eu quero em } \\
\text { rude verso altivo adamastórico/vermelho } \\
\text { colossal, d'estrépito gongórico" (menção à } \\
\text { pompa da linguagem de Góngora, assim } \\
\text { como o fez Rubén Darío, poeta } \\
\text { "neobarroquista" nicaraguense) [PS-RA- } \\
\text { LACMBR-PAJC]. Haroldo observa que Cruz e } \\
\text { Sousa ainda não representa a faceta mais } \\
\text { radical do barroquismo, como Pedro Kilkerry } \\
\text { (CAMPOS, 1977a, p. 212). }\end{array}$ \\
\hline Raul Pompeia (1863-1895) & $\begin{array}{l}\text { Escritor brasileiro. O Ateneu (1888) [SB- } \\
\text { LACMBR-PAJC]. }\end{array}$ \\
\hline Euclides da Cunha (1866-1909) & $\begin{array}{l}\text { Escritor brasileiro. Os sertões (1902) [SB- } \\
\text { LACMBR-PAJC]. }\end{array}$ \\
\hline Rubén Darío (1867-1916) & $\begin{array}{l}\text { Poeta nicaraguense, autor de Cantos de vida } \\
\text { y esperanza (1905). Precursor do } \\
\text { modernismo em língua espanhola, } \\
\text { considerado por Haroldo de Campos como } \\
\text { neobarroco. O poema "Letanía de nuestro } \\
\text { señor Don Quijote", integrante de Cantos de } \\
\text { vida y esperanza, exalta o idealismo e o lado } \\
\text { picaresco de Dom Quixote [PAJC]. }\end{array}$ \\
\hline James Joyce (1882-1941) & $\begin{array}{l}\text { Escritor irlandês. Finnegans Wake (1939) } \\
\text { [BT]. }\end{array}$ \\
\hline
\end{tabular}




\begin{tabular}{|c|c|}
\hline Augusto dos Anjos (1884-1914) & $\begin{array}{l}\text { Poeta brasileiro. "Eu" (1912). Trata-se de } \\
\text { uma poética de transgressão, pluralista; por } \\
\text { isso, encaixa-se no "roteiro" neobarroco de } \\
\text { Haroldo de Campos [RA-SB-PAJC]. }\end{array}$ \\
\hline Ezra Pound (1885-1972) & Escritor americano. Poesia [BT]. \\
\hline Oswald de Andrade (1890-1954) & $\begin{array}{l}\text { Escritor paulistano. Duas obras do autor } \\
\text { apresentam elo com a tradição viva do que } \\
\text { Haroldo considera barroco: Memórias } \\
\text { sentimentais de João Miramar (1924); } \\
\text { Serafim Ponte Grande (1933) [RA-SB- } \\
\text { LACMBR]. }\end{array}$ \\
\hline Mário de Andrade (1893-1945) & $\begin{array}{l}\text { Escritor brasileiro. Macunaíma (1928) [RA- } \\
\text { LACMBR]. }\end{array}$ \\
\hline E. E. Cummings (1894-1962) & Poeta americano. Poesias [BT]. \\
\hline Guimarães Rosa (1908-1967) & $\begin{array}{l}\text { Escritor brasileiro. Grande sertão veredas } \\
\text { (1956) [RA-SB-LACMB-PAJC]. }\end{array}$ \\
\hline Lezama Lima (1910-1976) & $\begin{array}{l}\text { Escritor cubano. Paradiso (1966) [BT-RA-SB- } \\
\text { LACMBR-PAJC]. }\end{array}$ \\
\hline Décio Pignatari (1927-2012) & $\begin{array}{l}\text { Escritor brasileiro. Fadas para Eni (1952); } \\
\text { Beba coca-cola (1958) [BT-RA-PAJC]. }\end{array}$ \\
\hline Affonso Ávila (1928-2012) & $\begin{array}{l}\text { Escritor mineiro. Cantaria barroca (1975) } \\
\text { [LACMBR-PAJC]. }\end{array}$ \\
\hline Haroldo de Campos (1929-2003) & $\begin{array}{l}\text { Escritor brasileiro. Ciropédia, Claustrofobia } \\
\text { (1952); Galáxias (1963-1976); Educação dos } \\
\text { cinco sentidos (1985); Crisantempo (1998) } \\
\text { [RA-PAJC]. }\end{array}$ \\
\hline Mario Faustino (1930-1962) [PAJC] & Escritor brasileiro. Poesias [PAJC]. \\
\hline Paulo Leminski (1944-1989) & $\begin{array}{l}\text { Escritor brasileiro. O catatau (1975). Pela } \\
\text { linguagem experimental, é considerada } \\
\text { prosa neobarroca [PAJC]. }\end{array}$ \\
\hline Claudio Daniel (1962- ) & $\begin{array}{l}\text { Poeta, prosador, ensaísta paulistano. Contos } \\
\text { neobarrocos Romanceiro de Dona Virgo } \\
\text { (2004b) [PAJC]. }\end{array}$ \\
\hline
\end{tabular}

A seguir, o esquema resumido por nós do cânone barroquista de Haroldo de Campos: 


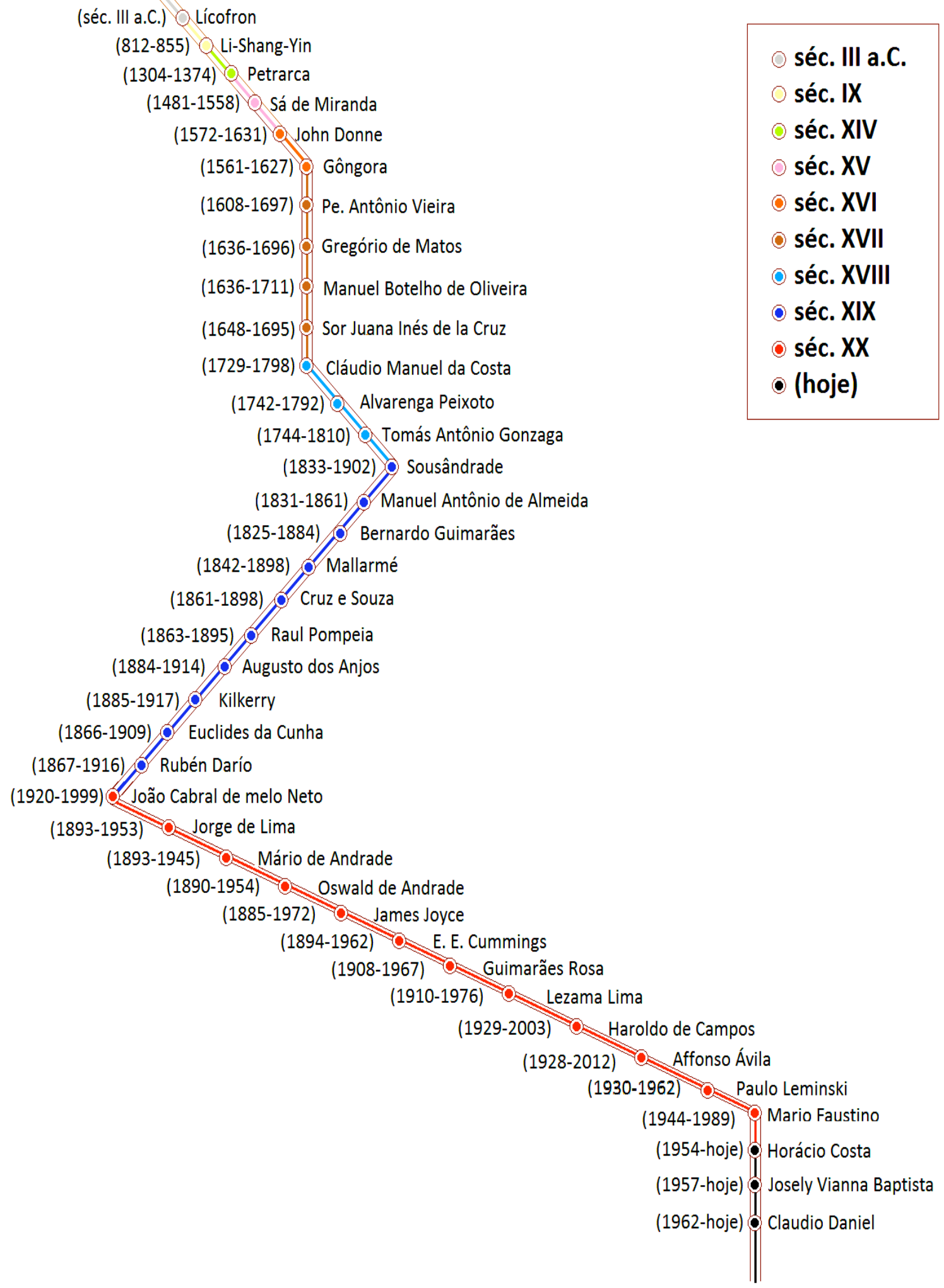




\title{
3.3 CenÁRIo da EUForização barRoQuista
}

Além dos barroquistas citados, pertencem ainda ao cânone haroldiano os seguintes nomes: Homero, Píndaro, Ovídio, Arnaut Daniel, Goethe, Hölderlin, Poe, Kafka, Maiakóvski, Ponge (cf. PERRONE-MOISÉS, 2009, p. 66-69).

O estabelecimento de um mapeamento barroquista sobretudo na literatura brasileira tem-se tornado uma constante. Haroldo de Campos reitera em variados momentos de sua obra ensaística um elenco revisado a cada artigo subsequente. Ele considera como barroquista ora um autor, ora uma obra apenas de um autor, ora um poema e, em alguns casos, como vimos nos quadros 3.1 e 3.2, versos de um poema.

Outros autores, como Ávila (2008a, 2008b), Horácio Costa ([1991] 2010), Ivan Teixeira (1997-1998), Sant'Anna (2000), dão continuidade, com algumas divergências de autores e obras, a essa preocupação em estabelecer uma linha de tradição das formas ditas barrocas. Reproduzimo-las aqui por necessidade de tornar preciso o que veio a ser essa euforização barroquista na história da literatura.

As listagens demonstram tradição de inventividade, do esmaecimento dos contornos, em direção à poesia de ordem mais fluida, resultado de acentuação da operação de agudeza. Ávila (2008b, p. 32) afirma: "toda criação, não obstante a sua modernidade, a sua novidade, está apoiada sempre numa linha de tradição". O poeta agudo tem em relação à linguagem uma atitude de permanente consciência crítica, que se exerce pela capacidade de inventar e reformar as formas de expressão e conteúdo da língua natural.

No artigo "Barrocolúdio: transa chim?", constante de O segundo arco-íris branco, Haroldo de Campos (1997) entende que, se há uma constante formal capaz de caracterizar a produção literária da América Latina,

\begin{abstract}
esta se encontrará no fundo cultista-conceitista do barroco gongorino (e também quevediano) "transculturado" em nossas literaturas excêntricas por figuras marcantes de poetas como a mexicana Sor Juana Inés de la Cruz, o brasileiro Gregório de Matos, o peruano Caviedes, o colombiano Hernando Domínguez Camargo, para só citar esses nomes que remontam ao acervo mnemônico do passado colonial (CAMPOS, 2010, p. 215).
\end{abstract}

Em seguida, elenca como continuadores do barroco Lezama Lima, Alejo Carpentier, Severo Sarduy, Cabrera Infante, Guimarães Rosa, Clarice Lispector, Júlio Cortázar. Haroldo encontra no "extravagante e sofisticado" Li Shang-yin, que viveu entre os anos 812 e 858, um fazer poético barroco chinês: "penso que será menos despistador aplicar o conceito de 
barroco a Li Shang-yin do que usar outros termos de origem ocidental como romantismo ou esteticismo" (CAMPOS, 2010, p. 219). E, com base em James J. Y. Liu (autor de A arte da poesia chinesa), aponta como característica dessa poesia a sutileza, a obliquidade, a ambiguidade, a tensão entre espiritualidade e sensualidade, a busca do extraordinário e da intensidade na engenhosidade literária.

Como temos discutido, a repetição do traço barroquista tem encontrado na história da crítica literária e artística autores como Ernst Curtius, Gustav Hocke, Eugenio D’Ors, que tangenciam semelhante ponto de vista. A diferença é que, enquanto os autores citados mencionam um barroco cíclico transistórico, Haroldo vê uma continuidade inventiva da linguagem poética, do que se depreende não se tratar de um retorno do barroco de tempos em tempos.

O conceito de sincronia haroldiano implica "a ideia de progresso, não no sentido de hierarquia de valor, mas no de metamorfose vetoriada, de transformação qualitativa, de culturmorfologia: make it new", contemporizando, em um continuum que transborda a história, "Homero e Pound, Dante e Eliot, Góngora e Mallarmé" (H. CAMPOS In: CAMPOS; PIGNATARI; CAMPOS, 2006, p. 43, destaque nosso). Perrone-Moisés (2009, p. 44) entende a expressão "metamorfose vetoriada de transformação qualitativa" como "sucessivos cortes sincrônicos" que configuram uma "linha diacrônica orientada para um futuro, um progresso qualitativo". Nesse sentido, entendemos ser a posição de Haroldo de Campos idealista, pois que defende a espacialização do tempo quando imobiliza, segundo seu conceito eufórico de barroquismo, alguns autores e obras e, ao mesmo tempo, defende a ideia de metamorfose vetoriada e de transformação qualitativa.

Ao euforizar a posição sincrônica, Haroldo está na companhia de Pound, Borges, Calvino, Octavio Paz, Eliot, Butor, Sollers. Todos eles "coincidem na negação da pertinência e/ou da conveniência de uma história literária diacrônica e linear" (PERRONE-MOISÉS, 2009, p. 38). Enquanto Eliot reforça a conservação do passado no presente, Pound elege o presente como reforma do passado; Borges, por sua vez, nega o tempo, subvertendo a linearidade e Octavio Paz relativiza o tempo na literatura, estabelecendo que a poesia é simultaneamente temporal e atemporal; já Butor advoga a recriação do passado, tendo em vista um graduado "melhoramento", ao passo que Calvino sugere uma releitura que atualiza os clássicos. Finalmente, Sollers defende a reformulação da escrita a fim de romper com a tradição filosófica, política e estética. 
Os autores citados estabelecem uma lista de escolhas ditadas muitas vezes por gosto pessoal, mas justificadas por argumentos estéticos ou pelo próprio fazer poético. Para Pound, haveria autores que ultrapassam seu tempo e, como uma semente, frutificam no futuro literário. Constituem seu cânone: Homero, Safo, Sófocles, Ovídeo, Catulo, Propércio, El Cid, Arnaut Daniel, Dante, Chaucer, Villon, Shakespeare, John Donne, Voltaire, Stendhal, Gautier, Whitman, Flaubert, Swinburne, Corbière, Rimbaud, Laforge, Joyce, Eliot. Como se pode observar, entre as escolhas poundianas e as haroldianas há semelhanças e divergências. Em Pound, consta Safo e Sófocles; em Campos, Píndaro e Lícofron; Pound não cita Goethe nem Allan Poe como Campos etc. (cf. PERRONE-MOISÉS, 2009, p. 66 ss).

Até aqui temos visto que o neobarroco haroldiano pretende a reconquista sincrônica do barroco. Para ele, não se trata de continuidade em termos histórico-ideológicos, mas de herança de traços barroquistas sobretudo no que se refere ao aspecto inventivo da linguagem. A expressão genérica de Ávila (2008b, p. 32) de que "toda criação, não obstante sua modernidade, está apoiada sempre numa linha de tradição" pode ser especificada com o que expusemos do pensamento de Sarduy, na seção 2.3, bem como com o que vimos em 2.6. Finalmente, utilizamos informações constantes do ensaio de Haroldo sobre Sousândrade (In: CAMPOS; CAMPOS, 2002, p. 33) apresentadas em 3.1. As propriedades relacionadas têm como característica a dominância da agudeza visual e/ou sonora nos objetos estéticos do final do século XX.

De nossa parte, verificamos que a inventividade apoia-se na agudeza e que a agudeza dos seiscentos não é igual à agudeza do final do século XX; as propriedades poéticas que Haroldo de Campos denomina barroquistas não seriam mais que uma acentuação da inventividade linguística, que identificamos coma agudeza, ora mais para sonoridade, ora mais para visualidade.

A função poética, segundo Jakobson (2005, p. 130), "projeta o princípio de equivalência do eixo de seleção sobre o eixo de combinação". Nesse caso, o que Haroldo considera formas barroquistas equivaleria ao princípio poético jakobsoniano. Agora, não se trata apenas de projeção de um eixo sobre outro, mas de vivificação sensível por meio de subversão da organização sintagmática, envolvendo corte de palavras no final dos versos, separação de fonemas das sílabas; amálgama de lexemas, uns grudados aos outros; condensação aguda de sons; procedimentos anagramáticos; utilização de tmeses, de 
paronomásias, de aliterações; aproveitamento do espaço branco da página, entre outros recursos formais do PE e do PC.

Uma característica marcante desse tipo de poesia é a plasticidade poética, em que o poema transforma-se em um objeto estético-visual. Essa propriedade aguda não é uma criação barroca nem do final do século XX. A história da arte registra exemplos de poesias visuais já no século III a.C., como podemos ver no poema "Ovo" de Símias de Rodes:

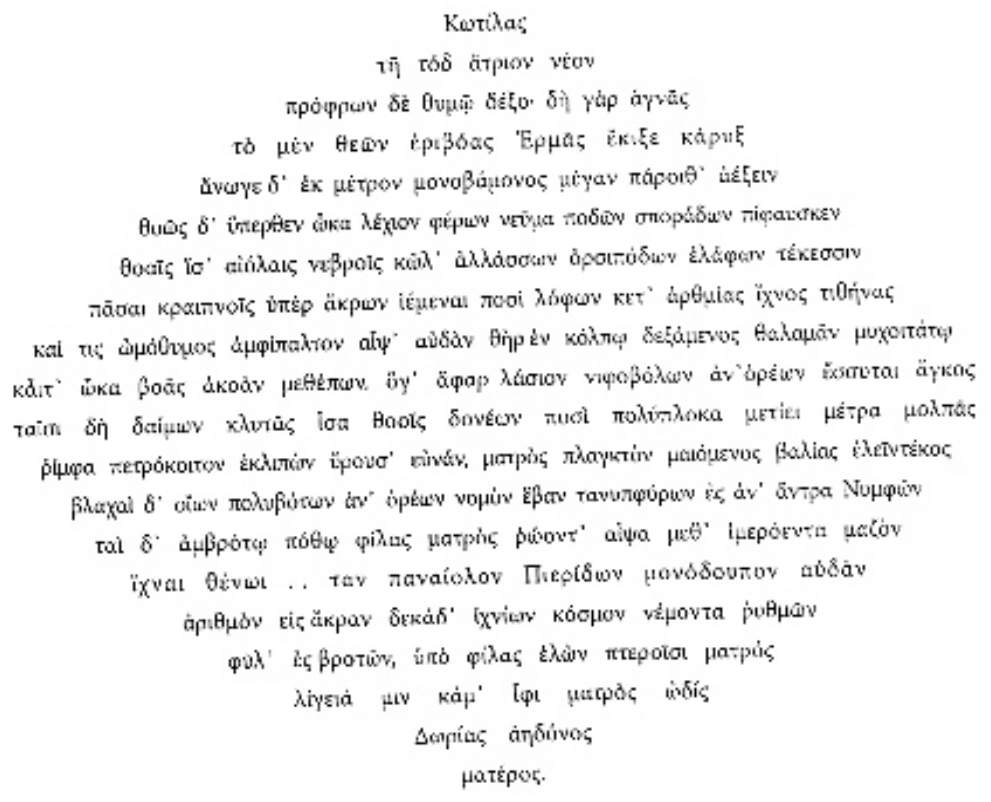

Outros exemplos de poesia visual encontramos nos anagramas de Luís Nunes Tinoco (ca. 1648-ca.1718); em "Ao mesmo por suas altas prendas" (século XVII), atribuído a Gregório de Matos; em "Labirinto cúbico" (1727) de Aires de Penhafiel; em "Tempestade" (1869) de Gonçalves Dias; em "SI(LEN)CIO" (1955-1956) de Haroldo de Campos; em "Velocidade" (1957) de Ronaldo Azeredo; em "Beba coca cola" (1958) de Décio Pignatari; em "Gagárin" (1964) de Cassiano Ricardo; em "Zen" (1966) de Pedro Xisto; em "Rosa Tumultuada" (1967) de Manuel Bandeira; em "Código" (1973) de Augusto de Campos; em “Hospício da terra santa" (1973-1975); em “Metade" (2003) de Arnaldo Antunes.

Horácio Costa (2010, p. 42) adverte, porém, que prefere "trabalhar sobre dois eixos conceituais, considerando aspectos sincrônicos e diacrônicos ao mesmo tempos" e que o termo tradição pode produzir "conotações conservadoras quando inserido em um discurso crítico". Nesse sentido, o risco de se falar em tradição seria o de pensar em culto de "obras canonizadas". 
A seguir vejamos o barroquismo na visão de outros autores.

\subsection{Barroquismo para Ávila, Sant'Anna, Costa, Hatherly, Teixeira}

Nesta seção, veremos que há uma gama imensa de autores que discutiram o barroquismo como o fez Haroldo de Campos. Embora os autores apresentem algumas diferenças em relação ao amplo conceito haroldiano de neobarroco, todos eles observam um ofício formal intenso. Assim é que Ana Hatherly (1995, p. 190), em A casa das musas, afirma que por tendência barroca se deve entender

o culto de certos valores formais e até emocionais do estilo barroco, histórico, que persistiu (e persiste ainda) em Portugal e no Brasil a partir dos anos 50, e que se pode verificar quer na poesia quer na prosa, tanto de Experimentalistas como de seguidores de outras tendências, e que veio a constituir aquilo a que hoje se chama Neobarroco Português (destaques nossos).

O conceito de Hatherly, concebido do ponto de vista semiótico, reafirma tratar-se o barroquismo de uma forma que engenhosamente acentua os refreamentos para re-formar o enunciado poético. A mesma posição vamos encontrar em Aguilar (2005, p. 321). Para ele, as estratégias formais que Sarduy erigira como neobarrocas são aplicáveis sem dificuldade à obra Galáxias de Haroldo: “o esbanjamento, o artifício (com suas substituições, proliferações e condensações) e a paródia [...]. Talvez o que poderia ser considerado como o núcleo barroco da escritura latino-americana seja, além dos apontados por Sarduy, a consideração da linguagem como realidade última sobre a qual se exerce uma violência" (destaques nossos).

O enunciador que se vale de "violência na linguagem" atinge uma agudeza de grau vívido, cujo refreamento formal e cuja sobreposição do paradigma em relação ao sintagma engendram um objeto de ordem da fluidez, ou seja, uma poesia cujos contornos nítidos são esmaecidos, ficando latentes (cf. ZILBERBERG, 2011a, p. 44).

A seguir, vejamos o ponto de vista de Affonso Ávila, não o poeta, o crítico.

\subsubsection{Tradição Criativa do barroco em AfFonso Ávila}

Em 1968, no artigo "O barroco e uma linha de tradição criativa”, Ávila (2008b, p. 1933) já contestava a historicidade literária baseada na divisão de períodos e de escolas de estilo. A história cronológica e biográfica das artes apresentava distorções e era preciso uma nova visão dos objetos artísticos. Segundo o autor, "mais que simples reflexo de época ou 
projeção subjetiva" (p. 19), o estudo da arte exigia um instrumental que a visse como "um instante de plenitude" da experiência humana; por si só, ela se constituía em "um instrumento permanente de que se vale o homem para intuir, repensar e modificar criadoramente a realidade" (p. 19-20).

Por isso, Ávila, antes que observar a arte de um período determinado, dá preferência "às formas assumidas pela arte numa dada curva do devir humano" (p. 20). Daí sua sugestão para um estudo da evolução de formas no processo estético. Propõe, então, uma crítica de perspectiva sincrônica, segundo a qual o objeto artístico atual deveria ser examinado "como um degrau novo desdobrado de uma sequência de outros degraus, todos eles compondo $o$ itinerário de ascensão e descensão do homem na sua ânsia de dar linguagem e expressão estética à sua consciência de si e do mundo" (ÁVILA, 2008b, p. 20, destaques nossos). Assim, seria possível verificar a permanência de resíduos de formas em toda a arte brasileira. A partir dessa remanescência formal, o barroquismo em Ávila coloca-se como elemento estruturante, não se tratando de puro gosto estético ou de subjetividade analítica.

Além dessas características formais, o homem atual e o homem dos séculos XVI-XVII vivem experiências humanas comuns, como certa tensão existencial: "o homem barroco e o do século XX são um único e mesmo homem agônico, perplexo, dilemático, dilacerado, entre a consciência de um mundo novo [...] e as peias de uma estrutura anacrônica que o aliena" (p. 22). Ainda que os destinadores de suas produções sejam diferentes, ambos vivem a paixão da angústia, da instabilidade. Ademais, a forte presença de um destinador social faz do poeta seiscentista e do final do século XX um sujeito preocupado em constituir-se também destinador, promovedor de uma continuidade literária, que transfere suas paixões de angústia e perplexidade para seus objetos. Sua performance consiste em vivificar seu fazer poético imagético. Daí sua escolha de valor ser por excessos de cor, de formas reelaboradas, propostas de labirintos e fluidificação dos contornos, assumindo a arte formas obnubiladas.

A acentuação da sensibilidade visual do sujeito, cuja paixão de alma é a da euforia barroquista, conduziu o poeta a refletir sobre a fluidez das formas que utilizava; ora, é essa abertura de possibilidades formais que engendrará formas híbridas, que na poesia aguda do final do século XX configuram-se misturas formais que ultrapassam os limites do verso linear, do enunciado analítico e propõem nova distribuição do enunciado poético no espaço da página. A poesia que era soberanamente temporal, sequencial, agora manifesta-se 
espacialmente e seu enunciado pretende ser sensivelmente simultâneo: ela pode ser lida de forma vertical, horizontal, em círculos, em elipses. Enfim, o enunciatário é convocado a empreender o restabelecimento dos contornos. O verso barroquista ganha o estatuto de objeto plástico.

Affonso Ávila assevera que o barroco contempla duas linhas, que orientam dois tipos de análises diversas:

- Uma filosófica, marcada pelos valores da contrarreforma, que escolhe o fechamento, o conservadorismo, a triagem.

- Outra estética, cujos valores são de abertura, de mistura; esta última corrente, com sua maleabilidade criadora, serve de contraponto à primeira.

Como Haroldo de Campos, o ensaísta vê o barroco como "a nervura central da autêntica arte brasileira, como o núcleo detonador de nossa potencialidade criativa, como o fio condutor de nossa essencialidade peculiar ao longo do processo estético nacional" (ÁVILA, 2008b, p. 32). Seu pensamento apresenta uma família barroquista extensa, que vai de Gregório de Matos a Haroldo de Campos, conforme podemos ver no quadro 3.3.

Quadro 3.3 Autores barroquistas* sugeridos por Ávila ([1968] 2008b, p. 29-32).

\begin{tabular}{|l|l|}
\hline Padre Antonio Vieira (1608-1697) & Sermões \\
\hline Gregório de Matos (1636-1696) & Poesias \\
\hline Matias Aires (1705-1763) & $\begin{array}{l}\text { Reflexões sobre a vaidade dos homens } \\
(1752)\end{array}$ \\
\hline Claudio Manoel da Costa (1729-1789) & $\begin{array}{l}\text { "Desses penhascos fez a natureza/o berço } \\
\text { em que nasci" }\end{array}$ \\
\hline Lobo de Mesquita (1746-1805) & Antífona (1787) \\
\hline Sousândrade (1832-1902) & O Guesa (1876) \\
\hline Oswald de Andrade (1890-1954) & $\begin{array}{l}\text { Memórias sentimentais de João Miramar } \\
\text { (1924) }\end{array}$ \\
\hline Mario de Andrade (1893-1945) & Macunaíma (1928) \\
\hline Jorge de Lima (1893-1953) & Invenção de Orfeu (1952) \\
\hline Carlos Drummond de Andrade (1902-1987) & "Confidência do Itabirano" (Sentimento do \\
\hline Oscar Niemeyer (1907-2012) & Obras arquitetônicas** \\
\hline
\end{tabular}




\begin{tabular}{|l|l|}
\hline João Guimarães Rosa (1908-1967) & Grande Sertão Veredas (1956) \\
\hline João Cabral de Melo Neto (1920-1999) & Poesias \\
\hline Wlademir Dias Pino (1927- ) & “Sólida” (1956) \\
\hline Haroldo de Campos (1929-2003) & Poesias \\
\hline
\end{tabular}

* Organizados segundo data de nascimento.

** Affonso Ávila inclui em seu cânone até Oscar Niemeyer.

Como sabemos, Affonso Ávila é um estudioso do chamado barroco dos séculos XVI e XVII, tendo publicado obras como Resíduos seiscentistas em Minas: textos do século do ouro e as projeções do mundo barroco (1967), bem como o ensaio "O barroco e uma linha de tradição criativa" (1968), o lúdico e as projeções do mundo barroco (1971), Iniciação ao barroco mineiro (1984). Tanto no livro O lúdico... como no Resíduos seiscentistas... constam a expressão projeções, o que o aproxima da visão tão difundida de barroco sincrônico, ou de um barroco que ultrapassou os seiscentos. Cantaria barroca, obra poética de 1973 a 1975, é outra demonstração da afirmação do barroquismo além do tempo histórico, com ironia e humor.

Uma das características do suposto neobarroco relaciona-se à diversidade de formas que encontra em cada artista em particular. Desse modo, não haveria propriamente um fazer neobarroco único; Ávila diferencia-se de Augusto de Campos, que se diferencia de Haroldo de Campos, que se diferencia de Pignatari, que se diferencia de Horácio Costa, de Claudio Daniel, e assim por diante.

Camila Diniz Ferreira, em "Affonso Ávila, o poeta de Minas", texto introdutório de Fortuna crítica de Affonso Ávila (2006, p. 9-10), considera que os estudos que Ávila fez sobre o chamado barroco engrandecem sua poesia, bem como que "sua pesquisa se vale da criação poética, formando um todo que, longe de se fechar, abre-se continuamente para novas indagações". Segundo ela, essa seria a principal característica que o diferencia "de outros poetas cujas pesquisas incidiram em sua obra criativa".

Além de poeta ensaísta, observador cauteloso das mudanças formais que as vanguardas propunham, Ávila manifesta "descontentamento em relação à cultura, sua 'mumificação' e 'anulação da ousadia'”, sem deixar de problematizar a poesia brasileira, sobretudo no que diz respeito à vertente experimentalista. Essa consciência crítica refuta modismos e chama a atenção para uma forma singular de colocar-se o poeta como 
pensador, reavaliando continuamente seu fazer poético marcado pela criação e reflexão, que compreendia duas orientações, a da tradição e a da ruptura.

\subsubsection{Barroquismo enigmático de Affonso Romano de Sant'Anna}

Em Barroco: do quadrado à elipse, Sant'Anna (2000, p. 69-81) elenca alguns autores que corroboram o pensamento de Haroldo de Campos de que o barroco conhece sua faceta transistórica também na modernidade. Para ele, os conceitos de labirinto, enigma, mistério e jogo constituem o núcleo da forma barroca, que se estende para antes e depois do período seiscentista. Mario Perniola (2009, p. 153), nessa mesma tônica do barroco enigmático, ressalta que, na obra de Gracián e de modo geral nas letras seiscentistas, "o aspecto intelectual é inseparável do aspecto afetivo". Uma das astúcias da arte é não ser completamente desdobrada; a arte pretende a hesitação, a falta, nunca se mostrando totalmente.

No quadro 3.4, apresentamos uma síntese do elenco de barroquistas enigmáticos eleitos por Sant'Anna em ordem cronológica da publicação das obras.

\begin{tabular}{|c|c|c|}
\hline Autor & Característica barroca & hra \\
\hline James Joyce & $\begin{array}{l}\text { O enunciatário enfrenta uma peripécia filológica, } \\
\text { uma aventura enigmática dada pela erudição. } \\
\text { Enquanto avança, sente-se poderoso por ter } \\
\text { vencido os enigmas propostos pelo enunciador, } \\
\text { que utiliza a linguagem como labirinto. }\end{array}$ & $\begin{array}{l}\text { Retrato do artista } \\
\text { quando jovem (1916) } \\
\text { - Irlanda }\end{array}$ \\
\hline Guimarães Rosa & $\begin{array}{l}\text { O décimo primeiro conto de Primeiras estórias, } \\
\text { "O espelho", divide o livro em duas metades } \\
\text { estruturalmente espelhadas, porque é precedido } \\
\text { e seguido de dez contos. Os temas da primeira } \\
\text { parte incidem de forma especular nos contos da } \\
\text { segunda metade. O enunciador programou, } \\
\text { nesse caso, uma obra esférica, circular, labiríntica } \\
\text { e, de acordo com Leibniz (DELEUZE, 2011a, p. 13), } \\
\text { como dobra: a primeira parte dobra-se sobre a } \\
\text { segunda parte. } \\
\text { Affonso Romano Sant'Anna (2000, p. 79) } \\
\text { esclarece ainda que Guimarães Rosa, praticante } \\
\text { da numerologia, combina matematicamente a } \\
\text { obra, programando um total de contos de } \\
\text { número ímpar (21): dez contos de cada lado, com } \\
\text { o conto “O espelho" no meio; esse conto é o de } \\
\text { número } 11 \text { (ímpar também). }\end{array}$ & $\begin{array}{l}\text { Primeiras estórias } \\
\text { (1962) - Brasil }\end{array}$ \\
\hline
\end{tabular}




\begin{tabular}{|c|c|c|}
\hline $\begin{array}{l}\text { Enrique } \\
\text { Lafourcade }\end{array}$ & $\begin{array}{l}\text { O enunciador opta por um tipo de letra ao narrar } \\
\text { uma história nas páginas ímpares e por outro tipo } \\
\text { de letra para narrar uma história completamente } \\
\text { diferente nas páginas pares. As duas se } \\
\text { justapõem no final do romance: os dois } \\
\text { percursos, duas vozes, cruzam-se no final do } \\
\text { labirinto. }\end{array}$ & $\begin{array}{l}\text { Invención a dos voces } \\
\text { (1963) - Chile }\end{array}$ \\
\hline Julio Cortázar & $\begin{array}{l}\text { O enunciador "indica para o enunciatário" um } \\
\text { roteiro de leitura, mencionando que seu livro, na } \\
\text { verdade, não é um só, e reforça que } 0 \text { jogo da } \\
\text { amarelinha constitui-se de dois livros. O roteiro } \\
\text { tem base aguda, em dobras, contendo rastros da } \\
\text { lei da combinatória dos matemáticos Leibniz e } \\
\text { Pascal. } \\
\text { O primeiro livro vai de } 1 \text { a } 56 \text { em sequência (e em } \\
56 \text { aparecem "três vistosas estrelinhas" } \\
\text { indicadoras de fim (cf. CORTÁZAR, 2008, p. 5-6). } \\
\text { O roteiro do segundo livro começa no capítulo } 73 \\
\text { e continua conforme a ordem indicada ao final de } \\
\text { cada capítulo. O enunciador, declaradamente } \\
\text { destinador, propõe a ordenação da leitura e } \\
\text { menciona ironicamente que, em caso de } \\
\text { confusão ou de esquecimento, o enunciatário } \\
\text { deve consultar o roteiro numérico das páginas } 5 \\
\text { e } 6 \text {. Trata-se de um jogo, com base em um } \\
\text { contrato lúdico. }\end{array}$ & $\begin{array}{l}\text { O jogo da amarelinha } \\
\text { (1964) - Argentina }\end{array}$ \\
\hline Gustavo Sáenz & $\begin{array}{l}\text { O enunciador utiliza até mesmo a forma gráfica } \\
\text { da letra para configurar a circularidade e o } \\
\text { labirinto. }\end{array}$ & $\begin{array}{l}\text { Obsessivos } \\
\text { circulares (1965) - } \\
\text { México }\end{array}$ \\
\hline Guimarães Rosa & $\begin{array}{l}\text { Para Sant'Anna, Tutameia é um legítimo } \\
\text { exemplar de barroco da modernidade. O } \\
\text { enunciador escolhe os desarranjos sintáticos, a } \\
\text { reinvenção de palavras, ao mesmo tempo em } \\
\text { que opta por uma arquitetura labiríntica das } \\
\text { partes da narrativa. O método de composição } \\
\text { dos contos faz lembrar a espiral e o labirinto, } \\
\text { figuras comuns no chamado barroco. O sumário } \\
\text { dos contos na obra segue a ordem do alfabeto } \\
\text { (de A a Z), iniciando pelo conto "Aletria e } \\
\text { Hermenêutica" e terminando com "Zingaresca". } \\
\text { Quando o enunciatário chega ao conto de letra J, } \\
\text { é impactado por um acontecimento estranho em } \\
\text { relação à ordem dos contos, que, em vez de ter } \\
\text { sequência na ordenação esperada, "L, M, N, O", } \\
\text { retoma a letra G e logo em seguida R. Assim: } \\
\text { "J oão Porém, o criador de perus" } \\
\text { "G rande Gedeão" } \\
\text { "R eminisção". }\end{array}$ & $\begin{array}{l}\text { Tutameia (1967) } \\
\text { Brasil }\end{array}$ \\
\hline
\end{tabular}


Depois da introdução das iniciais de seu nome em três contos, retoma a sequência interrompida:

"Lá, nas campinas?"

"M echéu"

"M elim-Meloso"

"N o prosseguir"

[...]

"U mas formas"

"V ida ensinada"

"Z ingaresca"

Ao inscrever-se dentro da obra com "JGR" (João Guimarães Rosa), à semelhança do que fez Velázquez, em As meninas, e Van Eyck, na tela Casal Arnolfini, cria um efeito de sentido de aproximação de que engenhosamente esteve presente no aqui e agora do enunciado. Dessa forma, o enunciador se diz EU, inscrito no enunciado, aproximando-se, pois, do enunciatário (TU).

A inscrição do enunciador na obra é uma estratégia aguda, reveladora da capacidade de o artista criar enigmas, de obscurecer de propósito o PE, bem como o PC, de forma que o enunciatário se detenha, interrompa a continuidade da leitura, ou a pressa de chegar ao fim, e possa degustar essas artimanhas formais. É um jogo labiríntico, como o Jogo da amarelinha, em que Cortázar simula que está dentro da obra, orientando seu leitor.

Se o enunciatário segue os passos do enunciador, é surpreendido quando atinge o conto $J$, ficando em meio ao labirinto instaurado pela inscrição do autor na obra.

Em Tutameia, antes do sumário, há uma epígrafe de Schopenhauer em que o enunciador revela seu intento: "Daí, pois, como já se disse, exigir a primeira leitura paciência, fundada em certeza de que, na segunda, muita coisa, ou tudo, se entenderá sob luz inteiramente outra" (In: ROSA, 1967, antes do sumário inicial).

Ao final do livro, de modo raro e estranho para o enunciatário, o enunciador repete o sumário, com outra epígrafe de Schopenhauer ("Já a construção, orgânica e não emendada do conjunto, terá feito necessário por vezes ler-se duas vezes a mesma passagem" [ROSA, 1967, p. 193]), parecendo querer retomar a epígrafe inicial; no entanto, provoca uma reflexão diversa da primeira. Nesse momento, agrupa os quatro prefácios, alertando o enunciatário de que 


\begin{tabular}{|c|c|c|}
\hline & $\begin{array}{l}\text { Tutameia reflete sobre o próprio poetar. A } \\
\text { agudeza, o "barroco" nos termos de Sant'Anna, } \\
\text { está em conjugar mestria técnica e fazer artístico, } \\
\text { mesclando-se em um jogo especular. }\end{array}$ & \\
\hline George Perec & $\begin{array}{l}\text { La disparition erige-se pela combinatória } \\
\text { pascaliana. Na edição original, o enunciador } \\
\text { projeta-se como um arquiteto formal: } 312 \\
\text { páginas sem nenhum lexema com a letra e. Tal } \\
\text { procedimento é denominado lipograma. Gregos, } \\
\text { romanos e espanhóis já utilizavam esse } \\
\text { procedimento, que, posteriormente, veio a ser } \\
\text { aproveitado pelos vanguardistas europeus e } \\
\text { latino-americanos. } \\
\text { No período do chamado barroco, os poetas da } \\
\text { agudeza, arquitetos da linguagem, já utilizavam } \\
\text { estratégias de refreamento das formas do PE e } \\
\text { do PC para mostrar a habilidade que tinham com } \\
\text { os jogos de palavras (os chamados cultismo e } \\
\text { conceptismo). }\end{array}$ & $\begin{array}{l}\text { La disparition (1969) - } \\
\text { França }\end{array}$ \\
\hline Osman Lins & $\begin{array}{l}\text { Avalovara dialoga com o "Labirinto cúbico" de } \\
\text { Penhafiel, inserindo-se no mesmo espaço de } \\
\text { euforia barroquista de seu tempo (Haroldo de } \\
\text { Campos, Severo Sarduy, Lezama Lima). } \\
\text { O enunciador escolhe uma espécie de labirinto } \\
\text { barroco, o palíndromo, arquitetando } \\
\text { matematicamente sua narrativa com base em um } \\
\text { enunciado latino, o quadrado espiralado do } \\
\text { poema "Sator arepo tenet opera rotas". } \\
\text { Quadrado espiralado, porque o poema pode ser } \\
\text { apreendido pelo enunciatário em forma de } \\
\text { quadrado ou espiral, lido de frente para trás, de } \\
\text { trás para a frente, resultando sempre no mesmo } \\
\text { enunciado. } \\
\text { Esse movimento labiríntico é espiralado: o } \\
\text { enunciatário gira, gira, gira e cai no mesmo lugar. } \\
\text { Cada capítulo da obra conta com um número } \\
\text { progressivo de linhas, que tem o } \\
\text { desenvolvimento de uma espiral e, ainda, seu } \\
\text { tema singularizado se encontra correlativamente } \\
\text { em modo ascensional. Dessa forma, o romance } \\
\text { vai se fazendo num jogo entre quadrado e } \\
\text { espiral. }\end{array}$ & $\begin{array}{l}\text { Avalovara } \\
\text { 2005)-Brasil }\end{array}$ \\
\hline
\end{tabular}

Como vimos no quadro 3.4, prevalece na visão de Affonso Romano de Sant'Anna o entendimento de que o barroco é caracterizado por uma acentuação de enigmas e 
labirintos, como em Osman Lins, em Guimarães Rosa, em Cortázar, em James Joyce, entre outros.

Além de uma combinatória formal de significante e significado, observamos uma estratégia aguda, que abrange a totalidade dos enunciados, como a disposição especular dos contos em Primeiras estórias; os enigmas de Cortázar em Jogo da amarelinha, cuja direção implica um corre-corre atrás das páginas para formar um sentido, e, nesse caso, temos uma deslinearização da formatação da sequência canônica; o jogo, que também se resolve em enigma, tem a sequência alfabética interrompida pela introdução de três contos, cujas iniciais, JGR, endossam a simulação da presença do autor na obra; finalmente, a introdução do palíndromo em Avalovara, ao mesmo tempo que recupera uma tradição literária da Antiguidade latina, mostra que o fazer poético é labiríntico, espiralado, renovando-se em seu experimentalismo linguístico.

Em Ávila, verificamos a necessidade de uma consciência crítica no aproveitamento das tradições literárias, bem como na rejeição dos modismos e, em Sant'Anna, uma preocupação em mostrar que o barroquismo funda-se no jogo linguístico e nos enigmas labirínticos, o que afasta a literatura do eixo icástico e a direciona para o eixo fantástico, que se constitui em experimentalismo com a palavra. Deixa a literatura de ser sentenciosa para constituir-se mestria linguística. Quanto mais habilidade poética, maior a agudeza, maior o prazer sensível e inteligível; portanto, uma poesia duplamente prazerosa.

\subsubsection{TRAdIÇÃo VISUAL NO NEOBARROCO PORTUGUÊS NA OBRA CRÍTICA de ANA HATHERLY}

O chamado neobarroco não é uma estética apenas latino-americana. Em Portugal, Ana Hatherly tem se dedicado ao estudo do experimentalismo do século $X X$, não como ruptura do passado, mas como resgate da tradição dinamizada. Sua preocupação concentrase em verificar as perspectivas da poesia visual e, nesse sentido, há uma vivificação do passado no presente. Propõe, então, uma releitura crítica da tradição.

Seu livro A casa das musas (1995) cuida da arqueologia da poesia experimental. Daí a grande quantidade de textos, que exploram anagramas, labirintos e a espacialização da poesia, cujos enigmas produzem um ludismo poético. Hatherly (1995, p. 26-28) opõe-se à visão dos estudiosos que veem na poesia barroca futilidade e superficialidade, bem como jogo inútil de formas. Afirma ainda que o barroco português apresenta relações com a mística judaica e o esoterismo. 
Como os seiscentos foi um período marcado por repressão religiosa e política, aos poetas da agudeza competia uma produção regulada pelos jogos de corte, constituindo o fazer poético um contrato. Ao poeta, compelido às formas "estranhas", não restava outra alternativa que escolher a agudeza como introdutora de certa obscuridade no enunciado poético. Essa obscuridade confere ao barroco uma dimensão fantástica do inesperado, da surpresa. Diferentemente do clássico cujo ideal era uma "suposta" clareza, resultado da correspondência entre uma palavra e apenas um sentido, o barroco explora justamente a ambiguidade introdutora de enigmas (cf. SARAIVA, 1980, p. 11).

Segundo Hatherly (1995, p. 40-41), os historiadores literários admitem a existência de formas utilizadas na Antiguidade que continuam a ser exploradas. Para eles, há certas formas literárias da modernidade que retomam um fazer artístico adormecido; por isso, o interesse em compreender por que certas formas são produzidas em certas épocas, outras mantêm-se ao longo da história literária e outras ressurgem. O surto de determinadas formas e de seu recrudescimento cíclico tem sido objeto de muitos estudos; a forma labiríntica, por exemplo, tem-se mantido ao longo do tempo, mas houve uma época em que ela atingiu um desenvolvimento tal que se pode dizer que acabou por identificar o período estético do chamado barroco (séculos XVI-XVII).

Para nós, no entanto, as formas vão-se re-formatando, metamorfoseando-se. Admitir uma repetição das formas ditas barrocas seria uma impertinência, pois que o contrato enunciativo dos seiscentos era regulado por convenções apoiadas em tratadistas que seguiam a Retórica aristotélica. Já o contrato enunciativo do final do século XX é regido por outro tipo de contrato, que enfatiza particularmente os experimentalismos com o $\mathrm{PE}$, como Mallarmé, Joyce, Pound, Cummings.

A discussão do século XX é outra: sobre o próprio fazer artístico, cuja agudeza engendra um objeto mais fluido em relação aos seiscentos, e propõe um andamento ainda mais vívido. Dando continuidade a um tipo de configuração espacial verificado já nos seiscentos, como nos mostra Ana Hatherly, o enunciador enovela o enunciado em um emaranhado de fonemas, grafemas, cortes, recortes, rupturas, junções, que promovem a intensificação da obscuridade das formas. Opacidade comparável, assim, à dos labirintos seiscentistas. Tendo em vista ser o destinador poético dos séculos XVI e XVII diferente do destinador poético do final do século XX, prevalecem no primeiro valores da contrarreforma e nestes últimos, valores voltados para a fluidificação fantasiosa e experimental do poema. 
Enganam-se os que defendem que o apelo barroquista seja aos sentidos tão somente; seu apelo compreende tanto o sensível quanto o inteligível, o duplo prazer de que temos discutido. Mesmo quando intensifica características do sensível, como acentuação de sons e de cores, tais elementos não se configuram apenas artifício das formas do PE, visto que engendram formas de conteúdo passíveis de prazer intelectual.

Como temos estudado até aqui, os rótulos neobarroco e barroco são marcados por certa imprecisão, proporcionando dificuldade a qualquer investigação que tome como base tanto textos seiscentistas quanto os produzidos no final do século XX e outros produzidos ao longo da história literária. Como designar os labirintos poéticos que perpassam a literatura, bem como os textos cuja característica é a exploração espacial?

Para esses objetos poéticos visuais, que compõem uma figura, Ana Hatherly (1995, p. 99) propõe chamar textos visuais:

\begin{abstract}
a Poesia Visual viu o seu âmbito de tal maneira alargado que hoje engloba a produção dum vasto grupo de textos e/ou objetos que, nem sempre tendo a ver com a poesia de tipo tradicional (dependente de certas regras rítmicas e certos recursos retóricos), sempre tem a ver com o discurso criativo, mesmo quando deixa de ser verbal.

Entre nós, essa prática foi inicialmente levada a cabo pelos poetas que constituíram o Movimento da Poesia Experimental Portuguesa - PO.EX -- e que, em contacto com o Movimento da Poesia Concreta e com o Experimentalismo mundial, exerceram a sua acção durante os anos 60 e 70 (HATHERLY, 1995, p. 113).
\end{abstract}

Acrescenta ainda que a poesia visual não se iniciou com Mallarmé nem com os caligramas de Apollinaire nem com os experimentos dos futuristas ou dos dadaístas, pois que remonta aos gregos, fato que Haroldo de Campos e seus parceiros não deixaram de apontar em seus primeiros estudos, quando introduziram na década de 50 referência ao "Ovo", de Símias de Rodes, que Augusto de Campos (2007, p. 94) re-formatou em "Ovo novelo"2:

\footnotetext{
${ }^{2}$ Como o corpus de nossa tese é constituído apenas de textos brasileiros, especificamente Haroldo de Campos, Affonso Ávila, Arnaldo Antunes e Horácio Costa, e porque a própria Ana Hatherly cita a Poesia Concreta, optamos por um exemplo de poesia visual de Augusto de Campos ("Ovo novelo").
} 


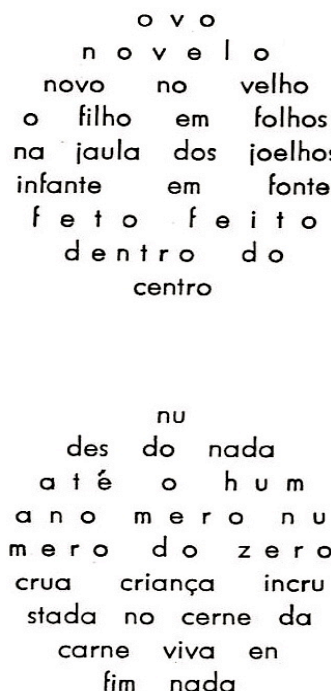

fim nada
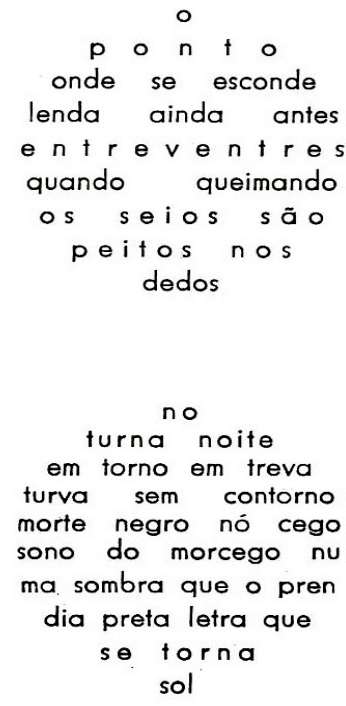

Para a estudiosa portuguesa, os labirintos poéticos propõem uma palavra-imagem: “já não se trata de fazer acompanhar um texto por uma imagem ou vice-versa, trata-se de produzir um texto que seja simultaneamente texto e imagem, numa só consistência, como acontecera na Antiguidade" (HATHERLY, 1995, p. 45). Como temos defendido, a forma experimentalista moderna, antes que repetir a antiga, reformula-a; o "Ovo", de Símias de Rodes, não ganha uma reprodução com o "Ovo novelo", de Augusto de Campos, mas uma recriação.

O texto original de Símias de Rodes forma a figura de um ovo. Nele, temos a trama de uma mãe cantante. Hermes, mensageiro dos deuses, arrebata-a e lança-a entre os homens 
para multiplicar-se. O ovo figurativiza a isotopia do nascimento e do mistério da vida, ao mesmo tempo que desencadeia a isotopia metalinguística, ou seja, a da formação do próprio texto.

Em Augusto de Campos, a sucessão de quatro ovos, distribuídos verticalmente como estrofes, configura a multiplicação do "Ovo" de Símias: agora, são quatro ovos erigidos pela distribuição espacial de fonemas e de grafemas em esferas. Ocorre que em A. Campos temos duas figuras: a do ovo e a do novelo. Enquanto a figura do ovo tematiza a fertilidade literária, cujos textos brotam uns dos outros, num diálogo intertextual permanente, a do novelo tematiza a continuidade de uma tradição estética, cuja linha estabelece o trabalho reflexivo, criativo e de tessitura da linguagem poética.

Novelo engloba ovo e significa amontoado de fios têxteis enovelados. Ora, texto e tecido têm etimologicamente a mesma formação: "texto vem do latim texo, is, xui, xtum, ere, tecer fabricando, [...] compor ou organizar o pensamento em obra escrita" (HOUAISS; VILLAR, 2001); "entrelaçamento, tecido" (CUNHA, 1996). Portanto, temos algumas direções:

1. A da multiplicação da vida e da fertilidade literária.

2. A da continuidade da tradição: os enunciados são formadores de textos entretecidos.

No lugar de repetição de formas, há um trabalho de re-forma da forma original, ou seja, A. Campos dá continuidade visual à tradição, mas o faz segundo uma forma renovada. Assim é que, no primeiro ovo do poema de Augusto, o enunciado estabelece diálogo com o texto original: "ovo /novelo / novo no velho". A palavra novelo aglutina "novo + velho = novelo", bem como figurativiza o enovelar-se.

Nesse caso, a literatura enreda o velho no novo e o novo no velho; enovela-se, não se sabendo onde está a ponta inicial da linha do novelo, o que é o velho, o que é novo. É, pois, com base nas formas da expressão e do conteúdo que Augusto de Campos atualiza Símias de Rodes. As aliterações em /v/, /f/, /j/ produzem um desdobramento rítmico de uma linha que se enovela, cujos sons se dobram uns sobre os outros.

Por exemplo:

- em /v/: ovo / novelo / novo no velho

- em /f/: o filho em folhas; infante em fonte; feto feito

- em /j/: na jaula dos joelhos 
Diferentemente do "Ovo" de Símias, em "Ovo/novelo" temos a aglutinação aguda de duas figuras: ovo + novelo. Logo no início, numa justaposição de imagens, "o filho em folhos (babadouro)" dentro do berço ("na jaula") observa a mãe tecendo ("ovo novelo").

No segundo ovo/novelo, continuam a multiplicar-se as imagens, e o enunciatário é convidado a desenovelar os enunciados de dentro do novelo/ovo. O menino nu agora tem um ano: "nu des do nada" anagrama de "desnudado" até o úmero $\rightarrow$ "hum ano mero nu" = humano, úmero, um ano, mero [simplesmente] nu, número. Os anagramas intensificam a pouca idade da criança e a dependência da genitora: "mero do zero / crua criança incru/stada no cerne da / carne viva en/ fim nada". As vibrantes / cr/, em crua, criança, e incrustada, no PE, são acentuadamente vibrantes sonoras, ressoando no PC a agitação da criança com assaduras ("incrustada no cerne da carne viva") e a dependência absoluta em relação ao seu ser formador ("en/fim nada"). Considerando a isotopia da formação do texto, o enunciado revela a dependência de um texto em relação a outro: o novo texto seria como uma criança desnuda atrelada aos elos de sua formação, os textos da tradição.

No terceiro ovo/novelo, o enigma mantém-se tonificado ("o/ ponto onde se esconde / lenda"); segundo o enunciado, a lenda esconde-se nas entranhas ("lenda ainda antes/ entreventres"). Numa imagem altamente aguda e dolorida, visto ser a literatura um trabalho intenso e doloroso como queimar os bicos dos seios ("queimando/ os seios"), o poeta queima a ponta dos dedos no exercício da escritura ("peitos nos dedos"). Destitui, portanto, a ideia de literatura que tenha em vista as musas como fonte inspiradora do poetar. Outra isotopia é a do erotismo: a relação do poeta com o texto é a mesma dos amantes, que se bulinam; nesse caso, os textos têm uma relação erótica e tátil com outros textos ("queimando os seios são peitos nos dedos").

Finalmente, no último ovo/novelo, o enunciador escolhe os valores da literatura como trabalho. Labor incansável: "no/ turna noite"; "em torno em treva", que se entrava como batalha insistente. Em "no/turna noite", temos englobados noturna e turno; este último como virada da noite (turna a noite). Na aliteração em /t/: "turna", "noite", "torno", "treva", "turva", "contorno", "morte", temos no PE uma oclusiva surda insistente, que evidencia no PC a solidão do poeta ocluso, sozinho em seu labor. Além disso, a metáfora do "morcego" configura a isotopia de sugar o sangue de outro para sobreviver. Decorre daí o sentido de que a literatura sanguessuga outras literaturas para sobreviver na tradição. Ao poeta, não resta nenhuma saída ("morte", "nó cego", que não desata), a não ser liberar luz 
(última linha do poema: "sol") por meio de seus poemas ("preta letra que/ se torna sol") e saltar no branco da página.

Menos que reproduzir a lenda original, a preocupação de OVO/NOVELO é com a agudeza. Ainda que em Símias de Rodes a acentuação do PE seja evidente, em A. Campos a agudeza recrudesce, pois os fonemas repartem-se, distanciam-se, os sons duplicam-se, um fonema sai do outro, uma palavra da outra, os contornos esmaecem-se, sempre no sentido de recuperação da isotopia original de ovo como semente, como embrião, como início. 0 novo está no velho, e o velho no novo, "novelo". Ademais, a multiplicação dos ovos em Augusto ideogramatiza, no visual da página, a multiplicação que um ovo como gérmen proporciona. A tradição multiplica-se, ressoando continuamente na literatura.

A ensaísta portuguesa Ana Hatherly $(1995$, p. 13) esclarece que os poetas experimentalistas portugueses e concretistas brasileiros "puseram em prática as mais modernas teorias da Linguística, do Estruturalismo, da Semiótica, da Teoria da Informação". Ernesto M. de Melo e Castro (In: CASTRO; GOTLIB, 1993) e Ana Hatherly (1995, 2003), ao advogarem a poesia barroca, fazem-no por alguns motivos:

1. Como a poesia barroca era criticada escancaradamente, defendê-la era assumir uma posição subversiva.

2. Na criação da poesia barroca, visual ou não, encontram-se valores lúdicos e retóricos que, em desuso, sob nova luz, surgiram como "belos", "dinâmicos".

3. Porque há nessas obras barroquistas elementos idiossincráticos que possibilitam compreender a sensibilidade artística portuguesa atual, diferentemente da visão de neobarroco surgida tempos depois.

Embora Ana Hatherly não seja seguidora das ideias de Eugenio D’Ors, reconhece aspectos formais do chamado barroco na poesia do final do século XX. Como os textos poéticos do final do século XX nem sempre apresentam a característica de um objeto plástico-visual, optamos pela nomenclatura, como temos reforçado, de poesia aguda.

A seguir, vejamos o posicionamento de Horácio Costa e Ivan Teixeira.

\subsubsection{VISUALIDAdE BARROCA EM HORÁcIo COSTA E CONTEMPORANEIDADE BARROQUISTA EM IVAN TEIXEIRA}

Ao estudar o panorama da poesia brasileira do século XX, Horácio Costa (2010, p. 31) entende que "a partir de Claro enigma, de 1951, Drummond encontra-se com a tradição 
barroca hispano-portuguesa e abre-se à Modern Tradition de Valéry e Eliot". Para ele, já não fazem sentido as designações de escolas, nem a divisão do fluxo poético em gerações. Vê ainda que na poesia de Murilo Mendes há uma pulsação barroquizante.

Focalizando a poesia de João Cabral de Melo Neto, vê nela "a persistência de metáforas 'ósseas' ou 'cortantes'", o que o leva a considerar um maneirismo do mínimo e ainda: "sem deixar de ser coloquial, sua linguagem reflete a persistência da fala antiga, principalmente de extração barroca" (COSTA, 2010, p. 34). Segundo ainda Horácio Costa, João Cabral se deixa "influenciar por Max Bense tanto como por Jorge Guillén. Talvez valesse para ele a definição paradoxal de funcionalista barroco" (p. 25).

Quando no seu panorama chega aos poetas Augusto de Campos, Décio Pignatari e Haroldo de Campos, esclarece que os modernistas tinham como adversários os formalistas e a alienação parnasiano-simbolista, enquanto os concretistas, por sua vez, "tinham no verso, na linearidade, na sequencialidade do poema moderno, seus marcos para superar" (COSTA, 2010, p. 37). Daí procurarem uma imagem poética sensualmente intensa, verbo-gráficavisual, em substituição de uma sintaxe sujeito-verbo-predicado.

Reconhece Horácio Costa (2010, p. 42-70), em seu artigo "Sobre a poesia visual brasileira", que o Brasil teria conhecido na década de 50 o mais importante movimento de poesia visual: a poesia concreta, porém "não tão frequentemente estudada com a profundidade condizente" (p. 42). Segundo ele,

a crítica parecia ter esquecido existirem, "no 'arquivo' da poesia escrita em português, profundas raízes de consciência dos valores visuais na palavra impressa desde o século XVI. Em minha opinião, a consistência e a persistência desta consciência pode ser considerada como um traço específico na tradição poética luso-brasileira" (COSTA, 2010, p. 42).

Abdica Costa de um inventário minucioso em prol de um trabalho sobre os eixos conceituais ao mesmo tempo sincrônicos e diacrônicos. Considerando a sincronia, ele "pressupõe a distribuição de um modus barroco em nossa tradição poética" e, considerando a diacronia, seleciona, segundo a linearidade histórica, "um número limitado de poemas que guardam um certo nível de consciência ou de preocupação com a visualidade, escritos por diversos autores ao longo de períodos culturais consecutivos" (COSTA, 2010, p. 42). Horácio Costa, além de definir tradição e barroco, salienta ainda que muitos dos textos escolhidos por ele não teriam sido considerados como pertencentes a nenhuma tradição barroca. 
Normalmente, tradição pode ser traduzida por valores monolíticos. Nas palavras de Costa (2010, p. 42), "um quarto fechado repleto de altares em que um sentimento sublime de atemporalidade é preservado". Trata-se de uma escolha pela exclusão como forma de autoafirmação; ela se associa a uma visão única, ortodoxa, em que a identidade afirma-se para excluir a alteridade; todavia,

a partir de um ponto de vista contrário, na tradição a flexibilidade na seleção (ou na leitura) alia-se à possibilidade de diferenciar a percepção: o pluralismo alia-se à identidade. Em um corpo tão vivo como o da cultura, a tradição é um espaço em que impulsos ou discursos dissímeis coexistem em movimento, em que valores afins se unem para formar sequências fluidas de eventos. Em suma, é o espaço, por excelência, da floração, da heterodoxia, porque é onde, já decantadas pela passagem do tempo, a alteridade e o tempo podem ser compreendidos integralmente (COSTA, 2010, p. 43).

O conceito inclusivo de tradição é transistórico, afirmando a sincronia e mantendo a diacronia, prevalecendo "a especificidade de cada um dos textos, dos movimentos culturais, das vozes" (COSTA, 2010, p. 43). Esse conceito de tradição pela inclusão permite superar categorias ou rótulos, como vanguarda, experimentalismo, neobarroco, que são pouco esclarecedores. O romantismo, por exemplo, era vanguarda em relação ao neoclassicismo; Mário de Andrade teria usado uma linguagem experimental em suas poesias, assim como Sousândrade, Guimarães Rosa, Haroldo de Campos. E seriam, então, todos chamados de modernistas?

Horácio Costa (2010, p. 43) conclui que, como não podemos utilizar tais categorias para examinar textos escritos há alguns séculos, "é possível reconhecer neles um certo gosto, uma inclinação estética que os relaciona muito de perto como uma família de conceitos que se afirmaram depois, dando origem, portanto, a uma 'tradição'".

O barroco, na visão de Horácio Costa, que o considera um continuum, não configura um período historicamente limitado. Para ele, o barroco é inclusivo e não exclusivo, é mistura e não triagem; privilegia o significante, bem como a abertura ao não finito. Assinala ainda a propensão barroca para o lúdico, para o labiríntico. $O$ ensaísta afirma também não se sentir bem com o nome neobarroco, porque não percebe "nenhuma mudança estrutural entre o modus barroco de suas origens com o presente que possa responder através de uma avaliação diferenciadora entre os dois momentos" (COSTA, 2010, p. 49), considerando haver traços de barroco em variados momento da história literária, como no alto romantismo, no 
simbolismo e nas vanguardas do século XX, como vimos no cânone de Haroldo de Campos. Aqui, fazemos ressalvas às diferenças de contrato fiduciário e de destinadores nos seiscentos e no século $X X$.

Para esta tese também parece mais pertinente examinar os textos segundo o modus agudo, de nível tensivo, cujo andamento diferencia-se conforme a escolha do artifício acentuado, ora mais no $\mathrm{PE}$, ora mais no $\mathrm{PC}$, não importando o tempo de produção do texto.

No quadro 3.5, apresentamos um conjunto de poetas, marcados por traços barroquistas, na ordem em que aparecem citados por Horácio Costa.

Quadro 3.5 Mapeamento transistório da tradição do barroco visual, segundo Costa (2010, p. 42-70).

Novalis (1772-1801) - poeta alemão.

Mallarmé (1842-1898) - poeta francês.

Fernando Pessoa (1888-1935) - poeta português.

"estes três poetas [Novalis, Mallarmé, F. Pessoa] foram ameaçados - ou se deixaram seduzir -- por uma inclinação comum à fragmentação mais ou menos trabalhada em termos de uma estética consciente, que resultou em cada um deles em diferentes projetos literários e diferentes cenários linguísticos, na mise-en-abyme do 'eu'” (COSTA, 2010, p. 49).

Gregório de Matos (1636-1696) - poeta baiano. "Ao mesmo por suas altas prendas" (MATOS, 2010, v. 1, p. 320):

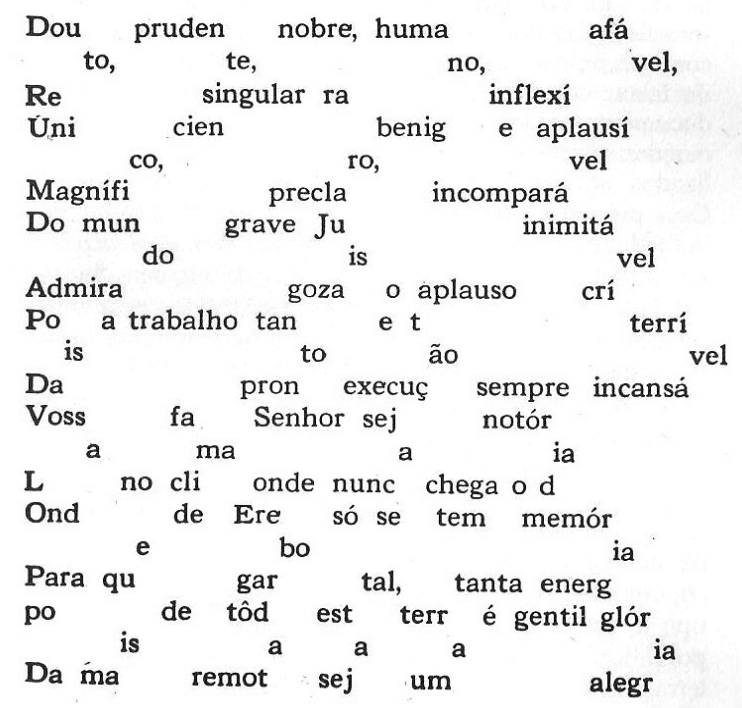

"no século XVII, a poesia brasileira desenvolveu um gosto pelos jogos visuais e por pequenas inovações formais e, sobretudo, apreciou as múltiplas possibilidades de leitura" (COSTA, 2010, p. 50).

"é considerado a primeira clara consciência autônoma no Brasil colonial, e como a primeira voz que constantemente se referiu às agonias da nova sociedade" (COSTA, 2010, p. 50).

Juan Lopez Cierra - poeta espanhol radicado na Bahia do século XVII: 


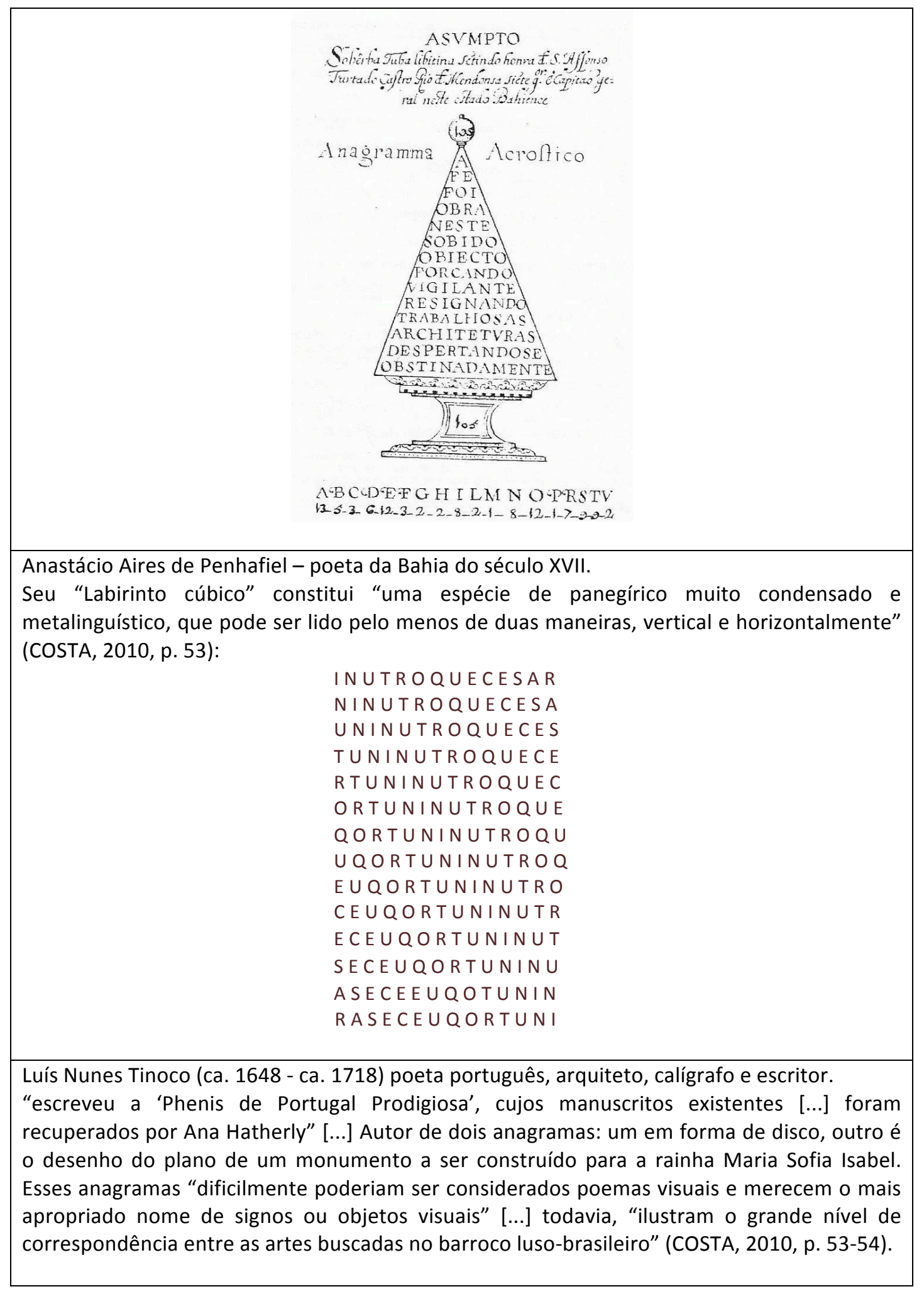




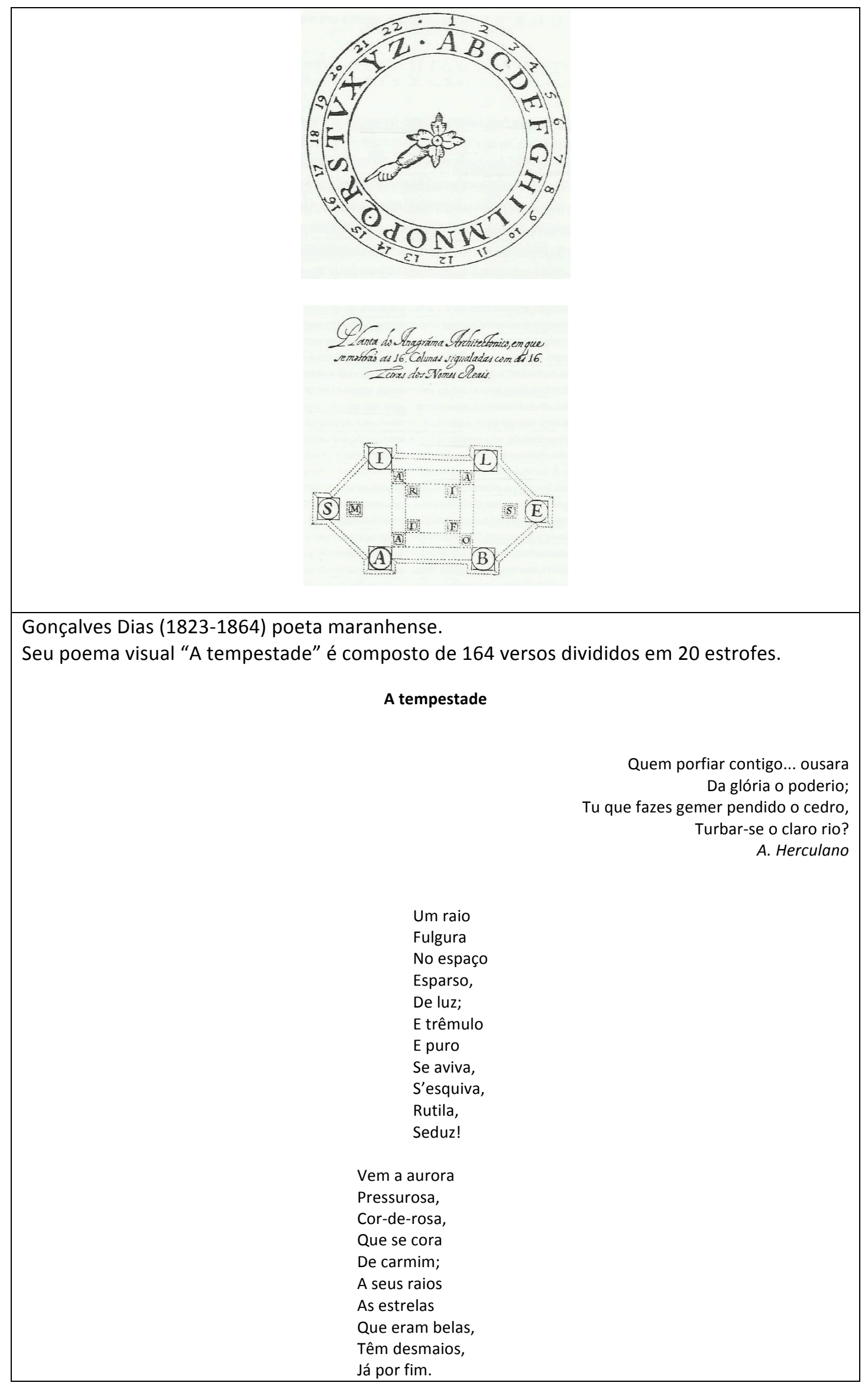


O sol desponta

Lá no horizonte

Doirando a fonte,

E o prado e o monte

E o céu e o mar;

E um manto belo

De vivas cores

Adorna as flores

Que entre verdores

Se vê brilhar.

Um ponto aparece,

Que o dia entristece,

O céu, onde cresce,

De negro a tingir;

Oh! Vede a procela

Infrene, mas bela,

No ar s'encapela

Já pronta a rugir!

Não solta a voz canora

No bosque o vate alado,

Que um canto d'inspirado

Tem sempre a cada aurora;

É mudo quanto habita

Da terra n'amplidão.

A coma então luzente

Se agita do arvoredo,

E o vate um canto a medo

Desfere lentamente,

Sentindo opresso o peito

De tanta inspiração.

Fogem do vento que ruge

As nuvens aurinevadas,

Como ovelhas assustadas

Dum fero lobo cerval;

Estilham-se como as velas

Que no alto mar apanha,

Ardendo na usada sanha,

Subitâneo vendaval.

Bem como serpentes que o frio Em nós emaranha, -- salgadas

As ondas s'estranham, pesadas

Batendo no frouxo areal

Disseras que viras vagando

Nas furnas do céu entreabertas

Que mudas fuzilam, -- incertas

Fantasmas do gênio do mal!

E no túrgido ocaso se avista

Entre a cinza que o céu apolvilha,

Um clarão momentâneo que brilha,

Sem das nuvens os seio rasgar;

Logo um raio cintila e mais outro,

Ainda outro veloz, fascinante,

Qual centelha que em rápido instante

Se converte d'incêndios em mar.

Um som longínquo cavernoso e oco

Rouqueja, e n'amplidão do espaço morre; 
Eis outro inda mais perto, inda mais rouco, Que alpestres cimos mais veloz percorre, Troveja, estoura, atroa; e dentro em pouco Do Norte ao Sul, -- dum ponto a outro corre: Devorador incêndio alastra os ares,

Enquanto a noite pesa sobre os mares.

Nos últimos cimos dos montes erguidos Já silva, já ruge do vento o pegão; Estorcem-se os leques dos verdes palmares, Volteiam, rebramam, doudejam nos ares, Até que lascados baqueiam no chão.

Remexe-se a copa dos troncos altivos, Transtorna-se, tolda, baqueia também; E o vento, que as rochas abala no cerro, Os troncos enlaça nas asas de ferro,

$E$ atira-os raivosos dos montes além.

Da nuvem densa, que no espaço ondeia, Rasga-se o negro bojo carregado, E enquanto a luz do raio o sol roxeia, Onde parece à terra estar colado, Da chuva, que os sentidos nos enleia, O forte peso em turbilhão mudado, Das ruínas completa o grande estrago, Parecendo mudar a terra em lago.

Inda ronca o trovão retumbante, Inda o raio fuzila no espaço,

E o corisco num rápido instante Brilha, fulge, rutila, e fugiu.

Mas se à terra desceu, mirra o tronco, Cega o triste que iroso ameaça, E o penedo, que as nuvens devassa, Como tronco sem viço partiu.

Deixando a palhoça singela, Humilde labor da pobreza, Da nossa vaidosa grandeza, Nivela os fastígios sem dó; E os templos e as grimpas soberbas, Palácio ou mesquita preclara, Que a noite do tempo poupara, Em breves momentos é pó.

Cresce a chuva, os rios crescem, Pobres regatos s'empolam, $E$ nas turvas ondas rolam Grossos troncos a boiar! O córrego, qu'inda há pouco No torrado leito ardia, E já torrente bravia, Que da praia arreda o mar.

Mas ah! do desditoso, Que viu crescer a enchente E desce descuidoso Ao vale, quando sente Crescer dum lado e d'outro O mar da aluvião! Os troncos arrancados Sem rumo vão boiantes; 
figurativiza a maior ou menor densidade da chuva.

Sousândrade (1833-1902) - poeta maranhense.

"mesmo que a criação de Gonçalves Dias represente, no meu ponto de vista, o melhor exemplo da consciência da visualidade na poesia brasileira do século XIX, dois outros nomes, pelo menos, devem ser citados" (COSTA, 2010, p. 56):

1. Sousândrade, com $O$ guesa: "tendência ao barroquismo (através do hibridismo, do neologismo, de elipses, de alusões e elisões) e uma inclinação a alguns procedimentos caros ao imagismo poundiano, tais como o impacto de muitas imagens verbais, livres de intelectualismo [...] o poema inventa uma anotação diacrítica particular, capaz de acompanhar os choques violentos de significados que, verso a verso, palavra a palavra, estão dispostos ao longo do texto" (COSTA, 2010, p. 56-57).

2. Olavo Bilac (ver comentário na célula abaixo).

Olavo Bilac (1865-1918) - poeta carioca.

“o poema 'Profissão de fé', publicado em 1888, [...] obedece a um conjunto muito estrito de regras limitantes e bem estabelecidas" (COSTA, 2010, p. 57)

"seu valor como construções verbais cuidadosas pode ser apreciado, apesar das reservas ideológico-estéticas que, durante muitas décadas, impediram seu trânsito na cultura brasileira para lá das áreas restritas dominadas pelos especialistas e pelos livros escolares [...]. O poema chama a atenção do leitor por sua forma, da mesma maneira que chama a sua atenção sobre o seu processo [...]. ... o texto abre uma noção basicamente contemporânea da 'obra em progresso'. [...] As palavras tornam-se pedras preciosas; a sintaxe, fios de ouro; os sons, seus reflexos. A superfície ultra refinada do poema mantém uma exata correspondência com seu conteúdo" (COSTA, 2010, p. 57-58).

Manuel Bandeira (1886-1968) - poeta recifense.

"escreve versos excepcionalmente compridos que, como em seu poema 'Poética', exemplificam o topos desenvolvido aos olhos do leitor: o da poesia como uma força libertadora, completamente adversa a qualquer tipo de controle métrico ou formal" (COSTA, 2010, p. 58).

Oswald de Andrade (1890-1954) - poeta paulistano - livro Pau-Brasil (1925).

Esse livro de poesia já manifesta "consciência dos recursos visuais" (COSTA, 2010, p. 59); "é Oswald de Andrade o mais importante 'tradutor cultural' entre os modernistas, graças à sua extensa exposição e compreensão da vanguarda europeia, foi quem, por sua vez, buscou uma forma extremamente condensada de comunicação poética, em que as palavras ou versos, alterando a sintaxe, se justapõem, em um clima de plurissignificação, para criar um novo impacto sobre o leitor [...]. Oswald reforçou a ideia de fragmentação textual como um veículo próprio para um conteúdo contínuo [...]. O engenho, a economia e a limpeza trabalham lado a lado com a paródia, a colagem e a montagem. Por várias razões, ele foi o precursor dos poetas concretos. [...] foi Oswald de Andrade que cunhou a expressão 'concretista'" (COSTA, 2010, p. 58-59).

Biblioteca Nacional

A Criança Abandonada

O Doutor Coppelius

Vamos com Ele

Senhorita Primavera

Código Civil Brasileiro

A arte de ganhar no bicho

O Orador Popular

O Pólo em Chamas (O. ANDRADE, 2003, p. 167) 
Nesse elenco de obras, nota-se a ironia do enunciador com relação à pobreza de nossa biblioteca nacional. Os versos são constituídos por títulos de obras, que se juntam sem nenhum critério.

\section{São José del Rei}

Bananeiras

O sol

O cansaço da ilusão

Igrejas

O ouro na serra de pedra

A decadência (O. ANDRADE, 2003, p. 180).

Já em "são josé del rei" a condensação imagética atrai o enunciatário para a participação na elaboração do texto.

"... foi Oswald quem primeiro disse aos poetas brasileiros que escrevessem uma forma de poesia que não somente pudesse ser lida como também considerada inovadora no exterior" (COSTA, 2010, p. 59).

Carlos Drummond de Andrade (1902-1987) - poeta mineiro.

Murilo Mendes (1901-1975) - poeta mineiro Murilogramas e Graffitis.

Em Convergência (1966), Murilo Mendes publicou alguns 'Murilogramas' e 'Graffitis' - cujos títulos neologísticos enfatizam de maneira óbvia a plasticidade pretendida no poema --, assim como um visual 'Estudo da letra $V$ ', que apresenta uma espécie de choque surreal entre significado e forma, graças ao número de tipos gráficos usados nas ' $V$ 's maiúsculas que se distribuem pelo texto, paradoxalmente organizado pelo verso linear e pela sintaxe canônica" (COSTA, 2010, p. 69).

Vejamos "grafito num muro de Roma", de Murilo Mendes (1999, p. 627), poema em que o espaço branco no visual, no meio do quarto e quinto versos, homologa-se com performance de roer no conteúdo (o enunciado dos dois versos apresenta-se "roído"):

Um verme enorme rói

Um verme inerme rói

Qualquer julgamento

Presente futuro

Pessoal universal

Miquelangelesco ou não

Cassiano Ricardo (1895-1974) - poeta paulista. Jeremias.

Para os três poetas citados [C. Drummond, Murilo Mendes, Cassiano Ricardo], "a preocupação pela forma visual de seus poemas não é algo inato, mas uma 'importação' atrasada. [...] o ponto de inflexão definitivo, quando consideramos a operação visual na poesia brasileira contemporânea, foi dado pelo movimento concreto dos anos 50" (COSTA, 2010, p. 60).

"Tanto Cassiano Ricardo, como Carlos Drummond de Andrade [...] e Murilo Mendes [...] escreveram poemas em que é possível perceber uma consciência provinda dos recursos visuais. Os poemas de Drummond de Andrade "Isso é aquilo" e " $F$ " [...] suprimem, respectivamente, a sintaxe e o verbo em uma construção combinatória aparentemente temerosa (em "Isso é aquilo"), além de eliminar a linearidade a partir das distribuição das palavras (em "F").

O poema "Gágarin", constante de Jeremias sem chorar (1964), "imita a forma do Sputnik e emblematiza liricamente o encontro da natureza e do homem tecnológico na contemporaneidade: o círculo exterior do poema é um canto à 'bela ave', que é saudada 


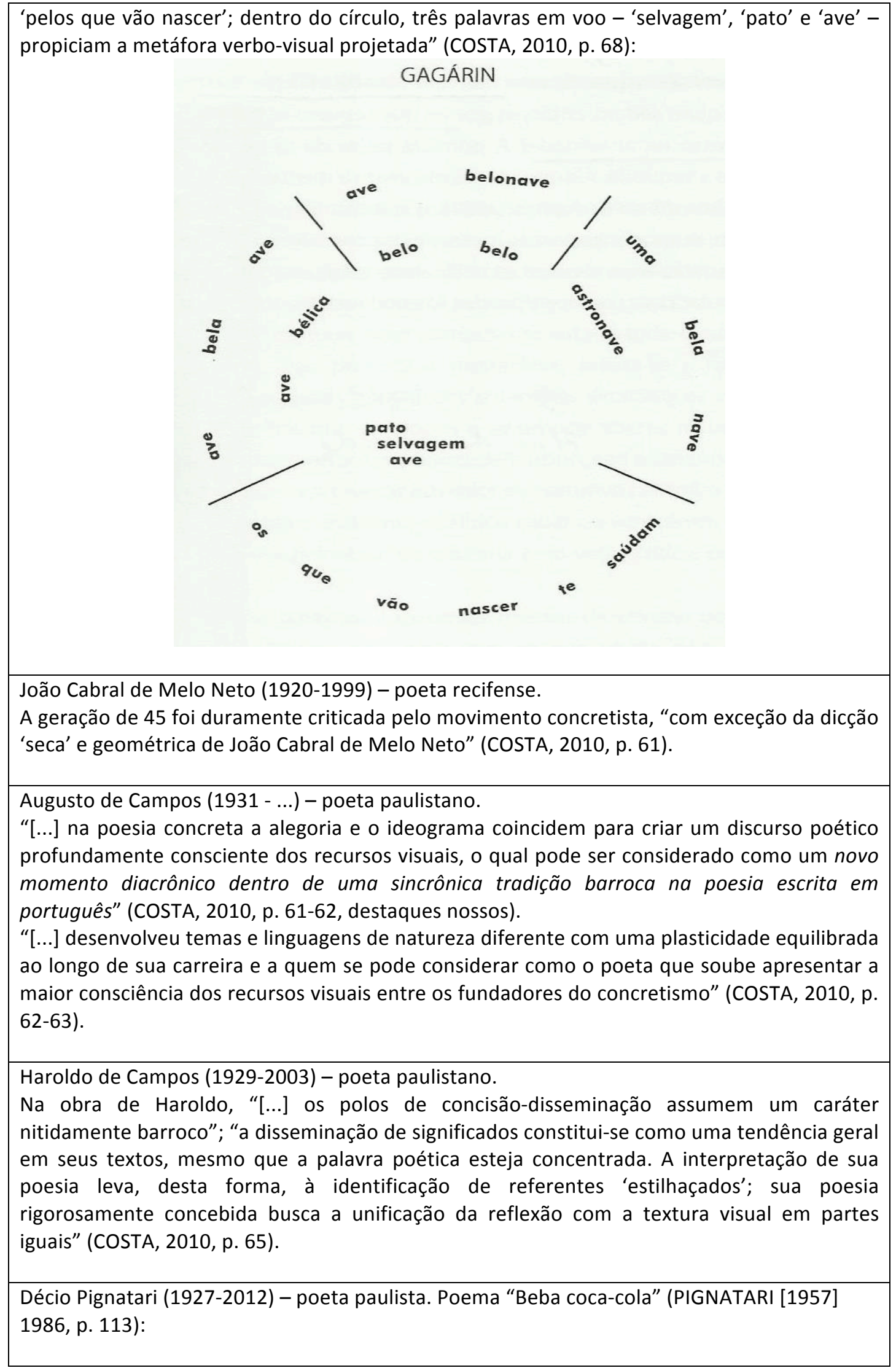




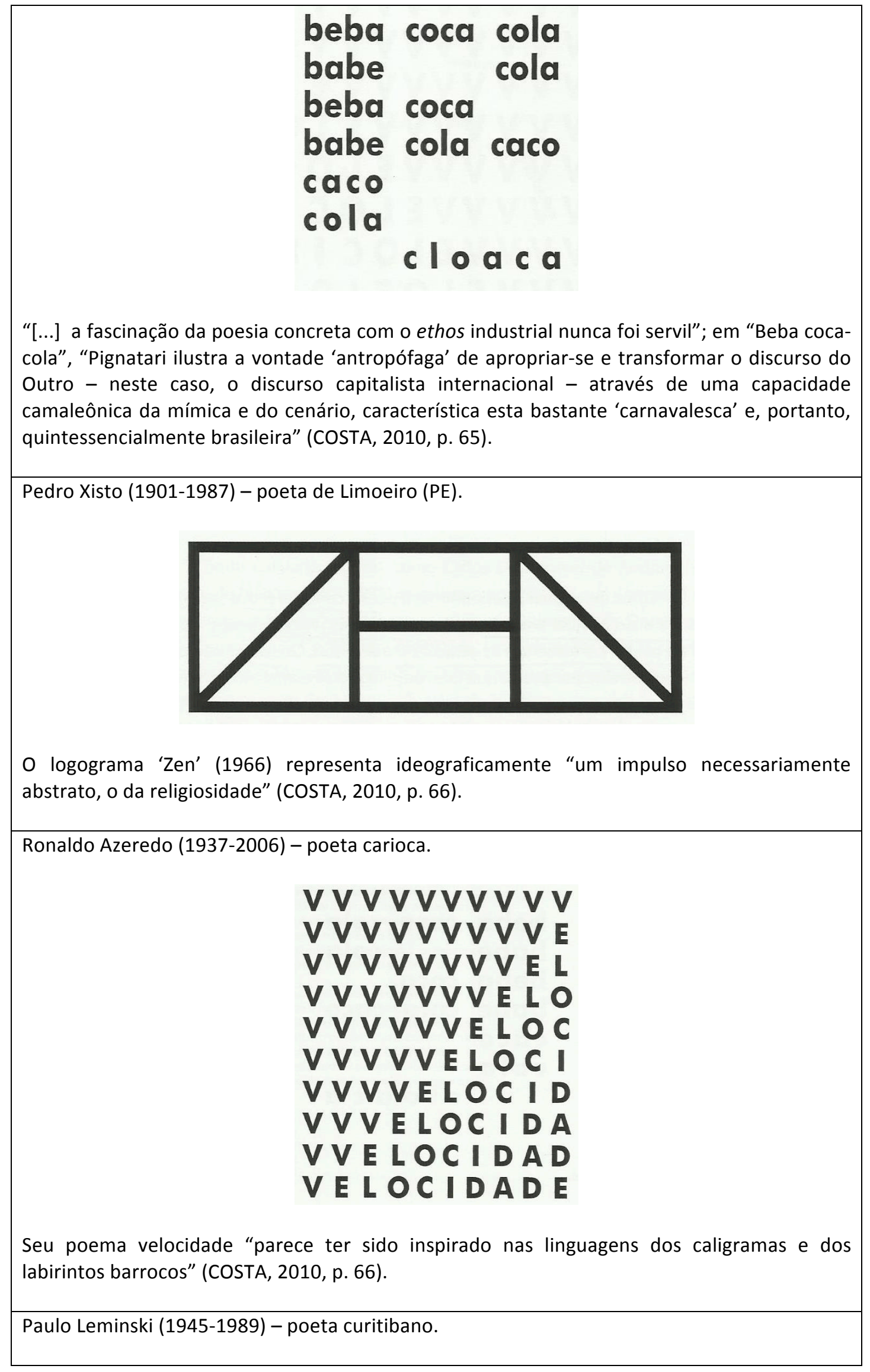


Júlio Castañón Guimarães (1951-...) - poeta mineiro.

Horácio Costa (1954-...) - poeta paulistano.

"As mudanças ou as mutações da consciência dos recursos visuais na poesia brasileira mais recente [Paulo Leminski, Júlio Castañón Guimarães e o próprio Horácio Costa] são difíceis de analisar agora, e mereceriam um espaço particular para serem enfocadas. Mesmo assim, a tradição a que me referi está viva, e vibra" (COSTA, 2010, p. 70).

Diferentemente de Horácio Costa, que se apoia em um continuum barroco de tradição visual, Ivan Teixeira (1997-1998, p. 101-115) vê no Vorticismo inglês uma das "inúmeras manifestações da agudeza [barroca] na arte contemporânea" (p. 101).

Vorticismo é o nome da teoria estética de Ezra Pound, segundo a qual o poeta escolhe valores de estilização gráfica para configurar seus poemas. Pode ser considerado o precursor da poesia concreta. O poema vorticista é condensado, apresentando uma acentuada tonicidade como característica semiótica: a palavra vórtice significa movimento forte, giratório; redemoinho, turbilhão, voragem; movimento intenso de forma espiralada numa região fluida, ou seja, o poema concentra valores de intensidade, num turbilhão de formas subversivas e de imagens. Em suma, o vorticismo tem ponto de contato com a agudeza. É com esse olhar que Ivan Teixeira escolhe objetos que considera neobarrocos.

Também Ivan Teixeira (1997-1998) relaciona um conjunto de autores e obras que identificam uma linha de euforia barroquista na literatura. Esses autores são aqui elencados na ordem em que aparecem em seu texto*:

- Guimarães Rosa (1907-1967) - escritor mineiro. Corpo de baile, 1956.

- João Cabral de Melo Neto (1920-1999) - poeta pernambucano. Morte e vida severina, 1956.

- Haroldo de Campos (1929-2003) - poeta paulistano. Galáxias, 1963-1976.

- Luis de Góngora (1561-1627) - poeta espanhol.

- Francisco Gómez de Quevedo (1580-1645) - poeta espanhol.

- Sóror Maria do Céu (1658-1723) - poetisa portuguesa.

- Mário Chamie (1933-2011) - poeta paulista. Lavra Lavra, 1962.

- Frederico Barbosa (1961- ...) - poeta recifense.

- Arnaldo Antunes (1960 - ...) - poeta paulistano.

- Moacir Amâncio (1949- ...) - poeta paulista.

- Carlito Azevedo (1961- ...) - poeta carioca.

- Nelson Ascher (1958- ...) - poeta paulista. Seu texto apresenta uma "sintaxe inteligente e expandida, denunciadora de fôlego e concentração. Trata-se de um João Cabral cibernético, em quem a rima (geralmente rara) funciona não só como 
elemento de eufonia (melhor pensar em dissonância), mas também de humor e brincadeira" (TEIXEIRA, 1997-1998, p. 114-115).

- Rodrigo Lacerda (1969- ...) - poeta carioca. O mistério do leão rampante, 1995.

- Florisvaldo Menezes (1962- ...) - poeta paulistano.

- Gerardo Diego (1896-1987) - poeta espanhol.

- Ángel Crespo (1926-1995) - poeta espanhol.

* A lista de Teixeira, como vimos, contempla sobretudo nomes de poetas contemporâneos.

Até aqui discutimos a proposta barroquista de Haroldo de Campos, Affonso Ávila, Affonso Romano Sant'Anna, Horácio Costa e Ivan Teixeira. Todos elencam um conjunto de autores que seguiram a linha de tradição inclusiva na literatura brasileira. Há, porém, divergências no tratamento conceitual, como pudemos observar.

Horácio Costa (2010, p. 42) prefere a denominação poesia visual brasileira, bem como não se sente bem com o termo "neobarroco", opinião com a qual compartilhamos. Ainda, Costa, à página 58, estabelece uma divisão do aproveitamento dos recursos visuais na poesia brasileira no século XX, o qual pode ser dividido em dois períodos:

- Antes da poesia concreta - verso linear, ausência de artifícios que vivificam as formas do PE e do PC, uso de "formas seguras", como o soneto, uso da sintaxe canônica, tendência ao uso do verso livre, encaminhamento para a atenuação de agudezas, bem como utilização de paródias, colagens, montagens.

- Depois da poesia concreta - radical ênfase nos arranjos formais; arte geral da palavra; recusa do discurso romântico do "eu"; noção do poema-produto como objeto útil; objeto independente, em que o plano visual gráfico é protagonista do enunciado poético; uso do ideograma para criar um discurso poético consciente dos recursos visuais; sintaxe não canônica, quebra de palavras, separação de fonemas etc.

A poesia concreta, como vimos em Horácio Costa, apresenta afinidades com o chamado barroquismo. Segundo o próprio Haroldo de Campos (2006, p. 248), não obstante o despojamento, a economia de meios e a simulação discursiva da exclusão do "eu", a poesia concreta parece "irremediavelmente barroquista". 
Além dessas características, a metalinguagem é uma constante da lírica aguda do final do século XX. Em lugar do termo neobarroco, consideramos mais pertinente o termo inclusão de que fala Horácio Costa (2010, p. 43): a tradição é um espaço literário discursivo de coexistência de valores afins que "se unem para formar sequências fluidas de eventos". Espaço em que floresce o diverso, o diferente, porque o tempo permite a re-formatação das formas poéticas. O conceito inclusivo da tradição não é de triagem, mas de mistura do velho no novo, sem perder o elo diacrônico com a Antiguidade, que não se repete; decanta-se apenas.

\section{Tradição OU RUPTURA? CONTINUIDADE OU PARADA?}

Neste capítulo, estamos discutindo a questão do barroquismo, segundo autores como Haroldo de Campos, Omar Calabrese, Severo Sarduy, Lezama Lima, Affonso Ávila, Affonso Romano de Sant'Anna, Horácio Costa, Ivan Teixeira, Ana Hatherly. Como pudemos notar, há certa euforização do chamado barroco em determinados autores e nem sempre há consenso, nem um conceito preciso de neobarroco.

Os ensaios de Haroldo de Campos (1976b, p. 139-150; 1977c, p. 34-35; 1989, 2001, p. 372-379, 2006, p. 231-255; In: DANIEL, 2004a, p. 13-16; 2006, In: CAMPOS; PIGNATARI; CAMPOS, 2006, p. 49-53), de modo geral, em virtude da ambivalência de ensaísta e poeta, apresentam o barroco e o neobarroco de forma euforizada. Além disso, há certo hiato entre Haroldo ensaísta e Haroldo poeta. Nem sempre o que apregoa nos ensaios é seu modo de fazer artístico, muitas vezes destinado ainda por uma práxis classicista e não "neobarroca", como em A máquina do mundo repensada [2004b] (cf. PIRES In: FERNANDES; LEITE; BALDAN, 2006, p. 129), em que há retorno ao verso e aos valores de absoluto, como o da constituição do Universo. Parece haver aqui certa oscilação, pois, ao mesmo tempo que Haroldo afirma uma continuidade classicista na práxis enunciativa, nega-a na manifestação de seu enunciado de ensaísta crítico. Sugere uma continuidade barroquista quando mais pertinente seria afirmar uma continuidade da tradição clássica.

Nesse sentido, Krysinski (In: MOTTA, 2005, p. 77) aponta "a ligação de Haroldo com a fonte primeira da poesia ocidental, ou seja, com Homero". Há nele uma oscilação no modo de fazer poético, a ponto de ele dizer ao final de sua vida que não era mais um poeta concreto como os críticos ainda o viam. Pertence à sua visão a ideia de progresso na poesia, marcado pela "metamorfose vetoriada, de transformação qualitativa", que teria 
desabrochado nas formas vanguardistas da poesia brasileira (AGUILAR, 2005, p. 157). Para Haroldo de Campos, haveria uma linearidade progressiva na literatura que teria alcançado formas "mais elaboradas" no barroquismo das vanguardas brasileiras. Em alguns momentos de sua obra, Haroldo de Campos (1977a, p. 159) aproxima o barroquismo dos poetas concretos:

\begin{abstract}
A poesia concreta brasileira - tal como representada na série "Poetamenos" e em alguns outros poemas então inéditos - era mais complexa, de construção não bidimensional (ortogonal) mas pluridimensional, menos concentrada, participando de um barroquismo visual, que, pode-se dizer, constitui uma das constantes formais da sensibilidade brasileira, visível, por exemplo, em nossa arquitetura moderna (destaques nossos).
\end{abstract}

Em nota final ao artigo "Uma arquitextura do barroco", Haroldo de Campos (1976b, p. 144) afirma que "para a consideração de certos aspectos da própria poesia concreta brasileira do ângulo de um 'neobarroquismo'", o leitor de sua obra poderia retomar seu artigo de 1955, verificando que ele engloba no neobarroco a poesia concreta, visto que ela é um objeto visual:

eu tinha sempre uma espécie de casulo barroco na minha poesia, que consistia num tratamento bastante insistente, bastante radical do problema da metáfora, da estrutura fônica, de certas possibilidades semânticas, da decomposição de palavras. Já em 52 eu fazia constante montagem de palavras, composição vocabular, verdadeiros ideogramas semânticosvisuais, que, se ainda não respondiam àquela estrutura rigorosa que depois se desenvolveu na poesia concreta (preocupada, a certa altura, com um "geometrismo" acentuado), já manifestavam uma vocação construtiva e uma tendência barroquista [...] (CAMPOS, 1976b, p. 144, negritos nossos).

Em outro texto, Campos (1977a, p. 159) afirma haver identidade entre neobarroco e concretismo, manifestada na tradição de visualidade da poesia brasileira e no desejo de a poesia aspirar à condição de objeto visual. Para ele, o barroquismo visual "constitui uma das constantes formais da sensibilidade brasileira" (p. 159). A amplitude haroldiana do conceito de barroco permite sua inclusão numa vasta gama de objetos estéticos. Parece que o ensaísta identifica função poética de base jakobsoniana com barroco, pois a descrição apresentada ressalta elementos de projeção do paradigma no sintagma. Sob esse aspecto também as formas clássicas apresentam tais características, visto ser um projeto de qualquer poesia que pretende provocar estesia.

Também Pignatari (In: CAMPOS; PIGNATARI; CAMPOS, 2006, p. 57), no texto "Poesia concreta", aproximou o concretismo do barroco, quando ressalta que "Haroldo de Campos 
é, por assim dizer, um 'concreto' barroco, o que o faz trabalhar de preferência com imagens e metáforas, que dispõe em verdadeiros blocos sonoros". Ao propor tal barroquismo ao longo da história, ficam evidenciados o recorte sincrônico e a criação de uma estética transbarroca que perpassaria a literatura. A ideia de progresso de formas literárias posteriormente cedeu lugar ao que Haroldo denomina "leitura sincrônico-retrospectiva", isto é, "busca de grandes linhas de continuidade", em que a poesia de vanguarda não era propriamente ponto de chegada, mas uma continuidade poética (cf. AGUILAR, 2005, p. 157).

Como vimos, Haroldo elege um cânone composto de autores heterogêneos, mas que tinham um ponto convergente: todos eles apresentam um comportamento inovador e radical com relação à linguagem. Assim é que de Joyce, os vanguardistas (barroquistas e concretistas) assumem o amálgama de palavras; de Cummings, a desintegração morfológica; de Mallarmé, a disposição espacial prismática e em constelação, formando, por meio de palavras estilhaçadas, um mosaico visual; de Pound, o aproveitamento do ideograma de Fenollosa, bem como a reforma das tradições. Desse modo, a poesia "reformada", simultaneísta, estaria ligada à supressão dos elos sintáticos, que equivale na pintura aos efeitos da libertação da perspectiva. Embora Pound estabeleça como princípio orientador de sua poesia o ideograma, Octavio Paz (2013, p. 128) vê em Apollinaire e Pierre Reverdy fonte inspiradora de seu simultaneísmo.

Em sua composição artística, Haroldo é movido por relações estruturais gestálticas e manifestações visuais de influência de uma tradição visual que vem desde Símia de Rodes (Ovo de Símias) e alcança Apollinaire. É por isso que nos parece mais adequado considerar a poesia visual uma linha de identidade que perpassa toda a história da literatura e desemboca nas vanguardas brasileiras pós 1955, com o concretismo e, posteriormente, o convencionado neobarroco. Esse tipo de poesia apoia-se na plasticidade da linguagem, ou, dito de outra forma, na agudeza do PE.

Em Galáxias, com seus experimentalismos linguísticos, Haroldo parece ter atingido o que a semiótica tensiva chama de recrudescimento, ou seja, acréscimos cada vez mais de mais, atingindo formas agudas ainda não exploradas na sua fase de poeta concreto; em seguida, em A máquina do mundo repensada (2004b), retorna ao verso, à terza rima dantesca, ao decassílabo, diferentemente da exploração do verso livre, da despreocupação com os rigores da rima e do uso distribuição espacial do poema. Essa mobilidade conceitual, 
atingida na maturidade poética, permitiu-lhe um redirecionamento de seu cânone, recuperando autores da tradição do verso.

A partir de então, a vanguarda já não se faz como categoria operacional, mas apenas como um ponto na linha evolutiva. Nesse momento, temos um Haroldo de Campos que interroga a história literária de Antonio Candido, propondo-a não como formação, mas como transformação; menos como processo que se forma e mais como processo gerundivo, em que sobressaiam os momentos de ruptura, entendendo a tradição como um procedimento dialético, que coloca face a face diacronia e sincronia.

Talvez seja arriscada essa proposta de Haroldo de Campos, visto atribuir à ruptura um valor supremo. Nesse sentido, ver ruptura em muitos objetos literários constitui-se mais em uma idiossincrasia do que propriamente uma estratégia metodológica para o enfrentamento do texto. Como a Geração de 45 rejeitara as experiências da vanguarda de 22, os poetas concretos retomaram o modernismo apoiados no conceito de fazer literário como evolução, estabelecendo uma linha progressiva que via os poetas da geração anterior como retroativos.

Usar ou não o verso tradicional não se configura uma evolução poética, talvez técnica, mas isso não afeta o poético propriamente. O poético pode estar tanto no estilhaçamento do verso, na composição em constelação, como no soneto, na ode etc. Os poetas concretos, no entanto, consideravam menores as formas poéticas tradicionais.

Para nós, a linha de afinidade de determinadas práticas poéticas é constituída pela acentuação da agudeza fluidificadora, que conduz os objetos poéticos a maior ou menor visualidade, a maior ou menor sonoridade. As características poéticas arranjam-se, assim, segundo um jogo tensivo: mais ou menos acentuação de intensidade. Por isso, nesta tese, em vez do uso de barroco e neobarroco e de dar continuidade à euforização barroquista, optamos pela semiótica da agudeza, com as vertentes poesia aguda do PE e/ou do PC; a de expressão é marcada pela forte sensualidade, configurando um tipo de poesia visual e/ou de poesia altamente musicalizada.

Além disso, a construção de poemas visuais não é uma herança tão somente do chamado barroco. Essa forma poética transpassa toda a história da literatura e antecede até mesmo os séculos XVI e XVII, como se pode verificar em $O$ ovo, de Símias de Rodes (séc. III a.C.), em $O$ altar, de Porfyrius Optatianus (325 d.C). Nessa direção, Ana Hatherly (1995, p. 38-40) afirma: 
De entre os estudiosos da literatura, muitos sabem já que os textos visuais europeus mais antigos que até agora se conhecem são de gregos alexandrinos, destacando-se os nomes de Símias de Rodes, Disíadas e Teócrito, e que os textos que produziram estabeleceram o modelo básico para a maior parte da poesia figurada que se produziu ao longo de toda a Idade Média e, sobretudo, a partir do Renascimento, quando se deu o primeiro período de revivalismo das formas artísticas da antiguidade clássica.

Entre os vários pontos de vista do que seria a euforia barroca, a agudeza, com lastro na semiótica tensiva, parece constituir-se numa operação que permite observar uma linha poética de trabalho linguístico. Em uma relação de dependência, engrenam-se objetos fluidos, pictóricos na terminologia de Wölfflin, com objetos menos fluidos, mais nítidos, lineares/plásticos em Wölfflin. Os objetos mais fluidos ou fluidos, os fantásticos, são os de recrudescimento agudo. Todavia, na medida em que a direção é a da nitidez (vetor icástico), há certa atenuação da agudeza. Esse esquema tensivo pretende não apenas nos envolver pela performance com as formas, como também nos tocar pelo jogo constante entre fluidez/nitidez, estando uma na latência da outra.

A agudeza, como vimos, ocupa-se de acentuar os enunciados poéticos que acabam por maravilhar pelo estranhamento que provocam. Essa linhagem contempla, pois, uma razão poética. Embora o fluido esteja mais para o fantástico e o nítido para o icástico, não se pode falar propriamente em uma divisão binarista de tais dimensões.

No capítulo seguinte, examinamos a semiótica da agudeza no limiar do sensível e do inteligível. 
A POESIA AGUDA DO SÉCULO XX NO LIMIAR DO SENSÍVEL E DO INTELIGÍVEL

O objetivo da arte é dar a sensação do objeto como visão e não como reconhecimento; o procedimento da arte é o procedimento da singularização dos objetos e o procedimento que consiste em obscurecer a forma, aumentar a dificuldade e a duração da percepção.

V. Chklovski

O Enigma é uma das formas poéticas então correntes que ilustram claramente como o prazer intelectual se podia identificar com o prazer do jogo, entendido como uma duração do prazer de saber, do prazer de penetrar o mistério.

Ana Hatherly

"Valoriza a dimensão material da palavra" - mas que poema não faz isto? Alcir Pécora 


\section{A qUESTÃo do SENSívEL: A SEMIÓtICA GREIMASIANA E O DIÁLOGO COM A FILOSOFIA}

Na história da filosofia, Merleau-Ponty, sob influência husserliana, traz à tona a noção de corpo, de subjetivismo, via teoria da percepção.

E como o sensível, objeto que nos interessa mais de perto nesta tese, entrou na semiótica? Nesse sentido, a semiótica parece "namorar" a filosofia. Sem a preocupação de dar uma resposta categórica, mas a título de esclarecimento, empreenderemos a seguir uma apresentação sumária de como a semiótica flertou com as questões do sensível por meio do diálogo com a fenomenologia.

Por volta de 1990, dá-se uma aproximação da semiótica com a fenomenologia. Marsciani, que já fazia parte de um grupo de pesquisa encabeçado por Greimas em meados dos anos de 1980, defende tese de doutorado, cujas ideias dialogam com o pensamento fenomenológico e com a obra de Greimas e Fontanille, Semiótica das paixões ([1991] 1993). Embora a tese de Marsciani tenha sido publicada um ano antes da obra de seu mestre, supomos que sua pesquisa seja resultado de reflexões oriundas dos estudos greimasianos em Paris. Parecia-Ihe que "[...] una nuova epoca si stesse aprendo, o, più modestamente, una nuova possibilità di descrizione dei fenomeni di senso" // "uma nova época se estivesse abrindo, ou, mais modestamente, uma nova possibilidade de descrição dos fenômenos de sentido" (MARSCIANI, 2012a, v. 1, p. 17, tradução e grifos nossos).

De fato, novos horizontes se abriam: a semiótica iniciava, então, seu diálogo com a filosofia fenomenológica de Husserl e Merleau-Ponty, algo discutido por Marsciani no volume 1 de sua tese. Greimas, em Semântica estrutural ([1966] 1976), já apresentava algumas pinceladas fenomenológicas; em Semiótica das paixões ([1991] 1993), Greimas e Fontanille retomam mais fortemente o flerte com a fenomenologia.

Em Semântica estrutural, Greimas $(1976$, p. 16) menciona que a explicação dos fatos estéticos se situa sobretudo no nível da percepção da obra e "não mais no da exploração do gênio ou da imaginação". A linguagem, bem como as obras de arte, nas palavras de Cassirer (2009, p. 124), não pode ser concebida como "mera obra de espírito": o corpo, como mediador do sentido, entra em cena. E nesse momento o sensível coloca-se como operador 
da atração ou repulsão. Portanto, é a partir desse diálogo com a fenomenologia que o sujeito, antes de notar se o objeto é azul ou vermelho, será atraído ou repelido por ele. Por meio da atração ou da repulsão, dá-se o sentido, a direção, a foria, a força que leva o sentido adiante, conforme veremos com mais detalhes na próxima seção.

\section{ATRAÇÃo OU REPULSÃO: ENTRADA do SENSÍVEL NA SEMIóticA}

A segunda "Introdução" da tese de Marsciani (2012a, v. 1, p. 7-16) dialoga com a terminologia husserliana "doadora de sentido" na medida em que, para o Husserl, o sentido é a única realidade existente para a razão, pois sentimos e percebemos formas, ou seja, totalidades estruturadas e dotadas de sentido ou de significação. O percebido já é dotado de sentido, visto que o verde, por exemplo, é verde percebido em oposição ao azul. 0 percebido oferece-se, então, por perspectivas na relação do sujeito com o mundo. Ele seria interminável, sempre em devir. É a partir dessa relação do sujeito com o objeto percebido que Husserl ([1931] 2004, p. 166 ss, ed. Italiana consultada Meditazioni cartesiane) elabora o conceito "mundo-da-vida" (lebenswelt) como nova forma de pensar que traria à tona a intersubjetividade, tratada por Marsciani (2012a, v. 1, p. 25).

A tese de Marsciani (2012a, v. 1, p. 7), apresentada nos livros Ricerche semiotiche I e II, começa o volume 1 com uma citação de Merleau-Ponty retirada de $O$ olho e o espírito:

Quando vejo através da espessura da água o revestimento de azulejos no fundo da piscina, não o vejo apesar da água, dos reflexos, vejo-o justamente através deles, por eles. Se não houvesse essas distorções, essas zebruras do sol, se eu visse sem essa carne a geometria dos azulejos, então é que deixaria de vê-los como são, onde estão, a saber: mas longe que todo lugar idêntico. A própria água, a força aquosa, o elemento viscoso e brilhante, não posso dizer que esteja no espaço: ela não está alhures, mas também não está na piscina. Ela a habita, materializa-se ali, mas não está contida ali, e, se ergo os olhos em direção ao anteparo de ciprestes onde brinca a trama dos reflexos, não posso contestar que a água também o visita, ou pelo menos envia até lá sua essência ativa e expressiva (MERLEAU-PONTY, 2004, p. 37-38, destaque do original).

Instalado por alguns meses na casa que um pintor lhe alugara no Tholonet, perto de Aix na França, Merleau-Ponty morreria na primavera seguinte, não sem antes de escrever $O$ olho e o espírito no aconchego de seu quarto alugado no campo provençal. Fruindo a paisagem, o fenomenólogo volta a questionar a visão e a pintura.

A cena do azulejo e da piscina é uma paisagem que o espírito de Merleau-Ponty havia captado com o olhar; os objetos se difundem na memória do sujeito, memória, digamos, 
sempre distante dos objetos. O estar distante convoca a presença das coisas. O momento da escrita é uma presença que se dá em ausência, em que ser e parecer se permutam no ato de enunciar: a escrita constitui-se no que o espírito (a memória potencializada) havia captado com o olhar. O que vemos aí pode ser entendido como uma crítica de Merleau-Ponty à ciência que trata seus objetos como se nada tivessem a ver com o sujeito do conhecimento, mantendo um simulacro do ser distanciado que persegue a objetividade do racionalismo.

Para a fenomenologia merleau-pontiana, um objeto, antes de ser azul ou amarelo (qualidade), é atraente ou repulsivo. Esse fato nos aproxima da tensividade fórica de Semiótica das paixões (1993) e do debruçar do sujeito sobre o objeto em Da imperfeição: "L'oggetto estetico si trasforma in attore sintattico che, manifestando in tal modo la sua 'pregnanza', si pone dinanzi al soggetto-osservatore [o objeto estético se transforma em ator sintático que, manifestando de tal modo sua 'pregnância' avança sobre o sujeitoobservador]" (GREIMAS, [1987] 2004, p. 35, tradução nossa).

Em Sémiotique: dictionnaire raisonné de la théorie du langage (GREIMAS; COURTÉS, 1986, v. 2, p. 238-239), o verbete tímico, do grego thumós, timia, alma, espírito, coração, emoção, afetividade, origina a categoria tímica que articula o semantismo relacionado à percepção que o sujeito tem de seu corpo. Ela articula-se em "euforia e disforia", desempenhando a função de transformar microuniversos semânticos em axiologias (valores). De uma parte, a timia orienta o sentido, dando-lhe um valor positivo ou negativo; de outra parte, tem relação com a interoceptividade, isto é, a percepção que o sujeito possui de seu próprio corpo.

Parret (In: SILVA, 1996, p. 59), em nota de rodapé, destaca a posição de Fontanille no item 2 do mesmo verbete tímico, segundo a qual "a dimensão tímica subsume e organiza o jogo das atrações/repulsas objetais e intersubjetivas". Ao colocar em jogo as atrações e as repulsões, a foria dinamiza o percurso gerativo do sentido. Petitot, autor do item 3 do verbete, vai relacionar a timia à área dos prazeres e desprazeres com base em uma visada psicanalítica. Em Da imperfeição, Greimas volta-se para a estetização da categoria tímica, o que Parret vai chamar de semiótica lucreciana, porque é epicurista (todo prazer é uma sensação corporal).

A noção de percepção que vemos tanto em Semiótica das paixões como em $D a$ imperfeição pendula entre o prazer do corpo e o prazer estético. Enquanto o primeiro é um prazer pragmático, funcional, o segundo é gratuito, sem finalidades utilitárias. 
Nesse cenário de discussões "sujeito-corpo-objeto", engenhosamente, a primeira "Introdução" da tese de Marsciani, convertida em livro em 2012, é intitulada "Breve introdução apodítica (sobre o percurso gerativo do sentido)". Apodítica seria uma proposição de ordem lógica, não empírica, de natureza indubitável, que serve de inspiração para o quadrado semiótico de Greimas, momento ainda aquém da experiência do sujeito sensorial constante do livro Da imperfeição; nesta última obra greimasiana, o sujeito, em muitos momentos, se apassiva diante do objeto estético, sendo atraído por ele. E, nesse caso, estaríamos distantes dos racionalistas do objetivismo (os inatistas, os apodíticos).

A segunda "Introdução" de Marsciani, intitulada "Breve introdução desejante (sobre a doação de sentido)", coloca em cena uma semiótica de cunho estruturalista, aberta ao diálogo com a fenomenologia. À página 18 do v. 1, o semioticista italiano comenta o momento de uma epoché semiótica, apontando a hipótese de que a semiótica tenha sido e seja a resposta teórica às questões levantadas e deixadas sem resposta da parte das duas tradições mais influentes: "la fenomenologia, da un lato, e, con una portata differente, lo strutturalismo, dall'altro // a fenomenologia, de um lado, e, com uma abordagem diferente, o estruturalismo, de outro lado" (MARSCIANI, 2012a, v. 1, p. 19, tradução nossa).

E como será que a semiótica de viés saussuriano veio abrir uma janela para uma possível virada(?) fenomenológica. Será que essa virada aconteceu mesmo?

Para Merleau-Ponty, que critica o método cartesiano, o cogito não era ainda uma resposta indubitável para os questionamentos filosóficos; no máximo, o que se podia ver no cogito é a existência de uma filosofia por fazer. Ora, em "penso, logo existo", não se poderia duvidar da existência e do pensamento, por consequência. No entanto, na proposição cartesiana, o que temos é apenas uma solução da linguagem. Não há confirmação nem da existência do sujeito, nem do pensamento. Ademais, Merleau-Ponty defende que não existe pensamento puro e que, quando a filosofia indaga "o que é o mundo?", "o que é a história?", "o que é o tempo?", "o que é o espaço?", ela o faz por meio de palavras. É com base nesse pensamento que Greimas (1956, p. 192), no texto "A atualidade do saussurismo", afirma que

a linguística saussuriana reconhecerá com entusiasmo os esforços de $\mathrm{M}$. Merleau-Ponty na elaboração de uma psicologia da linguagem na qual a dicotomia pensamento/linguagem é abandonada, dando lugar a uma concepção da linguagem em que o sentido é imanente à forma linguística e que, guardados o tom peculiar do autor e a convergência de vários 
pensamentos, parece, em muitos aspectos, um prolongamento natural do pensamento saussuriano.

A seguir, destacamos alguns trechos do capítulo VI, "O corpo como expressão e a fala", constantes do livro Fenomenologia da percepção (MERLEAU-PONTY, [1945] 2006, p. 237-270). Por meio dos excertos, supomos, de um lado, que Greimas visitou a obra do fenomenólogo, quando reitera que Saussure reconheceu com entusiasmo os esforços de Merleau-Ponty. De outro lado, Merleau-Ponty, cuja obra foi publicada em 1945, muito depois da publicação do Curso de linguística geral (1916), visitou a obra do linguista genebrino. Veja no quadro 4.1 um confronto do pensamento fenomenológico com o pensamento saussuriano.

Quadro 4.1 Comparativo entre a filosofia merleau-pontiana e o estruturalismo saussuriano.

\begin{tabular}{|c|c|}
\hline $\begin{array}{l}\text { Excertos do capítulo VI de Fenomenologia da } \\
\text { percepção (FP) }\end{array}$ & $\begin{array}{l}\text { Possíveis reflexões com a } \\
\text { linguística saussuriana }\end{array}$ \\
\hline $\begin{array}{l}\text { "A denominação dos objetos não vem depois do } \\
\text { reconhecimento, ela é o próprio reconhecimento. } \\
\text { Quando fixo um objeto na penumbra e digo: 'É uma } \\
\text { escova', não há em meu espírito um conceito da } \\
\text { escova ao qual eu subsumiria o objeto e que, por } \\
\text { outro lado, estaria ligado à palavra 'escova' por uma } \\
\text { associação frequente, mas a palavra traz o sentido e, } \\
\text { impondo-o ao objeto, tenho consciência de atingi-lo" } \\
\text { ( } F P \text {, p. } 242 \text {, destaques nossos). } \\
\text { "A fala não traduz, naquele que fala, um pensamento } \\
\text { já feito, mas o consuma" ( } F P \text {, p. } 242 \text {, destaques } \\
\text { nossos) }\end{array}$ & $\begin{array}{l}\text { A manifestação do objeto já } \\
\text { contém a semiose entre a forma de } \\
\text { expressão e a forma de conteúdo, } \\
\text { visto que recortamos } \\
\text { semioticamente o mundo por meio } \\
\text { de formas. O sentido é imanente à } \\
\text { semiose (forma linguística) entre os } \\
\text { planos de qualquer linguagem } \\
\text { (pictórica, verbal), inclusive a do } \\
\text { mundo natural. } \\
\text { A visão merleau-pontiana encontra- } \\
\text { se com a visão da semiótica } \\
\text { greimasiana no quesito da } \\
\text { supremacia da linguagem. No } \\
\text { último trecho à esquerda, note-se } \\
\text { que a fala é que consuma o } \\
\text { pensamento, ou, em outras } \\
\text { palavras, ela é pensamento; o } \\
\text { pensamento constitui-se } \\
\text { linguagem. }\end{array}$ \\
\hline $\begin{array}{l}\text { "Nada há ali de comparável à resolução de um } \\
\text { problema, em que se descobre um termo } \\
\text { desconhecido por sua relação a termos conhecidos" } \\
\text { (FP, p. } 243 \text {, destaques nossos). }\end{array}$ & $\begin{array}{l}\text { Para o filósofo, um termo é } \\
\text { descoberto em relação a outros } \\
\text { termos já conhecidos. Para } \\
\text { Saussure (1996, p. 134-135), esse } \\
\text { pensamento de Merleau-Ponty } \\
\text { corresponde à noção de valor. }\end{array}$ \\
\hline $\begin{array}{l}\text { "Toda a linguagem se ensina por si mesma e introduz } \\
\text { seu sentido no espírito do ouvinte. Uma música ou } \\
\text { uma pintura que primeiramente não é compreendida, }\end{array}$ & $\begin{array}{l}\mathrm{Na} \text { linguagem verbal, como } \\
\text { possuímos recortes formais da } \\
\text { língua natural, temos a ilusão de }\end{array}$ \\
\hline
\end{tabular}




\begin{tabular}{|c|c|}
\hline $\begin{array}{l}\text { se verdadeiramente diz algo, termina por criar por si } \\
\text { mesma seu público, quer dizer, por decretar ela } \\
\text { mesma sua significação" (FP, p. } 244)\end{array}$ & $\begin{array}{l}\text { que já possuímos em nós o que é } \\
\text { preciso para entender qualquer } \\
\text { texto. } \\
\text { Na música, por exemplo, uma nota } \\
\text { pode ser compreendida somente } \\
\text { em relação a outra nota do sistema } \\
\text { musical manifestado. } \\
\text { Em uma obra literária, o sentido } \\
\text { brota imanentemente do ato } \\
\text { semiótico entre formas de } \\
\text { expressão e de conteúdo. } \\
\text { Música, literatura, pintura são } \\
\text { sistemas semióticos, } \\
\text { significação se dá nas relações } \\
\text { entre formas. }\end{array}$ \\
\hline
\end{tabular}

Como vimos, Merleau-Ponty bebeu em águas saussurianas. Tatit (In: OLIVEIRA; LANDOWSKI, 1995, p. 161), em "A semiótica e Merleau-Ponty", comenta que Greimas levou em consideração um componente fenomenológico para o estabelecimento do conceito de existência semiótica do objeto ou do discurso, pois o sentido, nesse caso, "deve ser sempre considerado como imanente à expressão, seja esta de natureza verbal ou não verbal, e, mais que isso, na medida em que esta concepção supera definitivamente a dicotomia entre pensamento e linguagem". E acrescenta que é "difícil distinguir o que é original do pensamento do filósofo francês e o que deve ser debitado diretamente aos cursos do linguista suíço" (TATIT In: OLIVEIRA; LANDOWSKI, 1995, p. 161).

Talvez não seja relevante procurar saber quem originou o quê, mas constatar a existência de um percurso paralelo entre a fenomenologia e a linguística. Tanto uma quanto outra superaram a preocupação ontológica e ocupam-se de discutir o pensamento e a linguagem. A semiótica greimasiana, por lidar com objetos estéticos (sobretudo de Semiótica das paixões para a frente), passou a lidar com a entrada do corpo em suas discussões.

A noção de corpo, fulcro do pensamento merleau-pontiano, desse modo, será destaque no quadro epistemológico da semiótica das paixões. Corpo, para Merleau-Ponty, é um termo mediador que se propõe superar o abismo entre sujeito e objeto, subjetivismo e objetivismo, racionalismo e empirismo, metafísica e positivismo. O corpo englobaria o sujeito do conhecimento (o observador) e o objeto observado. E o sujeito abarcaria o mundo e seria abarcado por ele. 
A partir de 1991, com Semiótica das paixões, temos a proposta de um nível sintáxico profundo de onde se depreendem valores tensivos que se movem pelas instâncias do percurso gerativo do sentido. E é nesse cenário que temos a conceituação da tensividade fórica. Para Tatit (In: OLIVEIRA; LANDOWSKI, 1995, p. 164),

se considerarmos a tensividade fórica como uma protossintaxe - uma orientação pressuposta que neutraliza as tensões próprias da relação sujeito/objeto (protensividade do primeiro/atratividade do segundo) e que constitui ponto de partida para se pensar as articulações realizadas, em outros níveis, pelas operações de "parada", e retomada da continuidade ("parada da parada") --, estaremos então concebendo, antes de tudo, um fluxo temporal cujo continuum é pressuposto tanto pela descontinuidade como pela própria continuidade.

A ideia de descontinuidade implica a existência de uma continuidade, que subjaz a ela. Não há, portanto, dissenção, pois que, antes da descontinuidade entre um e outro, há um continuum pressuposto, neutralizando as tensões entre sujeito/objeto. É a partir desse continuum que se pode pensar nas operações missivas de "parada" e de "parada da parada", uma suscitando a outra. Portanto, no nível tensivo fórico, não haveria separação entre sensível e inteligível. Nesse sentido, a semiótica afasta-se das concepções filosóficas do inatismo e do empirismo.

Com Zilberberg ([1988] 2006b), essa proposta inicial ganhou avanço. Os anos de 1990 acolheram esse clima intelectual: tese de Marsciani, propostas de Greimas e Fontanille, de Zilberberg, de Parret. Perceber, de um ponto de vista da semiótica tensiva, atinge uma região teórica de retenções (a disforia, a parada ou a remissividade) e de distensões (a euforia, a parada da parada ou a emissividade). Estava dado o passo da semiótica em direção ao flerte com a fenomenologia.

\section{DA ESTATICIDADE AO MOVIMENTO: DIÁLOGO DA FENOMENOLOGIA COM A SEMIÓTICA TENSIVA DE ZILBERBERG}

Entre o pensamento de Merleau-Ponty e a semiótica tensiva zilberberguiana há elos a serem considerados. Na concepção merleau-pontiana, corpo e mundo formam um campo de presença e dele podem ser apreendidas as relações perceptivas do mundo sensível. Para o fenomenólogo, não podemos compreender o sujeito em sua pura forma, mas na intersecção de suas dimensões, sendo preciso "considerar o tempo em si mesmo, e é seguindo a sua dialética interna que seremos conduzidos a refazer nossa ideia de sujeito" (MERLEAU-PONTY, 2006, p. 550). 
Analisando o tempo, sujeito e objeto surgem como dois momentos de estrutura única que é a presença. O ser é então pensado por meio do tempo, visto que é mediante a interdependência entre o tempo sujeito e o tempo objeto que compreendemos as relações entre o sujeito e o mundo. Para Tatit (In: OLIVEIRA; LANDOWSKI, 1995, p. 167), "as intuições temporais de Merleau-Ponty chegam a propor uma equivalência entre Eu e Tempo", levando em consideração que a enunciação pressupõe um tempo enunciativo, o presente em que se enuncia.

E, ao considerar o tempo como um objeto qualquer, o fenomenólogo afirma que "ele [o tempo] só tem sentido para nós porque nós 'o somos'. Nós só podemos colocar algo sob esta palavra porque estamos no passado, no presente e no porvir. [...] É pelo tempo que pensamos o ser [...]" (MERLEAU-PONTY, 2006, p. 576-577).

Para Zilberberg (2011a, p. 215; cf. TATIT In: OLIVEIRA; LANDOWSKI, 1995, p. 166 ss) entendido o sentido como uma direção, temos uma linha que segue a partir de um ponto estabelecido no mundo. Se o sujeito se ancora no presente e toma uma retrodireção, vai ao passado; se ele se orienta para um tempo à frente, caminha para o porvir, o futuro. Esse tempo é marcado também por um ritmo, cujos funtivos são aceleração ou desaceleração, que abalam os afetos do sujeito, surpreendendo-o (sobrevir) ou fazendo-o esperar (pervir). O sujeito é polarizado ou orientado por uma seleção de andamento (acelerado ou desacelerado). Na descontinuidade, temos a surpresa, a rapidez, o pulo inesperado de uma etapa a outra; na continuidade, o esperado, a desaceleração, a graduação das etapas, uma a uma: um ponto de partida e um ponto de chegada.

O sujeito "perceptivo" merleau-pontiano fica refletido, pois, no sujeito enunciativo zilberberguiano, que escolhe um ponto dêitico e engendra uma seleta de valores espaçotemporais que se relacionam com essa ancoragem escolhida. Vejamos o que Merleau-Ponty (2006, p. 576) tem a nos dizer em diálogo com a semiótica tensiva de Zilberberg:

Não haveria direção sem um ser que habite o mundo e que, por seu olhar, trace ali a primeira direção-referência. Semelhantemente, só se entende o sentido de um tecido para um sujeito que pode abordar o objeto de um lado ou do outro, e é por meu aparecimento no mundo que o tecido tem um sentido. Da mesma maneira ainda, o sentido de uma frase é seu propósito ou sua intenção, o que supõe ainda um ponto de partida e um ponto de chegada, uma visada, um ponto de vista. [...] Sob todas as acepções da palavra sentido, nós reconhecemos a mesma noção fundamental de um ser orientado ou polarizado em direção à aquilo que ele não é" (destaques nossos). 
Merleau-Ponty parte da estaticidade da pura observação (objetividade) para o fenômeno do movimento, da direção: "Precisamos conceber um mundo que não seja feito apenas de coisas, mas de puras transições" (MERLEAU-PONTY, 2006, p. 370). A semiótica tensiva, por sua vez, partindo do raciocínio merleau-pontiano, pode ser considerada como a semiótica do movimento e não mais a da estaticidade do apoditismo. Sai de cena a relação do sujeito puramente com o objeto e entra em jogo o dinamismo do sujeito com o devir. Agora, a semiótica se depara com o sujeito em movimento e em um cenário de afetos dinâmicos, que afetam a percepção do ser. E os objetos, por seu turno, perdem a passividade, atraindo ou repelindo os sujeitos.

Vejamos no quadro 4.2 os pontos de contato entre a fenomenologia e a semiótica, no que diz respeito ao corpo.

Quadro 4.2 Considerações sobre o corpo na fenomenologia e na semiótica.

\begin{tabular}{|c|c|c|}
\hline Merleau-Ponty (FP, [1945] 2006) & $\begin{array}{l}\text { Zilberberg ([1988] 2006b, } \\
\text { Razão e poética do sentido) }\end{array}$ & $\begin{array}{l}\text { Greimas-Fontanille ([1991] } \\
\text { 1993, Semiótica das } \\
\text { paixões) }\end{array}$ \\
\hline $\begin{array}{l}\text { Corpo - } \\
\text { conhecimento }+\quad \begin{array}{r}\text { do } \\
\text { objeto }\end{array} \\
\text { observado } \\
\text { implicação espaço-temporal } \\
\text { "O presente vivido encerra em } \\
\text { sua espessura um passado e um } \\
\text { futuro. O fenômeno do } \\
\text { movimento não faz senão } \\
\text { manifestar de uma maneira mais } \\
\text { sensível a implicação espacial e } \\
\text { temporal” (FP, p. 371). } \\
\text { “O ser pré-objetivo, o movente } \\
\text { não tematizado não põem outro } \\
\text { problema que o espaço e o } \\
\text { tempo" (FP, p. 371). }\end{array}$ & $\begin{array}{l}\text { Corpo como terceiro termo: } \\
\text { dissolução da separação } \\
\text { entre objeto e sujeito. A } \\
\text { semiótica vê a percepção } \\
\text { como flutuação tensiva entre } \\
\text { parada (descontinuidade) e } \\
\text { parada da parada } \\
\text { (continuidade). }\end{array}$ & $\begin{array}{l}\text { Corpo que percebe, que } \\
\text { sente: estado de coisas + } \\
\text { estados de alma } \\
\text { Estado de coisas ("mundo"): } \\
\text { semas exteroceptivos } \\
\text { (figurativos); } \\
\text { Estados de alma (sujeito): } \\
\text { semas interoceptivos } \\
\text { (abstratos); } \\
\text { Corpo que percebe: semas } \\
\text { tímicos proprioceptivos } \\
\text { (GREIMAS; COURTÉS, 1983, } \\
\text { p. 393, verbete sema). }\end{array}$ \\
\hline
\end{tabular}

Merleau-Ponty, antes de considerar a "qualidade" da sensação presente nos objetos (cor, por exemplo) como dado inicial, entende a percepção como ato significante. Na segunda parte de Da imperfeição, "Imanência do sensível", Greimas (2004, p. 58; 2002, p. 74) faz referência direta a Merleau-Ponty, quando trata de formas plásticas e afirma que "la pittura si mette a parlare il proprio linguaggio" [a pintura se põe a falar sua própria 
linguagem], mencionando a possibilidade da leitura plástica e terminando a seção sugerindo a "imanência do sensível". Então, as portas abriam-se para o futuro do sensível na semiótica.

Como vimos, a filosofia embrenhou-se em uma caminhada em que lidou, de um lado, com os inatistas (racionalismo, mentalismo) e, de outro, com os empiristas. Sujeito e objeto estavam separados nessa primeira visada filosófica. A partir do século XVIII, com Locke, Hume, Hobbes, Kant, o percurso toma uma nova direção.

Kant, mais fortemente, propõe o casamento entre o inteligível (pensamento) e o sensível. Husserl e Merleau-Ponty entram em cena. E com este último, o corpo. Consideramos que a semiótica não disputa com a filosofia, mas apresenta um percurso próprio e também admite a suspensão da dicotomia entre sujeito e objeto a partir dos anos de 1990 com os estudos sobre as paixões e a introdução da afetividade na linha de frente das considerações sobre o sentido. $E$, nesse ponto, ela observa atentamente a fenomenologia merleau-pontiana. Para o autor de Fenomenologia da percepção, corpo é a um só tempo sujeito observador e objeto observado e é ainda o terceiro termo, que confirma a relação de participação entre sujeito e objeto, guiando o processo perceptivo, porque é um elo contínuo, um parâmetro de medida, de atração ou de repulsão.

Desde Semântica estrutural (1966), parece-nos que entre a semiótica e a fenomenologia ocorre não um conflito, mas um flerte. Greimas (1976, p. 15), ao tratar da significação e percepção, afirma:

Ficamos ingenuamente espantados quando nos pomos a refletir acerca da situação do homem que, de manhã à noite e da idade pré-natal à morte, é atormentado por significações que o solicitam por toda parte, por mensagens que $o$ atingem a todo momento e sob todas as formas. Ingênuas - desta vez no sentido não científico da palavra - parecem as pretensões de certos movimentos literários que desejam fundar uma estética de não-significação.

Comentando a presença de duas cadeiras em uma peça teatral que teriam causado preocupação a Allan Robbe-Grillet pelo poder de evocação, Greimas admite que uma cadeira somente já seria suficiente para formar um sentido. Um objeto sozinho já seria "bastante significante", pois que funciona como um paradigma linguístico. Daí não se poder falar em ausência de significação, visto tudo suscitar um efeito de sentido.

Em um poema agudo, por exemplo, um grafema isolado no branco da página é dotado de sentido: por catálise, afloram relações provocadas pelos elementos paradigmáticos in absentia. Aproxima, então, a semântica da teoria do conhecimento. 
Hjelmslev já percebera o "desconforto" dessa aproximação com a filosofia, mas reconhecia que era o "destino de qualquer ciência, e não somente da linguística" (GREIMAS, 1976, p. 15).

$\mathrm{Na}$ seção "Significação e percepção", de Semântica estrutural, Greimas, diferentemente do que ocorrerá a partir de Semiótica das paixões, ainda admite "a percepção como o lugar não linguístico onde se situa a apreensão da significação" (p. 15). Para a Semiótica das paixões, no entanto,

\begin{abstract}
les traits, les figures, les objets du monde naturel, dont ils constituent pour ainsi dire le "signifiant", se trouvent transformés, par l'effet de la perception, en traits, figures et objets du "signifié" de la langue, un nouveau signifiant, de nature phonétique, se substituant au premier. C'est par la médiation du corps percevant que le monde se transforme en sens en langue --, que les figures extéroceptives s'intériorisent et que la figurativité peut alors être envisagée comme un mode de pensée du sujet (GREIMAS; FONTANILLE, 1991, p. 12) ${ }^{1}$.
\end{abstract}

A mediação do corpo não é inocente, visto que acrescenta "categorias proprioceptivas que constituem de algum modo seu 'perfume' tímico" (GREIMAS; FONTANILLE, 1993, p. 13). A partir de Semiótica das paixões, constrói-se um sujeito epistemológico que não é puro sujeito cognitivo racional, deparando-se, em seu percurso rumo à significação, com uma fase de sensibilização tímica.

Corpo e junção constituem respectivamente, nas palavras de Tatit (In: SILVA, 1996, p. 202), "a face material e a face abstrata da continuidade entre sujeito e objeto, preconizado tanto por Merleau-Ponty como por Greimas no De l'imperfection". O sentido visa reintegrar sujeito (1) e objeto (2). A cisão da unidade fundida $(1+2)$ percebida pelo corpo é que propicia o ingresso na esfera inteligível. A reintegração das partes cindidas, 1 e 2, refaz o ser do sujeito, proporcionando-Ihe um sentido.

Sintetizando, o corpo é constituído por um espaço e um tempo, conforme vemos no quadro 4.3.

\footnotetext{
${ }^{1} \mathrm{Na}$ tradução brasileira: "os traços, as figuras, os objetos do mundo natural, de que constituem por assim dizer o 'significante', acham-se transformados, pelo efeito da percepção, em traços, figuras e objetos do 'significado' da língua, substituindo-se ao primeiro um novo significante, de natureza fonética. É pela mediação do corpo-que-percebe que o mundo transforma-se em sentido - em língua --, que as figuras exteroceptivas interiorizam-se e que a figuratividade pode então ser concebida como modo de pensamento do sujeito" (GREIMAS; FONTANILLE, 1993, p. 13, acréscimo de hifens nossos).
} 
Quadro 4.3 Corpo como espaço-tempo.

\begin{tabular}{|l|l|}
\hline Espaço & Tempo \\
\hline Abertura & Parada da parada \\
\hline Fechamento & Parada \\
\hline Criação de distância & Continuação no tempo (durações) \\
\hline Concentração & Antecipação (sobrevir) \\
\hline Difusão & Previsão (pervir) \\
\hline
\end{tabular}

A separação entre sujeito e objeto, acelerada ou desacelerada, gera arroubos, levando o corpo a sofrer um rompimento: a desaceleração proporciona a reconstituição da junção entre ambos, desmantelado pela aceleração. A participação do corpo na semiótica dá-se pela enunciação, cabendo à atividade enunciativa a tarefa de regular o grau da participação do corpo na constituição do sentido. É nesse cenário que se encontra a semiótica, recebendo atualmente de Zilberberg os frutos do diálogo com o pensamento de Merleau-Ponty, que já recomendava ser preciso

(A) que o pensamento de ciência - pensamento de sobrevoo, pensamento do objeto em geral - torne a se colocar num "há" prévio, na paisagem, no solo do mundo sensível e do mundo trabalhado tais como são em nossa vida, por nosso corpo, não esse corpo possível que é lícito afirmar ser uma máquina de informação, mas esse corpo atual que chamo meu, a sentinela que se posta silenciosamente sob minhas palavras e sob meus atos. [...] (MERLEAU-PONTY, 2004, p. 14, destaque nosso).

(B) Tudo o que vejo por princípio está ao meu alcance, pelo menos ao alcance do meu olhar, assinalado no mapa do "eu posso" (MERLEAUPONTY, 2004, p. 16).

(C) Visível e móvel, meu corpo conta-se entre as coisas, é uma delas, está preso no tecido do mundo, e sua coesão é a de uma coisa (MERLEAUPONTY, 2004, p. 17)

Em (A), o uso da metáfora sentinela mostra um corpo ativo e não passivo, atento ao que se passa ao redor, pronto para as avaliações e resoluções. A ele caberia a guarda do ser, ou da preciosidade de nossa existência, constituída particularmente pelo sentido; em (B), há uma prevalência do sentido do olhar que permite a avaliação de nossas forças (poder); finalmente em (C), Merleau-Ponty chama a atenção para o fato de que somos coisas entre 
as coisas do mundo. Pertencemos, pois, ao tecido do mundo e não se separando ele: sujeito e objeto constituindo um só complexo.

Em $O$ olho e o espírito, última obra em vida, Merleau-Ponty traz de certa forma prenúncios da gramática dos afetos de Zilberberg, quando pondera que "qualidade, luz, cor, profundidade, que estão a uma certa distância diante de nós, só estão aí porque despertam um eco em nosso corpo, porque este as acolhe" (MERLEAU-PONTY, 2004, p. 18, destaques nossos).

O sujeito é, então, acolhedor das qualidades dos objetos, visto que eles "despertam" em nós afetos, ou de repelência ou de atração; para a semiótica, foria, seria um vetor dinâmico que nos leva adiante. Nesse sentido, o objeto é que determina efetivamente o modo de sua apreensão. E aqui a semiótica do contínuo assimila os termos "foria", "sujeito sensível", "tensividade". A partir de De L'imperfection, Greimas incorpora na configuração do sentido a apreensão perceptiva e a estesia. E essa entrada do sensível seria algo pacífico para uma ciência cuja epistemologia é de cunho estruturalista? E a imanência? E como seria a imanência do sensível?

Durante muito tempo, na história do conhecimento, filósofos e cientistas pensaram o estético, o sensível, em meio às turbulências do pensamento objetivista. Vigorava na arte a regra de o artista submeter seu fazer a um fazer semelhante ao mundo observado. Eis aí uma arte destinada por um observador rigoroso, distante, que sanciona o destinatário positivamente se ele cumprir o programa do fazer icástico; nesse caso, valia o regime de representação.

Jacques Rancière (2009, p. 32-33) afirma que "no regime estético da arte, as coisas da arte são identificadas por pertencerem a um regime específico do sensível": "a arte singular", desobrigada da "barreira mimética", cinde as maneiras de fazer arte representativa de outros modos de fazê-la. A seguir, com base em Merleau-Ponty (2006, 2007), Zilberberg (2006b) e Bertrand $(2003,2008)$, focalizaremos a percepção estética nos objetos.

\section{Fé perceptiva no objeto estético agudo: “Retrato de Dom Luís dE GÓNGORA", DE HORÁCIO COSTA}

No texto "Sujeito perceptivo e mundo em Merleau-Ponty", Marcus Sacrini A. Ferraz (2008, p. 193-206) salienta que o pensamento de Merleau-Ponty sobre as relações entre o 
sujeito perceptivo e o mundo alteram-se ao longo de sua obra. Não é a mesma a posição em Fenomenologia da percepção (1945) que em O visível e o invisível, escrito entre 1959 e 1960 e em $O$ olho e o espírito (publicado em Art de France em 1961). Em Fenomenologia da percepção, entende o filósofo que o sentido de nossas experiências não é ordenado por nossa capacidade cognitiva conceitual, mas por habilidades perceptivo-motoras de nosso corpo. Assevera que a direção das experiências por meio dos fenômenos não se concatena pela capacidade intelectiva do sujeito, mas pela percepção intermediada pelo corpo.

Assim, esse "dote mental" como antecipador do sentido cai por terra quando concebemos, por exemplo, recortes culturais do uso do corpo; diferentes modos de vivência perceptiva engajam o sujeito não como controlador e observador do objeto, mas alguém passível de ser invadido por ele.

Uma camada de sentido, da ordem do excesso, ultrapassaria as categorias lógicas e objetivantes, ou seja, existiria um sentido intenso que vai além do que o inteligível pode apreender: trata-se de uma camada de sentido que não é antilógica, mas pré-lógica (FERRAZ, 2008, p. 195). Nesse caso, não haveria uma regência inteligível para ordenar nossa capacidade de captação da experiência sensível. Talvez pudéssemos pensar em retirar do inteligível a primazia sobre a capacidade de antecipar o sentido do sensível: "a riqueza significativa dos fenômenos excede aquilo que as capacidades conceituais usualmente apreendem da experiência" (p. 195). Vejamos um exemplo que Merleau-Ponty apresenta em Fenomenologia da percepção:

O vermelho e o verde não são sensações, são sensíveis, e a qualidade não é um elemento da consciência, é uma propriedade do objeto. [...] Essa mancha vermelha que vejo no tapete, ela só é vermelha levando em conta uma sombra que a perpassa, sua qualidade só aparece em relação com os jogos de luz e, portanto, como elemento de uma configuração espacial. [...] Enfim, este vermelho não seria literalmente o mesmo se não fosse "o vermelho lanoso" de um tapete. A análise descobre portanto, em cada qualidade, significações que a habitam. [...] Nós acreditamos saber muito bem o que é "ver", "ouvir", "sentir", porque há muito tempo a percepção nos deu objetos coloridos ou sonoros. Quando queremos analisá-la, transportamos esses objetos para a consciência. [...] Construímos a percepção com o percebido (MERLEAU-PONTY, 2006, p. 25-26).

Ferraz (2008, p. 197) admite que a ordenação da experiência se faz segundo "regras imanentes ao campo fenomenal, cuja inteligibilidade nascente nada deveria ao aprendizado cultural". Dessa forma, Merleau-Ponty não se reduz a descrever as diversas maneiras de apreender a experiência; o filósofo francês objetiva revelar uma "lógica perceptiva geral", 
que organiza a manifestação sensível do mundo. Embora a citação seja longa, vale a pena retomar um exemplo de Merleau-Ponty (2006, p. 273-274) apresentado na segunda parte de $F P$, "O mundo percebido":

Do ponto de vista de meu corpo, nunca vejo iguais as seis faces do cubo, mesmo se ele é de vidro, e todavia a palavra "cubo" tem um sentido; o cubo ele mesmo, o cubo na verdade, para além de suas aparências sensíveis, tem suas seis faces iguais. À medida que giro em torno dele, vejo a face frontal, que era um quadrado, deformar-se, depois desaparecer, enquanto os outros lados aparecem e tornam-se cada um, por sua vez, quadrados. Mas para mim o desenrolar dessa experiência é apenas a ocasião de pensar o cubo total com suas seis faces iguais e simultâneas, a estrutura inteligível que lhe dá razão. $E$, mesmo para que minha caminhada em torno do cubo motive o juízo "eis um cubo", é preciso que meus deslocamentos estejam eles mesmos localizados no espaço objetivo e, longe de a experiência do movimento próprio condicionar a posição de um objeto, ao contrário é pensando meu próprio corpo como um objeto móvel que posso decifrar a aparência perceptiva e construir o cubo verdadeiro (destaques nossos em negrito).

Haveria, pois, um apelo do "exterior" que desencadeia uma manifestação sensível. Nosso corpo reconstitui as estruturas do mundo como corpo que sente. Merleau-Ponty defende a tese de que nossa capacidade de perceber com o corpo não é mera representação do mundo e de que a percepção é capaz de organizar e apresentar as estruturas do mundo. Ora, esgotar a capacidade de apresentar o mundo intermediado pelo corpo já é linguagem, o que nos leva a considerar a linguagem com pré-requisito para a compreensão do mundo. O sensível já seria regido pela linguagem. Sensações de frio, quente, expressamo-las e sentimo-las, porque conhecemos os recortes de nossa língua natural.

A partir do final a década de 50 , depois de tomar contato com as posições do psicólogo Kurt Koffka, Merleau-Ponty alterou alguns posicionamentos sobre a percepção. As causas da percepção não podem ser confundidas com o que é percebido (cf. FERRAZ, 2008, p. 199-200). Haveria uma diferença entre o que as coisas são e o que se percebe delas. Assim é que entre "mundo" que endereça a percepção e o "objeto percebido" há uma tela do parecer, chamado por Merleau-Ponty de campo fenomenal; é essa tela que hierarquiza os dados sensíveis segundo uma razão que se afasta do positivismo. O que é identidade no mundo natural pode ser alteridade no mundo percebido e o que é alteridade no mundo natural pode ser identidade no mundo percebido: 
qualidade, luz, cor, profundidade, que estão a uma certa distância diante de nós, só estão aí porque despertam um eco em nosso corpo, porque este as acolhe. [...] Eu teria muita dificuldade de dizer onde está o quadro que olho. Pois não o olho como se olha uma coisa, não o fixo em seu lugar, meu olhar vagueia nele como nos nimbos do Ser, vejo segundo ele ou com ele mais do que o vejo (MERLEAU-PONTY, 2004, p. 18, destaque do original).

A hierarquização da percepção não se sujeita a uma simples "decifração objetivante" do mundo natural, deixando de lado a submissão a critérios objetivos. Nesse sentido, o mundo-percebido não se confunde com mundo que estimulou a percepção. Daí que a percepção não é uma encenação perfeita do mundo exterior.

O enunciatário da poesia do final do século XX, particularmente de Affonso Ávila, pode encontrar nela eco da fenomenologia de Merleau-Ponty: a organização do mundo simulada não corresponde exatamente a nossos critérios inteligíveis. No PE, a desorganização perceptiva é que o sensibiliza em primeiro lugar (cf. poesia "Casa de Gonzaga", "Pilar"). Esse desarranjo formal corresponderia a uma visão que a instância da enunciação tem do mundo, um mundo desarranjado. Não haveria razão em ordená-lo objetivamente se tem em vista apresentá-lo sensivelmente. Uma instância da enunciação de valores positivistas, como os de Émile Zola, Flaubert, escolheria um enunciado organizado sintaticamente de forma a simular um mundo objetivo, arranjado, higienizado e apreendido em conformidade com o inteligível.

Se em FP, Merleau-Ponty afirmava que o sujeito era capaz de apreender todo o ser possível, no final dos anos 50, com o curso "As ciências do homem e a fenomenologia", bem como na obra $O$ visível e o invisível, passa a entender que o mundo percebido não se iguala plenamente ao mundo que motiva a percepção (cf. FERRAZ, 2008, p. 201). Ademais, Merleau-Ponty (2007, p. 15 ss), em O visível e o invisível, dialogando com as lições de Koffka, renuncia ao termo "percepção" e assume de vez a expressão "fé perceptiva", que seria uma aderência ao mundo natural sem a segurança intelectiva; o movimento agora orienta-se para as experiências vividas segundo um sujeito que sente seu objeto, mas não tem controle sobre ele, porque o objeto lhe escapa.

É a fé perceptiva que dá acesso ao mundo, mas nem sempre, pois que muitas vezes obscurece esse mesmo mundo, que então não pode ser apreendido facilmente. $\mathrm{O}$ sujeito jamais pode ter garantias de que sua percepção exaure a compreensão do objeto. Dessa 
forma, a fé perceptiva seria uma "porta" para o mundo natural que paradoxalmente não elimina a possibilidade de opacidade do ser.

Como estamos vendo, Merleau-Ponty ocupa-se com uma filosofia apoiada no corpo e no mundo percebido. Sua filosofia é um caminho aberto e inacabado, uma interrogação contínua, que faz do sujeito um ser maravilhado, como se estivesse sempre tomando contato com o mundo sensível pela primeira vez. Contrapõe-se ao cartesianismo, paradigma do pensamento objetivo, e afasta-se, portanto, de um pensamento que seja transparente, que não permite o enigma. Para ele, o essencial origina-se da experiência que não se reduz a uma construção puramente intelectiva. O mundo não se limita ao que pensamos ser o mundo. E nesse sentido a semiótica, tendo em vista uma poesia fluida e de contornos desmanchados, como a de Affonso Ávila ([1975] 2008a) em Cantaria barroca, volta seus olhos para a fenomenologia, mas seu objeto e metodologia são próprios e diferentes dos da filosofia; enquanto seu interesse concentra-se na linguagem e no engendramento de sentido, a filosofia tem em vista apresentar discussões ao longo da história do conhecimento.

Ao tratar da figuratividade e da percepção, Bertrand (2003, p. 234 ss) vai buscar no conceito greimasiano de tela do parecer subsídios para suas considerações sobre a guinada que a semiótica deu a partir de De l'imperfection (1987): o sentido estaria a partir daí atrelado ao sensível e a seu julgamento estético.

Subjacente ao conceito de tela do parecer temos um CRER "verdadeiro", que se fundamenta em um contrato enunciativo que estabelece um mundo textual. Com base nesse contrato, as figuras que surgem no texto não são engendradas no sentido pacífico de representação do mundo natural; antes, essas figuras escolhidas têm em vista polemizar e obnubilar o enunciado, configurando uma arena semiótica que lhe é própria. E essa tensão semiótica consiste não em permitir uma visibilidade do objeto, mas em deixar vê-lo sob a tela do parecer. Assim, o contrato enunciativo vigora com base na fidúcia, que é um gesto de crença, de confiança.

Bertrand (2003, p. 250) aproxima o conceito fenomenológico de fé perceptiva do conceito semiótico de crer. Esclarece ainda que esse conceito se articula em duas modalidades:

1. Uma centrada no objeto formado na percepção, com características "noemáticas", que dizem respeito às modalidades aléticas dos lógicos. A 
estrutura modal alética é produzida por um enunciado modal regido pelo dever (GREIMAS; COURTÉS, 1983, p. 17): necessidade (dever ser), impossibilidade (dever não ser), possibilidade (não dever não ser), contingência (não dever ser); o real, o necessário, o possível, o duvidoso, o contingente etc.

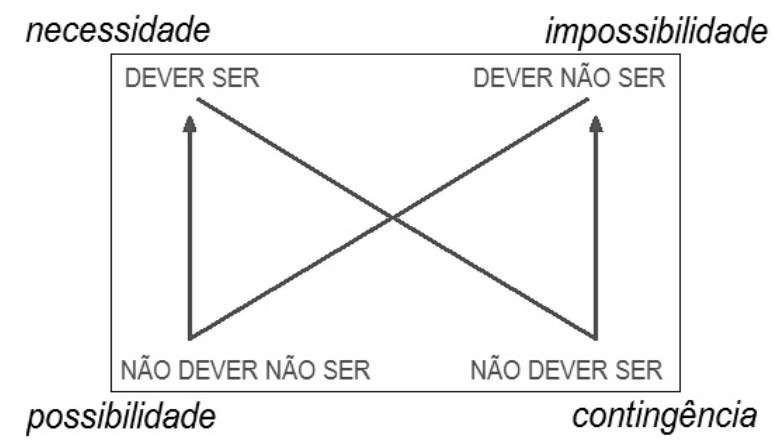

2. Outra centrada no CRER do sujeito e não mais no objeto, noutros termos, fundase na maneira de apropriar-se do objeto que percebe. As modalidades epistêmicas tratam da competência do sujeito que, com base em seu fazer interpretativo, assume sua posição intelectiva. Desse modo, a avaliação epistêmica pelo sujeito consiste em assumir o noumenon a partir do fenômeno interpretado com base no contrato de crença, o fiduciário (cf. GREIMAS; COURTÉS, 1983, p. 151). Agora, as características dessa crença são "noéticas", isto é, dizem respeito às modalidades epistêmicas da lógica: crença certa, crença conjectural, crença provável etc.; certeza (crer ser), improbabilidade (crer não ser), probabilidade (não crer não ser), incerteza (não crer ser).

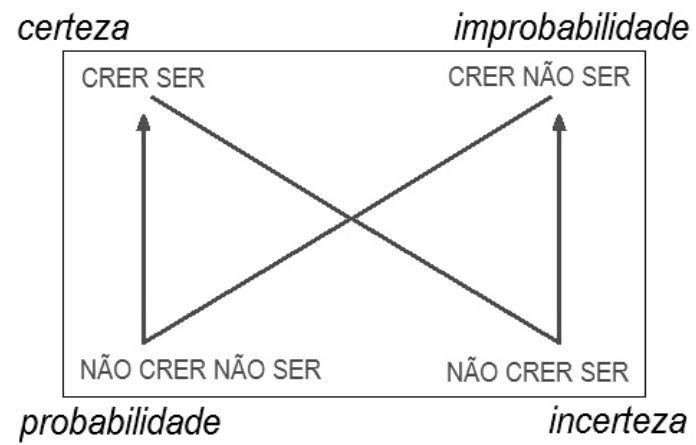

Diferentemente das modalidades aléticas em que podemos notar no exemplo entre possivel/impossivel, caracterizadora de uma contradição que excluiria um terceiro termo, para Greimas e Courtés (1983, p. 151) a modalidade epistêmica comporta oposições 
graduais e relativas, aproximando-se da semiótica do contínuo. O CRER da modalidade é para Bertrand (2003, p. 251) bivalente, ou seja, há duas ordens de crença que regem a fidúcia:

- A primeira é de cunho intersubjetivo, em que enunciador e enunciatário são solidários, compartilhando a realização discursiva do objeto; temos aqui um CRER da doxa partilhado culturalmente.

- A segunda é de cunho intrassubjetivo, visto que "enuncia as condições para a adesão do sujeito da percepção ao parecer sensível" (BERTRAND, 2003, p. 252); temos aqui um CRER dóxico regido pela crença intersubjetiva.

Em "A linguagem espacial em La Bête Humaine", Bertrand (2008, p. 148) focaliza novamente o estatuto da figuratividade e considera-a um conceito operatório da teoria da linguagem, distinguindo dois níveis: (a) uma figuratividade de superfície, que simula o mundo natural e oferece-o ao enunciatário; (b) uma figuratividade mais profunda, de ordem tensiva, denominada por Zilberberg (2006b, p. 147) de figural, que oscila segundo a crença estabelecida; os efeitos de verdade construídos asseguram sua credibilidade. É pois com base nesses conceitos que Bertrand confronta duas estações ferroviárias, uma de Zola, estação Saint-Lazaire na obra La bete humaine, e outra de Claude Simon, extraída de L'Acacia.

Considerando a estação de Zola, Bertrand (2008, p. 152) examina o modo de funcionamento da realidade perceptiva exposta no texto, cuja a forma se embasa em projeto filosófico de inteligibilidade caracterizado pela simulação de reprodução de estruturas da realidade. Aqui, o inteligível sustenta-se com apoio no sensível e este último parece mais "real" quando se confirma pelo inteligível. Trata-se de uma crença atenuada. A instância da enunciação em Zola vale-se de um saber suficiente e competente para enunciar discursivamente a realidade.

Diferentemente de Zola, o texto de Claude Simon caracteriza-se por um "golpe de força nas formas sedimentadas pelo uso, ao se fazer desligar das figuras sensíveis que a tradição discursiva da percepção apresentava, isoláveis e unificadas, como 'evidentemente' nomeáveis" (BERTRAND, 2008, p. 154). Em Zola, a descrição produz efeito de sentido de realidade, é icástica, preocupada em constituir para o enunciatário um simulacro da estação ferroviária; já em Simon, a nitidez desfaz-se em fluidez, dando lugar a uma estação 
obnubilada, marcada por uma instância da enunciação que se vale de um saber insuficiente para enunciar o que vê. É de visão opaca, da ordem do fantástico, cujo efeito de sentido não é só de explorar fantasia, mas também de apresentar pela distorção outra visão do objeto.

No primeiro caso, há a existência de um saber suficiente, enquanto no segundo, o saber é substituído por um crer e, nesse caso, temos, então, uma "percepção irrefletida, sujeita ao movimento de uma 'fé perceptiva'” (BERTRAND, 2008, p. 156).

\section{Estação de Zola}

Debaixo dos alpendres das linhas principais, a chegada de um comboio de Mantes animara o cais, e ele seguiu com os olhos a máquina de manobras, uma maquinazinha tender, de três rodas baixas e emparelhadas, que começava o desmanchar do comboio, ativa, mexida, levando, empurrando os vagões para as vias de armazenagem. Outra máquina, essa mais poderosa, máquina de expresso, com duas grandes rodas devoradoras, estacionava isolada, lançando pela chaminé uma grossa fumaça preta, que subia direta e vagarosa, no ar tranquilo. Mas toda a sua atenção foi atraída pelo comboio das três e vinte e cinco, com destino a Caen, já cheio de viajantes e que esperava apenas pela máquina. Não podia ver esta máquina, pois estava parada além da ponte da Europa; ouvia-a apenas pedir passagem, com pequenos silvos apressados como alguém que começa a impacientar-se. Foi dada uma ordem, ela, com silvo breve, mostrou que compreendera. Depois, antes de pôr-se em marcha, foram abertas as válvulas da frente, o vapor silvou rasando o solo num jato ensurdecedor. E viu então aparecer por cima da ponte aquela brancura que se alastrava, redemoinhante como uma penugem de neve, voando através das armações de ferro. Um bom espaço ficou branco de vapor, ao passo que o fumo sempre crescente da outra máquina alargava o seu véu negro. Por detrás, abafavam sons prolongados de cornetas, vozes de comando, abalos de plataformas gigantes. Produziu-se um rasgão, e ele distinguiu, ao fundo, um comboio de Versalhes e outro de Auteuil, um ascendente e outro descendente, cruzando-se (ZOLA, Émile. A besta humana. Tradução de

\section{Estação de Simon}

A um só tempo aérea e monumental, avançando mais lentamente como que levada por uma nuvem, com os jatos de vapor fundindo-se entre as bielas cobertas de óleo amarelecido, sacudindo o solo sob sua massa, puxando, atrás de si, um conjunto de vagões de um modelo antigo tirados dos depósitos em que eram conservados, talvez à espera desse dia (feitos de madeira, pintados de uma cor marrom descascada e providos de um bagageiro em cada uma de suas extremidades), a locomotiva entrou com um rumor surdo sob a vidraça da estação onde, na plataforma, se acotovelava uma multidão compacta cuja primeira fila recuou um passo ao vêla aproximar-se, não propriamente por medo de ser consumida pelo vapor ou cair sob as rodas, mas por uma espécie de horror instintivo, de intuitivo instinto de repulsão que lhe ordenava conservar, pelo maior tempo possível entre si e a parede vertical dos vagões, que desfilavam cada vez mais lentamente, um ilusório e último intervalo de vida, como um fosso, um estreito vale, ou melhor, uma invisível muralha, um invisível paredão para além do qual, uma vez transposto, seria perpetrado algo de irremediável, definitivo e trivial (SIMON, Claude. L'Acacia. Paris: Éd. Minuit, 1989. p. 153-154. In: BERTRAND, 2003, p. 129, destaques nossos). 
Eduardo Nunes Fonseca. São Paulo: Hemus, 1982. p. 5-6. In: BERTRAND, 2003, p. 128129).

$\mathrm{Na}$ descrição das duas estações, temos em Zola um enunciador que assume a "verdade" do que vê; o mundo narrado é ordenado pelo saber, competência do enunciador. Em Simon, ao contrário, o enunciador opta por não fazer ver o que enuncia, escolhendo um espaço impreciso, opaco, regido pela dúvida e pela crença (cf. BERTRAND, 2003, p. 130):

- Enunciador em Zola - fonte do saber, vigilante do conhecimento, o sujeito organiza-se, tendo o controle do objeto.

- Enunciador em Simon - fonte do crer; observa-se um enfraquecimento do sujeito, que se abala diante do objeto e, por isso, as figuras construídas não apresentam delineamento nítido. O objeto escapa do sujeito dada a sua fluidez.

De igual forma, comparando um poema parnasiano com um poema de agudeza do final do século XX, de Horácio Costa, observamos a mesma ocorrência:

\begin{tabular}{|c|c|}
\hline "A volta da galera" de Alberto de Oliveira & $\begin{array}{l}\text { “O retrato de Dom Luís de Góngora" de Horácio } \\
\text { Costa }\end{array}$ \\
\hline $\begin{array}{l}\text { Quase em Corinto. As velas esquisitas, } \\
\text { Purpúreas velas de real trirreme, } \\
\text { Pandas ondulam; a água escura freme } \\
\text { E ouve-se a espaço a voz dos talamitas. } \\
\text {-- Praias do iônio mar, sede benditas! } \\
\text { A torre vejo e a luz que vela e treme; } \\
\text { Frínia me espera e desolada geme, } \\
\text { Do alto encarando as águas infinitas. } \\
\text { Tal ao compasso de impelidos remos } \\
\text { Ouvia a noite alguém que velejava, } \\
\text { A alma espraiando em lágrimas e extremos; } \\
\text { E perto as praias nítidas medindo, } \\
\text { Curvas, sem termo, a sombra meditava. } \\
\text { Do ombro a clâmide aos ventos sacudindo. } \\
\text { (OLIVEIRA, Alberto. In: MolsÉS, 1976, p. 219.) }\end{array}$ & $\begin{array}{l}\text { cara de vampiro, nariz boxeado pela vida, } \\
\text { stiffness, teu legendário orgulho desmesurado, } \\
\text { sem ironia ou sorriso a boca nos cantos desce, } \\
\text { não vejo tuas mãos, estarão escrevendo, } \\
\text { estarão manipulando o ábaco da sintaxe, } \\
\text { preocupado te vejo em encontrar tesouros } \\
\text { dormentes, na folha branca brilham larvais, } \\
\text { e já fixos me perfuram teus olhos de esfinge, } \\
\text { que imitam tuas orelhas em leque, teu manteau } \\
\text { absoluto, mole de lã ou veludo, sempre Diretor } \\
\text { dum hospital barroco antes do Grand Renfermement, } \\
\text { para quem posas, cantas o Esgueva do pensamento } \\
\text { de teus contemporâneos, o radical suspiro da Natureza } \\
\text { em cio profundo, linguagem láctea, campo blau, } \\
\text { e me avalias, por fora Ácis, por dentro Polifemo, } \\
\text { assim é o mundo Dom Luís, para mim estás posando, } \\
\text { pré-kafkiana barata insigne vai de ante em ante-sala, } \\
\text { paciente expõe seu elástico decoro enfático, tanto } \\
\text { tens que suportar, por fora Hyde, por dentro tão menino, } \\
\text { pois és menino e más allá da moldura deste quadro } \\
\text { como os negros falas - é de noite que em pérola } \\
\text { se transforma a banalidade, e tua calva preenche } \\
\text { o céu, cede o vazio, e tua palavra uma berceuse escapa. } \\
\text { (In: DANIEL, 2004a, p. 85.) }\end{array}$ \\
\hline
\end{tabular}


Em Alberto de Oliveira, tal como em Zola, temos um enunciador que simula objetividade, pretende mostrar o "visível". Seu olhar segue as velas purpúreas, assegurando que as velas pandas estão ondulando, que a água está escura. Garante ainda que se ouve "a voz dos talamitas". Sua presença na cena fá-lo ouvir até mesmo uma voz que diz: "Praias do iônio mar, sede benditas!" Introduz-se na cena e diz que vê a torre e a luz da vela que treme. A narrativa é erigida segundo um saber suficiente e seguro, garantindo ao enunciatário a posse do visível. Em seguida, antropomorfizando a noite, assegura que ela ouvia uma voz de alguém em prantos.

Finalmente, o saber ganha amplitude, não deixando margem à descrença ou à dúvida. O enunciador tem um saber onisciente, penetrando até mesmo na consciência do ator (personificado em sombra) em prantos: "a sombra meditava". Trata-se, pois, de um enunciador absolutamente seguro e controlador do objeto, capaz de representar, simulando um efeito de "realidade". No poema parnasiano, o conhecimento, proporcionado pela visibilidade dos objetos na cena, configura-se pela certeza do SABER.

Diferentemente, no retrato de Luís de Góngora, de Horácio Costa, a visibilidade é apenas uma possibilidade do conhecimento, entrando em cena o visível e o invisível. Agora, o jogo tensivo ganha intensidade por meio da fé perceptiva, ou seja, entre o olhar e o saber há um intervalo. E esse intervalo é ocupado pelo CRER. O crer da fé perceptiva encaminha a nitidez para o fluido, o visível para o invisível. É esse crer da percepção que nos conduz à distinção entre objetos vistos e sujeitos que veem. Se não fosse a fé perceptiva, talvez estivéssemos irremediavelmente imersos na massa amorfa do mundo e confundidos com os próprios objetos, bem como estaríamos impossibilitados de pronunciar o visível. Além disso, a fé perceptiva implica a existência de um contrato de crença, que se apoia na existência da própria linguagem.

Tomemos o poema "O retrato de Dom Luís de Góngora" de Horácio Costa e observemos a posição do enunciador diante dos objetos enunciados. A imagem "cara de vampiro" busca atualizar o pouco visível: a vívida metáfora aguda "nariz boxeado pela vida" apresenta-se como uma escolha pela opacidade semântica; em seguida, o enunciador acrescenta à imagem do "nariz boxeado" o aposto stiffness, que quer dizer "nariz rígido" e que pode ser lido em duas direções, a da descrição fotográfica de um órgão rígido e a direção erótica. 
Ao longo do poema, o enunciador mantém a posição não de quem é capaz de tomar posse do objeto e de seus contornos pelo saber, visto que vê, mas de quem opta por dizer o que vê segundo uma linha de intensidade e não de extensidade, colocando em jogo o visível e o invisível. É por isso que diante de enunciados como "teu legendário orgulho desmesurado, sem ironia ou sorriso, a boca nos cantos desce", o enunciatário é convocado a aproximar-se para formar uma imagem por meio das valências perceptivas. A tonicidade é vívida, não sendo possível detectar os contornos do objeto.

Não é o Góngora em carne e osso que está sob a mira do enunciador, mas o retrato discursivo que faz dele um grande artista do chamado barroco. Valendo-se do mesmo processo discursivo de Góngora, que compreende figuratividade antitética, metáforas agudas e hipérbatos, Horácio Costa passeia por toda a obra de Góngora:

- Figuratividade antitética: "por fora Ácis, por dentro Polifemo"; "barata insigne (grandiosa)"; "por fora Hyde, por dentro tão menino"; "é de noite que em pérola / se transforma a banalidade"; "tua calva preenche / o céu cede o vazio".

- Metáforas agudas: "ábaco da sintaxe"; "linguagem láctea”.

- Hipérbatos: "sem ironia ou sorriso a boca nos cantos desce"; "preocupado te vejo em encontrar tesouros / dormentes"; "e já fixos me perfuram teus olhos de esfinge".

Essas figuras retóricas têm como função atualizar a manifestação discursiva gongorina. Nesse sentido, as constantes alusões à obra de Góngora são escolhas que visam à constituição desse retrato: "em cantas o Esgueva do pensamento de teus contemporâneos", reconhece-se uma referência direta a um trecho de Soledades; em "por fora Ácis, por dentro Polifemo", dá-se uma referência a obra Fábula de Polifemo e Galateia.

Em vez de uma somatória de qualidades sensoriais, o retrato de Góngora vai-se constituindo por percepções organizadas pela fé perceptiva, ou seja, dando-se por reconstituições, que se perfazem como ausências, que são da esfera do invisível. O contrato fiduciário estabelecido com o enunciatário é que permite uma recomposição do artista espanhol moldada pela palavra. "Legendário orgulho desmesurado" possibilita a simulação discursiva de um objeto que escapa ao controle: lenda designa "toda narrativa em que um fato histórico se amplifica e transforma sob o efeito da imaginação popular. Não raro, a 
veracidade se dissipa no correr do tempo, deixando subsistir apenas a versão folclórica dos acontecimentos" (MOISÉS, 2011, p. 259). Aceitar como legendário é afirmar o crer e não o saber. Daí o objeto escapar ao sujeito. A posição de dúvida do enunciador diante de seu objeto continua: "não vejo tuas mãos, estarão escrevendo, / estarão manipulando o ábaco da sintaxe".

Todo o enunciado se constrói na imaginação do sujeito, diferentemente, pois, do enunciador de "A volta da galera", que se vale, como um físico, do telescópio para simular com precisão a realidade. Parece querer alcançar o distante como se estivesse próximo. 0 poeta agudo de "O retrato de Dom Luís de Góngora" visa à formação de uma imagem do estado de alma do retratado. Assim é que diz vê-lo "manipulando o ábaco da sintaxe", numa configuração de um artista ocupado do jogo de linguagem.

Comparando Horácio Costa com Alberto de Oliveira, notamos aí uma diferença fundamental: enquanto o primeiro apoia-se em apresentar um objeto invisível, fluido, voltando-se para o crer do contrato enunciativo fantasioso, o segundo vê o objeto poético como mimesis do mundo, algo possível de se apreender icasticamente, tornando-se visível.

Em Horácio Costa, as sensações mais diretamente ligadas à percepção de ver o "real" ("vejo tuas mãos" / "te vejo em encontrar tesouros dormentes") direcionam o enunciado à esfera do não visível. E é esse modus operandi, acentuado na intensidade que apresenta um objeto que escapa, que se dilui diante do sujeito. E, por desligar-se da percepção do visível, penetra no figural (não no figurativo) da esfera das escolhas tensivas do poeta espanhol. 0 retrato de Góngora agora é muito mais vívido e sensível do que se o enunciador tivesse optado por arrolar escolhas paradigmáticas descritivas das percepções como possibilidade do saber e do conhecimento. Estamos aqui mergulhados na seara dos afetos que direcionam o objeto com muito mais força para um encaminhamento estético. Em vez da realidade plana, direta, superficial, a afetividade aproxima-se da crença perceptiva.

O poema de Horácio Costa revela-se, pois, um objeto estético justamente por afastar-se da esfera do saber cognitivo e direcionar-se à esfera do crer, da fé perceptiva, portanto. A postura do enunciador, diante de uma reprodução pictórica de Góngora, é de tecer com palavras a imagem do objeto que tem em mãos; nesse objeto, contempla nariz, boca, mãos, olhos, orelhas, calva, mas o retrato que pinta distancia-se do que vê, pois o que vê não é o que vê; vai além da figuratividade. Nesse sentido, acaba jogando o mesmo jogo de Góngora, escondendo no processo sintagmático o que tem a dizer. Daí nos versos "na 
folha branca brilham larvais, / e já fixos me perfuram teus olhos de esfinge", o enunciador revelar imagens de Góngora que são tão vívidas e mais tonificadas (brilham larvais = aterrorizam e maravilham esteticamente) que lhe perfuram os olhos.

O poder criativo do poeta agudo faz ver uma realidade invisível aos olhos do enunciatário. A metáfora da esfinge direciona o enunciado para a simulação de um ser enigmático, misterioso, devorador de quem não consegue decifrar o mistério proposto pela esfinge (HOUAISS; VILLAR, 2001, verbete esfinge). Nesse sentido, a postura do enunciador diante da literatura é crítica: os poemas agudos, da ordem da fluidez e não dos contornos definidos, solicitam um enunciatário pressupostamente apto para dirimir os enigmas e não ser engolido pela esfinge.

As metáforas seguintes ocupam-se de transmitir a postura altiva de Góngora e do seu fazer poético: "teu manteau / absoluto, mole de lã ou veludo, sempre Diretor / dum hospital barroco antes do Grand Renfermement, / para quem posas"; "cantas o Esgueva do pensamento / de teus contemporâneos, o radical suspiro da Natureza / em cio profundo"; "linguagem láctea". O que se nota aí é um desencadeador de isotopias, que figurativiza um fluxo contínuo, permitindo a passagem da isotopia de corrente fluvial, rio que corre, para a isotopia metalinguística, o fluxo de sua arte. Esgueva, conector de isotopia, é um rio da Espanha, bem como faz alusão ao poema de Góngora, em que canta o rio Esgueva, "Qué lleva el señor Esgueva?"2.

Ainda dentro da isotopia da natureza, podemos observar que a figura de "via láctea" transforma-se em "linguagem láctea", que é ao mesmo tempo linguagem leitosa, que contribui para a opacidade do objeto sensível, bem como para a figurativização de linguagem mãe, que alimenta os poetas da tradição viva do final do século XX. Além disso, a metáfora "linguagem láctea" também nos revela tratar-se de linguagem luminosa, advinda

\footnotetext{
${ }^{2}$ Trechos do poema: "Qué lleva el señor Esgueva? / Yo os diré lo que lleva. // Lleva este río crecido, / y llevará cada dia, / la cosas que por la vía / de la cámara han salido, / y cuanto se ha proveído, / según leyes de Digesto, / por jüeces que, antes desto, / lo recibieron a prueba. / Qué lleva el señor Esgueva? / Yo os diré lo que lleva. // Lleva el cristal que le envía / una dama y otra dama, / digo el cristal que derrama / la fuente de mediodía, / y lo que da la otra vía, / sea pebete o sea topacio, / que, al fin, damas de palacio / són ángeles hijos de Eva. / Qué lleva el señor Esgueva? / Yo os diré lo que lleva.// Lleva lágrimas cansadas / de cansados amadores, / que, de puro servidores, / son de tres ojos lloradas; / de aquel, digo, acrecentadas, / que una nube le da enojo, / porque no hay nube de este ojo / que no truene y que no llueva. / Qué lleva el señor Esgueva? / Yo os diré lo que lleva// [...] Lleva, sin tener su orilla / árbol ni verde ni fresco, / fruta que es toda de cuesco, / y, de madura, amarilla; / hácese della en Castilla / conserva en cualquiera casa, / y tanta ciruela pasa, / que no hay quien sin ella beba. / Qué lleva el señor Esgueva? / Yo os diré lo que lleva" (Disponível em: www.upf.edu/todogongora/poesia).
} 
de via láctea, que é uma galáxia em espiral da qual o Sol faz parte. Nosso enunciador intensifica e atualiza suas paixões, estabelecendo um diálogo com Góngora: "assim é o mundo, Dom Luís, para mim estás posando".

Novamente, diferentemente de Alberto de Oliveira, que não participa do objeto construído, em Horácio Costa o sujeito é tocado pelo objeto, que o invade e é por ele ativado. Sujeito e objeto aproximam-se, considerando que o intervalo entre o olhar e a "coisa olhada" é regido pela modalidade do /crer/, da fé perceptiva, que lhe permite estabelecer uma relação de confiança e não de saber suficiente e certo, pois que o sujeito está enfraquecido e titubeante.

Por isso, afirma nos versos seguintes ter em mãos um objeto que é ao mesmo tempo coisas tão opostas: "por fora Hyde, por dentro tão menino". A metáfora "por fora Hyde" convoca no enunciado o ator Mr. Hyde do livro O médico e o monstro (1885), de Robert Louis Stevenson. O ator discursivo Hyde é produto de observações científicas e rigorosas do médico Jekyll, que acreditava ter pleno controle sobre o objeto. Até aqui estamos na esfera do sujeito que tem pleno SABER para controlar o objeto (cf. Zola e Alberto de Oliveira). Entretanto, o objeto, ator Mr. Hyde, escapa ao controle do observador científico (o médico), dominando-o. Tendo invadido o sujeito, a narrativa ganha em intensidade, aproximando-se dos objetos sensíveis estetizados, como o trecho da "Estação de Simon" e o poema de Horácio Costa.

Paradoxalmente, Góngora é uma somação aguda de Hyde e de "menino". A figura menino revela uma isotopia de ingenuidade, de leveza, capacidade de admirar-se com as coisas, aproximando-se da fantasia, e a de monstro desperta assombro.

O retrato pintado por Horácio Costa é constituído por cores fortes, acentuadas, que antes que reproduzir estática e distantemente a figura de Góngora, fá-lo de modo vívido e próximo do sujeito. Ao mesmo tempo que se aproxima do sujeito, não permite um controle total do visível, como ocorreu com Dr. Jekyll e Mr. Hyde. O sujeito da enunciação no poema mostra tensivamente a impossibilidade de um controle vigilante sobre o objeto.

Nos três últimos versos, deparamos com metáforas relacionadas ao fazer poético: elas mantêm a ambiguidade antes que precisar os limites semânticos. A isotopia de obscuridade é convocada para esclarecer o processo artístico. O literário brotaria não de temas grandiloquentes, mas do fazer engenhoso do poeta: "é de noite que em pérola / se transforma a banalidade". Para transformar-se em pérola seria preciso convocar a noite, ou 
seja, o enunciado poético não convive bem com a transparência da luz do dia, pois a opacidade lhe é inerente.

Finalmente, a isotopia da musicalidade revela-se pela metáfora "berceuse escapa". Das palavras de Góngora escapam poesias que são como uma "berceuse" (do fr., significa acalanto, cantilena, cantiga de ninar, de embalar, cf. PETIT ROBERT, 2008). E mais uma vez temos o objeto encantando e embalando o sujeito.

Vejamos agora na poesia de Horácio Costa duas ocorrências no PE que corroboram a fluidez no PC: (a) abrir o enunciado poético com letra minúscula e prosseguir assim até o final do poema; (b) não utilizar ponto final em nenhum momento, exceto no final do último verso.

- Em (a), a pouca ênfase no PE pelo uso das letras minúsculas dá intensidade ao PC do retratado: essa escolha faz sobressair o retratado e obnubila, de certa forma, o enunciador, dando-Ihe menor acentuação; ele parece querer passar despercebido ou reduzido em relação a Góngora. Além disso, a opção pela letra minúscula confirma continuidade no $\mathrm{PE}$, não havendo parada que anuncia quebra e origem dos versos; no poema de Costa, pela linearidade, temos um grande verso único; nesse sentido, temos um só ponto final no término do enunciado.

- Em (b), a ausência de ponto final em todo o poema, com exceção do último verso, reforça a fluidez dos contornos e a ausência de quebras e limites dos versos tradicionais, simulando um acúmulo de vivificação sensorial na busca do retrato de Góngora, que sempre escapa, acentuado por uma sonoridade que se soma à ausência de paradas que o ponto final causaria no PE. O poema seria apenas um fio, semelhando o fluxo de um rio, contínuo e sem paradas, o que reforça certa continuidade reguladora do fluxo poético que atualiza Góngora ao longo da história da literatura. A expansão discursiva do poema não se faz pela ruptura, não havendo retorno ao passado, o que configuraria uma parada no tempo presente e retorno ao tempo anterior; antes, temos um "passado presente" que escorre sem interrupção. Ocorre que o conjunto de verbos no tempo presente do indicativo forma uma cadeia que presentifica e imortaliza o "retrato de Góngora": "a boca nos cantos desce"; "não vejo tuas mãos"; "preocupado te vejo"; "na folha branca brilham 
larvais"; "me perfuram teus olhos de esfinge"; "que imitam tuas orelhas em leque"; "para quem posas, cantas o Esgueva"; "me avalias"; "para mim, estás posando"; "expõe seu elástico decoro"; "tanto tens que suportar"; "pois és menino"; "como os negros falas"; "tua calva preenche"; "cede o vazio"; "uma berceuse escapa". Não temos, pois, o retrato de um poeta morto, uma imagem do passado, mas a vivificação de um artista sempre atual. No poema de Horácio Costa, nota-se, portanto, versos que presentificam Góngora, simulando as águas de um rio que escorrem ininterruptamente e desembocam na tradição viva. Outrossim, a essa aparente atenuação da tonicidade na intensidade, engendrada pela descrição estática dos particípios, somam-se a força da dinamicidade dos gerúndios. Eis uma mola tensiva que leva o poema de Costa adiante:

\begin{tabular}{|l|l|}
\hline Particípio & Gerúndio \\
\hline "teu legendário orgulho desmesurado" & $\begin{array}{l}\text { "tuas mãos, estarão escrevendo, estarão } \\
\text { manipulando o ábaco da sintaxe" }\end{array}$ \\
\hline "preocupado te vejo" & "para mim, estás posando" \\
\hline
\end{tabular}

Sinteticamente, concluímos que a continuidade impera no poema "O Retrato de Dom Luís Góngora". O tempo desenrola-se à frente do enunciatário, em um movimento caudaloso, determinado por uma presentificação de temporalidade originante, com verbos no presente e no gerúndio. $O$ andamento do poema estabelece-se segundo uma tensão entre a estaticidade, mais desacelerada, requerida pela descrição de um retrato, e a dinamicidade, mais acelerada, da narrativa que compõe as ações de Góngora.

Essa tensão entre dinâmico e estático também pode ser observada no fechamento produzido pela acentuação na intensidade com o uso do artigo definido em "o retrato", "으 ábaco da sintaxe" e "o radical suspiro da natureza" e na abertura produzida pela atenuação da intensidade devida ao plural em "encontrar tesouros dormentes", "pensamento de teus contemporâneos", bem como pelo uso intemporal em "é de noite [compreende todas as noites de qualquer tempo] que em pérola se transforma a banalidade". Nota-se ainda uma oposição entre o fechamento produzido pelo artigo definido em "o retrato" e uma abertura no sintagma do último verso produzida pelo artigo indefinido "uma berceuse escapa". 
Finalmente, essa tensão entre estático e dinâmico produz um efeito de sentido que reflete no próprio fazer poético: nesse caso, Góngora não se estatiza no século seiscentista, mas transborda e atualiza-se no poema de Horácio Costa, que seria uma amostra das produções da tradição viva.

Até aqui, focalizamos a fluidez dos objetos segundo o namoro com a fenomenologia, que é responsável também pela mudança de perspectiva na observação da relação sujeito/mundo natural. Vejamos a seguir outras considerações igualmente originadas da visada fenomenológica que a semiótica tem revisitado. Nesse sentido, o conceito de semiocepção é de total pertinência.

\section{Semiocepção de Beividas: o sensível e o inteligível em “)Lacraias”, de Haroldo de Campos}

Beividas (In: MARCHEZAN; CORTINA; BAQUIÃO, 2011, p. 13-33), no texto "A dimensão do afeto em semiótica: entre fenomenologia e semiologia", trata da dimensão do afeto e do sentido. Entende que o jogo entre fenomenologia e semiótica é "uma boa partida", mas que precisa ainda ser jogada (p. 32). Segundo ele, tem sido comum na pesquisa atual a expressão tournant phénoménologique, ou seja, virada fenomenológica. Discute a aspectualidade terminativa de "virada", propondo então o termo "viragem", visto que o diálogo entre fenomenologia e semiótica é um processo cujo percurso mal se iniciou. Daí preferir entender esse momento como o de uma "mirada fenomenológica" (p. 14).

Para ele, o risco de assumir uma virada fenomenológica seria o de abandonar o imanentismo do texto, partindo para a primazia do sensível sobre o inteligível; esse deslocamento poderia levar ao "esquecimento" de algo inaugurado por Saussure que é primordial à semiótica: o papel essencial do arbitrário da fundação dos signos (p. 15). Mais do que um princípio, a arbitrariedade parece constituir-se em estatuto de "um autêntico ato e pacto semiológico" (p. 15). O ato semiológico seria um estatuto epistemológico pressuposto ao ato da percepção. Toda percepção do mundo fenomenal seria antecedida, então, por um ato semiológico; daí sua primazia epistemológica sobre os afetos, ou seja, a percepção do sensível só pode ser apreendida por um ato semiológico.

É pela semiose que o "sujeito falante descobre ou inventa o mundo a ser-lhe então o seu mundo percebido. A língua, via semiose, guia a percepção via sentidos" (BEIVIDAS In: MARCHEZAN; CORTINA; BAQUIÃO, 2011, p. 31, destaque nosso). O sujeito não percebe pelos órgãos do sentido, mas segundo a organização de sua língua natural, ou seja, percebe 
apenas "aquilo a que a sua linguagem o levou a categorizar" (p. 31). Daí a percepção humana ser antes de tudo uma semiocepção.

A semiose é entendida aqui segundo o sentido simples do conceito saussuriano de ato semiológico, isto é, relação entre PE e PC. Língua é forma e toda substância é recortada por uma forma. Se falamos de forma, falamos de substância, conceitos que se separam apenas para efeito de análise. O conceito de semiose está relacionado, portanto, ao da convenção, da arbitrariedade do signo (SAUSSURE, 1996, p. 81; cf. BEIVIDAS In: MARCHEZAN; CORTINA; BAQUIÃO, 2011, p. 26).

Qualquer signo poderia "designar" qualquer coisa. Banana para um falante da língua italiana do Vêneto tem um recorte mais restrito do que o dos brasileiros. Enquanto recortamos o continuum em /banana-maçã/, /banana-prata/, /banana-nanica/, /bananaouro/, /banana-da-terra/, os venezianos recortam apenas /banana/. Isso, todavia, não impede que a partir de determinado momento a língua passe a fazer novos recortes. Portanto, como estamos vendo, não é a percepção que antecede o ato semiológico, mas é este último que direciona a percepção, constituindo-se, como diz Beividas, em "semiocepção" (p. 31).

Embora para pesquisadores saussurianos, a língua não seja uma etiqueta, Ivã Lopes (In: MARCHEZAN; CORTINA; BAQUIÃO, 2011, p. 103) afirma que "essas noções, hoje um tanto óbvias para os pesquisadores da área, ainda estão, contudo, longe de penetrar no senso comum e podemos nos indagar se aí penetrarão um dia". Em 1956, Greimas já notava, em "A atualidade do saussurismo", que Merleau-Ponty havia superado a dicotomia pensamento e linguagem e colocava o sentido como imanente à forma linguística.

A reflexão fenomenológica apoiada em Merleau-Ponty dá ênfase ao sensível. Todavia, para Beividas (In: MARCHEZAN; CORTINA; BAQUIÃO, 2011, p. 15) a primazia do sensível sobre o inteligível constitui uma ruptura epistemológica. É a língua que estabelece a semiose, permitindo a apreensão perceptiva do mundo.

Tomemos um poema de Haroldo de Campos, do livro Xadrez de estrelas ([1971-1972] 2008 , p. 184), para ilustrar como o ato semiológico (semiose no sentido simples) antecede a percepção. Vejamos como isso ocorre: 


Jlacraias
turvam
o
fio
de
á
g
u
a

O poema abre-se com um parêntese de fechar [ ")" ], uma agudeza visual para figurativizar a parte dianteira do inseto peçonhento, a lacraia, que é um tipo de escorpião ou centopeia. O uso de um parêntese constitui um recorte linguístico usado para revelar "intercalação de uma informação, digressão, desvio momentâneo do assunto" (HOUAISS; VILLAR, 2001, verbete parêntese). Os falantes escolarizados de uma língua natural quando entram em contato com a abertura de um parêntese aguardam seu fechamento. Ora, o poema de Haroldo de Campos já apresenta no início do primeiro verso um parêntese de fechar, o que leva o enunciatário a procurar o sentido em seu conjunto de atos semiológicos.

Portanto, é o ato semiológico que vai direcionar a apreensão perceptiva de um poema visual altamente sensível, como o apresentado. Se o parêntese não está funcionando como rege o esquema da língua, é preciso buscar outra direção, que não está na percepção, mas em um ato semiológico, engendrado pelas escolhas do enunciador. Quando se depara com "lacraias", desencadeia-se a necessidade de juntar o "parêntese de fechar" com "lacraias". Novamente, a língua natural em seu recorte "lacraia" orienta o sentido para um inseto possuidor de duas antenas, que, em movimento para a esquerda, lembram um parêntese de fechar. Se tudo dependesse apenas da regência da percepção, continuaríamos a ver o parêntese de fechar como algo sem sentido. No entanto, o ato semiológico ilumina o sensível e vemos não um erro tipográfico, mas um signo. Além disso, esse signo tem uma função estética que nos permite entender o recorte e visualizar "lacraia".

Ao verticalizar a distribuição do sintagma "fio de água", separando as consoantes e as vogais da palavra "água", mas mantendo o sintagma "fio/de", o enunciador ideogramatiza a passagem de lacraias que turvam o fio de água. Novamente, os recortes "fio" e "água" dãonos a posse da semiose desses dois recortes. Ocorre que a distribuição visual permite-nos pela língua natural buscar um sentido para a escolha substitutiva da horizontalidade pela 
verticalidade. Temos então uma agudeza visual -- as letras distribuídas verticalmente - que condensa dois planos de conteúdo; o poema de Haroldo de Campos é, pois, uma intersecção visual e semântica de lacraias e fio de água turva.

As lacraias, assim como o fio de água são apresentados visualmente para o enunciatário. A disposição de "fio", em um verso, e da preposição "de", em outro verso, configura certa sinuosidade que figurativiza a linha do corpo da lacraia em movimento. Se a língua natural não tivesse o recorte de "lacraia" como inseto esguio, a combinação com "fio de água" seria dissonante. Não é, pois, a visualização sensível e perceptiva que coordena a apreensão do sentido. Além disso, a distribuição espacial dos grafemas permite que o próprio fio de água se turve; turva, porque temos um recorte de "turvo" como o "que se movimenta muito, agitado, falto de transparência" (HOUAISS; VILLAR, 2001, verbete turvo).

Só reconhecemos a distribuição grafemática como imagem ideogramática de lacraia e de um fio de água após a intelecção do ato semiológico que compõe o sintagma "lacraias turvam o fio de água". Salta-nos, pois, à vista lacraias, insetos delgados e compridos, com filamentos sinuosos à cabeça, que obnubilam um de fio de água.

Dessa forma, por mais que o enunciado poético acima seja visualmente sensível, o ato perceptivo em jogo não tem primazia em relação ao ato semiológico, pois só percebemos "lacraias" no desenho dos grafemas dispostos no branco da página, porque, anteriormente, a língua recorta como forma o inseto e arbitrariamente o convenciona como LACRAIA. A partir desse recorte é que visualizamos lacraias movimentando-se no poema. Da mesma forma, é-nos visível o fio de água. Mesmo que o desarranjo e o esmaecimento das formas da expressão e do conteúdo dificultem o reconhecimento do objeto fluido, o ato semiológico é a porta de entrada para a apreensão do sentido, ou seja, é como se, diante da forma em curto-circuito do poema, buscássemos em nossa semiose de falante um modo de reorganizar a forma "sensivelmente" desarrumada.

Se o enunciatário não dispusesse do ato semiológico anterior, ele contemplaria a forma nova, mas não a converteria em sentido. Daí dizer Beividas (In: MARCHEZAN; CORTINA; BAQUIÃO, 2011, p. 16) que o concebido semiologicamente tem primazia sobre percebido, que o percebido já é um ato semiológico e que "a condição fenomenológica da percepção humana só pode ser semiológica" (destaques nossos).

Se o poema fosse apresentado horizontalmente e sem o parêntese inicial, lacraias turvam o fio de água 
teríamos um objeto sintagmamente "arrumado", de baixa sensibilização estética. Colocado na vertical, o poema de Haroldo de Campos é um enunciado vívido e ativado que pode despertar a sensibilidade do sujeito (ZILBERBERG, 2006b, p. 143-145), que, apassivado, experimenta um enlevo emocional provocado pelo objeto (cf. TATIT, 2010, p. 91).

Ainda para Beividas (In: MARCHEZAN; CORTINA; BAQUIÃO, 2011, p. 23), no exame da percepção nos estudos semióticos, "Greimas não acolheu a fenomenologia com o grau de penetração que por vezes se the atribui". E, à página 24 , transcreve uma pergunta constante de Elementos de semiótica tensiva (ZILBERBERG, 2006a, p. 8; 2011a, p. 12): “Fazendo suas as posições da fenomenologia, em especial a que se configura na obra de Merleau-Ponty, não estaria a semiótica se afastando de sua dupla referência, saussuriana e hjelmsleviana?"

O propósito de Beividas (p. 25), bem como o nosso, não é dar uma resposta à questão de Zilberberg, mas

\begin{abstract}
atenuar um pouco o jugo intimatório dessa viragem fenomenológica, e, quem sabe, tentar colaborar em nome de uma dosagem mais justa dos pesos que cabe ao prato perceptivo e aqueles que cabe [sic] ao prato semiológico na balança do fato da significação. Nesse sentido, limito-me a apontar algo que considero ter escapado ou estar permanecendo numa espécie de limbo do esquecimento: a força conceptual e epistemológica do princípio da arbitrariedade do signo saussuriano e sua natureza de ato semiológico na apreensão do mundo, perante as forças fenomenológicas da percepção.
\end{abstract}

Com Beividas (p. 30), enfatizo que é o ato semiológico que impõe ao sujeito falante o modo como vai perceber o mundo, e que não é o mundo percebido que rege sua apreensão. Daí os sujeitos não perceberem os objetos pelos órgãos do sentido, mas pela sua linguagem. Percebem o que sua linguagem Ihes permite categorizar: "a percepção humana é antes uma semiocepção" (p. 31).

Após essas discussões, passemos agora a algumas considerações de ordem morfológica: percepção e concepção têm em comum a raiz "cepção", do latim ceptio, derivado de capio, que quer dizer tomar, agarrar, pegar com.

Vejamos o significado de conceber (concepção) e perceber (percepção): 


\begin{tabular}{|l|l|}
\hline $\begin{array}{l}\text { Con, co, cum, cor (prefixos latinos) - } \\
\text { Conceber }\end{array}$ & $\begin{array}{l}\text { Per (prefixo latino) - } \\
\text { Perceber }\end{array}$ \\
\hline $\begin{array}{l}\text { Concomitância: de acelerada apreensão } \\
\text { intelectiva. }\end{array}$ & $\begin{array}{l}\text { Profundidade, intensidade (através de): } \\
\text { como se dá por meio dos sentidos, a } \\
\text { apreensão intelectiva é mais desacelerada. }\end{array}$ \\
\hline Compreender (pegar com), gerar, entender & $\begin{array}{l}\text { Agarrar (pegar com) por meio dos sentidos } \\
\text { (visão, tato, audição, olfato, paladar) }\end{array}$ \\
\hline Gerar com & Gerar profundamente \\
\hline Aceleração do inteligível & Desaceleração do inteligível \\
\hline
\end{tabular}

Finalmente, tanto em concepção quanto em percepção, há o traço "pegar com"; enquanto em concepção o prefixo con- tem a cifra tensiva de aceleração e concomitância, o prefixo per- de percepção apresenta a cifra tensiva de profundidade e menor aceleração. Trata-se, pois, de uma questão de diferença de andamento: enquanto em concepção temos aceleração inteligível (mais tênue no sensível), na percepção temos retardamento do inteligível (mais acentuado no sensível).

A seguir, vejamos concentração e difusão em Affonso Ávila e Horácio Costa.

\section{INTENSIDADE/CONCENTRAÇão E EXTENSIDADE/DIFUSÃo EM AfFonso Ávila E \\ HORÁCIO COSTA: O JOGO DE FLUIDEZ E NITIDEZ}

Neste capítulo, temos discutido a entrada do sensível nos estudos semióticos, considerando o ponto de vista em que inteligível e sensível não se encontram em posição dual, mas sob regência de uma gradação tensiva. A poesia da agudeza ordena-se então segundo um jogo entre sensível, da esfera da intensidade, e inteligível, da esfera da extensidade.

As grandezas extensas são responsáveis pela dinamicidade nos planos do conteúdo e da expressão. Na teoria de Zilberberg (2006a, 2006b), a importação desses termos exigiria alguns cuidados teóricos, uma vez que para Hjelmslev o fundamental é o contraste entre uma grandeza dinâmica (verbalização) e uma grandeza estática (nominalização). Do ponto de vista da semiótica tensiva de Zilberberg (2006a), porém, não teríamos uma, mas duas dinâmicas: 
- Uma dinâmica intensiva: gramática intensiva.

- Uma dinâmica extensiva: gramática extensiva.

Paralelamente aos termos intensidade e extensidade, utilizados por Zilberberg (2006a, 2006b), são empregados sem limites definidos os lexemas extenso e intenso, intensivo e extensivo. Para Zilberberg (2006a, p. 216; 2011a, p. 258-260), intensidade/extensidade e intensivo/extensivo "não se recobrem mutuamente" nos escritos hjelmslevianos e deleuzianos. Afirma ainda, em Eléments de grammaire tensive (2006a, p. 214-215; 2011a, p. 253-257), que, na obra de Hjelmslev, convivem os pares intensivo/extensivo, intenso/extenso e intensional/extensional.

Hjelmslev recorta os pares intenso e extenso, visto pertencerem a uma categorização linguística. Nesse sentido, extensas são as grandezas que apontam um sentido, uma direção: no plano da expressão, as modulações; no plano do conteúdo, os morfemas verbais: "grosso modo, os morfemas extensos são os morfemas verbais". Para ele, ao contrário da dinamicidade verbal, os morfemas intensos são os nominais (HJELMSLEV, 1991, p. 175) (destaques nossos).

Hjelmslev (1999), em La categoria dei casi, fundamenta seus estudos sobre a estruturação lexical, mostrando que a casa intensiva concentra a significação, enquanto a casa extensiva difunde a significação sobre as demais casas, cobrindo todo o domínio semântico. Assim, feminino é o termo intensivo, pois restringe a abrangência semântica, enquanto o masculino é extensivo, porque abarca ambos os gêneros, ou seja, um número maior de seres e coisas, uma extensidade ampla:

Esta escolha de apenas um termo da área como base do sistema depende de um princípio segundo o qual apenas uma casa é escolhida como intensiva, enquanto as outras são extensivas. A casa escolhida como intensiva tem a tendência de concentrar o significado, enquanto as casas escolhidas como extensivas têm uma tendência de estender o significado sobre outras casas de tal modo que invada o complexo do domínio semântico ocupado pela área (HJELMSLEV, 1999, p. 198-199, tradução nossa) $)^{3}$.

Vejamos um exemplo:

\footnotetext{
${ }^{3}$ Questa scelta di un solo termine della zona come base del sistema dipende da un principio secondo cui una sola casella va scelta come intensiva, mentre le altre sono estensive. La casella que viene scelta come intensiva ha una tendenza a concentrare il significato, mentre le caselle scelte come estensive hanno una tendenza ad estendere il significato sulle altre caselle in modo tale da invadere il complesso del dominio semantico occupato della zona.
} 
O homem é um animal que ri.

$\rightarrow$ Homem, nesse caso, indica homem e mulher; é termo extensivo.

A mulher é um animal que ri.

$\rightarrow$ Mulher, nesse caso, indica gênero feminino; é termo intensivo.

0 italiano gosta de futebol.

$\rightarrow$ Italiano, nesse caso, indica italiano e italiana; é termo extensivo.

A italiana gosta de futebol.

$\rightarrow$ Italiana, nesse caso, indica gênero feminino; é termo intensivo.

Em vez de oposição intensidade/intensivo versus extensidade/extensivo, Zilberberg adota um ponto de vista de uma linha tensiva que vai do concentrado ao difuso. De Aristóteles a Kant distinguem-se grandezas intensivas, relacionadas com a qualidade, das grandezas extensivas, relacionadas com a quantidade (ZILBERBERG, 2006a, p. 216-217; 2011a, p. 257-258). E nesse sentido o par intensivo/extensivo não se caracterizaria então como problemático, visto que não há uma oposição e sim um contínuo que se estende do concentrado ao difuso. Todavia, o fato de Hjelmslev dispor a articulação [int.- vs. ext.] em três oposições distintas [intensivo vs. extensivo]; [intenso vs. extenso]; [intensional vs. extensional], não fazendo uso do termo extensidade, causa dificuldade de compreensão terminológica.

A semiótica tensiva zilberberguiana (2006a, p. 215-216; 2011a, p. 258-260) relaciona intensidade e extensidade, reaproveitando o modelo hjelmsleviano, voltado para a extensão, e o modelo deleuziano, voltado para a energia.

Conjugando esses dois modelos, a intensidade seria a tensão entre o impactante e o tênue (tônico ou átono) em correlação inversa ou conversa com o eixo da extensidade:

- Inversa: maior a intensidade menor a extensidade e vice-versa.

- Conversa: menor a intensidade menor a extensidade; maior a intensidade maior a extensidade.

Para explicar o termo energia, transcrevo um trecho do texto de Deleuze (2006, p. 315):

só conhecemos formas de energia já localizadas e repartidas no extenso, extensos já qualificados por formas de energia. A energética definia uma energia pela combinação de dois fatores, o intensivo e o extensivo (por exemplo, força e comprimento para a energia linear, tensão superficial e superfície para a energia de 
superfície, pressão e volume para a energia de volume, altura e peso para a energia gravitacional, temperatura e entropia para a energia térmica...). É claro que, na experiência, a intensio (intensidade) é inseparável de uma extensio (extensidade) que a refere ao extensum (extenso). Nestas condições, a própria intensidade aparece subordinada às qualidades que preenchem o extenso (qualidade física de primeira ordem ou qualitas, qualidade sensível de segunda ordem ou quale).

Desse modo, só podemos conhecer a intensidade se ela estiver diluída no extenso e já recoberta por qualidades e é a partir disso que podemos considerar a quantidade intensiva como algo inquantificável. Mais adiante à página 321, o filósofo menciona que, como a intensidade identifica-se com a diferença, ela tem correspondente no extenso, que a desdobra, e na qualidade, que a envolve. A tendência dessa diferença é que ela se anule no extenso. Assim, a diferença se desdobra, embora não desdobrável, porque tende a anular-se no sistema em que se desenvolve. Desdobrar-se, para ela, é anular-se.

A diferença (intensidade) é resultado de uma operação lógica, a da implicação; noutros termos, a intensidade se dispersa na extensidade. Enquanto o explicado é da égide da extensidade, o implicado é da ordem da intensidade; assim "a intensidade se explica, desenvolve-se numa extensão" (DELEUZE, 2006, p. 321):

Implicado $\rightarrow$ é diferença [intensidade] que tende a anular-se na ordem da extensidade, que a explica [explicado]

Podemos considerar esclarecedora a teoria semiótica tensiva no sentido de que Zilberberg (2006a, p. 215; 2011a, p. 259) conjuga os conceitos intensivo/extensivo de Hjelmslev e os de intensidade/extensidade de Deleuze, homologando-os da seguinte forma:

\begin{tabular}{|l|l|l|}
\hline Hjelmslev $\rightarrow$ & intensivo & extensivo \\
\hline Deleuze $\rightarrow$ & intensidade (implicado) & extensidade (explicado) \\
\hline Zilberberg $\rightarrow$ & $\begin{array}{l}\text { intensidade } \\
\text { (extensidade latente) }\end{array}$ & extensidade \\
\hline $\begin{array}{l}\text { Ou é concentrada ou é } \\
\text { difusa } \rightarrow \text { concentrada }\end{array}$ & difusa \\
A intensidade é também \\
$\begin{array}{l}\text { extensidade, em duas } \\
\text { vertentes: ou pouco } \\
\text { (concentrada) ou muito } \\
\text { diluída (difusa). por sua vez, é } \\
\text { A extensidade, por } \\
\text { resultado da pouca diluição } \\
\text { (concentrada) ou muita } \\
\text { diluição (difusa) da } \\
\text { intensidade. da }\end{array}$ & \\
\hline
\end{tabular}


As diferenças são evidentes, então, entre o modelo hjelmsleviano e o deleuziano, que, na visão de Zilberberg (2006a, p. 217; 2011a, p. 258), não são equivalentes.

Resumidamente, para a semiótica tensiva, temos: (i) a implicação dá estatuto à intensidade e a explicação nos possibilita conceber a diluição de tal intensidade; (ii) enquanto, para Hjelmslev, o par implicado/explicado corresponde ao par intenso/extenso, no modelo tensivo equivale ao par concentrado/difuso, ambos da extensidade; (iii) a tensão, do ponto de vista da semiótica tensiva, gera na extensidade concentração/difusão.

Por isso, optamos por vetorizar o gráfico de Zilberberg, considerando não dois eixos, mas um contínuo em que é possível visualizar a diluição e a concentração:

$\leftarrow$ concentrado --------------------------------- difuso $\rightarrow$

(da intensidade à extensidade)

[Fluidez dos contornos formais Nitidez dos contornos formais]

Ainda com base em Deleuze, Zilberberg (2006a, p. 216; 2011a, p. 257) afirma que a relação entre intensidade $\boldsymbol{e}$ extensidade é assimétrica e, se assimétrica, não caberia, portanto, a conjunção "e", mas as preposições indicativas de direção $(d a=d e+a / a ̀=a+a)$ : “'da' intensidade 'à' extensidade". Nesse caso, seria mais pertinente pensar a intensidade como um dividendo e a extensidade como um divisor: a intensidade decresce, dividindo-se, desenrolando-se, dispersando-se, como se o valor fosse o quociente, o resultado. A dimensão intensiva com suas duas subdimensões, vívido e tênue, possibilita que, ao diminuir a tonicidade na extremidade da intensidade, dá-se um processo de difusão na extensidade. Quando a tonicidade é acentuada, impactante, dá-se a concentração. Se tênue (mais atonizado), temos, na correlação extensa, a difusão.

Retomando o poema "Pilar", de Affonso Ávila", saltam à vista, de um lado, os impactos que os rearranjos formais promovem no enunciado poético, que se encontra, nesse caso, mais próximo da forma mais concentrada, mais vívida; nos termos desta tese, temos um objeto mais fluido, porque desarranjado nas formas do PE e do PC.

De outro lado, no poema "Cetraria", de Horácio Costa, essa intensidade impactante é mais diluída, uma vez que as formas de expressão e de conteúdo são arranjadas com base na semiose do (re)conhecido (mais facilmente do que em "Pilar") pelo enunciatário. Esse 
tipo de poesia aguda encaminha-se para a nitidez e produz-se com auxílio de elos sintáticos que permitem o recrudescimento da restituição do contorno pelo fluir lógico do discurso poético e, nesse caso, estamos mais próximos do difuso da extensidade zilberberguiana. Vejamos como se dá a intensidade (concentração) e a extensidade (difusão) na poesia aguda, de Affonso Ávila e Horácio Costa:

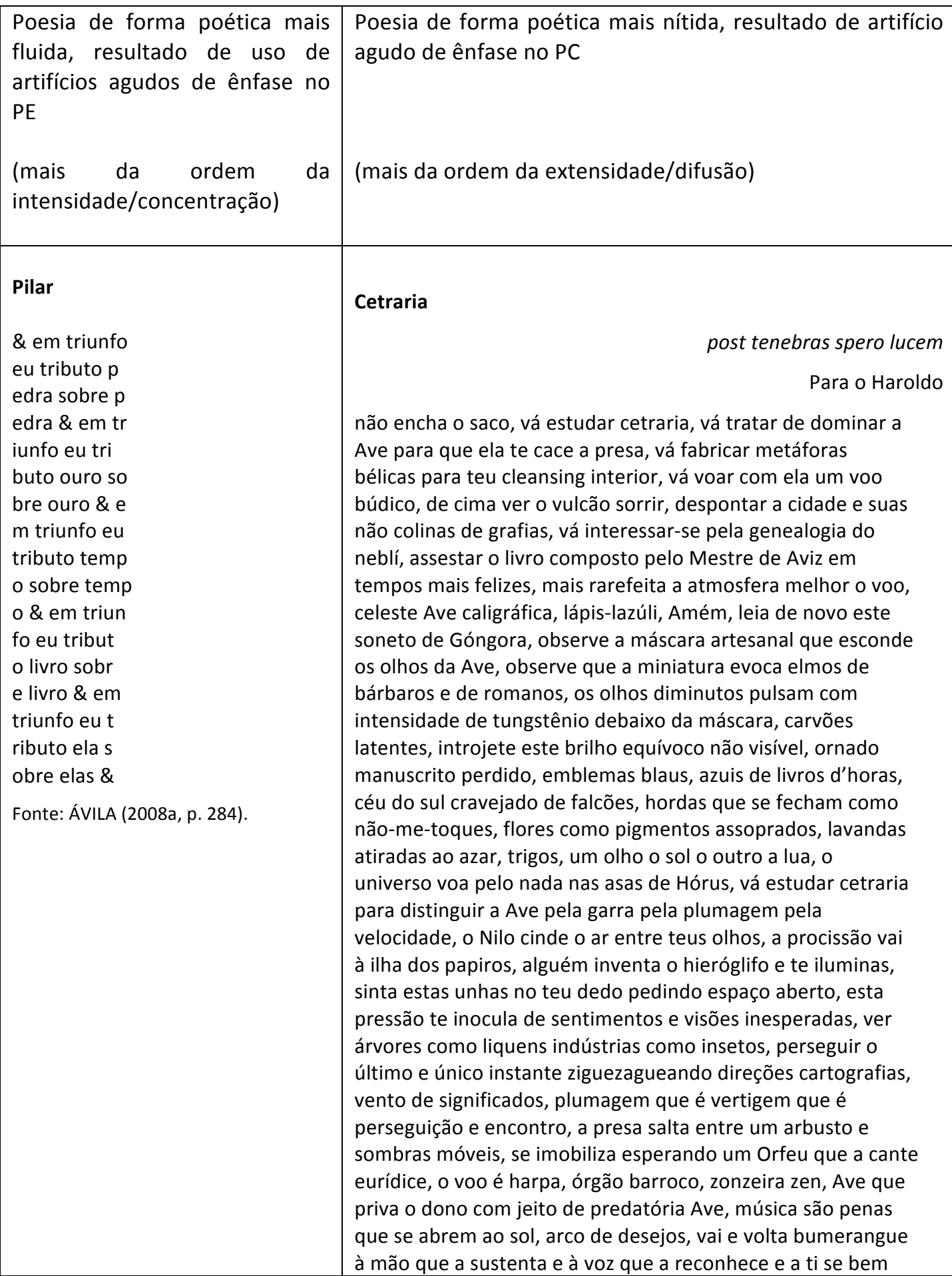




\begin{tabular}{|l|l|}
\hline quiseres, Ave friso ilusório, perdizes que se estampam na \\
paisagem como cornucópias, Ave radical, cristalizada e já \\
movente, passa teus lábios por seu bico rude, por um \\
momento falas sua língua, um agora imenso nos olhos do \\
animal, vais com ele nunca mais serás o mesmo, ao alvo, ao \\
alvo, ao alvo, a Ave corta o céu com rapidez de palavra, cai \\
na terra como dardo de poesia no plano da página, enfáticas \\
brasas, micro explosão, demolição interior, fósforo e nada, \\
estás imóvel e a acompanhas em seu voo, rapaz em busca da \\
carne branda da leitura, veja o mundo como um vitral, o \\
agora imenso nos olhos do animal se faz memória, gárrulo \\
epigramático, zênite, singraste-me, a caça terminou e aqui \\
tens o teu prêmio, libera o animal, \\
read me again \\
Fonte: COSTA (In: DANIEL, 2004a, p. 86-87).
\end{tabular}

A agudeza configura-se em "Pilar" pela acentuação na intensidade dada pelo tumulto de significantes: nesse sentido, temos um objeto de ênfase visual, apreendido espacialmente de forma imediata. Antes que seja reconhecido intelectivamente, apreendemos sua forma visual. Se comparado a "Cetraria" é pouco extenso, mais comedido; no lugar da maximização, temos a minimização.

"Cetraria" de Horácio Costa, como vimos no exemplo, tem um movimento tensivo diverso do de "Pilar".

Suponhamos quatro tipos de agudezas:

- Agudeza sonora do PE.

- Agudeza visual do PE.

- Agudeza do PC.

- Agudeza de somação, a mista.

Se o enunciador opta pela dominância da agudeza visual, engendra um objeto cujo contorno pode ser mais fluido ou mais nítido, a depender do poema. Contrapondo "Pilar" de Ávila com "A onda" de Manuel Bandeira (1993, p. 267), vemos no primeiro um poema de contorno do tipo mais fluido, pois que os limites silábicos, lexicais e de pontuação desmancham-se; já no segundo, temos uma agudeza visual de contorno do tipo mais nítido, porque, embora a forma seja nova, os versos permanecem nítidos em seus contornos, sem quebras abruptas. No primeiro verso de "A onda", escrito todo em letras maiúsculas espacejadas, temos um efeito de grande volume e de salto intervalar, dado pelo espaço branco, entre uma onda e outra: nessa agudeza, estabelece-se no conteúdo o sentido de sucessão no tempo, uma onda atrás da outra. O contorno, porém, é visualmente preciso, 
não se desmancha fluidamente: as palavras todas do poema de Bandeira têm seus limites precisos. É possível assim acompanhar com os olhos os limites lexicais, bem como o limite de um verso que se encaminha para outro; ainda que haja enjambement, o enunciatário reconhece os sintagmas mais rapidamente do que em "Pilar":

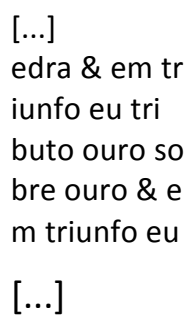

Vejamos lado a lado os dois poemas:

\begin{tabular}{|c|l|}
\hline A onda & Pilar \\
A O N D A & $\begin{array}{l}\text { \& em triunfo } \\
\text { eu tributo } p \\
\text { edra sobre } p \\
\text { edra \& em } t \\
\text { iunfo eu tri } \\
\text { buto ouro so } \\
\text { bre ouro \& e } \\
\text { m triunfo eu } \\
\text { tributo temp } \\
\text { o sobre temp } \\
\text { o \& em triun } \\
\text { fo eu tribut } \\
\text { o livro sobr } \\
\text { e livro \& em } \\
\text { triunfo eu } t \\
\text { ributo ela s } \\
\text { obre elas \& }\end{array}$ \\
a onda ainda \\
ainda onda \\
ainda anda \\
aonde?
\end{tabular}

No poema "Pilar", o enunciatário é convocado a restabelecer os contornos formais, a restituir os limites desarranjados. Diferentemente do poema "A onda", estamos numa escala de contorno mais nítido, com participação menor do enunciatário no rearranjo do objeto.

Quando há acúmulo de agudeza de ênfase no PC e agudeza de ênfase sonora no PE, como em "Cetraria", a fluidez é diferente, ocorrendo em três pontos:

1. Na agudeza de expressão sonora: os sons mesclam-se e somam-se.

2. Na agudeza visual: o poema não conhece ponto final e, portanto, todo o enunciado aparece como um bloco, uma massa fluida. 
3. Na agudeza do PC, temos a fluidez das imagens metafóricas, que se imbricam no conteúdo, sobrepondo-se, somando-se, como ocorre em: "vá tratar de dominar a Ave para que ela te cace a presa"; a metáfora de Ave produz, ao mesmo tempo, o efeito de sentido de ave plumátil/ave canora, que, por sua vez, desencadeia outra isotopia: a do fazer poético.

Essa agudeza esclarece-se por somatória no enunciado seguinte: "vá fabricar metáforas bélicas", quando então podemos ver em "Ave", personificada no poema em letra inicial maiúscula, a figura do poeta, construtor de metáforas "bélicas", que detonam por serem estrondosas. O enunciador contesta esses valores de produção poética retumbante, altamente retóricas e excessivas, participantes do estilo condoreiro.

Ainda, em "vá dominar a Ave", teríamos uma apóstrofe de "vá, poeta, dominar as artes poéticas". Essa metáfora soma-se a outra que vem logo em seguida: "vá voar com ela um voo búdico", que engendra um efeito de sentido de "pairar sobre as coisas, ver do alto, despregar-se do chão", acrescentando-se que deve fazê-lo em termos "búdicos", ou seja, “em estado plácido, de meditação" (HOUAISS; VILLAR, 2001).

O acúmulo de imperativos empresta ao enunciado um sentido autoritário, que se junta com o sentido de domesticação de uma ave, que, por extensão, atinge um tipo de adestramento poético dos que procuram fórmulas do "bom poetar". Na performance da cetraria, tapa-se o olho do falcão para domesticá-lo. O que ocorre aqui é uma crítica a fórmulas mágicas: "vá estudar cetraria para distinguir a Ave pela garra pela plumagem pela velocidade". A mestria poética assemelha-se ironicamente a domesticar falcões para aprender "fabricar metáforas".

Contestando a identificação do fazer poético como adestramento metafórico, o enunciador assevera: "nunca mais serás o mesmo", pois "a Ave corta o céu com rapidez de palavra, cai na terra como dardo de poesia no plano da página, enfáticas brasas, micro explosão, demolição interior, fósforo e nada"; "e aqui tens o teu prêmio, libera o animal". E uma última metáfora fecha o poema: Read me again, que produz o efeito de sentido de retorno que recomenda ao enunciatário que leia de novo o poema de Horácio Costa para entender que não se domestica um poeta. O ofício do poeta que o enunciado afirma e a enunciação nega implicaria: "vá ler de novo", "não encha o saco", que soa como voz de recusa a toda fórmula poética dada. 
Se em "Pilar" temos um poema fluido no PE, em "Cetraria" a fluidez atinge tanto o PE quanto o PC. No primeiro, a fluidez advém de desmanches inesperados de sílabas, de morfemas, lexemas etc., artifícios que acentuam mais ainda o visual. No segundo, a fluidez é dupla: no PE ocorre o desmanche dos limites do verso, dando a impressão de que não se trata de poema versificado; não há estrofação; há mistura de línguas e de tipos gráficos. No PC, as metáforas se aglutinam, se simultaneízam como numa pintura: "ver árvores como liquens indústrias como insetos". As metáforas podem ainda produzir imagens que interferem na aspectualização: "um agora imenso nos olhos do animal", que se repete mais acentuadamente pelo uso do artigo definido ao final do poema, em "o agora imenso nos olhos do animal". Pode ainda a fluidez ser resultado de acentuação, ao mesmo tempo, do PE e do PC, como nas repetições: "ao alvo ao alvo ao alvo".

Em "Cetraria", nota-se uma oscilação entre a extensidade do PC, que convoca um conjunto de imagens em sequência, e a intensidade das imagens convocadas, altamente vívidas. A acumulação que vemos no PC está espelhada no PE: os sons multiplicam-se, produzindo um volume sonoro denso e contínuo, num ritmo acentuado, marcado particularmente pelo uso dos verbos no imperativo, que emprestam ao texto um caráter de rigidez e inflexibilidade. A série de apóstrofes imperativas dá acentuação à extensidade de apelos:

não encha o saco

vá estudar cetraria

vá tratar de dominar a ave

vá fabricar metáforas bélicas

vá voar com ela um voo búdico

vá interessar-se pela genealogia do neblí

leia de novo este soneto de Góngora

observe a máscara artesanal

observe que a miniatura evoca elmos de bárbaros e de romanos

introjete este brilho equívoco

vá estudar cetraria

sinta estas unhas no teu dedo (altamente intenso - convoca a sensação do tato)

veja o mundo como um vitral

Essas repetições apostróficas produzem um efeito de sentido vivificado, em que sobressai a ironia do enunciador: parece haver aqui uma afirmação no enunciado que vai em direção contrária à da enunciação. "Cetraria" atualiza uma crítica aos que se julgam destinadores de um fazer poético que surripia a liberdade criativa do poeta. Nesse sentido, a mestria poética não se compara à aprendizagem de cetraria. 
Vejamos especificamente a cifra tensiva dos três poemas em discussão:

"Cetraria" $\rightarrow$ agudeza dupla; no PC: objeto de acentuada tonicidade sensível (metáforas que se imbricam); no PE sonoro: esmaecimento dos contornos, que provoca retardamento no reconhecimento inteligível. Temos então agudeza duplamente vivificada.

"Pilar" $\rightarrow$ agudeza de dominância do PE visual: esmaecimento dos contornos, produzindo rápido andamento devido à tonificação da intensidade e delongamento do reconhecimento.

"A onda" $\rightarrow$ se comparado a "Pilar", a agudeza é mais tênue no PE visual; se comparado a "Cetraria" e a "Pilar", a agudeza é mais tênue no PC, resultando em maior nitidez de contorno e atenuação da intensidade.

Estamos distinguindo os três poemas apenas para fins de esclarecimento argumentativo; todos eles são obras poéticas que configuram graduações tensivas de difícil precisão, ou seja, entre um e outro o que se observa é apenas a existência de "mais" ou de "menos" na cifra tensiva.

A fluidez e a nitidez vistas em Bandeira, Ávila e Costa de variada acentuação aguda nos direcionam para o exame da semiótica da agudeza como suporte de conservação dos objetos estéticos, o que Zilberberg denomina perobjeto.

\section{A poesia aguda de Horácio Costa como Perobjeto}

A fé perceptiva de Merleau-Ponty (2006), como vimos, rege-se pela modalização do crer. Ora, examinando o Capítulo 4 de Zilberberg (2006b) "Para introduzir o fazer missivo", verificamos que, para organizar o fluxo discursivo, a semiótica tensiva colocou em cena, a partir de Semiótica das paixões, o estudo do sensível. A foria, força que leva adiante um discurso, articula-se em tensão e em relaxamento, com a operação das categorias extenso/intenso:

\footnotetext{
Tensão $\rightarrow$ intenso $\rightarrow$ tempo do inesperado (passado) $\rightarrow$ sobrevir

Relaxamento $\rightarrow$ extenso $\rightarrow$ tempo de espera $\rightarrow$ pervir
} 
Na esfera do sobrevir, temos um antiprograma, que no nível missivo, corresponde a um fazer remissivo, a uma parada (ruptura); na esfera do pervir, temos um programa, que no nível missivo, corresponde a uma parada da parada ou fazer emissivo ou continuativo.

O estudo semiótico da poesia tem conhecido contribuições de diversos autores, entre os quais se destacam Jakobson (1973, 2005, 2007), Greimas et al. (1976), Zilberberg (2006b) entre outros; no Brasil, são relevantes os trabalhos de Lopes $(1978,1997)$, de Tatit (2010), de Pietroforte (2011) entre outros. Os progressos da teoria semiótica trouxeram à cena poética o fazer missivo zilberberguiano.

Vejamos brevemente a teoria da missividade de Zilberberg (2006b, p. 129-147). Ao enunciar, o sujeito da enunciação produz uma oscilação tensiva, que privilegia ora as paradas (limites e contrações), ora as difusões do fluxo fórico.

O texto em que Zilberberg apresentou inicialmente o modelo do fazer missivo data de 1986 (volume 6, n. 3, da revista canadense Recherches Sémiotiques). Logo em seguida, retomou-o em Razão e poética do sentido ([1988] 2006b). No Brasil, o conceito de missividade foi introduzido por Tatit, em Musicando a semiótica (1997), reunindo alguns estudos do início dos anos de 1990 que empreendem uma reflexão sobre o tempo na canção.

Pietroforte, mais recentemente, em Análise textual da história em quadrinhos (2009), aplica o conceito de missividade à análise de HQs, defendendo que ela pode oferecer respostas à compreensão de seu fluxo narrativo e discursivo (cf. também TOMASI, 2012; PORTELA; TOMASI, 2012).

Nos estudos de Zilberberg sobre o fazer missivo, o fazer profundo que rege o devir das narrativas, a temporalidade e a espacialidade relaciona-se com as categorias fechamento (intensidade) e abertura (extensidade). Zilberberg (2006b, p. 135) afirma que "parece que o fazer missivo discretiza o tempo, permitindo-nos domesticar o tempo antes do tempo". O já e o ainda são reguladores do presente. Pela temporalidade remissiva, distinguimos o "atraso", tempo anterior ao presente; se dominante a parada remissiva, o tempo emissivo inibe-se, ficando suspenso.

Com respeito ao tempo -- que está em relação solidária com o espaço --, etimologicamente, os termos cronopoiese e cronotrofia, com base no radical grego, têm na estrutura morfológica, "khrónos", "tempo", e correspondem a duas formas distintas e complementares de os sujeitos implicados nas narrativas vivenciarem o tempo. 
O termo cronopoiese é formado de "poiesis" (do grego), "criação". Do ponto de vista figurativo, o fazer remissivo, portador da parada, é cronopoiético, ou seja, sua temporalidade é expectante, cria o tempo da espera ou da recordação. A cronopoiese é desacelerada e intensa. Desacelerada, porque estabelece a descontinuidade na ação, produzindo limites e demarcações (a base do ritmo); intensa, porque é acelerada no eixo do sensível, impactando o sujeito que busca um entendimento sobre o que estaria ocorrendo em seu percurso, ou seja, o porquê da parada. A cronopoiese é acompanhada de fechamento espacial. Quando a parada prevalece (nível tensivo), a remissividade instaura-se (nível missivo), o fluxo narrativo interrompe-se (nível modal e narrativo) e produz a retenção do tempo e do espaço (nível discursivo).

Já cronotrofia é um termo formado por "trophê" (do grego), "alimentar", "desenvolver-se". Do ponto de vista figurativo, o fazer emissivo, portador da parada da parada, é cronotrófico, ou seja, sua temporalidade é "originante", consome o tempo, que se torna o tempo que passa, o tempo cronológico (linear). A cronotrofia é acelerada e extensa. Acelerada, porque estabelece a continuidade na ação, produzindo gradações e durações; extensa, porque é desacelerada no sensível, desdobrando-se figurativamente. Uma vez que seu espaço é aberto, sua narrativa se desenrola, o sujeito entra em estado de relaxamento. Ela é sempre acompanhada de abertura espacial. Quando a parada da parada prevalece (nível tensivo), a emissividade instaura-se (nível missivo), o fluxo narrativo avança (nível modal e narrativo) e produz a distensão do tempo e do espaço (nível discursivo).

O tempo na narrativa, desde longa data, é objeto de investigação. Para citar alguns autores, Santo Agostinho (1989), Bergson (1999, 2006), Paul Ricœur (1994 [t. 1], 2010a [t. 2], 2010b [t. 3]) inquietaram-se com esse assunto. Todos estão, de modo geral, de acordo que o tempo humaniza-se quando articulado narrativamente no vivido e na memória. Segundo cada narrativa -- seja prosa, seja poesia --, o tempo se cria, o tempo se atrofia, o espaço se fecha ou se abre. Para exemplificar, vejamos essa questão do tempo em outro poema agudo de Horácio Costa (1999, p. 57-59; In: DANIEL, 2004a , p. 88-89): 


\section{Os jardins e os poetas}

Wang Wei pintava jardins e cultivava plantas

$\mathrm{Na}$ China Imperial pintar plantar jardins

Era bem mais nobre que discursar frente a um senado inexistente narcotizado

Cícero perora Quintiliano chora

Os senadores não prestam atenção

Porque observam as barrigas das pernas musculosas dos guardas

Dácios \& Mésios \& Beócios principalmente Beócios

O jardim romano era um pátio de recepção

Com 8 roseiras geométricas

64 vasos de cerâmica 128 plantas de gerânio perfeitamente retóricas

Horácio queria um jardim regular

O número de folhas de suas roseiras seria contado

O número de pétalas das rosas seria minuciosamente contado

Como sílabas de poemas estritamente sintáticos

As rosas amarelas seriam assonâncias

As rosas vermelhas consonâncias

O jardim horaciano é um Mondrian avant-la-lettre

Mas Horácio não teve dinheiro para comprar escravos que contassem pétalas e folhas

Silábicas

As pedrinhas das áleas como pausas poéticas

Por isso o jardim de Horácio nunca existiu

Quando nós pensamos nele nos lembramos de um jardim inexistente

De um jardim civil como Demóstenes

Um ágora iluminado

Por plantas cidadãos atentos à perorata

Plantas como ouvidos vegetais

Nardos como microfones

E o cipreste que se entrevê

um agente de imprensa

Wang Wei cultivou seu jardim

E enquanto plantava pintava

Seus microcosmos caligráficos com pedras trazidas de longe

Que o lago e a corrente duplicavam nas sutis tardes outonais

Etc.

Wang Wei cultivava jardins

Wang Wei pintava paisagens

Mas Ella, ah,

Ella

Ella cantava boleros

Interessa-nos neste momento mostrar como as escolhas enunciativas temporais estão diretamente relacionadas à missividade. No poema de Horácio Costa, a escolha pelo imperfeito "pintava" e "cultivava" (primeiro verso) interrompe o presente e cria um tempo durativo anterior ao tempo da enunciação. Adiante, há uma neutralização desse passado continuativo com a instauração de uma presentificação de um fato passado, concomitante 
ao tempo da enunciação (versos 5 e 6: "Cícero perora Quintiliano chora/Os senadores não prestam atenção").

Mais adiante ainda, assistimos a uma remissividade: verso 13, "Horácio queria um jardim regular"; se queria, é porque não o tinha, mostrando uma anterioridade em relação ao presente da enunciação, tendo, portanto, seu percurso interrompido (sujeito disjunto de seu objeto - "queria"). E, quase ao final do poema, deparamos com a pontualidade de uma ação no passado: verso 33, "Wang Wei cultivou seu jardim". Trata-se de uma ação pontual já extinta no passado pela remissividade no percurso do sujeito. Enfim, a tensão entre o tempo presente e o passado permite o progresso narrativo, bem como a organização da narratividade em variados níveis temporais: o do tempo originante e o do expectante, diferentemente do tempo cronológico que é linear (só vai para a frente, é emissivo).

A remissividade é imperante nesse poema, porque o desenrolar dos percursos dos sujeitos se dá no passado, na memória. Aqui, o tempo é humanizado pela memória, que faz durar acontecimentos de um tempo anterior (cultivava, pintava...), interrompendo remissivamente o fluxo do tempo presente ou, ainda, presentificando o tempo passado, ao estabelecer uma parada remissiva no fazer poético regular e geométrico -- comparável ao fazer pictórico de Mondrian -- de Horácio, o romano.

O enunciador, ao eleger a ironia, disforiza as poéticas inflexivelmente regradas por normas e pelo formalismo excessivo: "o jardim romano era um pátio de recepção / com 8 roseiras geométricas / 64 vasos de cerâmica 128 plantas de gerânio perfeitamente / retóricas / Horácio queria um jardim regular / O número de folhas de suas roseiras seria contado / O número de pétalas da rosas seria minuciosamente contado / como sílabas de poemas estritamente sintáticos" (destaques nossos). Os enunciados encontram-se acentuados pelo excesso de números, advérbios e adjetivos da ordem da cifra de regularidade excessiva.

Contrapondo a essa posição, o poema começa e termina com a alusão a um poeta oriental que "pintava jardins e cultivava plantas / Na China imperial pintar plantar jardins / Era bem mais nobre que discursar frente a um senado / inexistente narcotizado [...] Wang Wei cultivou seu jardim / E enquanto plantava pintava / Seus microcosmos caligráficos com pedras trazidas de longe / [...] Wang Wei cultivava jardins / Wang Wei pintava paisagens".

Essa posição do enunciador diante de seu objeto identifica-se com a posição de Ezra Pound, que teve como seu mentor Fenollosa, um americano expert em arte oriental. 
Segundo Haroldo de Campos (1977b, p. 31), em "Ideograma, anagrama, diagrama", "Fenollosa procurou descobrir na análise intrínseca dos caracteres ideográficos as fontes do prazer estético que os textos de poesia sino-japonesa the proporcionavam". A poesia chinesa propiciou a Fenollosa observar homologias entre o PE e o PC. Ademais,

Fenollosa não admitia o naturalismo "copista" em pintura, mas, ao contrário, propendia para a reorganização das relações naturais numa nova síntese criativa, que tomasse a natureza não como molde para o decalque imitativo, mas como modelo dinâmico; o "pictograma", no seu quadrículo virtual, no estágio de evolução que se apresentava a Fenollosa, era já uma pequena pintura cubista" (CAMPOS, 1977b, p. 40)

O processo poético de Wang Wei, de fazer das descrições verdadeiras pinturas, é conhecido retoricamente pelo nome de hipotipose: ela se dá quando, nas descrições, os fatos enunciados revelam-se como se estivessem diante dos olhos. Em vez de narrar, o poeta mostra os objetos (cf. MOISÉS, 2011, p. 223).

Desse modo, a poética de Wang Wei está em tensão com a regularidade horaciana: “Horácio queria um jardim regular / O número de folhas de suas roseiras seria contado / $\mathrm{O}$ número de pétalas das rosas seria minuciosamente contado / Como sílabas de poemas estritamente sintáticos."

Paradoxalmente, o enunciado "o jardim horaciano é um Mondrian avant-la-lettre" revela uma possibilidade de nova leitura da regularidade em Horácio: suas preocupações com a precisão teriam desembocado no geometrismo mondrianesco. Ora, assim como há uma linha de fazer criativo horaciana que sai da Antiguidade e chega a Mondrian, há uma linha de fazer poético que sai de Wang Wei e atinge os nossos dias.

O enunciador, no entanto, logo depois de afirmar que o jardim horaciano é um Mondrian antes do tempo, nega a existência de um jardim horaciano: "o jardim de Horácio nunca existiu" e, se nos lembramos de um jardim construído segundo os princípios de Horácio, tudo que nele vemos é apenas a apresentação de um fazer poético formal: "um jardim civil como Demóstenes / um ágora iluminado / por plantas cidadãos atentos à perorata / plantas como ouvidos vegetais / nardos como microfones / e o cipreste que se entrevê um agente de imprensa".

As metáforas agudas escolhidas disforizam o fazer poético sob a vigilância da regularidade e da ausência de sensibilidade: "de um jardim civil como Demóstenes". Ora, não se trata de um jardim de flores, mas de um jardim discursivo do grande orador 
Demóstenes, em que sobressai a isotopia do discurso persuasivo, das argumentações silogísticas.

Já a metáfora "ágora iluminado" simula o espaço da transparência poética, que se afasta da visão de uma poesia sensibilizada pela opacidade, o invisível a que Merleau-Ponty se refere. Nesse jardim, as plantas não são vegetais, mas "cidadãos atentos à perorata"; o próprio "cipreste que se entrevê" personifica um "agente de imprensa", um jornalista mensageiro, cuja preocupação é simplesmente transmitir saber. Diferentemente, pois, de Wang Wei que cultiva jardins e que enquanto planta pinta. Aqui, a vívida acentuação é estética, não tendo em vista noticiar o conteúdo, mas construir imagens por meio dos artifícios agudos: "Wang Wei pintava paisagem".

O poema de Horácio Costa evidencia, assim, um jogo agudo entre a isotopia da jardinagem (cultivo natural) e a isotopia do fazer poético (cultivo cultural), ambiguidade que perpassa todo o poema, encerrando-se apenas quando o enunciador, no relaxamento da repetição da figura "poeta-jardineiro", introduz um enunciado da ordem do sobrevir, do não esperado, "Ella [Fitzgerald] cantaba boleros", ilustrando seu próprio fazer. Bolero figurativiza a continuidade e a repetição no tempo: é um ritmo invariável, com uma melodia uniforme e repetitiva.

Se retomarmos o início do poema "bolérico", verificaremos que a última estrofe repete o conteúdo desses versos, dividindo-o, no espaço branco da página, em dois sintagmas, agora de mais intensidade que a do primeira verso, dada a repetição sonora do nome "Wang Wei":

$1^{\circ}$ verso:

Wang Wei pintava jardins e cultivava plantas (uma vez)

versos 38 e 39:

Wang Wei cultivava jardins

Wang Wei pintava paisagens (duas vezes)

Essa repetição "bolérica" ainda ocorre nos versos 33 e 34:

Wang Wei cultivou seu jardim

E enquanto plantava pintava 
Enfim, todos os poetas, pintores e cantores, cultivam seus jardins, suas criações poéticas, conforme o título do poema: OS JARDINS E OS POETAS. Nesse caso, seriam jardineiros-poetas Horácio, Mondrian, Wang Wei, Ella Fitzgerald e o nosso enunciador na pele discursiva de Horácio Costa, cujo fazer poético agudo é constituído de um jardim da ordem da mistura poética, cultivando assim o princípio da condensação da metáfora aguda. Outra agudeza que se pode notar concentra-se na metáfora de poetas jardineiros. A poesia considerada flor é uma constante na literatura. Ocorre que, em Horácio Costa, a flor aparece como produto laborioso do jardineiro (poeta), o arquiteto da linguagem:

Na tradição poética literária: Poesia $=$ flor $\rightarrow$ da ordem da triagem, pois só poesia é flor.

No poema agudo de Horácio Costa, Poeta: jardineiro arquiteto = produtor das mais variadas flores poéticas $\rightarrow$ da ordem da mistura.

A poesia compreenderia um jardim verbovocovisual: poesia, música, pintura.

Ao selecionar no último verso "Ella cantaba boleros", temos a opção, então, pela escolha tensiva da repetição, da invariabilidade, engendradora de um andamento. E, nesse caso, o fazer poético revela-se um fazer que assume a reiteração como poética (poiesis); o fazer poético seria um fazer que implica uma temporalidade rítmica, ou seja, ele é basicamente ritmo. Em "Os jardins e o poetas", a desaceleração opera a remissividade dos tempos imperfeitos e circulares, constituindo um poema em círculo, como se fossem as notas de um bolero.

Diferentemente de "O Retrato de Dom Luís de Góngora", cuja continuidade do fluxo narrativo determina uma dominância da emissividade, o poema "Os jardins e os poetas" erige-se segundo uma prevalência do fazer remissivo, verificável no pretérito imperfeito, que simula uma parada durativa no tempo ("pintava jardins"; "cultivava plantas"; "o jardim romano era um pátio de recepção"; "Horácio queria um jardim regular"; "e enquanto plantava pintava"; "que o lago e a corrente duplicavam"; "Wang Wei cultivava jardins"; "Wang Wei pintava paisagens"; "Ella cantaba boleros").

Há ainda uma tensão, que oscila entre a duratividade do imperfeito e a pontualidade dos verbos no presente e no pretérito perfeito: "Cícero perora Quintiliano chora / Os senadores não prestam atenção / Porque observam as barrigas das pernas musculosas dos guardas"; "O jardim horaciano é um Mondrian avant-la-lettre"; "E o cipreste que se 
entrevê"; "Mas Horácio não teve dinheiro para comprar escravos"; "Por isso o jardim de Horácio nunca existiu”; "Wang Wei cultivou seu jardim”. Nesse sentido, a remissividade no poema intensifica-se ainda mais pela distinção de duas rupturas, ou seja, duas aspectualidades imperantes debreadas: (a) a de um passado imperfeito durativo, que se debreia em um passado perfeito, e portanto pontualizado, e (b) em um presente vivo do passado. No verso "Cícero perora Quintiliano chora", por exemplo, nem as ações de Cícero nem as de Quintiliano dão-se no presente da enunciação, mas no presente contemporâneo ao presente de Cícero e de Quintiliano.

Outra tensão manifestada no poema dá-se pela conjunção adversativa MAS, estrategicamente introduzida quase na metade do poema (vigésimo verso), que revela a aproximação do enunciador "Mas Horácio não teve dinheiro para comprar escravos que / contassem pétalas e folhas", bem como pela locução conjuntiva conclusiva POR ISSO: "Por isso o jardim de Horácio nunca existiu" e, ainda, pela debreagem interna a primeira pessoa do plural "nós" é projetada no enunciado.

Todos esses elementos de aproximação simulam a posição estética do enunciador: "quando nós pensamos nele nos lembramos de um jardim inexistente". Não nos deixa em dúvida, portanto, com relação ao fazer poético de sua predileção: em vez do poema marcado pela regularidade rígida e pela transparência dos enunciados, opta por uma poesia obnubilada pela sensibilidade visual. Essa presença do enunciador no enunciado homologase com o PE, quando da escolha de grafema em itálico "Ella cantaba boleros" e da ampliação de um espaço branco no interior do sintagma do verso 32:

E o cipreste que se entrevê um agente de imprensa (verso 32)

Essa subjetividade de sentinela, acompanhada pela ausência de pontuação em todo o PE do poema, convoca no PC uma abertura, que desconhece fronteiras poéticas. Assim é que Wang Wei, Mondrian, Ella Fitzgerald e o enunciador de "Os jardins e o poetas" relacionam-se segundo uma hierarquia tensiva.

Enquanto Wang Wei, poeta, pinta jardins e cultiva plantas, Cícero, Demóstenes e Quintiliano funcionam no texto como retóricos cujos enunciados são argumentativos. Há, portanto, uma tensão entre o poetar à moda de Wang Wei -- capaz de criar imagens poéticas e sensibilizar pela fé perceptiva, pelo crer -- e o persuadir da ordem do saber. No 
primeiro caso, o objeto erige-se pela dominância do sensível; no segundo, pela dominância do inteligível. Outra tensão detectável no poema advém do choque entre Horácio, enquanto regrador rígido do fazer poético, e Ella Fitzgerald na figura do bolero, capaz de engendrar um efeito de sentido circular, de obra inacabada, acentuado pela ausência de ponto final em todo o poema.

"Ella cantaba boleros" introduz tanto no PE (itálico e espanhol) quanto no PC o inesperado, ou seja, suspende o fio intelectivo das isotopias poéticas (os enunciados anteriores cuidavam do fazer poético como regularidade ou como pintura), acrescentando surpreendentemente em seu lugar a isotopia da musicalidade e da presença feminina no poema.

Enfim, temos no jardim de Horácio Costa uma poesia-pintura, como queria Wang Wei e Fenollosa. Todavia, não caberia opor a poesia do Ocidente à do Oriente, visto que o enunciador ocidental de "Os jardins e os poetas" incorpora em seu objeto os processos wangveianos. Assimila à tradição viva a tradição passada, uma diacronia sincronizada: a sucessividade de figuras convocadas ergue-se como uma pintura mondrianesca, uma montagem que simultaneíza uma paleta de cores poéticas.

Como vimos, se há um enunciador regulador, o objeto semiótico produzido configura-se um complexo de tempo/espaço, cifrados pelo saber e pelo crer. Os valores emissivos de continuidade são erigidos pela modalidade do CRER, que para Merleau-Ponty se identifica com a fé perceptiva; e, nos termos de Zilberberg (2006b, p. 143), um PEROBJETO. Explicitemos o que vem a ser isso.

A modalidade do saber é da ordem dos valores remissivos. Enquanto o crer conserva seu objeto, o saber o extenua. Se extenuado, temos um an-objeto, ou melhor, um antiobjeto (cf. ZILBERBERG, 2006b, p. 143). Ilustrando esses conceitos, podemos afirmar que um poema da ordem do perobjeto -- como é o caso da poesia analisada de Horácio Costa e de "Pilar", de Affonso Ávila -- pode ser extenuado se decifrado pelo saber, pelo inteligível. O analista inteligivelmente elucida o objeto pelo saber; o criador, por sua vez, obscurece seu objeto com base no crer. Valéry, citado por Zilberberg (2006b, p. 143), afirma:

O mundo continua, assim como a vida e o espírito, em razão da resistência que nos impõem as coisas difíceis de conhecer. Assim que tudo fosse decifrado tudo se dissiparia, o universo revelado seria tão improvável quanto uma trapaça desvendada ou um lance de prestidigitador do qual já se conhece o segredo. 
Na dimensão pragmática ou utilitária, o sujeito, ao engendrar valores emissivos, considera que o objeto é apenas um subobjeto; e ao eleger valores remissivos, virtualizados, assume tais objetos como abjetos. Tanto valores emissivos como remissivos pragmaticamente modalizados por amar e odiar, respectivamente, produzem objetos disfóricos. A relação do sujeito com o objeto é de controle e de superioridade; o objeto é-lhe subjugado.

Na dimensão cognitiva, o sujeito, ao engendrar valores remissivos, considera que o objeto é um an-objeto (antiobjeto); e, ao eleger valores emissivos, tais objetos constituemse perobjetos. Tanto valores remissivos quanto emissivos cognitivamente modalizados por saber e crer, respectivamente, produzem um objeto eufórico e um disfórico. A dinâmica agora é de atração e de repulsão e a relação do sujeito com o objeto não é mais de controle; o sujeito pode assim ser atraído ou repelido pelo objeto. O sujeito, invadido e atraído pelo objeto, é modalizado pelo crer; eis aqui o perobjeto. Pelo saber, ao contrário, o sujeito o repele; eis aqui o an-objeto; diferentemente, pois, da dimensão pragmática em que o sujeito tem o total controle do objeto.

\begin{tabular}{|l|l|l|}
\hline Valores & Dimensão pragmática & Dimensão cognitiva \\
\hline emissivos & $\begin{array}{l}\text { sub-objeto } \\
\text { (amar) }\end{array}$ & $\begin{array}{l}\text { per-objeto } \\
\text { (crer) }\end{array}$ \\
\hline remissivos & $\begin{array}{l}\text { a-bjeto } \\
\text { (odiar) }\end{array}$ & $\begin{array}{l}\text { an-objeto } \\
\text { (saber) }\end{array}$ \\
\hline
\end{tabular}

Fonte: adaptado de Zilberberg (2006b, p. 143).

Zilberberg (2006b, p. 144), partindo dessa classificação, sugere que, além de todas essas dimensões, consideremos a dimensão estética, dimensão que nos interessa mais de perto nesta tese. Acrescenta ainda que, antes que constituir-se a estética uma dimensão, trata-se de uma operação sintáxica, denominada por ele de estetização. Vejamos em que consiste essa operação:

- Em sub-objeto, o prefixo sub indica incompletude do objeto, colocando-o em uma categoria hierárquica que o distingue do sujeito. Temos um objeto subjugado. O sujeito sente-se atraído por apreciar o objeto. A modalidade, escolhida por Zilberberg (1986, p. 248), para acompanhar o sub-objeto é aimer, que em francês tem o sentido de apreciar (PETIT ROBERT, 2008, 
verbete aimer). É essa relação de apreciação por parte do sujeito que o torna controlador do objeto. O verbo apreciar tem um cifra tensiva de distanciamento. Só aprecia quem está distante, observando com superioridade.

- Em a-bjeto, o prefixo $a$ indica privação. Temos um não-objeto; o objeto deixa de ser um objeto. O verbo escolhido por Zilberberg é häir, que em francês tem o sentido de ter aversão por depreciação. Aqui, a cifra tensiva do distanciamento tonifica-se ainda mais e o sujeito, controlador do objeto, passa a depreciá-lo.

- Em an-objeto, o prefixo an, no Dicionário Houaiss (2001), indica um objeto invertido, ao revés. O sujeito, no controle, tem o saber, recolocando o objeto na condição de objeto.

Nesse sentido, conceberíamos os objetos cognitivos e os pragmáticos, cada um com sua característica sintáxica. E o perobjeto? Os perobjetos, por sua vez, suspendem a condição de an-objeto, do sub-objeto e de a-bjeto. E é do perobjeto que vamos tratar especificamente. O prefixo per tem no Dicionário Houaiss (2001) o sentido de "movimento através de", "duração", "continuidade", "perambular", "perenidade". Fiquemos com o sentido de duração. E é esse sentido que nos direciona a uma cifra tensiva de conservação, que atravessa o tempo, que continua. Portanto, o perobjeto carrega consigo valores emissivos de duração. Daí Zilberberg (2006b, p. 144) indicar que, se não suspensas as condições de an-objeto, de sub-ojeto, de a-bjeto, o objeto se extenuaria, se dissiparia.

A duratividade, própria do objeto estético, é que faz dele um perobjeto. Para Zilberberg, ou o objeto estético ganha a duratividade do perobjeto ou ele se deforma; deformado, transforma-se em an-objeto, sub-objeto, a-bjeto. E somente como objeto estetizado é que ele duraria.

A conservação do objeto estético organiza-se em duas dimensões:

1. Conservação pragmática - dá-se pelo estabelecimento de um espaço para a arte, um espaço social. Exemplos: museus, exposição, saraus, os tratados poéticos seiscentistas, academias do século XVIII, grupo de poetas que pensam seu fazer artístico, como os do final dos séculos XIX e XX etc. 
2. Conservação cognitiva - compreende uma tensividade entre saber e não saber: "eu sei [saber] que não sei [não saber]". Afirmar, por exemplo, que um poema de Affonso Ávila é estetizante, do ponto de vista do saber e do não saber, é confessar seu potencial enigmático e grandioso. A arte do enigma afasta-se e aproxima-se da ordem cognitiva: ao mesmo tempo que o saber pode dissipar o objeto, o não saber pode conservá-lo. É por isso que Zilberberg (2006b, p. 144) afirma que a "estética é conservadora -- como um culto, uma devoção". Não podemos conhecer em sua totalidade o objeto estético, o perobjeto; só podemos cultuá-lo e acreditar nele (regência do crer). No entanto, fica-nos uma questão: até que ponto o desvelamento do objeto por cognição o extenua? Em alguns casos, o saber não poderia ser adjuvante do crer na conservação estética?

Na gramática do perobjeto, o saber, a explicitação plena do objeto estético funcionaria como se ele fosse objeto de consumo. Ao consumi-lo, o enunciatário transformaria um objeto estético em objeto pragmático. Portanto, eliminaria suas possibilidades estéticas. O não saber, por sua vez, conserva-o, no sentido de que a aproximação do objeto estético se dá pelos sentidos e não pelo saber. Nesse caso, o enunciatário não consegue interferir nas propriedades estéticas do objeto. Do ponto de vista subjetal, na condição de perobjeto, há ativação do objeto e apassivação do sujeito. Paralelamente à estetização, a essa gramática do perobjeto, consideramos também a operação sintáxica da etização.

O objeto ético, da ordem do saber, da moralização, exige um sujeito ativo, que tem o saber moralizante, e um sujeito passivo, aquele que sofre, que deve obedecer. Na literatura, temos alguns exemplos de poemas que se ocupam da moralização. Já na didascália "Queixase o poeta em que o mundo vai errado, e querendo emendá-lo o tem por empreza dificultosa" do poema atribuído a Gregório de Matos (2010, v. 1, p. 347), notamos um saber a ser transmitido: de um sujeito ativo conjunto com um saber moral dos comportamentos que julga adequados para um sujeito passivo disjunto desse conhecimento.

Esse tipo de poesia pertence a um tempo discursivo que tem contrato enunciativo e regras compartilhadas pelas letras seiscentistas. Muitas vezes, transportar valores de um tempo discursivo para outro pode causar uma mudança de sentido. Tentemos um exercício de leitura: 


\section{Queixa-se o poeta em que o mundo vai errado, e querendo emendá-lo o tem por empreza dificultosa}

Carregado de mim ando no mundo, E o grande peso embarga-me as passadas, Que como ando por vias desusadas, Faço o peso crescer, e vou-me ao fundo.

O remédio será seguir o imundo Caminho, onde dos mais vejos as pisadas, Que as bestas andam juntas mais ornadas, Do que anda só o engenho mais profundo.

Não é fácil viver entre os insanos, Erra, quem presumir, que sabe tudo, Se o atalho não soube dos seus danos.

O prudente varão há de ser mudo, Que é melhor neste mundo o mar de enganos Ser louco cos demais, que ser sisudo.

Fonte: Matos (2010, v. 1, p. 347)

Nos dois primeiros quartetos, o sujeito mostra-se em tensão com outros sujeitos (ele, alteridade revelada pela figura "mundo"); a alteridade é vista por ele disforicamente: "carregado de mim ando no mundo / E o grande peso embarga-me as passadas" (destaques nossos). Na condição ética, considera o mundo a-bjeto: "o remédio será seguir o imundo / caminho, onde dos mais vejo as pisadas". Nos dois tercetos finais do soneto, tonifica-se a etização, e o sujeito, em relação a outro sujeito passivo, manifesta quão dificultoso é superar as dificuldades do "mundo [que] vai errado": "não é fácil viver entre os insanos".

O sujeito ético moraliza, assim, o sujeito apassivado, doutrinando-o a reconhecer os seus danos. No primeiro terceto do segundo verso, "erra, quem presumir que sabe tudo, / se o atalho não soube dos seus danos", o verbo errar é, ao mesmo tempo, "incorrer em erro" e "andar sem rumo certo, errante; apartar-se do caminho, perder-se" (HOUAISS; VILLAR, 2001, verbete errar). Contrapondo-se ao homem presunçoso e insano, que "erra no mundo" (destaques nossos), estabelece uma regra ética para superar os antissujeitos, as rupturas do mundo: “o prudente varão, há de ser mudo, / Que é melhor nesse mundo o mar de enganos / Ser louco cos demais, que ser sisudo".

Trata-se, pois, de uma tensão paradoxal entre o sujeito que admite que o mundo é errado, mas, ao mesmo tempo, não admite ser apassivado moralmente: "não é fácil viver entre os insanos", mas "o prudente varão há de ser mudo", pois que "é melhor neste 
mundo" "ser louco cos demais, que ser sisudo"; em outros termos, ele nega o saber moralizante de um outro sujeito. No entanto, o paradoxo revela-se quando seu próprio saber tende a apassivar outro sujeito, que ele avalia como "insano". Nesse caso, a boa conduta seria não moralizar, emudecer ("o prudente varão há de ser mudo").

Há duas direções tensivas: (a) uma que vai no sentido da não etização: o sujeito afirma que o mundo vai errado, mas não admite que alguns sujeitos tenham o direito de apassivar outros sujeitos por acreditarem "saber tudo" e (b) outra que vai no sentido da etização: esse mesmo sujeito, antimoralista, apassiva outros sujeitos, afirmando que, por prudência, deve-se ficar mudo e ser "louco cos demais". O poema funcionaria segundo uma engrenagem tensiva:

\section{Antietização $\rightarrow$ Etização $\rightarrow$ Antietização $\rightarrow$ Etização...}

A apassivação convoca uma ativação que convoca uma apassivação, que convoca uma ativação, um ciclo entre etização e antietização. São duas forças que não se excluem, mas se justapõem para se neutralizarem. Tensionado por uma moralização, o sujeito passivo ativa-se, propondo outro programa que neutralize a moralização recebida. Trata-se por fim de uma tensão que advém de um sujeito, que rejeita a moralização da alteridade, mas que impõe outra moralização, de acordo com seus próprios valores.

Essa mesma tensão do PC verifica-se no PE: há uma oposição rímica nos dois primeiros quartetos: no esquema rímico ABBA (cf. GOLDSTEIN, 2011, p. 60; KAISER, 1968, p. 125), temos nas rimas $B$ emparelhamento e nas $A$ interpolação, de modo que estabelece uma tensão entre a posição do sujeito e a posição da alteridade (no poema, figura "mundo"). É como se o sujeito se reconhecesse como parte desse mundo, que ele avalia como "imundo". Nesse caso, temos identidade (BB) englobada pela alteridade $A(B B) A$, ou seja, esse sujeito é mais um que erra: "o remédio será seguir o imundo / Caminho, onde dos mais vejo as pisadas".

Nos tercetos, porém, o esquema rímico é de rimas alternadas (cf. GOLDSTEIN, 2011, p. 60; KAISER, 1968, p. 125), CDC, DCD, o que indica agora uma separação dos valores da identidade em relação à alteridade, o mundo imundo. Essa alternância rímica na expressão revela-nos no conteúdo uma alternância de pontos de vista: o sujeito não contesta nem as ações da alteridade, nem as próprias ações, mas a moralização (etização) daqueles sujeitos hipócritas que o apassivam. 
Em MUNDO, IMUNDO, MUDO temos agudezas anagramáticas, que manifestam no PC posição do sujeito. Mundo imundo não comporta outra ética que não a de considerar-se parte do mundo e imundo de igual forma. E, portanto, somente a mudez (isotopia da quietude, da serenidade que dão ao poema ares do historicismo de Sêneca) seria um valor que retiraria esse sujeito da "alteridade", do mundo imundo. Ora, se não podemos mudar os outros, mudemos nossa atitude em relação a eles, sejamos loucos com os loucos. Pelo PE visual e sonoro não haveria escapatória: MUDO está contido anagramaticamente em MUNDO e IMUNDO e, aqui, teríamos novamente a identidade (eu mudo) dissolvida na alteridade (do mundo).

\begin{tabular}{|l|c|c|c|}
\hline & Ativação do sujeito & Passivação do sujeito & Ativação do objeto \\
\hline Estetização & -- & + & + \\
\hline Etização & + & + & -- \\
\hline
\end{tabular}

Assim é que o objeto de dominância ética, diferentemente do estético, coloca em tensão dois sujeitos, um ativo, que tem o saber moralizador, e um sujeito passivo, que recebe/reage, como vimos no poema, a um "recado moral". Como se vê, a passividade não é da ordem do relaxamento; não é durativa, portanto. Na etização, há, pois, a transmissão de um saber direcionado de um sujeito ativo para um sujeito passivo. $O$ sujeito ético teria um dever com o saber, criando tensões para o sujeito apassivado que deveria se submeter ao saber moralizador do sujeito ativo. A diretividade, nesse tipo de objeto ético, é dada, portanto, pelo conflito de valores entre os do sujeito ativo e os do sujeito passivo.

O perobjeto, por sua vez, comporta um objeto ativo e um sujeito passivo. Se ativo, o perobjeto atrai ou repele o sujeito. Nessa atração ou repulsão, entra em jogo a opacidade, o invisível e a fé perceptiva de que fala Merleau-Ponty; sua diretividade é assegurada pelo crer. Essa opacidade não se coaduna, portanto, com o saber da ética. O sujeito, nesse caso, é levado a crer no objeto e não a conhecê-lo, porque a operação do saber pode arruinar o perobjeto.

Para usar uma ilustração rasteira, uma paráfrase de um poema destrói suas qualidades estéticas de elaborações formais. A inversão sintática do hipérbato funciona como uma necessidade de opacidade requisitada por qualquer objeto poético. Essa 
opacidade tem uma função no poema: o presunçoso busca esconder seus danos, encobrir seus erros para justamente não ser apassivado por um programa de moralização.

Graficamente, temos:

\begin{tabular}{|c|c|}
\hline Etização & Estetização \\
\hline Sujeito ativo & Sujeito passivo \\
Sujeito passivo & Objeto ativo \\
Dever-saber & Crer \\
& Maravilhamento estético: \\
& atração ou repulsão \\
& \\
& Perobjeto \\
\hline
\end{tabular}

A proposta de Zilberberg sugere, portanto, duas ordens de consideração a etização e a estetização. De um lado, temos a influência das poéticas clássicas de Aristóteles e Horácio, em cujo cerne está a catarse e o docere cum delectare, da ordem da etização; de outro, temos uma influência forte de Valéry e, consequentemente, a euforização do per-objeto, que é da ordem da estetização.

\section{AGUDEZA E FLUIDEZ: O LABIRINTO TENSIVO, AS COMBINAÇÕES ANAGRAMÁTICAS E AS DOBRAS}

A literatura labiríntica ou de agudeza estrutura-se na modalidade veridictória do segredo (ser e não parecer, cf. GREIMAS; COURTÉS, 1983, p. 391 e 487-488). E o que Greimas e Courtés chamam de modalidade do segredo? Na primeira acepção do termo, os autores convocam o conceito de suspensão da antiga retórica. Trata-se de uma estratégia em que o orador mantém por algum tempo seu auditório em expectativa, em reticência, em segredo, sob enigma, portanto. Para a semiótica,

a suspensão surge como um dos "propulsores dramáticos" do discurso narrativo. Se bem que sua teoria se ache longe de estar elaborada, parece que ela se manifesta inicialmente como a projeção de categorias paradigmáticas sobre o eixo sintagmático do discurso. Assim, por exemplo, o surgimento, na narrativa, da função proppiana "instauração da falta" produz um suspense, uma expectativa da função "liquidação da falta". 0 procedimento parece mais elaborado e mais complexo ainda quando, por exemplo, a suspensão da modalização epistêmica faz surgir, num momento dado, um fazer informativo neutro, provocando assim uma "inquietação" no enunciatário, abandonado na ignorância do estatuto veridictório do saber recebido. Em outros casos -- o da isotopia do secreto, por exemplo --, a dificuldade reside no reconhecimento das marcas do secreto, vale dizer, a alusão que insinua que o não parecer esconde pelo menos um ser: é 
evidente que sem essas marcas o secreto não existiria (GREIMAS; COURTÉS, 1983 , p. 448-449, destaques nossos).

$\mathrm{Na}$ acepção 2 do verbete, os autores mencionam ainda que a suspensão, promovedora do drama, da expectativa, estava longe de ser elaborada teoricamente. Hoje, a teoria do acontecimento de Zilberberg (2006a, 2011a) talvez constitua um refinamento do problema da suspensão.

O conceito greimasiano de suspensão "premedita" o conceito de acontecimento, quando afirma que a suspensão manifesta-se em um primeiro momento como projeção do paradigmático sobre o sintagmático (função poética de Jakobson). E que relação tem o acontecimento com a função poética e com a suspensão retórica? Vejamos:

No Dicionário Houaiss (2001), suspensão é

1. Ato ou efeito de suspender, interrupção temporária;

$[\ldots]$

4. Estado de elevação espiritual e de fruição estética; êxtase;

5. Estado de ansiedade, devido à incerteza do que vai acontecer;

[...]

10. Espécie de miragem incompleta, na qual os objetos parecem suspensos no ar;

11. Interrupção intencional de uma frase; pausa, reticência.

Do verbete, depreendemos a cifra do que Zilberberg (2007, p. 25; 2011a, p. 235) propõe como acontecimento (sobrevir + impacto + concessão):

- Interrupção temporária: intensidade da parada (o susto).

- Fruição estética, estado de êxtase: consequência da acentuação da tonicidade sensível do objeto estético.

- Incerteza do que vai acontecer: o sobrevir é uma premissa para o acontecimento, que é concessivo (ZILBERBERG, 2007, p. 25).

- Miragem completa: o sujeito, invadido pelo objeto, fica surpreso e desmantelado.

O enunciatário fica em suspensão; segundo o mesmo dicionário, sujeito "suspenso" é aquele que, pelo estado de êxtase, permanece suspenso por alguns instantes em suas ações cognitivas; assim, invadido por algum acontecimento, desarranja-se em perplexidade sensível. E esse é o caso do enunciatário diante dos poemas agudos, como "Pilar" (século $X X$ ), de Affonso Ávila, e "Labirinto cúbico" (século XVII, ver adiante), de Penhafiel. No 
entanto, por se tratar de um desafio cognitivo, a suspensão inicial, que é sensível, cede lugar posteriormente a uma operação intelectiva: a descoberta do objeto.

Com base no verbete greimasiano de suspensão, entendemos também que ela se manifesta quando da projeção do paradigmático sobre o sintagmático. E o que ocorre quando o paradigma projeta-se no sintagma? Em outras palavras, o que acontece quando uma oposição em ausência, virtual, presentifica-se, provocando um estranhamento, um maravilhamento?

Zilberberg (2011a, p. 103-105) elucida a questão, mencionando a diferença de velocidade entre as escolhas paradigmáticas e as combinações sintagmáticas em um mesmo poema.

O poeta seiscentista e alguns poetas do século XIX-XX descobriram a importância da música no andamento dos objetos poéticos. Muitos poemas agudos chamam a atenção justamente por contemplarem diferentes andamentos melódicos, que ora são mais vívidos e mais rápidos, ora menos vívidos e menos rápidos. No caso de esmaecimento de contornos formais, constante de "Labirinto cúbico", de Penhafiel, de "Pilar" e de "Caminho novo", de Affonso Ávila, por exemplo, as determinações de vivificação do andamento, presentes no enunciado, se fazem pela concomitância de assimetrias cifras tensivas dentro de um mesmo poema, mas essas oscilações não se estabelecem apenas comparativamente, por exemplo, entre Ávila e Penhafiel; elas podem ocorrer entre uma estrofe e outra de um mesmo enunciado poético.

Pelo recurso saussuriano da linearidade, o verso não poderia conter quebras inesperadas. Cada verso teria seu próprio andamento e sua linha seguiria "sem quebra" até o final dele. No entanto, os versos do poema agudo "Pilar" e "Caminho Novo" contêm quebras inesperadas nas sílabas, nos morfemas, ou seja, há um rompimento na organização linear dos sintagmas, o que implica uma oscilação de andamento, conforme a quebra abrupta estabelecida. Um poema clássico, por sua vez, sem quebras abruptas, apresenta uma homogeneidade de andamento, mais tênue, em relação aos poemas agudos de Ávila, por exemplo.

Na coluna da direita do quadro 4.4, "remontamos" para um exercício de leitura os versos de Affonso Ávila, segundo o princípio da linearidade saussuriana. Nesse caso, teríamos uma poesia próxima dos enunciados analítico-discursivos, em que prevalece a linearidade do eixo sintagmático, atenuando o sensível e antecipando o reconhecimento 
inteligível, uma vez que não se encontram escancaradas, em presença visível, as escolhas paradigmáticas. Na poesia linear discursiva, o sintagma é explicitado como nos discursos de prosa.

Na coluna da esquerda do quadro 4.4, a verticalidade paradigmática é explicitada, tonificando sensivelmente o enunciado poético, pois que não é constituído por versos lineares. O poema, percebido visualmente, é um bloco, um poema visual (inteligivelmente desacelerado). Quando as escolhas paradigmáticas, in absentia no processo, revelam-se na poesia e vivificam o sensível, elas obnubilam o sintagma, que será então reconhecido pelo enunciatário (se não explicitada a organização sintagmática, o objeto visual pode não sobreviver, cf. ZILBERBERG, 2006b, p. 200). Façamos um exercício de leitura:

Quadro 4.4 Deslinearização e linearização de "Pilar" (p. 284) e "Caminho novo" (p. 310), de Affonso Ávila (2008a).

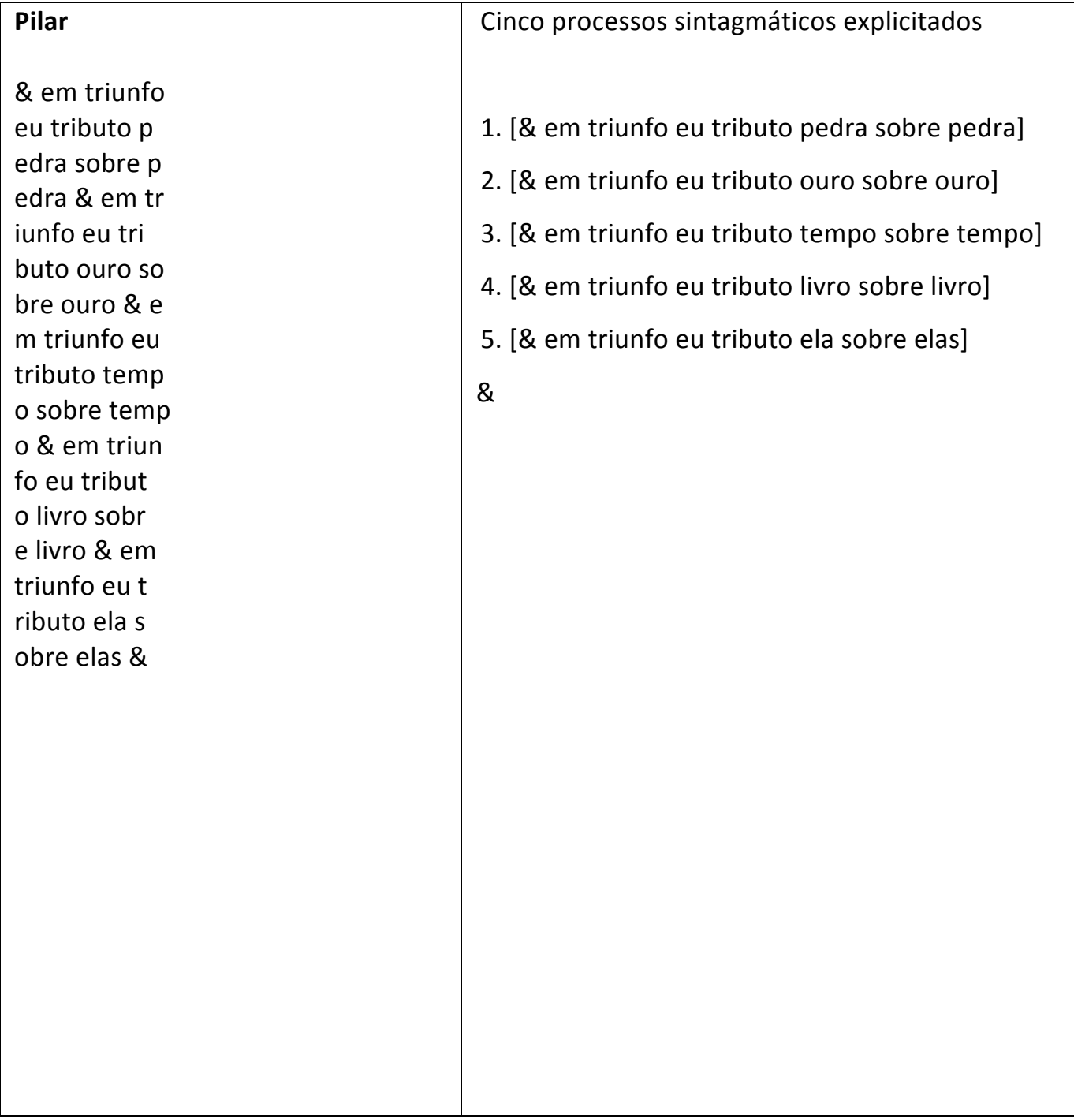




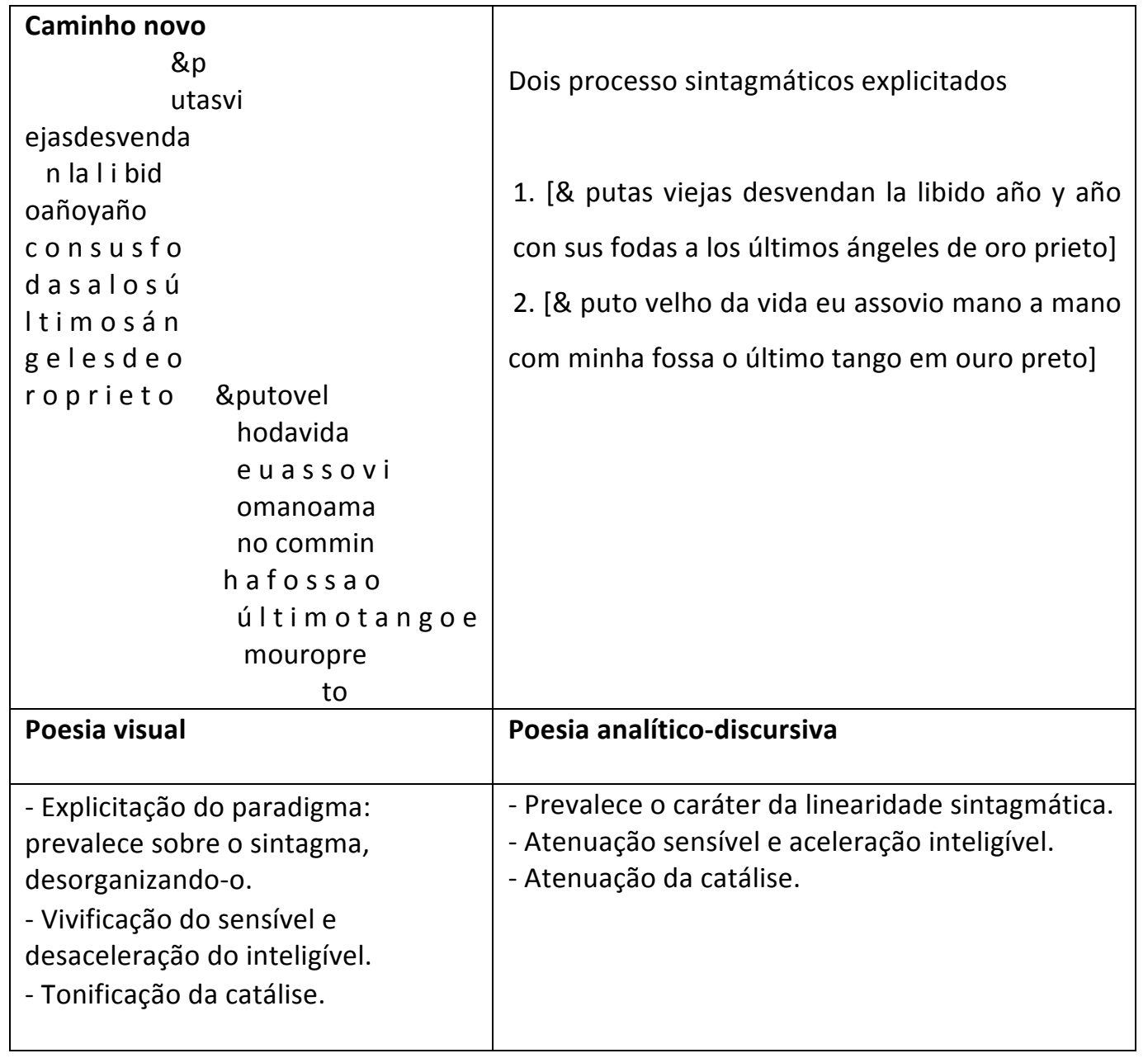

A disposição linear dos versos, exercício da coluna da direita, funciona apenas para efeito de demonstração, visto que destruiria o objeto estético. No enunciado original do poema "Pilar" (coluna à esquerda do quadro 4.4), depreendemos a manifestação de andamentos diversos, construídos sob a escolha de uma organização sintagmática inesperada. Mallarmé (In: CAMPOS; PIGNATARI; CAMPOS, 2010, p. 151-152; citado também por ZILBERBERG, 2011a, p. 106) menciona, no prefácio de Um lance de dados jamais abolirá o acaso, que a distância que mentalmente separa grupos de palavras ou palavras entre si "afigura-se o acelerar por vezes e o delongar também do movimento, escandindo-o, intimando-o mesmo segundo uma visão simultânea da Página: esta agora servindo de unidade como alhures o Verso ou linha perfeita".

Diante de poemas mais fluidos como os de Affonso Ávila -- visuais, concretos, labirínticos --, há uma tensão de velocidades entre: (1) a aceleração dada pelo enunciado poético de vivificação sensível, que tem como destino a resolução da espera e (2) o sujeito que responde lentamente para a entrada no inteligível. Nesse sentido, a fórmula é 
constituída pelo já do poema [para] $\rightarrow$ o ainda não do enunciatário. O enunciatário, diante de "Pilar", deseja uma trégua, um retardamento restabelecedor da nitidez do contorno do enunciado do poema: a trajetória do tempo perfaz um caminho de retorno, do já para um não ainda. Zilberberg (2011a, p. 107) chama essa possibilidade de sintaxe do refreamento.

Nesse tipo de poesia, haveria então uma troca do mais pelo demais? Para Zilberberg (2011a, p. 114, destaques no original),

[o] demais seria o significante que marcaria, na intensificação de uma vivência, a irrupção da primeira atenuação, em suma, de uma singularidade, do mesmo modo que Saussure, em Princípios de fonologia, atribuía o efeito vocálico, o ponto vocálico à primeira implosão. O demais, representando um basta!, viria interromper o curso ascendente dos mais que se sucedem, se concebermos a cadeia das vivências tensivas como sucessão orientada, sequenciada, rítmica, ora de mais, ora de menos (destaques em negritos nossos).

Atinge-se um valor de acontecimento/sobrevir a cada momento que o recrudescimento de agudeza de ênfase no PE atualiza uma interrupção, uma parada: o crescimento da acentuação engendra na manifestação um basta, que estabelece limites para quebra de palavras, composição anagramática, separações de fonemas de sílabas, desarranjos sintagmáticos em prol da exploração paradigmática. O sujeito responde a esse acontecimento, a esse desarranjo, com o que Zilberberg (2011a, p. 114-115) chama de suficiência. Se ultrapassado esse limite, chegaríamos ao que Zilberberg chama de demasiadamente mais. Nesse caso, o objeto se fluidifica de tal forma que retornaria possivelmente a uma massa desconhecida.

O que seria, pois, o conceito de suficiência?

O demais e o pouco demais encaminham o sujeito a ter ciência dos limites de seu campo de presença sensível. Percebemos isso, por exemplo, quando estamos diante do demais nos poemas agudos "Pilar" e "Caminho novo". Tais qualidades excessivas, em muitos casos, passam a não ser mais sensíveis, pois não as sentimos nem as sofremos. Assim, não sentimos, segundo Pascal (2002, artigo XVII - Conhecimento geral do homem), nem o extremo quente nem o extremo frio. As coisas extremas funcionam para nós como se passássemos a não senti-las mais e para elas nós também não existimos; é uma sensação de "tanto faz". Escapamos delas talvez porque elas escapem de nós.

Daí Merleau-Ponty (2006), em Fenomenologia da percepção, entender o corpo como mediador e, nesse caso, o conhecimento reconhece seus limites no corpo do sujeito. E o 
excessivo seria muito para o homem. Uma poesia desarranjada na escala do demasiadamente mais ultrapassa o basta de organização sintagmática; noutros termos, o sintagma saturadamente desmantelado leva a um não reconhecimento cognitivo de tal ordem que coloca à prova a suficiência da competência da função semiótica.

Assim, os poemas da agudeza de ênfase no visual e no sonoro, os paroxísticos principalmente (v. capítulo 5), percorrem o fio da navalha do limite dessa suficiência, quando engendram um labirinto formal intensificado, atingindo o que Zilberberg (2011a, p. 114) chama de basta (ou demais) ${ }^{4}$. Ao atualizar-se uma interrupção por um basta, alcança-se um valor de maravilhamento.

No outro extremo, encontra-se o insuficiente, o pouco demais, que levaria a um relaxamento tal que o sujeito talvez caísse em estado de apatia e se desinteressasse do objeto estético. Pelo parâmetro das vanguardas poéticas do século $X X$, talvez seja exemplo do pouco demais, da ordem do relaxamento tedioso, o poema "A flor do maracujá", de Fagundes Varela, cujo enunciado contempla rimas pobres em A, estrofes de seis versos de redondilha maior, elementos regulados pela espera. Ao final do texto, o enunciador, simulado na pele de um ator "escravo da amada", pede ao enunciatário, na pele de um ator "sinhá", "senhora, dona dele", que não se "enoje" das rimas em "a". Trata-se de uma manipulação para conquistar o objeto de seu desejo.
A flor do maracujá
Pelas rosas, pelos lírios,
Pelas abelhas, sinhá,
Pelas notas mais chorosas
Do canto do sabiá,
Pelo cálice de angústias
Da flor do maracujá!
Pelo jasmim, pelo goivo,
Pelo agreste manacá,
Pelas gotas de sereno
Nas folhas do gravatá,
Pela coroa de espinhos
Da flor do maracujá!

\footnotetext{
${ }^{4}$ Zilberberg oferece-nos duas possibilidades terminológicas para limite da suficiência. Preferimos o termo basta no lugar de demais, porque este último significa "em excesso", "além da conta" (HOUAISS; VILLAR, 2001). Ora se é "além da conta", já seria mais do que o basta. Além disso, enquanto basta mantém-se no limite da suficiência, o demais encaminha-se para uma ultrapassagem da suficiência da função semiótica como ato semiológico.
} 
Pelas tranças da mãe-d'água

Que junto da fonte está,

Pelos colibris que brincam

Nas alvas plumas do ubá,

Pelos cravos desenhados

Na flor do maracujá!

Pelas azuis borboletas

Que descem do Panamá,

Pelos tesouros ocultos

Na minas do Sincorá,

Pelas chagas roxeadas

Da flor do maracujá!

Pelo mar, pelo deserto,

Pelas montanhas, sinhá!

Pelas florestas imensas

Que falam de Jeová!

Pela lança ensanguentada

Da flor do maracujá!

Por tudo o que o céu revela!

Por tudo o que a terra dá

Eu te juro que minh'alma

De tua alma escrava está!...

Guarda contigo este emblema

Da flor do maracujá!

Não se enojem teus ouvidos

De tantas rimas em - a -

Mas ouve meus juramentos,

Meus cantos ouve, sinhá!

Te peço pelos mistérios

Da flor do maracujá!

(VARELA In: REBELO, 1967, p. 212-213).

Distante do enunciado poético tedioso, demasiadamente pouco agudo, tênue, estão as formas labirínticas.

Segundo Sant'Anna (2000, p. 66), os artifícios de vivificação aguda estão vinculados ao percurso de um sujeito peregrino, que, na escolha tensiva de um movimento de aceleração, escava os labirintos formais. O período seiscentista foi fértil em obras labirínticas; o final do século XX de euforia barroquista também o foi. O enunciador (EU) propõe um enigma, ao passo que o TU aproxima-se dele, ativando-se para descobrir o mistério, o que confere também ao enunciatário certo poder de criação. 


\subsection{LABIRINTO TENSIVO}

Nesta seção, propomos o estudo do labirinto como operador determinante de tensividade na semiótica da agudeza. Para isso, vejamos algumas definições de dicionário.

\section{Labirinto:}

- [...] Do grego, Labúrinthos: edifício dividido internamente em numerosos compartimentos que se comunicam por passagens tortuosas. A palavra chegou-nos pelo latim labirinthus (séc. XVI); 2. p. ext. estrutura, conjunto que forma uma complicada rede de elementos [...] em meio aos quais é possível perder-se; dédalo; 3. fig. coisa muito enredada; complicação inextricável; emaranhado, imbróglio, dédalo (HOUAISS; VILLAR, 2001).

- [...] 2. construção com divisões tão complicadas que se torna difícil achar a saída. 3. qualquer lugar com um emaranhado de passagens [...]. 6. embaraço; complicação (BORBA, 2002).

- [...] fig. complicação de negócios difíceis; grande embaraço; meada de difícil desenredo (AULETE, 1970).

- Em francês. p. ext.: [...] rede complicada de caminhos tortuosos, de galerias da qual é penoso sair; fig. complicação inextricável (PETIT ROBERT, 2008, tradução nossa).

- Em italiano: 1. no mundo antigo, estrutura arquitetônica tão complexa que se torna difícil orientar-se ou encontrar uma saída dela: o labirinto de Creta, aquele construído por Minos, para aprisionar o Minotauro; [...] 3. fig. emaranhado de dificuldade inextricável; situação muito complicada (GARZANTI, 2002, tradução nossa).

- Em inglês: [...] Complicada série de caminhos em que é difícil encontrar um meio de sair (OXFORD, 2010, tradução nossa).

A palavra labirinto, segundo Massaud Moisés (2011, p. 256), designa um tipo de construção poética durante os séculos XVI e XVIII, em que o arranjo dos versos permitia uma leitura em diferentes direções de combinações anagramáticas ilimitadas de letras ou de versos: "alguns deles chegavam à 'cifra astronômica de 14.996 .480 combinações possíveis', como é o caso do Labirinto métrico, de Luis Nunes Tinoco". Mais que o simples objeto visual embaraçoso, como é o caso do poema "Labirinto cúbico", de Anastácio Ayres de Penhafiel, o 
poema labiríntico propõe um jogo de desafios; em termos zilberberguianos, desafio à suficiência semiótica.

No capítulo "Uma experiência programática da poesia labirinto portugueses dos séculos XVII e XVIII", Ana Hatherly (1995, p. 41) afirma:

A explicação para o surto de determinadas formas [o basta zilberberguiano], e para o seu recrudescimento cíclico, tem sido tentada por muitos pensadores e no que diz respeito ao labirinto, multiplicam-se os estudos e as interpretações, pois se é certo que o labirinto, pela sua forma privilegiada de percurso-impasse, se tem mantido, ao longo dos tempos e em todas as culturas, como uma constante, há uma época em que essa forma atinge um tal desenvolvimento que praticamente pode ser assumida como seu emblema: o período que vai de princípios do século XVI a meados do século XVIII, geralmente designado por maneirista-barroco (destaques nossos).

A estudiosa portuguesa adiante apresenta uma interpretação do uso do labirinto poético. Num mundo

em que tudo se torna confuso pela profusão, o labirinto é o lugar de desafio à capacidade mental, analítica e lógica. A descoberta da verdade, numa época em que domina o absolutismo político no poder temporal e o dogma e o racionalismo no poder intemporal, tem de ser um percurso cheio de impasses, do qual só é possível sair-se vitorioso através da meditação sobre a dificuldade e a misteriosidade da vida: é assim que a arte se alia à ciência (HATHERLY, 1995, p. 60, sublinhas nossas).

Considerando o enunciado do poema labiríntico, o enunciatário é convocado a participar na "reestruturação do poema", pois de "cada nova leitura surge um novo poema" (cf. HATHERLY, 1995, p. 95). Segundo ela, a fruição das possibilidades de leitura de um poema labiríntico convoca um jogo entre "uma escrita codificante e uma leitura descodificadora" (p. 107).

A multiplicidade de sentidos nesse tipo de poesia aguda tem uma base matemática, como temos discutido, em diálogo com as Artes combinatórias de Leibniz e Pascal. Reforça Hatherly ainda que no labirinto "tudo tem um objetivo, que deve ser identificado" (p. 107). A característica fundamental dos labirintos é "sua natureza enigmática de desafio" (p. 107). 0 mesmo prazer experimentado pelo "decodificador" do labirinto é o do enunciatário na poesia aguda do final do século XX; diferenciam-se, no entanto, pelos valores de seus destinadores: o período seiscentista, de um lado, regido pelo impasse entre mistério da vida e ciência, entre arte e cientificidade (uma e outra ou uma ou outra?); e o século XX, de 
outro, pós-iluminista, destinado pelo movimento de afirmação da arte e a negação do positivismo na literatura realista, naturalista. Assim é que "encontrar a saída do reconhecimento", por exemplo, do "labirinto" em "Pilar", de Affonso Ávila, embora possa causar desafio ao intelecto e certo prazer, talvez não seja o programa da poesia do final do século $X X$, visto que seu enunciador não vê a complexidade de seus enunciados como uma falta a ser suprida.

O labirinto poético do século XVII é fundamentalmente produzido para ser visto e lido. Sua decodificação contempla uma leitura visual, mas, ao mesmo tempo que permite variadas possibilidades de leitura ("sabendo nós, que, na época, a leitura era feita em voz alta"), "a sua estrutura sonora tem de ser um valor a ter em conta" (HATHERLY, 1995, p. 108).

Em geral, os labirintos poéticos são compostos por elementos que se reiteram -sílabas, fonemas, palavras, sintagmas - e introduzem nos poemas visuais "algo da sua origem essencialmente propiciatória, reinserindo-se, pelo menos em parte, na categoria dos mantras, das ladainhas, das litanias e das outras formas de oração encantatória" (HATHERLY, 1995, p. 109). O ritmo de litania é outro elemento da agudeza de ênfase no PE que, além de visual é acentuadamente melódico. Esse ritmo faz-se em movimento de dobras, de elipses, que se repetem.

O que se nota nas definições de labirinto mencionadas é a constituição de uma cifra tensiva que vai do demais [limite] ao demasiadamente mais ("excesso", "inextricável"). É uma forma acentuada e vivificada que, ao mesmo tempo que engendra um objeto extremamente sensível, engendra também um objeto extremamente inteligível e que, como já enfatizamos em outras oportunidades, promove dois momentos de estesia:

- No primeiro, o sujeito é invadido pelo objeto, comovendo-se.

- No segundo, o sujeito, desafiado, coloca-se no programa do fazer intelectivo, buscando saídas para apreendê-lo cognitivamente.

- Trata-se, portanto, de duplo percurso semiótico: o do prazer sensível e o do prazer inteligível.

Os labirintos seiscentistas eram de vários tipos: em cruz, em círculo, em polígono, em forma quadrangular. Eram construídos em madeira, em vegetais (jardins), em pedra. Os percursos labirínticos, que resultavam em uma saída única, eram chamados de espirais e 
eram das civilizações agrárias. Já os de base quadrangular eram urbanos e de múltiplas saídas (cf. DANIEL, 2009, p. 29 ss; HOCKE, 2005, p. 161-170).

Os labirintos de saída única, que oferecem um obstáculo de menor acentuação na intensidade, são lineares; temos aqui uma organização implicativa zilberberguiana, ou seja, se o enunciado está fechado e há uma saída única, espera-se encontrá-la, diferentemente, pois, dos labirintos de múltiplas saídas, de maior acentuação na intensidade, em que prevalece uma organização concessiva, marcada pelo sobrevir (ZILBERBERG, 2011a, p. 242 e 263). Neste último caso, o encontro da saída é imprevisto, inesperado, e teríamos assim um vivificação sensível e uma atenuação inteligível.

Para Daniel (2009, p. 32), “o caráter lúdico da arquitetura labiríntica tem o seu equivalente literário nos textos visuais do barroco". O jogo literário permite diversas possibilidades de leitura originadas de estratégias anagramáticas, condensações, desarranjos de formas de expressão e de conteúdo. Essa estratégias configuram uma tensividade de um mais mais de entraves, que corre o risco de saturação; caminhando-se aqui no limiar do mais, ou seja, da possibilidade de não encontrar uma saída, que se constituiria numa parada na continuidade do sentido. Essa fronteira é vista aqui euforicamente, porque permite ao enunciatário, respeitando-se os limites do embaraço, ter o prazer da conquista intelectual.

O labirinto teria encontrado durante o chamado barroco seu momento de glória. A admiração pela forma labiríntica moveu a produção de vários objetos na época, como o de Sóror Maria do Céu, que escreveu A preciosa, uma novela em forma labiríntica.

Affonso Romano de Sant'Anna (2000, p. 57) chama a ocorrência labiríntica de "fenômeno barroco". O poema "Labirinto cúbico" de Anastácio Ayres de Penhafiel (1724), escrito em latim na Bahia, foi dedicado ao vice-rei do Brasil, Vasco Fernandes César de Menezes. Segundo Sant'Anna, "esse autor que existe e não existe produziu não apenas algo insólito no panorama geral da poesia da época, mas um texto que se transforma na pedra de toque que possibilita, estrategicamente, uma releitura global do barroco" (p. 58, destaques nossos). E é essa releitura global do barroco que permite verificar uma virada na perspectiva. Em vez de enunciados clássicos ordenados tendo em vista o conforto da clareza, formas labirínticas agudas engendram um EU que aproxima e intensifica um TU para construir um enunciado poético regulado para suscitar o desconforto do estranhamento do sobrevir e da demora do reconhecimento.

Vejamos o poema "Labirinto cúbico": 
INUTROQUECESAR

NINUTROQUECESA

UNINUTROQUECES

TUNINUTROQUECE

RTUNINUTROQUEC

ORTUNINUTROQUE

QORTUNINUTROQU

UQORTUNINUTROQ

EUQORTUNINUTRO

CEUQORTUNINUTR

ECEUQORTUNINUT

SECEUQORTUNINU

ASECEEUQOTUNIN

RASECEUQORTUN I

Esse painel de grafemas, direcionado pelo título, "Labirinto cúbico", ao mesmo tempo que é um objeto visual, um "cubo", é também um labirinto, um enigma, que lembra um lance de dados com inúmeras combinatórias de sentido. No poema de Penhafiel, há muitas e permutáveis direções de leitura, o que o "aproxima estruturalmente do Labirinto de Fernão Álvares do Oriente" (ÁVILA, 1980, p. 91), a ser visto adiante.

A visualidade gráfica e concreta do poema seiscentista agudo, marcada por escolhas de um enunciador que opta por soluções de natureza fonológica, morfológica, léxica, sintagmática, manipula linguisticamente o enunciatário num jogo de muitas línguas e de formas "desarrumadas".

Para Affonso Ávila (1980, p. 81),

o barroco, na sua singularidade de arte de prevalência lúdica, ensejou obviamente ao poeta um trato bastante flexível e versátil da língua e a liberdade com que este encarou os problemas de ordem técnica da composição abriu-lhe caminho para uma forma que, mesmo quando não atingindo o desejado nível criativo, acabou por infletir sempre para uma faixa ainda que mínima de inventividade.

O poeta, arquiteto da palavra, constitui-se, portanto, num hábil arquiteto linguístico. Haroldo de Campos, que, em várias oportunidades chama Vieira de enxadrista da linguagem, também escreveu um livro de poesia que chama a atenção pela propriedade do jogo poético, Xadrez de estrelas. A mestria do artista assemelha-se às mais variadas estratégias de um jogador, que movimenta suas peças no tabuleiro, tendo em vista driblar o adversário para mostrar competência no jogo. 
Cita ainda Ávila (1980, p. 82) os cancioneiros engenhosos que jogam ao escolherem artifício melódicos e linguísticos, tendo Camões como representante: "e não se interrompe aí essa linha de tradição nitidamente pronunciada, pois a veremos projetar-se mais contemporaneamente na obra dos principais poetas de fins do século XIX e primeiras décadas do XX - um Cesário Verde, um Antônio Nobre, Camilo Pessanha, Sá-Carneiro ou Fernando Pessoa". O crítico e poeta Ávila chama-os de "excepcionais criadores", pois fazem do "texto poético uma estrutura efetivamente aberta, inauguram em seu país uma linguagem de modernidade inventiva, possibilitando a implantação a longo prazo de uma mentalidade de renovação e vanguarda" (p. 82).

No poema "Labirinto cúbico", como o nome já diz, há um desafio logo no título para o enunciatário: restituir os contornos esmaecidos. E o que significa INUTROQUECESAR no poema? As letras seiscentistas brasileiras utilizavam, além da língua natural portuguesa, o italiano, o latim, o espanhol, como artifício. In utroque Cesar quer dizer "tanto faz um César por outro" ou "um César em lugar de outro". Analogamente, teríamos "um significante no lugar de outro": um jogo misterioso de seleção paradigmática para formar um processo, uma combinação sintagmática. A cada escolha, porém, não há apenas uma troca, uma substituição, mas a constituição de uma nova possibilidade de produção de sentido. Assim como no xadrez o deslocamento de um peão não tem o mesmo efeito do deslocamento de um bispo, ou de uma torre, também na linguagem as trocas não são ingênuas. 0 mesmo poema de Penhafiel, se escrito em português ou em letras minúsculas, já produziria outros efeitos de sentido. Já as variadas possibilidades de leitura parecem homologar PE e PC: assim como a troca de direção "dá sempre na mesma", leva sempre ao mesmo resultado, no PC também não há alteração, pois "tanto faz um César por outro". Nesse sentido, "Labirinto cúbico" pode ser lido da esquerda para a direita, de baixo para o alto entre outras possibilidades. Iniciando sempre na letra I, dobrando à esquerda, à direita, ziguezagueando, o sintagma será sempre o mesmo: Inutroquecesar. Esse ludismo de formas engenhosas constitui-se uma das operações da semiótica da agudeza.

Como temos discutido, Leibniz e Pascal desenvolveram a análise combinatória, cujo pensamento influenciou o desenvolvimento dos objetos ditos barrocos: "há mais lógica e matemática no barroco do que supõe sua comum interpretação apenas expressionista, apenas cultista, apenas sentimental e arrebatadoramente mística e religiosa" (cf. SANT'ANNA, 2000, p. 59-60). 
É, pois, a partir das formas combinatórias agudas que o poeta torna-se arquiteto, combina, arranja, permuta, joga com a seleção paradigmática, sobrepondo-a ao eixo sintagmático. São as possibilidades combinatórias formais que buscam velar o enunciado, engendrando um enigma para o enunciatário.

É assim que a leitura de "Labirinto cúbico" pode ser feita, respeitando-se o quadrado ou a curva; reta e curva justapõem-se, portanto. Para ilustrar a noção das estratégias labirínticas, Sant'Anna (2000, p. 60) cita I carceri (1745 - figura 4.1), de Giambatista Piranesi, cuja obra é considerada o clímax do jogo barroquista.

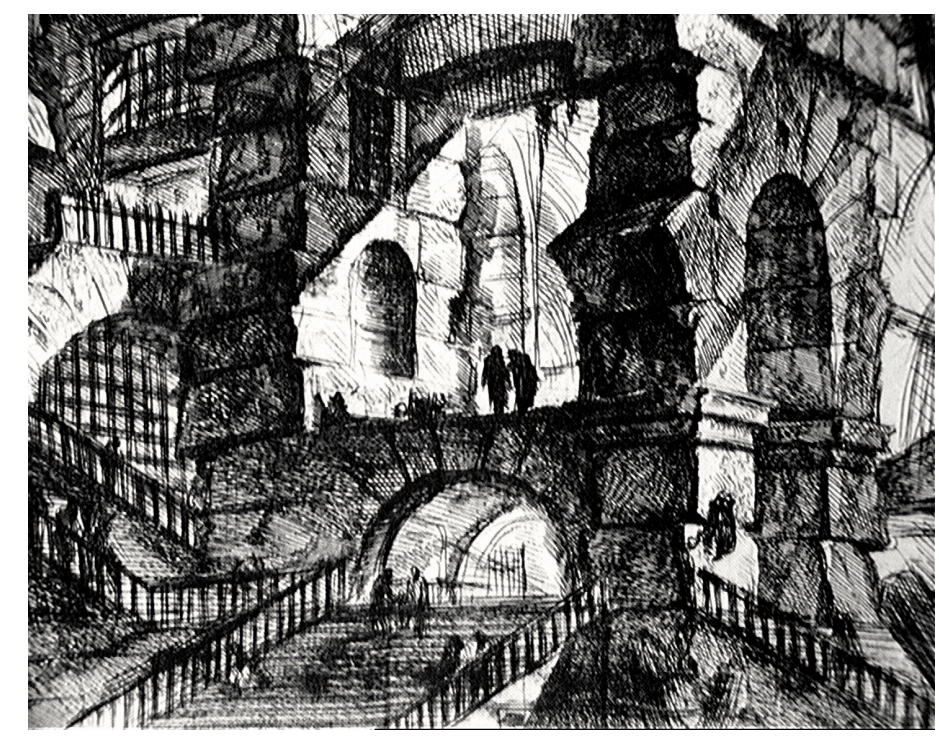

Figura 4.1 Os cárceres, de Piranesi (1745).

As múltiplas escadarias, arcos, passagens, portas constroem um simulacro de um pesadelo de uma saída impossível. Esse tema labiríntico percorre 16 telas do artista veneziano Piranesi.

O mesmo ludismo de Inutroquecesar verificamos ainda em "Laberinto" de Fernão Álvares do Oriente, que é um exemplo de poesia aguda seiscentista de formas renovadas, que contempla múltiplas direções de sentido: 


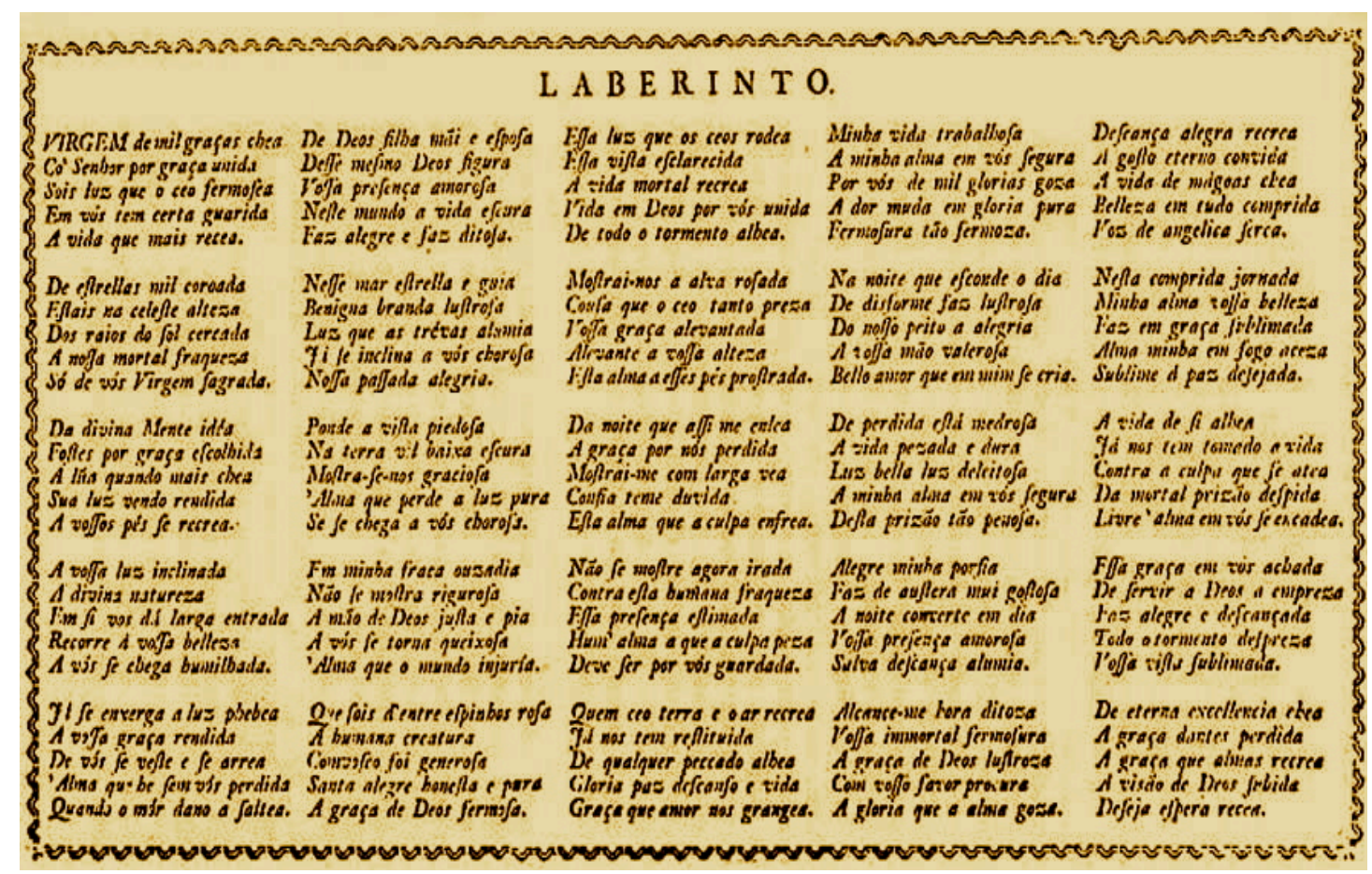

Esse poema é um típico caso de agudeza, que explora a propriedade da forma combinatória e do labirinto: "embora medíocre como concepção da ideia poética e sem maior brilho de linguagem, o Laberinto é exemplo do que, dentro da conceituação de Umberto Eco, pode-se entender por uma estrutura aberta" (ÁVILA, 1980, p. 84). Noutros termos, estamos diante de um enunciado passível de várias leituras, derivadas do artifício do ordenamento de versos e estrofes, da exploração do recurso do paralelismo das frases e da estratégia de reiterada recombinação gráfica.

"Laberinto" é um poema composto de 25 estrofes de cinco versos de sete sílabas cada um, de esquema rímico ABABA. As estrofes estão dispostas em cinco blocos que podem ser lidos na horizontal ou na vertical. As combinatórias de leitura multiplicam-se tanto na esfera dos blocos quanto na esfera das estrofes e dos versos. E os versos, por sua vez, arranjam-se de modo apreensível tanto na linha horizontal como na vertical e até na diagonal. Uma possível sequência de leitura obedece à ordem comum dos versos (A): 1 -> 2 $>3->4$ > 5 ou à ordem contrária (B): 5 -> 4-> $3 \rightarrow 2$-> 1 . O enunciatário, desafiando a abertura do enunciado, pode construir outro enunciado poético de ordem aleatória (C): 3 -> 2 -> 5 -> 4 -> 1. Outra saída (D) ainda é percorrer os versos iniciais horizontais, ou, ainda, perseguir verticalmente a sequência dos versos iniciais das estrofes que ocupam a primeira posição à esquerda (E). Vejamos: 
(A): Virgem de mil graças chea Co' Senhor por graça unida Sois luz que o ceo fermosea Em vós tem certa guarida A vida que mais recea.

(B) A vida que mais recea Em vós tem certa guarida Sois luz que o ceo fermosea Co' Senhor por graça unida Virgem de mil graças chea.

(C) Sois luz que o ceo fermosea Co' Senhor por graça unida A vida que mais recea Em vós tem certa guarida Virgem de mil graças chea.

(D) Virgem de mil graças chea De Deos filha mãi e esposa Essa luz que os ceos rodea Minha vida trabalhosa Descansa alegra recrea.

(E) Virgem de mil graças chea De estrelas mil coroadas Da divina Mente idéa A vossa luz inclinada Já se enxerga a luz phebea.

Seria difícil exaurir as possibilidades de combinatórias de leitura oferecidas pelo poema, pois se trata de um enunciado composto segundo um jogo matemático, estruturado de modo aberto. Desde os seiscentos, o poema agudo, vivificado mais por combinações formais de PE e de PC, torna-se mais sensível sonoramente e/ou visualmente, como temos observado.

"Soneto per Eccos", final de Prosopopeia (1601), de Bento Teixeira, é apresentado por Affonso Ávila (1980, p. 87) como um exemplar de poesia visual do século XVII: 


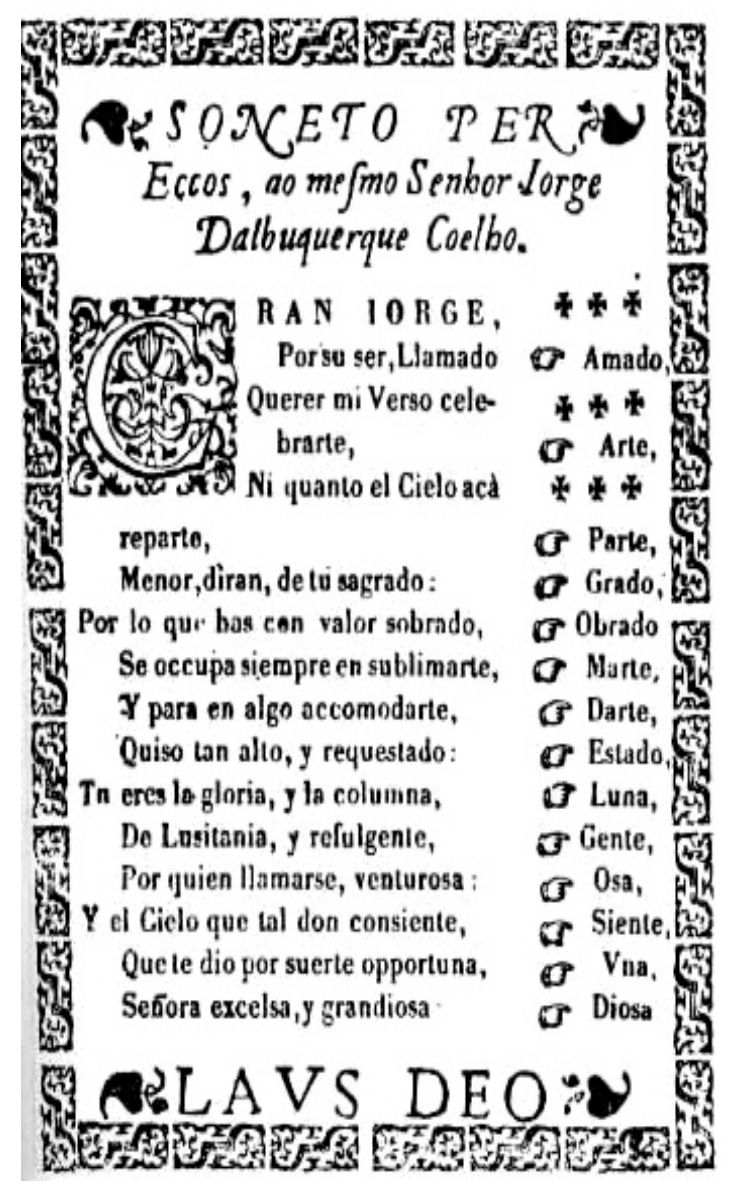

A inventividade poética nesse soneto é de ordem visual, visto que utiliza já no século XVII arte tipográfica e ideogramática. Essa ênfase visualista é uma tradição revisitada posteriormente, no final do século XX, nos poemas de Cantaria barroca (1973-1975) e de Barrocolagens (1968-1975) do próprio Affonso Ávila, reunidos no livro Homem ao termo (2008a).

No poema a seguir, "Ao mesmo [desembargador Dionizio de Ávila Varreyro] por suas altas prendas", atribuído a Gregório de Matos (2010, v. 1, p. 320), o enunciador opta pelo aproveitamento do espaço da página, construindo um enunciado visual em que ficam explícitas as escolhas paradigmáticas por meio do paralelismo estrutural. É notável o simulacro de presentificação do eixo paradigmático no sintagmático, programa de toda e qualquer função poética. No final dos três últimos versos, por exemplo, glória e alegria comungam o sufixo "ia" (glor/alegri/ia/). De baixo para cima, nos versos 4-5-6, energia e memória compartilham o mesmo sufixo "ia” (memór/energ/ia). Nas escolhas paradigmáticas simuladas em presença, fica exposto o lavor do poeta dos séculos XVI-XVII. Essas estratégias de agudeza serão re-formatadas e acentuadas na poesia do final do século XX, configurando 
outro tipo de agudeza, evidentemente. Diferentemente da língua natural, na poesia aguda é prática corrente "fingir" no processo sintagmático o que normalmente pertence ao sistema virtual, in absentia. A soberania paradigmática é marca dessa poesia de invenção, como se nota em "Ao mesmo por suas altas prendas":

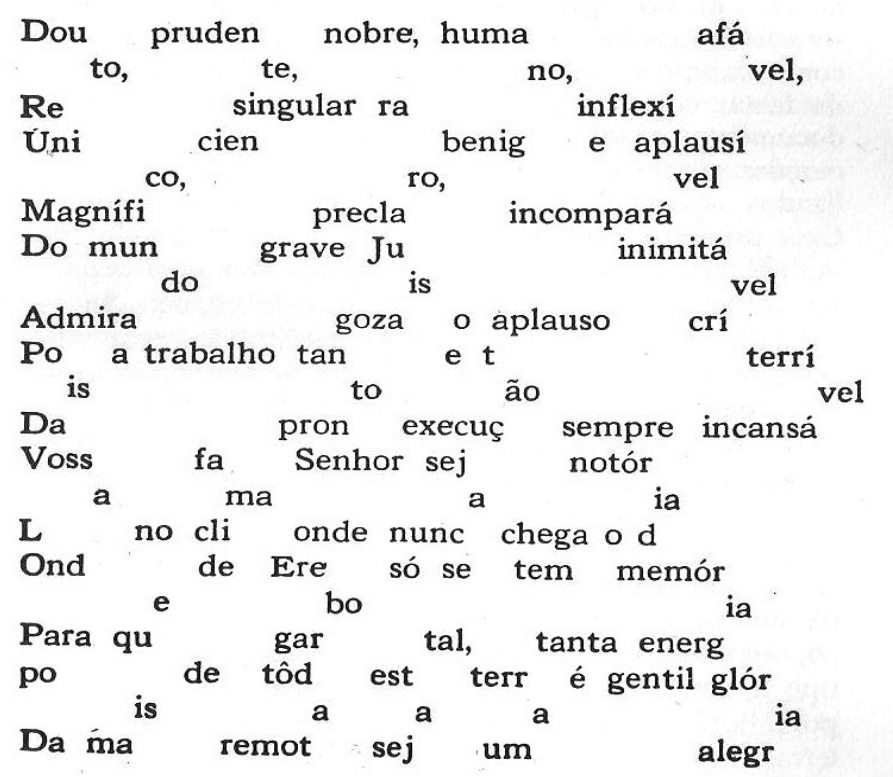

A poesia atribuída a Gregório de Matos seria iniciadora entre nós de uma poesia de agudeza; ele não deixa de "ser igualmente o maior e mais autêntico criador dentre os poetas da literatura barroca de nosso idioma [...]". Seus poemas evidenciam a "propensão lúdica dominante na arte seiscentista, a atração pelo jogo das ideias e das palavras" (ÁVILA, 1980, p. 94). Ao contrário do jogo de veladura dos poetas seiscentistas, o que se atribuía a Gregório de Matos explora mais intensamente a melodia (melopeia). O poema visual acima é uma exceção na obra do poeta. Sua produção era mais para o ouvido do que para a visão, buscando "utilizar-se das formas indicadas para reforçar a comunicabilidade de sua mensagem, para estimular a receptividade do ouvinte ou leitor, recorrendo a composições ou soluções em que predominam elementos de iteração, de repetição, de redundância, tais como os refrãos, os ecos, as consoantes forçadas" (ÁVILA, 1980, p. 97).

Os sujeitos da enunciação seiscentistas são destinados por um tempo discursivo em que a linguagem poética era presa aos moldes clássicos. Suas combinações agudas eram muitas vezes contestadas e acabaram marginalizadas nas histórias literárias; semelhantemente, o poeta agudo do final do século XX, por se dedicar também ao trabalho 
com a linguagem, vivencia uma época de sanção também negativa. Neste último caso, os sujeitos da enunciação, por privilegiarem elementos estruturais, como o aleatório, as múltiplas combinações, o jogo, a criatividade, às vezes recebem sanções disfóricas de alheios à realidade. O que se vê nesse tipo de poesia é uma reformatação, por parte do fazer poético, das formas engenhosas agudas e não puramente repetição de um discurso que nos séculos XVI e XVII contava com outros valores. Embora haja uma linha de tradição de trabalho criativo da linguagem poética, não herdamos as preocupações ideológicas dos seiscentos.

A linha de tradição poética, objeto desta tese, contempla a agudeza visual que não herdamos do século XVI, não sendo, portanto, "barroca", visto que ela aparece em objetos poéticos anteriores aos seiscentos. Veja a seguir o misterioso quadrado mágico da Roma Antiga "SATOR-AREPO", que comunga anagrama e palíndromo:

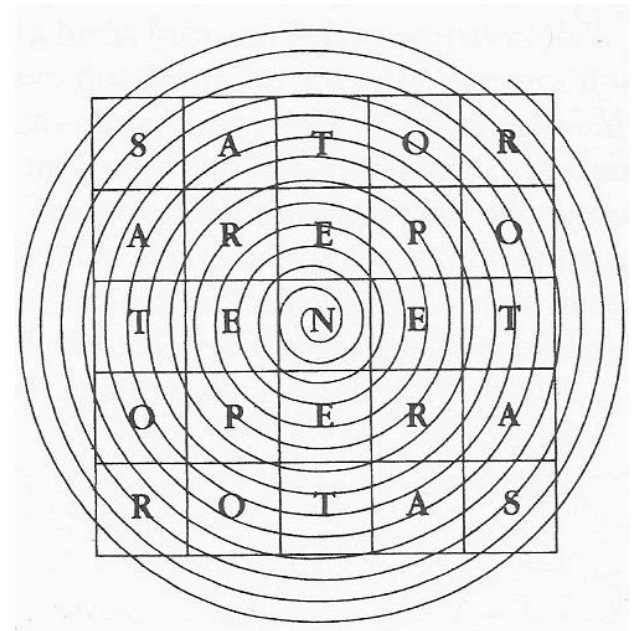

SATOR AREPO TENET OPERA ROTAS é uma frase inventada por um escravo da Pompeia Antiga. Composto de cinco palavras de cinco letras cada uma, pode ser lido em mais de um sentido nos 25 quadrados que formam o quadrado maior em que está contida a espiral. As palavras não apenas se sobrepõem na horizontal, como também se estendem nas colunas verticais, visto que o poema pode ser lido da esquerda para a direita, da direita para a esquerda, de cima para baixo, de baixo para cima, em muitas direções. Duas delas seriam:

1. O lavrador mantém cuidadosamente o arado nos sulcos.

2. O lavrador sustém cuidadosamente o mundo em sua órbita. 
O poema apresenta o percurso do escravo Loreius que, em 200 a.C., morava em Pompeia e tinha sonhos enigmáticos. Seu senhor Publius Ubonius Ihe propôs um desafio: escrever uma única frase de apenas cinco palavras com cinco letras cada uma que pudesse ser lida de frente para trás e de trás para a frente, sempre com o mesmo sentido. $O$ escravo aceitou o desafio, criou a frase, mas demorou a mostrá-la ao seu senhor; em uma noite, bêbado, acabou revelando sua frase em lugar público. $O$ enunciado mágico acabou correndo de boca em boca e, por fim, descoberto, antes mesmo da revelação ao patrão. Loreius, desesperado, suicidou-se. No século XX, Osman Lins, à semelhança da combinação matemática da frase produzida pelo escravo de Pompeia, escreve Avalovara ([1973] 2005), com a precisão de um relógio, que progride em espiral. Cada capítulo possui um número progressivo de linhas, cruzando cada um deles, de tema específico, com outro correlativo e em ascensão. Consciente de seu fazer combinatório, segundo Sant'Anna (2000, p. 79), Osman Lins pode ser considerado autor de um enunciado fluido, manifestamente acentuado.

O labirinto enigmático de "SATOR" permite a criação de 13 frases anagramáticas e ainda a frase "Pater Noster". Hocke (2011, p. 46) apresenta para o enigma uma interpretação religiosa: "Deus (Sator) domina (tenet) a criação (rotas), as obras dos homens (opera) e os produtos da Terra (arepo = arado)".

Também na música encontramos exemplo desse gosto por combinatórias labirínticas. Em uma das 14 peças de Bach, "Arte da Fuga", o enunciador simula sua presença na partitura, utilizando as quatro letras de seu nome:

\section{B-A-C-H}

Nos países anglo-saxônicos,

B é si bemol

A é lá

Cé dó

H é si

Bach, assim como João Guimarães Rosa e Johannes van Eyck, como vimos no capítulo 3 , criam um simulacro discursivo, em que se projetam como "autor" dentro do enunciado da obra, assinando-a como se o autor pudesse de fato vivificar-se em seu próprio texto. Haveria 
nos exemplos citados a paixão de um enunciador vaidoso, que quer deixar sua marca, mostrando competência metalinguística, desejoso de tornar-se discursivamente imortal, pertencendo a uma tradição literária?

\subsection{COMBinaçõEs ANAGRAMÁticas}

O artifício agudo promove a aproximação do sujeito da enunciação. Uma das estratégias agudas é o anagrama, que permite uma multiplicidade de combinações que acentuam e sensibilizam o enunciado poético. Huizinga (1996, p. 14) explicita que ilusão significa literalmente "em jogo", expressão que teria origem em ilusio, illudere ou inludere. Em latim, a palavra ludus tem o sentido de jogo, mas também de irreal, ilusório. Em sânscrito, lila significa parecer, fingir, simular a aparência das coisas. Ao aproximar "poesia" e "jogo", ilusão, segundo Huizinga (1996, p. 147-148, destaque nosso):

Não é apenas exterior a afinidade existente entre a poesia e o jogo; ela também se manifesta na própria estrutura da imaginação criadora. Na elaboração de uma frase poética, no desenvolvimento de um tema, na expressão de um estado de espírito há sempre a intervenção de um elemento lúdico. Seja no mito ou na lírica, no drama ou na epopeia, nas lendas de um passado remoto ou num romance moderno, a finalidade do escritor [...] é criar uma tensão que "encante" o leitor e o mantenha enfeitiçado.

O conceito greimasiano nos ajuda a entender o sentido de ilusão e de enigma na poesia da agudeza: enquanto a ilusão é modalizada por "parece, mas não é" (mentira no quadrado semiótico), o enigma é modalizado por "é, mas não parece" (segredo no quadrado semiótico). Dessa forma, a agudeza opera na tensão entre (1) parecer e não ser e (2) ser e não parecer, sem perder a noção de jogo discursivo: finge jogo quando parece e não é, finge enigma quando é e não parece. Nessa operação tensiva, a escolha aguda é pelas combinações vívidas das formas da expressão e do conteúdo.

Os poemas agudos são poemas semióticos por excelência, visto que operam na simulação entre segredo e mentira (ilusão), que são os dois trunfos da literatura. O jogo entre segredo e ilusão é estruturado segundo técnicas anagramáticas: comutação ou transposição de letras de uma palavra (ou um complexo de palavras) de um enunciado, de maneira que os novos arranjos formem enunciados diferentes dos iniciais. As novas combinações não são de ordem exclusiva, mas inclusiva, e os sentidos, em vez de apenas 
somarem-se, ganham novas possibilidades e proporcionam opacidade e ambiguidade ao poema.

$\mathrm{Na}$ esfera anagramática, não se faz necessário respeitar a ordem das letras do original. Walter Benjamin (2004, p. 228-229; cf. também 1999, p. 182-183), ao estudar a linguagem do chamado barroco, evidencia o motivo fundamental do modo alegórico e afirma:

\begin{abstract}
Nos anagramas, nas expressões onomatopaicas e em muitos outros artifícios de linguagem, a palavra, a sílaba e o som, emancipados das correntes articulações de sentido, desfilam como coisas à espera de serem alegoricamente exploradas. A linguagem do Barroco está constantemente a ser abalada pelas rebeliões dos seus elementos. [...]

A linguagem é, assim, fragmentada para nos seus fragmentos adquirir uma expressão diferente e mais intensa. Foi o Barroco que instituiu o uso das maiúsculas na ortografia alemã. Nisso se revela, não apenas a vontade de pompa, mas também o princípio da fragmentação e da dissociação, próprio do ponto de vista alegórico. [...] A língua estilhaçada deixou de ser nos seus fragmentos mero instrumento de comunicação, e, objeto recém-nascido, coloca a sua nova dignidade ao lado de deuses, rios, virtudes e figuras da natureza semelhantes, todas elas reverberantes de sentidos alegóricos (destaques nossos).
\end{abstract}

Para Benjamin, as formas anagramáticas, ao emanciparem-se das articulações linguísticas esperadas e conhecidas, são levadas a outro nível, o da categoria de objetos estéticos "à espera de serem alegoricamente explora[dos]". Com base nessa reflexão, a agudeza participaria de um esquema tensivo, promovendo "abalos" provenientes das "rebeliões de seus elementos". Parece-nos que os significantes insurgem-se no processo sintagmático para ressignificarem a poesia da agudeza, adquirindo um valor tensivo mais vívido, acentuado, de mais tonificação na intensidade. Deixam, assim, os enunciados de ter finalidade apenas comunicativa e adquirem finalidades estéticas.

Starobinski (1974, p. 50), estudando os anagramas de Saussure e examinando o enunciado:

\title{
AD MEA TEMPLA PORTATO.
}

\section{A $\quad$ PL $\quad 0 \quad 0$}

verifica-se tratar-se de um complexo anagramático de APOLLO (em latim, com dois Ls), iniciando por $\mathbf{A}$ e terminando por $\mathbf{0}$. Salienta ainda que "todo complexo não contém necessariamente os elementos integrais do anagrama. Este os contém, com a única 
inexatidão de que a palavra é tratada como APOLO por um L simples" (p. 50). Como já afirmamos, as composições anagramáticas não seguem rigorosamente a disposição dos enunciados. Assim, as letras que formam Apolo estão em desordem, pois o L está antes do primeiro $\mathrm{O}$.

Para Arrivé (2010, p. 170), "Saussure se vê constrangido a indicar explicitamente a infração cometida contra a linearidade: 'Vemos o A inicial e, em seguida, PLO, que podemos aceitar como POL'." O regime anagramático entende que o significante não se conforma ao princípio de linearidade.

A superação desse princípio de linearidade é um recurso de que se vale o poeta nas operações agudas. O texto labiríntico desarranja-se no nível do significante, acarretando desdobramentos no nível do significado. Arrivé (2010, p. 176) conclui que, "do ponto de vista da literaridade ${ }^{5}$, a especificidade anagramática reside indissoluvelmente no regime de seu significante e na polifonia que esse regime implica" (destaque nosso). Além disso, o anagrama constitui-se em "perplexidade", nas palavras de Arrivé, em relação à linearidade. Duas outras considerações seriam:

1. A regência do significante na poesia aguda.

2. Os novos arranjos do significante engendram novas organizações do significado, provocando ambiguidades e multiplicidade de sentidos.

Em suma, o texto anagramático não se submete à evolução no tempo nem à linearidade: constrói-se "como objeto monstruoso, que põe em causa os próprios princípios da semiologia, fato pelo qual Ihe escapa" (sic) [O texto traduzido parece querer dizer 'fato que lhe escapa', ou melhor, 'fato que escapa à semiologia'] (ARRIVÉ, 2010, p. 178).

Os poemas agudos aqui tratados são exemplos que exigem olhos bem abertos para o significante. Augusto de Campos (1986, p. 40-41), comentando um anagrama de Vieira,

\footnotetext{
${ }^{5}$ No capítulo "Saussure às voltas com a literatura" (ARRIVÉ, 2010, p. 161-181), ao analisar a terceira perplexidade, a tradução brasileira apresenta o termo literaridade. É possível que tenha havido um engano de tradução, ou falha de revisão, porque de "literário" temos "literariedade"; de "literal", temos "literalidade". Como o texto parece argumentar que a linearidade de que fala Saussure seria a da sucessão visual de grafemas, parece que seria mais conveniente que a tradução escolhesse a palavra literalidade. Se está em discussão, então, a ordem de grafemas (letras), o termo mais pertinente seria literalidade. Os dicionários de língua portuguesa registram tão somente "literalidade" e não "literaridade"; "literariedade", termo apresentado pelo dicionário e utilizado pela teoria literária, tem o sentido de "literário" e não de sucessão de fonemas (som), letras (visual). Na técnica anagramática, "literalidade" significaria manipulação de letras, tendo em vista um efeito visual e a constituição de novos sentidos.
} 
destaca a necessidade de não se passar como cego diante dos significantes, caminhando diretamente para o significado.

No "Sermão do mandato", Vieira agudamente nota que sciens era anagrama de nescis ou vice-versa; os homens não haviam percebido que sciens (ciência) engloba também nescis (ignorância). Uma seria da parte de Cristo, outra da dos homens:

só Cristo amou finamente; porque amou sabendo: Sciens: e só os homens foram finamente amados, porque foram amados ignorando: Nescis: Unindo-se, porém, e trocando-se de tal sorte o sciens com o nescis, e o nescis com o sciens, que estando a ignorância da parte dos homens, e a ciência da parte de Cristo, Cristo amou, sabendo, como se amara, ignorando: e os homens foram amados, ignorando, como se foram amados, sabendo. Vá agora o Amor destorcendo estes fios. E espero que todos vejam a fineza deles" (VIEIRA, 2000, v. 1, p. 344; cf. também CAMPOS, A., 1986, p. 40-41).

Vejamos como S C I E N S engloba anagramaticamente N E S C I S (e vice-versa):

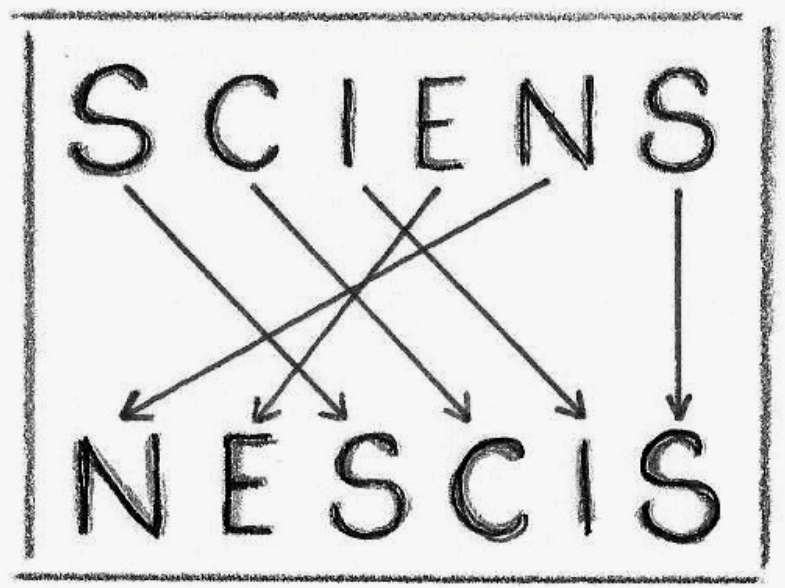

Em // dramma barocco tedesco, Benjamin (1999, p. 153) afirma:

Il poeta non può nascondere la sua attività combinatória a meno che non voglia far tacere il tutto, giacché proprio la messa in mostra della sua costruzione era al centro degli effetti perseguiti. Di qui l'ostentazione della fattura, che, specialmente in Calderón, affiora allo scoperto come la struttura muraria di un edificio dall'intonaco scrostato.

[O poeta não pode esconder seu fazer combinatório, porque o que quer mostrar não é tanto o todo [conteúdo como grande mensagem] como sua construção posta à vista [arranjos de forma de expressão e forma de conteúdo]. Por isso, a ostentação de processos construtivos, que, sobretudo, em Calderón, mostra-se como uma parede de alvenaria cujo reboco caiu] (tradução, destaque e acréscimos nossos). 
Os labirintos poéticos, como sabemos, são compostos anagramáticos. A agudeza constitui-se mais em exibir os processos de construção poética do que propriamente ensinar conteúdos. O poeta quer-ser engenheiro, pensador de seu próprio fazer-construtor.

Para Barbosa (2009, p. 14), entre a linguagem poética e o enunciatário, o enunciador erige-se como o fazedor de enigmas. Ambiguidade, opacidade, polissemia, violação da linearidade, capacidade de fingir são artimanhas da linguagem literária e não "patologia barroca", como entendiam os críticos apoiados num classicismo rigoroso.

Finalmente, a encenação da competência poética na semiótica da agudeza talvez seja mais importante que propriamente a performance ou o produto final do fazer poético.

\subsection{TeNSIVIDADE DAS DOBRAS AGUDAS}

Deleuze (2011a), em A dobra: Leibniz e o barroco, anuncia a dobra como metáfora básica dos seiscentos. É como se Tutameia, de Guimarães Rosa, a tela O casal Arnolfini, de Van Eyck, e a composição de Bach tivessem "dobras" (plis prega em francês) em seu meio, como se elas se dobrassem sobre si mesmas enigmaticamente e em forma de elipse, rompendo com a linearidade e o distanciamento do sujeito da enunciação clássico.

Projetando-se na obra poética, enunciador e enunciatário dobram-na e redobram-na, propondo a busca do fio de Ariadne, reorganizando assim os emaranhados dos enunciados labirínticos e elípticos. Elipse, do grego elleipsis, significa "lacuna", "falta". O discurso elíptico é aquele semioticamente da ordem da fluidez, deixando uma lacuna para o encaminhamento na direção da nitidez. O tema musical da Arte da fuga de Bach, por exemplo, constitui-se em objeto que se direciona para o eixo fluido: é repleto de dobras e de sinuosidades.

Tanto quanto Osman Lins, Guimarães Rosa é outro de nossos literatos que se ocupa de um fazer agudo de fluidez. Vimos que Primeiras estórias é composto de 21 contos, distribuídos em dobras especulares. Sant'Anna (2000, p. 111), ao discutir sobre a presença de um barroquismo engenhoso na modernidade, comenta essa estrutura artificiosa de Guimarães Rosa:

Calculava quantas páginas e capítulos deveriam ter suas extensas narrativas ou quantos contos deveriam ter suas obras mais curtas. Adepto da gematria - que atribui valores numéricos às letras - preferia números ímpares, como o 9, considerado mais perfeito e redondo que outros. Em Corpo de baile a novela "O recado do morro" não somente expõe a temática de um enigma a ser resolvido, mas utiliza-se estruturalmente do 
artifício de um jogo de cartas para se armar, sendo essa narrativa um jogo que se articula.

Euclides da Cunha (Os sertões, 1902) e Glauber Rocha (Deus e o diabo na terra do sol, 1964), segundo Sant'Anna (2000, p. 120 ss), possuem agudezas em comum. Ambos se valem do episódio da Guerra dos Canudos como figura central. Além disso, tanto um quanto outro encaminham-se na direção do eixo da fluidez:

1. Glauber Rocha constrói uma obra elíptica, cujas dobras vão se sobrepondo, num movimento de câmera mais fluidificado e diluído em ziguezague; seu fazer dialoga com Os sertões euclidiano, quando faz citações e paráfrases.

2. Euclides da Cunha compõe a figura do ator Conselheiro que "parece saída de uma pintura barroca" (SANT'ANNA, 2000, p. 122). As sílabas, as palavras do enunciado de Os sertões compõem uma peça aguda, cuja estrutura geometrizada protagoniza um enunciado acentuado na intensidade.

A título de ilustração, em Os sertões dos Campos: duas vezes Euclides, Augusto e Haroldo de Campos (1997, p. 11-50) apresentam um sem-número de enunciados dos Sertões de Euclides da Cunha (1984), que constituem uma geometria em decassílabos e dodecassílabos:

O/ pla/nal/to/ cen/tral/ do/ Bra/sil/ des/ce... (10 sílabas)

... as/li/nhas/ es/sen/ciais/ do /cri/me e/ da/lou/cu/ra. (12 sílabas)

Euclides, como um engenheiro, projeta uma obra de brilhante domínio em relação ao encadeamento sonoro das palavras na frase, como se nota pela precisão das escolhas de fonemas vocálicos, que vão se permutando entre categorias de abertura e de fechamento, de atenuação e vivificação, como se pode ver em:

"o tropear soturno das fileiras" = /o/ /o/ /e/ /a//o/ /u/ /o/ /a/ /i/ /ei/

Essas escolhas estruturais calculadas, em certo sentido, objetivam a produção em espelho de ecos onomatopeicos: "um cascalhar de risos abafados" (CAMPOS; CAMPOS, 1997, p. 30). Augusto e Haroldo de Campos (1997, p. 13) chegam a contar mais de "500 decassílabos significativos, com predominância dos sáficos (acentuados na $4^{\mathrm{a}}$ e $8^{\mathrm{a}}$ sílabas) e heroicos (acentuados na $6^{\mathrm{a}}$ ), e a pouco mais de duas centenas de dodecassílabos (dentre os quais muitos alexandrinos perfeitos)". 
Esse trabalho com a linguagem, de precisão matemática, dialoga a todo o momento com as composições seiscentistas. Não é à toa que, quando pensamos nas composições de Bach, de Euclides da Cunha, surge-nos como pano de fundo certa engenharia. Ocorre que os autores ditos conceitistas, nesta tese denominados agudos, partem de estruturas tensivas como a da evolução melódica, engendrando no enunciado uma geometria que engrena elementos fortes e fracos em dobras. E é esse tipo de composição que coloca Bach, Vieira, Osman Lins, Euclides da Cunha, Glauber Rocha na direção de uma semiótica vívida na intensidade.

No "Sermão de quarta-feira de cinzas" e no "Sermão da sexagésima", de Vieira, por exemplo, as figuras são colocadas umas após as outras, misturando-se agudamente até o final do enunciado do sermão. As frases de Vieira seguem um ritmo compassado, formando simetrias, com processos sintagmáticos que progridem e regridem, como dobras, pregas, elipses, que funcionam como as simultaneidades das saídas num labirinto. Vejamos:

Sermão de quarta-feira de cinzas (VIEIRA, 2000, v. 1, p. 55-70)

1. “Que dizem aquelas letras? ( $1^{\text {a }}$ figura: letras)

2. Que cobrem aquelas pedras? ( $2^{\mathrm{a}}$ figura: pedras)

3. As letras dizem pó, as pedras cobrem pó, e tudo o que ali há, é o nada que havemos de ser: tudo pó" (p. 55) (1 + 2: mistura de duas figuras, resultando a conta na figura "pó").

Trata-se de um processo de comutação de sons e de grafemas, que explodem em um jogo, em que o significante não é apenas um veículo nem tem um sentido único, mas conduz o enunciatário a várias direções ou pontos de fuga:

Porque cada um é o que foi, e o que há de ser. A Vara de Moisés antes de ser Serpente foi vara, e depois de ser Serpente, tornou a ser vara; e serpente que foi vara e há de tornar a ser vara, não é serpente, é vara (VIEIRA, "Sermão da Quarta-feira de cinzas", 2000, v. 1, p. 57).

Os sintagmas mudam de lugar, formando um $\mathrm{X}$, um quiasmo: 
A Vara de Moisés antes de ser serpente foi vara.

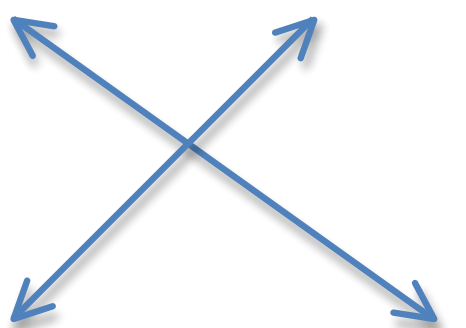

E depois de ser Serpente, tornou a ser vara.

No exemplo, observamos um ofício linguístico, uma manipulação entre os lexemas vara e serpente, que mudam de lugar, produzindo encantamento. Estamos de novo diante dos conceitos greimasianos de segredo e ilusão. No trecho de Vieira, o presente incorpora o passado, porque o passado produz o presente, que resulta no futuro. Anterioridade resulta no agora, que engendra a posteridade. E tudo isso alcança-se com a simples permutação de lexemas, redistribuindo-os no processo sintagmático:

Sermão da sexagésima (VIEIRA, 2000, v. 1, p. 29-52):

Será por ventura o estilo que hoje se usa nos púlpitos? Um estilo tão empeçado, um estilo tão dificultoso, um estilo tão afetado, um estilo tão encontrado a toda a arte e a toda natureza? Boa razão é também esta. [...] A queda é para as coisas, a cadência para as palavras, o caso para a disposição. A queda é para as coisas, porque hão de vir bem trazidas em seu lugar; hão de ter queda. A cadência é para as palavras, porque não hão de ser escabrosas nem dissonantes, hão de ter cadência. $O$ caso é para a disposição, porque há de ser tão natural e tão desafetada que pareça caso e não estudo. Cecidit, cecidit, cecidit (p. 39).

No trecho transcrito, notamos a preocupação do enunciador em escolher valores que emprestam à frase uma cadência rítmica que permite que ela não caia em relaxamento sonoro da ordem do tédio, da sonolência. O processo de permutação lexemática cria no enunciatário uma espera em sucessão. Assim, as figuras "queda", "cadência" e "caso" predispõem o enunciatário a esperar pelo desfecho discursivo da narrativa de cada um dos temas. Embora o inteligível enlace os temas coesivamente por implicação (tudo tem um porquê), há também uma espera sensível pelo som. E talvez por dominar ambos os sistemas (sensível e inteligível) é que os sermões de Vieira podiam durar duas, três horas, sem provocar o tédio do ouvinte.

Os sermões de Vieira são de veio poético: o enunciador propõe uma isotopia, lançando seu contraponto, um tipo de fuga musical em forma de espelho; o uno faz-se 
múltiplo, havendo multiplicidade de pontos de vista, mudança de perspectiva que, como sabemos, ocorreu do clássico para a arte seiscentista:

\begin{tabular}{|l|l|}
\hline $\begin{array}{l}\text { Clássico (perspectiva de Alberti e } \\
\text { Brunelleschi) }\end{array}$ & $\begin{array}{l}\text { Ponto de fuga no horizonte engendrador do } \\
\text { quadrado }\end{array}$ \\
\hline Arte seiscentista & $\begin{array}{l}\text { Multiplicidade de pontos de vista; mudança } \\
\text { de perspectiva }\end{array}$ \\
\hline
\end{tabular}

A semiótica da poesia aguda, com temos discutido nesta tese, compreende a sintonia tensiva entre a gradação acentuada de sensível e o delongamento prazeroso do reconhecimento inteligível: o prazer sensível inicial encaminha-se para o prazer do inteligível. Prazeres alcançados ora pela duração do significante (sensível), ora pela descoberta cognitiva demorada, uma fruição dupla, sendo o fazer poético humano sensação e razão; nem só razão, nem só sensação, o que nos leva a pensar que, sem a composição engrenada de sensível-inteligível, nenhum objeto poderia ser concebido (cf. KANT, 1999, p. 92).

No capítulo 5, examinaremos a agudeza do final do século XX constituidora de um objeto fluido. 
A AGUDEZA DO FINAL DO SÉCULO XX NA DIREÇÃO DO OBJETO POÉTICO FLUIDO

O poema é a mais condensada forma de expressão verbal.

Ezra Pound

O verso é uma espera organizada.

Paul Valéry

Cada verso é uma imagem e pode ser dito com uma só emissão da voz.

Octavio Paz 


\section{TEATRALIZAÇÃO DA CRISE DE VERSO: O DISCURSO DA POESIA FLUIDA E A POTENCIALIZAÇÃO DA POESIA NÍTIDA}

Nas palavras de Marcos Siscar (2010, p. 105), "a poesia brasileira nunca deixou de ser escrita em verso, apesar do abalo concretista". No artigo "A obra de arte aberta", publicado no Diário de S. Paulo, de 3 de julho de 1955, Haroldo de Campos (In: CAMPOS; PIGNATARI; CAMPOS, 2006, p. 49) estabelece as linhas de força do labor poético criativo moderno, que, segundo o autor, se apoiaria em Mallarmé ["Un coup de Dés"], Joyce, Pound e Cummings. Haroldo de Campos efetivamente nunca abandonou o verso, apesar das experimentações do branco da página. Em A máquina do mundo repensada (CAMPOS, 2004b), vale-se da terza rima, bem como de versos decassilábicos, rimados à moda de Dante Alighieri ${ }^{1}$. Décio Pignatari também retorna ao verso no início dos anos 80 e Augusto de Campos conserva em seu fazer poético lastros da métrica tradicional (cf. SISCAR, 2010, p. 105).

Por que se teria falado então em crise de verso?

O estilhaçamento do verso teve influência de Mallarmé. A estrutura pluridividida ou capilarizada, característica do poema-constelação mallarmiano, instaura um discurso de fim do percurso sintático linear com princípio, meio e fim, em vista de uma organização espacializada, da valorização do branco da página. Os sintagmas são fragmentados e o todo é maior do que a soma das partes (princípio gestaltiano); cada unidade verbivocovisual representa a totalidade da obra.

À inovação mallarmeana juntaram-se as conquistas estruturais de Pound, Cummings e Joyce, ou seja, misturaram-se as subdivisões prismáticas de Mallarmé, o método ideogrâmico de Pound, a simultaneidade de Joyce e a mímica de Cummings ${ }^{2}$.

\footnotetext{
${ }^{1}$ Sobre a A máquina do mundo repensada, encontramos relevante estudo de Diana Junkes Toneto (2008) em sua tese de doutorado sob orientação da Prof. Dr. Maria de Lourdes Ortiz Baldan.

${ }^{2}$ A divisão prismática é um recurso que permite ao enunciador a estratégia de divisão de elementos (fonemas e sílabas isolam-se ou juntam-se a morfemas, por exemplo) para formar novo conteúdo. O método ideogrâmico consiste em sugerir imagens poéticas por meio de uma semiose inesperada no enunciado do poema. A simultaneidade de Joyce utiliza o recurso da condensação, aproximando, ao mesmo tempo, unidades semânticas distantes, outra característica do sobrevir da agudeza de expressão e de conteúdo. A mímica de Cummings reorganiza fonemas para produzir um gesto visual.
} 
A título de ilustração da reorganização da poética do século $X X$, consideremos o poema "No thanks", de Cummings, para verificar como o enunciador, repetindo ou invertendo as palavras "bright, star, big, soft, near, calm, holy, deep, alone, yes, who", compõe o ideograma de uma noite estrelada. Em vez de formar estrelas com as palavras, Cummings produz o efeito plástico de dinamismo por meio da combinatória aguda do plano da expressão em que uma letra maiúscula movimenta-se dentro da palavra "bright".

Assim, temos na tradução de Augusto de Campos (CUMMINGS, 2012, poema 21):

\begin{tabular}{|c|c|}
\hline brllha & brlght \\
\hline $\begin{array}{l}\text { bRilha estr??? Grande } \\
\text { (suave) }\end{array}$ & $\begin{array}{l}\text { bRight s??? big } \\
\text { (soft) }\end{array}$ \\
\hline $\begin{array}{l}\text { suave perto calma } \\
\text { (Brilha) } \\
\text { calma estre?? santa }\end{array}$ & $\begin{array}{l}\text { soft near calm } \\
\text { (Bright) } \\
\text { calm st?? holy }\end{array}$ \\
\hline $\begin{array}{l}\text { (suave briLha longe) } \\
\text { siM perto estrel? calma estrela grande sIm } \\
\text { só } \\
\text { (qUem }\end{array}$ & $\begin{array}{l}\text { (soft briGht deep) } \\
\text { yeS near sta? calm star big yEs } \\
\text { alone } \\
\text { (wHo }\end{array}$ \\
\hline $\begin{array}{l}\text { Sim } \\
\text { perto longe quEm grande só suave perto } \\
\text { longe calma longe } \\
\text { ????Ha ?????A) } \\
\text { Quem(santa só)santa(só santa)só }\end{array}$ & $\begin{array}{l}\text { Yes } \\
\text { near deep who big alone soft near } \\
\text { deep calm deep } \\
\text { ????Ht ?????T) } \\
\text { Who(holy alone)holy(alone holy)alone }\end{array}$ \\
\hline
\end{tabular}

As letras maiúsculas que ocupam ao longo do poema diversas posições nas palavras cumprem uma trajetória que configura a performance do movimento e do brilho das estrelas. E, portanto, aqui não temos a representação imagética da estrela (um caligrama), mas uma mímica (o sentido é visual). A poética do século XX herdou também de Cummings a possibilidade de espalhar fonemas e fragmentar morfemas, formando novos planos de 
conteúdo. Além disso, um dos elementos fundamentais dessa poética é a utilização e distribuição de fonemas no espaço branco da página, introduzindo rupturas de reafremento do plano da expressão: a sílaba, por exemplo, é comumente descompactada em fonemas dispersos no espaço branco da página.

Mallarmé, autor do texto "Crise de vers", trata a morte de Victor Hugo como um marco histórico decisivo para a poesia, pois ele seria o representante do verso alexandrino:

\begin{abstract}
Algum leitor francês, com os hábitos interrompidos pela morte de Victor Hugo, não pode senão se desconcertar. Hugo, em sua tarefa misteriosa, carregou toda a prosa, filosofia, eloquência, história, para o verso, e, como ele era o verso em pessoa, quase acabou por confiscar, de quem pensasse, discorresse ou narrasse, o direito de se enunciar. [...] O verso, acredito, esperou com deferência que o gigante que o identificava à sua mão tenaz e sempre mais firme de ferreiro, desertasse, para, então ele mesmo, romperse (MALLARMÉ, 2008, p. 151).
\end{abstract}

Sobre a "morte" do verso tradicional, Siscar (2010, p. 108-109) comenta que, longe de o fazer poético ser, na visão de Mallarmé, uma ruptura, teríamos a manipulação do verso, ou seja, um investimento em suas variações: "é quase o verso tradicional", mas "não chega a sê-lo": "a poesia não se manifesta naquilo que está além do verso, mas estabelece um outro 'gosto', uma variação no seu uso". Desse modo, o texto de Mallarmé estaria distante da operação de ruptura das vanguardas como corte na tradição. Além disso, o efeito visual é produzido segundo os moldes de uma sinfonia musical. O modelo de fazer poético para Mallarmé é, pois, a música, estando a poesia em uma semiótica que opera, de um lado, a unidade e, de outro, a pluralidade; entre o uno do verso e o todo da página.

Esclarece Siscar (2010, p. 110) que, rigorosamente, não há no pensamento de Mallarmé nenhuma assertiva para que se depreenda a visualidade como substituta do verso ou como opção para seu revigoramento. $\mathrm{O}$ espaço configuraria um programa paralelo ao do programa do percurso da linha do verso, ou seja, o espaço branco seria também protagonista de uma variação de organização do verso. Para Siscar, o verso não é pura e simplesmente um problema formal, mas uma questão discursiva; nesse sentido, temos mais um discurso sobre a ruptura do que propriamente uma ruptura. Não há, portanto, "fim do verso porque não há além do verso" (cf. p. 112-113).

Durante muito tempo, ouviu-se falar de poesia verbal, de um lado, e poesia visual, de outro. Siscar considera "crise de verso" uma tradução mais pertinente para o texto de Mallarmé do que "crise do verso", visto que crise de verso evidenciaria uma ruptura como 
encenação discursiva, uma parada no programa do verso, ou seja, uma "irritação" do verso; ele se manifesta nervosa e irritadamente, em estado crítico (cf. SISCAR, 2010, p. 107-108).

Nesse sentido, considero como exemplo de teatralização da crise do verso as poesias de Cantaria barroca, de Affonso Ávila; uma delas é "Pilar", um enunciado que serve de espaço discursivo para a encenação do verso em crise. Em vez de "crise" e "sumiço" do verso, teríamos apenas o discurso da crise e a teatralização do verso em desmanche, o que se pode verificar pelos exercícios de leitura a serem vistos neste capítulo.

Retrocedamos ao sentido de verso para depreender o que chamamos de "teatralização da crise de verso".

Verso: do latim, versus, sulco que dá volta; formação em linha de pessoas ou coisas; linha da escrita; de vertere, que significa voltar, retornar. Movimento de retorno: cada linha, pelo movimento cíclico, completa a próxima (MOISÉS, 2011, p. 465-470). Com base nessa definição, elencamos algumas características do verso com a finalidade de depreender sua cifra tensiva:

- Sucessão de fonemas ou sílabas que compõem uma unidade rítmica e melódica, que equivalem ou não a uma linha do poema.

- Sequência de fonemas ou sílabas.

- Movimento cíclico e de retorno.

Com base nessas características, podemos afirmar que o verso permite o retorno ao ponto de partida, o que, de certa forma, entrava-lhe a continuidade, produzindo o movimento oscilante de aceleração e desaceleração; o verso tradicional metrificado, com rima interna e externa, distribuído em estrofes regulares, tem andamento diferente do verso que teatraliza a "crise de verso".

A sucessão, a sequência e o movimento cíclico compõem um traço tensivo que é o da continuidade e extensidade, atributos que permitem uma configuração de volta sem entrave. Nesse cenário, os brancos distribuídos pela página e as quebras de palavra, em nível profundo, seria uma ruptura ou uma parada no programa do verso. Esse antissujeito "branco", por exemplo, promove um contraprograma que, no cenário das poesias do século XX (nesta tese, Affonso Ávila, Haroldo de Campos, Horácio Costa, Arnaldo Antunes e outros), cumpre a função de actante-chave para a constituição da teatralização da "crise de verso". 
Para Mallarmé (2008, p. 153), o verso livre, imbuído de novidades, dissolve a regularidade da tradição, que imperava na poesia até meados do século XIX e que tinha como destinador um cânone influenciado pela Antiguidade greco-latina. Em geral, essa poesia atendia aos pressupostos de regularidade, de isometria, bem como de organização das estrofes. As operações formais, como pausa, cesura, estrutura do poema, esquemas rímicos, seguiam o príncipio da regularidade. Ainda que houvesse nessa época algum tipo de experimentação, obedecia-se às regras formais. No romantismo, dá-se um movimento discursivo de ruptura dessa camisa de força, libertando-se assim o verso do cânone clássico (cf. MOISÉS, 2011, p. 470-471).

A partir de então, ao lado dessa irregularidade proposta pelos românticos, institui-se um novo ritmo, um novo andamento de tom mais popular. No parecer, aproxima-se a poesia da prosa. Para o sentido de prosa, todavia, temos outra cifra tensiva. Vejamos:

Prosa: do latim, prosa, que significa "discurso em linha reta" (cf. MOISÉS, 2011, p. 371). Se é em linha reta, depreendemos que a cifra tensiva da prosa é de continuidade e de extensidade semelhante à do verso. No entanto, na cifra tensiva de verso verifica-se um "além-prosa", ou seja, temos a intensidade do retorno, do movimento cíclico. Daí verso implicar uma soma de extensidade da continuidade mais a intensidade do movimento de ruptura, de retorno. E essa intensidade configura-se por um artefato precioso, o ritmo.

Vejamos as definições de ritmo:

- "Sucessão de tempos fortes e fracos que se alternam com intervalos regulares em um verso ou em uma frase musical” (cf. HOUAISS; VILLAR, 2001).

- Ritmo, musical ou poético, constitui-se pelo retorno, a intervalos iguais, de um som -- nota musical ou sílaba -- mais forte que os outros (cf. MOISÉS, 2004, p. 394).

- "Ritmo é o que nos impressiona quer a vista, quer o ouvido, pela sua repetição frequente com intervalos regulares" (SAID ALI, 2006, p. 29).

- "Geralmente, chama-se ritmo a toda alternância regular; e não nos interessa a natureza do que a alterna. O ritmo musical é a alternância dos sons no tempo. O ritmo poético é a alternância das sílabas no tempo. O ritmo coreográfico, a alternância dos movimentos no tempo [...]. Em suma, falamos de ritmo em toda parte onde podemos encontrar uma repetição periódica 
dos elementos no tempo ou no espaço" (BRIK In: EIKHENBAUM et al., 1978, p. 131).

- "Compreender-se-á o verso a partir do movimento rítmico", não a partir da linha do verso (BRIK In: EIKHENBAUM et al., 1978, p. 132).

- "O domínio do ritmo não é o da contagem" (TOMACHEVSKI In: EIKHENBAUM et al., 1978, p. 143).

- "[...] le rythme se donne comme contraste" (ZILBERBERG, 1985, p. 19): "I'unité rythmique n'est pas produite par duplication mais par contraste des parties accentuéés avec les parties inaccentuées [...]" (p. 20). Tradução nossa: "o ritmo dá-se como contraste": "a unidade rítmica não se constrói por duplicação, mas por contraste entre partes tônicas (acentuadas/fortes) e partes átonas (fracas)", cf. ZILBERBERG, 1985, p. 19-20).

- "As estruturas rítmicas constituem-se do jogo de dois modos intervalares, tempo longo e tempo curto, claramente distintos um do outro" (FRAISSE In: ZILBERBERG, 1985, p. 47, tradução nossa).

O ritmo advém dos engendramentos estruturais da poesia; ao contrário da contagem métrica e da escansão, o ritmo, segundo Wolfgang Kayser (1968, p. 315-360), em Interpretação e análise da obra literária, filia-se a uma qualidade própria do verso, a musicalidade:

Hay muchos poemas correctos en cuanto al metro, es decir, en que los tempos marcados y los no marcados, así como las pausas, ocupan su lugar proprio, etc., y, no obstante, resultan insípidos y sin brillo: les falta el ritmo uniforme, activo (KAYSER, 1968, p. 317).

Há muitos poemas justos em relação ao metro, ou seja, em que os tempos tônicos e os átonos, bem como as pausas, ocupam seu próprio lugar, etc., e, não obstante isso, resultam insípidos e sem brilho: falta-lhes um ritmo uniforme, ativo (KAYSER, 1968, p. 317, tradução nossa).

Na sua origem, o poetas produziam poesias para serem recitadas. Ainda que silenciosa, pulsa dos versos a sonoridade das sílabas do texto poético. O ritmo faz-se ainda pelo destaque das sílabas "fortes" em meio as "fracas". Essa oscilação entre tênue e vívido engendra a cadência poética. $O$ ritmo contesta o tempo como noção de continuidade (cf. ZILBERBERG, 1985, p. 29 e 57), havendo nele uma reiteração de contrastes. A repetição não engendra, pois, um ritmo; ao contrário, é o ritmo que permite depreender uma repetição ( $p$. 
57). Ao ritmo subjaz um traço tensivo que perpassa o tempo, organizando-se em cifras mais vívidas e cifras mais tênues dentro de um mesmo sistema (cf. KAYSER, 1968, p. 321).

Os elementos que caracterizam o ritmo são o acento e a modulação. Mais ainda, os elementos extensos correspondem à modulação e os intensos aos acentos (HJELMSLEV, 1966, p. 143-145): “o ritmo se situa no PE e a sintaxe no PC" (cf. ZILBERBERG, 1985, p. 47, tradução nossa). A articulação desses operadores tensivos, de intensidade e de extensidade, engrena-se na poesia, produzindo uma alternância dinâmica entre o exercício da cifra de descontinuidade sobre a cifra de continuidade ou, ainda, sobre a própria descontinuidade (cf. TATIT, 1997, 131 ss).

Nesse sentido, temos na poesia um movimento silábico por excelência. Zilberberg (1985, p. 33), em L'essor du poème, afirma que não é certamente o número das sílabas que faz o ritmo, mas o contraste entre elementos átonos, não acentuados, e elementos tônicos, acentuados. Subjacente a todo processo verbal encontra-se o ritmo: "as palavras juntam-se e se separam respeitando certos princípio rítmicos [...]. O poeta cria por analogia. Seu modelo é o ritmo que move todo o idioma. O ritmo é um ímã. Ao reproduzi-lo - por meio de metros, rimas, aliterações, paronomásias e outros procedimentos --, ele convoca palavras" (PAZ, 2012, p. 60). Para Octavio Paz, "a função predominante do ritmo distingue o poema de todas as outras formas literárias" (p. 63).

A função do ritmo encontra-se, pois, regida:

- Pelo constraste/tensão entre elementos acentuados (tônicos) e não acentuados (átonos).

- Pela localização do acento, seja no começo ou no final do sintagma rítmico.

- Pela espera (tempo longo) e pelo impacto da ruptura (tempo curto).

- Pelo movimento "rápido/lento", que, anteriormente em dissonância, conduzse à consonância (cf. PLATÃO, 2010, p. 55).

- Pelo retorno do traço tônico em intervalos esperados ou iguais (cf. VERRIER In: KAYSER, 1968, p. 323).

Ritmo é retorno, conforme afirma Verrier; e retorno também é a condição do verso. Não seria, pois, pertinente assumir uma crise de fato do verso, pois que simular o desmanche da linha é apenas teatralização, uma operação da ordem do parecer. A poesia, 
de Affonso Ávila e de Haroldo de Campos, por exemplo, esmaecida em seus contornos, fazse com base no ritmo e no verso.

"Klimt: tentativa de pintura", de Haroldo de Campos (1985, p. 37), poesia a ser vista neste capítulo, é esmaecida em seus contornos, simulando o verso em crise. Essa irregularidade na métrica constitui por fim uma complexidade rítmica. Tal complexidade no plano sonoro (e visual) evidencia no conteúdo do poema a diversidade da obra pictórica de Klimt:

\section{Klimt: tentativa de pintura}

(com modelo ausente)

1.

lourovioleta: um monstro uma

figura em outro cin

zelada das unhas à raiz (crin

a) metalizada dos cabelos pedi curada em roxo um traço bis (não de bistre) um risco de li lás as pálpebras dobradas como mariposas (como mari posas) sim pedicurada em roxo e as pontiagudas unhas só li lás da mesma cor do pij ama uma figura um monstro sim (quimono): klimt.

2. e sob isto tudo como sob uma panóplia (armada) um pavilhão de pedraria (um baldaquino) dra pejantes panos (um azul turquinho) (caravelas ao largo) bandeiras de um (impossível) impromptu ultra (biombo grand'aberto gonfalão panóplia) violeta

o corpo (a ci catriz li

lás) o branco albino se diria o corpo um cor po de me nina 
Como se nota pela leitura, salta à vista a metrificação, estruturador rítmico do poema, disposto no espaço branco da página como antiverso. Já na segunda linha do poema temos a quebra da palavra "cin/zelada" e no terceiro a quebra de "crin/a". Transcrevemos a seguir um exercício de leitura que nos permita observar o metro para tornar mais evidente o que estamos afirmando:

1.

lourovioleta: um monstro

uma figura em ouro

cinzelada das unhas à raiz

(crina) metalizada dos cabelos pedicurada

em roxo um traço bis (não de bistre)

um risco de lilás as pálpebras dobradas

como mariposas (como mariposas) sim

pedicurada em roxo

e as pontiagudas unhas só lilás

da mesma cor do pijama

uma figura um monstro

sim (quimono): Klimt.

2.

e sob isto tudo como sob uma panóplia (armada)

um pavilhão (um baldaquino)

drapejantes panos (um azul turquinho)

(caravelas ao largo) bandeiras

de um (impossível) impromptu ultra

(biombo grand'alberto gonfalão panóplia)

violeta o corpo (a cicatriz lilás)

o branco albino se diria

o corpo de uma menina

Essa disposição revela-nos um texto estruturado em versos, que oscilam entre seis e doze sílabas. O corte do verso tem, segundo Franchetti (2008, p. 6), duas funções: (a) dificultar o reconhecimento imediato do poema; (b) encenar o parecer de crise do verso. 
No caso de "efetividade da poiese", o poeta do final do século XX recusa-se a seguir modelos fixados pelo cânone. Por exemplo: normalmente em um alexandrino (verso de 12 sílabas) há um acento e uma cesura na sexta sílaba e, portanto, teríamos dois acentos, um na sexta sílaba e um na décima segunda. Em um segundo modelo, teríamos acentos na quarta, oitava e décima segunda sílabas. Para Zilberberg (2006b, p. 183), no entanto, havendo efetividade da poiese "não há categorias fixadas, mas para cada ato semiótico há uma poiese que recomeça", ou seja, o enunciador poiético inventa sempre novas maneiras de articular o ritmo ou de produzir enunciados rítmicos.

Essa discussão sobre a crise do verso, nome sugerido por Mallarmé, destinador dos poetas do século XX, instiga-nos a procurar ainda mais o verso (cf. FRANCHETTI, 2008, 9 p.). "Pilar", ao encenar em seu enunciado a "falta" de verso, leva-nos a perguntar: "esse texto está escrito em versos?"

E é com base nessa pergunta que demonstraremos, por meio dos exercícios de leitura, nas seções seguintes que, ao contrário de crise de verso, o século XX, ao fluidificar os contornos, instaurou a falta e a busca desenfreada pelo verso.

\section{INTENSIFICAÇÃO DA AGUDEZA VISUAL NO CENÁRIO DA CRISE DE VERSO}

A acentuação dos efeitos visuais e sonoros não é exclusividade nem da poesia seiscentista nem da do final do século XX. Em qualquer objeto estético, encontramos refreamentos formais. Na poesia aguda de expressão, porém, o PE tem outra função: já não serve apenas para homologar-se com o PC, mas constitui-se ele próprio um regente retardador do inteligível, evitando que o reconhecimento supere a experiência estética.

O poeta da agudeza explora a plasticidade do signo, apresentando não um conteúdo, mas um objeto sonoro-visual da ordem da fluidez. Essa poesia fluida liberta-se cada vez mais da estrutura discursiva da linguagem de contrato icástico, eliminando os nexos de coesão sintática. Por isso, a forja de compostos, as invenções vocabulares, as palavras-montagem, o mosaico de línguas naturais, a violentação sintática, a enumeração caótica, as mutações léxicas, as conjunções e disjunções fonéticas.

Valéry considerou "Un coup de dés" um espetáculo ideográfico, um poema em que Mallarmé teria desejado transformar uma página em constelação. Segundo Haroldo de Campos (1997, p. 260), a revolução da poesia de Mallarmé "não é apenas lexical e semântica, mas, além disto, sintática e epistemológica". O poeta francês seria um subversor 
da sintaxe. Seu poema constelar dissemina uma forma inovadora, que dilacera a estrutura fixa e estrófica, colocando em xeque o verso tradicional. Daí podermos afirmar que a poesia de Mallarmé é de um experimentalismo linguístico da linha da agudeza.

A semiótica da agudeza engloba o que Haroldo de Campos (1997, p. 259 ss) entende como traços barroquistas:

1. A linguagem estilhaçada de Hölderlin (1770-1843).

2. A inconclusividade e o fragmentarismo de Giacomo Leopardi (1798-1837).

3. O fragmentário de Giuseppe Ungaretti (1888-1970).

4. A enumeração imagética de Ezra Pound (1885-1972) cujos Cantos são organizados conforme o princípio da justaposição ideogrâmica, da citação intertextual e da utilização prismática do fragmento.

5. A fragmentação grafemática de E. E. Cummings (1894-1962).

6. Os versos escalonados, espacializados no branco da página em forma de escada, de Vladimir Mayakovski (1893-1930).

7. A abolição das fronteiras entre poesia e prosa de James Joyce (1882-1941).

8. A poesia visual de Gomringer (1925 - ).

9. A espacialidade da poesia visual brasileira.

Todas esses experimentalismos contribuem para a vivificação do objeto estético fluido, sob exame a seguir. Investigaremos ainda outras qualidades, como (a) a condensação; (b) a constelação e a deformação agudas, com seu fragmentarismo e seu desmanche grafemático; (c) a enumeração caótica; (d) as mutações léxicas; (e) a justaposição imagética e (f) o paroxismo.

\subsection{Condensação aguda: a fluidez em “Metade”, de Arnaldo Antunes}

Como temos afirmado, uma das características da poesia aguda é a fluidez, que se reflete na agregação de fonemas, de sílabas, de palavras, produzindo o esmaecimento de contornos, ou seja, uma condensação em que os limites e os recortes não são bem definidos.

“Metade", de Arnaldo Antunes (2006, p. 205), é um desses objetos fluidos, visual e sonoramente condensado, cuja sucessão linear e repetitiva de fonemas engendra um efeito de sentido de brevidade que se estabelece pela sucessão dos grafemas no branco da página e pela realização dos fonemas subsequentemente encadeados. Trata-se de um experimento 
estético, que se apresenta verticalmente na página e propõe uma direção de leitura de baixo para cima. Essa verticalização da linha, sem indicação de ponto final, é mais um dos entraves do PE nesse objeto agudo. A ausência de pontuação funciona segundo uma orientação das ações em sequência.

Vejamos o poema: 
Lendo de baixo para cima, temos:

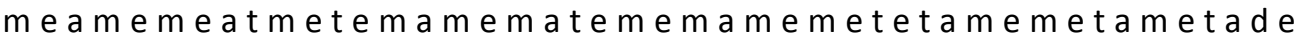

A consoante nasal bilabial vozeada $/ \mathrm{m} /$ perpassa todo o poema, constituindo a categoria da identidade no PC, identidade porque é através desse fonema que se forma toda a performance relativa ao EU (me ame, me mate, me ate), que se expande para o TU. A nasalização do fonema /m/ indica no PE fechamento que se homologa no PC com o fechamento das paradas e rupturas da ação do sujeito, que é paralisado: "me ate, me mate". A alteridade do TU no conteúdo se dá no PE por meio do fonema /d/ em /metade/. O único fonema consonantal diferente de $/ \mathrm{m} / \mathrm{e} / \mathrm{t} /$ é o $/ \mathrm{d} /$, que aparece uma única vez no fechamento do poema para mostrar-se "alteridade" (tu).

Ademais, cada fechamento consonantal implica abertura da vogal que se the segue, /a/ ou /e/. Novamente, nesse jogo assistimos a uma abertura vocálica que conhece seu fechamento no entrave consonantal, produzindo no PC a mesma relação de abertura e fechamento. Nesse sentido, cabe evocar a teoria da sílaba de Saussure (1996, p. 64 ss), utilizada por Zilberberg (2006b, p. 137), para explicar a noção de ritmo: a passagem de uma implosão à explosão ( $>$ ) produz o efeito de abertura e fechamento, correspondente, no plano narrativo, a uma espera e a uma surpresa, e, no plano missivo, a valores emissivos e remissivos (cf. TATIT, 1999, p. 69).

A poiesis, no seu sentido primário de criação, é uma função silábica por excelência e o movimento que a rege é o de expansão. Trata-se de um jogo de remissividade e emissividade, que produz no texto de Arnaldo Antunes um ritmo cíclico, em que abertura e fechamento encadeiam-se em uma única linha constituidora do poema. Notamos ainda que os fonemas estão separados por meio de um espaço regular em toda a linha do poema, marcando-o com um ritmo sincopado:

me ame

me eat

me ate

me tema

me mate

me mame 
me teta

me meta

metade

Esse movimento repetitivo do eu -- representado no poema pelo pronome me -- em direção ao tu - rege-se pela regularidade. A reiteração de me produz sonoramente um efeito de uniformidade, de continuidade, ao passo que a reiteração dos espaços entre os grafemas engendra a ruptura, a descontinuidade. Nesse sentido, no PC, enquanto "me ame", "me eat" [me coma] apresenta continuidade, abertura, emissividade e fluir narrativo, "me mate", "te mate" apresenta uma parada da continuação, fechamento, remissividade e retensão narrativa. Ainda, a regularização sonora (e visual) de repetidos $/ \mathrm{m} /$ configura um andamento de batida contínua que promove um pervir do próximo $/ \mathrm{m} /$ em rede. Nada se altera do começo ao fim da linha. Por um lado, "parece" monótono, mas o tédio na expressão convoca no conteúdo uma multiplicidade de ações velozes entre um EU e um TU:

me ame, me eat, me ate, me tema, me mate, me mame, me teta, me meta.

A distribuição dos fonemas e morfemas permite ao enunciatário o deleite que provém das figuras que vão se formando conforme a direção e a segmentação que ele estabelece. O sentido orienta-se inicialmente, recortando "me ame" e, logo em seguida, "me eat" (comer); se lermos "meatemete" anagramaticamente, ao contrário, temos "metame", fazendo sobressair a isotopia sexual, marcada visualmente pela sugestão de cópula de letras aglutinadas na vertical, que sugerem ereção. Além da isotopia sexual, há no poema uma isotopia metalinguística do movimento de expulsão de grafemas, de fonemas, de lexemas, de sintagmas, que saem um do outro, numa ejaculação verbovocovisual.

Ademais, temos outras condensações:

- Em "me ate", de atar, amarrar, temos a isotopia do erotismo sadomasoquista, bem como novamente a do fazer poético: o texto é resultado de fios que se atam, que se amarram.

- Em "me teta" (de mamilos), a criação do neologismo configura outra imagem aguda. Ainda em "me ate", que condensa igualmente o hibridismo "me eat", as metáforas de "prender, perder a liberdade" e de "alimento, saciação" 
conjugam duas grandezas muito distantes: o outro (tu), embora nos leve a perder a liberdade, nos sacia.

- Em "tema", de temer, e em "me mate e te mate", indicativos da convocação de "eu e tu", o "eu" depende do "tu" não só na isotopia sexual, como também na isotopia metalinguística para a formação do texto (complexo "eutu" benvenístico). Pela isotopia sadomasoquista, também é possível o entendimento de um estado de alma de um sujeito que, depois de pedir que um "tu" o ate e o mate, diz AMEM "meamem" (de amar), que é também anagrama de amém, que quer dizer "assim seja", "faça isso".

Considerando o estado de alma desse sujeito, notamos, em uma primeira leitura, um eu voltado para si mesmo, que vê a "metade" - última palavra do poema - como objeto auxiliar para a realização de suas performances: "me ame, me coma, me ate, me mate, te mate". As reiterações de fonemas (vogais e consoantes) conduzem o sujeito (identidade "eu") ao "tu" (alteridade) e, nesse caso, em vez de auxiliar, o tu passa a constituir-se em METADE do eu, ou seja, o tu faz parte do eu e a identidade engloba a alteridade.

A enunciação enunciativa ainda revela um eu que utiliza uma sequência de verbos no imperativo, produzindo um efeito de elevada intensidade emotiva: o eu implora ao tu que atue em prol de seus desejos "me ame, me eat (coma), me ate". Ao escolher a palavra metade para designar a alteridade, o outro, manifesta valores utópicos, em que o tu configura-se um participante remediador dos males. E, ao ver o outro como participante, vê a si mesmo como ser em falta, não completo, pois que lhe falta uma "metade".

Essas emoções atingem um recrudescimento, um ápice, quando hiperbolicamente diz "me mate", configurando um estado de alma de aflição implorativa, exigindo do tu uma dedicação máxima. Aqui, o ator eu revela mais uma de suas características: o outro está a serviço de sua completude, de satisfazer seus prazeres. A responsabilidade pelo seu bemestar caberia ao outro. Ainda, os verbos no imperativo dão uma intensidade pontual ao enunciado poético, estabelecendo que as ações devem ser imediatas (por exemplo: "me ate", "me meta"). Evidencia-se então que o enunciador fala de um ponto de vista irônico, na medida em que escolhe a figura do ator "eu" excessivamente em falta e dependente que se vale da voz imperativa e exagerada para mendigar um pouco do tu. 
Parece-nos apoiar-se esse enunciador numa tradição que recua a Aristófanes, em que o amor é fundamentalmente uma busca incessante pela conjunção completa com o tu, a fim de juntar novamente o todo que foi cindido em partes. Aristófanes, em $O$ banquete, de Platão (1983, p. 23), afirma:

Depois de laboriosa reflexão, diz Zeus: "Acho que tenho um meio de fazer com que os homens possam existir, mas parem com a intemperança, tornados mais fracos. Agora com efeito, continuou, eu os cortarei a cada um em dois, e ao mesmo tempo eles serão mais fracos e também mais úteis para nós, pelo fato de se terem tornado mais numerosos; e andarão eretos sobre duas pernas. Se ainda pensarem em arrogância e não quiserem acomodar-se, de novo, disse ele, eu os cortarei em dois, e assim sobre uma só perna eles andarão saltitando." Logo que o disse pôs-se a cortar os homens em dois, como os que cortam as sorvas para a conserva, ou como os que cortam ovos com cabelo; a cada um que cortava mandava Apolo voltar-lhe o rosto e a banda do pescoço para o lado do corte, a fim de que, contemplando a própria mutilação, fosse mais moderado o homem, e quanto ao mais ele também mandava curar. [...] Por conseguinte, desde que a nossa natureza se mutilou em duas, ansiava cada um por sua própria metade e a ela se unia, e envolvendo-se com as mãos e enlaçandose um ao outro, no ardor de se confundirem, morriam de fome e de inércia em geral, por nada quererem fazer-se longe um do outro. E sempre que morria uma das metades e a outra ficava, a que ficava procurava outra e com ela se enlaçava, quer se encontrasse com a metade do todo que era mulher - o que agora chamamos mulher - quer com a de um homem; e assim iam-se destruindo (destaques nossos).

Além disso, a palavra metade aparece no final do poema sem nenhuma necessidade de reconstituição anagramática por parte do enunciatário, criando um efeito de clareza, de forte inteligibilidade: o outro é a nossa metade. Metade que se constitui finalmente em um desencadeador de isotopia e, a partir dele, outra leitura se torna possível: a alteridade (tu) não é mero auxiliar da identidade (eu), mas metade em relação de dependência e solidariedade; o ego seria uma junção de eu+tu.

Como estamos vendo, é o esmaecimento de contornos formais mais nítidos, em que todos os grafemas estão encadeados visualmente em sequência fluida, que nos apresenta o PC de um "eu e tu" que são metades em cooperação. Ainda no PE visual, essa função conjuntiva evidencia-se na representação de todos os fonemas e grafemas amalgamados, formando um signo único. Dessa forma, eu e tu não se separam nem na expressão nem no conteúdo.

Semissimbolicamente, temos: 
PE : categoria de conjunção (visualmente uma linha de fonemas concatenados em rede) :: PC : categoria de conjunção "eu+tu" formam um todo de "metades"

Observando atentamente o PE de todo o poema, verificamos que, por meio do método anagramático, acrescentando um fonema /d/ em muitas das formações sugeridas, teríamos várias "metades" preenchidas no interior da sequência de fonemas, ou seja, uma reiteração no PE que acentua a intensidade do PC.

Nesse caso, a alteridade outra vez dá contorno à identidade. E é também a ausência dos fonemas /d/ que endereça o contorno nítido para o fluido do esmaecimento, conservando esteticamente o objeto. De igual forma, no PC há também fluidez entre "eu+tu", pois que as fronteiras entre eu e tu têm seus contornos obscurecidos. O eu deseja juntar-se ao tu, constituindo-se uma unidade apenas.

Considerando "Metade" como objeto fluido, sobressai a regência da cifra da acentuação no eixo da intensidade; quando restabelecemos os recortes e definimos os limites, sobressai a regência da extensidade e da atenuação da vivificação. E, nesse segundo caso, o estético cede lugar ao entendimento, de tal forma que, para manter a estesia, não há outra saída que não segurar-se nos frágeis fios da experiência sensível. Repetindo Greimas (2002), eis a nostalgia da imperfeição: a arena do relâmpago passageiro.

\subsection{Acentuação da fluidez aguda em “Caminho novo”, de Affonso Ávila}

Se as produções poéticas de Gôngora eram chamadas de enigmáticas, há quem também chame assim a poética de Affonso Ávila e de Haroldo de Campos, variando, porém, a foria, a força que leva adiante, pois no século XX o enunciador valoriza sobretudo as estratégias de "entravamento", evidenciando o PE, enquanto nos seicentos valorizava mais os artifícios dialéticos de ênfase no PC.

A força da acentuação da poesia aguda visual produz um efeito de enigma ${ }^{3}$ : suas formas intensas, porque vívidas e em desmanche, orientam o enunciatário na direção da busca da nitidez, de expansão do que está fluido e obscurecido.

\footnotetext{
${ }^{3}$ Para outras informações, ver "Pedro Xisto: entre o fazer sentir e o fazer saber" (TOMASI In: PORTELA et al., 2012).
} 
“Caminho Novo", de Affonso Ávila (2008a, p. 310), poema da vertente da agudeza visual, apresenta inúmeras formas em desmanche provocadoras de rupturas, que imprimem uma cifra vívida na percepção do objeto estético. Se comparado a um soneto, menos fluido em seus contornos formais, verificaremos que estamos diante de um objeto estético de elevado refreamento sensível e retardado no reconhecimento inteligível. 0 restabelecimento dos contornos, por sua vez, destrói um princípio fundamental da estetização, sua conservação.

Vejamos o poema:

\begin{tabular}{cl}
\multicolumn{2}{c}{ Caminho novo } \\
\&p & \\
utasvi & \\
ejasdesvenda & \\
n la l i bid & \\
oañoyaño & \\
consusfo & \\
dasalosú & \\
Itimosán & \\
gelesdeo & \\
roprieto & \&putovel \\
& hodavida \\
& e ua ssovi \\
& omanoama \\
& no commin \\
& hafossa o \\
& últimotangoe \\
& mouropre \\
& to
\end{tabular}

"Caminho novo" é um objeto visual, cuja forma gráfica desenha dois caminhos paralelos que se cruzam no décimo verso, o que evidencia um cruzamento de duas literaturas, a latino-americana (primeira estrofe) e a brasileira (segunda estrofe). Esse tipo de fazer poético conhecido como neobarroco regula-se pelo princípio da irmandade das literaturas das colônias latinas da América. Outro aspecto visual que salta do poema é a utilização de espaços entre os grafemas/fonemas e ausência de recortes entre unidades semânticas, bem como a total ausência de pontuação, promovendo uma continuidade sem parada que se homologa com a ausência de fronteiras do conteúdo, um caminho que não conhece rupturas (começa com \& e termina sem pontuação). O caminho novo seria o percurso da literatura latino-americana que traça uma continuidade sem limites, incorporando e re-formando em sua trajetória formas do colonizador? 
A primeira estrofe é escrita em espanhol e vai até o décimo verso que se intersecciona e mistura parte em espanhol e parte em português; a segunda estrofe é escrita em português e compreende oito versos. Essas duas estrofes, na verdade, constituem dois versos, se pensados pela lógica do verso tradicional de destino horizontal. 0 verso horizontal implica a ideia de linearização do sentido, de orientação de um enunciado comum aos falantes da língua natural. E os elementos concatenam-se sintagmaticamente em causa e consequência.

Destino do verso tradicional:

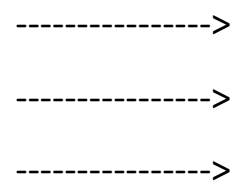

Já o verso vertical implica nova orientação de leitura: enunciador/enunciatário são coenunciadores ativos no preenchimento das unidades semânticas desmanteladas e fluidas. Os olhos, em um movimento do alto para baixo, escorrem verticalmente:

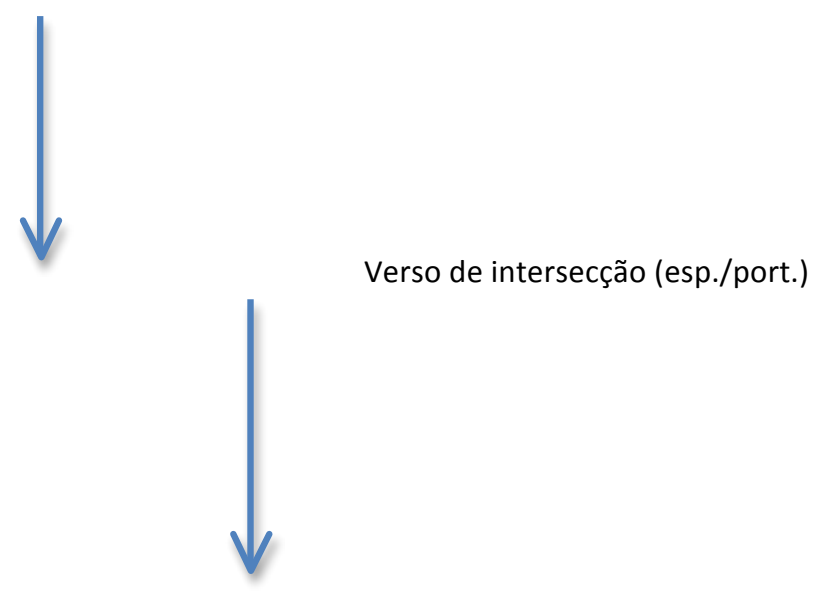

Os fonemas vocálicos orais contracenam com os nasais:

- Orais: putas; viejas; libido; fodas; los; oro; prieto; puto velho; vida; eu; assovio; fossa; ouro preto.

- Nasais: desvendan; año (2x); con; últimos; ángeles; mano a mano; com; minha; último; tango; em. 
Nos orais, há uma oposição entre vogais anteriores, /é/, /ê/, /i/ (viejas, prieto, preto, velho, eu), e posteriores, /ó/, /ô/, /u/ (libido, foda, oro, prieto, puto, velho, assovio, fossa, ouro, preto). Enquanto as vogais orais são executadas com o palato levantado, fazendo o ar escoar todo pela boca, as nasais são produzidas com o ar, que, impedido de passar todo pela boca, tem parte escoada pelas fossas nasais, o que produz uma ressonância. O timbre vocálico ora aberto ora fechado também produz oscilações. O que notamos nas duas estrofes em relação à produção vocálica é um jogo, uma tensão contínua no PE. E essa tensão, conforme veremos, revela-se também no conteúdo.

Os fonemas consonantais fricativos alveolares das duas estrofes contrapõem-se nos traços vozeado [sonoro] /z/ e não vozeado [surdo] /s/. Na primeira, em espanhol, prevalece o traço vozeado; na segunda, em português, o não vozeado. Esse traço de agudeza no PE homologa-se com traços agudos no PC, sugerindo um andamento mais veloz na primeira estrofe e um mais lento na segunda estrofe. Os fonemas fricativos são realizados pela compressão da corrente de ar. $\mathrm{O}$ ar, que roça na boca, produz um ruído comparável ao de uma fricção.

Ao lado desses fonemas, salta à vista a vogal /i/, que perpassa todo o poema. Quanto à intensidade, prevalece no poema o /i/ acentuado: caminho, libido, vida, minha. Quanto ao timbre elas são particularmente fechadas, alcançando maior fechamento na nasalização de caminho, título do poema. O fechamento no PE configura no PC uma restrição, um estreitamento das vias que dão acesso à casa das putas, produzindo um efeito de sentido de ação que, para realizar-se, faz-se por caminhos exíguos. Assim como a agudeza do fonema /i/, a busca da prostitua se faz também por um caminho estreito e agudo no plano visual do poema. No enunciado do primeiro e do último verso, esse fechamento ganha intensidade, culminando em duas agudezas visuais:

$1^{a}$ ponta: "\&p" (primeiro verso);

$2^{\text {a }}$ ponta: "to" (último verso).

No PC, dá-se essa mesma tensão. Na primeira estrofe do poema, configura-se a ação das "putas viejas" e um entra e sai das pessoas que frequentam seu quarto; putas experientes, cuja performance de anos e anos, servem à libido de seus "anjos de ouro 
preto". Pelo conhecimento enciclopédico, sabemos que as famílias tradicionais brasileiras introduziam seus filhos ("anjos") na vida sexual por meio de putas experientes. No plano visual, a categoria multiplicidade, indicando os espaços que separam os fonemas no branco da página na primeira estrofe, homologa-se com a categoria multiplicidade no PC, indicando o grande número de clientes atendidos individualmente. E ainda o verso "oañoyaño", amalgamado, representa visualmente no PC a cópula erótica.

$\mathrm{Na}$ primeira estrofe, prevalece no PC a figura da prostituta e da velocidade ininterrupta de sua atividade sexual ("sus fodas"). O plural "sus fodas" configura sucessividade e rapidez dos atos realizados; no PE, essa velocidade advém da fluidez dos grafemas imbricando-se uns nos outros e tendo seus contornos esmaecidos por espaços regulares entre eles (c o n s u s f o). O adjetivo de "últimos ángeles" também contribui para uma cifra de vivificação e rapidez do andamento, visto que dizer "últimos" subentende a presença de outros muitos "ángeles" anteriores.

Na segunda estrofe, a coloquialidade da figura "puto velho" sugere um sujeito experiente. Ele resolve sua libido sozinho, por meio do onanismo, que aparece no poema no verso paronomásico /"omanoama" $/ \rightarrow(\mathrm{m})$ ano $=$ ona $=$ onã $(\mathrm{m})$, por metonímia onanismo, que, por nova metonímia, masturbação. A cifra tensiva dessa segunda estrofe pode ser depreendida no PE pelo espacejamento regular ritmado do espaço branco entre os grafemas, que figurativizam saltos, demandando mais aceleração e vivacidade. Essa noção de aceleração da segunda estrofe também pode ser vista no PC em "e u a s s o v i o", que marca o acompanhamento da ação ritmada do sujeito solitário (no commin/h a f o s s a o), que pratica a "omanoama" (no verso "com minha fossa"), assoviando enquanto se masturba ("assovio mano a mano").

A repetição lexemática em "manoamano" revela a continuidade do ato masturbatório, ao mesmo tempo que reproduz no $\mathrm{PE}$, por meio dos grafemas grudados em sequência temporal e linear, a ausência de paradas dos gestos. Nos dois últimos versos ainda, o enjambement confirma essa continuidade.

Semissimbolicamente, temos: 
$\mathbf{1}^{\mathrm{a}}$ estrofe: PE: categoria de sonoridade [fonema vozeado /z/] :: PC: categoria de sonoridade: "o barulho do cotidiano das putas".

$\mathbf{2}^{\mathrm{a}}$ estrofe: PE: categoria de ausência de sonoridade (fonema não vozeado /s/) :: PC: categoria de ausência de sonoridade: "silêncio do sujeito que se recolhe para resolver seus desejos sexuais sozinho".

Para explicitação das características do $\mathrm{PE}$, como metro, rima, ritmo, vejamos os versos na horizontal:

$1^{\text {a }}$ estrofe:

$\& / \mathrm{pu} / \mathrm{tas} / \mathrm{vie} / \mathrm{jas} / \mathrm{des} / \mathrm{ven} / \mathrm{dan} / \mathrm{la} / \mathrm{li} / \mathrm{bi} / \mathrm{do} /$ año y / año $\rightarrow 14$ sílabas

con/ sus/fo/das / a/los úl/ti/mos/án/ge/les/ de o/ro/ prie/to $\rightarrow 14$ sílabas

$2^{\text {a }}$ estrofe:

$\& / \mathrm{pu} / \mathrm{to} / \mathrm{ve} / \mathrm{lho} / \mathrm{da} / \mathrm{vi} / \mathrm{da}$ eu/as/so/vio /ma/no a /ma/no $\rightarrow 14$ sílabas

$\mathrm{com} / \mathrm{mi} / \mathrm{nha} / \mathrm{fos} / \mathrm{sa}$ o/ úl/ti/mo/tan/go/ em/ ou/ro /pre/to $\rightarrow 14$ sílabas

No exercício de leitura, cada verso de 14 sílabas métricas é composto de dois versos de sete sílabas, denominados redondilha maior. A redondilha é um verso popular, melódico e frequente em canções e quadrinhas; daí seu ritmo cadenciado, marcado, forte. Essa marcação forte imprime uma acentuação vívida nas duas estrofes. Na primeira, aceleram-se os passos em busca da puta; na segunda, aceleram-se os gestos da mão na masturbação.

Em relação às rimas, mais que as finais, prevalecem as rimas internas: "viejas e libido"; "fodas, oro - vida e assovio"; "mano a mano, tango"). As rimas finais obedecem ao esquema $A B A B$ :

año (A) / prieto (B) ; mano (A) /preto (B)

As alternâncias das rimas ( $A B A B)$ no $P E$ encontram homologação nas alternâncias do PC:

- na primeira estrofe, temos "sujeito + prostituta" (eu + ele), que se alterna, na segunda estrofe, em "sujeito + sujeito" (eu + eu). 
Essa alternância também se verifica pelo tempo:

- $1^{\text {a }}$ estrofe: juventude: eu + putas ("últimos ángeles")

- $2^{\text {a }}$ estrofe: velhice: eu + eu ("e u a s s o vi/ omanoama/no commin/ h a fos s a o")

Da mesma forma, no PC, a rapidez da cena ganha em vivacidade e aceleração com a troca de debreagem. Se na primeira estrofe, a debreagem é enunciva, da ordem da extensidade, da emissividade acelerada do trabalho da puta em seu dia-a-dia; na segunda estrofe, a debreagem é enunciativa, em primeira pessoa, da ordem da intensidade, da remissividade da memória, menos acelerada, do sujeito que se masturba enquanto recorda o passado.

No final do poema, o enunciado "eu assovio mano a mano com minha fossa o último tango em ouro preto" manifesta um estado de alma de um eu presunçoso, bazofiador, que se gaba. Parece sugerir que o caminho novo escolhido por ele é superior aos que procuram a casa de prostituição. No entanto, a expressão ambígua "mano a mano com minha fossa" configura um sujeito que fica na mão, sem o parceiro, acalmando sua libido de modo solitário, na medida em que figurativiza um sujeito em conformidade com seu estado de alma.

Discursivamente, algumas figuras sobressaem no poema: "caminho novo"; "putas viejas", "puto velho", "último tango", "ouro preto", "ángeles". Elas ocupam posições estratégicas no texto: título, início da primeira estrofe (putas viejas), início da segunda estrofe (puto velho), fim da primeira e da segunda parte "ouro prieto" e "ouro preto".

Até aqui temos visto a isotopia sexual; há, porém, algumas figuras que desencadeiam a isotopia metalinguística: "desvendan", "ouro prieto", "mano a mano", "tango", "ouro preto". Vejamos detidamente:

- Desvendan: desvendar é revelar, descobrir, tirar a venda dos olhos; na isotopia erótica, a iniciação sexual permitiria à pessoa a vivenciar algo novo; a partir de então, passaria a perceber o que antes não percebia; na isotopia metalinguística, o enunciador sugere o aproveitamento inicial do fazer artístico alheio (putas) para iniciar uma caminhada nas artes, um caminho novo; nesse caso, o diálogo entre pares seria essencial. 
- Último tango, que dialoga com o poema "Pneumotórax", de Manuel Bandeira (1993, p. 128); nesse poema, um doente com tuberculose interroga seu médico depois do exame: "-Então, doutor, não é possível tentar o pneumotórax? / - Não. A única coisa a fazer é tocar um tango argentino." Enquanto no poema bandeiriano, o estado de alma irônico revelado é de um médico em diálogo bem humorado com seu paciente, em Affonso Ávila é o próprio sujeito um trocista, um gozador de si mesmo, capaz de tirar prazer da própria solidão, assoviando uma música de características dramáticas enquanto se masturba. A própria palavra masturbação tem o sentido de brincar consigo mesmo.

- Ouro Preto, puto velho, putas viejas. Ouro Preto, figura de intersecção, recobre o tema das igrejas e da religiosidade barroca; o enunciador, no único enunciado debreado em primeira pessoa, identifica-se como o ator discursivo "puto velho": "puto velho da vida eu assovio". Ora se "puto velho" é poeta, "putas viejas" são as próprias poesias que circulam de mão em mão: "mano a mano", como os poemas atribuídos a Gregório de Matos, que circulavam em cópias manuscritas do Brasil Colonial. Na segunda estrofe, ao mudar o registro linguístico para o português e mostrar um eu recolhido em seus aposentos, manifesta-se um voltar para o próprio fazer poético, tirando dele um prazer que se assemelha ao sexual. O enunciador identifica então a mestria poética com um orgasmo, cuja duratividade é pontual. Notamos essa acentuação sensível também no conjunto de adjetivos que são distribuídos pelo poema: "novo", "viejas", "últimos", "prieto", "velho", "minha”, "último", "preto" e também pelas repetições anagramáticas "año y año" e "mano a mano".

A leitura metalinguística leva-nos a questionar o que seria um caminho novo. Seria a troca da promiscuidade literária pela intimidade dos próprios aposentos? Ou seria a troca de uma forma de poetar seiscentista por uma forma do século $X X$, em que o poema, em vez de focalizar temas transcendentais, espirituais, volta-se para a própria linguagem? Em vez de considerar a morte euforicamente como no chamado barroco seiscentista, em Affonso Ávila 
a euforia está do lado da vida, com o homem no centro, como um criador de poesia, um homo poietico.

Outrossim, a primeira parte da poesia é escrita em terceira pessoa do plural, sendo o centro da estrofe "putas viejas", que se endereça para "poesias como objeto". A segunda parte, por sua vez, é escrita em primeira pessoa do singular. E, nesse caso, "puto velho" traz a mestria do poeta para a centralidade.

Diferentemente das letras seiscentistas, na poesia aguda latino-americana, como vimos em Affonso Ávila, há a mistura não só dos elementos visuais e sonoros, como também a mistura das línguas latinas: espanhol e português, artifício muito utilizado também por Haroldo de Campos. Outra tensão recorrente perpassa todo o poema: a desencadeada pela antítese "viejas/velho" e o título "caminho novo". A tensão de dois conteúdos distintos mais a tensão do PE - ausência de contornos definidos entre grafemas e fonemas -- reorienta o sentido para a tensão entre formas agudas, a da tradição seiscentista e a da tradição viva do final do século XX.

O poema contempla, finalmente, duas agudezas: no primeiro caso (PE), a disposição visual verticalizada do enunciado poético produz o efeito de um novo caminho a ser trilhado pela poesia aguda do final do século XX: distribuição espacial dos grafemas no branco da página; ausência de preocupação de métrica, de rima; perda dos contornos nítidos; elevação do poema a um objeto estético-visual instaurado pela "crise de verso". No segundo caso (PC), a metáfora da literatura como orgasmo seria um novo caminho: a poesia deixa de ser apenas conteúdo a ser reconhecido pelo saber e passa também a ser objeto de prazer sensível: visual e sonora, verbovocovisual.

Na poesia, quando apreendemos a síntese do conteúdo, perde-se o essencial (as estratégias e os refreamentos do plano da expressão), enquanto na prosa utilitária apreendemos o essencial pela síntese do conteúdo. Resumindo, temos:

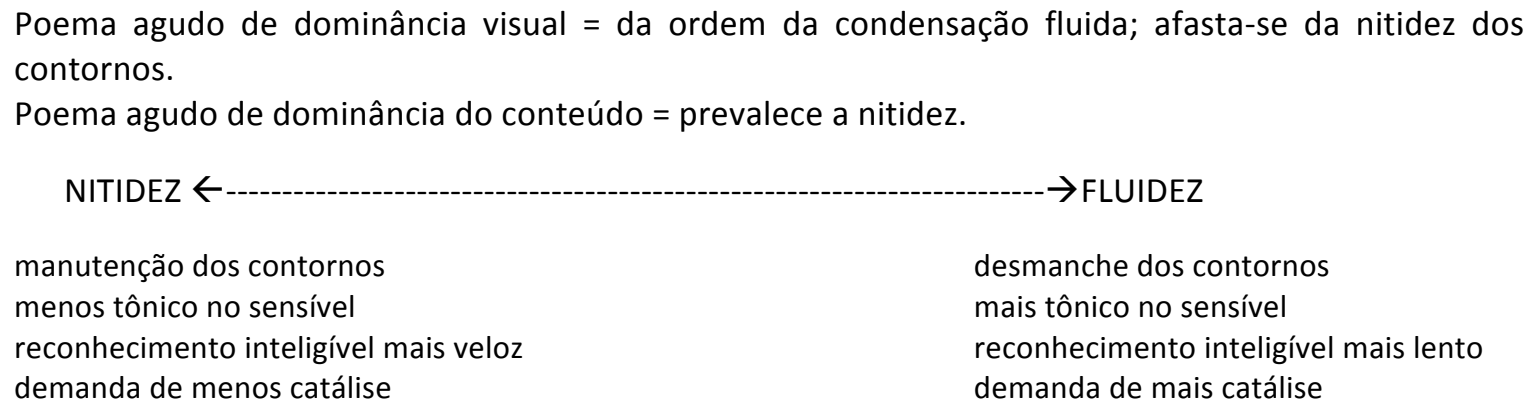


Graficamente, o esquema tensivo entre nitidez e fluidez é gradual, recusando-se as posições extremas; dificilmente, um objeto estético revela-se ou pura nitidez ou pura fluidez. Por mais transparente que seja, haverá sempre algum contorno a ser restabelecido; por mais fluido que seja, haverá sempre um caminho para o reconhecimento intelectivo.

Nas duas seções anteriores, examinamos a fluidez e a nitidez, bem como a condensação no PE. A seguir, examinaremos outra característica da poesia aguda, a constelação.

\title{
2.3 Constelação aguda em “Por Gertrude Stein”, de Affonso Ávila
}

No artigo "Pontos-periferia-poesia concreta", Augusto de Campos (In: CAMPOS; PIGNATARI; CAMPOS, 2006, p. 31-42) focaliza "Un coup de Dés", de Mallarmé, e afirma que o poeta francês seria o inventor

\begin{abstract}
de um processo de composição poética cuja significação se nos afigura comparável ao valor da "série", introduzida por Schönberg, purificada por Webern e, através da filtração deste, legada aos jovens músicos eletrônicos, a presidir os universos sonoros de um Boulez ou um Stockhausen. A esse processo definiríamos, de início, com a palavra estrutura, tendo em vista uma entidade onde o todo é mais que a soma das partes ou algo qualitativamente diverso de cada componente (p. 31-32).
\end{abstract}

Mallarmé utilizara para conceituar seu método compositivo "subdivisões prismáticas da Ideia" (cf. p. 32). Seu poema "Un coup des Dés" apoia-se num conjunto de estratégias:

- Uso de tipos gráficos diversos.

- Posição espacial das linhas tipográficas no branco da folha.

- Aproveitamento do espaço gráfico.

- Utilização singularizada da folha.

- Utilização do fundo preto como adjuvante do poema fluido exposto em grafemas brancos.

- Ausência de pontuação.

- Estilhaçamento de palavras.

- Esmaecimento dos contornos.

- Combinações anagramáticas.

Para Augusto de Campos (p. 35), essas estratégias dão uma "ideia, ainda que pálida, da ossatura poderosa e inquebrantável que a consciência estrutural e musical de Mallarmé armou para o seu admirável poema". O poema mallarmeamo, ainda segundo Augusto, 
constitui "uma rigorosa e irrepreensível constelação de palavras" (p. 35). Nesse tipo de poesia aguda, os fragmentos não são atrelados por uma lógica da gramática da língua, mas por uma lógica da imagem, do visual, que estabelece uma ordenação espacializada que se afasta da organização sintagmática da espera. Por isso, o reconhecimento intelectivo desse tipo de poesia requer uma razão poética.

Uma das características do objeto fluido é a ruptura sintagmática e a geometrização do espaço, configurando um poema que tem seus contornos esmaecidos e que se aproxima de um objeto visual em constelação. Para Haroldo de Campos (In: CAMPOS; PIGNATARI; CAMPOS, 2006, p. 49),

a concepção de estrutura pluridividida ou capilarizada que caracteriza o poema-constelação mallarmeamo, liquidando a noção de desenvolvimento linear seccionado em princípio, meio e fim em prol de uma organização circular da matéria poética, torna perempta toda relojoaria rítmica que se apoie sobre a rule of thumb do hábito metrificante.

Para Décio Pignatari (In: CAMPOS; PIGNATARI; CAMPOS, 2006, p. 97), em seu artigo "Poesia concreta: pequena marcação histórico-formal", o poema visualmente figurativo, encontrável em Rabelais, Lewis Carroll, nos dadaístas e futuristas, era considerado revolucionário por Apollinaire: "porque é necessário que a nossa inteligência se habitue a compreender sintético-ideograficamente em lugar de analítico-discursivamente" (p. 97).

As explicações relativamente à constelação poética valorizam o objeto de percepção visual; todavia, todo ato perceptivo sensível tem como primazia a semiose em sentido mais simples, ou seja, a das relações reconhecidas pelo pacto semiológico estabelecido pela língua natural. O sujeito percebe não pelos sentidos, mas pela categorização de sua linguagem. Sua percepção seria antes uma "semiocepção" (cf. BEIVIDAS In: MARCHEZAN; CORTINA; BAQUIÃO, 2011, p. 31).

O nome constelações surge na década de 50 com Eugen Gomringer, que chamava suas criações poéticas de constelações, caracterizadas pelo rompimento do sintagma tradicional dos versos e pela redistribuição espacial e visual das palavras no branco do papel.

Haroldo de Campos (1997, p. 262) considerava, por exemplo, "Un coup de dés" um poema constelação, afirmando: "também em nossa América o poema-constelação de Mallarmé encontrou um congenial âmbito de ressonâncias" e teria influenciado o chileno Vicente Huidobro (Altazor, 1919-1931), o peruano César Vallejo (Trilce, 1922), o argentino Oliverio Girondo (En la masmédulo, 1957), o cubano Lezama Lima (Paradiso, 1966), o 
argentino Julio Cortázar (O jogo da amarelinha, 1963), o mexicano Octavio Paz (poema "Blanco", 1967). A mesma técnica vamos encontrar em Haroldo de Campos, Augusto de Campos, Décio Pignatari, Affonso Ávila, Horácio Costa, Claudio Daniel, Arnaldo Antunes entre tantos outros.

Tomemos o poema "Por Gertrude Stein", de Affonso Ávila (2008a, p. 349), constante de Masturbações. Nele, os lexemas organizam-se agudamente por constelação e condensação:

\section{por gertrude stein}

$\begin{array}{ll}\text { rosa } & \text { melhor uma } p \\ \text { rosa } & \text { melhor ainda uma } p \\ \text { rova } & p\end{array}$

rovar gertrude stein e espor

rar uma

rosa

A palavra rosa é associada sonoramente a prosa, assim como o é a "prova", "provar", "esporrar". Se observarmos esta constelação visual de associações, a repetição da palavra rosa orienta o enunciatário a identificar o fazer poético do enunciador ao de Gertrude Stein. A reiteração do lexema rosa configura novos sentidos:

$\rightarrow$ Não se trata de pura repetição, mas da produção do efeito de sentido de reproduzir o processo poético de Gertrude Stein (um dos seus versos mais conhecidos é "uma rosa é uma rosa é uma rosa"// "A rose is a rose is a rose").

E, ao fazer isso, o poema enfatiza não só a isotopia da flor, mas também a do fazer poético da escritora americana, amiga de Pound, Mallarmé, Cummings, Joyce, que compartilhavam o mesmo clima intelectual poético.

Na primeira estrofe, a instância da enunciação escolhe o isolamento do fonema oclusivo /p/: há uma ruptura formal por meio da fragmentação do vocábulo "p/rosa" (nos dois primeiros versos) e "p/rova" (no terceiro verso). Na realização da oclusiva /p/ -- que no poema fica mais evidente, pois está isolado no final dos três primeiros versos --, o ar sai 
como uma explosão; a categoria explosão no PE homologa-se com a categoria explosão no PC: "esporrar" é expelir, explodir, pôr para fora. Ademais, esse isolamento do /p/ nos três primeiros versos, além de sonoro, tem sentido plástico, sugerindo visualmente os espinhos do ramo da rosa. $O$ engenho da poesia aguda, assim como a rosa, produz espinhos de ordem remissiva.

Além disso, há uma parada na cadeia sonora, que transforma o fonema vibrante $/ r$ / alveolar fraco e continuativo de prosa e prova em fonema vibrante / $r$ / velar forte /R/ remissivo (rosa, rova). E, no $\mathrm{PC}$, essa ruptura do $\mathrm{PE}$ evidencia $\mathrm{ROSA}$ e $\underline{\mathrm{R}} \mathrm{OV} \underline{\mathrm{A}}$. Este último lexema, "rova", pode ser apreendido também como anagrama de VOAR, que reveste o tema da liberdade da criação poética, uma constante da poesia aguda do final do século XX.

Todos os versos iniciam-se por fonema vibrante /R/ velar de intensidade forte, fazendo prevalecer o jogo sonoro ROS(V)AR que é condensado no último verso em ROSA. O enunciador evidencia anagramaticamente "rosa" dentro de "prosa" e, no terceiro verso, comutando /z/ por / $/$, recria [p]rosa em [p]rova, que deságua em rosa. Além do sentido de a produção poética de Gertrude Stein valorizar o objeto enquanto objeto que pode ser sentido, recusando-se defini-lo inteligivelmente (e por isso a tautologia), bem como efetuar a operação de acentuação poética, temos aproximação de prosa e flor, contracenando com o sentido de que, assim como a poesia, a prosa também é flor. Tal qual Gertrude Stein, o enunciador do poema de Ávila atualiza o fazer literário da escritora americana: é preciso sentir o mundo, a natureza, sem muita ciência: "rosa é rosa".

Na segunda estrofe, a interrupção ocorre, no final do primeiro verso, com o fonema $/ r /$. Semissimbolicamente, a fragmentação do verso e do verbo "espor/rar" homologa o PE com o PC:

$\rightarrow$ No PE, assim como a sílaba "rar" é expelida do verso e da palavra, no PC de "esporrar" dáse o ato de pôr para fora, expelir algo à maneira de Gertrude Stein.

Várias são as isotopias do poema: (1) a reprodução biológica da flor ROSA; (2) a sexual: a de esporrar (ejacular); (3) a metalinguística, em que a composição do texto é resultado de: (a) uma escolha enunciativa de fragmentar as palavras do poema, expelindo figuras variadas; (b) recursividade, característica fundamental da linguagem poética. 
Os sentidos de rosa acentuam-se pela propriedade da condensação. A palavra rosa participa de outros campos lexicais, ocorrendo uma mistura aguda de elementos distantes: entre e ROSA e PROVA/PROVAR não há nenhuma associação "conhecida".

Aqui, observamos não só uma agudeza no PE, como também no PC.

Vejamos:

$\rightarrow \mathrm{Em} \mathrm{E}+\mathbf{S}+\mathbf{P}+\mathbf{O}+\mathbf{R}+\mathrm{R}+\mathbf{A}+\mathrm{R}$, vemos anagramaticamente condensada a palavra $\mathrm{R}+\mathrm{O}+\mathrm{S}+\mathrm{A}$. Os fonemas constituidores de rosa estão dentro dos fonemas constituidores de esporrar.

Outra condensação ocorre entre o enunciador Affonso Ávila e Gertrude Stein constantes do título ([Affonso Ávila] POR GERTRUDE STEIN). No mundo pragmático, uma secretária, ao assinar uma correspondência na ausência de um superior hierárquico, coloca à frente do nome de um diretor, p. ex., um " $p$ " indicador de "por", que significa no lugar de. No poema, visualmente, temos três /p/ isolados nos três primeiros versos. Nesse sentido, 0 enunciador coloca-se no lugar da destinadora Gertrude Stein.

Outro elemento a ser observado no poema é a verticalização da distribuição da composição: o espaço branco dos dois primeiros versos e o espaço branco ainda maior do terceiro verso da primeira estrofe contribuem para a formação do sentido, quer no aspecto visual, ideogramatizando o poema, quer no aspecto semântico, em que os brancos atualizam saltos contínuos do desabrochar do poema:

$\begin{array}{ll}\text { "rosa } & \text { melhor uma } \mathrm{p} " \\ \text { "rosa } & \text { melhor ainda uma } \mathrm{p} "\end{array}$

Na segunda estrofe, o enunciador simula desistir do fazer poético à maneira de Gertrude Stein e afirma que melhor é ler, provar da poeta (provar gertrude stein e esporrar uma rosa): "p / rovar gertrude stein e espor/ rar uma / rosa". Provar é metáfora-metonímica aguda de consumir, ler suas poesias. E "esporrar uma rosa" também é metáfora de gerar uma rosa.

Sintetizando, paralelamente à constelação visual - em que os enunciados são distribuídos no branco da página como estilhaços de estrelas no céu --, temos a constelação formada anagramaticamente: num primeiro nível no interior da palavra "prosa" está 
condensada a palavra "rosa", assim como dentro de "provar" está "prova". Em um segundo nível de agudeza mais acentuado ainda, há uma constelação dentro de "esporrar", em que se condensam "es(x)por", "porra", "por" e "rosa":

$$
\begin{gathered}
\text { ESPORRAR }=\text { ES }(X) P O R \\
\text { ESPORRAR }=\text { ROSA } \\
\text { ESPORRAR }=\text { PORRA } \\
\text { ESPORRAR }=\text { POR }
\end{gathered}
$$

A disposição do poema de Ávila sugere ideogramaticamente o desabrochar de uma rosa; no caso, temos a ejaculação de um poema e de uma rosa. Não se trata, no entanto, de um caligrama, cujos versos formariam a imagem de rosa. À maneira de Cummings, vemos que a fragmentação do fonema /p/ $(P E)$ da palavra "prosa" configura visualmente o aparecimento de uma rosa (PC) ainda não aberta completamente:

- Na leitura vertical, a coluna da esquerda espacializa a rosa e produz um efeito de sentido de visualização simultânea: o objeto apresenta-se diante dos olhos.

- Na leitura horizontal, os saltos brancos configuram o tempo da narrativa: o desabrochar da rosa, que amadurece, desfolha e se desmancha (desmanche dos contornos silábicos do PE: o /p/ isolado no final dos versos).

As estratégias agudas escolhidas sugerem um efeito de sentido que oscila da rapidez da explosão e da conversão do botão em flor à desaceleração do processo da queda das pétalas que, paulatinamente, descolam-se do final dos versos, introduzida esta última aspectualização visual por uma queda demorada. Ao ver os /p/ finais, o enunciatário sente não um cair pontual, mas uma queda que dura. É como se as pétalas caíssem em slow motion, em câmera lenta. Temos então um gerúndio visual. Paradoxalmente, cair tem aspectualização pontual, mas pela agudeza visual de Affonso Ávila vemos no poema um cair durativo produzido pela iteração de um fonema isolado ao final dos três primeiros versos.

Embora o estado de alma do enunciador revele modéstia e insegurança retórica sobre sua criação poética, que poderia ser melhor, vemos o nascimento de um poema, que homenageia Gertrude Stein. E assim como o botão se transforma em rosa e depois perde o viço e caem as pétalas, o objeto poético nasce de uma engenhosidade -- tanto no PE quanto 
no PC --, que tem na base a combinação de dois elementos distantes (S1 - rosa e S2 ejacular) para formar um poema (S3), que por não se comparar ao de Gertrude Stein presentifica-se modestamente como rosa despetalada.

Assim como o desenvolvimento de uma rosa dá-se de forma processual, mas tem um desabrochar que parece repentino, também o fazer poético conhece a mesma tensão: seu fazer é por acúmulo de criatividade, mas o objeto estético parece surgir para o enunciatário como um jorro. A propósito, Drummond ironicamente dizia que seus leitores viam seus poemas prontos como se tivessem brotado repentinamente de sua cabeça, desconhecendo seus rascunhos (trabalho intenso) arremessados na lixeira.

POESIA vem de POIESIS, criação, fabricação; porra = sêmen, semente criativa, origem. ROSA -> POESIA -> PORRA (esporrar)

Concluímos haver no poema uma tensividade entre:

- A dominância de entraves no PE da primeira estrofe (fragmentação de fonemas, grafemas soltos " $p$ ", presença de brancos, fluidez nos contornos pela quebra sintagmática), bem como no PC (hesitação no enunciado configurado em "melhor", cuja repetição indica ênfase em "melhor ainda").

- E a dominância de emissividade da segunda estrofe: as reiterações da primeira estrofe desaparecem, dando lugar a um aceleração, que alcança elevada tonicidade em "esporrar", que, como sabemos, é um ato que se dá de uma vez e abruptamente, sem o controle total do sujeito.

Assim como a natureza cria rosas, o poeta "eSpORrA" (e[x]spor rosa) cria rosas discursivas. A lógica que ordena o poema não é a analítico-discursiva, da nitidez, mas a sintético-visual, da égide dos contornos fluidos. O poema ejaculado no enunciado de Affonso Ávila "passa a ser um objeto útil, consumível, como um objeto plástico" (In: CAMPOS; PIGNATARI; CAMPOS, 2006, p. 81). Na seção seguinte, "Pilar" é um típico exemplo da agudeza verbovocovisual em Affonso Ávila. 


\title{
2.4 Agudeza visual e sonora em "Pilar", de Affonso Ávila
}

O poema "Pilar", constante de Cantaria barroca (ÁVILA, 2008a, p. 284), obra escrita entre 1973 e 1975, diferentemente das poesias dominantemente agudas do PC, é da ordem do esmaecimento sintagmático, da fluidez, prevalecendo nele a agudeza sonora e visual:

\author{
Pilar \\ \& em triunfo \\ eu tributo $p$ \\ edra sobre $p$ \\ edra \& em tr \\ iunfo eu tri \\ buto ouro so \\ bre ouro \& e \\ $m$ triunfo eu \\ tributo temp \\ o sobre temp \\ o \& em triun \\ fo eu tribut \\ o livro sobr \\ e livro \& em \\ triunfo eu $\mathrm{t}$ \\ ributo ela s \\ obre elas \&
}

Cantaria barroca compreende um conjunto de poemas que tratam de eventos e objetos seiscentistas, que têm como espaço Ouro Preto: a estrada real, a praça Tiradentes, o relógio da casa de câmara, o Museu da Inconfidência, o Hospício da Terra Santa, a ponte do Xavier, o palácio da Rua Nova, o Beco do Escorrega, a Casa de Gonzaga, a Igreja de São Francisco de Assis, a procissão do Triunfo, a Casa da Ópera, o Chafariz da Glória, o Largo da Alegria, o Cemitério dos Pardos de São José, a Casa dos Contos. "Pilar", especificamente, figurativiza uma igreja de Ouro Preto.

O poema explora o aspecto visual na mancha da página, em que a sucessão dos versos estreitos configura um pilar (coluna). O grafema $\&$ perpassa todo o poema e toda a obra Cantaria barroca de Affonso Ávila, iniciando e finalizando os poemas e produzindo um efeito visual de coluna barroca cheia de ornatos.

"Pilar" é um típico caso de teatralização da crise de verso. Onde eles estaria?

Os símbolos gráficos \& marcam o início de cada um dos versos. O destaque da linha no branco da página não é o mesmo da pausa da diç̧ão do verso, nem de um processo sintagmático comum. No poema, a quebra visual não se faz pela medida, nem pelo ritmo, uma vez que o verso do final do século XX opera casualmente a quebra da linha, mas não da 
ruptura do verso ou do ritmo. A regularidade rítmica, portanto, faz-se pela cisão do verso a cada símbolo gráfico \&. Vejamos a redistribuição proposta no exercício de leitura:

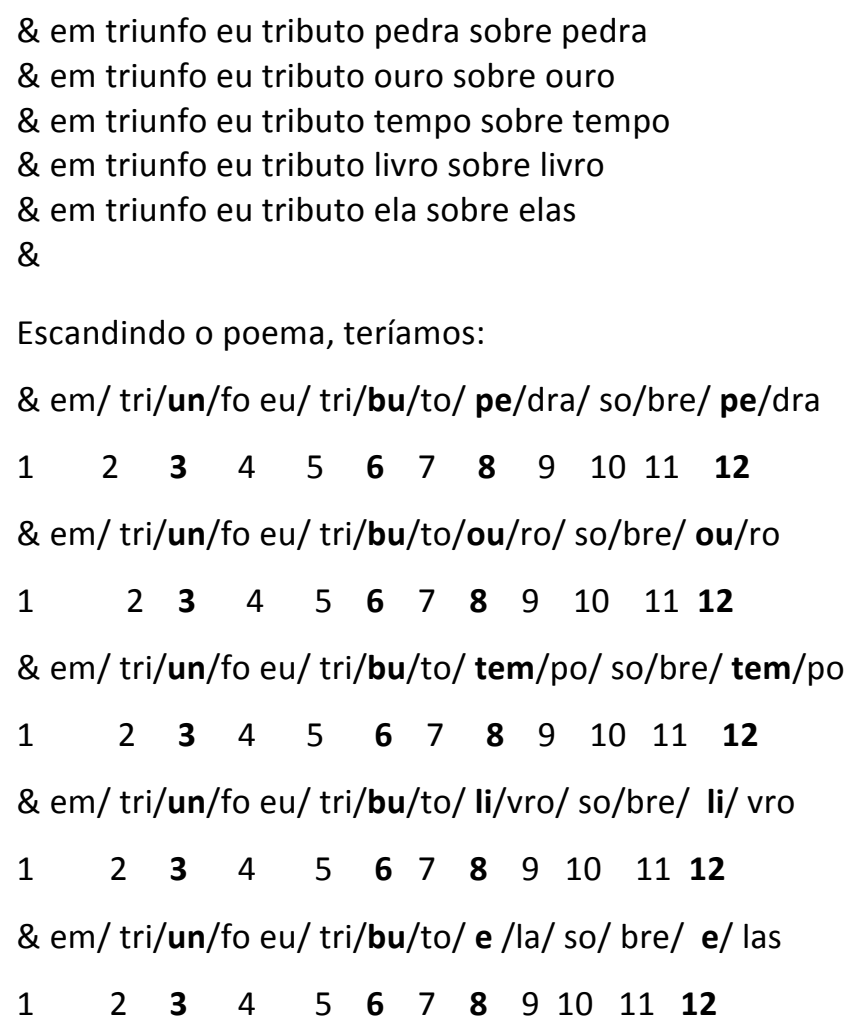

Nos alexandrinos de "Pilar, como vimos no exercício, o afastamento do esquema rítmico tradicional (primeiro esquema: acentuação na $6^{\mathrm{a}}$ e $12^{\mathrm{a}}$ sílabas métricas; segundo esquema: acentuação nas $4^{\mathrm{a}}, 8^{\mathrm{a}}$ e $12^{\mathrm{a}}$ sílabas métricas) evidencia uma acentuação rítmica na $3^{\mathrm{a}}, 6^{\mathrm{a}}, 8^{\mathrm{a}}$ e $12^{\mathrm{a}}$ sílabas, que parece justificar-se pela necessidade de criação de uma sonoridade ímpar, categoria de singularidade que se homologa com PC pela categoria de singularidade, a soberania da Igreja do Pilar sobre as outras, ELA sobre ELAS. Assim, a ampliação da acentuação, que empresta ao poema certa vivificação formal contrastante com a arquitetura de um verso alexandrino tradicional que não seria suficientemente forte para os motivos do enunciador. Observa-se também que a atribuição de maior força à terceira sílaba poética dá-se com uma sílaba fechada nasal que implica maior duratividade ("un" de triunfo). Triunfo figurativiza a procissão do século XVII que ocorreu em Ouro Preto, assinalando a transferência do Santíssimo para a Igreja do Pilar.

No poema, organizou-se o enunciado de forma que a palavra triunfo fosse distribuída estrategicamente, colocando-a no início ( $3^{\mathrm{a}}$ sílaba acentuada) de todos os versos; marca-se assim um ritmo que dá saliência ao som vívido "un" na batida do poema, de intensidade 
sonora mais forte: a categoria ascendência no PE, em "UN", homologa-se com a categoria ascendência no PC (a Igreja do Pilar sobre todas as outras de Ouro Preto).

Ao lado do parecer discursivo, temos os versos alexandrinos, que não confirmam essa crise. Ao contrário, afirmam o verso.

Com base no exercício de leitura, depreendemos a cifra tensiva de acentuação na recorrência do ritmo. Pelo ritmo poético, temos o retorno de um som - uma sílaba -- mais forte que as outras, num movimento cíclico, "uma operação dupla e ondeante: progressivoregressiva, regressivo-progressiva" (BOSI, 2004, p. 41). Depreende-se verso a partir do movimento rítmico, não apenas a partir de sua linha propriamente.

A função semiótica do ritmo é provocar uma espera; quando ele se altera, ficamos em choque, maravilhados. O ritmo suscita em nós a paixão da ansiedade que não se arrefece porque, ao contrário do esperado, sobrevém uma variação, provocadora de uma ruptura, de um sobrevir. Assim, ritmo seria o movimento de direção a algo que nos surpreende, porque viola o esperado.

Ritmo sem variação: há uma espera; a repetição nos leva a esperar que algo aconteça.

Introdução de deformação no ritmo (caso de "Pilar"): temos um movimento surpreendente que não confirma o esperado: embora se espere sempre o mesmo, ocorre sua negação (concessividade zilberberguiana)

Em "Pilar", de Affonso Ávila, ao acentuarem-se a terceira e a sexta sílabas poéticas, o enunciatário é levado a esperar uma regularidade do acento na nona, para a qual também contribui o acento na décima segunda. A regularidade seria "3/6/9/12", mas o que ocorre no poema é uma antecipação do acento na oitava sílaba. No PE, ao deslocar o acento para a oitava sílaba, vivifica-se no PC o sentido das figuras que se sucedem no poema: "pedra, ouro, tempo, livro, ela", todas manifestações da isotopia religiosa, quer do mundo material (pedra/ouro), quer do mundo espiritual (bíblia e templo sagrado da Igreja do Pilar).

Tomando a figura tempo, há ainda uma paronomásia com templo. O ritmo forte das batidas intensificam a louvação do tributo à Igreja do Pilar. Essa regularidade irregular do ritmo de "Pilar", em vez de eliminar o verso, confirma-o, porque ao final de cada enunciado retorna-se ao início para perfazer um movimento cíclico, próprio da poesia. Se não houvesse 
verso, ou seja, se se afirmasse sua crise, não haveria retorno e sim o desmanche não da linha do verso, mas da poesia.

Observando inicialmente a forma visual de um pilar e o simulacro de "sumiço" do verso, o que temos, em verdade, é teatralização, pois que numa segunda leitura os versos alexandrinos saltam à vista.

Como pudemos verificar na operação de leitura do poema "Pilar", os versos se deixam ler sem esforço: "a crise não é apenas referida, mas sim encenada" (FRANCHETTI, 2008, p. 2). Affonso Ávila e Haroldo de Campos, ao teatralizarem a crise, acabam por vivificar verso.

Se a quebra da linha não se justifica pela medida do verso, seria apenas negação do verso, um apelo retórico do verso em curto-circuito?

A quebra aleatória da linha no poema do final do século XX é um fator promovido pelos destinadores do fazer poético contemporâneo:

[...] a quebra arbitrária da frase, sem que se perceba na quebra mais do que o desígnio de quebrar, é o recurso mais abusado da poesia contemporânea. Ou, dizendo de outro modo: uma das estratégias mais características (e banalizadas, tenho de dizer) da poesia pós-concreta de interesse - isto é, da poesia contemporânea que se contrapõe à facilitação dominante no âmbito da neo-geração-de-45 - é a operação sobre o verso a partir do corte (FRANCHETTI, 2008, p. 3).

O verso é o regente da:

- Função visual: o corte (o desmanche de contorno) encaminha o verso a um papel visual, pretensão da poesia do final do século XX.

- Função de retardamento do reconhecimento inteligível: o objeto esmaecido em seu contorno, fluido, pretende-se "resistente" à recomposição. Caminha, no entanto, no fio da navalha, pois um objeto que não se deixa reconhecer pode se desmanchar.

Resumindo, é notável nos poemas de Affonso Ávila o emprego de algumas agudezas, como: (1) tipos gráficos diversos; (2) verticalização do verso; (3) posição das linhas tipográficas na página; (4) uso especial do branco na página; (5) ausência de pontuação; (6) sintagmatização inesperada; (7) estilhaçamento de sílabas e de morfemas; (8) combinatória de morfemas na página; (9) uso de símbolos gráficos, como o " $\&$ "; (10) formação de 
constelação lexemática: grupo de palavras associadas no conteúdo e na expressão, que ao, formarem uma constelação, produzem também um novo sentido: [S1+S2=S3, e $S 3>S 1+S 2]$ ).

O esmaecimento dos contornos no PE (poema em forma de coluna) produz um poema da égide da fluidez. O exercício de leitura proposto reconstrói os contornos, mostrando-nos uma arquitetura rigorosa do fazer poético em versos alexandrinos, os quais proporcionam, segundo Said Ali (2006, p. 102), agradável sonoridade à audição do enunciatário.

A regularidade dos versos de Ávila é arquitetada de modo que os fonemas isolados ao longo do poema, bem como a divisão silábica não consignada gramaticalmente, introduzem rupturas na continuidade linear do verso, quebrando não apenas o verso, mas também a cadeia da sílaba. Ocorre ainda uma tensividade entre a parada da continuação do verso (quebra de sílabas) e a parada da parada, configurada no poema pelo símbolo " $\&$ ", que abre e fecha cada um dos versos em movimento de continuidade, teatralizando na manifestação discursiva o desmanche dos contornos, proporcionando esse efeito de fluidez.

A parada, configurada pela ruptura a cada isolamento fonemático, produz outra remissividade no PC, levando-nos ao tempo de então da inauguração da Igreja mineira do Pilar. O isolamento destaca Pilar no tempo e no espaço. Assim como no poema anterior "Por Gertrude Stein", nota-se em "Pilar" o destaque visual dos fonemas isolados, bem como a sucessão de palavras num processo contínuo de fluidez/nitidez, por meio de condensação e decifração, que aproximam inicialmente o enunciatário para o deleite e fruição do maravilhamento suscitado pelo desmanche do poema e, em seguida, para o encaminhamento do reconhecimento intelectivo, que também é um tipo de prazeroso.

Embora não haja preocupação com a rima final, a redistribuição do poema em versos alexandrinos mostra-nos a existência de rimas internas, produzindo uma cadência regular de louvação. No PE apenas visual, notamos 17 versos ou pequenas manchas que constituem uma mancha preta única, verticalizada no branco da página.

O grafema \& revela-se no conteúdo uma conjunção coordenativa, que introduz enunciados paratáticos em consonância com a figura da Igreja do Pilar, que é a única que deve sobressair. Enunciados hipotáticos compreenderiam subordinação, incompatível com a ideia de "triunfo". Além disso, o monograma \& é a combinação do desenho de duas letras sobrepostas " $\mathrm{e}$ " e " $\mathrm{t}$ " (et) num único sinal, usado para aumentar a velocidade da escrita manual, desenvolvido por Marco Túlio Tirão, secretário de Cícero, orador romano. Para 
poder registrar os discursos ditados por Cícero, Tirão, escravo liberto, criou várias formas de acelerar a escrita, sendo considerado o pai da taquigrafia. Embora o traçado do símbolo tenha evoluído, em algumas famílias de fontes tipográficas, ainda é possível enxergar as duas letras que esse monograma representa. A presença do " $e$ " no poema dá sempre a ideia de continuidade, de labirinto, de enigma, característica dos objetos do final do século XX, produzindo um efeito de sentido de continuidade de um tempo que se esvai e recomeça, oscilando como um pêndulo entre a parada e a parada da parada.

A desconstrução das palavras nos versos, às vezes, vai às últimas consequências do isolamento de um fonema apenas, que produz o efeito de sentido de fluidez, de abertura das formas. Assim sendo, o obscurecimento do PE (fragmentação visual do grafema e fragmentação sonora da sílaba) engendra uma ressignificação e produz novo conteúdo, típica operação de agudeza.

Os morfemas e fonemas entram em conjunção e disjunção na composição do poema. Para formar o pilar, nota-se a escolha do fonema oclusivo bilabial não vozeado /p/, produzido pelo fechamento espacial dos lábios. O mesmo ocorre com a oclusiva alveolar não vozeada /t/. Esse fechamento é ainda produzido por fonemas nasais em "triunfo", "tempo" e pela preposição "em". Esses valores de estreitamento no PE podem ser homologados no PC com o estreitamento espacial da figura de um pilar. Os fonemas descritos produzem uma aspectualidade pontual, que é corroborada morfologicamente pelo presente do indicativo "eu tributo".

Esse elevar da voz que se repete em eco tem o efeito de um estado de alma que quer se fazer ouvir. Por que então a oscilação entre fonemas não vozeados, surdos, e fonemas vibrantes? Parece que essa escolha sugere um ritmo de um sujeito que quer se fazer ouvir, sem grande estrondo. Sabe da importância do monumento estético "A Igreja do Pilar", mas sabe também que não é preciso gritar estridentemente para mudar os valores.

Ademais, o fonema alveolar vibrante /r/ em "triunfo", "tributo", "pedra", "sobre", "livro" produz um som ressoante, introdutor de acentuação e vivificação sonora, que sugere não só o fazer humano na construção em alvenaria de um pilar, mas também o ecoar da homenagem à Igreja do Pilar. Os sons vibrantes ainda contribuem para a sonoridade e a solenidade retumbante, escolha do enunciador que quer tornar seu objeto ímpar, enunciando-o com vibração. 
A agudeza do PE, meticulosamente arquitetada, revela no PC a estrutura dos elementos que compõem o pilar:

- Os grafemas do PE compõem a imagem da coluna no branco da página.

- Esses fonemas e grafemas rearranjados mostram no PC a estrutura arquitextônica do pilar: partículas no branco da página se sobrepõem visualmente para deleite estético.

PE: categoria da identidade [eco dos fonemas não vozeados (/t/ e /p/ e dos vibrantes $/ r /$ )] :: PC: categoria da identidade [ressoar da singularidade da Igreja do Pilar]

PE : categoria da composição [visualização de grafemas no branco da página] :: PC : categoria da composição [reconhecimento do conteúdo de um PILAR]

Por meio da isotopia metalinguística desencadeada pela palavra livro, o enunciador chama a atenção para o trabalho com as palavras: um trabalho linguístico de desmanche da nitidez. Na agudeza, como vimos em "Por Gertrude Stein", é comum o princípio da constelação: no PE, distribuição visual de grafema no espaço da página; no PC, grupo de palavras ligadas por associação semântica, entendida aqui como a utilização de um lexema principal que funcionaria como aglutinador, formando assim uma constelação.

Em "Pilar", ao lexema TRIUNFO aglutinam-se em constelação "tributo", "ouro", "livro" etc. Triunfo dialoga com o Triunfo Eucarístico, nome de um opúsculo publicado em Lisboa, em 1734, por Simão Ferreira Machado, em que descreve uma festa que acontecera um ano antes, em 24 de maio de 1733, em Ouro Preto, e que marcou a inauguração da Matriz do PILAR. A Eucaristia estava provisoriamente na Igreja de Nossa Senhora do Rosário e, na inauguração da Igreja do Pilar, preparou-se grande festa para a trasladação do Santíssimo em procissão TRIUNFAL: no poema, perpassa o lexema triunfo, marcando-o reiteradamente de modo indelével.

Dissemos que os versos alexandrinos do poema são compostos de dois hemistíquios esmaecidos em seus contornos para retardar o reconhecimento intelectivo do objeto. Se colocarmos os hemistíquios um sobre o outro verificaremos que temos cinco versos que reiteram: "\& em triunfo eu tributo" e cinco que são diferentes: "pedra sobre pedra"; "ouro sobre ouro"; "tempo sobre tempo"; "livro sobre livro"; "ela sobre elas". O que se observa 
aqui é uma estrutura poética paralelística, que determina um ritmo litânico de procissão religiosa. Nos cinco diferentes, as figuras em destaque são "pedra", "ouro", "tempo", "livro", "elas", ou seja, em nenhum desses versos aparece explicitamente a figura da Igreja do "Pilar".

Por nosso conhecimento enciclopédico, sabemos que o enunciador, na pele discursiva de Affonso Ávila, é mineiro e conhece as tradições ditas barrocas de Ouro Preto. A Igreja do Pilar aparece no poema reduzida metonimicamente a "PILAR", constante do título. Como a palavra-constelação é TRIUNFO, forma-se um campo semântico religioso:

- Procissão do TRIUNFO.

- Igreja do PILAR: a expressão bíblica 'pedra sobre pedra' configura a isotopia da origem da Igreja.

- "tempo sobre tempo": isotopia do escoamento do tempo, figura querida das letras seiscentistas.

- "livro sobre livro": isotopia da manifestação da palavra divina (Bíblia).

Ao final do poema, o enunciatário depara-se com os dêiticos "ELA [sobre] ELAS" que desencadeiam nova isotopia. O enunciado 'ela sobre elas' direciona o sentido para o destaque da Igreja do Pilar em relação a todas as outras igrejas de Ouro Preto. O "pilar" do título não é apenas uma figura do pilar como coluna de sustentação, mas do grandioso monumento arquitetônico em Ouro Preto, construído no ciclo do ouro (figura discursiva "ouro sobre ouro", que aparece no enunciado).

Ao afirmar reiteradamente "eu tributo", o enunciador aproxima-se do objeto, homenageando-o. O verbo tributar tem o sentido de prestar homenagem (HOUAISS; VILLAR, 2001). O ato de louvação implica a existência de um objeto singular a que se presta um preito. Nesse sentido, trata-se de um sujeito cuja paixão se traduz em admiração, que é um estado de conjunção com o maravilhamento que o objeto "Igreja do Pilar" suscita. Estamos diante de um sujeito sensibilizado por um objeto estético arquitetônico. Essa aproximação também configura a posse do saber: é capaz de avaliar a preciosidade artística do monumento.

A metonímia do título, juntamente com outras metonímias, também forma uma constelação semântica que atualiza os festejos religiosos na Igreja do Pilar. Daí triunfo ser metonímia de procissão do triunfo; ouro ser metonímia de Ouro Preto e das colunas 
douradas da igreja; livro ser metonímia da Bíblia e pedra ser metonímia de Igreja, que está na raiz de PEDRO, o pilar da Igreja, representante, para os católicos, de Deus na Terra.

A agudeza, como temos visto, tem como um dos elementos a ideia de constelação, efeito produzido aqui pelo labirinto sonoro dos fonemas e visual dos grafemas e pelos morfemas, que compõem o poema, possibilitando variadas combinações; essa agudeza acentuada torna o objeto poético ainda mais vívido no sensível. Também pertence à operação da agudeza a metáfora de PILAR, que é a soma de dois conteúdos diversos: (1) pilar coluna do templo + (2) Igreja do Pilar, e desses dois depreende-se um terceiro: (1) pedra, formadora da coluna + (2) Pedro, "pedra" constitutiva da Igreja.

Ademais, sobressai outra agudeza de condensação das figuras elencadas em uma isotopia central: a Igreja do Pilar contém (condensa) as outras igrejas de Ouro Preto (ver ELA sobre ELAS), constituindo-se em modelo seiscentista de igreja, não só por sua constituição física, mas também por sua vivificação no presente, mantendo-se desde o final do século XVII até os dias de hoje.

Em relação aos fonemas vocálicos, constatamos a maior incidência de /i/ e de /u/. São eles mais fechados, mais agudos. As duas vogais que aparecem no primeiro verso (tr I U nfo) cedem lugar para as vogais de maior abertura (que é o A presente em ELA/ELAS). Somase à fluidez do plano visual -- promovida pelos grafemas na mancha da página e, no plano sonoro, pelo som mais fechado (/i/ e /u/) que vai para o mais aberto /a/ no final do poema -a fluidez do PC, visto que o enunciatário se sente desorientado, porque não encontra no enunciado do poema nenhum referente para os dêiticos ELA e ELAS.

Enquanto ELA figurativa a isotopia estética - monumento "Pilar" - e a religiosa formação da igreja, o pronome ELAS configura também uma isotopia estética: as outras igrejas seiscentistas de Ouro Preto. A preposição sobre de "Ela sobre elas" acentua as qualidades estéticas da Igreja do Pilar, soberana em relação às outras igrejas. Nos fonemas vocálicos mais fechados do poema (/i/ e / $/$ /) e nos sons nasais /em/, /triunfo/, /tempo/, notamos no PC a apresentação de um espaço e tempo compactado pela fluidez, mais remissivo, o invisível da penumbra do sentido, na medida em que nos fonemas mais abertos /a/ temos, no PC, uma passagem da remissividade para a emissividade, do invisível escuro para o visível claro. O esmaecimento encaminha-se para o restabelecimento dos contornos: a claridade revela a Igreja do Pilar soberanamente nítida no final do poema: 
ELA sobre elas

\begin{tabular}{ll}
\hline FLUIDEZ & \multicolumn{1}{c}{ NITIDEZ } \\
PE:: /i/ / $/$ / $/$ nasais/ & Emissividade \\
Remissividade & Claro/aberto \\
Escuro/fechado & Menos catálise \\
Mais catálise & A Igreja do Pilar \\
Pilar da construção civil & (ELA sobre ELAS) \\
Fazer poético fluido, com entraves formais & Poema mais nítido com menor
\end{tabular}

Assim, a dança dos fonemas vocálicos engendra um efeito de movimento do PC, que direciona o sentido inicial de "triunfo", simples procissão, ao triunfar da Igreja do Pilar, que sai da penumbra para ocupar um lugar de maior claridade.

Concluindo, a intensificação da fluidez também se nota na ausência de pontuação e no grafema \& (et), que finaliza o poema, produzindo o efeito de ausência de fim, ou seja, a narrativa fica aberta a novas continuações. De igual forma, manifesta a segurança de um enunciador que caminha desenvolto pelas vias de Ouro Preto, transitando de uma igreja a outra. Além disso, o uso de símbolos gráficos e de sinais matemáticos é largamente utilizado na poesia do final do século XX para a constituição de efeito imagético e para 0 engendramento do obscurecimento. Em Ávila, produz-se um efeito de sentido de objeto estético da tradição, atualizando-se o passado no presente.

O resultado do trabalho com a linguagem, que estamos vendo nesta tese, é regulado pela liberdade criativa no $\mathrm{PE}^{4}$; é ela que possibilita o efeito de fluidez, fazendo o enunciatário deter-se nos significantes para retardar o reconhecimento inteligível do objeto estético.

Se o enunciatário, movido pelo sensível, encontrar uma saída rápida para o inteligível, é sinal de que o objeto é pouco fluido, porque requisita pouca catálise. Se, no entanto, depois do impacto do sensível, demorar-se ainda mais para encontrar uma saída para o reconhecimento, a fluidez mostra-se eficaz, solicitando ainda mais catálise.

\footnotetext{
${ }^{4}$ Cf. Antonio Vicente Pietroforte (2011), na obra O discurso da poesia concreta. Nessa obra, faz detida análise semiótica da poesia concreta de Augusto de Campos, Pedro Xisto, Haroldo de Campos, Décio Pignatari, Edgar Braga, Arnaldo Antunes.
} 
Fluida ou nítida, a poesia do século XX pretende-se também pintura, o que veremos na seção 2.5 .

\subsection{Ut PICTURA POESIS NA CONSTRUÇÃo DA POESIA DO SÉCULO XX}

Écfrase, segundo o Dicionário Houaiss (2001), define-se como "descrição minuciosa de uma pessoa ou objeto". O dicionário convoca o termo evidentia, conceituando-a como "descrição viva e minuciosa de um objeto, realizada com a enumeração de suas particularidades sensíveis, reais ou fantasiosas; o que se deixa ver". Seu sentido original de evidência articula-se com o grego enárgeia, que significa "representação ou descrição extremamente realística em um discurso; descrição pinturesca, hipotipose; visão clara, clareza, evidência"; o que é brilhante, o que é claro.

As acepções nos encaminham à percepção dos sentidos, particularmente o visual. 0 conceito de écfrase ampliou-se, imbricando-se no de ut pictura poesis e no de descriptio latina. Esta última é uma forma de representar verbalmente os objetos e as pessoas. Em ut pictura poesis, procurava-se uma representação verbal à semelhança da pintura.

Hipotipose, um tipo específico de écfrase, vem do grego e significa: "representação, imagem, modelo, quadro". É a descrição de uma cena ou de um objeto, que utiliza uma cifra tensiva vívida, intensa, que faz o enunciatário ter a sensação de presentificação do objeto ou da cena retratada verbalmente:

Para a retórica antiga, essa figura [hipotipose] pinta as coisas de um modo tão vívido e enérgico, que parece colocá-las sob os olhos do leitor. A figuratividade é uma forma de construir discursos, os figurativos, organizados preponderantemente como palavras concretas, as figuras. A hipotipose intensifica essa propriedade da linguagem, é a saturação da figuratividade. É, portanto, uma descrição que apresenta uma saliência perceptiva, o que significa que ela é tingida pela subjetividade daquele que descreve, o que lhe dá uma intensidade muito grande (FIORIN, 2014, p. 155).

A écfrase, mais especificamente, a hipotipose atribui ao discurso poético características visuais, que aproximam os textos literários da pintura. $\mathrm{O}$ abade Jean-Baptiste Du Bos ([1719] In: LICHTENSTEIN, 2008, v. 7, p. 66-67), no ensaio "Reflexões críticas sobre a poesia e a pintura", afirma que

o poeta chega mais próximo à imitação do objeto que o pintor. Um poeta pode empregar vários artifícios para descrever a paixão e o sentimento de um personagem. Se alguns deles se perdem, se não atingem sua finalidade com precisão, se não produzem com exatidão a ideia que se deseja exprimir, outros traços podem servir de apoio aos primeiros. Juntos, farão 
aquilo que um recurso sozinho não pode fazer, exprimindo assim a ideia do poeta em toda sua força. [...] O mesmo não ocorre com o pintor, que pinta seus personagens uma única vez e não pode empregar senão um traço para exprimir uma paixão em cada parte do rosto na qual essa paixão deve ser ressaltada. Se não elabora bem o traço que deve exprimir a paixão; se, por exemplo, quando pinta um movimento da boca, o contorno não é precisamente a linha que deveria ser traçada, a ideia do pintor é destruída e o personagem, em vez de exprimir uma paixão, não faz mais que uma careta.

A aproximação entre pintura e poesia é um tema que tem atravessado séculos e desembocou no Realismo, no Parnasianismo, no Modernismo (Surrealismo, Futurismo, Cubismo), no Concretismo, na poesia do final do século XX. Em Portugal, os poemas de Cesário Verde constituem um exemplo da escolha de valores pictóricos na poesia. As vanguardas do modernismo também valorizam as experiências do fazer poético espelhado no fazer pictórico.

Horácio aproxima a poesia da pintura (ut pictura poesis). Nesse sentido, o fazer poético, assim como o fazer pictórico, mostra-se tão sensível visualmente quanto uma pintura:

Suponhamos que um pintor entendesse de ligar a uma cabeça humana um pescoço de cavalo, ajuntar membros de toda procedência e cobri-los de penas variegadas, de sorte que a figura, de mulher formosa em cima, acabasse num hediondo peixe preto; entrados para ver o quadro, meus amigos, vocês conteriam o riso? Creiam-me, Pisões [o tratado de Horácio é uma carta dirigida pelo poeta a seus amigos, os Pisões, pais e filhos], bem parecido com um quadro assim seria um livro onde se fantasiassem formas sem consistência, quais sonhos de enfermo, de maneira que o pé e a cabeça não se combinassem num ser uno.

-- A pintores e poetas sempre assistiu a justa liberdade de ousar seja o que for (HORÁCIO In: ARISTÓTELES; HORÁCIO; LONGINO, 2008, p. 55).

Para Hansen (1997, p. 179), Horácio valoriza a visão em prejuízo da audição e cita os seguintes versos horacianos de Arte poética: "As coisas que entram pelo ouvido impressionam os ânimos mais debilmente que as oferecidas ao fiel testemunho dos olhos e que o espectador percebe diretamente." A poesia seria sobretudo imagem: "assim como o pincel imita os topoi narrativos das écfrases de autoridades, também a pena deve imitar o pincel, produzindo metáforas visualizantes de efeitos maravilhosos, simultaneamente adequados à utilidade e ao prazer" (HANSEN, 1997, p. 179). Horácio estabelecia ainda um critério retórico como determinante do decoro. Cito duas traduções, porque me parecem complementares: 
Como a pintura, a poesia: haverá aquela que, se estiveres mais perto, ti moverá mais, e outra, se estiveres mais longe; esta ama o obscuro, quer esta sob a luz ser vista, do juiz esta não teme o agudo juízo; esta agradou uma vez, esta dez vezes repetida agradará (HORÁCIO, tradução de HANSEN, 2011, p. 55).

Poesia é como pintura; uma te cativa mais, se te deténs mais perto; outra se te pões mais longe; esta prefere a penumbra; aquela quererá ser contemplada em plena luz, porque não teme o olhar penetrante do crítico; essa agradou uma vez; essa outra, dez vezes repetida, agradará sempre (HORÁCIO In: ARISTÓTELES; HORÁCIO; LONGINO, 2008, p. 65).

O ut pictura poesis estabelece, assim, uma proporção para o decoro, fundamentando-lhe a apreciação como uma avaliação do juízo. Os versos horacianos citados propõem haver uma forma específica para cada gênero. É, portanto, o ut pictura poesis

uma doutrina genérica da verossimilhança necessária em cada obra, segundo sua invenção, disposição e elocução para que possa cumprir as três grandes funções retóricas de docere delectare e movere (HANSEN, 2011, p. 55).

Com base nessa doutrina, três relações podem ser citadas:

- Distância: em termos de perto/longe (o objeto mais fluido pede maior aproximação do enunciatário).

- Claridade: em termos de clareza/obscuridade (para nós, nitidez/fluidez).

- Número: em termos de uma vez/várias vezes (nesse sentido, o objeto mais fluido pede mais de uma leitura).

Enquanto rejeita o longe, a obscuridade e várias vezes (o que deve ser lido várias vezes para ser compreendido), Horácio valoriza a clareza (perto, claro, uma vez). Daí Hansen (2011, p. 56, destaques no original) afirmar em relação aos sermões (no caso os de Vieira):

Pensando-se o sermão cenograficamente, a relação de proporcional/desproporcional (icástico/fantástico) implica não qualquer proximidade ou qualquer distanciamento para a recepção, mas, sempre, a correta distância, a distância exata, matematizada no estilo como commensuratio ou proportio. A ideia correta de distância prescreve nem o muito longe, nem o muito perto, de um ponto fixo adequado. É a partir desse ponto fixo de observação encenado no estilo que os dois eixos, perto/longe, se interceptam e normalizam, produzindo-se a recepção adequada.

Apresenta Hansen (1997, p. 182) uma alegoria de Emanuele Tesauro, que é esclarecedora: os atenienses teriam encomendado uma cabeça de Palas Atena a Fídias e a Alcmene, que seria posta num lugar alto. Depois de prontas e submetidas aos juízes, estes 
riram da obra de Fídias, que Ihes parecia grosseira, mal esboçada e admiraram a obra de Alcmene, posto que esta mostrava contornos mais nítidos. Fídias, no entanto, tinha "engenho mais agudo" e pediu que as cabeças de Palas Atena produzidas fossem colocadas nas alturas sobre duas colunas elevadas. Como a de Fídias havia sido produzida segundo a proporção adequada da distância, pareceu mais bela que a de Alcmene, que foi então considerada tosca e mal formada. É com base nesses enunciados que se pode sugerir que a poesia do final do século XX é para ser vista segundo uma distância adequada para que não se perca o deleite estético.

Nesse cenário, Leon Battista Alberti foi o primeiro pintor renascentista que se interessou por amenizar a desvantagem dos pintores em relação aos poetas e para isso escreveu De pictura (1435), obra que se apoia em retores, como Horácio e Quintiliano. Por isso, a teoria das artes plásticas nasceu dependente dos tratados de retórica e de poética.

Dá-se com Leonardo Da Vinci uma inversão da hierarquia que estabelecia a precedência da poesia sobre a pintura (SELIGMANN-SILVA In: LESSING, 2011, p. 12 ss). Para ele, a pintura seria superior à poesia, pois teria a virtude da visibilidade, visto que coloca as coisas diante dos olhos do enunciatário. Nesse caso, colocar diante dos olhos revela-nos a força dos signos da pintura, da ordem da evidência, que torna vívido, simultâneo e espacializado o objeto representado.

Segundo Da Vinci, o enunciatário vê por meio da pintura tudo de uma só vez, o que dá ao objeto pictural uma velocidade maior de recepção em relação à poesia (p. 15). No século XVII, no entanto, verificou-se que o predomínio da mimesis marginalizava o papel do enunciatário, que, diante do objeto, pouco tinha a contribuir no reconhecimento do objeto. Com o aparecimento da pintura e da arte seiscentista, o enunciatário aproxima-se para efetuar o restabelecimento dos contornos menos nítidos dos objetos.

Boileau introduz na França do século XVII a publicação da obra Sobre o sublime, de Longino [ignora-se a autoria e a data da obra original, provavelmente do século I d. C.; dizem ser de Longino ou Dionísio, ou ainda Dionísio Longino] (In: ARISTÓTELES; HORÁCIO; LONGINO, 2008, p. 70-114). Nessa obra, tanto a sonoridade quanto o estilo da poesia são colocados em jogo como meio de maravilhamento, de comoção estética.

Com Du Bos ([1719] In: LICHTENSTEIN, 2008, v. 7, p. 60-73; cf. também LESSING, 2011, p. 21-29), temos uma ruptura entre a tradição retórica/poética clássica e a construção da abordagem estética do fenômeno artístico. Dá-se, então, uma transformação da tradição 
da retórica poética da Antiguidade. Assim, o docere [ensinar como transmissão de um saber] é marginalizado. Para Du Bos, o poeta deve criar sob o efeito do furor poeticus, sendo o fazer poético um dom natural que tem papel maior que o docere na criação artística. Nesse sentido, como a arte tem finalidade de emocionar, ela não pode ser prontamente reconhecida: na poesia, o fundamental seria a invenção de imagens.

No século XVIII, o tema ut pictura poesis volta a ser objeto de estudo, principalmente com G. E. Lessing (2011), na obra Laocoonte: ou sobre as fronteiras da pintura e da poesia, publicado, na Alemanha, em 1766 (cf. GONÇALVES, 1989, p. 177-184).

Nos capítulos XV e XVI de sua obra, Lessing (2011, p. 191-196) discute:

- "Por que algumas pinturas poéticas desse tipo [pinturas musicais que deixam o pincel ocioso, como a ode de Dryden; representação de objetos que não os visíveis] são inúteis para o pintor e, por outro lado, algumas pinturas propriamente ditas perdem a maior parte de seu efeito quando tratadas pelo poeta?" (p. 191)

- "Que mais precisa um pintor além de objetos visíveis para preencher a sua superfície? Eis o nó da questão. Por mais que os dois objetos [poesia e pintura] enquanto visíveis sejam passíveis de ser propriamente pintados: ainda assim encontra-se uma diferença essencial entre eles, pois aquela é uma ação visível progressiva cujas diferentes partes acontecem uma após a outra na sequência temporal, esta, em contrapartida, é uma ação visível inerte cujas diferentes partes se desenvolvem uma ao lado da outra no espaço." (p. 191-192)

- "Se, portanto, a pintura, devido aos seus signos ou ao meio da sua imitação que ela só pode conectar no espaço, deve renunciar totalmente ao tempo: então ações progressivas não podem, enquanto progressivas, fazer parte dos seus objetos, mas antes ela tem que se contentar com ações uma ao lado da outra ou com meros corpos que sugerem uma ação através das suas posições." (p. 192)

Enquanto a pintura utiliza figuras e cores no espaço, a poesia vale-se de sons articulados linearmente no tempo. Ou seja: 
- Se a pintura se vale para suas imitações de signos diferentes dos da poesia constituídos de formas e cores de ordem espacial, os signos da poesia articulam-se na relação entre forma da expressão e forma do conteúdo no tempo.

- Como os signos são relações arbitrárias e convencionais entre significante (PE) e significado (PC), os signos dispostos uns ao lado dos outros no espaço representam objetos, que se encontram uns ao lado dos outros; já os signos, que se sucedem no tempo, só revelam objetos que se dão sucessivamente.

- Ora, como sabemos, os objetos não se encontram apenas no espaço, mas também no tempo. Eles têm um andamento, mostrando-se diferentemente a cada instante, pois que vão produzindo novas relações na função semiótica entre PE e PC. Nesse caso, a pintura pode mimetizar também ações, mas o faz de modo indireto por meio da figurativização do corpo. A poesia, por sua vez, pode figurativizar o corpo, mas o faz indiretamente através de ações.

Vejamos no quadro 5.1 uma síntese comparativa entre poesia e pintura.

Quadro 5.1 Espacialidade e temporalidade na pintura e na poesia.

\begin{tabular}{|c|c|c|}
\hline Pintura & Espacial & $\begin{array}{l}\text { Através do corpo estático, } \\
\text { figurativiza o movimento }\end{array}$ \\
\hline Poesia & Temporal & $\begin{array}{l}\text { Através do movimento, } \\
\text { figurativiza o corpo estático }\end{array}$ \\
\hline $\begin{array}{l}\text { Poesia aguda de evidência do } \\
\text { plano do conteúdo (PC) }\end{array}$ & $\begin{array}{l}\text { Privilegia o tempo: conta com } \\
\text { intensificadores sensíveis, } \\
\text { adjetivos e advérbios. }\end{array}$ & $\begin{array}{l}\text { Sonetos, Odes etc. } \\
\text { Nesta seção, "Klimt: tentativa } \\
\text { de pintura (com modelo } \\
\text { ausente)", de Haroldo de } \\
\text { Campos. }\end{array}$ \\
\hline $\begin{array}{l}\text { Poesia aguda de evidência do } \\
\text { plano da expressão (PE) }\end{array}$ & $\begin{array}{l}\text { Privilegia o espaço: conta com } \\
\text { intensificadores sensíveis, como } \\
\text { disposição inusitada dos } \\
\text { grafemas no branco da página, } \\
\text { anagramas visuais, } \\
\text { fragmentação de lexemas. A } \\
\text { poesia aqui é sobretudo um } \\
\text { objeto estético de ordem visual. }\end{array}$ & $\begin{array}{l}\text { Poesia visual ("Pilar", "Caminho } \\
\text { novo", "Por Gertrude Stein", de } \\
\text { Affonso Ávila; poesia concreta } \\
\text { etc.). } \\
\text { Nesta seção, "Poema-cauda", } \\
\text { de Lewis-Carroll e "Il pleut", de } \\
\text { Apollinaire. }\end{array}$ \\
\hline
\end{tabular}


O poeta, na construção de seus artifícios, deve ter como princípio a distância da relação imagem produzida/olho que observa o objeto, bem como operar a aplicação de agudeza de PC e de PE adequada a cada gênero, conforme o contrato fiduciário em jogo. Examinando a sátira atribuída a Gregório de Matos, Hansen (1997, p. 185) opõe-se à crítica brasileira que vê nela um fazer mal realizado e estilisticamente "tosco", quando comparada à lírica religiosa e amorosa do poeta. Tanto a sátira gregoriana quanto a de Caviedes regemse pelo contrato fiduciário de um "gênero baixo", que pede um olhar à distância: "nela, o efeito de mal acabamento é programático, como aplicação de uma técnica refinadissimamente precisa de produção de inacabamento" (p. 185).

Não se trata de inabilidade do fazer poético, mas de aptidão para fingir discursivamente a incapacidade para produzir um texto "bem acabado". As imagens do pincel satírico são regidas por escolhas tensivas do exagero: elevada tonicidade de deformação, falta de congruência, intensificação das paixões, desproporção das caricaturas, efeito de monstruosidade da mistura; todas essas operações ferem o princípio de verossimilhança, da representação icástica/mimética. Um tema elevado como a épica, por sua vez, exige traços da ordem da extensidade na caracterização dos personagens e de suas performances. Por isso, trata-se de um objeto mais tênue na intensidade, menos agudo no $\mathrm{PE}$, mais nítido em seus contornos, o que permite aumentar a distância do olhar do enunciatário.

A sátira de Gregório de Matos, por sua vez, pede o encurtamento da distância do olhar do enunciatário para poder ser bem vista. A redução do distanciamento convoca a intensidade, como em "Klimt: tentativa de pintura (modelo ausente)", no "Poema-cauda", em "Il pleut", em "Pilar", que exigem do leitor o cuidado de vê-los variadas vezes para fazer vir à luz o que está obscurecido; fazer mais claro o escuro.

Todavia, entre os poemas agudos há uma diferença a se notar:

1. A poesia aguda de dominância do PC ainda guarda uma relação de distância entre o objeto e sua representação, que se pode verificar pela partícula comparativa como: "poesia é como pintura", mas não é pintura.

2. Na poesia aguda de dominância do $\mathrm{PE}$, no entanto, verificamos redução do distanciamento da relação entre o objeto e sua representação, e o objeto deixa de ser mera representação icástica para ser criação de um objeto que se encaminha para a fluidez: poesia que ser pintura em termos plásticos e não icásticos. 
O poema-cauda de Lewis Carroll dialoga com o ut pictura poesis. Os poemas visuais, no entanto, lançam mão de um artifício novo: as novas elaborações do PE compõem um enunciado visual, que apresenta ao enunciatário a figura retratada, que não quer ser como pintura, mas quer ser pintura, na condição de objeto visual. Nesse sentido, a poesia visual aguda substitui a modéstia do "como" pela pretensão de "ser pintura": no lugar dos adjetivos e dos advérbios (a écfrase do PC), os intensificadores da écfrase do PE são os detalhes sensíveis engendrados pela disposição dos grafemas na página, pela fragmentação das palavras, que colocam diante dos olhos do enunciatário a figura da "chuva", a da "cauda do rato" etc.

O "Poema-cauda", por exemplo, vale-se da plasticidade na distribuição de morfemas e fonemas na página, assim como veremos no caligrama "Chuva" de Apollinaire.

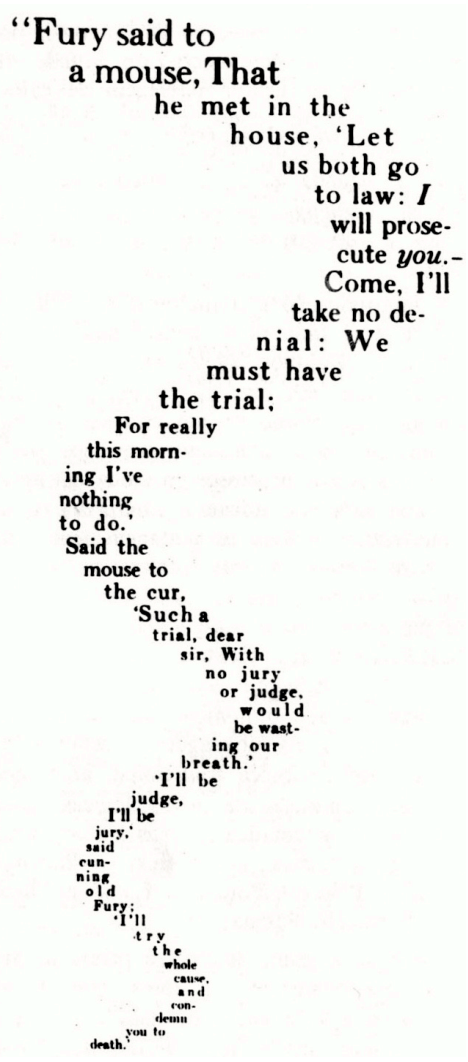

Nota: Tradução de Augusto de Campos -- "Disse o gato/pro rato:/façamos um trato. Pe/rante o/tribunal/eu te de-/nuncia-/rei. Que/a justiça/se faça./Vem, deixa/de negaça,/é preciso,/afinal,/que cum-/pramos/a lei./Disse o/rato pro/gato:/-- Um/julga-/mento/tal, sem/juiz nem/jurado, seria um/disparate/-- O juiz/e o jura/do se-/rei eu,/disse/o ga-/to. e/tu,/ra-/to,/reu/nato,/eu con-/deno/a/meu/pra-/to." 
Em Lewis Carroll, os morfemas fragmentam-se e produzem, com sua distribuição plástica sinuosa, a cauda de um gato e de um rato condensadas, porque estão em diálogo. 0 PC casa-se com o PE na medida em que, no início, a cauda é mais volumosa e vai num movimento de afinação, figurativizando o desaparecimento da voz e do sujeito no corpo do ator "rato":

$1^{\text {a }}$ etapa - PE : categoria de recrudescimento do volume da mancha :: PC : categoria de recrudescimento do poder soberano do gato

$\mathbf{2}^{\mathrm{a}}$ etapa - PE : categoria de minimização do volume da mancha :: PC : categoria de minimização: a subjugação e o desaparecimento do rato

"Il pleut", de Apollinaire:

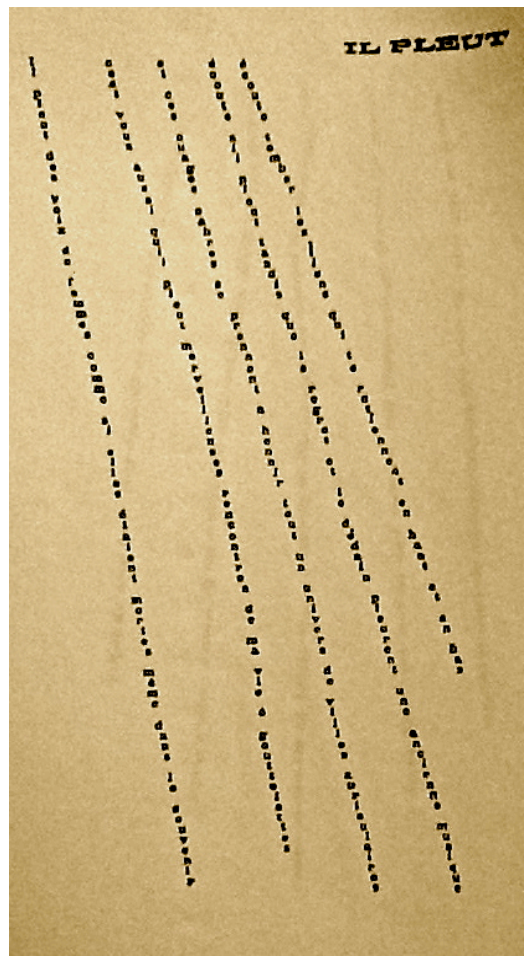

Vejamos o poema de Apollinaire, composto de cinco versos, na tradução de Álvaro Faleiros (2009-2010, p. 12):

Verso 1: "Il pleut des voix de femmes comme si elles étaient mortes même dans le souvenir" [Chovem vozes de mulheres como se estivessem mortas até mesmo na lembrança] 
Verso 2: “c'est vous aussi qu'il pleut merveilleuses rencontres de ma vie, ô gouttelettes" [vocês também chovem maravilhosos encontros de minha vida ó gotículas]

Verso 3: "et ces nuages cabrés se prennent à hennir tout un univers de villes auriculaires" [e estas nuvens revoltas se põem a relinchar todo um universo de vilas auriculares]

Verso 4: "écoute s'il pleut tandis que le regret et le départ pleurent une ancienne musique" [escuta se chove enquanto a mágoa e o desdém choram uma antiga música]

Verso 5: "écoute tomber les liens qui te retiennent en haut et en bas" [escuta caírem os laços que te retêm em cima e em baixo]

As formas gráficas não devem ser vistas nem como um meio transparente ou opaco, mas como um PE que se homologa com um PC. Por isso, o caligrama não se constitui apenas em um desenho. Os versos de Apollinaire representam o percurso de uma chuva que cai: são dispostos inclinadamente. Cada grafema figurativiza uma gotícula da chuva que cai continuamente. Trata-se de um fazer continuativo: "o cair da chuva". Visualmente, o primeiro verso é plasticamente uma mancha (linha preta) mais afastada das outras linhas pretas (os outros quatro versos). Essa linha inicial é o ponto de partida de um "chover" que se origina de cima para baixo. No poema original, o fonema vibrante /r/, cabré, prennent, hennir, univers, auriculaires, configura, no PE, a materialidade sonora do desaguar da água, e, no PC, notamos que as "nuvens revoltas se põem a relinchar todo um universo de vilas auriculares".

Finalmente, o enunciador convida o enunciatário a ouvir o cair da chuva (isotopia pragmática - chuva que está fora do sujeito); depois, a ouvir a vida que pulsa na cidade (vilas), com suas paixões:

- Isotopia passional que marca os estados de alma - chuva que cai dentro do sujeito no quarto verso, "escuta se chove enquanto a mágoa e o desdém choram uma antiga música".

\begin{tabular}{|l|l|}
\hline $\begin{array}{l}1^{\text {a }} \text { isotopia da água - chuva externa } \\
\text { ao sujeito }\end{array}$ & $\begin{array}{l}2^{\text {a }} \text { isotopia do choro - chuva interna } \\
\text { ao sujeito }\end{array}$ \\
\hline "escuta se chove enquanto" & $\begin{array}{l}\text { "a mágoa e o desdém choram uma } \\
\text { antiga música" }\end{array}$ \\
\hline
\end{tabular}

Como podemos verificar, não se trata tão somente da reprodução de um desenho, da performance de uma chuva que cai. Existe uma tensão entre o PE e o PC. No PE, a disposição 
dos versos, inclinados na vertical, acelera o sentido visual da chuva caindo emissivamente. No PC, verificamos o movimento contrário: há uma desaceleração remissiva no reconhecimento das dores da memória, do passado, que provocam seu estado de alma no presente. Temos então uma força de sentido no poema, que vai do alto para baixo, assim como é o movimento das paixões humanas: são altos e baixos que povoam a alma do sujeito, que chora como a chuva. Assistimos, pois, à acumulação intensa de emoções armazenadas na memória, que é potencializada.

\subsection{1 “Klimt: tentativa de pintura”, de Haroldo de Campos}

É com base nos conceitos de poesia como pintura (ut pictura poesis) que podemos verificar a elevada intensidade não só dos caligramas, como também dos poemas agudos do final do século XX, como é o caso "Klimt: tentativa de pintura (com modelo ausente)", de Haroldo de Campos (1985, p. 37; In: DANIEL, 2004a, p. 75). Além disso, como vimos, é o conceito horaciano que nos permite a aproximação ou o distanciamento do objeto estético, que é regido pela proporção: deverá ser visto de perto ou de longe? No caso do poema seguinte, qualquer distanciamento desproporcional poderá levar o enunciatário a perder as orientações do sentido:

\section{Klimt: tentativa de pintura}

(com modelo ausente)

1.

lourovioleta: um monstro uma

figura em outro cin

zelada das unhas à raiz (crin

a) metalizada dos cabelos pedi

curada em roxo um traço bis

(não de bistre) um risco de li

lás as pálpebras dobradas

como mariposas (como mari

posas) sim pedicurada em roxo

e as pontiagudas unhas só li

lás da mesma cor do pij

ama uma figura um monstro

sim (quimono): klimt.

2.

e sob isto tudo como sob

uma panóplia (armada) um pavilhão

de pedraria (um baldaquino) dra

pejantes panos (um azul turquinho) 
(caravelas ao largo) bandeiras de um

(impossível) impromptu ultra

(biombo grand'aberto gonfalão panóplia)

violeta

o corpo (a ci

catriz li

lás)

o branco albino se diria

o corpo um cor

po de me

nina

5 jul. 1984

O enunciador apresenta-nos uma imagem plástica à semelhança das pinceladas de Klimt. O poema é formado de duas estrofes irregulares, segmentadas no próprio enunciado pelo número 1 e pelo número 2: a primeira, com treze versos; a segunda, com quinze versos.

A primeira estrofe constitui-se em um bloco de versos sem métrica regular, cuja distribuição na página chama a atenção pelas fragmentações inesperadas, por quatro expressões entre parênteses e término com ponto final. A segunda estrofe é formada de dois blocos: o primeiro não apresenta quebras inesperadas de palavras, mas contempla um conjunto de rupturas parentéticas, que impedem a fluência da leitura (seis expressões entre parênteses). A segunda parte da segunda estrofe é a que se apresenta mais fluida, mais dilacerada, suscitando certo maravilhamento.

A instância da enunciação recorta no título tratar-se seu poema de uma "tentativa de pintura", o que nos leva dialogar com o enunciado "ut pictura poesis", constante de Arte Poética de Horácio (Epistula ad Pisones), já citado, em que há pintura que cativa pela proximidade e outra pela distância. A primeira é a da penumbra, da fluidez; a segunda, da clareza, da nitidez.

Nos objetos mais nítidos, os detalhes estariam discretizados com tal clareza inteligível que pouco sobrevir proporcionaria ao enunciatário. O poema de Haroldo de Campos prefere a penumbra e requer uma presença "mais perto". O desmanche de contornos definidos faz dele o que chamamos de objeto fluido, que pede um deleite delongado. Também não é um objeto para ser visto "uma vez", mas "dez vezes", diferentemente, pois, de objetos marcados por mais nitidez. 
Em "Klimt: tentativa de pintura", não há propriamente uma figurativização do retrato de Klimt ou de uma única obra do pintor. O que vemos no poema é a tentativa de pintar com palavras a arte decorativa e detalhista de Klimt. Entre esses pormenores, destacam-se:

- A fragmentação lexical, que produz o mesmo efeito que as fragmentações dos corpos em Klimt.

- O uso abundante de expressões entre parênteses, atraindo o olhar do enunciatário para o detalhe interno (é o ver "de perto" de que fala Horácio), como se estivéssemos diante de uma obra do pintor e nos ocupássemos de suas inúmeras peças singulares, que produzem efeito de puzzle; nesse caso, nota-se a estrutura de organização geométrica da tela.

- Desmanche e singularização de algumas sílabas no final do verso e começo do verso seguinte.

Outra característica desse poeta-pintor reside na apurada escolha paradigmática; em geral, são palavras de uso raro, que produzem um efeito de um artista em busca de elementos de requinte vívido, mais extasiantes para o objeto: "lourovioleta", "cinzelada", "metalizada", "pedicurada”, "bistre", "pontiaguda”, "quimono", "panóplia”, "baldaquino", "drapejantes", "turquino", "gonfalão". Além disso, a tessitura verbal compreende ainda o uso de uma expressão latina impromptu ultra, que significa "ultra improviso", produzindo um efeito de mestria técnica da ordem do sobrevir, da concessão, do surpreendente, portanto.

As figuras discursivas haroldianas vão se misturando como as cores, apresentando-se como uma mancha poética. Essas estratégias visuais agudas visam produzir no PC as qualidades plásticas de Klimt que revelam uma arte vividamente decorativa. Assim como o pintor mistura suas tintas na paleta, vemos em "lourovioleta" uma mistura de cores que se condensam, provocando com palavras uma imagem semelhante à das escolhas pictóricas de Klimt.

Logo no primeiro verso, um lexema chama a atenção pela novidade da forma, lourovioleta, sem hífen. Outros impactos advêm, como já dissemos, da fragmentação inesperada dos vocábulos, que não utilizam hífen para a quebra, nem são separados silabicamente da forma tradicional: 


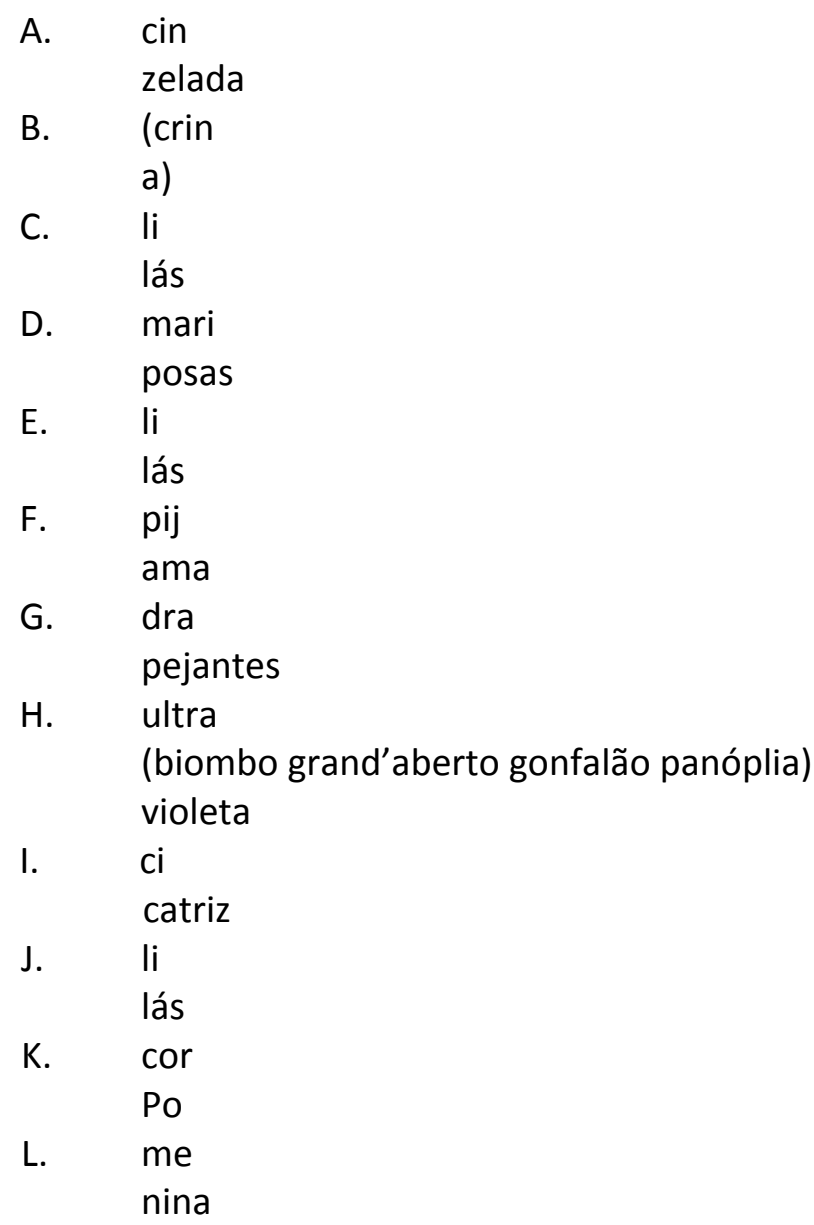

Todos esses artifícios revelam um enunciador que se ocupa de refrear as formas, delongando a conservação estética e retardando o reconhecimento. 0 mesmo maravilhamento se dá por meio do artifício da enumeração, que se acumula num processo de somação intensa, impedindo a manutenção dos contornos.

Vejamos alguns exemplos de enumeração:

- "raiz (crin / a) metalizada dos cabelos" que se junta a "pedi / curada em roxo". Estamos diante de um puzzle: o enunciado revela-se por processo de simultaneidade e de acumulação: a cor dos cabelos ("metalizada") mais a cor das unhas ("roxo"). Nesse caso, o esmaecimento dos contornos convoca o enunciatário a montar o quebra-cabeça sintagmático.

- "um pavilhão / de pedraria" que se junta a "dra / pejantes panos". Essa enumeração engendra o efeito de simultaneidade, semelhante à operação dos elementos na pintura. Trata-se de uma tentativa de espacialização do 
objeto poético, poesia como pintura; no caso, pintura com palavras para ver de perto.

- "como mariposas (como mari / posas)": funciona também por acumulação, acentuando as imagens pelo uso de reiteração de "como mariposas"; a palavra "monstro" do primeiro verso repete-se no penúltimo verso da primeira estrofe, assim como ocorre repetição em: "o corpo um cor / po"; a palavra "violeta" aparece nas suas várias nuanças em gradação da cifra tênue à cifra vívida: lilás $(3 \mathrm{x})$, violeta $(2 \mathrm{x})$, azul turquino, roxo. Nessa acumulação de tons de roxo, verificamos não só aproximação do texto poético que se quer objeto pictórico, como também uma aproximação das escolhas de cores klimtinianas.

O enunciador surpreende-nos por meio da figura de um monstro, que diz pintar e que, de fato, vai se configurando à frente do enunciatário; no final do poema, esse monstro cede lugar, paradoxalmente, a uma figura frágil e delicada da última estrofe:

o corpo (a ci

catriz li

lás)

o branco albino se diria

o corpo um cor

po de me

nina (destaques nossos)

Considerando que o poema-tela faz-se com modelo ausente, podemos deduzir que o enunciador dialoga com várias telas de Klimt, como:

- Palas Atena (1898 - ver figura 5.1): na tela, sob o rosto da deusa aparece em seu peito a figura de uma carranca, mostrando a língua e arregalando os olhos; além disso, uma peça de sua veste aparece toda dourada. Aqui, há um diálogo com o segundo verso do poema de Haroldo de Campos, que diz: "figura em ouro cin/zelada".

- Retrato de Emile Flöge (1902 - ver figura 5.2): tela em homenagem à sua companheira de vida; notamos a riqueza dos detalhes do tecido da vestimenta da modelo, ator do enunciado. Ela era dona de uma boutique de alta costura; Klimt desenhava os tecidos de seu ateliê. Talvez aí o enunciador 
do poema tenha se apoiado para a reiteração de tonalidades de roxo (lilás, violeta, azul turquino): "pedi/curada em roxo um traço bis"/ "pejantes panos (um azul turquinho)". A aproximação do poema em relação às telas de Klimt busca criar com palavras o mesmo efeito da beleza plástica da pintura.

- O Friso Beethoven (1902 - ver figuras 5.3 e 5.4) divide-se em duas partes: (a) A aspiração à felicidade e (b) As forças inimigas. Na primeira parte, vemos um guerreiro vestido com sua armadura: "[...] gonfalão panóplia [armadura]". Em As forças inimigas, notamos um pormenor, a figura de um macaco monstruoso com cauda de serpente e asas: "[...] uma figura um monstro".

- Judith II (Salome) [1909 - ver figura 5.5]: no enunciado da tela, misturam-se as figuras de Salomé e Judith, aglutinadas no mesmo espaço discursivo. O conhecimento enciclopédico leva-nos a reconhecer duas figuras bíblicas, Judith e Salomé, que não se misturariam por serem antagônicas; nesse caso, temos uma mistura aguda. Enquanto a sedutora Salomé (63 a.C.) revela um estado de alma perverso, a sedutora Judith (II a.C.) personifica um estado de alma de coragem. Herodes Antipas, depois de ver a sobrinha Salomé dançar, promete satisfazer-Ihe um desejo. Ela, manipulada por sua mãe, Herodias, pede a cabeça de João Batista, o qual estava preso no palácio por divergir da união de Herodes Antipas com Herodias. Enfim, João Batista é degolado. Judith, por sua vez, é uma viúva corajosa, que, para salvar seu povo oprimido, vai ao acampamento do exército inimigo para, com sua beleza, seduzir Holofernes, que embriagado tem sua cabeça cortada por Judith. O título da tela Judith II (Salome) de Klimt parece influenciar o enunciador poético, que se apoia nessa agudeza de condensação de duas figuras femininas antitéticas, ambas sedutoras ("pontiagudas unhas"), mas com objetivos diversos.

- Mäda Primavesi (1912 - ver figura 5.6): temos a figura de uma menina frágil e delicada, que talvez pinte a figura da "menina" do fechamento do poema. Vejamos as telas de Klimt nas figuras 5.1 a 5.6: 


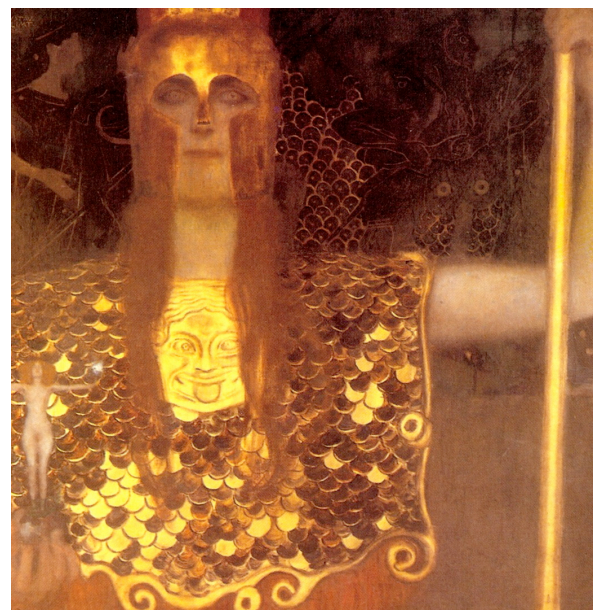

Figura 5.1 Palas Atena

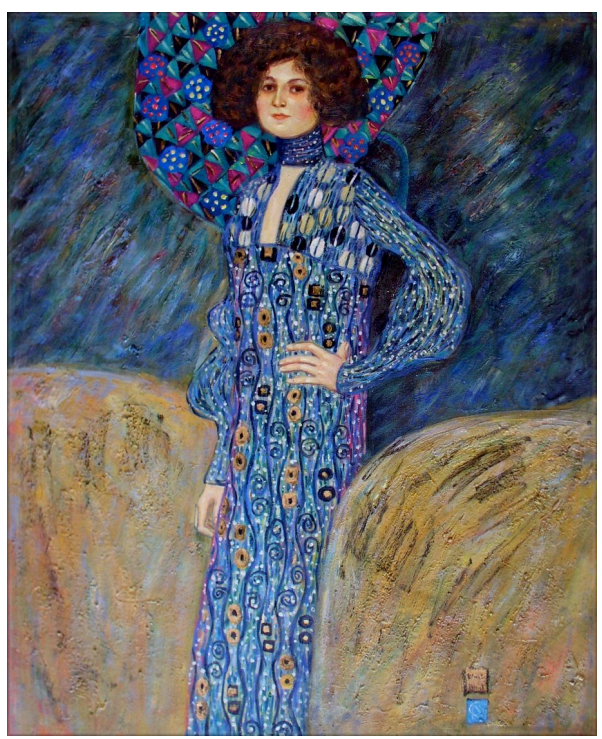

Figura 5.2 Retrato de Emilie Flöge

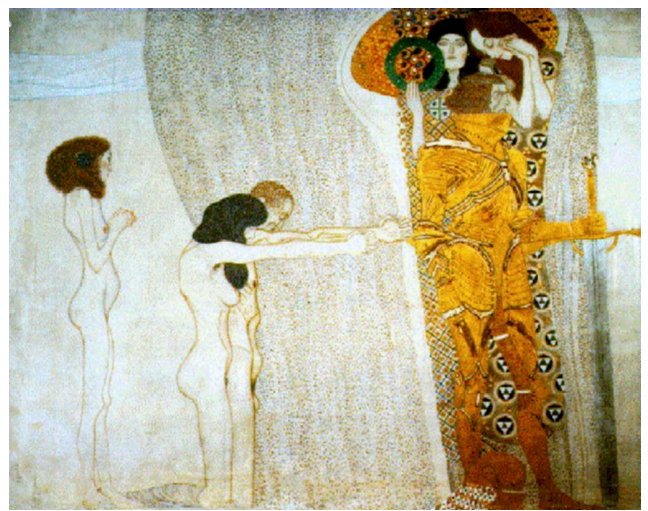

Figura 5.3 Friso Beethoven: a aspiração à felicidade. 


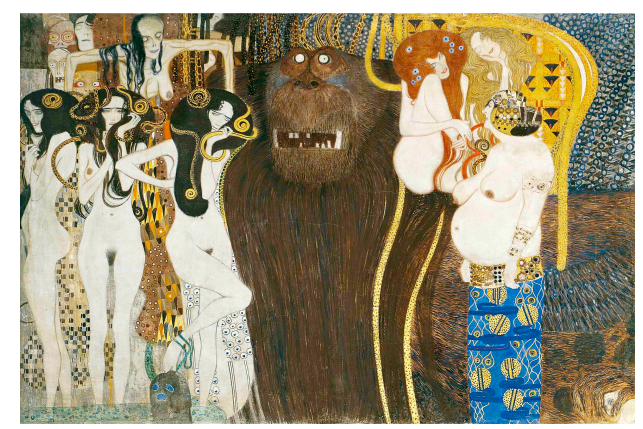

Figura 5.4 Friso Beethoven: as forças inimigas.

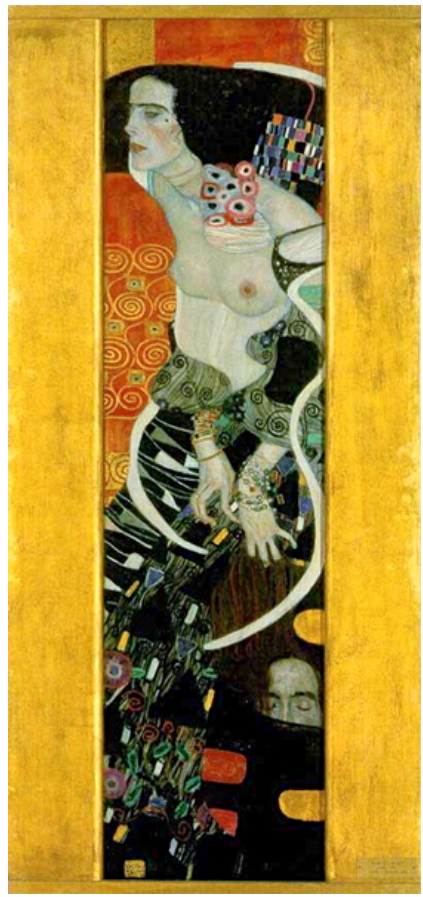

Figura 5.5 Judith II (Salome).

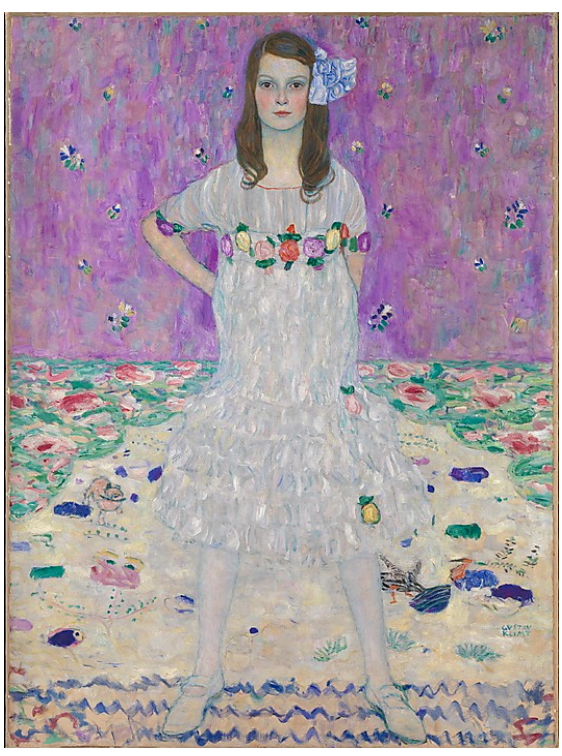

Figura 5.6 Mäda Primavesi. 
Sem pretender esgotar todas as relações entre o poema de Haroldo de Campos e a obra de Klimt, podemos verificar que "Klimt: tentativa de pintura (modelo ausente)" faz-se pela somação de particularidades do processo klimtiano. O poema revela-nos um passeio pelas obras do artista austríaco, bem como os procedimentos plásticos do pintor.

A incidência de fonemas oclusivos em $/ \mathrm{p} /$ e $/ \mathrm{m} /$, juntamente com as escolhas de fonemas nasais que levam ao fechamento da produção sonora, contribuem para o entrave da elocução no poema, formando um som "estranho" aos ouvidos; esse estranhamento ocorre também no PC pela escolha dos adjetivos e substantivos raros para a formação da figura do monstro no primeiro e no penúltimo versos da primeira estrofe.

Três leituras podemos fazer desse monstro:

- $\mathrm{O}$ enunciador não se sente competente como o pintor homenageado e, por isso, acredita que a "tela verbal" construída é um monstro.

- O monstro, que aparece no poema, dialoga com o que aparece na tela da figura 5.4 .

- O monstro, segundo a isotopia de grandioso, é Klimt (versos 12 e 13: "ama uma figura um monstro / sim (quimono): klimt."; e, nesse caso, o enunciador revela a figura discursiva do ator "Klimt vestido de quimono" (figura 5.7):

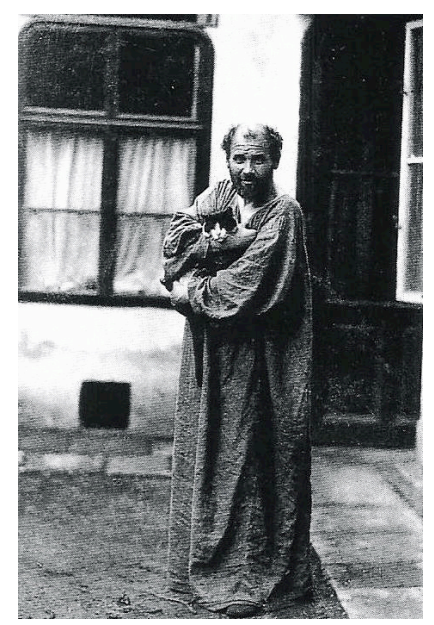

Figura 5.7 Klimt de quimono e seu gato.

Na segunda estrofe, o enunciador lança mão de um conjunto diversificado de imagens que se ombreiam à pintura colorida de Klimt. Essa escolha, apoiada no método concessivo, da égide do improvisado, "impromptu", revela um esforço verbal para reproduzir cores acentuadas e vívidas: "ultravioleta", "pavilhão de pedraria", "drapejantes 
panos", "azul turquino", "caravelas ao largo", "bandeiras de um (impossível) impromptu ultravioleta", "gonfalão panóplia".

A habilidade poética deságua na última parte da segunda estrofe, marcada pela delicadeza e pelo inesperado do "pincel linguístico" que nos apresenta um sobrevir: desaparece a figura do monstro e emerge a figura do corpo de uma menina, que ganha maior delicadeza ainda ao ser reduzida a "nina" no último verso.

Pelo jogo tensivo, nota-se que na primeira estrofe prevalecem simultaneamente valores de intensidade e de extensidade. As figuras "monstro, unhas, cabelos, pálpebras, mariposa, pijama, quimono, monstro, Klimt", pela enumeração, originam extensidade e, pela repetição, intensidade.

As frases nominais do poema elidem o verbo, que está latente na frase. Por exemplo: em "lourovioleta: um monstro uma figura", é possível perfeitamente perceber a elipse do verbo "ver": "vejo um lourovioleta: um monstro uma figura". Pela subtração dos verbos, o enunciado distancia-se da extensidade do verbo e encaminha-se para a intensidade da "tentativa de pintura". Sem os verbos, as imagens fixam-se, como num quadro. Na segunda estrofe, igualmente, é possível depreender a elipse verbal: "e sob isto tudo como sob / uma panóplia (armada) um pavilhão" = "e sob isto tudo observo também como sob uma panóplia armada um pavilhão". E, finalmente, em "o corpo (a ci / cicatriz li / lás)" = "noto ainda o corpo a cicatriz lilás".

A tela poética de Haroldo de Campos encena, portanto, uma tensão entre intensidade e extensidade:

- Da ordem da extensidade: elenco de figuras panóplia, pavilhão, pedraria, baldaquino, panos, caravelas, bandeiras, biombo, panóplia (duas vezes).

- Da ordem da intensidade: o corpo da menina, que é tonificado e evidenciado no PE pela redução do espaço gráfico do verso e de seu isolamento, até restar apenas "menina" e, em seguida, mais vívido ainda, "nina".

E assim vão se sucedendo as escolhas de valores de ruptura nas duas primeiras estrofes. Rupturas que se mostram visualmente nos morfemas apresentados entre parênteses na primeira estrofe: (crina), (não de bistre), (como mariposas), (quimono) e na primeira parte da segunda estrofe: (armada), (um baldaquino), (um azul turquinho), (caravelas ao largo), (impossível), (biombo grand'aberto gonfalão panóplia). 


\section{Especificando:}

$1^{\text {a }}$ estrofe: só contamos com nominalizações (cinzelada, metalizada, pedicurada, dobradas, pedicurada novamente), cuja característica é descritiva e, por descrever, paralisa as ações como numa pintura. O discurso aqui é remissivo: temos a espera (tentativa) da formação de um quadro poético, construído pela intertextualidade com a obra de Klimt.

$2^{\mathrm{a}}$ estrofe - primeira parte: novamente, temos a ausência de verbos, imperando as nominalizações, que contribuem para a realização de novas pinceladas do enunciador verbal. Prevalecem valores de remissividade formados pela incursão na memória sobre as telas de Klimt.

$2^{a}$ estrofe - segunda parte: finalmente, a remissividade encaminha-se para a emissividade. Aqui, temos o fazer artístico finalizado por meio do único verbo de todo o poema: "se diria". A modalização "se diria" simula atenuar a afirmação do enunciador que manifesta cautela diante de seu fazer quando o apresenta ao enunciatário: "se diria" "corpo de menina". Esse estado de alma de modéstia ajusta-se ao que temos afirmado nesta tese: os objetos agudos do século XX preferem a fluidez à nitidez.

Este último segmento da segunda estrofe aparece afastado da margem esquerda, deslocamento espacial que se configura pela aproximação do objeto. Dessa forma, enquanto na primeira e na segunda estrofes (primeira parte) temos uma enunciação enunciva de valores de afastamento do sujeito da enunciação -- enunciador e enunciatário estão afastados --, neste último segmento notamos uma maior acentuação, cuja aproximação ao objeto produz um efeito de delicadeza tal como a da obra de Klimt.

E a surpresa maior está dentro da expressão "corpo de menina"; nela, está evidenciada e englobada a palavra COR, que é, entre outras tantas, uma das escolhas paradigmáticas do pintor. Vejamos como se dá o anagrama:

$\begin{array}{ll}\text { Antepenúltimo verso: } & \text { o corpo um cor } \\ \text { Penúltimo verso: } & \text { po de me } \\ \text { Último verso: } & \text { nina }\end{array}$

Tradicionalmente, Klimt escolhia cores douradas, figuras de mulheres, figuras eróticas. Em 1909, ele vai a Paris e entra em contato com as obras de Toulouse-Lautrec e com o fauvismo, cuja característica é a serenidade e a pureza. A partir de então, Klimt, em vez das escolhas geométricas e das cores douradas suntuosas, passa a valorizar enunciados 
pictóricos menos acentuados de cores mais fracas, como podemos verificar no quadro Mäda Primavesi de 1912. O pintor, que viria a morrer seis anos depois de pintar esse quadro, nunca havia pintado meninas, manifestando um enunciador que, depois de passar por vários estágios de competência, adota valores mais tênues: cores pálidas no lugar do dourado forte, figuras destituídas de valores exuberantes. A estrofe final do poema manifesta essa mesma simplicidade da fase final de Klimt. Acentua-se o PE gradativamente na medida em que o metro vai perdendo sílabas $(8,4,2,1)$; atenua-se, por sua vez, o PC por meio da subtração da primeira sílaba do lexema menina.

o branco albino se diria

o corpo um cor

po de me

nina

Em suma, pudemos verificar no poema de Haroldo de Campos a oscilação entre valores de extensidade e valores de intensidade. Igual tensão dá-se entre poesia e pintura:

- A poesia precisa da acumulação de figuras discursivas para pintar um quadro com palavras, ou seja, ela precisa da extensidade da enumeração e da intensidade da repetição de detalhes para ser tão intensa como a pintura.

- A pintura vale-se da intensidade e da sensibilidade, sobretudo a da escolha, e da operação das cores para simular a extensidade da poesia.

\subsection{2 "Anatomia do gol", de Haroldo de Campos}

Além de "Klimt: tentativa de pintura", ao final de a "A educação dos cinco sentidos", Haroldo de Campos (1985, p. 89-105) publica seis "metapinturas" e um "meta-retrato", homenageando Mary Vieira, Antonio Dias, Alfredo Volpi, Claudio Tozzi, Regina Silveira, Mário Schenberg. Nesses textos, ele visita a obra dos pintores citados e delas recolhe traços para compor seus poemas. Por exemplo:

1. Alfredo Volpi: traz para a poesia as cores do pintor. Inicia a poesia com "um / rouxinegro / canta no azul- / volpi"; na segunda estrofe, chama atenção para o triângulo e para o branco, elementos da composição volpiana. Na terceira, "bandeira branca" intertextualiza uma característica marcante de Volpi, as bandeirinhas. 


\section{Nomeação do azul-volpi}

um
rouxinegro
canta
no azul-
volpi
uma
asa
violeta
a escanteio
triângula
no
branco
volpinveste
um vermelho
de vermelhos
e iça a
bandeira
branca
roságua
o rosa
e abre
para este
canto
o rouxinegro
azula
ogivando-se
e
q
quadrosquadros
o s


2. Claudio Tozzi: traz para sua poesia a pigmentação das cores e a transparência da luz:

\section{Cláudio Tozzi: cor pigmento luz}
a cor
pensar a cor
a cor da cor
se transparenta
e é luz
pensar a luz
a luz da luz
se fragmenta
e é cor
a palavra cor
na cor
a palavra luz
na luz
o pó
a poeira
o pigmento
luz em pó
cor em pó
cor-luz
luz-cor
o íris no íris
o desarcoíris
no cinza
no quase
no
branco
. .
jaula negra
onde a cor
se enquadra
onde a cor
quase-cor
no corpo a cor
da cor
se exquadra 


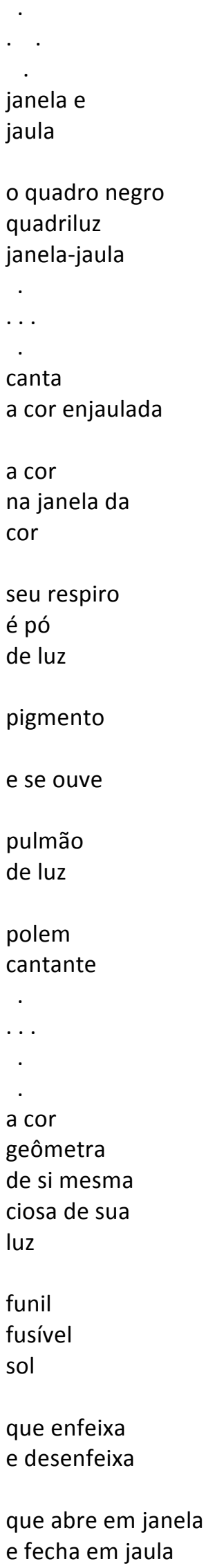




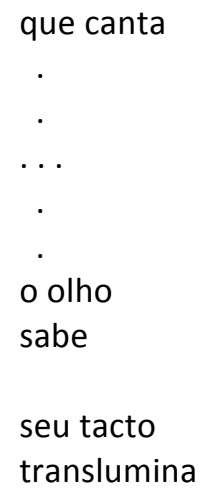

Entre esses textos, destaca-se o poema "Anatomia do gol" (CAMPOS, 1985, p. 100103), em homenagem a Antonio Lizárraga, escultor, pintor e artista gráfico argentino, radicado em São Paulo, em 1956, onde atua até 1967 no jornal O Estado de S. Paulo como ilustrador do caderno "Suplemento Literário". Seu fazer artístico é de construção formalista, tanto na pintura como na escultura, dedicando-se também à composição geométrica minimalista. Participou de quatro bienais (IX a XII) internacionais de São Paulo.

A partir de 1970, sua criação concentra-se em gravuras, esculturas, atuando no espaço urbano da cidade por meio de instalações. O enunciado poético, além de revelar-se homenagem ao artista Lizárraga, contempla o ut pictura poesis: "um jogo entre pintura e poema". Ao final do poema, Haroldo de Campos apresenta-nos a ilustração do "Quadrado mágico", de Lizárraga.

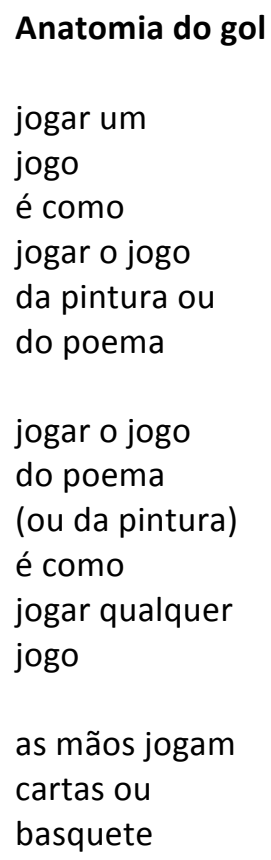


na

mesa ou na

quadra

os pés jogam

bola

no

campo ou na

praia

mas quem joga

mesmo é o

cérebro

suas bossas e

cerebelo

seus lobos:

um jogo de luz

sem peso

que faz passar por

um triz

por um cabelo

ou acertar

em cheio:

mão de baralho

plena

ou pé no tiro

certeiro

antonio

lizárraga joga

um jogo de

cartas marcadas

um jogo onde tudo joga

e tudo se faz jogada

um futebol de papel

com peças de diamante triângulos

setas

arestas

acuando o círculo

migrante

retranca aberta

dábliu-eme

pelo meio

ferrolho suíço

casados contra solteiros

ponta recuado

overlapping

pelas pontas

triangulagem

carrossel holandês

quadrado mágico 
chegados nesse quadrado

a gente para e medita:

se o círculo ficou acuado

se pensa como o estagirita

ou se ainda foge $\rightarrow$

evasivo $\rightarrow$

perseguido por sagitas $\rightarrow$

o que se vê é o centro:

um triângulo $\Delta$ uma tríade

(como charles sanders peirce

gostava de ver com a mente)

toda de branco o habita

é o uno posto no trino?

é o primeiro

concluso no seu

terceiro?

são as de Pitágoras

últimas categorias

primevas?

não sei não sabemos

por mais

que a gente dê tratos

à bola

ninguém atinge essa

meta (sol)

onde se exaure a pintura

e o poema:

sede secreta

(gol)
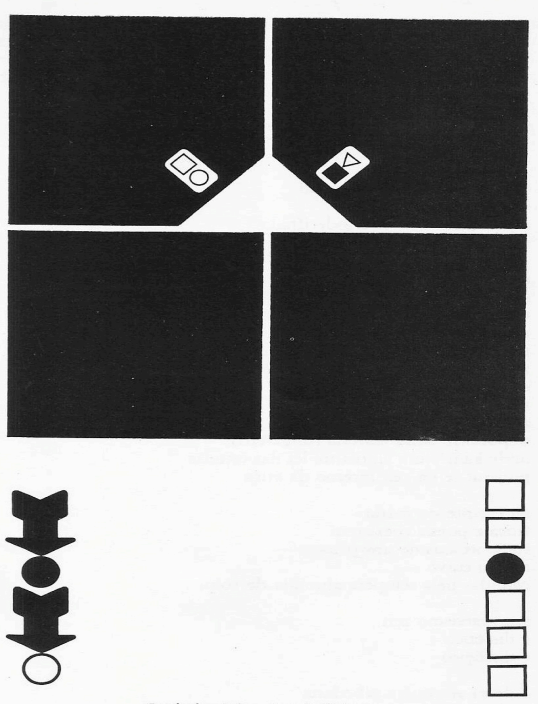
Façamos agora um exercício de leitura:

1. jogar um jogo é como jogar o jogo da pintura ou do poema

2. jogar o jogo do poema (ou da pintura) é como jogar qualquer jogo

3. as mãos jogam cartas ou basquete na mesa ou na quadra

4. os pés jogam bola no campo ou na praia

5. mas quem joga mesmo é o cérebro suas bossas e cerebelo seus lobos:

6. um jogo de luz sem peso que faz passar por um triz por um cabelo ou acertar em cheio:

7. mão de baralho plena ou pé no tiro certeiro

8. antonio lizárraga joga um jogo de cartas marcadas

9. um jogo onde tudo joga e tudo se faz jogada

10. um futebol de papel com peças de diamante

11. triângulos setas arestas acuando o círculo migrante retranca aberta dábliueme pelo meio ferrolho suíço casados contra solteiros ponta recuado overlapping pelas pontas triangulagem carrossel holandês quadrado mágico

12. chegados nesse quadrado a gente para e medita:

13. se o círculo ficou acuado se pensa como o estagirita ou se ainda foge $\rightarrow$ evasivo $\rightarrow$ perseguido por sagitas $\rightarrow$ o que se vê é o centro:

14. um triângulo $\Delta$ uma tríade (como charles sanders peirce gostava de ver com a mente) toda de branco o habita é o uno posto no trino? é o primeiro concluso no seu terceiro? são as de Pitágoras últimas categorias primevas?

15. não sei não sabemos

16. por mais que a gente dê tratos à bola ninguém atinge essa meta (sol) onde se exaure a pintura e o poema: sede secreta (gol) 
O poema "Anatomia do gol" foi publicado inicialmente no álbum Anatomia do gol, de Antonio Lizárraga, que foi lançado na abertura da exposição "Lizárraga/Presente", em dezembro de 1985 (FABRIS, 2000, p. 36 ss). O material foi organizado por Marcelo Tápia e editado no ano de 1984 por Massao Ohno/Timbre Editores. A obra é constituída de onze lâminas do artista plástico, retrospectiva do trabalho gráfico do artista, acompanhadas de um poema de Haroldo de Campos.

As lâminas apresentam graficamente várias táticas de um jogo de futebol. A sétima estrofe do enunciado do poema de Haroldo de Campos trata do conjunto de pranchas de Lizárraga: "retranca aberta", "dábliu-eme", "pelo meio", "ferrolho suíço", "casados contra solteiros", "ponta recuado", "overlapping", "pelas pontas", "triangulagem", "carrossel holandês". "Quadrado mágico", porém, só consta do livro A educação dos cinco sentidos (cf. SILVEIRA, 1994, p. 50-63).

Na figura 5.8, apresentamos as lâminas de Lizárraga citadas no poema:
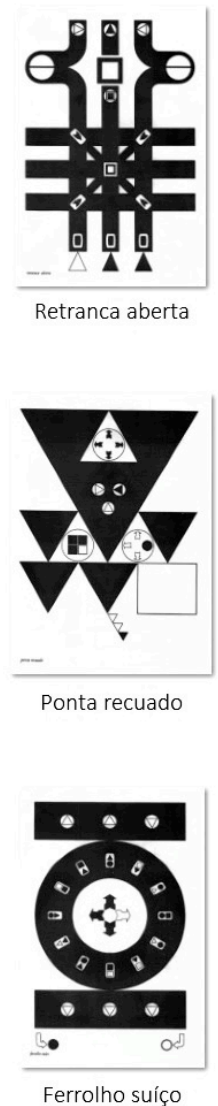
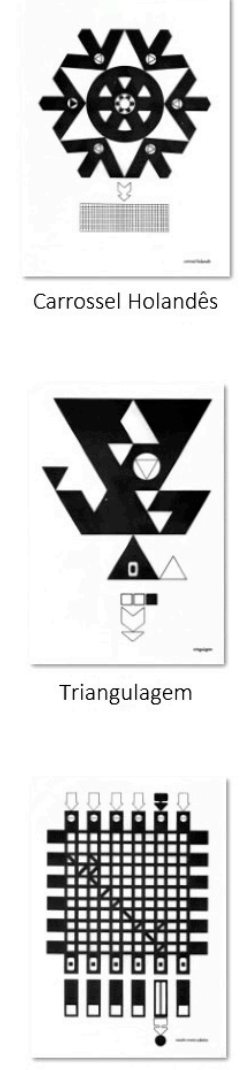

Casados contra solteiros
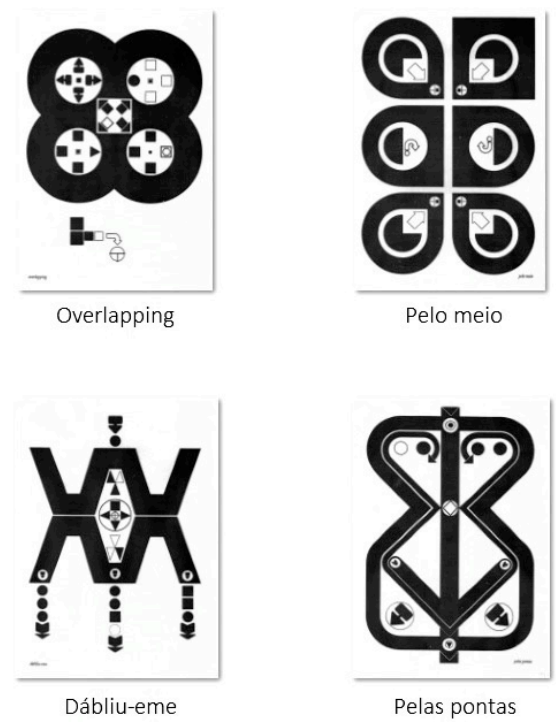

Figura 5.8 Lâminas de Antonio Lizárraga, objeto da sétima estrofe do poema "Anatomia do gol", de Haroldo de Campos. 
"Anatomia do gol" apresenta, como diz o nome, uma dissecação, desconstrução analítica do "gol poético" no jogo com a pintura.

Causa-nos estranhamento a utilização dessa palavra em texto que não figurativize "corpo de ser vivo". Ao mesmo tempo, porém, que provoca impacto, predispõe-nos a ver o texto como se estivéssemos em uma bancada de laboratório prestes a realizar um trabalho de retaliação analítica.

Organizado como fizemos em nosso exercício de leitura, notamos um enunciador que se interessa por apresentar em forma de versos o que poderia muito bem ser exposto em forma estendida. Estamos diante de um poema de métrica irregular, distribuído em 12 estrofes irregulares, em que não há preocupação com rima externa.

A distribuição dos versos simula figurativizar no PE a anatomia do poema. Nesse sentido, o enunciatário pode notar um número muito grande de versos constituídos de uma só palavra, ocupando um mínimo espaço na página, como ocorre com as duas preposições "na" do verso 16 e "no" do verso 21. Simulam também corte de bisturi o espaço dentro do verso 84 , os símbolos flechas ( $3 x$ nos versos $69,70,71$ )/triângulo (verso 73) e a utilização de parênteses no verso 9, versos 74-75, verso 89, verso 93. Em todos esses casos, dá-se a presença da simulação de um tratadista da anatomia do objeto estendido à sua frente.

Tomando o quadrado mágico de Antonio Lizárraga, reproduzido no final do poema, observamos a contraposição de figuras geométricas e flechas totalmente escurecidas (preto) e outras esvaziadas (branco da página). Nesse caso, podemos observar o fundo preto conduzindo ao negativo (branco), que é a chave do triângulo, como se dissesse que a explicitação de um objeto parte de seu segredo. Se eliminamos a densidade do preto, eliminamos também a composição branca do triângulo. É um paradoxo, pois a destruição do segredo elimina o objeto-chave.

Assim, as linhas que seccionam o quadrado mágico também mostram no PC O percurso dos cortes, simulando um estudo de "anatomia".

O poema, seguindo nossa recomposição de leitura, pode ser segmentado (dissecado) em cinco segmentos (ver as chaves do exercício proposto, à direita do poema): 
Segmento 1 - De 1 a 4;

Segmento 2 - De 5 a 7;

Segmento 3 - De 8 a 11;

Segmento 4 - De 12 a 14;

Segmento 5 - De 15 a 16.

Considerando o ritmo, verificamos sílabas fortes e fracas em todo o texto. Nota-se uma completa irregularidade de andamento, pois que a sílaba forte ora avança, ora recua, figurativizando no PC a presença de dissonância de uma partida de futebol, em que o movimento dos jogadores não é como o de um balé clássico. Se pensarmos numa partida de baralho, figura do enunciado, em que o ritmo das jogadas é irregular, o sons produzidos e o andamento das jogadas não são harmônicos; também no poema de Haroldo de Campos, registra-se a mesma dissonância de sons. No basquete e no futebol, figuras do poema, as jogadas, da mesma forma, funcionam a cada momento segundo um andamento inesperado: ora rompante, ora sossegado:

jogar um jogo é como jogar o jogo da pintura ou do poema jogar o jogo do poema (ou da pintura) é como jogar qualquer jogo as mãos jogam cartas ou basquete na mesa ou na quadra os pés jogam bola no campo ou na praia

Em relação à rima, também se verifica uma despreocupação com a rima externa, embora se possa perceber certa harmonia dada pela rima interna. Assim é que jogar faz parelha com jogar; pintura com pintura; jogam com jogam; ponta com pontas. Em alguns casos, a rima interna sobressai, como em:

"cheio/certeiro";

"diamante/migrante";

"meio/solteiros";

"quadrado/acuado";

"estagirita/sagitas/habita";

"primeiro/terceiro";

“(sol)/(gol)". 
As rimas externas parecem não coadunar-se com o objeto do poema, o fazer anatômico, que se ajusta com mais pertinência às rimas internas, uma rima de certa forma interiorizada, segredada. Ainda no PE há um jogo de aliteração entre /j/ e /p/: jogar um jogo do (poema ou da pintura). Zilberberg (2006b, p. 184) afirma que a aliteração não é um dado da ordem da intensidade, visto que ela se distribui pelo texto inteiro. Parece-nos que a interpretação de Zilberberg leva em conta a explanação de Saussure (STAROBINSK, 1974, p. 17-18), que, com base em versos saturninos, afirma em carta de 14 de julho de 1906:

Todo o fenômeno da aliteração (e também das rimas) que se observa no Saturnino é tão somente uma parte insignificante de um fenômeno mais geral ou melhor, absolutamente total. A totalidade das sílabas de cada verso Saturnino obedece a uma lei de aliteração, da primeira à última sílaba; e sem que uma única consoante - nem mesmo uma única vogal --, nem tampouco uma única quantidade de vogais, deixe de ser escrupulosamente levada em conta ${ }^{5}$. O resultado é tão surpreendente que somos levados a nos perguntar, antes de tudo, como os autores desses versos (em parte literários como os de Andronicus e Naevius) podiam ter tempo para se dar a este tipo de quebra-cabeça: pois o Saturnino é um verdadeiro jogo chinês, independentemente de qualquer consideração sobre a métrica. Eu precisaria de uma epístola considerável para alinhar exemplos, mas bastam-me duas linhas para dar a lei:

1. Uma vogal não tem o direito de figurar no Saturnino a não ser que tenha sua contravogal em um lugar qualquer do verso [...].

2. Lei das constantes. Ela é idêntica e não menos estrita, e nenhuma consoante, mesmo entre as implosivas como stabant, e entre as finais como Loucanam, não é levado em conta menos rigorosamente que o último $e$ [breve] ou $a$ [breve] da série vocálica. Há sempre um número par para toda consoante e sobretudo é preciso não esquecer as consoantes que aparecem nos grupos: assim a palavra qvod será certamente seguida no verso: $1^{\circ}$ de um outro $q$ ou $c ; 2^{\circ}$ de um outro $v ; 3^{\circ}$ de um outro $d$; e somente de um único $q$-c; de um único outro $v$, de um único outro $d$; -- a menos que não haja 4,6 ou 8 delas fazendo sempre par.

Os versos saturninos caracterizam-se pela imprevisibilidade e por uma estrutura fluida sobre a qual não há unanimidade entre os estudiosos: haveria um ritmo quantitativo, constituído pela sucessão de sílabas longas e breves ou pelo ritmo vívido, constituído por uma alternância de sílabas tônicas e átonas ou, ainda ao mesmo tempo, quantitativa e intensiva.

\footnotetext{
${ }^{5}$ Fizemos alguns acertos na tradução de Carlos Vogt, conforme sugestões de Ivã Carlos Lopes, Luiz Tatit e Waldir Beividas, tradutores de Razão e poética do sentido de Zilberberg (2006b, p. 184).
} 
Norma Goldstein (2011, p. 26) afirma que entre os latinos e gregos da Antiguidade Clássica o sistema poético imperante era o quantitativo, ou seja, alternância entre sílabas longas e breves: "a unidade de tempo seria a sílaba longa representada pelo sinal /--/. A sílaba breve, representada pelo sinal $\cup$, correspondia à metade da longa, ou seja, duas breves seriam equivalentes à duração de uma sílaba longa".

Posteriormente, no lugar da duração ou da alternância de longas e breves, passou-se para o critério de intensidade, oscilação de sílabas tônicas e átonas. É por isso que tendo em conta o verso saturnino e apoiado na terminologia de Hjelmslev, Zilberberg (2006b, p. 184) afirma que "a aliteração não é um dado, local, pontual, e sim um dado extenso, textual, geral".

Todavia, considerando que o PE produz efeito no PC, segundo a atualização de cada enunciado poético, ressaltamos que no poema "Anatomia do gol", de marcação temporal diversa da do saturnino analisado por Saussure, o processo aliterante é um dado intenso, marcador de um ritmo vívido, que oscila não mais entre breve e longa, mas entre tônico e átono, como o é o andamento do futebol, o do basquete e o do jogo de cartas, com suas oscilações de ritmo forte e fraco. Além disso, gol é uma palavra de cifra tensiva acelerada, pois que sua realização se faz num átimo e repentinamente. Tatit (2010, p. 160) afirma que "aquilo que irrompe, que se apresenta de maneira abrupta traz sempre um coeficiente de alta velocidade [...]. A aceleração produz rupturas no modo contínuo próprio da desaceleração".

No primeiro segmento, temos uma enunciação enunciva modalizada por um querer saber de que se compõe o gol, alegoria aguda em relação ao fazer poético. Gol, ao mesmo tempo que é "espaço limitado por travessões, onde deve entrar a bola", é também "o ponto obtido quando a bola transpõe o gol"; "fim para o qual se dirigem esforços; meta; objetivo"; "fronteira, limite" (HOUAISS; VILLAR, 2001). Há um traço isotopante que não se pode esquecer em relação à figura do gol: ao mesmo tempo que proporciona satisfação, o gol é um limite que deve ser ultrapassado por uma esquadra e cuja ultrapassagem deve ser impedida por outra esquadra; se transposta a linha limite proporciona frustração ao adversário.

Nesse sentido, gol e anatomia estão em tensão. Se fizermos a anatomia e ultrapassarmos os limites do segredo do gol, provocaremos satisfação e descontentamento ao mesmo tempo. É um jogo de limites. 
No segundo segmento, o enunciador introduz uma ruptura no verso 24 por meio da adversativa "mas" e rejeita todas as operações anteriores como reveladoras do conhecimento do objeto de que se pôs em busca: é um intensificador da subjetividade sensível, visto que introduz uma ruptura abrupta de sentido, mudando a direção anterior. Paradoxalmente, faz o jogo advir de operações racionais, quando utiliza a figura "cérebro; cerebelo; lobos" e não de operações factivas ("mãos jogam"; "pés jogam"). Ao rejeitar o saber proposto, abandona uma zona mais superficial e concreta ("cartas", "mesa", "quadra", "campo", "praia") para adentrar um nível mais profundo, o do "cérebro", como responsável pela competência do jogo (versos 24 a 26), ou seja, afasta-se do concreto sensível para encaminhar-se para uma região do inteligível, que não se pode tocar.

No terceiro segmento, o processo se acentua ainda mais, porque se reduz a uma única figura, a de "Antonio Lizárraga", que, segundo o enunciado, "joga um jogo de cartas marcadas".

No jogo de Lizárraga, todos os elementos estão em rede solidária de relações internas. E essa sinédoque "cartas marcadas" figurativiza as relações solidárias de todos os elementos: tudo seria um jogo de "sobrevires", quer na pintura quer na poesia. Nada estaria predeterminado onde "tudo joga e onde tudo se faz jogada". E, portanto, surpreende novamente, visto tratar-se de um jogo discursivo: futebol de papel, seguindo-se uma série enumerativa, que contempla um conjunto de estratégias, metáforas do fazer poético: "retranca aberta, dábliu-eme, pelo meio, ferrolho suíço etc.". Fiorin (2014, p. 141) entende que se expande um texto com enumerações "e, com isso, intensifica-se o sentido". Assim, o discurso revela-se mais acentuado por meio da soma de descritivos. Falar em extensidade implicaria reconhecer uma temporalidade que não há no poema, pois que tudo ocorre pelo acúmulo sucessivo de imagens.

No quarto segmento, o enunciador dá as mãos ao enunciatário: "a gente para e medita". Essa aproximação acentua a intensidade afetiva, impossibilitando a recusa do enunciatário, constrangido a seguir o pedido da voz de "a gente", englobadora do tu. Doravante, o caminho a ser percorrido parece ser menos árduo, porque "eu + tu" seguem juntos na busca da anatomia do gol.

Nesse sentido, os enunciados "se pensa como o estagirita" e "o que se vê é o centro" têm apenas efeito retórico, figurativizando uma verdade estabelecida por um consenso. A atenuação, introduzida em "se pensa" = podemos pensar como e em "o que se vê é o 
centro" = o que podemos ver é o centro, orienta o sentido para uma zona de conforto do enunciador: como se trata de um consenso, não há como discordar. A assertiva ganha valores de certeza e não de dúvida, garantindo um estado de alma de confiança do enunciatário. Por isso, as três interrogações que seguem apenas simulam dúvida, tendo um sentido apenas retórico: os versos é "o uno posto no trino" e "é o primeiro concluso no seu terceiro?" comparam a poesia ao mistério da Santíssima Trindade, que compreende Pai, Filho e Espírito Santo em uma só pessoa, uma verdade de difícil reconhecimento inteligível.

A terceira pergunta dialoga com Pitágoras: "são as de Pitágoras últimas categorias primevas?" Aqui, o hipérbato surpreende pela justaposição de duas figuras antitéticas: últimas e primeiras. Nesse caso, a enunciação joga com o acaso: as categorias primárias de Pitágoras teriam sido as últimas a constituírem objeto de estudo do matemático? Diferentemente da primeira interrogação que leva ao mundo sensível, a terceira é de égide da razão, da geometria, que se constitui intertextualidade com o fazer artístico de Lizárraga em variadas obras.

No quinto e último segmento, o enunciatário depara-se com um enunciador hesitante; inicialmente, esconde-se, apresentando apenas marcas na terminação verbal ("sei"), em seguida, suspende o pensamento (PE: espaço branco no verso 84) para novamente convocar o "tu" no enunciado ("não sabemos"). Essa duplicidade de jogadas enunciativas orienta o sentido voltado para a incerteza, para a dúvida. Nesse caso, a introdução do " $\mathrm{tu}$ " no enunciado, ao mesmo tempo que irmana "eu + tu", hierarquiza as posições: o "eu" é que afirma que o "tu" também não sabe. Assim, retorna um enunciador firme que não permite contraposição, posições divergentes da sua: "por mais que a gente dê tratos à bola ninguém atinge essa meta (sol)". Se ninguém consegue, não é o "tu" que vai conseguir. Esse enunciado, por sua vez, não se limita a responder às questões apresentadas no quarto segmento, mas desencadeia uma nova isotopia. O gol ou a meta (sol) não figurativiza aqui o lance decisivo do futebol: é de poesia e pintura que está tratando:

"ninguém atinge essa meta (sol) onde se exaure a pintura e o poema: sede secreta (gol)"

Ao mesmo tempo que há uma grande extensão na figura "ninguém", a metáfora “meta (sol) / (gol)" é acentuada, porque gol é da ordem da ruptura, desconhece a duratividade. Ao contrário do jogador que pode atingir a meta do gol, o artista da pintura ou 
da poesia não a exaure, jamais atingindo a meta, visto que tanto a pintura como o poesia moram numa "sede secreta". O poeta e o pintor estão sempre em falta com seu fazer.

"Anatomia do gol" apresenta ainda um jogo em que prevalece a oscilação entre vogais abertas /a/ e fechadas /o/ e /u/. Além disso, a dominância da nasalização em todo o enunciado (pintura, poema, jogam, mãos, campo, quem, um, sem, triângulos, acuando, migrante, retranca, ponta, gente etc.) conduz o poema para uma região de realização fonética fechada. É essa oscilação no PE entre abertura e fechamento, que promove o percurso do PC entre a busca do saber do que se compõe o gol e a busca do saber fazer "anatomia do gol". Por isso, já afirmamos em outra parte desta tese que a poesia aguda do final do século XX modaliza-se não por um por fazer saber (transmitir informações), mas por um saber fazer poiético.

O conteúdo oscila ainda entre a busca racional do saber, que é da ordem da emissividade, da abertura, da clareza, e as dificuldades de atingir esse saber, da ordem da remissividade, do fechamento, da obscuridade. O poema é ambiguamente uma "sede secreta", ver verso 92, que se pode ler tanto como "sede, secura", desejo de saber, quanto como "sede, como local", lugar do poema ou da pintura.

Observando as consoantes, temos na palavra jogo, que percorre todo o poema, uma fricativa aveopalatal vozeada $/ \mathrm{j} /$, que se contrapõe ao fonema $/ \mathrm{p} /$, oclusivo bilabial não vozeado, das palavras poema, pintura, pé, papel, peso etc. O fonema vozeado revela no PC uma abertura emissiva na busca do conhecimento no percurso da anatomia do gol, enquanto a oclusividade do $/ \mathrm{p} /$ faz parelha com o fechamento remissivo, que se configura no PC um segredo de difícil acesso.

Paralelamente a essa oposição, percorre o poema a fricativa alveolar vozeada /z/, em cartas, mesa, pés, mesmo, lobos, luz, peso, triz, cartas marcadas, peças, triângulos, setas, arestas, casados, holandês, evasivo, exaure etc., que contrasta com a fricativa alveolar não vozeada /s/, em cérebro, bossas, cerebelo, seus, passar, certeiro, sem, peças, suíço, carrossel, círculo, nesse, perseguido, sagitas, sem centro, peirce, terceiro, sei, essa, sol, sede. Esse jogo entre vozeado e não vozeado produz uma regularidade rítmica entre um som átono (não vozeado) e tônico (vozeado) de um andamento célere. No PC, temos duas isotopias: a do futebol, em que o sujeito busca aceleradamente o gol, e a metalinguística, em que o poeta ou o pintor busca atingir o poético, o estésico. 
Ora o poema desliza, acelera-se, recua, retarda. Ademais, a oscilação entre fazer-se ouvir e fazer-se não ouvir, entre sonoro e surdo, manifesta no conteúdo o quanto o objeto se mostra e o quanto se esconde. Daí configurar um sujeito desejoso de fazer desobscurecer o que não pode ser visível.

Tomando a primeira estrofe, verificamos ainda um jogo entre artigo indefinido, que por natureza é mais extenso por abranger mais elementos, e definido, que é mais intenso, pois focaliza e concentra uma única figura. Assim é que temos "jogar um jogo" $\rightarrow$ "jogar o jogo".

Na segunda estrofe, dá-se o contrário, partimos do artigo definido para o indefinido, ou seja, do intenso para o extenso: "jogar o jogo do poema" $\rightarrow$ "jogar qualquer jogo". Aqui novamente, extenso e intenso oscilam entre e sensibilidade e inteligibilidade. Enquanto "jogar o jogo do poema" concentra e especifica, acrescentando traços afetivos, "jogar qualquer jogo" dilui-se em generalidades e perde em afetividade.

A partir da quarta estrofe, a afetividade cede lugar à razão nos versos 24 até 83 para, finalmente, mergulhar numa atmosfera hesitante e ao mesmo tempo decisiva em relação à anatomia do gol, quando afirma com conviç̧ão que "ninguém atinge essa meta (sol)", paronomásia de "gol".

Como temos visto na análise, o enunciador em certos momentos manifesta-se seguro como um mestre ensinando discípulos. Nas três primeiras estrofes, temos enunciados da ordem da extensidade que funcionam como afirmações de valor generalizante: "jogar um jogo é como jogar o jogo da pintura ou do poema"; "os pés jogam bola no campo ou na praia". Na quarta estrofe, o enunciado atenua-se em generalização, reduzindo-se em espacialização; nesse momento, especifica o cérebro como lugar do jogo. Na quinta, sexta e sétima estrofes, ganha ainda mais em acentuação, porque se concentra na arte de Antonio Lizárraga, homenageado do poema. Da oitava à décima segunda estrofes, a concentração no fazer de Lizárraga desloca-se para concentrar-se no fazer artístico.

Depreendemos do sentido de anatomia do título do poema de Haroldo de Campos uma sintaxe do fazer poético, um movimento que vai do interior para o exterior, do paradigma para o sintagma. O poeta, assim como o anatomista, corta, recorta, secciona do interior do sistema (paradigma) unidades que se associam para formar um sintagma de ordem exterior. Assim é o poema: do seu interior erige-se o exterior, em que a relação 
sintagmática, in praesentia, é fruto de uma escolha de termos entranhados no sistema, in absentia.

Os refreamentos agudos visuais, sonoros (PE) e de conteúdo (PC), se entretecem para atravancar o jogo do reconhecimento intelectivo. E esse jogo poético faz-se secretamente por seleção e combinação: o uso linguístico manifesta o esquema, sendo a manifestação uma função contraída pelo esquema e pelo uso (HJELMSLEV, 1975, p. 83). A anatomia do esquema manifesta assim o uso, e o poema, fim do fazer poético, acaba por revelar o esquema, a oficina da mestria anatômica do poeta.

Averiguamos nesta seção, portanto, que o conceito de ut pictura poesis (como pintura, assim a poesia) compreende particularmente o que a retórica clássica chama de écfrase e hipotipose, ou seja, apresentar vividamente um simulacro de imagem ao enunciatário, imagem que deve, segundo a proporção, ser vista de perto ou de longe, na claridade ou na penumbra (no recolhimento da reflexão), uma vez ou várias vezes.

$\mathrm{Na}$ agudeza do final do século XX, retoma-se o conceito original de ut pictura poesis, visto mais detalhadamente nos poemas "Klimt: tentativa de pintura" e "Anatomia do gol", de Haroldo de Campos. No primeiro, o enunciado simula o detalhismo da pintura de Klimt, convocando suas obras para compor o poema; assim, sempre que seleciona um elemento do paradigma, por exemplo, por meio da escolha de "panóplia" (sinédoque de guerreiro), o enunciatário pressuposto, conhecedor da obra de Klimt, retoma o quadro Friso Beethoven: $a$ aspiração à felicidade. Em "Anatomia do gol", saltam à vista na sétima estrofe a composição das imagens das lâminas de Lizárraga; além disso, no próprio poema notamos uma distribuição dos enunciados de forma a sugerir visualmente uma anatomia, particularmente da obra do artista plástico homenageado.

Na seção seguinte, retomamos a acentuação da re-forma, bem como explicitaremos o simulacro de materialização.

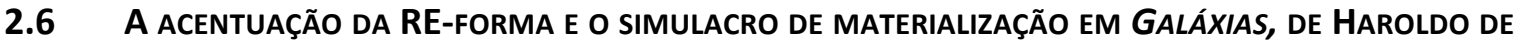 CAMPOS}

\subsubsection{ENTRE PROSA E POESIA}

Galáxias, de Haroldo de Campos, tem sido considerada obra de ruptura de gênero, de "abolição das fronteiras entre poesia e prosa" (CAMPOS, 1977c, p. 53). Paralelamente a essa consideração, existe um consenso sobre Galáxias ser um livro que mistura concretismo 
e neobarroco. No entanto, em "Momento crítico (meu meio século)", em conversa com amigos, Pécora (2004, p. 44-87) contesta essa afirmação:

-- Para mim - disse o Régis, sem morder a isca provocativa - Galáxias também não é um livro que funde concretismo e neobarroco, como está escrito. É mais roseano, joyciano, poundiano de Cantos. Tem muito pouco de concretista, minimalista, a não ser na paronomásia como recurso de narração, na linha "palavra puxa palavra" (p. 82).

Em seguida, vê disforicamente o "neobarroco", chamando-o de "coisa que aparece bem mais tarde na teorização de Haroldo, que então a projeta para trás" (p. 82). A sintaxe da teoria haroldiana faz-se com base em um movimento para trás e para a frente, instaurando uma tradição de transposição, que ele chama de transbarroco: o presente é valioso como tradição viva, visto projetar o barroco como categoria para o presente. E o passado como manifestação avant la lettre, como manifestação do presente. Duas questões sobressaem:

1. Galáxias seria proesia? [Haroldo de Campos, o teórico, confirma essa mistura em seu texto Ruptura de gêneros (1977c, p. 18-35)].

2. Galáxias seria um texto neobarroco?

Vejamos.

Ponto 1. Em "O que fazem os poetas com as palavras", Roman Jakobson (1972, p. 59) considera que o problema essencial da poesia é saber o que ela é. A origem grega da palavra poesia, poiesis, leva-nos ao significado de criar, de fazer alguma coisa. Ela seria "o domínio mais criador da linguagem" (p. 6). Esclarece ainda o linguista que a raiz da palavra verso é a mesma de prosa, "visto que prosa deriva de provorsa, proversa; oratio proversa é aquela que caminha resolutamente em frente, com uma direção estrita" (p. 6). O significado de versus (verso) é retorno, "um discurso que comporta regressos" (p. 6). E o de prosa seria o de discurso que vai sempre em frente.

Com Novalis, Edgar Allan Poe, Nerval e Baudelaire, ocorre uma ruptura com relação à retórica clássica, os gêneros prosa e poesia perdem as fronteiras nítidas de seus contornos, fluidificando-se. A poesia passa então a incorporar elementos da prosa. Não só a poesia foi invadida pela linguagem prosaica, como também a prosa foi invadida pela da poesia. São exemplos dessa complexidade de prosa-poesia: Memórias sentimentais de João Miramar (1924), de Oswald de Andrade; Finnegans Wake ([1939] 2002-2004), de James Joyce; Grande 
sertão veredas ([1956] 2001), de Guimarães Rosa; Galáxias ([1963-1976] 2011a), de Haroldo de Campos; Catatau ([1975] 2013), de Paulo Leminski; Romanceiro de Dona Virgo (2004b), de Claudio Daniel.

No lugar de antitetismo entre poesia e prosa, porque não pensar em interação entre essas duas dimensões? Ou mesmo considerar o trânsito entre uma coisa e outra? Talvez nossa cultura assuma valores de uma tradição maniqueísta, como é a religiosa, a mística, que o realismo ingênuo vê como uma operação de contrários. Para nós, porém, poesia e prosa são funtivos de uma função complexa que é a poética.

Hjelmslev (1985 [data original jun. 1933], p. 49-50), em "Corrélations morphématiques", considera duas vertentes para o estudo de uma categoria: a por dimensões e a por subdivisão:

L'analyse par dimensions consisterait à reconnaître, à l'intérieur d'une catégorie, deux ou plusieurs sous-catégories qui s'entrecroisent et se compénètrent. [...]

L'analyse par subdivision consisterait à répartir les membres de la catégorie supérieure sur deux ou plusieurs classes dont une au moins comporterait au moins deux membres. [...]

La différence opérative entre les deux procédés consiste en ceci que, dans l'analyse par dimensions on établit simultanément deux (ou plusieurs) souscatégories qui sont absolument coordonnées, tandis que dans l'analyse par subdivision on établit successivement deux (ou plusieurs) sous-catégories dont la deuxième est subordonnée à la première (la troisième à la deuxième, et ainsi de suite s'il y a lieu $)^{6}$.

A categoria por subdivisão, jakobsoniana, subdivide os membros da categoria superior em duas ou mais classes; nesse caso, entre prosa e poesia haveria uma relação de subordinação. Já a categoria por dimensões, hjelmsleviana, reconhece no interior de uma categoria duas ou mais subcategorias que se entrecruzam e interpenetram; nesse sentido, são coordenadas entre si; dessa forma, todos os termos seriam complexos (mas não da mesma maneira), não havendo, pois, termos puramente simples. Melhor, os termos prosa ou poesia não são simples oposições paradigmáticas, mas são intervalares, na medida em que contêm avaliações, graduam-se (cf. ZILBERBERG, 2011a, p. 39, 200, 242 e 276). Ao

\footnotetext{
${ }^{6} \mathrm{~A}$ análise por dimensões consistiria em reconhecer, no interior de uma categoria, duas ou mais subcategorias que se entrecruzam e imbricam. [...] A análise por subdivisão consistiria em cindir os membros da categoria superior em duas ou mais classes, que suportaria pelo menos dois membros. [...] A diferença operativa entre os dois procedimentos operacionais consiste, na análise por dimensões, em estabelecer simultaneamente duas (ou mais) subcategorias que são absolutamente coordenadas, na medida em que na análise por subdivisão estabelecemos sucessivamente duas (ou mais) subcategorias em que a segunda é subordinada à primeira (a terceira à segunda, e assim por diante) (HJELMSLEV, 1985, p. 49-50 tradução nossa).
} 
contrário, pois, da relação de diferença, consideramos que prosa e poesia assumem uma relação de dependência:

o fato poético moderno apresenta duas características singulares, provavelmente solidárias entre si: de um lado, a supressão da cisão entre prosa e poesia, supressão que acaba instaurando a cisão "no meio" da própria prosa; de outro lado, o advento da imagem [...]. Essa poética tem por objeto interno o que Bachelard denomina "novidade da imagem" (ZILBERBERG, 2011a, p. 181).

No entanto, o que Bachelard afirma como "novidade da imagem" não vai muito além do que já estabelecia Baltazar Gracián, no século XVII, por meio do conceito de agudeza, em relação à poesia seiscentista que tinha como objetivo atingir o maravilhamento, também da ordem do sobrevir. Para a argumentação de que o sentido se faz pela intensidade, pela diferença estabelecida entre tênue e vívido, Zilberberg, apoiado em Aristóteles (Retórica, $A$ poética), em Longino (Do sublime, século I d.C.), em Boileau (Art poétique, 1674), em César Chesneau Dumarsais (Trattato sull'alegoria, 1730) e em Pierre Fontanier (Les figures du discours, 1821 - edição consultada 1977) ${ }^{7}$, bem como em Deleuze (Diferença e repetição, 1968 - edição consultada 2006), ressemantiza o que se diluiu com a passagem do tempo e põe na ordem do dia a necessidade da oscilação entre intensidade e extensidade nos enunciados.

Ademais, no que tange "poema-poesia/prosa" ${ }^{8}$, segundo Alberto Pucheu (2009, p. 23), "a partir do século XIX, uma das maiores dificuldades da teoria literária é conseguir estabelecer uma diferença entre poema e prosa, já que, em um movimento de mão dupla, tanto o primeiro incorporou a segunda, como esta, aquele, misturando-se". Pucheu ainda ressalta que, em muitos casos, "através da radicalização do uso das imagens, dos ritmos, dos metros, das invenções sintáticas, das significações ou daquilo que Pound chamou de melopeia, fanopeia e logopeia, ambos já assimilaram uma linguagem carregada de sentido ao máximo grau possível" (destaques do original), atingindo assim "maior condensação da forma verbal como requer, para o poeta americano, as exigências da poesia".

Pucheu (2009, p. 25), apoiado em Agamben, considera, por exemplo, o enjambement (pausa sonora no final do verso que invade o verso seguinte), "verso anterior adentrando o

\footnotetext{
${ }^{7}$ Argumenta ainda Zilberberg (2011a, p. 13) "o ponto de vista tensivo mostra-se - felizmente, a nossos olhos como um ponto de confluência e uma garantia de continuidade: aviltada, denegrida, ridicularizada, a retórica resiste, por se solidária de nossos funcionamentos íntimos, dos quais somos menos agentes do que pacientes". ${ }^{8}$ Utilizamos, nesta tese, o termo "poema" no sentido restritivo. Por exemplo, poema "Pilar"; poema "Casa de Gonzaga", de Affonso Ávila. Não é de interesse aqui discutir a diferença terminológica entre poema e poesia.
} 
próximo", um dos responsáveis por engendrar no poema "uma elasticidade que o estende para além de sua pausa métrica"; essa "exclusão da pausa final prevista confund[e] o verso com a prosa em um ponto de coincidência ou em uma bodas mística do som e do sentido. 0 enjambement, então, estaria a serviço da penetração da prosa no poema" (destaques no original). Desse modo, verso e sintaxe participam de um jogo tensivo, que é constante no fazer poético do século XX. Agamben ([1996] 2002, p. 142) entende que "a poesia não vive senão na tensão e no contraste [...] entre o som e o sentido". Em seguida, consciente da relevância da oposição entre segmentação métrica e a semântica, assevera que o enjambement (encavalgamento) é "o único critério que permite distinguir a poesia da prosa".

No caso de Galáxias, assistimos a um constante encavalgamento; um verso adentra o outro, imbricando-se. Reforça Pucheu (2009, p. 26): “no fim do verso, flagra-se um tempo de parada sonora e um lugar de interrupção plástica que podem condizer ou não com uma cessação sintática da oração, que é passível de continuar". Nesse caso, os objetos poéticos do século XX foram esmaecendo-se em seus contornos, fluidificando-se.

Ponto 2. Para considerar Galáxias um texto neobarroco, seria necessário admitir a existência do chamado barroco, mas, como vimos no capítulo 1, o dito barroco é uma categoria criada no final do século XIX. Não seria, portanto, conveniente nesta tese o rótulo neobarroco; se o utilizamos aqui é apenas pelo fato de os textos do final do século XX serem usualmente conhecidos por barroquistas. Uma denominação sugerida ao longo desta pesquisa é a de semiótica de agudeza: uma poesia de oscilação tensiva entre os artifícios de ênfase no PE, no PC ou em ambos.

Não seria coerente considerar Galáxias e outros tantos textos considerados como barroquistas um obra "neobarroca", pois Mallarmé erige-se como principal destinador do fazer poético do século XX. Como sabemos, os destinadores das produções seiscentistas ditas barrocas são outros: os preceptistas do século XVII. Não só: trata-se de valores e de contratos enunciativos muito diferentes. Vejamos o que afirma Mallarmé (In: CAMPOS; PIGNATARI; CAMPOS, 2010, p. 151-152, tradução de Haroldo de Campos) no prefácio de Un coup de dés:

- "Les 'blancs' en effet assument l'importance, frappent d'abord [...]." / "Os 'brancos' com efeito assumem importância, agridem de início [...].” 
- 'L'avantage, si j'ai droit à le dire, littéraire, de cette distance copiée qui mentalement separe des groupes de mots ou les mots entre eux, semble d'accélérér tantôt et de ralentir le mouvement, le scandant, l'intimant même selon une vision simultanée de la Page: celle-ci prise pour unité comme l'est autre part le Vers ou ligne parfaite." / "A vantagem, se me é lícito dizer, literária, dessa distância copiada, que mentalmente separa grupos de palavras ou palavras entre si, afigura-se o acelerar por vezes e o delongar também do movimento, escandindo-o, intimando-o mesmo segundo uma visão simultânea da Página: esta agora servindo de unidade como alhures o Verso ou linha perfeita."

- "La fiction affleurera et se dissipera, vite, d'aprés la mobilité de l'écrit, autor des arrêts fragmentaires d'une frase capitale dès le titre introduite et continuéé." / "A ficção assomará e se dissipará, célere, conforme à mobilidade do escrito, em torno das pausas fragmentárias de uma frase capital desde o título introduzida e continuada."

Sarduy (In: CAMPOS, 1979, p. 125), no entanto, assume o lado barroquista de Galáxias: "neobarroco, ou melhor, outro classicismo", ponto de vista do qual divergimos, pois optamos pela semiótica da agudeza e não pela continuidade de barroco. Gonzalo Aguilar (2005, p. 320), na linha de Robayna e de Sarduy, afirma o barroquismo em Haroldo de Campos:

a recuperação do barroco não é historicista nem estilística, mas se opera pelo uso do "pli selon pli" mallarmeano nas estruturas abertas das Galáxias [...]. O "pli selon pli" que Gilles Deleuze menciona como característica central do barroco está dado aqui pelo desdobramento e redobramento dos significantes em linhas de escritura (que não tem medida nem fim, já que o enjambement força-as constantemente), em um movimento que Robayna qualificou de "contração" e "dilatação".

A recuperação do barroco não seria, pois, para Aguilar, nem historicista nem estilística, mas se operaria pelo uso do "pli selon pli", que ele traduz como desdobramento e redobramento dos significantes, em movimento de contração e dilatação. Afinal, de que barroco se trata? Do barroco anterior ao rótulo, anterior ao recorte, visto como deformidade, subversão? Do barroco de Wölfflin, que o considera como uma evolução das 
formas clássicas? Que considera ser cíclica a história da arte e que todos os movimentos se encaminham para o barroco?

Robayna (In: CAMPOS, 1979, p. 138), bem como Sarduy e Aguilar, defende que Galáxias é barroca, não só na textura como também na estrutura parassintética (composição de palavras por meio da adição de um prefixo e um sufixo). Ora, essa estrutura parassintética não é exclusiva dos objetos seiscentistas nem do chamado neobarroco. Tratase de um artifício caro a qualquer fazer poético; o poeta é desde sempre um mestre no trabalho com a linguagem, engendrando refreamentos mais ou menos acentuados no enunciado. O que temos defendido é que a agudeza, seja nas poesias dos séculos XVI-XVII, seja nas do século $\mathrm{XX}$, erige ora objetos mais fluidos ora objetos mais nítidos, ora mais fantástico, ora mais icástico, ora para se ver mais de perto, ora mais de longe.

Alexandre Barbosa (In: CAMPOS, 1979, p. 21), por sua vez, não assume declaradamente o barroquismo em duas obras haroldianas, Xadrez de estrelas e Galáxias, mencionando apenas que era o autor que se intitulava um neobarroquista: "se não bastasse a indicação do próprio Haroldo de Campos acerca da retomada barroca de sua fase inicial!” Nos dizeres do próprio Haroldo (CAMPOS, 2006, p. 262): “Desde 1955 [...], venho refletindo sobre as possibilidades desse 'neobarroco'”'. E, em seguida, Haroldo cita Lezama:

Se quiserem outros parâmetros, comparem o elogio do barroco, como "estilo utópico" [...], com a concepção do cubano Lezama Lima [...]. Para Lezama, o barroco ibero-americano é uma "arte da contraconquista", um estilo "plenário", que ele define corrosivamente como "uma grande lepra criadora" (por oposição a um barroco europeu já "degenerescente").

Nesse cenário barroquista, Haroldo de Campos também se questiona sobre as possibilidades ou não de um neobarroco. Mais que possibilidade de neobarroco como estrutura, o que notamos é a repetição de fórmulas constantes de manuais e dicionários, que identificam a arte seiscentista como caudalosa, abundante. E o chamado neobarroco seria, para o ensaísta, uma operação de tentativa de resgate dos valores do barroco na América Latina como certa compensação afetiva. Em poucas oportunidades, descreve o que seria uma "estrutura barroquizante" e, quando a descreve, o faz de passagem:

afinal, o oxímoro (a coexistência dos contrários) é a figura-rainha do Barroco e barroquismo não se opõe a construtivismo (Bach, o matemático da fuga, é um músico barroco; a geometria curvilínea de Niemeyer em Pampulha ou em Brasília é, ao mesmo tempo, construtiva e barroquizante). Preferi uma poética de "pontos luminosos" a uma retórica de facilidade e recheio (CAMPOS, 2006, p. 272). 
Dificultam aqui a intelegibilização do trecho citado as figuras "poética de pontos luminosos" e "retórica de facilidade e recheio". Nesse caso, o próprio enunciador erige-se em sancionador de suas produções que seriam superiores, porque não cedem a uma "retórica de facilidades". Quais? Não sabemos.

Ora assertivo em relação ao barroquismo, ora vendo apenas como possibilidade, Haroldo propõe as expressões "neobarroco" e "barroco moderno", como proposta da matriz barroca em termos contemporâneos, num texto de 1955 (cf. CAMPOS, 2006, p. 272 em nota de rodapé). Dentro dessa discussão ainda, propõe o oxímoro como figura rainha do barroco. Como temos enfatizado, a agudeza de ênfase no PC contém em seu cerne a cifra tensiva da condensação dos sobrecontrários, que no nível discursivo revela-se ora como oxímoro, ora como paradoxo, ora como antítese, ora como hipérbole etc.

Além do oxímoro, ele observa outro traço, a geometria curvilínea. A agudeza de palavras, para nós agudeza do $\mathrm{PE}$, engendra nos objetos, seja dos seiscentos seja do século $\mathrm{XX}$, cifras tensivas diferentes, visto promover o esmaecimento dos contornos; o objeto agudo de ênfase no PE tem seus significantes refreados, o que Ihes permite características de fluidez, curvilinidade, abertura, movimento, acentuação sensível e delongamento no reconhecimento inteligível.

Galáxias, como temos discutido, do ponto de vista desta tese, não é nem neobarroca, nem concretista, pois se afasta deste último, na medida em que reincorpora a enunciação enunciativa, o verso e o poema longo, que os concretistas tanto repeliam. Sai de cena ainda a tensão entre verso e ideograma, pano de fundo da poesia concreta (cf. AGUILAR, 2005, p. 320).

A seguir, vejamos com mais detalhes os formantes de Galáxias e como as agudezas vivificam o objeto.

\subsubsection{AGUDEZA DO PE EM GALÁXIAS: RITORNELLO SONORO E EXPANSÃo DA LINHA NO BRANCO DA PÁGINA}

Galáxias é uma obra composta por dois formantes fixos em itálico, o inicial e o final, e outros 48 "cantares", "num total de aproximadamente 2000 versículos" (CAMPOS, 2006, p. 272). O termo formante advém de um empréstimo terminológico da música:

O formante inicial (um termo que tomei de empréstimo à terminologia do compositor Pierre Boulez) foi escrito em 1963. O formante final (que é o reverso simétrico do primeiro) é de 1976 . Um longo arco de tempo, no qual os acontecimentos, como cicatrizes, foram deixando também as suas marcas textuais, a sua borra e o seu sarro. Pois as Galáxias não são apenas 
um livro de epifanias, mas também, ao mesmo tempo, um registro crítico e paródico de antiepifanias [...]. No plano das técnicas literárias, [tento] dialetizar a questão da ruptura dos gêneros (poesia/prosa) [...] (CAMPOS, 2006, p. 269-270).

O próprio Haroldo de Campos (2011a, p. 119; 2006, p. 270), considerando-o um poema longo em 50 cantares, situado "na fronteira entre prosa e poesia", dialetiza a questão da ruptura dos gêneros. Galáxias encontra-se "semeado de palavras-montagem" e "estruturado em segmentos rítmicos-prosódicos".

Como não há marcação do número de páginas, o enunciatário preenche os intervalos de Galáxias, segundo a ordem que lhe interessar, o que lhe permitirá reconstruir o objeto poético a seu bel-prazer:

Imaginei de início um livro-objeto, um multilivro manipulável como uma escultura cinética. Claro que as novas anotações, as novas partituras da música de vanguarda, então preocupada com o aleatório, estavam presentes no meu pensamento. Lembro-me de uma opinião de Guimarães Rosa, por ocasião de uma longa conversa que tivemos [...]. A uma certa altura, ele me disse: "Você não sabe o que tem nas mãos. Isto é o demo. Esta sua prosa é o demo!" E depois de uma pausa, referindo-se ao projeto do livro: "Mas veja: não publique em folhas soltas, faça um livro comum, costurado... Não dificulte o difícil... [...], não dei maior atenção à observação, e respondi brincando, provocativo: "Isto não importa. Ao demo o que é do demo. Sou um kamikaze da literatura..." Hoje, penso diferentemente. $O$ livro de folhas soltas não convida o leitor à leitura, ao manuseio. É belo como projeto gráfico, mas inibitório como prática de leitura. [...] No mais, o livro pode ser lido a partir de qualquer página, aleatoriamente (CAMPOS, 2006, p. 274).

No trecho transcrito, se considerarmos a fala de Guimarães Rosa em termos Zilberberguianos, diríamos que a observação rosiana afirma um basta além do qual Haroldo não deveria passar: "não dificulte o difícil".

O primeiro formante inicia-se com "e começo aqui e meço aqui este começo e recomeço e remeço e arremesso" e o último com "fecho encerro reverbero aqui me fino aqui me zero não canto não conto". Notamos imediatamente uma acentuação da sonoridade, que engendra um efeito de poesia hipnótica, que vai paralisando o enunciatário com a confluência de sons semelhantes, constituidores melódicos. Mais que um reconhecimento rápido das imagens, o texto, em sua segunda edição revisada, acompanhado de um CD, ocupa-se de maravilhar o enunciatário pelo encanto da musicalidade: 
A oralização das galáxias sempre esteve implícita no meu projeto. [...] Como se verá (como se ouvirá), trata-se de um livro para ser lido em voz alta, que propõe um ritmo e uma prosódia, cujas zonas "obscuras" se transparentam à leitura e cujas palavras, oralizadas, podem ganhar força talismânica, aliciar e seduzir como mantras. Não por acaso convidei o poeta e músico Alberto Marsicano para acompanhar-me ao sitar ("cítara"), enquanto eu lia os dois formantes (assim sublinhados): a mobilidade das ragas indianas, onde o aleatório é controlado por estruturas de repetição, soa congenial ao meu texto-partitura. No mais, algumas poucas pistas referenciais são suficientes para aclarar o curso galáctico. Quanto às palavras e frases em outros idiomas - sempre de valor mântrico, "transmental", ainda quando não imediatamente alcançável no nível semântico - essas palavras e frases são, via de regra, traduzidas ou glosadas no contexto, fluindo assim e confluindo para o ritmo do todo (CAMPOS, 2011a, p. 119).

Transcrevemos o longo trecho de Haroldo de Campos, porque faz parte integrante do texto, de forma que pode ser considerado uma extensão das Galáxias. Nele, o enunciador na pele discursiva de um ator-narrador em primeira pessoa antecipa-se às avaliações do sancionador, afirmando que suas palavras, "oralizadas, podem ganhar força talismânica, aliciar e seduzir como mantras". Esse simulacro de diálogo com o enunciatário revela valores assumidos por um grupo de literatos, como Júlio Cortázar no "Tabuleiro de direção", em $O$ jogo da amarelinha ([1964] 2008], e Paulo Leminski, em "Quinze pontos nos iis" de $O$ catatau ([1975] 2013). Nesses textos, os enunciadores informam aos seus enunciatários os passos a serem seguidos para uma leitura "bem sucedida" de seus textos.

Cada um dos formantes de Galáxias funciona como um microcosmo; cada uma das peças é autônoma e encaixa-se em qualquer parte e em qualquer ordem: "em cada fragmento, estão todas e cada uma das Galáxias" (CAMPOS, 2006, p. 272). O texto de Galáxias seria infinitamente divisível: parte, subpartes, grandes partes são regidas pelo princípio de similitude.

Tomando o formante inicial de Galáxias (2011a), verificamos que o enunciado

[...] o avesso da estória que pode ser escória que pode ser cárie que pode ser estória tudo depende da hora tudo depende da glória tudo depende de embora e nada e néris e reles e nemnada de nada e nures de néris de reles de ralo de raro e nacos de necas e nanjas de nullus e nures de nenhures e nesgas de nulla res e nenhumzinho de nemnada [...]

associa paradigmas para compor um sintagma que se propõe ser sensível numa simulação de materialidade sonora: "esse texto é uma galáxia de significantes, não uma estrutura de significados [...]; os códigos que ele mobiliza se perfilam a perder de vista; [...] seu número 
não será jamais fechado, tendo por medida o infinito da linguagem" (CAMPOS, 2010, p. 244, destaques nossos).

Como sabemos, não é possível haver um enunciado de língua natural sem forma da expressão e forma do conteúdo. Por fim, percebemos que os recortes e as escolhas aparecem já no processo sintagmático, tendo como princípio orientador a construção de um efeito de sentido de volume sonoro, cujo reconhecimento inteligível é delongado, proporcionando maravilhamento e prazer imediato pelo encantamento melódico, bem como deleite estético.

Além de obra que tece e destece, num processo contínuo de palavra que puxa palavra, avolumam-se em Galáxias conexões com outras artes, com outras obras literárias, um projeto de obra-tradição-viva: nela, estão presentes Homero, Virgílio, Camões, Dante, Pound, James Joyce e tantos outros irreconhecíveis, compondo a circularidade da reescrita, uma operação de intertextualidade:

Pound, Ponge, Ferlinghetti, o velho escultor Vantongerloo no seu minúsculo estúdio parisiense, a casa imaculada de William Carlos Williams em Rutherford, New Jersey... Flashes nem sempre reconhecíveis, porque logo absorvidos pelo fluxo obsidiante da linguagem. Esta, o verdadeiro e principal personagem do livro. Que tem, em certo sentido (como uma vez me observou Anatol Rosenfeld, quando verteu para o alemão dois fragmentos galácticos, em 1966), uma estrutura de estória detetivesca, já que a intriga é constantemente interrompida, suspensa, e o leitor fica à busca do "quem" e do "quê" do texto... (CAMPOS, 2006, p. 272).

O enunciador convida o enunciatário a fazer uma viagem pela literatura, assumindo uma função ativa; agora, viajar pelas galáxias é como jogar um jogo: pela experiência linguística, poeta e leitor participam como jogadores ativos e coenunciadores da obra.

Vejamos no quadro 5.2 comentários e exemplos da intertextualidade em Galáxias:

Quadro 5.2 Galáxias: comentários e exemplos de intertextualidade.

\begin{tabular}{l|l}
$\begin{array}{l}\text { Seleta de trechos de formantes de Galáxias } \\
\text { (CAMPOS, 2011a). }\end{array}$ & $\begin{array}{l}\text { Trechos entre aspas de "Ora, direis, ouvir } \\
\text { galáxias" (CAMPOS, 2011a, p. 119-122). }\end{array}$ \\
$\begin{array}{l}\text { Formante inicial: "e começo aqui e meço aqui } \\
\text { este começo e recomeço [...]" }\end{array}$ & \\
$\downarrow$
\end{tabular}




\begin{tabular}{|c|c|}
\hline $\begin{array}{l}\text { enunciatário para preencher o objeto fluido, } \\
\text { esmaecido e sem contorno definido. }\end{array}$ & $\begin{array}{l}\text { andamento vívido ("que se faz sem esforço, com } \\
\text { rapidez" - HOUAISS; VILLAR, 2001, verbete } \\
\text { cursivo), produz o efeito de intensidade do } \\
\text { desejo por parte do enunciador de contar suas } \\
\text { viagens galácticas pela literatura. } \\
\text { Nota: No formante final, o uso da letra cursiva } \\
\text { funciona como ausência de parada na narrativa; } \\
\text { o sujeito mantém-se acelerado tanto quanto } \\
\text { seus enunciados, produzindo o efeito de } \\
\text { incompletude, como se a viagem ainda não } \\
\text { tivesse chegado ao fim, podendo continuar } \\
\text { aberta. Esse sentido de continuidade pode ser } \\
\text { verificado no enunciado pela ausência de ponto } \\
\text { final na obra inteira, inclusive no último } \\
\text { formante. }\end{array}$ \\
\hline $\begin{array}{l}\text { "[...] reza calla y trabaja em um muro de granada } \\
\text { trabaja y calla y reza y calla y trabaja y reza em } \\
\text { granada um muro da casa }[. . .] "\end{array}$ & 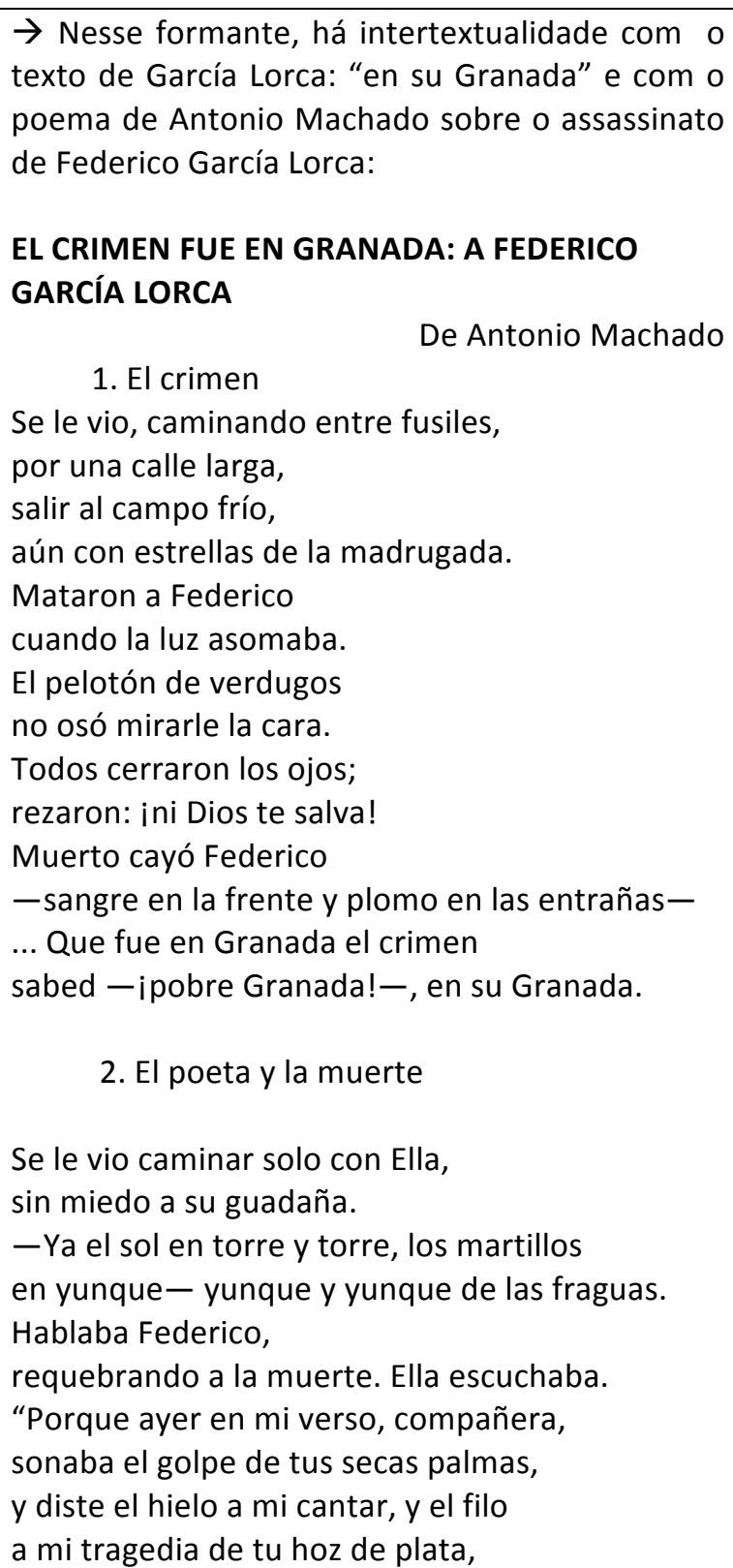 \\
\hline
\end{tabular}




\begin{tabular}{|c|c|}
\hline & $\begin{array}{l}\text { te cantaré la carne que no tienes, } \\
\text { los ojos que te faltan, } \\
\text { tus cabellos que el viento sacudía, } \\
\text { los rojos labios donde te besaban... } \\
\text { Hoy como ayer, gitana, muerte mía, } \\
\text { qué bien contigo a solas, } \\
\text { por estos aires de Granada, imi Granada!" } \\
\qquad 3 . \\
\text { Se le vio caminar... } \\
\quad \text { Labrad, amigos, } \\
\text { de piedra y sueño en el Alhambra, } \\
\text { un túmulo al poeta, } \\
\text { sobre una fuente donde llore el agua, } \\
\text { y eternamente diga: } \\
\text { el crimen fue en Granada, ien su Granada! }\end{array}$ \\
\hline $\begin{array}{l}\text { "[...] multitudinous seas incarnadine o oceano } \\
\text { oco e regougo a proa abrindo [...] (destaques } \\
\text { nossos)" } \\
\text { ao final desse formante: "[...] ademais mareando } \\
\text { marujando marlunando marlevando marsoando } \\
\text { polúphloisbos }[. . .] \text { (destaques nossos)" }\end{array}$ & $\begin{array}{l}\rightarrow \text { Diálogo com um verso de Shakespeare de } \\
\text { Macbeth, II, cena II: "referência ao mar } \\
\text { multitudinoso, que de verde se transmuda em } \\
\text { vermelho-sangue, verso da predileção de Ezra } \\
\text { Pound e também de Borges" (cf. CAMPOS, } \\
\text { 2011a, p. 119). } \\
\rightarrow \text { O vocábulo grego "polúphloisbos" tem o } \\
\text { sentido de polissonoro; foi utilizado por Homero } \\
\text { (llíada, I, 34) para engendrar o efeito do bater } \\
\text { das ondas do mar. }\end{array}$ \\
\hline $\begin{array}{l}\text { "[...] sasamegoto a fala daquela dona coisa de } \\
\text { fala mascada ou molhada marulho ou murmulho } \\
\text { cicio ou sussúrrio balcúcie ou borbulha ou } \\
\text { mussitar ou musselina e sasamegoto sachet } \\
\text { mascado na língua whispering aquela dona } \\
\text { companheira de carruagem diria buson ou bashô } \\
\text { buson enquanto a primavera haru same ya chove } \\
\text { palavras maceradas [...] aquela fala hikari dô a } \\
\text { luz curva como lâmina de ouro [...] (destaques } \\
\text { nossos)" }\end{array}$ & $\begin{array}{l}\rightarrow \text { Nas palavras de Haroldo de Campos (2011a, p. } \\
\text { 120-121): "em japonês 'coisa de palavras', } \\
\text { vocábulo tão onomatopaico (o significado é o } \\
\text { mesmo) quanto o nosso 'sussuro' (que deformei } \\
\text { expressivamente em 'sussúrrio', para abranger } \\
\text { também murmúrio)". } \\
\rightarrow \text { Ainda, temos alusão a Bashô e a Buson, } \\
\text { entretecendo esse formante; "duas viagens: } \\
\text { uma, num cenário de primavera, de carruagem; } \\
\text { outra, num cenário de inverno, de trem" (p. 121). } \\
\text { Tais imagens convocam no enunciado a figura } \\
\text { feminina, que parece interseccionar-se tanto } \\
\text { num texto quanto no outro, uma no cenário } \\
\text { japonês, a outra no de Praga. }\end{array}$ \\
\hline $\begin{array}{l}\text { "[...] apenas uma dona contra o biombo de papel } \\
\text { dum leque imaginário sussurrando coisas } \\
\text { monogatari estórias de papel num leque o oval } \\
\text { azul subindo como uma lua tsuki aoi tsuki mas } \\
\text { ahoj quer dizer também olá ou alô adeus }[. . .] \\
\text { (destaques nossos)" }\end{array}$ & $\begin{array}{l}\rightarrow \text { "A palavra aoi ('azul' em japonês), } \\
\text { superpondo-se (ou 'subpondo-se') à palavra ahoj } \\
\text { (em tcheco, uma saudação, 'olá') deflagra o } \\
\text { 'momento da metamorfose' em que as duas } \\
\text { linhas tênues de história se intrincam (se } \\
\text { intrigam) no texto" (cf. CAMPOS, 2011a, p. 121). }\end{array}$ \\
\hline
\end{tabular}




\begin{tabular}{|c|c|}
\hline $\begin{array}{l}\text { "[...] açafrão amarelo ovo vermelho tirante a } \\
\text { zarcão pompeiano se poderia dizer depois de ter } \\
\text { visto pompeia os frisos de amorini sobre o fundo } \\
\text { giallorosso mas aqui é roma as cores romanas } \\
\text { bandeirando o azul finíssimo friíssimo da } \\
\text { rarefeita manhã de janeiro o inverno brando } \\
\text { aquele ano quase primaverando nos primeiros } \\
\text { verdes e vermelhos e ourofulvo e zarcoamarelo e } \\
\text { ovojalde e carmesim e velhas revelhas paredes } \\
\text { imperiais e velhosrevelhos palazzi barrocos }[\ldots . .] \text { " }\end{array}$ & $\begin{array}{l}\rightarrow \text { “Cenário barroco de Roma. Uma tentativa de } \\
\text { 'conto do vigário'. Uma viúva deblaterando } \\
\text { contra o 'perigo vermelho'. Praças e fontes. O } \\
\text { Museu Etrusco de Villa Giulia. A Vênus } \\
\text { ('dedimármora', à maneira, mais uma vez, de } \\
\text { Odorico Mendes) Capitolina. O Forum Romano } \\
\text { abandonado pelos deuses. Uma ungarettiana } \\
\text { 'Signora Andrea' (o 'oro velino' alude à textura } \\
\text { da pele) preside à imagem do livro, que se } \\
\text { articula como uma escultura portátil (da viaggio, } \\
\text { 'para viagem'), a exemplo daquelas concebidas } \\
\text { pelo futurista-construtivista Bruno Munari” (cf. } \\
\text { CAMPOS, 2011a, p. 122). }\end{array}$ \\
\hline $\begin{array}{l}\text { "[...] circuladô de fulô ao deus ao demodará que } \\
\text { deus te guie porque eu não posso guia eviva } \\
\text { quem já meu deu circuladô de fulô e ainda quem } \\
\text { falta me dá }[\ldots] \text { ". }\end{array}$ & $\begin{array}{l}\rightarrow \text { Texto construído por meio de operações de } \\
\text { som e de sentido, um jogo entre PE e PC; um } \\
\text { enunciado nos moldes "dos 'desafios' dos } \\
\text { cantadores nordestinos, reminiscentes, por seu } \\
\text { jogo elaborativo, das justas trovadorescas" } \\
\text { (CAMPOS, 2011a, p. 121). }\end{array}$ \\
\hline $\begin{array}{l}\text { "[...] como quem escreve um livro como quem } \\
\text { faz uma viagem como quem descer descer } \\
\text { descer katábasis até tocar no fundo e depois } \\
\text { subir subir subir anábasis subir até aflorar à tona } \\
\text { das coisas mas só as pontas as cristas as arestas } \\
\text { assomam topos alvos de icebebergs agulhas } \\
\text { fagulhas [...] peles vogais molhadas líquidas } \\
\text { vogais eslavas pipilando ptítsas outoniça beleza } \\
\text { ainda segura de si nos cílios ruivo-claros quase } \\
\text { sem mover o rosto que o queria como um filho } \\
\text { que ninguém ninguém o conseguira deter do } \\
\text { brasil para a Alemanha e fôra para o fronte russo } \\
\text { porque quisera sombras na majólica sim } \\
\text { porquequisera [...] (destaques nossos)" }\end{array}$ & $\begin{array}{l}\rightarrow \text { Convoca no enunciado as vogais do idioma } \\
\text { russo, comparadas a pássaros, "ptítsa" (em } \\
\text { russo). A figurativização feminina revela-se pelo } \\
\text { adjetivo de cor da pele, "majólica". Nesse } \\
\text { formante, "há um 'fio' de história: russa branca, } \\
\text { enfermeira de um hospital de campanha, tenta } \\
\text { comunicar aos parentes de um jovem soldado } \\
\text { alemão, de origem brasileira, que este sofrera } \\
\text { amputação das duas pernas, gangrenadas; a } \\
\text { carta, por um descuido, cai nas mãos do } \\
\text { paciente, que se suicida com um tiro. Um chofer } \\
\text { lituano, radicado no Brasil, conta a seu } \\
\text { passageiro o que significa a guerra no inverno, } \\
\text { para depois perder-se em reminiscências } \\
\text { idealizadas da terra natal, da qual saíra fugido. A } \\
\text { 'majólica' segue palrando [emitir sons sem } \\
\text { sentido; tagarelar], refere-se a um gorro de peles } \\
\text { moscovita e ao marido. Aparententemente, tudo } \\
\text { se passa numa cama, ao ritmo de um subir } \\
\text { (anábasis) e de um descer (katábasis), cadência } \\
\text { elementar, vai e vem orgásmico do mundo (do } \\
\text { livro)" (CAMPOS, 2011a, p. 120). }\end{array}$ \\
\hline $\begin{array}{l}\text { “[...] aquele como se chama americano louco } \\
\text { crazy american disse Miguel com seu perfil de } \\
\text { príncipe azteca e disse também gringo mas não } \\
\text { para ofender amistosamente comprara um carro } \\
\text { e se botara de new York a méxico city com } \\
\text { mulher e filhos mal sabendo guiar e não falando } \\
\text { nenhuma palavra de espanhol só gracias gracias }\end{array}$ & $\begin{array}{l}\rightarrow \text { Os atores do enunciado, um casal jovem, } \\
\text { judeus americanos, com suas crianças, no } \\
\text { México, fazem um passeio de carro a Toluca. O } \\
\text { ator, narrador, cumpre o papel de intérprete do } \\
\text { casal, nada podendo fazer para acalmar a } \\
\text { teimosia do americano, que dirige } \\
\text { "atabalhoadamente seu veículo alugado pelas }\end{array}$ \\
\hline
\end{tabular}


e no compreendo se chamava harry sim e a mulher sara judia de olhos amêndoas para o méxico pouco dinheiro e com vontade de ficar your contry is not killing people por trás dos olhos claros in vietnam guiando às tontas baratatonta fuck it pela trama dos calles quase duas horas para chegar a churubusco perto de la ermita damn it fuck it praguejava tonto [...] nessa mão a direita descobre a coxa tatuada jarreteira ouro à altura do joelho e celhas riscoblíquas sobre os olhos amêndoa em lentacâmera o looping e o carro virado sobre si mesmo a carretera também virada sobre si mesma nem sangue nem fogo nem fezes no coalho de óleo intactos na lata amassada entre vidros puídos e você e harry e sara e crianças arreliando com voz de pato donald e sara e harry e você para toluca e crianças para toluca vivos viva-a-vida para o mercado cor tortilla de toluca [...]".

"[...] na coroa de arestas das manchetes quinas de letras feito espinhos quebrados e polira sua vontade como um diamante que-sim apesar dos pulmões cansados velhos foles abrasados de asma ou rustidas esponjas cor de carne [...] a velha com suas cabras mensageira do averno a uma légua de higueras e duas de pucara caminhos entrecaminhos descaminhos a vontade polida é um diamante e cintila com sua crista viril [...] esse cristal aqui o livro para câmbio tríptico agora a cena aclara marilyn marilinda amarílis de Marilyn em vermelho e preto e louro e rodomel [...] está sentada nua e meio aberta post ludium vel post coitum meio aberta manuseada talvez ou publiolhada multitacteada aberta fornicada [...] sentada se respalda num coto de antebraço os seios são glândulas mamárias e pesam como laranjas de cera [...] poderia estar assim a cavalo de um bidê fúnebre coxas em garfo [...] aqui no livro o tríptico e o triunfo de vênus [...] a terceira marilyn está morta nua e morta cavalgando o bidê fúnebre cores psicoldélicas rosa-choque e azul-magneto drop dead para a mira de um fuzil de dallas na coroa de arestas das manchetes [...]"

"[...] cheiro de urina de fécula de urina adocicada e casca de banana de manga rosa quando esmagada no chão o calçamento desliza nos pés como se você estivesse entrando por uma região viscosa um aberto de vagina em mucosa pedrenta tudo cheirando vida ou morte ou vidamorte um cheiro podre de orgasmo rançoso ruas e rodovias mexicanas. Palavras astecas, visões e reminiscências de gente e paisagem, constelam a narração, o 'textoviário'. A morte, a mirada lorquiana da morte, vai-se insinuando no fluxo do texto, até o desfecho (um acidente na estrada visualizado em câmera lenta) e a eufórica afirmação da vida, no júbilo da sobrevivência" (CAMPOS, 2011a, p. 122).

$\rightarrow 1^{\circ}$-- Duas figuras da morte:

Che Guevara $\rightarrow$ na manchete: "pulmões abrasados de asma", "à desconfiança dos camponeses, a Las Higueras, à 'velha condutora de cabras', a um diário de campanha" (CAMPOS, 2011a, p. 121).

Presidente Kennedy $\rightarrow$ "morte à americada"; "passa uma bala perdida = "drop dead para a mira de um fuzil de dallas" (CAMPOS, 2011a, p. 121).

$\rightarrow 2^{\circ}$-- Figura feminina + Figura morte $\rightarrow$ no enunciado, a práxis de um artista "polindo a sua vontade como um diamante", "um tríptico (à maneira de Andy Warhol) dedicado a Marilyn Monroe", convocada no texto "como uma suicida por náusea": "uma tigresa a cavalo de um bidê fúnebre, macabro triunfo de Vênus" (CAMPOS, 2011a, p. 121).

$\rightarrow$ Espaço da narrativa: Salvador. Haroldo de Campos (2011a, p. 120) comenta o formante: "o barroco 'mestiço', ibérico e afro-índio ('arte da contraconquista', como quer Lezama Lima). O ouro dos altares e os azulejos 'legíveis' dos claustros. A capoeira no mercado das Sete Portas. A festa de lansã. A alegria da cultura 
e peixe e postas de carne ao sol a muleta solavanca um aleijão que come farinha com dedos apinhados cor cafre café ocre moca o peito apoja debaixo da fazenda rala e emborca para uma zona tórrida de coxas colantes e grelo fio-de-mel agora é a mulata de olhos bistrados que reolha um espelho de lata e esmalte e correm para o oval de reflexos fósforos faíscas um cio remontado de cachorros também cheiros gritos trilos psius o fartum da rua [...] eu repito como veio sem pensar repito como o om da mandala refalo remoo repasso colorless green ideas sleep furiously dormem incolores ideias verdes dormem furiosamente verdes dormem furiosamente" (destaques nossos). negra e o 'espanto sagrado'. A 'comida santa'. O convite ao ágape ritual, participatório e propiciatório".

$\rightarrow$ Observar o uso de figuras relativas aos sentidos que lhe dão intensidade:

1. Olfato: cheiro, cheirando vida ou morte, cheiro podre, cheiros fartum da rua.

2. Tato: esmagada, desliza nos pés, região viscosa, come farinha com dedos, fazenda rala, zona tórrida, coxas colantes.

3. Visão: cor cafre, mulata de olhos bistrados, reolha um espelho, ideias verdes.

4. Audição: gritos, psios, onda mandala.

5. Paladar: urina adocicada.

Enfim, o trecho transcrito é uma festa para os sentidos; há uma acentuação pela ênfase do sensível.

$\rightarrow$ Há uma aproximação aqui do enunciador, revelado no ator "eu", que assume seus escritos como vindos "sem pensar", acompanhados da musicalidade de "om da mandala"; fica ao enunciatário o efeito de sentido de frase solta, "agramaticidade e falta de sentido" chomskiano, citado diretamente no texto pelo enunciado: "colorless green ideas sleep furiously". Haroldo de Campos (2011a, p. 120) revela que, além do sentido de frase solta, a frase de Chomsky dentro desse formante seria um '“achado' poético, imantando-se de cores e sons". Desse modo, mais que a direção de "agramaticidade", teríamos em Galáxias o encantamento hipnótico dos sons que se entrelaçam, formando cores e imagens vívidas da ordem da intensidade.

"[...] tudo isto tem que ver com um suplício chinês que reveza seus quadros em disposições geométricas pode não parecer mas cada palavra pratica uma acupunctura com agulhas de prata $[\ldots]^{\prime \prime}$

"[...] um sistema simpático de linfas ninfas que se querem perpetuar por um simples contagio de significantes essa torção de significados no instante esse deslizamento de superfícies fônicas $\rightarrow$ Descrição de um suplício chinês, que serve de base para a comparação com o suplício da palavra: "cada palavra pratica uma acupunctura com agulhas de prata". A figura acupunctura com /c/ antes do /t/ traz no próprio significante um ferrão que espeta, tornando o enunciado ainda mais vívido. Vê-se na animização prosopopeica ("cada palavra pratica uma acupunctura") como o enunciador entende a literatura: entende-a como palavras que produzem efeito porque são vívidas e espetam como agulhas.

$\rightarrow$ “As 'ninfas' de Mallarmé viram 'linfas' de um sistema simpático que subjaz ao texto e o rege" (CAMPOS, 2011a, p. 121). Aqui, temos um destinador evidenciado: Mallarmé. 
que por mínimos desvãos criam figuras de rociado rosicler et volucres veneris mea turba columbae mas é também um suplício chinês [...] (destaques nossos)"

"[...] passando entre rodízios tinguunt gorgoneo de vento o sangue não aflora contido em capilares preso em paredes venosas cuja textura punica rostra lacu [...] (destaques nossos)"

"[...] feito um oco então nostrademo cacofante descriptará os renogramas pétreos cacata carta na frase de catúlio cat-face e se ouvirá o seu testremento [...]" (destaques nossos).
"[...] passatempos e matatempos eu mentoscuro pervago por este minuscoleante instante de minutos instando alguém e instado além para contecontear uma estória scherezada minha fada quantos fados há em cada nada nuga meada noves fora fada scherezada scherezada uma estória milnoitescontada então o miniminino adentrou turlumbando a noitrévia forresta e um drago dragoneou-lhe a turgimano com setifauces furnávidas e grotantro cavurnoso meuminino quer-saber o desfio da formesta o desvio da furnesta só dragão dragoneante sabe a chave da festa e o dragão dorme a sesta entãoquão meuminino começou sua gesta $\rightarrow$ Citação de versos de Propércio (43 a. C. - 17): "et volucres Veneris, mea turba, columbae / tinguunt Gorgoneo punica rostra lacu // tradução de Haroldo de Campos (2011a, p. 121): "e os pássaros de Vênus, o meu bando, pombas / tocam o lago - bicos vermelhos - Gorgôneo"; poeta elegíaco e contador de mito romano. Nascido em Assis (Itália), Propércio foi um representante da escola de Calímaco. Seus versos foram traduzidos para o italiano no Renascimento; inspiraram também as Elegias Romanas de Goethe. Trata-se de um poeta de metáforas agudas e vívidas; de linguagem poética obscura que tem seus contornos esmaecidos.

$\rightarrow$ Alusão ao poeta italiano veronese Caio Valério Catulo (87 a. C. - 54 a. C.). Ambientado no círculo dos poetas "novos", Cícero os considerava disforicamente "modernos e novos". Esse grupo a que pertencia Catulo tem como programa romper com o passado literário romano, quanto utiliza temática considerada "menor" pelos críticos da linha de Cícero. Ademais, a mestria poética de Catulo, que explora a linguagem coloquial, simula com muita frequência o "improviso", lançando mão de um sintagma que se interrompe por orações paratáticas (frases justapostas, estanques e sem ligação por meio de conectivos conjuncionais coordenativos, portanto), por repetições de palavras e expressões, revelando um efeito de sentido de circularidade e dinamicidade.

$\rightarrow$ Temos nesse formante uma fábula da busca. No lugar da busca de um "talismã", busca-se aqui o próprio fazer do conto, o ator do "quem" da narração, à maneira de Guimarães Rosa. O ator "meuminino", perdido na floresta, dialoga com "Scherezada", com "a Bela Adormecida", com um "Dragão" que "parece o Jabberwocky de Lewis Carroll, Dânae e sua chuva de ouro, um cisne (mallarmeano: cigne / signe d'autrefois; [em Haroldo, "um cisne de outra vez"]) que profere o seu 'canto de cisne', fadas, o 'bicho malinmaligno' chamado 'Verossímil', a 'Fata Morgana', Mãe-das-Pedras-Preciosas" (CAMPOS, 2011a, p. 120). 
cirandejo no bosque deu com a bela endormecida belabela me diga uma estória de vida mas a bela endormida de silêncio endormia e ninguém lhe contava essa estória se havia meuminino disparte para um reino entrefosco que o rei morto era posto e o rei posto era morto mas ninguém lhe contava essa estória desvinda meuminino é sotoposto a uma prova de fogo devadear pelo bosque forestear pelo rio trás da testa-de-osso que há no fundo do poço no fundo catafundo catafalco desse poço numa testa-demorto meuminino transfunda adeus no calabouço mas a testa não conta a estória do seu poço se houve ou se não houve se foi moça ou foi moço um cisne de outravez lhe aparece no sonho e pro cisnepaís o leva num revoo meuminino pergunta ao cisne pelo conto este canta seu canto de cisne e cisnecanta-se [...] scherezada minha fada isto não leva a nada princesa-minha-princesa que estória malencontrada quanto veio quanta volta quanta voluta volada [...] e a lenda não conta do seu fadário se voltou ou não voltou se desse ir não se volta a lenda fechada em copas não-diz desdiz só da voltas [...]" (destaques nossos).

"[...] nudez o papel-carcaça fede-branco osso que supura esse esqueleto verminoso onde ainda é vida a lepra rói uma quina do edifício na rua 23 e vê-se um sol murchado margarida-gigante despetalar restos de plástico num vidro violentado como um olho em celofane sérum o bicho-tênia recede nas cavernas do amarelo muco esgotescroto quem move a mola do narrar quem dis para esse dis negpositivo [...] fezes vermicego verminíquio vermicoleando augúrios uma labirintestina oudisseia perderás todos os companh tautofágica retornarás marmorto fecalporto gondondoleando em nulaparte tudonada solilóquio a lunavoz oudisseu nenhumnome et devant l'agression rétorquer a margarida despetalada violentada [...] new york grooviest men's club the gemini porta partida em coração lovely masseuses sauna waterbeds circe ao cono esplêndido benecomata oudisseu nenhumnome parou aqui este livro uma tautodisseia dizendo-se parou aqui e passou além morto roxo exposto como um delfim tot rot und offen à beira-vênus num nascimento de vênus aphródes escumante e deixar que tudo se organize num azul sutilíssimo tapeçaria $\rightarrow$ Essa busca infinita revela-se um novelo de imagens intertextuais, que evidencia o percurso de um sujeito, ator criança, o meuminino, que se perde no labirinto de uma floresta de tradições literárias. $\rightarrow$ Haroldo de Campos (2011a, p. 122) chama esse formante de "tautodisseia": uma "'Odisseia Tautológica'. Um Ulisses 'solitudinário', como um 'bicho-tênia', faz uma viagem sem volta, às voltas com seu 'intestino escritural'".

$\rightarrow$ Comenta ainda que essa metáfora metalinguística de trabalho do fazer poético no interior do texto sobrepõe-se à caricatura do episódio de Circe, trecho de Odisseia de Homero, em que Circe, uma feiticeira, aconselha Ulisses a cobrir os ouvidos dos marinheiros com cera para que não ouçam o canto da sereia; nesse sentido, o formante de Haroldo de Campos intertextualiza Circe, ambientado agora em uma casa de massagens nova-iorquina, em que a deusa converte-se numa "beneconata" masseuse, Miss Pussy.

$\rightarrow$ A frase de Mallarmé ("et devant l'agression rétorquer que des contemporains ne savent pas lire") perpassa o texto de Galáxias que, segundo Haroldo de Campos (2011a, p. 122), "culmina numa visão à Hieronymus Bosch: um 'grande rebanho de ovelhas varicosas'". 


\begin{tabular}{|c|c|}
\hline $\begin{array}{l}\text { vitrificada por onde raiam caules de luz } \\
\text { amaranto [...] uma torção do tempo famosus ille } \\
\text { fabulator que se faz memória } \\
\text { mementomomentomonumental matéria } \\
\text { evêntica desventrada do tempo da marsúpia vide } \\
\text { espaço do tempo um livro também constrói o } \\
\text { leitor um livro de viagem em que o leitor seja a } \\
\text { viagem um livro-areia escorrendo entre os dedos } \\
\text { e fazendo-se da figura desfeita onde há pouco } \\
\text { era o rugitar da areia constelada um livro perime } \\
\text { o sujeito e propõe o leitor como um ponto de } \\
\text { fuga este livro-agora travessia de significantes } \\
\text { que cintilam como asas migratórias de novo a } \\
\text { quina pulverulenta do edifício da rua } 23 \text { de novo } \\
\text { circe [...] quem ouve a fábula exsurgindo entre } \\
\text { safira e fezes quem a vê que desponta sua réstia } \\
\text { de rádium entre lixívia e sêmen para um rebanho } \\
\text { de orelhas varicosas grandes ouvidos moucos } \\
\text { orelhas de abano flácidas bandeiras murchas que } \\
\text { des contemporains ne savent pas lire ouver [...]" } \\
\text { (destaques nossos). }\end{array}$ & $\begin{array}{l}\rightarrow \text { "travessia de significantes"; dá destaque ao } \\
\text { papel do significante nas composições do final do } \\
\text { século XX. Observar o verbo "cintilar" } \\
\text { relacionado a significantes: não são significantes } \\
\text { opacos, mas que cintilam tanto que, ao mesmo } \\
\text { tempo, obnubilam o conteúdo, delongando seu } \\
\text { reconhecimento. }\end{array}$ \\
\hline "[...] fecho encerro [...]" & \\
\hline
\end{tabular}

Galáxias inicia-se com uma cena que tem o efeito de sentido de revelar-se escritura no espaço branco da página: "e começo aqui e meço aqui este começo e recomeço". Nessa obra, segundo Aguilar (2005, p. 311), "Haroldo de Campos pode ampliar seu campo de ação, primeiro experimentando com a prosa poética (e encerrando a etapa concreta) e, depois, retornando ao verso (sobre o que pesava uma interdição na etapa ortodoxa)". Daí recuperar em seu texto poetas da tradição do verso, caminhando em direção aos poemas de um cânone passado.

Além disso, em Galáxias os começos repetem-se em todos os formante: "em cada repetição, ao mesmo tempo em que modificam retroativamente seu antecedente, geram uma translação rumo ao porvir. Uma escritura, como a definiu Severo Sarduy, 'cujo suporte funcional é a diferença e cujo motor é a repetição'" (AGUILAR, 2005, p. 313). Nas Galáxias, o enunciador projeta-se, ganhando acentuação de voz nas repetições e transformando tais repetições em um princípio ordenador:

por isso recomeço por isso arremeço por isso teço escrever sobre escrever [...] por isso começo descomeço pelo descomêço desconheço e me teço um livro [...] por isso começo pois a viagem é o começo e volto e revolto na volta recomeço reconheço remeço um livro [...] por isso não conto por isso não canto por isso a nãoestória me desconta ou me descanta [...] e aqui me 
meço e começo e me projeto eco do começo eco do eco de um começo em eco no soco de um começo em eco no oco eco de um soco [...] ou avante ou paravante ou à ré ou a raso ou a rés começo re começo rés começo raso começo [...] no osso do começo só conheço o osso o osso buco do começo a bossa do começo onde é viagem é maravilha de tornaviagem é tornassol viagem de maravilha $[\ldots]$

As palavras orbitam como se fizessem parte de uma galáxias; cada palavra é uma matriz de repetição paronomásica, que engendra no enunciado uma constelação de palavras semelhantes na sonoridade, cujo reconhecimento é retardado. As imagens proliferam-se numa simultaneidade que lembra uma pintura. Trata-se, pois, de reiterações, que se singularizam a cada atualização no processo de Galáxias, que tem em sua estrutura as seguintes características:

- O desdobramento do signo em "começo" -- começo - descomeço - recomeço - meço -- atribui à paronomásia o estatuto de operar pela diferença, a qual se encontra englobada pela repetição. Não temos nesse exemplo uma identidade nominal exata do significante que atua como diferenciador de significados distintos. Além disso, subjaz um efeito de sentido de semelhança sonora que engendra um efeito de identidade no conteúdo. O enunciador lança mão do excesso, da intensidade; a linguagem para ele tem uma sobra de recursos fonológicos, morfológicos, semânticos, sintáticos: "ele desempenha o papel de precursor sombrio, isto é, em que, falando de coisas diferentes, ele diferencia estas diferenças, relacionando-as imediatamente umas às outras em séries que ela faz ressoar" (DELEUZE, 2006, p. 177).

- A repetição das palavras não pode ser avaliada como desprovida de diferença. Galáxias reúne em seu enunciado uma quase excessiva série aparentemente despropositada, divergente; no entanto, constituem-se as figuras uma constelação semântica e uma constelação sonora. O conteúdo é entretecido por palavras-valises que "engendram o efeito do ideograma através da palavra" e incorporam em um continuum os vários elementos da ação ou da visão (cf. CAMPOS, 1977a, p. 58). Esses artifícios agudos, por meio de uma rede de relações de identidades e diferenças, formam-se à semelhança de um estribilho ou um ritornello sonoro, que ecoa em toda a obra. 
Haroldo de Campos espacializa a operação da escritura: o verso tem seu percurso visual sobre o branco da página, configurando um movimento acelerado do signo que puxa paronomasicamente outros signos e perfazendo, assim, o contínuo sintagmático do desenho de uma linha; as técnicas de disseminação e as anagramáticas utilizadas em Galáxias são comuns também a outros objetos do século XX, como estamos estudando nesta tese.

De mais a mais, cada formante, além de ser considerado como peça autônoma, espelha outro: "monodologicamente, em cada fragmento, estão todas e cada uma das Galáxias. Daí a possibilidade de sua livre leitura, a partir de qualquer página" (CAMPOS, 2006, p. 272).

No último formante, confirma-se um ludismo linguístico, com um aparente desarranjo do sentido que maravilha inicialmente; os entraves formais conduzem a uma demorada apreensão, estimuladora de novos sustos e deleites estéticos:

fecho encerro reverbero aqui me fino aqui me zero não canto não conto não quero anoiteço desprimavero me libro enfim neste livro neste voo me revoo mosca e aranha mina e minério corda acorde psaltério musa nãomaisnãomais que destempero joguei limpo joguei a sério nesta sêde me desaltero me descomeço me encerro no fim do mundo o livro fina o fundo o fim o livro a sina não fica traço nem sequela jogo de dama ou de amarela cabracega jogo da velha o livro acaba o mundo fina o amor despluma e tremulina a mão se move a mesa vira verdade é o mesmo que mentira ficção fiação tesoura e lira que a mente toda se ensafira [...]

[...] velho contador de lériaslendas aqui acabas aqui desabas aqui abracadabracabas ou abres sésamoteabres e setestrelas cada uma das setechaves sigilando à tua beira à beira-ti beira-nada vocêvoz tutresuvariantes tua gaia sabença velhorrevelho contador de palavras de patranhas parêmias parlendas [...]

Se comparado com enunciados poéticos que seguem a linha da organização sintagmática tradicional, o texto de Haroldo de Campos parece sem sentido; todavia, ele é regido por agudezas que o distanciam de textos que permitem um reconhecimento inteligível rápido.

No formante citado, o enunciador estabelece um balanço da rota da sua viagem e informa o enunciatário sobre o encerramento de suas histórias: "fecho encerro reverbero aqui me fino". As imagens metafóricas vão se formando plasticamente à vista do enunciatário, uma atrás da outra, sem nenhuma pontuação, de forma que tudo ocorre simultaneamente como numa tela pictórica: "me revoo mosca e aranha mina e minério corda acorde psaltério". Em seguida, procede a um diálogo intertextualizado, citando 
Camões ("nãomaisnãomais que destempero") e Cortázar ("jogo de dama ou de amarela cabracega"). O conjunto dessas imagens engendra uma écfrase, proporcionando uma vivificação do enunciado.

Além da plasticidade visual, o texto explora, como dissemos, a musicalidade, fazendo imperar os sons mais em um primeiro momento, mas só em um primeiro instante, visto que as metáforas agudas haroldianas são enredadas umas às outras como em uma elipse galáctica: "saltimboca e desemboca e pororoca nesse fim de rota". Enfim, o enunciador revela-se "mastigador de palavras malgastas", mostrando seu próprio fazer poético.

De modo geral, as metáforas de Galáxias aparecem em rede e são entretecidas na própria constituição morfológica das palavras, numa operação paronomásica, regida por escolhas sonoras, em que uma palavra atrai outra palavra de som correspondente.

Por exemplo, quando da escolha de "abracadabracabas ou abres sésamoteabres e setestrelas cada uma das setechaves", o enunciador opta pela agudeza sonora, proporcionando uma sonoridade imbricada e em cadeia. Como dissemos, porém, esse deleite sonoro é momentâneo; por mais que haja uma exploração na intensificação sonora, ainda assim subjaz a forma da expressão e do conteúdo. O caráter hipnótico dos enunciados, com sua densidade sonora acentuada, produz uma literatura que se apoia principalmente nos trabalhos formais, agudos.

Abracadabra é uma palavra que os antigos entendiam ter a virtude de curar moléstias. Além disso, sua escrita cabalística permitia-lhe ser lida em várias possibilidades combinatórias de sentido. A metáfora selecionada traz à tona também o efeito de sentido irônico de que o texto constituído é uma expressão sem sentido, ilógica, ininteligível. Por isso, os enunciados não seguem uma organização sintagmática esperada, embora se faça com partes do discurso popular, intertextualizando-se com outros textos da literatura. $\mathrm{O}$ próprio enunciador encarrega-se de mostrar ao enunciatário que a literatura é para iniciados. Um texto sai de outro, uma palavra sai de dentro de outra palavra. Nas palavras de Galáxias, ao poeta não cabe mostrar, mas antes enigmatizar: "cada uma das sete chaves sigilando" ou, rompendo esse hipérbato: sigilando cada uma das sete chaves.

O poeta é o feiticeiro-mágico que encanta seu enunciatário por meio de paronomásia e esconde-esconde de palavras, ou se quisermos, em termos de semiótica tensiva, o poeta sabe fazer seus enunciados ganharem sentido pela vivificação aguda e pela introdução de andamentos variáveis (ora pela cifra da vivificação, ora pela da atenuação). 
A agudeza da tmese -- corte pela separação de elementos normalmente adjacentes e pela inserção de um termo intermediário (cf. LAUSBERG, 2004, p. 205) --, que aparece em "abres sésamoteabres", novamente encaminha o enunciatário para a isotopia da literatura como mágica, ludismo, enigma labiríntico. Observa-se também no enunciado citado uma repetição enfática e vívida pelo uso da epanalepse: repetição de uma palavra no início e no fim de uma oração (FIORIN, 2014, p. 117), "abres sésamoteabres". E é essa vivificação formal que produz um efeito de intensificação de duração estética e não apenas de informação.

Ademais, opera-se um diálogo intertextual com "Abre-te, Sésamo", uma frase mágica de Ali Babá em As mil e uma noites. Trata-se de uma expressão-chave que permitia abrir automaticamente a porta do esconderijo de 40 ladrões. Sésamo, em português lusitano, significa gergelim; portanto, abrir como se abre a flor de gergelim, liberando as sementes; a figura sementes cria o efeito de palavra poética que esconde um mistério. Finalmente, o enunciado do poema troca o imperativo pelo indicativo, uma espécie de enálage: uma troca de um modo verbal por outro (FIORIN, 2014, p. 97-98). Ao usar o indicativo e não o imperativo, o enunciador aproxima-se do enunciatário, não configurando mais uma ordem, mas condensando agudamente sésamo na figura discursiva do "tu", o enunciatário. Essa troca verbal gera um efeito de sentido de conforto, de conversa entre amigos, um tom coloquial de quem conta peripécias de viagem, as galáxias, para um ouvinte confidente.

Zilberberg (2006b, p. 200), analisando o poema "Larme" de Rimbauld, afirma que a angústia que assola o enunciador poético é a de suspender momentaneamente a arbitrariedade do signo. Retomando as duas metáforas haroldianas amalgamadas no sintagma "sésamoteabres", o enunciatário pode orientar-se pelo efeito de sentido de estar diante de um mundo em que tudo se junta e se separa, solve-se e resolve-se, num jogo em que o PE homologado ao PC converte-se num enigma. Nesse sentido, o poeta desenvolve um programa de reformular o PE para recriar por meio do trabalho com os significantes novos significados. A sina do poeta é abrir-se como a flor de sésamo. Ou espalha as sementes ou acaba-se: "abracadabracabas ou abres sésamoteabres". Ou te abres para espalhar sementes poéticas ou te acabas.

Quase ao fim do último formante, o enunciador volta a insistir que o trabalho do poeta de "sonegador de fábulas" e de "contraversor de fadas loquilouco snobishomem" leva à salvação da alma: "tua alma está salva tua alma se lava nesse livro". Em "sonegador de 
fábulas", a metáfora aguda confere, por catálise, ao enunciador o papel ativo de selecionador: sonega algumas fábulas por irrelevantes e apresenta outras que considera mais oportunas. Já em "contraversor de fadas loquilouco snobishomem", temos uma acentuação pela acumulação de imagens. A agudeza "loquilouco" condensa:

"loquaz" + "louco":

loquaz = aquele que demonstra prazer em falar, que provoca ruído (HOUAISS; VILLAR, 2001);

louco = figurativiza aquele cujo comportamento é tido como extravagante (HOUAISS; VILLAR, 2001).

Daí ser o poeta "loquilouco", porque acumula o prazer de provocar "ruído" e ser "extravagante" nas relações associativas e nos processos sintagmáticos e nos maravilhamentos que produz com seu fazer poético.

Em "snobishomem", temos novamente a acumulação de duas imagens, a de ser "esnobe" e "lobisomem". Esnobe é próprio de quem tem gosto pelo excesso e de quem quer se fazer ver por suas escolhas raras, características da engenhosidade poética do homo poiético. Em "snobishomem", vê-se ainda uma anagrama de "lobisomem", figurativizando o comportamento enigmático e noturno de um ser singular. No sentido metalinguístico, o poeta é aquele que suga o "sangue" dos outros poetas para poder se manter ativo; assim, o poeta apodera-se da tradição para compor uma tradição viva. O que ocorre sempre nos enunciados de Galáxias é uma acumulação de agudezas: as imagens condensam-se por metáforas (PC) e acumulam-se por anagramas e paronomásias (PE), que, enredadas, produzem um efeito de sentido de elevada tonicidade na intensidade.

Em seguida, forma uma imagem de acentuação sensível em que se compara a uma vela que liberta a luz enquanto se consome: "enquanto o finas ele translumina essa linguamorta essa moura torta [...] pois o livro é teu porto velho". Neste último enunciado agudo, o livro velho aparece como um porto, podendo ser lido segundo duas isotopias: a de livro velho e a de porto velho. Aqui, temos uma hipálage, ou seja, uma agudeza de concentração semântica, em que um traço sêmico de um determinante passa a ter maior amplitude (FIORIN, 2014, p. 66); assim, um adjetivo passa a ter maior extensão, provocando maior intensidade de sentido. Comumente, na hipálage desloca-se um adjetivo que se acumula, qualificando mais de um substantivo: "livro é teu porto velho" = "livro velho + 
porto velho". Nesse sentido, há uma vivificação por acumulação (e deslocamento). Assim, "livro velho" figurativiza por acumulação a literatura da tradição somada à tradição como lugar seguro. Por isso, é também porto velho dos literatos, porto a que se retorna sempre. Com a mudança acumulativa proporcionada pela hipálage, dá-se uma intensificação do sentido, que se propaga para os dois substantivos.

Diferentemente das fábulas que ao final são neutralizadas por uma direção moralizante, a poesia aguda tonifica-se para atingir uma finalidade estética; e aqui a linguagem tem o papel principal. Nesse sentido, ela rompe com a tradição ética da literatura em que o enunciatário era conduzido, por meio da poesia, a realizar uma catarse para sair-se limpo de alma, descarregado de suas máculas morais. O enunciador que se encaminha para a agudeza, por sua vez, propõe uma literatura que não se extrapola da própria literatura, que não tem finalidade de ensinamento.

\subsubsection{O RECRUDESCIMENTO DA FLUIDEZ EM GALÁXIAS}

Há alguns objetos estéticos que conhecem o recrudescimento da fluidez, como ocorre em variados momentos de Galáxias. Vejamos um exemplo:

[...] coando como uma papa um mingau de gosma uma graxa gósmica escoando murcha / onde as coisas borram como bolhas bolham desossam descaroçam cartilagem / mucilagem água de lavagem coalhando na barrela agora você se lembra / uma dona fazendo um canudinho com uma nota de quantos dólares e pondo-a / atrás da orelha galante concha da orelha ivorio e falando e palrando e / palrinando com os companheiros de mesa um velho e uma gorda un grasso e una lorda nympholucrosmaragdomania [...] (CAMPOS, 2011a, fomante sem numeração, destaques nossos)

Os lexemas do fragmento transcrito apresentam contorno apenas aparentemente definidos, visto que estão um após outro em encadeamento fluido. Funcionam no texto como uma torrente de palavras sem limites definidos, que se entorna sobre o branco da página. O poema não conhece pontuação nem nexos sintáticos, o que contribui para 0 alongamento estético do plano da expressão (sons) e para o delongamento do reconhecimento do plano do conteúdo. Além disso, no trecho transcrito, o amontoado "nymphoLUCROSmaragdomania" perturba os limites ou contornos formais: temos aqui um lexema ou um amontoado sonoro de caixa registradora?

A palavra "ninfo---mania" (nymphomania) aparece separada (tmese), ocupando os extremos do lexema; o meio é preenchido pela paronomásia "pholu" que é uma aglutinação 
de "falo (pholu)" com "[eu] fodo (pho-do)", produzindo um efeito de sentido de corpos entrelaçados, em fusão. Outras combinações anagramáticas também contribuem para o rompimento dos limites. Ainda constam em "nympholucrosmaragdomania" SADOMASO (de sadomasoquista), MARA (maravilha), MAGDO (grandioso), LUCROS; esta última desencadeadora das isotopias "comércio de corpos", "prostituição". Enfim, a cópula carnal, cujos limites dos corpos já não se distinguem, homologa-se com a cópula verbal, em que uma palavra penetra na outra:

nymPHOluCROSMAragDOmania

O erotismo do texto vai obscurecendo e clareando partes do corpo e do ato sexual, embaralhando os limites; às vezes, antecipa fatos que ainda vão ocorrer, ou ocorrem apenas na imaginação do narrador. Assim, viscosidade aparece logo no início da cena atualizada por gosma, graxa, mucilagem, produtos da libido: "gosma uma graxa gósmica" (em que é notável a criação do verbo gosmar, como se dá adiante com o verbo bolhar [bolham]), bem como o declínio da cópula em "coisas borram" (anagrama de porra) e de perda da rigidez do falo ("murcha”): "desossam descaroçam cartilagem" (tecido do pênis).

Em gósmica, há um amálgama de gozo + cósmico: g[ozo c]ósmica[o]. "Escoando murcha", como já dissemos, antecipa o final da cópula: "mingau de gosma uma graxa gósmica (de gozo)". Assim, o processo de comer "comida" vai se confundindo com "comer" sexual.

Na perda de limites, sujeitos (atores: "um eu que narra", "um velho e uma gorda un grasso e una lorda") conversam à mesa e veem desfilar à sua frente uma prostituta nativa da Costa do Marfim (ivoriano, em italiano, significa originário da Costa D’Avorio [Marfim]). Ela desfila mostrando sua "orelha galante" (concha da orelha ivorio) com uma nota de "dólares" "atrás da orelha" com a qual ela faz "um canudinho". No Dicionário Houaiss (2001, verbetes concha e galante), um dos sentido de "concha" é vulva e de "galante" é "que revela certa malícia, picante". "Orelha galante concha da orelha ivorio" condensa parte do órgão auditivo com vulva, ambas da isotopia sexual. $\mathrm{O}$ adjetivo galante serve tanto para orelha galante quanto para concha (vulva) galante; nesse caso, os limites se confundem e o mesmo atributo serve a um e a outro substantivo, num processo que a retórica chama de hipálage, que serve para vivificar o enunciado. A vivificação dos sentidos sugere também um momento de suspensão da extensidade, com tudo o que implica inteligibilidade. Daí o 
espaço fechado (restaurante) e o tempo também limitado (o dia uma refeição). A pletora de sentidos envolvidos constitui-se de: audição (falando, palrando, palrinando), visão (murcha, borram, bolhas, coalhando, gorda, canudinho), olfato (água de lavagem coalhando na barrela), paladar (papa, mingau), tato (gosma, graxa, escoar). Enfim, um convite ao desfrute dos sentidos. A enunciação plasma um enunciador que quer ser competente para contar tudo o que se passa na cena. Investe-o de alta sensibilidade.

Nesse sentido, podemos dizer que, diferentemente da agudeza seiscentista, que privilegiava as relações inteligíveis, das quais sobressaía o cruzamento das dez categorias aristotélicas, na agudeza do final do século XX, persegue-se a sensibilidade. Varia também o programa de base, pois a arte dos séculos XVI-XVII era orientada pelo prodesse et delectare, enquanto hoje os artistas orientam-se pela autotelia. A poesia do final do século XX tem sua agudeza voltada para a visualidade e sonoridade, criando imagens "saturadas" de percepção dos sentidos. A arte que se volta para o homem, que também é corpo, mas que nem sempre ocupa um lugar euforizado. Nos seiscentos, mostra-se um homem preocupado em atenuar seus estados de alma pela razão; no final do século XX, inverte-se a operação e temos artistas que se preocupam em atenuar a razão para fazer sobressair o sensível e a sensibilidade material do poema.

Mais à frente, em "Lorda nympholucrosmaragdomania", vemos mais um caso de limite de esmaecimento do contorno, que seria para Zilberberg um basta. Lorda, em italiano, é impura, viciada (viciada em sexo e dinheiro (lucro), "nympholucro ... mania". Além disso, LUCRO + CROSMA junta-se ao mesmo tempo à palavra gosma citada duas linhas anteriores "papa um mingau de gosma". Todas da esfera da viscosidade.

A extensão colossal da junção de fonemas em nympholucrosmaragdomania sugere grandeza do vício, do falo e do ato sexual. O plano da expressão, assim como o plano do conteúdo têm seus limites formais atenuados: os sons se juntam como o prazer alimentício se junta ao prazer sexual; a gosma condensa mingau e a viscosidade do esperma.

Outro detalhe é a perda dos limites temporais quando afirma "agora você se lembra", o que faz notar uma enunciação enunciativa em primeira pessoa, presentificando um fato ocorrido há algum tempo e em outro espaço, configurando perda de nitidez entre passado (então) e presente (agora) e entre lá e aqui.

Uma das características dos poemas do final do século XX é a perda de limites entre as línguas. Em Ávila, é mais comum o uso do latim; em Haroldo, como vimos no trecho, o 
italiano e o latim confundem-se com o português no texto (it. ivorio, lorda, grasso; latim, phallus). Em Galáxias, encontramos outras misturas de inglês, português, latim, espanhol etc.

Outro elemento de mistura fluida é o ludismo presente nos anagramas, nas paronomásias, que propõe o desfrute de um labirinto linguístico. No caso do trecho analisado de Galáxias, temos perda de limites e recrudescimento de fluidez. A fruição, em Galáxias, depende de um reconhecimento inteligível retardado. O som e os grafemas visuais lentamente avolumam-se no plano da expressão, formando um volume sonora (mistura de línguas), um mantra, bem como uma massa visual de grafemas na página: eis a ênfase na agudeza de expressão; no plano do conteúdo, ocorre o mesmo, sentidos de duas áreas semânticas distantes se confundem, eis a ênfase na agudeza de conteúdo: mistura de paladar com prazer sexual. Galáxias mostra-se, como vimos no exemplo, um objeto da ordem de mistura acentuada de agudezas.

Tratar de Galáxias sem levar em conta Finnegans Wake seria desconsiderar o início de um caminho caracterizado por formações paroxísticas, como veremos na seção 2.6.4.

\subsubsection{Paroxismo em Finnegans Wake, de James Joyce}

Vejamos inicialmente como o dicionário define paroxismo:

PARoxISMo: 1. espasmo agudo ou convulsão; 2. momento de maior intensidade de uma dor ou de um acesso; 3. recorrência ou intensificação súbita [...]; 4. estertores de um agonizante; vascas; 5 . aceleração violenta da atividade vulcânica; ETIM (do grego): ato de excitar, de estimular; [...] momento de maior intensidade de um acesso (HOUAISS; VILLAR, 2001).

Da definição acima, inicialmente podemos depreender a cifra tensiva de paroxismo:

- "espasmo agudo" $\rightarrow$ espasmo: "arroubo, êxtase, arrebatamento, exaltação; estado de paralisia, espanto, petrificação" (HOUAISS; VILLAR, 2001) $\rightarrow$ tal como a definição de agudeza, o espasmo é também da égide do sobrevir zilberberguiano.

- "momento de maior intensidade" $\rightarrow$ cifra tensiva: vívida na intensidade.

- "recorrência" $\rightarrow$ repetição; reiteração = continuidade que acentua os artifícios de refreamento formal, procedimento comum em Finnegans Wake e em Galáxias. 
- "intensificação súbita" $\rightarrow$ recrudescimento abrupto em direção à saturação da vivificação (demasiadamente mais).

- "aceleração violenta" $\rightarrow$ andamento acelerado.

- "ato de excitar, de estimular" $\rightarrow$ invenção verbal levada ao limite, que conduz o objeto ao paroxismo e a uma elevada acentuação sensível; direciona o objeto poético a um retardamento inteligível tamanho que pode arriscar seu reconhecimento.

- "momento de maior intensidade de um acesso" $\rightarrow$ intensidade de risco, quase uma saturação, como veremos a seguir em Finnegans Wake.

A imanência, assunto muito discutido desde a glossemática de Hjelmslev, pode tornar-se alvo de discussão se nos deparamos com alguns objetos semióticos, como uma pintura abstrata, uma poesia aguda do final do século XX ou concreta ou, mais especificamente, uma obra como Finnegans Wake, de James Joyce (e também Galáxias, de Haroldo de Campos). Semioticistas greimasianos, diante deles, considerariam como ponto de partida para suas análises a imanência ou a relação entre as formas de expressão e de conteúdo. Cosimo Caputo (2006, p. 83), em edição italiana de Semiotica e linguistica, ressalta que

Il sistema delle dipendenze coincide con il sistema generatore della forma di una semiótica ed è a partire da questo dentro che pois aviene la proiezione verso un fuori, come si è potuto vedere nella definizione del segno datane da Hjelmslev nei Fondamenti (cfr. PAR. 4.3) e con la distinzione da noi fatta tra la "funzione semiologica" e la "funzione semiotica".

O sistema de dependências coincide com o sistema engendrador da forma de uma semiótica e é a partir desse dentro que então advém a projeção para um fora, como se pode notar na definição de signo dada por Hjelmslev nos Prolegômenos (cfr. PAR. 4.3) e na distinção por nós feita entre a "função semiológica" e a "função semiótica" (destaques do original e tradução nossa).

O pensamento de Hjelmslev é enfático no final de Prolegômenos, quando menciona que a imanência e a transcendência, conjugadas, formam uma unidade maior de base imanentista. Consideremos o ponto de vista de que a linguagem é anterior a nós, lugar em que se forma nossa consciência, nosso pensamento, nossa vida. Ainda mais, a linguagem é 
poesia, é música, é ciência, é memória. A história é linguagem. Tudo se dá na e pela linguagem.

No entanto, a linguagem está e esteve sempre na berlinda, perigando de ser entendida apenas como instrumento ou como meio para conhecermos algo que se daria "externamente" a ela: os povos, a literatura, a física. Esta última estaria sob um recorte transcendente do fenômeno linguístico. A história do pensamento relata-nos um litígio entre a linguagem e as ciências duras. A ebulição da água a $100^{\circ}$ graus, por exemplo, é considerada pelos físicos como um fato autônomo; nesse caso, a linguagem seria um instrumento. No entanto, a língua natural é que é anterior a qualquer fato físico no entendimento hjelmsleviano. E aqui estamos na imanência. Para Hjelmslev a Linguística deveria ocupar o mesmo patamar das ciências autônomas naturais.

A teoria de Hjelmslev iniciada em 1928 (o termo glossemática, porém, data de 1936) não foi terminada, pois o autor morreu precocemente em 1965. Leroy (1982, p. 114) comenta, em As grandes correntes da linguística moderna, que Hjelmslev aprimora a distinção saussuriana de que "língua é forma", ao mencionar que "a forma linguística é independente da substância na qual ela se manifesta". A forma seria reconhecida e definida se levássemos em conta a "função".

Assim, substância sem estrutura formal permaneceria "massa amorfa", "nebulosa" (HJELMSLEV, 1975, p. 55 e 57): “o sentido se torna, a cada vez, substância de uma nova forma e não tem outra existência possível além da de ser substância de uma forma qualquer" (p. 57). Estrutura, para o linguista dinamarquês, é "uma entidade autônoma de dependências internas" (HJELMSLEV, 1991, p. 115).

A substância saussuriana, ou seja, conteúdo semântico ou massa fônica, Hjelmslev a nomeia de matéria, ultrapassando então um pouco mais o pensamento de Saussure, quando afirma que as línguas naturais configuram-se pela relação entre formas do conteúdo e da expressão. E a partir daí o pensamento do dinamarquês embrenhou-se no clima intelectual de uma ciência linguística que estava por se construir. A teoria hjelmsleviana, ao tentar refinar o pensamento saussuriano, sofreu duras sanções negativas, sendo lembrada como ciência abstrata demais, de terminologia hermética, sem menção à sua prática efetiva.

As relações entre $\mathrm{PE}$ e $\mathrm{PC}$, por sua vez, não se limitam a mero aparelho de comunicação linguajeira quando se trata, por exemplo, da função poética, que renova, 
"destrói", rearranja os sistemas de significação. Estariam os poetas querendo transcender à linguagem?

Tomemos um excerto de Finnegans Wake, de James Joice:

A queda (bababadalgharaghatakamminarronnkonnbronntonnereonntuonnthunntrovarrhounawnskawntoohoohoordenenthurnuk!) de um ex-venerável negaciante é recontada cedo na cama e logo na fama por todos os recantores da cristã idade. A grande queda do ovalto do muro acarretou em tão pouco lapso o pftjschute de Finnegan, outrora sólido ovarão, que a humptyhaltesta dele prumptamente manda uma testemunha para oeste à cata de suas tumptytumtunhas: e o retrospicopontoepouso delas repausa em pés no parque onde oranjos mofam sobre o verde desde que o primoamor ao diblin levou lívia (Fragmento 3, Livro 1, Capítulo 1; fragmento 1 na tradução de Augusto e Haroldo de Campos, 1971, p. 35, grifos nossos).

The fall (bababadalgharaghatakamminarronnkonnbronntonnereonntuonnthunntrovarrhounawnskawntoohoohoordenenthurnuk!) of a once wallstrait oldparr is related early in bed and later on life down through all christian minstrelsy. The great fall of the offwall entailed at such short notice the pftjschute of Finnega, erse solid man, that the humptyhillhead of humself prumptly sends an unquiring one well to the West in quest of his tumptytumtoes: and their upturnpikepointandplace is at the knock out in the park where oranges have been laid to rust upon the green since devlinsfirst loved livvy ( $F W, 3$, grifos nossos).

Nota-se um enunciado que subverte gramáticas, dicionários, bem como relações esperadas entre formas de expressão e de conteúdo. No trecho citado, no destaque sublinhado há na manifestação uma tessitura linguística que simula um efeito de sentido da "matéria" hjelmsleviana ou da "massa amorfa" saussuriana. É o caso de

\footnotetext{
"bababadalgharaghatakamminarronnkonnbronntonnereonntuonnthunntrovarrhounawnskawntooho ohoordenenthurnuk!" (mesmo enunciado no original e na tradução)

$\mathrm{E}$

"pftjschute" (mesmo enunciado no original e na tradução)
} 
Nos excertos em destaque, o paroxismo, da ordem do espasmo, arroubo, êxtase, maravilhamento, espanto, petrificação (do sobrevir), engendra um objeto que se rearranja em direção ao desmanche dos contornos formais, à fluidez levada à saturação, cuja agudeza tem como cifra tensiva:

- Repetição e continuidade acentuadora dos refreamentos da forma da expressão e do conteúdo.

- Recrudescimento abrupto e saturação de tonicidade: demasiadamente mais.

- Andamento acelerado.

- Elevada tonicidade sensível (acúmulo de vogais e consoantes que se mostram à visualidade), direcionando o objeto poético a um retardamento máximo do inteligível, colocando em jogo seu reconhecimento.

- Quase saturação.

Trata-se de artifício do poeta para subverter a função semiótica e sua relação entre PE e PC, na tentativa de mirrar o semantismo do PC, levando a obra poética à categoria de objeto verbovocovisual. A poesia concreta ou a poesia do final do século $\mathrm{XX}$, a usualmente conhecida como neobarroca, não renuncia ao conteúdo, à carga semântica, mas traz para o enunciado poético as experiências linguísticas, as simulações da forma, almejando a poesia enfatizar efeitos sonoros e visuais.

No trecho em destaque, em ambas as línguas do enunciado (a original do poeta, o inglês, e a da tradução, o português), depreendemos o simulacro de dois fragmentos de "matéria", de "massa amorfa", e isso pode ser corroborado pelo fato de serem as mesmas massas (sonoras e gráficas), tanto em inglês quanto em português: parecem borrões amorfos em meio ao processo sintagmático da obra.

Em "Função poética e Ideograma”/"O argumento sinológico", Haroldo de Campos (1977b, p. 30-37; 37-60), o crítico literário, afirma a relevância de discutir o pensamento de Fenollosa, recusando-se a aceitar que em chinês as palavras aproximam-se mais das coisas do que em inglês; isso daria ao chinês uma condição de "língua mais poética", pensamento aceito pelo próprio Pound e Fenollosa. Octavio Paz ([1972] 2013, p. 132), por sua vez, entende que os pictogramas concebidos a partir de um princípio pictórico perderam boa parte de sua qualidade visual, e suas "formas modernas guardam escassa semelhança com os objetos que supostamente representam". 
O que mais "choca", na visão de Haroldo (CAMPOS, 1977b, p. 38), indo na direção do pensamento de Paz, "é a tônica argumentativa que Fenollosa põe na 'picturalidade' do chinês". Acrescenta ainda que "a crescente estilização dos pictogramas e as mudanças operadas através dos tempos, por obra inclusive dos letrados lexicologistas e de seus erros de transcrição e/ou idiossincrasias imaginativas, teriam tornado em larga medida irreconhecível a pictografia original". No uso corriqueiro, "o leitor chinês trataria os ideogramas à maneira do usuário das línguas alfabéticas", como o inglês, o português, o italiano, "sem mais distinguir neles a metáfora visual - a etimologia visível - que tanto impressionou Fenollosa e que teria sido por este sobreestimada" (p. 38).

Para refletir sobre essa questão, convoco simultaneamente dois conceitos o de arbitrariedade, de Saussure, e o de função poética, de Roman Jakobson.

Na seara das línguas naturais, partindo do princípio de arbitrariedade de Saussure, contrário ao argumento cratiliano, depreendemos que o que une uma imagem acústica dada a um conceito determinado, dando-Ihe valor de signo, é um elo arbitrário: "o laço que une o significante ao significado é arbitrário [...]. Assim a ideia de 'mar' não está ligada por relação alguma interior à sequência de sons $m$-a-r que Ihe serve de significante; poderia ser representada igualmente bem por outra sequência, não importa qual" (SAUSSURE, 1996, p. 81-82; cf. ARRIVÉ, 2010, p. 58-69).

Pensando agora na operação da função poética jakobsoniana, "toda coincidência fonológica é sentida como um parentesco semântico" (CAMPOS, 1977b, p. 39; cf. PERLOFF, 2013, p. 127-129), diferentemente, pois, da arbitrariedade da língua natural, para a qual não importa descobrir afinidades entre "remeço" e "arremesso" nem que "meço" está dentro de "começo". Na poesia, no entanto, "meço" e "começo" aproximam-se: eis uma agudeza, eis uma aproximação ao paroxismo:

\footnotetext{
"e começo aqui e meço aqui este começo e recomeço e remeço e arremesso" (formante inicial de Galáxias [CAMPOS, 2011a])
}

Qualquer semelhança fonológica (paronomásia) ou semelhança visual (grafemática) pode configurar uma analogia semântica. É como se recomeçar compreendesse também o ato de arremessar a linha do poema no papel. Tomemos "meço" e "começo": verifica-se em começo uma medida que orienta o poeta, figurativizando que os enunciados são realizados 
com uma medida, com um saber poético. Nesse caso, começar é também medir (meço), posto que todo começar implica uma medida, uma regra, um gênero, um efeito a ser produzido. Ademais, as palavras enredam-se cumprindo uma função poética, em que o meio material é o sentido; o poeta seleciona (no paradigma) e justapõe (no sintagma): as palavras funcionam como cores que se misturam.

Tomando a seleção paradigmática, temos a relação de dependência entre:

- Semelhança e dissemelhança.

- Proximidade e distância.

Tomando a combinação sintagmática, temos a linearidade, a sequência.

De um lado, quanto mais dissemelhança e maior distância, maior a agudeza que enfatiza o PC; de outro lado, quanto mais ruptura de linearidade, mais espacializada, mais agudeza que enfatiza o PE. Nesse sentido, quanto mais acentuada a agudeza, mais fluida será a poesia, encaminhando-se para o "intensamente agudo", para o paroxismo de Finnegans Wake. Em James Joyce, temos o que Zilberberg (2011a, p. 229) chama de recrudescimento, o sujeito da enunciação sente-se "transtornado", perdendo o controle, transformado pelo sobrevir que o assalta.

No estilo joyciano, simulador de matéria por meio da animação de formas inventivas, as palavras "reverbe[ram] o halo das coisas" (CAMPOS, 1977b, p. 33), ou seja, conhecem a luminosidade de um projeto de coisificação, que afronta a arbitrariedade saussuriana. Assim é que o enunciador não se ocupa em representar o objeto, mas em mostrá-lo. Nesse sentido, Finnegans Wake almeja o sensível ou, nos termos de Longino (In: ARISTÓTELES; HORÁCIO; LONGINO, 2008, p. 69-114), visa ao sublime, ponto ápice da ascendência da tonicidade. Esse objeto sensibilizado conhece seus limites, experimenta o basta, caminhando no fio da navalha da saturação da tonicidade, significando para o sujeito uma tormenta modal; aqui, o sofrer suplanta o agir (cf. ZILBERBERG, 2011a, p. 236 e 239). Conhecendo esse ápice, delonga-se o reconhecimento inteligível. Parece-nos que o signo poético pode ser visto segundo uma hierarquia de imanências: 
$2^{\mathrm{a}}$ imanência: PE [PE/PC] (metassemiótica) $\rightarrow$ PE semiótica própria $\rightarrow$ o do fazer poético: tem como base de criação o nível 1 da língua natural, o que chamamos de $1^{\mathrm{a}}$ imanência, para propor o nível 2, que é o da poiesis.

$\rightarrow$ Significado 2

$1^{\mathrm{a}}$ imanência da língua natural: PE/PC da língua natural (sempre é preservada, não se abala)

$\rightarrow$ Significado 1

Observamos em Finnegans Wake uma relação oblíqua entre um significado 1, "denotativo", e um significado 2, "conotativo". Para se postular a presença de um plano de conteúdo conotativo, teríamos como mediadora a função semiótica unindo o PC conotativo ao $\mathrm{PE}$. Como sabemos, este último não poderia ser o $\mathrm{PE}$ que se correlaciona ao $\mathrm{PC}$ denotativo, uma vez que resultaria nesse caso um só PC. Hjelmslev postula um PE que é inicialmente uma semiótica, como, por exemplo, é o da língua natural. Desse modo, essa semiótica conotativa seria um tipo de metassemiótica, uma semiótica que não é uma língua; antes, é um PE que se constitui como uma semiótica própria, engendrado pela relação entre PC e PE de uma semiótica denotativa (cf. HJELMSLEV, 1975, p. 125; GREIMAS; COURTÉS, 1983, p. 77, verbete conotação).

Finnegans Wake divide-se em quatro grandes partes ou livros sem título; eles são numerados de I a IV. Os irmãos Campos (1971, p. 79), apoiados na subdivisão de Campbell e Robinson, deram nomes aos livros e aos capítulos. Os títulos são adaptados segundo frases do próprio texto de James Joyce: 
Livro I - O livro dos pais (3-126)

Capítulo 1: A queda de Finnegan (3-29)

Capítulo 2: HCE - Seu apelido e reputação (48-74)

Capítulo 3: HCE - Seu julgamento e prisão (48-74)

Capítulo 4: HCE - Sua libertação e ressureição (75-103)

Capítulo 5: O manifesto de ALP (104-125)

Capítulo 6: Enigmas - Os personagens do Manifesto (126-168)

Capítulo 7: Shem, o escriba (169-195)

Capítulo 8: As lavadeiras no Vau (196-216)

Livro II - O livro dos filhos (219-399)

Capítulo 1: A hora das crianças (219-259)

Capítulo 2: O período do estudo - Triv e Quad (260-308)

Capítulo 3: A taverna em festa (309-382)

Capítulo 4: Navio-noiva e gaivotas (383-399)

Livro III - O livro do povo (403-590)

Capítulo 1: Shaun diante do povo (403-428)

Capítulo 2: Jaun diante da Academia de St. Bride (429-473)

Capítulo 3: Yawn sob inquérito (474-554)

Capítulo 4: HCE e ALP - Seu leito de julgamento (555-590)

Livro IV - Ricorso (593-628)

A chave da estrutura de Finnegans Wake encontra-se no título:

Tim Finnegan, da velha canção de "vaudeville", é um pedreiro irlandês que se embriaga, cai de uma escada e, aparentemente, morre. Os amigos promovem um velório em torno de seu caixão; durante as festividades alguém o respinga de uísque, com o que Finnegan desperta de novo para a vida e toma parte da dança generalizada. No fundamento desta cançãoburlesca Joyce assenta o título de sua obra. Mas a história não termina aí. Finnegan, o mestre-de-obras, é identificável primeiramente com Finn MacCool, capitão, por duzentos anos, dos heróis-guerreiros da Irlanda, e o mais famoso dos gigantes primevos de Dublin. Finn tipifica todos os heróis Thor, Prometeu, Osíris, Cristo, Buda - em cuja vida e através de cuja inspiração a raça humana se alimenta. E é porque Finn volta de novo (Finnagain) - em outras palavras, pela reaparição do herói - que a força e a esperança são devolvidas à humanidade (CAMPBELL; ROBINSON In: CAMPOS; CAMPOS, 1971, p. 107-108). 
Por meio de sua morte e de sua ressurreição, o pedreiro Finnegan atualiza com humor o mistério do deus-herói, ou seja, a carne desse deus alimenta o espírito dos homens. Assim é que no velório de Finnegan, os participantes comem tudo o que era do herói morto. Comem seu corpo e seus pertences como hóstia consagrada.

Na obra, dá-se a transição do herói anterior para seu sucessor, quando os convidados do velório deitam Finnegan e o exortam a descansar em paz. Contam ao morto que um recém-chegado em Dublin, Humphrey Chimpden Earwicker (HCE) o sucederá. Assim, na medida em que a narrativa se desenrola, nota-se que HCE é um cidadão dublinense, um típico taverneiro com uma corcunda bovina na parte dorsal do pescoço. Tipo simpático, vítima de sua madastra, introduz-se na trama com vários nomes, como Here Comes Everybody e Haveth Childers Everywhere. Todos esses nomes figurativam uma isotopia que evidencia nesse ator sua universalidade e sua função de procriador da raça humana.

Esse herói perambulou pelo mundo, deixando descendentes a cada parada em sua caminhada: em Troia na Ásia Menor, na terra dos godos, na dos nórdicos, na dos francos.

O rumor das armas rebomba nas primeiras páginas do livro, encenando as batalhas da história irlandesa; esse espaço é o locus da batalha na taverna, bem como das batalhas passionais de Earwicker. Igualmente ao marido (HCE) metamorfoseado em Adão e em Lord Nelson, ela também sofre transmutações: Eva, Ísis, Isolda, uma nuvem que passa, um riacho; enfim, a viúva que serve as bebidas no velório é também a velha anã que carrega a sujeira de Dublin. O percurso de Ana é um ciclo em movimento entre passado e presente, ou seja, passado conservado no presente e presente como fluxo contínuo do passado.

Earwicker e sua mulher têm dois filhos, Shem (Jerry) e Shaun (Kevin); esses dois atores entram em conflito durante a narrativa. Shem veste a pele discursiva de escritor, do artista marginalizado, e Shaun, do orador, do político, favorito entre as pessoas. Um seria o contraponto do outro: lados de uma mesma moeda. Enquanto Shem é passivo, oprimido, da ordem da estética, Shaun é ativo, opressor, da ordem do utilitarismo: antitetismos complementares que fazem a roda da narrativa girar (cf. CAMPBELL; ROBINSON In: CAMPOS; CAMPOS, 1971, p. 106-116).

Esta sinopse, além de funcionar como panorama geral, auxilia-nos na localização dos fragmentos traduzidos por Haroldo e Augusto de Campos, utilizados na análise do quadro 5.3. Consultamos também a tradução de Donaldo Schüler (JOYCE, 2004); no entanto, por 
apresentar-se rica de exemplos de transcriação poética e de paroxismo, demos preferência à dos irmãos Campos.

Quadro 5.3 Paroxismo: forte acentuação em Finnegans Wake.

\begin{tabular}{|c|c|}
\hline Original em Inglês & Tradução/transcriação de Haroldo de Campos \\
\hline $\begin{array}{l}\text { 1. "[...] (I am sure that that tiring } \\
\text { chabelshoveller with the mujikal } \\
\text { chocolat box, Miry Mitchel, is } \\
\text { listening) [...]" (JOYCE In: CAMPOS; } \\
\text { CAMPOS, 1971, p. 36, fragmento 13, } \\
\text { Livro I, Capítulo 1, destaques nossos). }\end{array}$ & $\begin{array}{l}\text { "[...] (Estou certo de que aquele chatigante matracavo } \\
\text { com sua caixa de chocolates mujicais, Muco Michel, está } \\
\text { escutando) [...]" (JOYCE In: CAMPOS; CAMPOS, 1971, p. } \\
\text { 37, fragmento } 13 \text { [número } 2 \text { na tradução], Livro I, } \\
\text { Capítulo 1, destaques nossos). }\end{array}$ \\
\hline $\begin{array}{l}\text { 2. "[...] Niggs, niggs and niggs again. For } \\
\text { this was a stinksome inkenstink, quite } \\
\text { puzzonal to the wrottel [...]" (JOYCE } \\
\text { In: CAMPOS; CAMPOS, 1971, p. 46, } \\
\text { fragmento 182, Livro I, Capítulo 7, } \\
\text { destaques nossos). }\end{array}$ & $\begin{array}{l}\text { "[...] Nicas, nicas e nelhas a mesmo. Pois aquele era um } \\
\text { intestinto fedornicho enzigmático, puzzando a bortel e a } \\
\text { manuscroto [...]" (JOYCE In: CAMPOS; CAMPOS, 1971, p. } \\
47 \text {, fragmento } 182 \text { [número } 5 \text { na tradução], Livro I, } \\
\text { Capítulo 7, destaques nossos). }\end{array}$ \\
\hline $\begin{array}{l}\text { 3. "[...] Night night! Telmetale of stem or } \\
\text { stone. Beside the rivering waters of, } \\
\text { hitherandthithering waters of. Night! } \\
\text { [...]" (JOYCE In: CAMPOS; CAMPOS, } \\
\text { 1971, p. 62, fragmento 216, Livro I, } \\
\text { Capítulo 8, destaques nossos). }\end{array}$ & $\begin{array}{l}\text { "[...] Noite noite! Fala-me-fala de planta ou pedra. As } \\
\text { riocorrentes águas de, as indo-e-vindo águas de. Noite! } \\
\text { [...]" (JOYCE In: CAMPOS; CAMPOS, 1971, p. 63, } \\
\text { fragmento } 216 \text { [número } 10 \text { na tradução], Livro I, Capítulo } \\
\text { 8, destaques nossos). }\end{array}$ \\
\hline $\begin{array}{l}\text { 4. "[...] It darkles, (tinct, tint) all this our } \\
\text { funnaminal world. [...]" (JOYCE In: } \\
\text { CAMPOS; CAMPOS, 1971, p. 66, } \\
\text { fragmento 244, Livro II, Capítulo 1, } \\
\text { destaques nossos). }\end{array}$ & $\begin{array}{l}\text { "[...] Escurece, tingetinto, nosso funamburlesco } \\
\text { mundanimal. [...]" (JOYCE In: CAMPOS; CAMPOS, 1971, } \\
\text { p. 67, fragmento } 244 \text { [número } 12 \text { na tradução], Livro II, } \\
\text { Capítulo 1, destaques nossos). }\end{array}$ \\
\hline $\begin{array}{l}\text { 5. "[...] Man looking round, beastly } \\
\text { expression, fishy eyes, paralleliped } \\
\text { homoplatts, ghazometron pondus, } \\
\text { exhibits rage. [...]" (JOYCE In: } \\
\text { CAMPOS; CAMPOS, 1971, p. 70, } \\
\text { fragmento 559, Livro III, Capítulo 4, } \\
\text { destaques nossos). }\end{array}$ & $\begin{array}{l}\text { "[...] Homem olhando em torno, bronquiaberto, olhos } \\
\text { piscosos, paralelípedos homoplatos, ghazometron } \\
\text { pondus, denota raiva. [...]" (JOYCE In: CAMPOS; } \\
\text { CAMPOS, 1971, p. } 71 \text {, fragmento } 559 \text { [número } 14 \text { na } \\
\text { tradução], Livro III, Capítulo 4, destaques nossos). }\end{array}$ \\
\hline $\begin{array}{l}\text { 6. "[...] Far calls. Coming far! End here. Us } \\
\text { then. Finn, again! Take. Bussoftlhee, } \\
\text { mememormee! Till thousendsthee. } \\
\text { Lps. The keys to. Given! A way a lone } \\
\text { a last a loved a long the" (JOYCE In: } \\
\text { CAMPOS; CAMPOS, 1971, p. 76, } \\
\text { fragmento 628, Livro IV, destaques } \\
\text { nossos). }\end{array}$ & $\begin{array}{l}\text { "[...] Longe gritos. Vindo, longe! Fim aqui. Nós após. Finn } \\
\text { équem! Toma. Bosculaveati, mememormim! Ati } \\
\text { mimlênios fim. Lps. As chaves para. Dadas! A via a uma a } \\
\text { una amém a mor além a" (JOYCE In: CAMPOS; CAMPOS; } \\
\text { 1971, p. 77, fragmento } 628 \text { [número } 16 \text { na tradução], } \\
\text { Livro IV, destaques nossos). }\end{array}$ \\
\hline
\end{tabular}




\section{Detalhando:}

\section{Em 1:}

- "tiring" (cansativo/fatigante) $\rightarrow$ "chatigante" (chato + fatigante);

- "chabelshoveller" (cha+ bell (sino) + shoveler = pássaro) $\rightarrow$ "matracavo" (matraca, ave gruiforme da família Rallidae, + "cavo", que significa rouco);

- "mujikal" (do ing. "musical") "chocolate box" $\rightarrow$ "caixa de chocolates mujicais" (do port. "musicais");

- "Miry Mitchel" (miry, do ing., "lama, enlameado"; em italiano "fangoso"); possível diálogo com o Canto VII da Divina Comédia, de Dante: "Vidi genti fangose in quel pantano, ignude tutte, con sembiante offeso" = "Gentes lodosas vi no lameirão, todas nuas, demonstrando irada mágoa" (ALIGHIERI, 1998, p. 65) $\rightarrow$ Haroldo de Campos traduziu "enlameado" por "Muco" para compor uma aliteração em "Muco Michel".

\section{Em 2:}

- "niggs, niggs and niggs again" $\rightarrow$ Na tradução, temos um conjunto aliterado, esmaecido semântico, que funciona como uma agudeza de expressão sonora;

- "stinksome inkenstink, quite puzzonal to wrottel":

○ stinksome $=$ stink - "fedor", que adiante convoca "puzzonal" (no italiano, "puzza" é mau cheiro); na tradução, temos "fedornicho", ou seja, um nicho de fedor;

○ inkenstink = ink - "impressão; marca; tinta"; stink - "mau odor; feder"; na tradução, temos "intestinto", isto é, intestino + instinto + extinto (o prefixo ex quer dizer pôr para fora, eliminar fezes). O que se vê na operação aguda de Joyce é uma justaposição de imagens;

○ puzzonal = anagrama de puzzle - enigma, mistério; na tradução, temos "enzigmático, puzzando". Ocorre que, no original, "puzzonal" engloba "puzzle", que indica "enigma" (na tradução "enzigmático"). Haroldo de Campos junta "enzima" com "enigma", relacionando ambos a "intestinto fedornicho". Essas duas palavras interseccionam-se com "puzzando", que vem do italiano e significa "fedendo". Teríamos então um intestino em decomposição que deixa a marca do mau cheiro; 
○ wrottel $=$ engloba wrote, que é o particípio passado do verbo escrever: "escrito"; na tradução, temos "manuscroto", que é um manuscrito + escroto ou a "mão no saco escrotal". O tradutor, transcriando a linha erótica do texto, optou pouco antes pela palavra "tectículo", que é ao mesmo tempo "minúsculo teto" + "testículo".

\section{Em 3:}

- "telmetale of stem or stone":

○ telmetale $=$ Tell + me + tale engloba "tell me", conta-me, mais "tale", narrativa, história; na tradução, temos "Fala-me-fala" (o segundo "fala" pode ser entendido como "fala, narrativa"). Em "stem" e "stone", temos a tradução de "planta" e "pedra", sem transcriação literária;

- "beside the rivering waters of, hitherandthithering waters of":

○ rivering waters of $=\mathrm{em}$ "rivering", juntam-se "river" + "ring", com o sentido de "rio que corre, que gira"; na tradução, "riocorrentes";

○ hitherandthithering = aglutinam-se "hither" + "and" + "thithering", que significa "aqui e acolá"; na tradução, "indo-e-vindo".

Em 4:

- "(tinct, tint)", temos "tint", que significa "tintura, tingir"; na tradução, "tingetinto";

- "funnaminal world"; nesse caso, juntam-se "fun" (divertido) + "aminal" (anagrama de animal); na tradução, "funamburlesco" amalgama "funâmbulo" + "burlesco". Funâmbulo é "acrobata", que diverte (fun) o público enquanto caminha na corda bamba e burlesco significa "grotesco".

\section{Em 5:}

- "beastly expression, fishy eyes, paralleliped homoplatts, ghazometron pondus, exhibits rage":

○ beastly = tremendo, horrendo, bestial; expression = expressão, gesto, face; na transcriação, "bronquiaberto";

○ fishy eyes = fishy: que parece peixe, que cheira a peixe, suspeito, turvo, oblíquo; na transcriação, "olhos piscosos", sendo piscosos um amálgama de písceo, "relativo a peixe" (HOUAISS; VILLAR, 2001), + "piscar"; 
○ ghazometron pondus (na tradução, temos a mesma expressão): anagrama de gaze, olhar fixo, + gasometer.

\section{Em 6:}

- "Finn, again! Take. Bussoftlhee, mememormee! Till thousendsthee":

- muitas palavra-valises acompanham a obra de FW. Por exemplo, em "Till thousendsthee", temos Till (até) "thousand + end + thee":

thousand $=$ mil

end $=$ fim

thee $=$ na linguagem poética, ti ou te

- na transcriação, ocorre outra experimentação linguística em recrusdescimento paroxístico: "Ati mimlênios fim"; nesse caso, há uma escolha aguda de PE e de PC, pois o "ti" e o "até" são englobados por "Ati". O "end" do original inglês aparece fragmentado em "mimlênios"; este último engloba o conteúdo de "thousand". O "mim" é recuperado da expressão antecedente "mememormee" (mememormim).

As condensações de palavras, a junção de línguas e de dialetos, as invenções de expressões inusitadas conduzem Finnegans Wake (FW) a uma acentuação, a um recrudescimento do experimentalismo linguístico, que leva a obra ao que chamamos de paroxismo. No branco da página, encontramos sedimentos linguísticos que são verdadeiros puzzles. Estamos diante de um enunciado miraculoso, que prolifera os significados, produzindo alusões e intertextualizações em rede; palavras e expressões soam como vozes que se sucedem e se entrelaçam como em uma fuga musical:

a essência revolucionária da obra de Joyce está precisamente na sua insubmissão [...] aos cânones linguísticos. Desse "crime" de lesa-língua não há como pretender expurgá-la. Assim como será impossível ficar fiel ao espírito da obra sem transportar a sua insubordinação linguística para o idioma em que se queira convertê-la. Insubordinação agravada, em nosso caso, por certas diversidades estruturais entre o inglês e o português. 0 caso requer antes uma inversão de preceito: traditore, traduttore (CAMPOS; CAMPOS, 1971, p. 127).

Ocorre que Joyce leva ao ápice o recrudescimento da operação da agudeza, ou seja, atinge o paroxismo, abusando das virtualidades paradigmáticas do sistema da língua inglesa, 
quando amalgama, intersecciona palavras, alcançando vocábulos de até cem letras, como vimos no início desta seção.

Os labirintos linguísticos de Joyce são infindáveis; a escolha enunciativa faz-se pela cifra do continuum, pela circularidade, pela "continuarração, rio-romance" (CAMPOS; CAMPOS, 1971, p. 81). Ascendências e descendências movem o fluxo da narrativa; Finnegans Wake constitui-se numa peça tensiva que oscila entre quedas e restabelecimentos: "a queda do pedreiro entra no rol de outras: a de Lúcifer, a de Adão, a de Roma, a de Humpty Dumpty, a de Charles Stewart Parnell, a do rei Marc, a de Tristão, a do Noé embriagado, a da maçã de Newton, a da chuva, a queda diária de todos os homens, sem excluir o colapso da bolsa de Wall Street" (SCHÜLER In: JOYCE, 2004, livro I, capítulo 1, p. 15).

Outra tensão dá-se na sonoridade: há uma oscilação de sons entre as línguas; o latim do Império Romano $($ Finn $=$ fim) mescla-se, por exemplo, com again (de novo, novamente, na língua inglesa), revelando outra vez a circularidade no PE sonoro. No PE visual, essa circularidade ocorre por meio da dança dos anagramas e dos grafemas no branco da página.

O título "Finnicius Revém", na tradução dos irmãos Campos, passa pelo francês (rêve, sonho), evidenciando a isotopia onírica do romance. Para Shüler (In: JOYCE, 2004, livro I, capítulo 1, p. 20), esse "romance alude, incorpora, modifica e parodia número imenso de obras, núcleos seminais de nova floração. Não há página em Finnegans Wake sem evocações literárias - as bíblicas superam todas - como se Joyce quisesse abarcar tudo o que se escreveu, fazendo de todos os textos um livro só". O enunciado contempla a escolha linguística da mistura: o texto atualiza, reúne e vivifica marcas de uma tradição literária, amalgamando diversas línguas, espaços, culturas e épocas.

Em Finnegans Wake, a seleção de refreamentos formais concentra intensamente o sentido numa operação de recrudescimento sensível, convocando uma renovação no sentido da leitura: a leitura linear não é suficiente; cada páragrafo, cada linha, cada palavra sobrepõe-se, unifica-se, suscitando uma leitura horizontal e espacializada. Além da visualidade ousada, há um conjunto sonoro, rítmico e verbal também investido de refreamentos, que aproximam a obra de Joyce da elevada tonicidade sensível. Nota-se no paroxismo de Joyce uma performance linguística que tem como finalidade o atraso do reconhecimento inteligível. 
A obra, segundo Schüler (In: JOYCE, 2004, livro I, capítulo 1, p. 24), recebeu o nome de Finnegans Wake apenas em 1938; em seu período de criação, seu título era "Work in Progress", "obra em criação/andamento"; acabada, sua obnubilação convida o enunciatário ao jogo sonoro, visual, ao jogo linguístico das metáforas agudas, preenchendo pouco a pouco seus contornos esmaecidos: a fluidez retornaria novamente para a nitidez latente. 0 poeta, como vimos no exemplo de Finnegans Wake, trabalha com uma agudeza do tipo paroxística: ele parte do matiz formal da língua natural (nível $1-1^{\mathrm{a}}$ imanência), compondo poieticamente combinações sintagmáticas de nível 2 ( $2^{\mathrm{a}}$ imanência).

Mikel Dufrenne (2008, p. 135), em Estética e filosofia, afirma que "o artista não está na arte porque ele está diante das obras de arte: as obras dos outros, que despertam sua vocação e o iniciam". Talvez o artista não queira falar sua língua materna como todo mundo fala; não lhe interessa um conteúdo inédito, mas um "acento pessoal" e quando essa marca se mostra, "introduz-se a arte na linguagem" (p. 135). A arte experimental de Joyce, agudamente paroxística, engendra uma língua própria. E nesse sentido Dufrenne assume que "a língua da arte não é verdadeiramente uma língua: ela não cessa de inventar sua própria sintaxe" e "cada obra comporta sua própria semântica de modo que toda tradução Ihe é desigual" (p. 136), motivo pelo qual assumimos para as traduções dos irmãos Campos o termo por eles mesmos utilizado, transcriação.

Quanto a esse jogo linguístico de Joyce, cito os parágrafos 203-204, 492 e 530 das Investigações filosóficas, de Wittgenstein ([1921] 1999, p. 58):

203. A linguagem é um labirinto de caminhos. Você entra por um lado e sabe onde está; você chega por outro lado ao mesmo lugar e não sabe mais onde está.

204. Posso inventar um jogo, estando as coisas como estão, que não será jamais jogado por alguém. - Mas seria igualmente possível que a humanidade não tivesse nunca jogado jogos; alguma vez, porém, alguém inventou um jogo - que, no entanto, nunca foi jogado?

[...]

492. Inventar uma linguagem poderia significar: inventar, com base em leis naturais (ou em concordância com elas), uma aparelhagem para uma determinada finalidade; tem, porém, um outro sentido também, análogo àquele em que falamos da invenção de um jogo.

[...]

530. Poderia haver também uma linguagem, em cujo emprego a 'alma' das palavras não desempenha nenhum papel. Uma linguagem na qual, por exemplo, não nos importaríamos de substituir uma palavra por uma outra, nova, arbitrariamente inventada. 
Em 203, o filósofo entende que a linguagem guarda segredos e mistérios; como num labirinto, conhecemos apenas o início da caminhada, mas nem sempre sabemos como sair desse enigma linguístico. Em 204, Wittigstein mostra os limites do jogo da linguagem: não posso inventar uma linguagem que não seja jogada pela coletividade. Nesse caso, ressalta-se a convenção. É preciso que as regras do jogo sejam as convencionadas pelo grupo. Em 492, dá-se uma confirmação de que a linguagem inventada só pode ser jogada se construída com base num contrato ("leis naturais"). Em 530, estaríamos na égide da invenção: há uma dicotomia entre PE e PC, ou seja, uma linguagem, na qual se substitui um palavra por outra arbitrariamente inventada, configurando-se uma ameaça ao sistema. Nesse caso, a linguagem, almejando materializar-se cada vez mais, seria pura arbitrariedade sem lastro no sistema, o que configuraria um paroxismo (o estágio do demasiadamente mais de que nos fala Zilberberg [2006a, p. 114]).

O que se nota, pois, na agudeza é uma gradação tensiva, para mais ou para menos. Assim é que podemos afirmar que mais próximo ainda do paroxismo está o exemplo visto anteriormente em Galáxias, "nympholucrosmaragdomania", em que as aglutinações esmaecem os contornos e os limites entre as formas da expressão e do conteúdo, sendo possível ainda o reconhecimento das formas. Em Joyce, porém, temos um ápice da agudeza paroxística:

"bababadalgharaghatakamminarronnkonnbronntonnereonntuonnthunntrovarrhounawnska wntoohoohoordenenthurnuk!".

Graficamente, podemos representar:

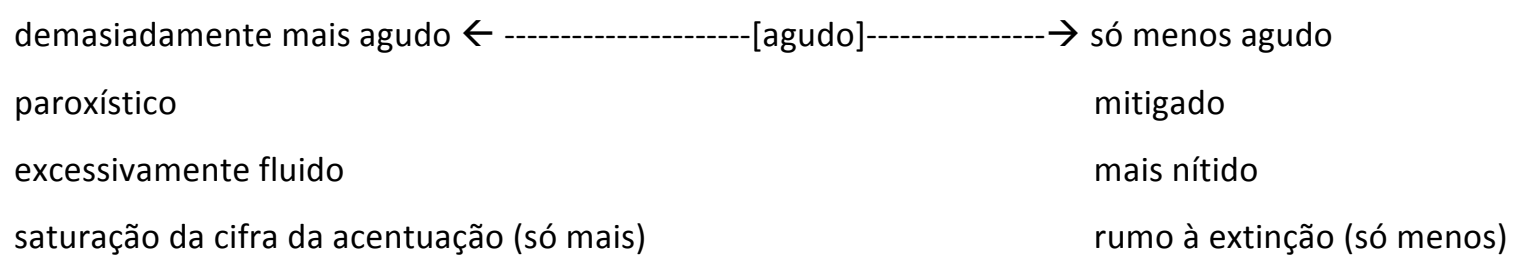

Nota: A semiótica tensiva não partilha de binarismos, pois tudo é gradação. Por isso, nesta tese, sugerimos uma semiótica da agudeza em que os objetos agudos são mais sensíveis e mais fluidos, demandando mais ou menos catálise. Os artifícios agudos é que os fazem oscilar: ora para uma cifra de "mais vívido", ora para uma cifra de "mais tênue". Se mais vívido, está mais concentrado na extensidade e, portanto, mais demorado é seu reconhecimento inteligível; se mais tênue, está mais difuso na extensidade e, portanto, mais rápido é seu reconhecimento. 
Para Wittigstein, "não nos importaríamos em substituir uma palavra por outra nova, arbitrariamente inventada", porque, nesse caso, trata-se de uma linguagem especial, poética, cuja finalidade não é relacionar PE e PC, mas simplesmente mostrar um efeito sensível que almeja o desmanche do PC. Nesse exemplo, o próprio enunciador mostra que seus enunciados obedecem a um limite, uma vez que, se sua invenção fosse levada ao paroxismo saturado, teríamos apenas borrões visuais como no trecho transcrito acima.

Recorrendo ao exemplo de Saussure comentado por Hjelmslev (1991, p. 38-39), podemos substituir um peão de madeira por um peão de metal num jogo de xadrez que nada se alteraria:

[...] uma peça de xadrez se define exclusivamente por suas relações com outras peças e por suas posições relativas no tabuleiro; a forma exterior das peças e a substância de que são feitas (marfim, madeira ou o que quer que seja) é irrelevante para o jogo. Uma peça, seja por exemplo um cavalo, que de ordinário tem a forma de uma cabeça de cavalo, poderia ser substituída por qualquer outra, desde que se convencionasse adotá-la para o mesmo propósito; se, durante o jogo, um cavalo cair acidentalmente ao chão e se quebrar, podemos tomar qualquer objeto de tamanho adequado e atribuirIhe o valor de um cavalo. De maneira análoga, um som pode ser substituído por outro som, por uma letra ou por quaisquer signos convencionais, e em todos os casos o sistema permanece o mesmo.

Os seguidores do folhetim G3R4Ç4O BR4S1L (2014) não têm nenhuma dificuldade em perceber que 3 substitui o "cavalo E", 4 substitui o "peão A" e 1 substitui a "bispo I" (a língua como forma e não como substância e uso). Há um contrato que subjaz à manifestação: o enunciatário lê normalmente o texto como se não tivesse nenhuma alteração, porque entra no jogo em que é possível a troca das peças, mas não a troca de valores. "Geração", com números substuindo letras ou não, manterá sempre o sentido de "gerar" e, nesse caso, temos uma homologação entre PE e PC: geração implica também invenção.

Com base no princípio da diferença e da semelhança, as invenções de Joyce (e também de Haroldo de Campos em Galáxias) sempre deixam um lastro de semelhança pelo qual podemos encarar a diferença.

Tomando, por exemplo, "esaùrido", apreendemos dois conteúdos semânticos: um ligado à Esaú, filho de Isaac, e outro ligado ao verbo "exaurir". Temos, então, um amálgama de Esaú + exaurido; por isso, o enunciador pode dizer um "novelho esaùrido", ou seja, a relação do pai com seu filho e a difícil decisão: a de executar seu filho, uma prova de sua fé. É toda essa narrativa que o enunciatário reconstrói a partir de uma nova invenção: a figura 
"esaùrido" tem algo de diferente, mas mantém algo de semelhante e é a semelhança, por menor que seja, que permite chegar a esse jogo de conteúdo e de expressão: “[...] nem ainda, embora logo mais veniesse, tinha um novelho esaùrido um velho e alquebrando isaac [...]" (CAMPOS; CAMPOS, 1971, livro I, capítulo 1, p. 35, fragmento 1 na transcriação dos Campos). Rege essa seleção, não propriamente as diferenças e identidades inteligíveis, mas a vivificação sensível, que carrega de afeto a aproximação do jovem Isaac com o envelhecido pai que precisa executá-lo como se fosse um cordeiro. E é em esaùrido que vemos essa tela do parecer, esse simulacro de um pedaço da história humana. Observe-se que o enunciador inverteu o sinal diacrítico. Onde era agudo pôs acento grave, homologando no visual gráfico a gravidade do momento vivido por pai e filho; a tensão, o imbricamento de sensível e inteligível, sugere no conteúdo um ser afetivamente descontrolado e no visual um inteligível também perturbado pela troca de sinais. Essa relação semissimbólica em que é possível verificar uma ocupação de tornar o signo motivado estamos chamando de metassemiótica.

Em última análise, o esquema de língua é um jogo e nada mais (cf. HJELMSLEV, 1991, p. 90). Além disso, "cada plano tem sua organização própria, é verdade, mas cada plano tem repercussões no outro" (p. 99). Para Augusto de Campos (In: CAMPOS; PIGNATARI; CAMPOS, 2010, p. 185), a estratégia do PE utilizada por Joyce é a da "fotomontagem léxica", que desemboca, além dos refreamentos do PE, em uma simultaneidade semântica.

A forma artística constitui-se em rito de desaceleração da linguagem com a finalidade de atingir outro tipo de aceleração, a estética, caracterizada pela vivificação da tonicidade. Nesse sentido, toda forma artística refreia a transposição do PE ao PC, atribuindo valor à organização rítmica do PE. Assim, uma comunicação rápida no cotidiano pressupõe acelerada conversão do PE em PC e leva ao descarte rápido do PE (cf. TATIT, 1997, p. 46). Essa enunciação mais utilitária afasta-se da sensibilização em nome do reconhecimento intelectivo.

Já no fazer artístico de Joyce, de Haroldo de Campos, de Affonso Ávila, de Horácio Costa, de Claudio Daniel, entre outros poetas vistos nesta tese, o maravilhamento encontrase na inversão da prática utilitária: a agudeza, das mais variadas espécies, como recursos rítmicos, aliterantes, anagramáticos, visuais, almeja preservar o PE e evitar que ele seja rapidamente descartado. A linguagem atuaria na poesia como iluminadora da própria 
linguagem: "eis o poeta brigando com [a] material verbal, obrigado a especular sobre o som e o sentido ao mesmo tempo" (VALÉRY, 2007, p. 203). Para Valéry, o poeta, muito além do utilitarismo de suas pernas, utiliza-as para dançar. Assim é a poesia:

não morre por ter vivido: ele é feito expressamente por renascer de suas cinzas e vir a ser indefinidamente o que acabou de ser. A poesia reconhecese por esta propriedade: ela tende a se fazer reproduzir em sua forma, ela nos excita a reconstituí-la identicamente (VALÉRY, 2007, p. 205).

A poesia do século XX tem fome de forma, de agudeza de expressão. A agudeza seiscentista, por sua vez, era faminta de engenhosidades de conteúdo, com suas metáfora agudas, com seus destinadores tratadistas. Como vimos, Finnegans Wake e Galáxias têm como influenciadores (destinadores), principalmente, Mallarmé. Os programas de uso se distanciam: nos seiscentos, a operação das categorias aristotélicas servem de apoio para a realização da metáfora; no século XX, os programas de espacialização, de reformulações formais desmanchadoras dos contornos encaminham o objeto para a fluidez. No entanto, o programa de base é o mesmo: os objetos estéticos tem por finalidade suscitar o maravilhamento.

\section{Para NÃo CONCLUIR...}

Antes de concluir, retomando duas questões que orientaram esta tese, o chamado barroco e a poesia do final do século $X X$, conhecida como neobarroca, enfatizo que o caminho que fiz partiu de Wölfflin, passou pelas considerações de Eugênio D'Ors, Focillon e chegou à crítica moderna com os trabalhos de Hansen e Pécora.

Wölfflin (2006, p. 28-29) considera que o Cinquecento italiano alcançou um estilo "tectônico", fechado, de grau máximo ou de máxima perfeição. Segundo ele, é necessária uma distinção inequívoca entre composição fechada, tectônica, e o estilo atectônico, aberto, do século XVII. A composição da ordem do fechamento representa discursivamente as coisas como elas são, da ordem do efeito de sentido icástico, e a composição da ordem do fechamento representa as coisas como elas parecem ser, da ordem do efeito de sentido de fantástico, de poiesis.

A definição wölffliniana de forma fechada como tipo de representação apresenta o objeto como simulacro de imitação da realidade; já a forma aberta mostra o objeto como um simulacro de processo em criação, aberto, esmaecido em seus contornos. Nesse sentido, o tipo de contorno nítido teria um efeito de sentido de tatilidade, diferentemente do tipo de 
contorno fluido, que teria outro efeito: o da tangibilidade dissolvida. Ao analisar a arte do século XVII, o chamado barroco, contrapondo-a à do século XVI, classicismo, Wölfflin (2006) afirma que no barroco o conjunto sugere "a impressão" de representar algo mais do que um fragmento casualmente extraído do mundo visível, entendendo o classicismo como busca da representação rigorosa do mundo natural.

A renovada arquitetura barroca dos séculos XVII-XVIII na Itália constitui-se em uma arte negada pelos críticos da época: os monumentos têm seus contornos abertos em elipse, multiplicados em desproporção. No cenário do século XIX surge Wölfflin que, segundo Thürlemann (In: OLIVEIRA, 2004, p. 208), "contribuiu sobremaneira para a reabilitação do barroco", tentando apreender as categorias de clássico e barroco de maneira imparcial; este último seria uma nova forma de produção artística que se opunha ao discurso arquitetural da Renascença". Os cinco pares wölfflinianos apresentam a evolução da forma clássica para a barroca e, nesse caso, os dois momentos da história da arte podem ser vistos como momentos que se sucedem e depois recomeçam, não obstante as curvas da evolução não sustentem a mesma uniformidade. É nesse sentido que Eugenio D'Ors (2011), em 1945, seguindo o pensamento de Wölfflin, sugere para a história da arte ocidental 22 momentos que teriam o rótulo de "barroco".

Há nas categorias dedutivas, independentemente de Thülerman considerá-las imparciais na teoria de Wölfflin, evidente euforização barroca fora do tempo seiscentista. 0 chamado barroco, nesse caso, ascenderia então a uma vertente estilística. Essa posição genérico-formalista pressupõe uma "progressão" das formas em movimento sucessivo de pré-clássico, clássico e barroco (cf. FOCILLON, 2001). A teoria de Wölfflin, portanto, tende a valorizar o chamado barroco como uma progressão das formas clássicas e, nesse caso, considera-o, em lugar do limitado e apreensível, um estilo colossal, ilimitado (cf. GOMES JÚNIOR, 1998, p. 86-87). Nessa comparação, podemos notar a falta de neutralidade de Wölfflin em relação a clássico e barroco.

Zilberberg (1992, p. 4; 2006a, p. 35; 2011a, p. 44), em "Présence de Wölfflin" e, posteriormente em Eléments de grammaire tensive, manteve a oposição clássico/barroco, bem como a valorização eufórica do barroco, considerando-o um acontecimento em termos de "maravilhamento", "sobrevir", "surpresa" e reservando para o classicismo a condição de estado. Nesses termos, identificou o acontecimento com um andamento rápido, vívido, e o clássico com um andamento lento, tênue. O barroco estaria no eixo de acentuada 
intensidade e o clássico estaria no eixo da intensidade mais diluída e atenuada, desembocando na extensidade, na expansão. Para Zilberberg, somente o barroco conheceria o acontecimento. Não haveria acontecimento no classicismo e em outras estéticas? Ou só haveria acontecimento nas estéticas cujas formas apresentassem "evolução" até atingir a "forma barroca"? Nas palavras de Wölfflin (2006, p. 337), "todo estilo passa pela sua fase barroca em dado momento".

Em conversa por e-mail, Luiz Tatit, para preservar o modelo, sugeriu-me que, ao situar barroco e clássico, Zilberberg não estaria tratando de uma oposição convencional entre intensidade e extensidade, embora tenha mantido, no eixo vertical, a noção de andamento, que é próprio da intensidade. A correlação, visto que Zilberberg se apoia nas categorias de expressão de contorno "aberto" (fluido) ou "fechado" (nítido) de Wölfflin, é entre conteúdo, associado a andamento no eixo vertical, e expressão, associada a contorno no eixo horizontal. Como o que está em jogo é a definição do contorno (mais nítido ou mais fluido), em vez de manter graficamente os extremos da extensidade, Zilberberg dá preferência à temporalidade breve/longa .

Mantida essa teoria ipsis litteris, não seria possível identificar acontecimento no clássico, constituindo-se exclusivamente o acontecimento um valor do chamado barroco. Todavia, o acontecimento é próprio de qualquer objeto estético que o suscite, não sendo exclusivo de nenhuma estética. Zilberberg (In: CAÑIZAL; CAETANO, 2004, p. 94) afirma que "a estesia exige o impacto". Ora, o impacto ou a surpresa é característica de qualquer tempo, do romantismo ou do simbolismo, do concretismo ou do chamado neobarroco.

A leitura de Zilberberg (2011a, p. 44), ao identificar barroco com acontecimento e clássico com estado, é um pouco diferente do que Wölfflin (2006, p. 317) afirma: "para a visão clássica, o essencial está na forma estável e permanente, que será apresentada com a maior precisão e com absoluta clareza; para a visão pictórica, o encanto e a garantia de vida estão no movimento. $\mathrm{E}$ o séc. XVI, evidentemente, não renunciou de todo ao motivo do movimento" (grifos nossos). Não seria, pois, pertinente identificar o chamado barroco com acontecimento, pois o que Wölfflin identificou no barroco foi um movimento acentuado, posto que no renascimento também há movimento, só que mais tênue. A oposição em Wölfflin é entre estático e movimento e não entre estático e acontecimento. O que se nota nos objetos estéticos de todas as épocas, porém, é uma gradação entre mais ou menos 
movimento e não entre estático e acontecimento. O termo estático utilizado por Zilberberg pode levar a uma disforia dos objetos estéticos renascentistas.

Vejamos primeiramente o gráfico 1 proposto por Zilberberg:

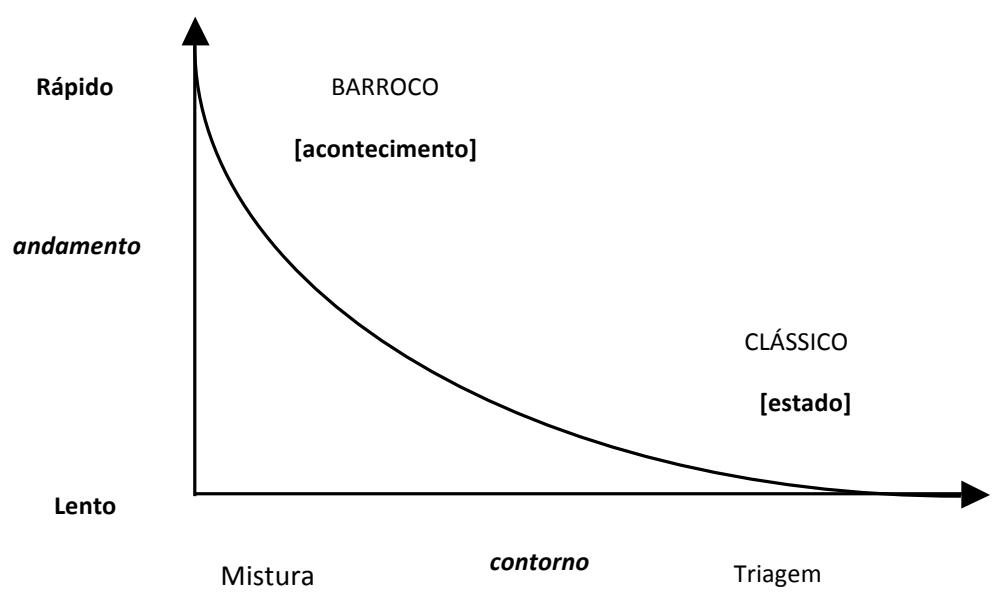

Gráfico 1 Correlação entre barroco e clássico (ZILBERBERG, 2011a, p. 44).

Como nos é apresentado, o gráfico citado gera algumas zonas de turbulência: (1) em primeiro lugar, considera o chamado barroco da égide do acontecimento e o clássico, da de estado; (2) em segundo lugar, aceitando o gráfico proposto por Zilberberg como esquema geral, ele funcionaria como modelo estático e, nesse caso, em análises específicas de inúmeros objetos poéticos, como deixar de reconhecer acontecimento em certas obras clássicas e estado em certas obras do chamado barroco?; (3) em terceiro lugar, posicionamento duvidoso de mistura e triagem no eixo da extensidade; enquanto a mistura está com menor extensidade, a triagem aparece com extensidade maior.

Como observamos nesta tese, a elevada acentuação da intensidade pode ocorrer em variados objetos estéticos, não sendo exclusividade, pois, da arte seiscentista. Dialogando ainda com o modelo de Zilberberg, em vez dos termos mistura e triagem, pareceram-nos mais pertinentes os termos esmaecimento dos contornos e manutenção dos contornos ou, respectivamente, fluidez e nitidez. Vejamos o que sugerimos no gráfico 2: 


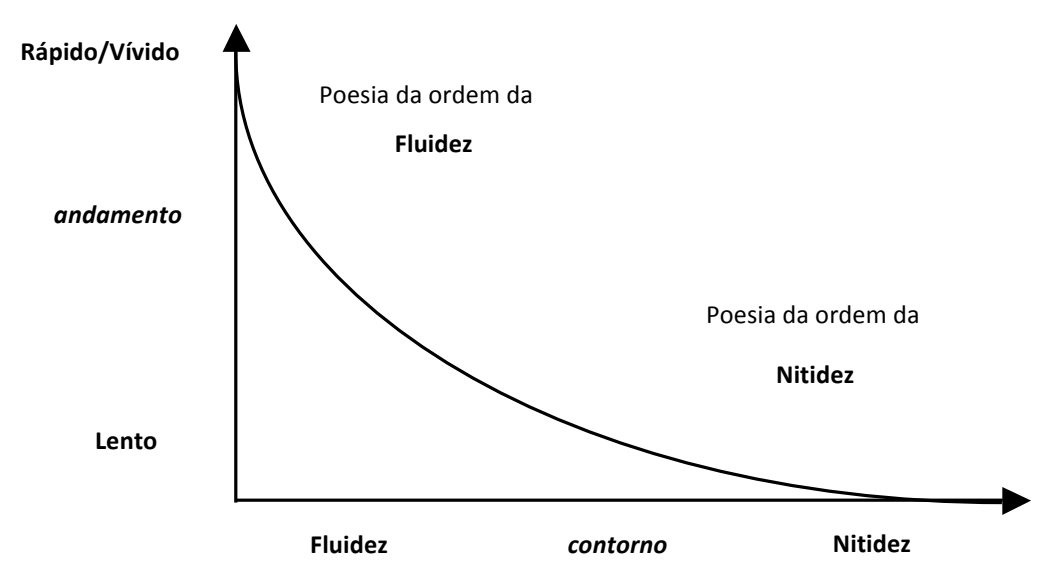

Gráfico 2 Correlação entre fluidez e nitidez.

Fonte: Elaborado com base em Zilberberg (2011, p. 44).

Ao longo da tese, a opção por estender o gráfico tem como resultado uma reta horizontal que apresenta a operação de maior ou de menor diluição da intensidade representada na reta vertical. Se há maior diluição da intensidade, a nitidez será o caminho do objeto; se há menor diluição da intensidade, a fluidez será o caminho do objeto. Nesse caso, temos:

$$
\leftarrow
$$

Fluidez

Nitidez

Rápido/vívido

Lento/Atenuado

Tomando o gráfico sugerido, desencadeiam-se as seguintes reflexões:

- No modelo inicial de Zilberberg, mistura estaria do lado da difusão, ou seja, do lado de "mais diluição" de intensidade. No gráfico 2, temos uma troca de posições entre triagem e mistura. Na concepção original, triagem aparece próxima da extremidade esquerda e mistura aparece na extremidade direita.

- Como Zilberberg admite no eixo da extensidade a categoria complexa "contorno" do plano da expressão (PE), adotei mistura como "esmaecimento de contornos", "fluidez", "abertura", e triagem como "permanência do contorno", "nitidez", "fechamento". E, nesse sentido, poderíamos, em vez de correlacionar "barroco" e "clássico", pensar em objetos de contorno mais 
fluidos e objetos de contorno mais nítidos (formas do PE e do PC) ${ }^{9}-$ ver gráfico 2.

- Tomando fluido e nítido, como lidaríamos com o eixo da intensidade? A um contorno esmaecido, fluido, teríamos, de um lado, elevada acentuação na intensidade e, como consequência, impacto, maravilhamento; de outro lado, a um contorno mais nítido, teríamos atenuação da intensidade e, como consequência, menor impacto. E a velocidade como explicá-la?

- Para fluidez, uma cifra da rapidez (vívido), da aceleração; para a nitidez, uma cifra da desaceleração, da lentidão. Em relação aos objetos fluidos, teríamos um delongado reconhecimento inteligível, ao contrário dos objetos encaminhados para a nitidez. Essas categorias não são estáticas, visto que um mesmo objeto pode contemplar ora nitidez ora fluidez e, muitas vezes, a mistura dessas ordens, bem como uma gradação das cifras.

- As poesias agudas mais fluidas aproximam-se do pictórico de Wölfflin, guardando na sua latência o enigma, o mistério, enquanto a poesia aguda mais nítida aproxima-se do linear (plástico) wölffliniano. O plástico, o nítido/o linear, contempla valores táteis e pode ser seguido pela linha, que foi valorizada no classicismo; já o pictórico, o fluido, contempla valores visuais e, portanto, é endossado pela confiança no olhar. Nesse sentido, se retomarmos "Pilar", "Caminho novo", de Affonso Ávila, Galáxias, de Haroldo de Campos, Finnegans Wake, de Joyce, a sensação que temos é de inacabamento. Nitidez e fluidez são percepções diversas do mundo, não se relacionando por avaliação hierárquica, ou seja, uma não é melhor nem mais artística do que a outra. Nitidez e fluidez são formas que permitem apenas ver de outra maneira, bem como ver outras coisas (cf. Wölfflin, 2006, p. 334).

Com base nessas reflexões, elaboramos o quadro 1 , demonstrativo da rede de dependências entre as categorias.

\footnotetext{
${ }^{9}$ PE e PC são separados aqui apenas para efeito didático (cf. HJELMSLEV, 1991, p. 45-46).
} 


\begin{tabular}{|c|c|c|}
\hline regidos $\rightarrow$ & poesias mais nítidas & poesias mais fluidas \\
$\downarrow$ & $\downarrow$ & $\downarrow$ \\
\hline $\begin{array}{c}\text { Contorno } \\
\text { (forma do PE } \\
\text { e do PC) } \rightarrow\end{array}$ & $\begin{array}{c}\text { Fechado } \rightarrow \text { valorização do } \\
\text { contorno }\end{array}$ & $\begin{array}{c}\text { Aberto } \rightarrow \text { valorização do } \\
\text { esmaecimento do contorno }\end{array}$ \\
$\begin{array}{c}\text { (agudeza de ênfase no } \\
\text { conteúdo) }\end{array}$ & $\begin{array}{c}\text { (agudeza de ênfase na } \\
\text { expressão) }\end{array}$ \\
\hline Direção $\rightarrow$ & Afastamento & Aproximação \\
\hline Andamento $\rightarrow$ & Desaceleração & Aceleração \\
\hline
\end{tabular}

Quadro 1 Semiótica da agudeza.

Fonte: Adaptado de Zilberberg (2006a, p. 167).

Os enunciados wölfflinianos pressupõem um enunciador que acolheu os valores do final do século XIX, triando e excluindo os valores dos destinadores tratadistas, Peregrini, Pallavicino, Gracián, Tesauro, Ferreira, que orientavam o fazer artístico seiscentista. Wölfflin, segundo Hauser (2003, p. 448), não teria percebido "a continuação da arte clássica da Renascença" no que hoje usualmente é conhecido como barroco. Essas categorias não se aplicam exclusivamente aos objetos artísticos dos séculos XVI e XVII, às vezes nem às dos seiscentos, como afirmam Hansen (2001, p. 17), Pécora e Hansen (2006, p. 87).

Também Wellek (197-, p. 113) rejeita a "transferência mecânica das categorias de Wölfflin à literatura" e estabelece que seria mais promissor um estudo que abordasse a estrutura dos objetos.

Com base nisso, estudamos nesta tese as variações da semiótica da agudeza, estabelecendo como modelo a nitidez e/ou a fluidez. Vejamos o movimento tensivo dos objetos agudos: 


\section{Tensividade na Semiótica da Agudeza}

MOVIMENTO TENSIVO DOS OBJETOS AGUDOS

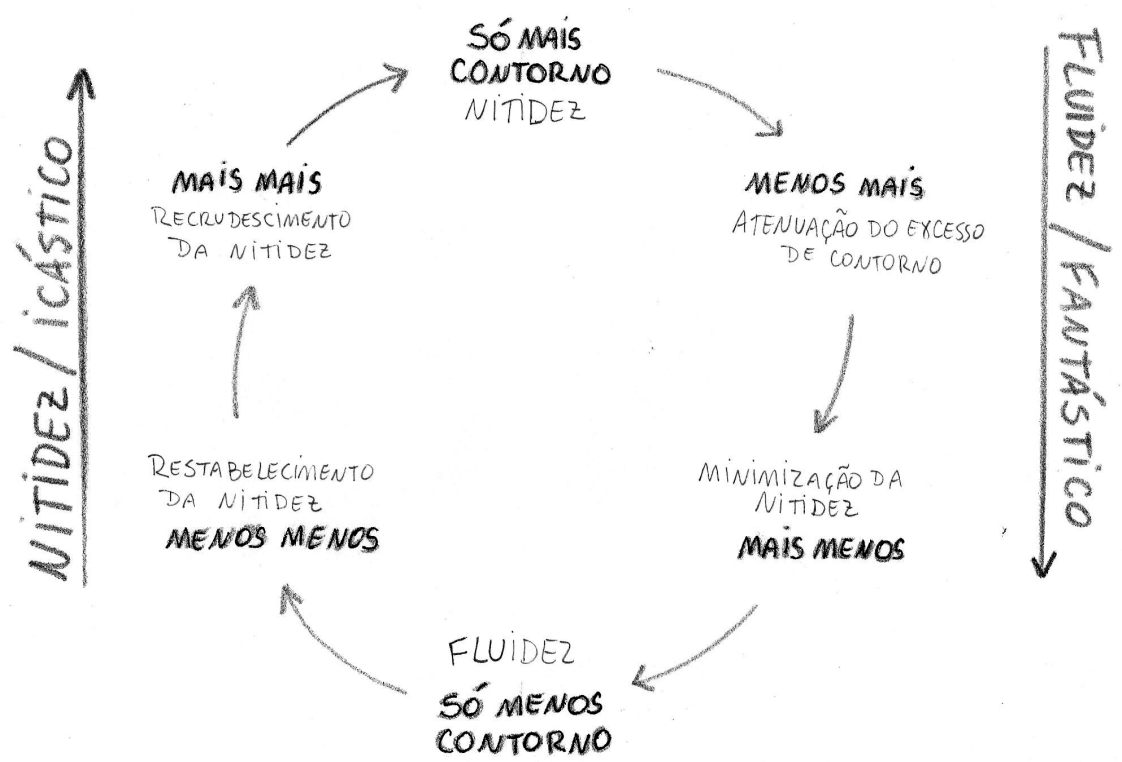

Retomando o gráfico original de Zilberberg (gráfico 1) e o quadro 1, a oscilação entre contornos mais fluidos e contornos mais nítidos opera-se não no antitetismo entre clássico e barroco nem no antitetismo entre estado e acontecimento, mas entre um jogo de contornos mais esmaecidos e outro de contornos mais nítidos. A operação de maior restabelecimento ou de menor restabelecimento é que suscita um enunciatário mais próximo, mais distante, mais ativo, mais passivo. Daí um objeto da ordem do acontecimento não se vincular necessariamente ao desmanche do contorno das formas (tanto do PE quanto do PC). Em vez desses rótulos barroco/clássico/neobarroco, optamos pela correlação, pela coexistência, de poesia aguda de expressão e de poesia aguda de conteúdo, ambas marcadas, como vimos, quer pela nitidez, quer pela fluidez.

Ademais, as categorias dedutivas de Wölfflin são de um período iluminista e positivista; o clima intelectual dessa época privilegia os valores formais, valores não conhecidos do século seiscentista. Homologar a tensão plástica entre a crescente desvalorização da linha, marca do que Wölfflin chama de barroco, e a crescente valorização de seu esmaecimento com o acontecimento, de um lado, com o estado, de outro, talvez colocasse o modelo de Zilberberg em risco.

Pudemos observar nesta tese que, quando se dão o esmaecimento e a flacidez dos contornos, temos um objeto que visa a um efeito de sentido de inacabado, de 
"aparecimento". E é esse aparecimento como sobrevir que poderia nos levar à categorização de "acontecimento". Ao lado desse tipo fluido (como "Pilar", "Casa de Gonzaga", de Affonso Ávila, Galáxias, de Haroldo de Campos, por exemplo), temos poesias cujos limites são atualizados, nítidos (como um soneto atribuído a Gregório de Matos), engendrando um efeito de contrato com a aparência de realidade, do tipo icástico da conhecida arte "linear".

Essa tensão ultrapassa qualquer rotulação: objetos clássico ou barroco? Da ordem do acontecimento ou não? Virtualização ou atualização dos contornos? Talvez seja essa a tônica da arte. A virtualização do contorno estaria vinculada a um enunciador que reconhece que é no paradigma, na ausência, que temos o jogo poético. E é essa estrutura tensiva que rege os enunciados. Não seria a manifestação discursiva do paradoxo, da antítese elemento caracterizador da fórmula "barroco"/"neobarroco", mas a tensividade da agudeza é que erige e dá orientação aos efeitos de sentido manifestados.

O desmanche dos contornos, antes que se configurar barroco ou clássico, ou outra estética qualquer, relaciona-se com o recrudescimento da agudeza que se segue de um fervilhar enunciativo que tem um enunciatário que se identifica de modo maravilhado, em êxtase, com o enunciador (cf. ZILBERBERG, 2011a, p. 220-221). Trata-se de uma identificação enunciativa que toca o enunciatário e convoca-o a atualizar a força acentuada e vívida da poesia potencializada pelos contornos fluidificados. Nesse sentido, o restabelecimento vívido pode ser entendido como acontecimento. Teríamos, pois, menos uma distinção entre barroco e neobarroco, entre barroco e clássico, entre parnasianismo e simbolismo etc. e mais coexistência. Tomando um soneto atribuído a Gregório de Mattos, considerado normalmente como barroco, ele pode encontrar-se na direção tensiva de maior nitidez que fluidez. Já tomando um poema visual da Antiguidade, como "O ovo", de Símias de Rodes, temos a direção da fluidez. Mais do que rótulos, temos estratégias agudas.

Nenhum texto artístico é, todavia, tão sublime ou extraordinário que não possa ser descoberto ou restabelecido em seus contornos. Caso contrário, talvez o objeto estético se desmanchasse por saturação tônica. Sem intenção de dar respostas definitivas e sem pretensão de romper com as investigações anteriores e mais com intuito de continuar refletindo sobre o pensamento de Greimas e de Zilberberg, na semiótica, de Hansen e de Pécora, na crítica literária, e de tantos outros autores aqui em diálogo com as letras seiscentistas e a euforização barroquista, termino sem a colocação de um ponto final... Nihil sub sole novum/Non c'è niente di nuovo sotto il sole. 
CONCLUSÃO 
Ao longo desta tese, divida em cinco capítulos, examinamos principalmente a poesia do final do século XX, de Affonso Ávila, Haroldo de Campos, Horácio Costa e alguns excertos de Galáxias, de Haroldo de Campos, de Finnegans Wake, de James Joyce, apoiando-nos em muitos casos nas letras seiscentistas das poesias atribuídas a Gregório de Matos, das poesias John Donne e dos Sermões de Pe. Antonio Vieira.

Inicialmente, verificamos que o recorte de barroco só veio a aparecer na história das artes a partir das obras de Wölfflin, que são do final do século XIX. Assim é que as obras seiscentistas não conhecem, no momento de sua criação, divisão em relação ao clássico. Observamos também que a avaliação disfórica dos objetos estéticos do século XVII não considera um conceito que lhes é contemporâneo e fundamental, a agudeza originária de tratadistas, como Matteo Peregrini, Baltazar Gracián, Emanuele Tesauro, Francisco Leitão Ferreira, que nada mais são do que a difusão de poéticas e retóricas clássicas, como as de Aristóteles, Horácio, Quintiliano.

Examinando a cifra tensiva do termo barroco, verificamos no capítulo 1 haver nele uma dominância do sobrevir e o fizemos com base em verbetes de dicionários, de variadas línguas, de 1865 a 2010. Investigamos ainda a sincronia e a diacronia do estado de barroco, concluindo que não se trata de ressurgimento do barroco no século XX nem de mudança de sistema, mas de objetos estruturados segundo a tutela de novos destinadores. Agora, os poetas ouvem Mallarmé, Holderlin, Leopardi, Ungaretti, Pound, Cummings, Mayakovski, Joyce, Gomringer.

Reconhecemos, pois, na agudeza uma estrutura que atualiza os tratadistas seiscentistas. Ao aparecimento de uma forma pode correlacionar-se o desaparecimento de outra forma, o que configuraria uma mudança semiótica: teríamos então uma agudeza seiscentista, estruturada com base nos contratos enunciativos da época, e uma agudeza do século XX, fundada em outro contrato enunciativo, que teatraliza, como vimos, a "crise de verso".

Nos manuais de literatura e em verbetes de dicionário, o nível tensivo, o da agudeza estruturante, foi substituído por figuras do nível discursivo, tais como bizarro, verrugoso, 
tumoral etc. Essa inversão levou a eliminação do específico formal das letras seiscentistas, bem como influenciou a denominação dos objetos do final do século $X X$, considerando-os como neobarroco por eleger algumas figuras de identidade no nível discursivo. No entanto, o que na manifestação parece identidade, no nível tensivo constitui-se alteridade, ou seja, trata-se de agudezas que participam de escolhas tensivas diferentes. Nesse caso, as figuras como caudaloso, exuberante, ornamentado, excessivo, que também são utilizadas para identificar neobarroco, têm substituído uma forma aguda específica do século $\mathrm{XX}$, a diluição mais acentuada ainda dos contornos, que são as escolhas de enunciadores como Mallarmé e Joyce.

Discutida a questão do recorte de barroco na continuidade clássica, passamos a examinar no capítulo 2 o jogo tensivo entre agudeza de expressão e agudeza de conteúdo. Concluímos então pela coexistência de uma poesia aguda de dominância do PC, em que a agudeza do PE permanece latente e uma poesia aguda de dominância do PE, em que a agudeza do PC permanece em estado latente. Como sabemos, PE e PC são separados apenas para demonstração argumentativa. Verificamos tratar-se a agudeza do PC de um enunciado em que convergem acordos e desacordos lógicos ou, em outras palavras, de uma concordância discordante ou uma discordância concordante. A agudeza, com a fusão de elementos normalmente inamalgamáveis, produzindo perda de contorno semântico, visa provocar êxtase, maravilhamento. Examinando a metáfora, ela se constitui pela substituição de um termo em ausência (paradigma) por um termo em presença (sintagma). Em termos de agudeza, há uma oscilação com relação à distância e assim temos metáforas mais agudas ou menos agudas, que promovem maior ou menor efeito de maravilhamento.

Considerando a semiótica da desigualdade dos intervalos, identificamos a metáfora aguda com a relação de sobrecontrários (S1 e S4) e a metáfora menos aguda com a relação de subcontrários (S2 e S3). A metáfora aguda é a que provoca o acontecimento de que nos fala Zilberberg. E, nesse caso, podemos estender essa agudeza à ênfase no PE: teríamos então aproximações sonoras e visuais que desmancham os contornos silábicos e fragmentam os grafemas no branco da página. É, pois, com base nas operações de agudeza que examinamos as propriedades estruturais dos objetos estéticos dos seiscentos e do final do século XX.

O jogo das agudezas faz-se com base na regência de cifras de andamentos diferentes, conforme o objeto. Inicialmente, os refreamentos das formas produzem maravilhamento de 
ordem sensível, delongando o reconhecimento inteligível. Já num segundo momento, o sensível perde em duração e em aceleração, promovendo outro tipo de prazer, inteligível. Então, o inteligível ganha em aceleração e ocorre o reconhecimento cognitivo do objeto. A poesia, por fim, seja ela qual for, tem como programa a duração sensível, que por sua vez é efêmera. Ora, a desejada duração sensível está em tensão permanente com o prazer delongado do encaminhamento inteligível.

No capítulo 3, examinamos a negação da euforia barroquista e consideramos, no lugar de neobarroco, a poesia visual da agudeza, que, em vez de apoiar-se em um número sem-fim de estilemas, faz-se segundo a operação de duas vertentes tensivas da semiótica da agudeza: poesia aguda de ênfase no PE e/ou poesia aguda de ênfase no PC. Em ambas as direções seguidas, as cifras de andamento rápido, vívido, e/ou lento do objeto poético produzem um movimento dinâmico de nitidez/fluidez.

A acentuação das formas não é exclusividade nem da poesia seiscentista nem da do século $X X$, com a diferença de que o poeta da agudeza fluida tem em vista apresentar não apenas um conteúdo, mas um objeto sonoro-visual. No estudo da fluidez, com apoio em Pound, segundo o qual a poesia seria a mais condensada forma de expressão verbal, propusemos uma visada tensiva para o entendimento do esmaecimento dos contornos nos objetos fluidos. Um soneto de cariz analítico-discursivo apresenta limites mais definidos e formas mais nítidas e expandidas, nitidez que imprime no enunciado certa atenuação da intensidade. Uma maior acentuação da poesia de agudeza fluida produz um efeito de enigma: suas formas vividamente desmanchadas orientam o enunciatário em direção da nitidez. Todavia, a tensão que é própria dos poemas fluidos se atenua quando de seu reconhecimento. Movido pelo sensível, o enunciatário pode encontrar ou não uma saída rápida para o inteligível, pois que dois são os vetores: pouco fluido/mais nítido e/ou mais fluido/pouco nítido.

As poesias do final do século XX caracterizam-se, portanto, pela escolha da agudeza visual, sonora ou de conteúdo constituída por um trabalho de inquietação linguística que substitui o conforto da organização sintagmática da espera pelo desconforto da organização sintagmática do inesperado. A acentuação da sensibilidade visual do sujeito marcado por uma paixão de alma de euforia aguda conduz o poeta a refletir sobre a fluidez das formas de expressão e de conteúdo que utiliza. Essa abertura de possibilidades formais engendra formas híbridas que ultrapassam os limites do verso linear, do enunciado analítico e propõe 
nova distribuição do enunciado poético no branco da página. Assim, a poesia que era particularmente temporal, linear, sequencial passou a manifestar-se espacialmente num enunciado que se pretende sensivelmente simultâneo. Daí poder ela ser lida vertical, horizontal, circularmente e até de forma elíptica.

Embora a poesia do final do século XX explore sobretudo o visual, a visualidade não é propriamente uma criação nova. Ana Hatherly fez extenso levantamento de poesias labirínticas de agudeza visual, que herdamos das mais remotas eras. Também com Horácio Costa depreendemos haver uma família de conceitos que se afirmam e dão origem a uma tradição visualista mais do que propriamente neobarroquista.

Em Haroldo de Campos, por sua vez, verificamos a organização de um cânone de autores que apresentam um ponto convergente, o da inovação poética com relação aos experimentalismos linguístico; foi com base nele que observamos que os destinadores da poesia aguda do século XX são outros que não os dos seiscentos. Por isso, consideramos tratar-se de uma agudeza própria do século XX e não simplesmente a repetição da agudeza nos moldes seiscentistas.

Um traço fundamental que se evidencia nos objetos agudos do final do século XX é seu distanciamento da poesia de "sentimento", de "mensagem", simuladora da "realidade", do contrato icástico. Uma das características dos românticos epigonais, por exemplo, era recorrer à vivência do poeta, produzindo uma poesia confessional, de tipo diário de sentimentos pessoais.

A poesia aguda do final século $X X$, muitas vezes, já não se vale da pontuação; a linearidade do sintagma é rompida a todo momento, as propostas de leituras se fazem nas mais diversas direções. As palavras nesse tipo de poesia não se comunicam por meio da tradicional relação gramatical de elos coesivos; elas se partem, repartem, se juntam de modo inovador. A tessitura sintagmática dilacera-se, simulando a prevalência do paradigma. A arquitetura linguística, a metalinguagem, a função poética levada ao ápice torna-se corrente e o fazer poético da semiótica da agudeza configura-se como um jogo secreto de possibilidades combinatórias da linguagem. Esse jogo sibilino, esse enigma, não atenua o poético; ao contrário, vivifica-o duplamente: o fruir estético passa a ser um fruir não apenas sensível, como também um fruir inteligível. O pintor Degas teria se queixado a Mallarmé que, quando deixava de lado a pintura para fazer, vez ou outra, poesias, ocorriam-Ihe ideias em demasia e isso, para ele, ameaçava seu fazer poético, podendo até destruí-lo. Mallarmé 
Ihe respondeu que versos não se fazem com ideias, mas com palavras. Enfim, permutação, combinatória, pluralidade de leituras são conceitos fundamentais para o entendimento do labirinto, que é regido, num primeiro momento, por um recrudescimento do sensível (artifícios refreadores das formas de expressão e do conteúdo) e, num segundo momento, por um recrudescimento do inteligível, quando do reconhecimento do objeto estético:

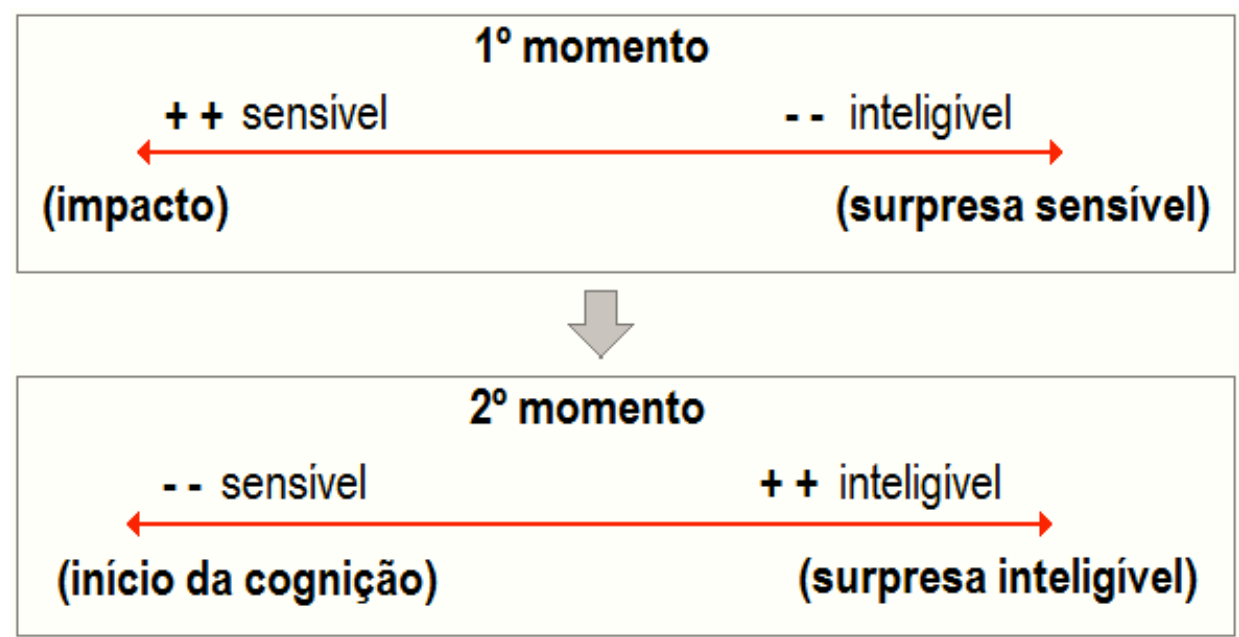

Vetores tensivos linearizados.

Com base no vetor apresentado, questionamos a impossibilidade matemática da correlação entre o eixo das ordenadas e o eixo das abscissas, constante de Eléments de grammaire tensive, de Zilberberg; por isso, "esticamos" o gráfico em uma reta tensiva, uma vez que o sensível é resultado e extensão do inteligível. São duas ordens que se interpenetram e, portanto, pertencem ao mesmo vetor. Trata-se apenas de gradação, como Zilberberg entende, para o mais ou para o menos. Nesse sentido, a semiótica da agudeza contempla as duas possibilidades em dois momentos semióticos subsequentes: (1) fruição sensível inicial e (2) fruição inteligível final. Dois deleites que se graduam na mesma reta: a ordem sensível conhece sua equalização na ordem inteligível.

Ao tratarmos do sensível e do inteligível, discutimos no capítulo 4 a estaticidade e o movimento, segundo o diálogo da semiótica tensiva com a fenomenologia. Consideramos ainda com base em Zilberberg que o sentido apresenta uma direção que conhece avanços e recuos. O sujeito, então, é orientado por uma seleção de andamento, acelerado ou desacelerado. Além disso, nas paradas, nos recuos, temos uma descontinuidade provocadora de surpresa, um salto inesperado de uma etapa para outra; já na continuidade, 
nos avanços, temos uma desaceleração, visto que tudo se dá da forma como se esperava. Há uma gradação das etapas, um início com chegada prevista.

A discussão dos limites entre sensível e inteligível também nos proporcionou verificar que um objeto é passível de percepções distintas: uma em que a fonte da percepção seria o saber e que leva o sujeito ao controle do objeto e outra em que a fonte da percepção seria o crer; neste último caso, há um enfraquecimento do sujeito, que se comove diante do objeto, que the escapa, dada sua fluidez. Daí que os poemas agudos fluidos, que apresentam contornos esmaecidos, solicitam maior aproximação do sujeito da enunciação para o restabelecimento dos contornos desmanchados. E ele o faz com base na fé perceptiva, no crer, e não apoiado na certeza do saber.

O sensível e o inteligível ainda encaminham a discussão para a primazia do ato semiológico sobre a percepção. Com base em Beividas, que se apoia em Saussure e no princípio de arbitrariedade dos signos, não haveria como admitir uma virada fenomenológica que estabelece a primazia do sensível sobre o inteligível. Daí o conceito de semiocepção que prevê ser toda percepção sensível apreendida por um ato semiológico.

Examinando os conceitos de percepção e concepção, depreende-se uma cifra tensiva de andamento: enquanto a concepção apresenta rapidez do reconhecimento inteligível e atenuação do sensível, na percepção ocorre o contrário: há desaceleração do reconhecimento inteligível e acentuação do sensível. Esses dois conceitos levaram-nos a admitir dois tipos de poesia, uma que se encaminha para a fluidez e outra para a nitidez. A poesia da ordem da nitidez é mais analítico-discursiva e preserva os contornos; já a da fluidez é estilhaçada, desmanchada, constituindo um objeto cuja apreensão intelectiva é lenta e também prazerosa. Por isso, afirmamos que a percepção e a concepção, o sensível e o inteligível, o opaco e o lúcido, o fluido e o nítido constituem atos semiológicos de diferentes cifras tensivas.

Na percepção do objeto estético, o sujeito é tocado ou pela substância do conteúdo ou pelas formas do conteúdo e da expressão. Se tocado pela substância do conteúdo, prevalece o eixo icástico, o simulacro de imitação da realidade; nesse caso, os objetos da agudeza de ênfase no PC estão próximos de uma estética da substância. Se tocado pelas formas do conteúdo e da expressão, prevalece o eixo fantástico ou poiético; nesse caso, temos um simulacro de reconstrução de formas da expressão e do conteúdo, uma arquitextura formal. Os objetos do eixo icástico não são destituídos de formas poiéticas, pois 
tanto o objeto icástico quanto o fantástico são criações discursivas. Daí termos optado por organizar os objetos estéticos segundo um continuum, em que a agudeza do conteúdo se aproxima mais do eixo icástico, mimético, e a agudeza da expressão mais do eixo poiético, da re-forma.

Consideramos ainda a poesia aguda fluida um perobjeto, da ordem do sobrevir, enquanto a poesia aguda mais nítida seria da ordem do relaxamento, do pervir. Os objetos distinguem-se pela estetização ou pela etização. Se neles domina a ética, temos uma tensão entre dois sujeitos, um ativo que tem o saber moralizador e um passivo que recebe tal saber. Se neles domina a estética, temos um perobjeto, que comporta um objeto ativo e um sujeito mais passivo que é levado a crer no objeto e não a conhecê-lo, posto que o saber pode levar o objeto à ruína. A estetização provoca um maravilhamento que tanto atrai como pode repelir o sujeito.

Finalmente no capítulo 5, ao tratar da agudeza do final do século XX, consideramos que ela erige um objeto estético que se encaminha para a fluidez. Agudezas acentuadas das formas da expressão e do conteúdo requerem maior aproximação do enunciatário para o restabelecimento dos contornos. Ele é convidado a rearranjar as formas fragmentadas e aglutinadas e levado a preencher as catálises para refazer o percurso das metáforas agudas.

Se o experimentalismo poético ultrapassar o ponto-limite de fluidez, corre o risco de produzir um objeto de difícil reconhecimento; se excessivamente nítido, pode destruir o estético. Nesse caso, o docere suplanta o delectare.

Ao término desta conclusão, enfatizo o que Zilberberg afirma quando analisa "Larme" de Rimbaud: a angústia que acomete o poeta é a de buscar suspender momentaneamente a arbitrariedade do signo. A mestria poética conta com a inovação das formas da expressão e do conteúdo para criar, por meio do trabalho com os significantes, novos significados. Por fim, mais que euforia barroquista ou mesmo sua negação, sobra-nos uma reflexão: tendo em visa que o poético consiste em acentuar cada vez mais os refreamentos das formas do PE e do PC para "experimentar" novas possibilidades de delongar mais e mais o reconhecimento inteligível, em que momento da curva tensiva se daria uma ruptura? Parece-nos que, tendo alcançado certa ruptura e seu estabelecimento, o que era acentuado e vívido encaminha-se novamente à atenuação, requerendo novas subversões, que podem se dar pelo retorno a uma tradição. Logo, qualquer iniciativa de ruptura configura-se uma teatralização, como foi a da crise de verso do final do século XIX e 
século XX. O novo contém uma semente tensiva do velho, em que a diferença brota da semelhança; novo e velho não se atitetizam; ao contrário, por serem faces de uma mesma moeda, estão continuamente em relação de dependência.

Todo ápice contempla, por consequência, o começo da queda e o movimento de retorno na direção oposta da teatralização discursiva da ruptura. Mesmo os experimentalismos linguísticos que funcionam num primeiro momento como acentuados perdem a vivacidade com sua extensidade, requerendo novamente uma parada. Em outras palavras, se escolher só valores da tradição, pode cair na repetição tediosa; se, por outro lado, prevalecer excesso nas operações de acréscimo de inovações e re-formas, que pode se constituir em pejoração, corre o risco de saturação por ininteligibilidade. A polêmica sobre se o barroco seiscentista seria uma decadência ou uma renovação da arte renascentista assemelha-se à seguinte questão: as formas do final do século XX são uma novidade ou apenas uma tentativa de resgate por continuidade? Sem pretensão de dar uma resposta, a arte parece manter-se em tensão entre um discurso de ruptura atrelado a uma continuidade do passado, ou por melhoração ou por pejoração. A dúvida do fazer artístico concentra-se entre o quanto conservar da tradição e o quanto rompê-la. Afinal... tradição ou ruptura? 


\section{REFERÊNCIAS}

ABRAMS, Meyer Howard. O espelho e a lâmpada. Tradução de Alzira Vieira Allegro. São Paulo: Unesp, 2010.

ACADEMIA BRASILEIRA DE LETRAS. Dicionário escolar da língua portuguesa. 2. ed. São Paulo: Nacional, 2008.

ACEVEDO, Edberto Oscar. Estudios sobre barroco y terminologia en hispanoamerica. Buenos Aires: Ciudad Argentina, 1999.

ACHCAR, Francisco. Lírica e lugar-comum: alguns temas de Horácio e sua presença em português. São Paulo: Edusp, 1994.

ADORNO, Theodor. W. Notas de literatura I. Tradução e apresentação de Jorge M. B. de Almeida. São Paulo: Duas Cidades; Editora 34, 2003.

AGAMBEN, Giorgio. O fim do poema. Tradução de Sérgio Alcides. Cacto, 1, Santo André, p. 142-149, ago. 2002.

AGOSTINHO, Santo. Santo Agostinho. Tradução de J. Oliveira Santos e Ambrósio de Pina. São Paulo: Nova Cultural, 1999. (Os Pensadores.).

AGUIAR E SILVA, Vitor Manuel de. Teoria da literatura. 3. ed. São Paulo: Martins Fontes, 1976.

AGUILAR, Gonzalo. Poesia concreta brasileira: as vanguardas na encruzilhada modernista. São Paulo: Edusp, 2005.

ALBUQUERQUE FILHO, Dhynarte. Haroldo e as Galáxias: um caso concreto de barroco. Conexão Comunicação e Cultura. Caxias do Sul: UCS, v. 5, n. 9, p. 175-195, jan./jun. 2006.

ALIGHIERI, Dante. A divina comédia. Tradução de J. P. Xavier Pinheiro. 4. ed. Rio de Janeiro: Atena Editora, 1962. . Tradução de Italo Eugenio Mauro. São Paulo: Editora 34, 1998. 3 v.

ALMEIDA, Maria Cândida Ferreira de. Tornar-se outro: o topos canibal na literatura brasileira. São Paulo: Annablume, 2002.

AMORA, Antônio Soares Amora. História da literatura: séculos XVI-XX. 3. ed. São Paulo: Saraiva, 1960.

Teoria da literatura. 4. ed. São Paulo: Editora Clássico-científica, 1961.

ANCESCHI, Luciano. Gli specchi della poesia. Torino: Enaudi, 1989.

Autonomia ed eteronomia dell'arte: saggio di fenomenologia delle poetiche. Milano: Garzanti, 1992.

ANDRADE, Carlos Drummond de. Poesia completa. Rio de Janeiro: Nova Aguilar, 2002.

ANDRADE, Mário de. Aspectos da literatura brasileira. 6. ed. Belo Horizonte: Editora Itatiaia, 2002.

. Os filhos da Candinha: crônicas. Rio de Janeiro: Agir, 2008.

ANDRADE, Oswald. Pau Brasil. 2. ed. São Paulo: Globo, 2003.

Estética e política. 2. ed. São Paulo: Globo, 2011.

A utopia antropofágica. 4. ed. São Paulo: Globo, 2011.

ANTUNES, Arnaldo. Como é que chama o nome disso. São Paulo: Publifolha, 2006. 
ARARIPE JÚNIOR, Tristão de Alencar. O leitor de Gregório de Matos. In: Teoria, crítica e história literária. Seleção e apresentação de Alfredo Bosi. São Paulo: Edusp, 1978. p. 275-312.

ARGAN, Giulio Carlo. Imagem e persuasão: ensaios sobre o barroco. Tradução de Maurício Santana Dias. São Paulo: Companhia das Letras, 2004.

ARISTÓTELES. Poética. Tradução de Eudoro de Souza. São Paulo: Abril Cultural, 1973. (Os Pensadores.)

Retórica das paixões. Tradução de Isis Borges B. da Fonseca. São Paulo: Martins Fontes, 2003. . Retórica. Tradução de Marcelo Silvano Madeira. São Paulo: Rideel, 2007.

ARISTÓTELES; HORÁCIO; LONGINO. A poética clássica. Tradução de Jaime Bruna. 12. ed. São Paulo: Cultrix, 2008.

ARRIGUCCI JR., Davi. O escorpião encalacrado: a poética da destruição em Julio Cortázar. São Paulo: Perspectiva, 1973.

ARRIVÉ, Michel. Em busca de Ferdinand de Saussure. Tradução de Marcos Marcionilo. São Paulo: Parábola, 2010.

AUERBACH, Eric. Ensaios de literatura ocidental. Tradução de Samuel Titan Jr. e José Marcos Mariani de Macedo. 2.ed. São Paulo: Duas Cidades; Editora 34, 2012.

AULETE, Caldas. Dicionário contemporâneo da língua portuguesa. 5. ed. Lisboa: Delta, 1970.

ÁVILA, Affonso. O lúdico e as projeções do mundo barroco. 2. ed. São Paulo: Perspectiva, 1980. . Iniciação ao barroco mineiro. São Paulo: Nobel, 1984. . O lúdico e as projeções do mundo barroco II. 3. ed. São Paulo: Perspectiva, 1994. (Org.). Barroco: teoria e análise. Tradução de Sérgio Coelho et al. São Paulo: Perspectiva,

1997. The baroque culture of Brazil. In: SULLIVAN, Edward J. Brazil, body \& soul. New York: Guggenheim Museum, 2001.

. Homem ao termo: poesia reunida [1949-2005]. Belo Horizonte: Editora UFMG, 2008 a. O poeta e a consciência crítica. 3. ed. São Paulo: Perspectiva, 2008b.

AZEVEDO FILHO, Leodegário A. de. Estruturalismo e crítica de poesia. Rio de Janeiro: Edições Gernasa, 1970.

BADIR, Sémir. Saussure: la langue et sa représentation. Paris: L’Harmattan, 2001. . Hjelmslev. Paris: Les Belles Lettres, 2004. . A noção de texto em Hjelmslev. Cadernos de Semiótica Aplicada, v. 3, n. 2, dez. 2005.

; KLINKENBERG, Jean-Marie. Figures de la figure: sémiotique et rhétorique générale. Limoges: Pulim, 2008.

BACHELARD, Gaston. La dialectique de la durée. 4. ed. Paris: Quadrige: PUF, 2006. La dialettica della durata. Traduzione di Domenica Mollica. Milano: Bompiano, 2010.

BAKHTIN, Mikhail. A cultura popular na Idade Média e no Renascimento: o contexto da obra de François Rabelais. Tradução de Yara Frateschi Vieira. São Paulo: Hucitec, 1987.

Questões de literatura e de estética: a teoria do romance. Tradução de Aurora Fornoni Bernardini et al. 2. ed. São Paulo: Hucitec, 1990. 
BAKHTIN, Mikhail (VOLOCHINOV). Marxismo e filosofia da linguagem. Tradução de Michel Lahud e Yara Frateschi Vieira. 8. ed. São Paulo: Hucitec, 1997.

2006.

Estética da criação verbal. Tradução de Paulo Bezerra. 4. ed. São Paulo: Martins Fontes,

BALLABIO, Eugenio. Barocco e fascismo: fenomenologia estetica e storica. Roma: Sovera Editore, 2003.

BANDEIRA, Manuel. Estrela da vida inteira. 20. ed. Rio de Janeiro: Nova Fronteira, 1993.

BAPTISTA, Josely Vianna. Roça barroca. São Paulo: Cosac Naify, 2011.

BARBOSA, João Alexandre. A metáfora crítica. São Paulo: Perspectiva, 1974a.

A tradição do impasse. São Paulo: Ática, 1974b.

- Um cosmonauta do significante: navegar é preciso. In: CAMPOS, Haroldo de. Signantia

quasi coelum Signância quase céu. São Paulo: Perspectiva, 1979. p. 11- 24.

. Opus 60: ensaios de crítica. São Paulo: Duas Cidades, 1980.

. A comédia intelectual de Paul Valéry. São Paulo: Iluminuras, 2007.

. As ilusões da modernidade. São Paulo: Perspectiva, 2009.

BARONCINI, Daniela. Ungaretti barocco. Prefazionedi Andrea Battistini. Roma: Carocci, 2008.

BARROS, Diana Luz Pessoa de. De la perfection: duas reflexões. In: LANDOWSKI, Eric; DORRA, Raúl; OLIVEIRA, Ana Claudia de. Semiótica, estesis, estética. São Paulo: Educ: Puebla: UAP, 1999. p. 119134.

BARTHES, Roland. Crítica e verdade. Tradução de Leyla Perrone-Moisés. São Paulo: Perspectiva, 1970.

. O óbvio e o obtuso. Tradução de Isabel Pascoal. Porto: Edições 70, 1984.

BASTIDE, R. (Coord.). Usos e sentidos do termo estrutura. Tradução de Maria Heloiza Schabs Cappellato. São Paulo: Herder: Edusp, 1971.

BASTOS, Alcmeno. Poesia brasileira e estilos de época. 2. ed. Rio de Janeiro: 7Letras, 2004.

BAUDELAIRE, Charles. Poesia e prosa. Tradução de Alexei Bueno. Rio de Janeiro: Nova Aguilar, 2002.

BEIVIDAS, Waldir. A dimensão do afeto em semiótica: entre fenomenologia e semiologia. In: MARCHEZAN, Renata Coelho; CORTINA, Arnaldo; BAQUIÃO, Rubens César (Org.). A abordagem dos afetos na semiótica. São Carlos: Pedro \& João Editores, 2011.

; LOPES, Ivã Carlos. Argumentação e persuasão: tensão entre crer e saber em "Famigerado", de Guimarães Rosa. Alfa, 53(2), p. 443-455, 2009.

BENJAMIN, Walter. Origem do drama barroco alemão. Tradução, apresentação e notas de Sergio Paulo Rouanet. São Paulo: Brasiliense, 1984.

.Il dramma barocco tedesco. Traduzione di Flavio Cuniberto. Torino: Enaudi, 1999.

2004.

. Origem do drama trágico alemão. Tradução de João Barrento. Lisboa: Assírio \& Alvim,

BENSE, Max. Pequena estética. Tradução de J. Guinsburg e Ingrid Dormien Koudela. 3. ed. São Paulo: Perspectiva, 2009.

BENVENISTE, Émile. Problemas de linguística geral I. Tradução de Maria da Glória Novak e Maria Luisa Neri. 5. ed. Campinas: Pontes, 2005. v. 1. 
BENVENISTE, Émile. Problemas de linguística geral II. Tradução de Eduardo Guimarães et al. 2. ed. Campinas: Pontes, 2006. v. 2.

BERGSON, Henri. Matéria e memória. Tradução de Paulo Neves. 2. ed. São Paulo: Martins Fontes, 1999.

Memória e vida. Tradução de Claudia Berliner. São Paulo: Martins Fontes, 2006.

BERTRAND, Denis. Caminhos da semiótica literária. Tradução do Grupo Casa, sob a coordenação de Ivã Carlos Lopes et al. Bauru: Edusc, 2003.

A linguagem espacial em La Bête Humaine. Tradução de Geraldo Majela de Morais Santos. Intertexto. Uberaba, UFTM, v. 1, n. 2, p. 147-166, jul./dez. 2008.

BILAC, Olavo; PASSOS, Guimaraens. Tratado de versificação: a poesia no Brasil, a métrica, gêneros literários. 9. ed. Rio de Janeiro: Francisco Alves, 1949.

BIRON, Berty R. R. Frutas do Brasil: uma alegoria do Novo Mundo. Revista do Núcleo de Estudos de Literatura Portuguesa e Africana da UFF, Rio de Janeiro, v. 2, n. 3, p. 47-57, nov. 2009.

BLOCH, Ernest. Filosofia del rinascimento. Bologna: II Mulino, 1981.

BONDI, Antonino. Louis Hjelmslev: fra lingua e linguaggio. Roma: Carocci, 2012.

BORBA, Francisco S. Dicionário de usos do português do Brasil. São Paulo: Ática, 2002.

BORDINI, Maria da Glória. Fenomenologia e teoria literária. São Paulo: Edusp, 1990.

BOSI, Alfredo. História concisa da literatura brasileira. 33. ed. São Paulo: Cultrix, 1995. Por um historicismo renovado: reflexo e reflexão na história literária. Teresa - Revista de Literatura Brasileira, São Paulo: Edusp: Editora 34, n. 1, p. 9-47, 2000. . O ser e o tempo da poesia. 7. ed. São Paulo: Companhia das Letras, 2004. . Entre a literatura e a história. São Paulo: Editora 34, 2013.

BOUISSAC, Paul. Saussure: um guia para os perplexos. Tradução de Renata Gaspar Nascimento. Petrópolis: Vozes, 2012.

BOUQUET, Simon. Introdução à leitura de Saussure. Tradução de Carlos A. Salum e Ana Lúcia Franco. São Paulo: Cultrix, 2000.

BUCI-GLUCKSMANN, Christine. La raison baroque: de Baudelaire à Benjamin. Paris: Galilée, 1984.

BUENO, Francisco da Silveira. Grande dicionário etimológico-prosódico da língua portuguesa. São Paulo: Saraiva, 1961. v. 2.

BUKDAHL, Else Marie; JUHL, Carsten; BUCl-GLUCKSMANN, Christine (Org.). Puissance du baroque: les forces, les formes, les rationalités. Paris: Galilée, 1996.

CALABRESE, Omar. Como se lê uma obra de arte. Tradução de António Maia Rocha. Lisboa: Edições 70, 1997.

A idade neobarroca. Tradução de Carmen de Carvalho e Artur Morão. Lisboa: Edições 70, 1999.

CAMÕES, Luís de. Obra completa. Rio de Janeiro: Nova Aguilar, 2003.

CAMPBELL, Joseph; ROBINSON, Henry Morton. A skeleton key to Finnegans Wake: unlocking James Joyce's Masterwork. Texto e notas de Edmund L. Epstein. 2. ed. Novato, CA: New World Library, 2005. 
CAMPLANI, Clara; SPINATO, Patrizia (Ed.). Anime del barocco: la narrativa latino-americana contemporanea e Miguel Ángel Asturias. Atti Del Convegno di Milano. Roma: Bulzoni Editore, 22 ott. 1999.

CAMPOS, Augusto de. Poesia antipoesia antropofagia. São Paulo: Cortez \& Moraes, 1978. . Re Visão de Kilkerry. São Paulo: Brasiliense, 1985. . O anticrítico. São Paulo: Companhia das Letras, 1986. . Viva vaia: poesia 1949-1979. 4. ed. São Paulo: Ateliê, 2007. ; CAMPOS, Haroldo de. Traduzir \& trovar. São Paulo: Papirus, 1968 . Panorama de Finnegans Wake. São Paulo: Perspectiva, 1971. . Os sertões dos Campos: duas vezes Euclides. Rio de Janeiro: Sette Letras, 1997.

CAMPOS, Augusto de; CAMPOS, Haroldo de. Re visão Sousândrade. 3. ed. São Paulo: Perspectiva, 2002.

CAMPOS, Augusto de; PIGNATARI, Décio; CAMPOS, Haroldo de. Teoria da poesia concreta: textos críticos e manifestos (1950-1960). São Paulo: Ateliê, 2006. . Mallarmé. 4. ed. São Paulo: Perspectiva, 2010.

CAMPOS, Haroldo de. A linguagem do IAUARETÊ. In: XISTO, Pedro; CAMPOS, Augusto de; CAMPOS, Haroldo de. Guimarães Rosa em três dimensões. São Paulo: Conselho Estadual de Cultural, 1970. Morfologia do Macunaíma. São Paulo: Perspectiva, 1973. . Metalinguagem: ensaios de teoria e crítica literária. São Paulo: Cultrix, 1976a. . A operação do texto. São Paulo: Perspectiva, 1976b.

Barroco em trânsito [Uma arquitextura do barroco]. A operação do texto. São Paulo: Perspectiva, 1976b [1971]. p. 139-144.

A arte no horizonte do provável. São Paulo: Perspectiva, 1977a. . Poética sincrônica. A arte no horizonte do provável. São Paulo: 1977a [1967]. p. 205-212. (Org.). Ideograma: lógica, poesia, linguagem. Textos traduzidos por Heloísa de Lima Dantas. São Paulo: Cultrix: Edusp, 1977b. . Ruptura dos gêneros na literatura latino-americana. São Paulo: Perspectiva, 1977c. . Signantia quasi coelum. Signância quase céu. São Paulo: Perspectiva, 1979. Deus e o diabo no Fausto de Goethe. São Paulo: Perspectiva, 1981. . A educação dos cinco sentidos. São Paulo: Brasiliense, 1985. - O sequestro do barroco na formação da literatura brasileira: o caso Gregório de Mattos. Salvador: FCJA, 1989. . La educación de los cinco sentidos. Barcelona: Àmbit Serveis Editorials, 1990. Sobre finismundo: a última viagem. Rio de Janeiro: Sette Letras, 1996. . O arco-íris branco: ensaios de literatura e cultura. Rio de Janeiro: Imago, 1997. . Literary and artistic culture in modern Brazil. In: SULLIVAN, Edward J. Brazil, body\& soul. New York: Guggenheim Museum, 2001. 
CAMPOS, Haroldo de. Barroco, neobarroco, transbarroco. In: DANIEL, Claudio (Org.). Jardim de camaleões: a poesia neobarroca na América Latina. Tradução de Claudio Daniel, Luiz Roberto Guedes e Glauco Mattoso. São Paulo: Iluminuras, 2004a. p. 13-21.

Crisantempo: no espaço curvo nasce um. São Paulo: Perspectiva, 2004a.

A máquina do mundo repensada. 2. ed. São Paulo: Ateliê, 2004b.

. Metalinguagem e outras metas. 4. ed. São Paulo: Perspectiva, 2006.

. Da razão antropofágica: diálogo e diferença na cultura brasileira. Metalinguagem e outras

metas. 4. ed. São Paulo: Perspectiva, 2006 [1981]. p. 231-255.

. Xadrez de estrelas. São Paulo: Perspectiva, 2008.

. Entremilênios. São Paulo: Perspectiva, 2009.

. O segundo arco-íris branco. São Paulo: Iluminuras, 2010.

Galáxias. 3. ed. São Paulo: Editora 34, 2011 a.

. O sequestro do barroco. 2. ed. São Paulo: Iluminuras, $2011 \mathrm{~b}$.

. Entrevista com Haroldo de Campos por Pedro Maciel. Jornal do Brasil, Rio de Janeiro, Caderno Ideias, 7 jul. 1995. Disponível em: <www.cronopios.com.br>. Acesso em: 5 ago. $2013 a$.

Um olhar sobre a América hispânica. Entrevista com o crítico e poeta Haroldo de Campos

por Rodolfo Mata. Ago. 1994. Disponível em: <www.jornaldepoesia.jor.br>. Acesso em: 7 ago. $2013 b$.

CANDIDO, Antonio. Literatura de dois gumes. In: . A educação pela noite \& outros ensaios. 2. ed. São Paulo: Ática, 1989. p. 163-180.

Dialética da malandragem. O discurso e a cidade. São Paulo: Duas Cidades, 1993a. p. 19-

54.

. Formação da literatura brasileira. 7. ed. Belo Horizonte: Itatiaia, 1993b. 2 v.

; CASTELLO, José Aderaldo. Presença da literatura brasileira: das origens ao romantismo. 8. ed. Rio de Janeiro: Difel, 1977.

; CASTELLO, José Aderaldo. Presença da literatura brasileira: das origens ao realismo. 2. ed. Rio de Janeiro: Difel, 1987.

CAÑIZAL, Eduardo Peñuela; CAETANO, Kati Eliana (Org.). O olhar à deriva: mídia, significação e cultura. São Paulo: Annablume, 2004.

CAPUTO, Cosimo. Semiotica e linguistica. Roma: Carocci, 2006.

CARONE NETTO, Modesto. Metáfora e montagem. São Paulo: Perspectiva, 1974.

CARPEAUX, Otto Maria. História da literatura ocidental. São Paulo: Leya, 2011. v. 2.

CARPENTIER, Alejo. A literatura do maravilhoso. Tradução de Rubia Prates Goldoni e Sérgio Molina. São Paulo: Revista dos Tribunais: Vértice, 1987.

Concerto barroco. Tradução de Josely Vianna Baptista. São Paulo: Companhia das Letras, 2008.

CARRETER, Fernando Lázaro. Stile barocco e personalità creatrice. Bologna: II Mulino, 1991.

CARVALHO, Maria do Socorro Fernandes de. Artifício de agudeza: estudo de glosa de Dom Francisco Manuel de Melo. Graphos. João Pessoa, v. 8, n. 1, p. 71-74, jan./jul. 2006.

. Poesia de agudeza em Portugal. São Paulo: Humanitas: Edusp, 2007.

CARVALHO, J.; PEIXOTO, V. Dicionário da língua portuguesa. 16. ed. São Paulo: Lep, 1964. 
CARVALHO, Ronald de. Pequena história da literatura brasileira. 10. ed. Rio de Janeiro: F. Briguiet, 1955.

CASSIRER, Ernest. A filosofia das formas simbólicas: primeira parte - a linguagem. Tradução de Marion Fleischer. São Paulo: Martins Fontes, 2009.

CASTILHO, Ataliba T. de. Nova gramática do português brasileiro. São Paulo: Contexto, 2010.

CASTRO, Aníbal Pinto de. Retórica e teorização literária em Portugal: do humanismo ao neoclassicismo. Lisboa: Imprensa Nacional - Casa da Moeda, 2008.

CASTRO, E. M. de Melo e; GOTLIB, Nádia Battella (Org.). O fim visual do século XX \& outros textos críticos. São Paulo: Edusp, 1993.

CHABROL, Claude. Semiótica narrativa e textual. Tradução de Leyla Perrone-Moisés et al. São Paulo: Cultrix, 1977.

CHIAMPI, Irlemar. Barroco e modernidade: ensaios sobre literatura latino-americana. São Paulo: Perspectiva, 1998.

Pierre Mabille e Alejo Carpentier: o surrealismo na encruzilhada do Caribe. In: PERRONEMOISÉS, Leyla. Do positivismo à descontrução: ideias francesas na América. São Paulo: Edusp, 2004. p. 159-193.

CHIAPPINI, Ligia; AGUIAR, Flávio Wolf de (Org.). Literatura e história na América Latina. 2. ed. São Paulo: Edusp, 2001.

[CÍCERO]. Retórica a herênio. Tradução e introdução de Ana Paula Celestino Faria e Adriana Seabra. São Paulo: Hedra, 2005.

CIDADE, Hernani. Lições de cultura e literatura portuguesas. 5. ed. Coimbra: Coimbra Editora, 1968. 2 v.

CINTI, Decio. Sinonimi contrari: dizionario essenciale. Novara: De Agostini, 2006.

COHEN, Jean. Estrutura da linguagem poética. Tradução de Lorencini e Anne Arnichand. 2. ed. São Paulo: Cultrix, 1978.

. A plenitude da linguagem: teoria da poeticidade. Tradução de José Carlos Seabra Pereira. Coimbra: Almeida, 1987.

COQUET, Jean-Claude. A busca do sentido: a linguagem em questão. Tradução de Dilson Ferreira da Cruz. São Paulo: Martins Fontes, 2013.

CORTÁZAR, Julio. O jogo da amarelinha. Tradução de Fernando de Castro Ferro. 13. ed. Rio de Janeiro: Civilização Brasileira, 2008.

COSERIU, Eugenio; LAMAS, Óscar Loureda. Linguagem e discurso. Tradução de Cecília Inês Erthal. Curitiba: UFPR, 2010.

COSTA, Horácio (Org.). A palavra poética na América Latina: avaliação de uma geração. São Paulo: Memorial, 1992.

. Quadragésimo. São Paulo: Ateliê Editorial, 1999.

. Mar aberto. São Paulo: Lumme Editor, 2010.

COUTINHO, Afrânio. Aspectos da literatura barroca. Rio de Janeiro: Editora A Noite, 1950. A tradição afortunada. Rio de Janeiro: José Olympio, 1968.

Introdução à literatura no Brasil. 17. ed. Rio de Janeiro: Bertrand Brasil, 2001a. 
COUTINHO, Afrânio (Dir.). A literatura no Brasil: era barroca e era neoclássica. 6. ed. São Paulo: Global, 2001b. v. 2.

Conceito de literatura brasileira. 2. ed. Petrópolis: Vozes, 2008.

COUTINHO, Eduardo; Coutinho, Afrânio (Org.). Guimarães Rosa: fortuna crítica 6. 2. ed. Rio de Janeiro: Civilização Brasileira, 1991.

CROCE, Benedetto. Storia dell'età barocca in Italia: poesia e letteratura. Milano: Adelphi, 1993. La poesia. Milano: Adelphi Edizione, 1994.

CRUZ, Juana Inés de la.. Primero sueño. México: Fondo de Cultura Ecónomica, 2009.

Antología. Buenos Aires: Eudeba, 2011.

CUMMINGS, E. E. Poem(a)s. Tradução de Augusto de Campos. 3. ed. Campinas: Unicamp, 2012.

CUNHA, Antonio Geraldo da. Dicionário etimológico nova fronteira da língua portuguesa. 2. ed. Rio de Janeiro: Nova Fronteira, 1996.

CUNHA, Euclides. Os sertões: Campanha de Canudos. 32. ed. Rio de Janeiro: Francisco Alves, 1984.

CURTIUS, Ernst Robert. Literatura europeia e Idade Média latina. Tradução de Teodoro Cabral e Paulo Rónai. São Paulo: Hucitec: Edusp, 1996.

. Tradução de Teodoro Cabral e Paulo Rónai. São Edusp, 2013.

DANIEL, Claudio (Org.). Jardim de camaleões: a poesia neobarroca na América Latina. Tradução de Claudio Daniel, Luiz Roberto Guedes e Glauco Mattoso. São Paulo: Iluminuras, 2004a.

. Romanceiro de Dona Virgo. Rio de Janeiro: Lamparina, 2004b.

. A estética do labirinto: barroco e modernidade. Dissertação (Mestrado em Literatura Portuguesa) - Faculdade de Filosofia Letras e Ciências Humanas, Universidade de São Paulo, São Paulo, 2009.

DAYRELL, João Guilherme. O brilho do (neo)barroco de Severo Sarduy: linguagem da voz, voz da linguagem. Raído, Dourados, v. 5, n. 10, p. 231-241, jul./dez. 2011.

13, jul./set. 2012.

. O espetáculo barroco: Osman Lins entre imagens. Desenredos, Teresina, ano 4, n. 14, p. 1-

DELEUZE, Gilles. Diferença e repetição. Tradução de Luiz Orlandi e Roberto Machado. 2. ed. Rio de Janeiro: Graal, 2006.

Proust e os signos. Tradução de Antonio Carlos Piquet e Roberto Machado. 2. ed. Rio de Janeiro: Forense Universitária, 2010.

$2011 a$.

A dobra: Leibniz e o barroco. Tradução de Luiz B. L. Orlandi. 6. ed. Campinas: Papirus, 2011b.

. Lógica do sentido. Tradução de Luiz Roberto Salinas Fortes. 5. ed. São Paulo: Perspectiva,

DE MAURO, Tullio. Prima lezione sul linguaggio. Bari: Editori Laterza, 2011.

DEPECKER, Loïc. Compreender Saussure a partir dos manuscritos. Tradução de Maria Ferreira. Petrópolis: Vozes, 2012.

DESCARTES, René. Discurso do método/As paixões da alma/Meditações. Tradução de Enrico Corvisieri. São Paulo: Nova Cultural, 1999.

Fontes, 2005

As paixões da alma. Tradução de Rosamary Costhek Abílio. 2. ed. São Paulo: Martins 
DEVOTO, Giacomo; OLI, Gian Carlo. Dizionario Devoto Oli compatto. Firenze: Le Monnier, 2005.

DIAS, Gonçalves. Poesia e prosa completas. Rio de Janeiro: Nova Aguilar, 1998.

DÍAZ-PLAJA, Guillermo. El espíritu del barroco. Barcelona: Editorial Crítica, 1983.

DICCIONARIO ESENCIAL DE LA LENGUA ESPAÑOLA. Coordenação de Walter Weiszflog. São Paulo: Melhoramentos, 2005.

DICK, André. Jardim "transbarroco". Disponível: HTTP://www.revistazunai.com/ensaios/andre_dick_jardim_transbarroco.htm. Acesso em: 27 março 2011.

(Org.). Signâncias: reflexões sobre Haroldo de Campos. São Paulo: Risco Editorial, 2010.

DIMAS, Antonio. O misterioso poeta seiscentista amado e odiado. In: MATOS, Gregório. Gregório de Matos. Seleção de textos, notas, estudos biográfico, histórico e crítico por Antonio Dimas. São Paulo: Abril Cultural, 1981.

DISCINI, Norma. O estilo nos textos. São Paulo: Contexto, 2004.

DORFLES, Gillo. Barocco nell'architettura moderna. Milano: Tamburini, 1951.

DORFLES, Gillo. O devir das artes. Tradução de Pier Luigi Cabra. São Paulo: Martins Fontes, 1992.

D’ORS, Eugenio. Cézanne. Barcelona: Acantilado, 1999.

. Lo barroco. Edición preparada por Ángel d’Ors y Alicia García Navarro de d'Ors. Madrid: Tecnos/Alianza, 2002. . Del barocco. A cura di Luciano Anceschi. Milano: Abscondita, 2011.

DUBOIS, Jean et al. Dicionário de linguística. Tradução de Frederico Pessoa de Barros et al. São Paulo: Cultrix, 1988.

DUfRENNE, Mikel. Estética e filosofia. Tradução de Roberto Figurelli. 3. ed. São Paulo: Perspectiva, 2008.

ECO, Umberto. A estrutura ausente. Tradução de Pérola de Carvalho. 2. ed. São Paulo: Perspectiva, 1974.

. Obra aberta. Tradução de Giovanni Cutolo. 4. ed. São Paulo: Perspectiva, 1986.

. La struttura assente: la ricerca semiótica e II método strutturale. Milano: Bompiani, 2004.

. Opera aperta: forma e indeterminazione nelle poetiche contemporanee. 8. ed. Milano:

Tascabili Bompiani, 2009.

EIKHENBAUM et al. Teoria da literatura: formalistas russos. Tradução de Ana Mariza Ribeiro Filipouski et al. Porto Alegre: Globo, 1978.

ELIOT, T. S. Ensaios. Tradução de Ivan Junqueira. São Paulo: Art Editora, 1989.

Ensaios de doutrina crítica. Tradução de Fernando de Mello Moser. 2. ed. Lisboa: Guimarães Editores, 1997.

FABRIS, Annateresa. Antonio Lizarraga: uma poética da radicalidade. Belo Horizonte: C/ Arte, 2000.

FALEIROS, Álvaro. Visilegibilidade em quatro traduções do poema "Il pleut" de Apollinaire. VI CONGRESSO NACIONAL ASSOCIAÇÃO PORTUGUESA DE LITERATURA COMPARADA. X Colóquio de Outono Comemorativo das Vanguardas - Universidade do Minho 2009/2010. p. 1-12.

FAUSTINO, Mario. Poesia e experiência. São Paulo: Perspectiva, 1977. 
FAUSTINO, Mario. De Anchieta aos concretos. Organização de Maria Eugenia Boaventura. São Paulo: Companhia das Letras, 2003.

FERNANDES, Francisco. Dicionário de sinônimos e antônimos da língua portuguesa. 29. ed. Rio de Janeiro: Globo, 1989.

FERNANDES, Maria Lúcia Outeiro; LEITE, Guacira Marcondes Machado; BALDAN, Maria de Lourdes Ortiz Gandini. Estrelas extremas: ensaio sobre poesia e poetas. Araraquara: Laboratório Editorial Unesp: Cultura Acadêmica, 2006.

FERRAZ, Marcus Sacrini A. Sujeito perceptivo e mundo em Merleau-Ponty. Doispontos, Curitiba, São Carlos, vol. 5, n. 1, p. 193-206, abr. 2008.

FERREIRA, Aurélio Buarque de Hollanda. Pequeno dicionário brasileiro da língua portuguesa. 10. ed. Rio de Janeiro: Civilização Brasileira, 1963.

. 12. ed. Rio de Janeiro: Civilização Brasileira, 1972.

Novo Aurélio século XXI: o dicionário da língua portuguesa. 3. ed. Rio de Janeiro: Nova Fronteira, 1999.

FERREIRA, Camila Diniz. Affonso Ávila, o poeta de Minas. Fortuna crítica de Affonso Ávila. Belo Horizonte: Secretaria de Estado de Cultura de Minas Gerais; Arquivo Público Mineiro, 2006.

FERREIRA, Francisco Leitão. Nova arte de conceitos. Lisboa: Oficina de Antônio Pedroso Galram, 1718-1721. In: CASTRO, Aníbal Pinto de. Retórica e teorização literária em Portugal: do humanismo ao neoclassicismo. Lisboa: Imprensa Nacional - Casa da Moeda, [1718-1721] 2008.

FERREIRA, João P. Do pícaro na literatura portuguesa. Lisboa: Ministério da Educação e Ciência, 1981.

FERREIRA, Joaquim. História da literatura portuguesa. 2. ed. Porto: Editorial Domingos Barreira, 196-.

FIGUEIREDO, Candido de. Dicionário da língua portuguesa. 5. ed. Lisboa: Bertrand, 1936.

FIGUEIREDO, Eurídice (Org.). Conceitos de literatura e cultura. 2. ed. Niterói: Eduff; Juiz de Fora: Edufjf, 2010.

FIGUEIREDO, Fidelino. História da literatura clássica. 3. ed. São Paulo: Anchieta, 1946. t. 1 a 3.

FIORIN, José Luiz. O corpo nos estudos da semiótica francesa. In: SILVA, Ignacio Assis. Corpo e sentido: a escuta do sensível. São Paulo: Unesp, 1996.

Objeto artístico e experiência estética. In: LANDOWSKI, Eric; DORRA, Raúl; OLIVEIRA, Ana

Claudia de. Semiótica, estesis, estética. São Paulo: Educ: Puebla: UAP, 1999. p. 101-118.

Ática, 2001.

. As astúcias da enunciação: as categorias de pessoa, espaço e tempo. 2. ed. São Paulo: . Introdução ao pensamento de Bakhtin. São Paulo: Ática, 2006.

. Elementos de análise do discurso. São Paulo: Contexto, 2008a.

. Em busca do sentido: estudos discursivos. São Paulo: Contexto, 2008b.

. Figuras de retórica. São Paulo: Contexto, 2014.

FLOCH, Jean-Marie. Forme dell'impronta. Roma: Meltemi, 2005.

FOCILLON, Henri. A vida das formas.Tradução de Ruy Oliveira. Lisboa: Edições 70, 2001.

FONTANIER, Pierre. Les figures du discours. Paris: Flammarion, 1977.

FONTANILLE, Jacques. Sémiotique et littérature: essais de méthode. Paris: Puf, 1999.

. Semiótica do discurso. Tradução de Jean Cristtus Portela. São Paulo: Contexto, 2007. 
FONTANILLE, Jacques; ZILBERBERG, Claude. Tensão e significação. Tradução de Ivã Carlos Lopes, Luiz Tatit e Waldir Beividas. São Paulo: Discurso Editorial: Humanitas, 2001.

FORTUNA CRÍTICA DE AFFONSO ÁVILA. Introdução de Melânia Silva de Aguiar. Belo Horizonte: Secretaria de Estado de Cultura de Minas Gerais, 2006.

FRANCASTEL, Pierre. A contra-reforma e as artes na Itália no fim do século XVI. In: . $A$ realidade figurativa. Tradução de Mary Amazonas Leite de Barros. 3. ed. São Paulo: Perspectiva, 2011. p. 371-421.

FRANCHETTI, Paulo. Crise de verso. Portal Cronópios - Literatura Brasileira Contemporânea. Disponível em: www.cronopios.com.br. 2 nov. 2008.

. Alguns aspectos da teoria da poesia concreta. 4. ed. Campinas: Editora Unicamp, 2012.

História literária: um gênero em crise. In: VIOLA, Alan Flávio (Org.). Crítica literária contemporânea. Rio de Janeiro: Civilização Brasileira, 2013, p. 81-100.

FREIRE, Laudelino. Grande novíssimo dicionário da língua portuguesa. Rio de Janeiro: Editora A Noite, 1939. v. 2.

FRIEDRICH, Hugo. Estrutura da lírica moderna: da metade do século XIX a meados do século XX. Tradução de Marise M. Curioni e Dora F. da Silva. São Paulo: Duas Cidades, 1978.

FUENTES, Carlos. O espelho enterrado: reflexões sobre a Espanha e o Novo Mundo. Tradução de Mauro Gama. Rio de Janeiro: Rocco, 2001.

GARZANTI. Dizionari italiano Garzanti. Milano: Garzanti Linguistica, 2002.

GENETTE, Gérard. Figuras. São Paulo: Perspectiva, 1972.

GENINASCA, Jacques. La parole littéraire. Paris: Puf, 1997.

GOLDSTEIN, Norma. Versos, sons, ritmos. 14. ed. São Paulo: Ática, 2011.

GOMBRICH, E. H. A história da arte. Tradução de Álvaro Cabral. 16. ed. Rio de Janeiro: LTC, 2009.

GOMES, Eugênio. Vieira: sermões. Rio de Janeiro: Agir, 1988.

GOMES JÚNIOR, Guilherme Simões. Palavra peregrina: o barroco e o pensamento sobre as artes e letras no Brasil. São Paulo: Edusp: Educ, 1998.

GOMES, Maria dos Prazeres. Outrora agora: relações dialógicas na poesia portuguesa de invenção. São Paulo: Educ, 1993.

GONÇALVES, Aguinaldo J. Ut pictura poesis: uma questão de limites. Revista USP, São Paulo, set./out./nov., p. 177-184, 1989.

GÓNGORA, Luis de. Fábula de Polifemo e Galateia e outros poemas. Tradução de Péricles Eugênio da Silva Ramos. São Paulo: Hedra, 2008.

Soledades. México: Fondo de Cultura Económica, 2009.

GRACIÁN, Baltazar. Art et figures de l'esprit. Tradução de Benito Pelegrín. Paris: Seuil, 1983.

GRACIÁN, Baltazar. L'acutezza e l'arte dell'ingegno. Tradução italiana de Giulia Poggi. Palermo: Aesthetica, 1986.

Agudeza y arte de ingenio. Madrid: Castalia, 1987.

GREIMAS, A. J. A atualidade do saussurismo. Tradução de Luciana S. Salgado e Sueli Ramos. Le français moderne, n. 24, p. 191-203, 1956.

Vozes, 1975.

Sobre o sentido: ensaios semióticos. Tradução de Ana Cristina Cruz Cezar et al. Petrópolis: 
GREIMAS, A. J. Semântica estrutural. Tradução de Haquira Osakabe e Izidoro Blikstein. 2. ed. São Paulo: Cultrix: Edusp, 1976.

Cultrix, 1981.

Semiótica e ciências sociais. Tradução de Álvaro Lorencini e Sandra Nitrini. São Paulo: Du sens II: essais sémiotiques. Paris: Éditions du Seuil, 1983.

jun. 1984.

Semiótica figurativa e semiótica plástica. Significação: Revista Brasileira de Semiótica, n. 4,

De la imperfección. Presentación, traducción y notas de Raúl Dorra. México: Fondo de Cultura Económica, 1997.

. Da imperfeição. Tradução de Ana Claudia de Oliveira. São Paulo: Hacker, 2002.

Dell'imperfezione. Introduzione de Paolo Fabbri. Traduzione di Gianfrancesco Marrone. Palermo: Sellerio, 2004.

; COURTÉS, J. Dicionário de semiótica. Tradução de Alceu Dias Lima et al. São Paulo: Cultrix, 1983.

Sémiotique: dictionnaire raisonné de la théorie du langage. Paris: Hachette, 1986. v. 2.

GREIMAS, A. J.; FONTANILLE, Jacques. Sémiotique des passions: des états de choses aux états d'âme. Paris: Seuil, 1991.

Ática, 1993.

Semiótica das paixões. Tradução de Maria José Rodrigues Coracini. São Paulo: Edusp, 1976.

et al. Ensaios de semiótica poética. Tradução de Heloysa de Lima Dantas. São Paulo: Cultrix:

GRUPO $\mu$ et al. Retórica geral. Tradução de Carlos Felipe Moisés, Duílio Colombini e Elenir de Barros. São Paulo: Cultrix: Edusp, 1974.

Retórica da poesia. Tradução de Carlos Felipe Moisés. São Paulo: Cultrix: Edusp, 1980.

GUIMARÃES, Bernardo. Poesias completas de Bernardo Guimarães. Organização de Alphonsus de Guimaraens Filho. Rio de Janeiro: Ministério da Educação e Cultura: Instituto Nacional do Livro, 1959.

Elixir do pajé. Poemas de humor, sátira e escatologia. Organização de Duda Machado. São Paulo: Hedra, 2010.

HANSEN, João Adolfo. Vieira, estilo do céu, xadrez de palavras, Discurso, São Paulo, n. 9, p. 173-192, 1978.

A sátira e o engenho: Gregório de Matos e a Bahia do século XVII. São Paulo: Companhia das Letras, 1989.

. Experimental/Exemplar: Hélio Oiticica Utopia Arquivo, Revista USP, São Paulo, n. 22, p.

138-153, 1994.

. Práticas letradas seiscentistas, Discurso, São Paulo, n. 25, p. 153-183, 1995.

. Ut pictura poesis e verossimilhança na doutrina do conceito no século XVII colonial. Revista de Crítica Literária Latinoamericana, Lima-Berkeley, ano 23, n. 45, p. 177-191, 1997.

Retórica da agudeza. Letras Clássicas, São Paulo, n. 4, p. 317-342, 2000.

- Barroco, neobarroco e outras ruínas. Teresa - Revista de Literatura Brasileira, São Paulo:

Edusp: Editora 34, n. 2. p. 10-66, 2001. 
HANSEN, João Adolfo. A sátira e o engenho: Gregório de Matos e a Bahia do século XVII. 2. ed. São Paulo: Ateliê; Campinas: Editora da Unicamp, 2004.

out. 2006a.

Agudezas seiscentistas, Floema Especial, Vitória da Conquista, ano 2, n. 2 A, p. 85-109,

2006b.

Alegoria: construção e interpretação da metáfora. São Paulo: Hedra; Campinas: Unicamp,

. Letras coloniais e historiografia literária. Matraga, Rio de Janeiro, v. 18, p. 13-44, 2006 c.

. Categorias epidíticas da ekphrasis, Revista USP, São Paulo, n. 71, p. 85-105, 2006d.

. Vieira e os estilos cultos: ut theologia rhetorica. Letras, Santa Maria, v. 21, n. 43, p. 25-62,

2011.

46, 2013a.

. Instituição retórica, técnica retórica, discurso, Matraga, Rio de Janeiro, v. 20, n. 33, p. 11-

. Romantismo e barroco. Teresa - Revista de Literatura Brasileira, São Paulo: Edusp: Editora 34, n. 12-13. p. 50-64, 2013.

HARKOT-DE-LA-TAILLE, Elizabeth. Sentir, saber, tornar-se: estudo semiótico do percurso entre o sensório e a identidade narrativa. Tese de Livre-Docência (USP), 2012.

HATHERLY, Ana. O espaço crítico: do simbolismo à vanguarda. Lisboa: Editorial Caminho, 1979.

A casa das musas: uma releitura crítica da tradição. Lisboa: Editorial Estampa, 1995.

. Poesia incurável: aspectos da sensibilidade barroca. Lisboa: Editorial Estampa, 2003.

; CASTRO, Ernesto M. de Melo. PO.EX: textos teóricos e documentos da Poesia

Experimental Portuguesa. Lisboa: Moraes, 1981.

HATZFELD, Helmut. Estudos sobre o barroco. Tradução de Célia Berretini. 2. ed. São Paulo: Perspectiva, 2002.

HAUSER, Arnold. O conceito de barroco. Lisboa: Vegas, 1997.

História social da arte e da literatura. Tradução de Álvaro Cabral. São Paulo: Martins Fontes, 2003.

. Maneirismo. Tradução de J. Guinsburg e Magda França. 2. ed. São Paulo: Perspectiva, 2007.

HEGEL, G. W. F. O belo na arte. Tradução de Orlando Vitorino. São Paulo: Martins Fontes, 1996.

. Curso de estética: o sistema das artes. Tradução de Álvaro Ribeiro. São Paulo: Martins Fontes, 1997.

HESSEN, Johannes. Teoria do conhecimento. Tradução de João Vergílio Gallerani Cuter. São Paulo: Martins Fontes, 2003.

HJELMSLEV, Louis. Le langage. Préface de Algirdas Julien Greimas. Traduit par Michel Olsen. Paris: Les Éditions de Minuit, 1966.

. Prolégomènes a une théorie du langage. Paris: Minuit, 1968.

Prolegômenos a uma teoria da linguagem. Tradução de J. Teixeira Coelho Netto. São Paulo:

Perspectiva, 1975. . La categoria de los casos. Madrid: Gredos, 1978.

. Nouveaux essais. Paris: PUF, 1985.

. Ensaios linguísticos. Tradução de Antônio de Pádua Danesi. São Paulo: Perspectiva, 1991. 
HJELMSLEV, Louis. La categoria dei casi: studio di grammatica generale. A cura di Romeu Galassi. Lecce: Argo, 1999.

Teoria del linguaggio. Résumé. Vicenza: Terra Ferma, 2009.

HOCKE, Gustav R.. Maneirismo: o mundo como labirinto. Tradução de Clemente Raphael Mahl. 3. ed. São Paulo: Perspectiva, 2005.

Maneirismo na literatura: alquimia linguística e arte combinatória esotérica. Tradução de Fernando de Moraes Barros. São Paulo: Perspectiva, 2011.

HOLANDA, Sergio Buarque de. Tentativas de mitologia. São Paulo: Perspectiva, 1979.

Capítulos de literatura colonial. Organização e introdução de Antonio Candido. São Paulo: Brasiliense, 1991.

HOUAISS, Antônio; VILLAR, Mauro de Salles. Dicionário Houaiss da língua portuguesa. Rio de Janeiro: Objetiva, 2001.

HUG, Alfons (Org.). Alegoria barroca na arte contemporânea. Rio de Janeiro: Centro Cultural do Banco do Brasil, 2005.

HUIZINGA, Johan. Homo ludens: o jogo como elemento da cultura. Tradução de João Paulo Monteiro. 4. ed. São Paulo: Perspectiva, 1996.

HUSSERL, Edmund. Meditazioni cartesiane. A cura di E. Natalini. Roma: Armando Editore, 2004. La crisi delle scienze europee e la fenomenologia trascendentale. Milano: Saggiatore, 2008.

JACKSON, Kenneth D. A prosa vanguardista na literatura brasileira: Oswald de Andrade. São Paulo: Perspectiva, 1978.

JAKOBSON, Roman. $O$ que fazem os poetas com as palavras. Disponível em: www.coloquio.gulbenkian.pt, 1972. . Questions de poétique. Paris: Éditions du Seuil, 1973.

Poética em ação. Seleção, prefácio e organização de João Alexandre Barbosa. São Paulo: Perspectiva: Edusp, 1990.

. Linguística e comunicação. Tradução de Izidoro Blikstein e José Paulo Paes. 20. ed. São Paulo: Cultrix, 2005.

. Linguística. Poética. Cinema. Tradução de Francisco Achcar et al. 2. ed. São Paulo: Perspectiva, 2007.

. Saggi di lingüística generale. Traduzione di Luigi Heilmann e Letizia Grassi. 3. ed. Milano: Feltrinelli, 2008.

JOYCE, James. Finnegans Wake/Finnicius Revém. Introdução, versão e notas de Donald Schüler. São Paulo: Ateliê, 2004. Livro 1, capítulo 1.

2003, Livro 1, capítulos 2, 3 e 4.

2004, Livro 1, capítulos 5, 6, 7 e 8.

2002, Livro 2, capítulos 9, 10, 11 e 12.

2003, Livro 3 e 4, capítulos 13, 14, 15, 16 e 17.

JOZEF, Bella. História da literatura hispano-americana. 2. ed. Rio de Janeiro: Francisco Alves, 1982.

KAYSER, Wolfgang. Interpretación y análisis de la obra literaria. Version de María D. Mouton Y. V. García Yebra. 4. ed. Madrid: Editorial Gredos, 1968. 
KANT, Immanuel. Crítica da razão pura. Tradução de Valerio Rohden e Udo Baldur Moosburger. São Paulo: Nova Cultural, 1999.

KLINKENBERG, Jean-Marie. El sentido retórico: ensayos de semântica literaria. Tradução de Matilde E. Navarro Martínez. Murcia: Universidad de Murcia, 1992.

KOSSOVITCH, Leon. Permanência e renovação nas artes. Discurso, São Paulo, n. 26, p. 83-93, 1996.

KRYSINSKI, Wladimir. Pensamentos fragmentários sobre Haroldo de Campos. In: MOTTA, Leda Tenório da (Org.). Céu acima: para um 'tombeau' de Haroldo de Campos. São Paulo: Perspectiva, 2005.

KUHN, Thomas S. A estrutura das revoluções científicas. Tradução de Beatriz Vianna Boeira e Nelson Boeira. 10. ed. São Paulo: Perspectiva, 2011.

LALANDE, André. Vocabulário técnico e crítico da filosofia. Tradução de Fátima Sá Correia et al. 15. ed. Porto: Rés, 1985. 2 v.

LANDOWSKI, Eric; DORRA, Raúl; OLIVEIRA, Ana Claudia de. Semiótica, estesis, estética. São Paulo: Educ; Puebla: UAP, 1999. . Para uma semiótica sensível. Educação realidade, São Paulo, n. 30(2), p. 93-106, 2005.

LAUSBERG, Heinrich. Elementos de retórica literária. Tradução de R. M. Rosado Fernandes. 5. ed. Lisboa: Fundação Calouste Gulbenkian, 2004.

LELLO, José; LELLO, Edgar. Dicionário enciclopédico luso-brasileiro. Porto: Lello, 1950.

LEMINSKI, Paulo. Catatau: um romance-ideia. São Paulo: Iluminuras, 2013.

LEONE, Massimo. Métalangages néobaroques, métalangages néoclassiques, Séminaire de Sémiotique, p. 1-13,5 déc. 2012.

LE ROBERT MICRO. Dictionnaire de la langue française. Rédaction dirigée par Alain Rey. Paris: Le Robert, 2006.

LEROY, Maurice. Les grands courants de la linguistique moderne. Paris: PUF, 1966.

Cultrix, 1982.

As grandes correntes da linguística moderna.Tradução de Izidoro Blikstein et al. São Paulo:

LESSING, G. E. Laocoonte: ou sobre as fronteiras da pintura e da poesia. Tradução de Márcio Seligmann-Silva. São Paulo: Iluminuras, 2011.

LEVY, Hanna. A propósito de três teorias sobre o barroco, Revista do Serviço do Patrimônio Histórico e Artístico Nacional, Rio de Janeiro, n. 5, p. 259-284, 1941.

LICHTENSTEIN, Jacqueline. A pintura: o paralelo das artes. Tradução de Alberto Martins e Jo Amado. 2. ed. São Paulo: Editora 34, 2008.

LIMA, Jorge de. Poesia completa. Rio de Janeiro: Aguilar, 1997.

LIMA, José Lezama. A expressão americana. Tradução de Irlemar Chiampi. São Paulo: Brasiliense, 1988. A dignidade da poesia. Tradução de Josely Vianna Baptista. São Paulo: Ática, 1996a.

1996b. Paradiso. Edición Crítica de Cintio Vitier. 2. ed. Madrid: Colección Archivos; São Paulo:

LIMA, Luiz Costa. Poesía. Edición de Emilio de Armas. 2. ed. Madrid: Catedra/LetrasHispánicas, 2000. Estruturalismo e teoria da literatura: introdução às problemáticas estética e sistêmica. Rio de Janeiro: Vozes, 1973. 
LIMA, Luiz Costa. Teoria da literatura em suas fontes. 2. ed. Rio de Janeiro: Francisco Alves, 1983. v. 1. Mímeses e modernidade: formas da sombra. 2. ed. São Paulo: Paz e Terra, 2003. História. Fiç̧ão. Literatura. São Paulo: Companhia das Letras, 2006.

LINS, Osman. Avalovara. 6. ed. São Paulo: Companhia das Letras, 2005.

LOBATO, Lúcia Maria Pinheiro. A semântica na linguística moderna: o léxico. Rio de Janeiro: Francisco Alves, 1977.

LOPES, Edward. Discurso, texto e significação: uma teoria do interpretante. São Paulo: Cultrix: Secretaria da Cultura, Ciência e Tecnologia do Estado de São Paulo, 1978. . Fundamentos de linguística contemporânea. 5. ed. São Paulo: Cultrix, 1981. Metáfora: da retórica à semiótica. 2. ed. São Paulo: Atual, 1987. . A palavra e os dias: ensaios sobre a teoria e a prática da literatura. São Paulo: Unesp: Unicamp, 1993. A identidade e a diferença. São Paulo: Edusp, 1997.

LOPES, Ivã Carlos; CELESTINO, Dayane (Org.). Semiótica da poesia. São Paulo: Annablume, 2011.

LUCAS, Fábio. Do barroco ao moderno: vozes da literatura brasileira. São Paulo: Ática, 1989.

MACIEL SILVEIRA, Francisco. Literatura barroca. São Paulo: Global, 1986.

MAIAKÓVSKI. Maiakóvski: poemas. Tradução de Boris Schnaiderman, Augusto de Campos e Haroldo de Campos. 8. ed. São Paulo: Perspectiva, 2011.

MALARD, Letícia et al. História da literatura: ensaios. 2. ed. Campinas: Unicamp, 1995.

MALLARMÉ, Stéphane. Crise do verso. Inimigo Rumor, n. 20, p. 150-164, 2008.

MARAVALL, José Antonio. A cultura do barroco. Tradução de Silvana Garcia. São Paulo: Edusp, 2009. MARCHEZAN, Renata Coelho; CORTINA, Arnaldo; BAQUIÃO, Rubens César (Org.). A abordagem dos afetos na semiótica. São Carlos: Pedro \& João Editores, 2011.

MARSCIANI, Francesco. Ricerche semiotiche I: il tema trascendentale. Bologna: Società Editrice Esculapio, 2012a. v. 1. Ricerche semiotiche II: in fondo al semiotico. Bologna: Società Editrice Esculapio, 2012b. v.

2.

; ZINNA, Alessandro. Elementi di semiotica generativa: processi e sistemi della significazione. Prefazionedi A. J. Greimas. Bologna: Progetto Leonardo, 1991.

MARTINET, André. A linguística sincrônica. Rio de Janeiro: Tempo Brasileiro, 1974.

MARTINS, Nilce Sant'Anna. O léxico de Guimarães Rosa. São Paulo: Edusp, 2001.

MATOS, Gregório de. Obra poética completa. Códice James Amado. 5. ed. Rio de Janeiro: Record, 2010. 2 v.

Gregório de Matos. Seleção de textos, notas, estudos biográficos, histórico e crítico por Antonio Dimas. São Paulo: Abril Cultural, 1981.

MEDVIÉDEV, Pável Nikoláievitch. O método formal nos estudos literários. São Paulo: Contexto, 2012. MELO NETO, João Cabral. Obra completa. Rio de Janeiro: Nova Aguilar, 1999.

MENDES, Murilo. Poesia completa e prosa. Rio de Janeiro: Nova Aguilar, 1999. 
MERLEAU-PONTY, Maurice. $O$ olho e o espírito. Tradução de Paulo Neves e Maria Ermantina Galvão Gomes Pereira. São Paulo: Cosac \& Naify, 2004.

Fenomenologia da percepção. Tradução de Carlos Alberto Ribeiro de Moura. 3. ed. São Paulo: Martins Fontes, 2006.

O visível e o invisível. Tradução de José Artur Gianotti e Armando Mora d'Oliveira. 4. ed. São Paulo: Perspectiva, 2007.

Elogio della filosofia. A cura di Carlo Sini. Milano: SE SRL, 2008.

MERQUIOR, José Guilherme. De Anchieta a Euclides: breve história da literatura brasileira - I. Rio de Janeiro: José Olympio, 1977.

MOISÉS, Massaud. A literatura brasileira através dos textos. 4. ed. São Paulo: Cultrix, 1976.

A criação literária: poesia. 9. ed. São Paulo: Cultrix, 1984.

. A literatura portuguesa através dos textos. 17. ed. São Paulo: Cultrix, 1988.

. As estéticas literárias em Portugal: séculos XVI a XVIII. Lisboa: Caminho, 1997.

. História da literatura brasileira. 5. ed. São Paulo: Cultrix, 2000.

Dicionário de termos literários. 15. ed. São Paulo: Cultrix, 2011.

MOLES, Abraham. Teoria da informação e percepção estética. Tradução de Helena Parente Cunha. Rio de Janeiro: Tempo Brasileiro, 1969.

MOREIRA, Marcello. Crítica textualis in caelum revocata? Uma proposta de edição e estudo da tradição de Gregório de Matos e Guerra. São Paulo: Edusp, 2011.

; ROCHA, Marília Librandi (Org.). Questões para João Adolfo Hansen. Floema - Caderno de Teoria e História Literária, Vitória da Conquista, ano 1, n. 1, p. 11-25, 2005.

MORENO, César Fernández (Org.). América latina em su literatura. México: Unesco, 1972.

MOTTA, Leda Tenório da (Org.). Céu acima: para um 'tombeau' de Haroldo de Campos. São Paulo: Perspectiva, 2005.

Haroldo francês. In: MOTTA, Leda Tenório da (Org.). Céu acima: para um 'tombeau' de Haroldo de Campos. São Paulo: Perspectiva, 2005.

NORMAND, Claudine. Saussure. Tradução de Ana de Alencar e Marcelo Diniz. São Paulo: Estação Liberdade, 2009.

NUNES, Benedito. O dorso do tigre. 2. ed. São Paulo: Perspectiva, 1976.

Xadrez de estrelas: percurso textual, 1949-74. In: CAMPOS, Haroldo de. Signantia quasi coelum signância quase céu. São Paulo: Perspectiva, 1979. p. 143-145.

OLIVEIRA, Ana Claudia; LANDOWSKI (Ed.). Do inteligível ao sensível: em torno da obra de Algirdas Julien Greimas. São Paulo: Educ, 1995.

(Org.). Semiótica plástica. São Paulo: Hacker Editores, 2004.

OLIVEIRA, Carla Mary S. Aloïs Riegl, o conceito de kunstwollen e o barroco: algumas considerações em história da arte. Saeculum - Revista de História, João Pessoa, n. 28, p. 13-27, jan.-jun. 2013.

OXFORD ADVANCED LEARNER'S DICTIONARY. Oxford: University Press, 2010.

PALLAVICINO, Pietro Sforza. Trattato dello stile e del dialogo, ove nel cercarsi l'idea dello scrivere insegnativo discorresi partitamente de'vari pregi dello stile sì latino come italiano e della natura dell'imitazione e dell'utilità del dialogo. Reggio Emilia: Torreggiani. In: SNYDER, Jon R. A estética do barroco. Lisboa: Editorial Estampa, 2007. 
PASCAL, Blaise. Pensamentos. Tradução Sérgio Milliet. 2. ed. São Paulo: Abril Cultural, 1979.

. Pensamentos (versão para ebook).Disponível em: www.ebooksbrasil.org. 2002.

Pensées. Paris: Gallimard, 2011.

PAZ, Octavio. El arco y la lira. 3. ed. México: FCE, 1972.

Sor Juana Inés de la Cruz o las trampas de la fe. 3. ed. México: FCE, 1983.

O labirinto da solidão. Tradução de Eliane Zagury. 4. ed. Rio de Janeiro: Paz e Terra, 1984.

Signos em rotação. Tradução de Sebastião Uchoa Leite. 2. ed. São Paulo: Perspectiva,

1990.

. O arco e a lira. Tradução de Ari Roitman e Paulina Wacht. São Paulo: Cosac Naify, 2012.

. Os filhos do barro: do romantismo à vanguarda. Tradução de Ari Roitman e Paulina Wacht. São Paulo: Cosac Naify, 2013.

PÉCORA, Alcir. Momento crítico (meu meio século). Sibila - Revista de Poesia e Cultura, São Paulo, v. 4, n. 7, p. 44-87, 2004.

Big bang, sublime e ruína. In: MOTTA, Lena Tenório da (Org.). Céu acima: para um tombeau de Haroldo de Campos. São Paulo: Perspectiva, 2005, p. 101-106.

Teatro do sacramento. 2. ed. São Paulo: Unicamp, 2008.

2013.

. A agudeza na poesia barroca. Revista Cult On Line, São Paulo, edição 177, ano 16, p. 1-2,

; HANSEN, João Adolfo. Categorias retóricas e teológico-políticas das letras seiscentistas da Bahia. Desígnio - Revista de História da Arquitetura e do Urbanismo, São Paulo, Annablume, n. 5, p. 87-109, mar. 2006.

PEREGRINI, Matteo. Delle acutezze, che altrimenti spiriti, vivezze, e concetti volgarmente si appellano. 2. ed. Torino: Edizioni Res, 1997.

PERLOFF, Marjorie. O gênio não original: poesia por outros meios no novo século. Tradução de Adriano Scandolara. São Paulo: Editora UFMG, 2013.

PERLONGHER, Néstor (Org.). Caribe transplatino: poesia neobarroca cubana e rioplatense. Tradução de Josely Vianna Baptista. São Paulo: lluminuras, 1991.

PERNIOLA, Mario. Enigmas: egípcio, barroco e neobarroco na sociedade e na arte. Tradução de Carolina Pizzolo Torquato. Chapecó: Argos, 2009.

PERRONE, Charles A. De Gregório de Matos a Caetano Veloso e "Outras Palavras": barroquismo na música popular brasileira contemporânea. In: ÁVILA, Affonso (Org.). Barroco: teoria e análise. Tradução de Sérgio Coelho et al. São Paulo: Perspectiva, 1997.

PERRONE-MOISÉS, Leyla (Org.). O Ateneu: retórica e paixão. São Paulo: Brasiliense: Edusp, 1988.

Pós-estruturalismo e desconstrução nas Américas. In: PERRONE-MOISÉS, Leyla (Org.). Do positivismo à descontrução: ideias francesas na América. São Paulo: Edusp, 2004. p. 213-236.

. Altas literaturas. São Paulo: Companhia das Letras, 2009.

PETIT ROBERT. Le nouveau Petit Robert de la langue française. Paris: Le Robert, 2008.

PIETROFORTE, Antonio Vicente. Retórica e semiótica. Tese (Doutorado em Linguística) - Faculdade de Filosofia, Letras e Ciências Humanas, Universidade de São Paulo, São Paulo, 2001.

. Análise do texto visual: a construção da imagem. São Paulo: Contexto, 2007. 
PIETROFORTE, Antonio Vicente. Análise textual da história em quadrinhos: uma abordagem semiótica da obra de Luiz Gê. São Paulo: Annablume: Fapesp, 2009.

O discurso da poesia concreta: uma abordagem semiótica. São Paulo: Annablume, 2011. A significação na pintura (no prelo).

PIGNATARI, Décio. Comunicação poética. São Paulo: Cortez \& Moraes, 1977.

. Poesia pois é poesia \& poetc: 1976-1986. São Paulo: Brasiliense, 1986.

Semiótica da arte e da arquitetura. 3. ed. São Paulo: Ateliê Editorial, 2004a.

Semiótica e literatura. 6. ed. São Paulo: Ateliê Editorial, 2004b.

PIRES, Maria Lucília Gonçalves. Xadrez de palavras: estudos de literatura barroca. Lisboa: Edições Cosmos, 1996.

PLATÃO. Diálogos. O banquete. Tradução de José Cavalcante de Souza, Jorge Paleikat e João Cruz Costa. 2. ed. São Paulo: Abril Cultural, 1983.

. A república. Tradução de Enrico Corvisieri. São Paulo: Nova Cultural, 1999.

Edipro, 2010.

Diálogos VI: Crátilo, Cármides, Laques, Ion, Menexeno. Tradução de Edson Bini. Bauru:

POE, Edgar Allan. Poemas e ensaios. Tradução de Oscar Mendes e Milton Amado. São Paulo: Globo, 2009.

POMORSKA, Krystyna. Formalismo e futurismo: a teoria formalista russa e seu ambiente poético. Tradução de Sebastião Uchoa Leite. 2. ed. São Paulo: Perspectiva, 2010.

PORTELA, Jean et al. Semiótica: identidade e diálogos. São Paulo: Cultura Acadêmica, 2012.

; TOMASI, Carolina. Cronopoiese e cronotrofia na História em Quadrinhos. Estudos

Semióticos, São Paulo, v. 8, n. 2, p. 21-27, 2012.

POTTIER, Bernard. Sémantique générale. Paris: PUF, 1992.

POUND, Ezra. A arte da poesia. Tradução de Heloysa de Lima Dantas e José Paulo Paes. São Paulo: Cultrix: Edusp, 1976.

Cultrix, 2008.

$A B C$ da literatura. Tradução de Augusto de Campos e José Paulo Paes. 4. ed. São Paulo:

. Os cantos. Introdução e Tradução de José Lino Grünewald. Rio de Janeiro: Nova Fronteira; São Paulo: Saraiva, 2012. 2 v.

PRAZERES, Armando Sergio; MACHADO, Irene; FECHINE, Yvana. Entrevista: Haroldo de Campos: entrevista. Galáxia, São Paulo, n. 1, 2001.

PROENÇA FILHO, Domício. Estilos de época na literatura. 11. ed. São Paulo: Ática, 1989.

PROENÇA, M. Cavalcanti. Roteiro de Macunaíma. 3. ed. Rio de Janeiro: Civilização Brasileira, 1974. . Trilhas no Grande Sertão. Rio de Janeiro: Ministério da Educação e Cultura, [s.d].

PUCHEU, Alberto. Do começo ao fim do poema. Boletim de Pesquisa NELIC, Florianópolis, v. 9, n. 14, p. 22-53, 2009.

QUINTILIANO, Marcus Fabio. Istituzioni oratorie. A cura di A. Pennacini. Testo latino a fronte. Torino: Enaudi, 2001.

RAMOS, Feliciano. História da literatura portuguesa. 2. ed. Braga: Livraria Cruz, 1956.

RAMOS, Maria Luiza. Fenomenologia da obra literária. 4. ed. Belo Horizonte: UFMG, 2011. 
RAMOS, Péricles Eugênio da Silva. Do barroco ao modernismo: estudos da poesia brasileira. São Paulo: Conselho Estadual de Cultura, 1967.

2. ed. São Paulo: Livros Técnicos e Científicos, 1979.

RANCIÈRE, Jacques. A partilha do sensível: estética e política. Tradução de Mônica Costa Neto. São Paulo: Editora 34, 2009.

REBELO, Marques. Antologia escolar brasileira. Rio de Janeiro: Companhia Nacional de Material de Ensino. Departamento Nacional de Educação. Ministério da Educação e Cultura, 1967.

RICOEUR, Paul. A metáfora viva. Tradução de Joaquim Torres Costa, Antônio M. Magalhães. Porto: Rés Editora, [1983].

. Tempo e narrativa. Tradução de Constança Marcondes César. Campinas: Papirus, 1994. t. 1.

2010a. t. 2. Tradução de Márcia Valéria Martinez de Aguiar. São Paulo: Martins Fontes, . Tradução de Claudia Berliner. São Paulo: Martins Fontes, 2010b. t. 3.

RIMBAUD, Arthur. Rimbaud livre. Introdução e tradução de Augusto de Campos. 2. ed. São Paulo: Perspectiva, 2009.

ROBAYNA, Andrés Sánchez. A micrologia da elusão. In: CAMPOS, Haroldo de. Signantia quasi coelum signância quase céu. São Paulo: Perspectiva, 1979. p. 127-141.

Barroco da leveza. Revista USP, p. 135-140, dez./jan./fev. 1990-1991.

RODENAS, Adriana Méndez. Severo Sarduy: el neobarroco de la transgresión. México: Universidad Nacional Autónoma de México, 1983.

ROMERO, Sílvio. História da literatura brasileira. Organização de Luiz Antonio Barreto. Rio de Janeiro: Imago, 2001. $2 \mathrm{t}$.

RONCARI, Luiz. Literatura brasileira: dos primeiros cronistas aos últimos românticos. 2. ed. São Paulo: Edusp, 2002.

RORTY, Richard. Verdade e progresso. Tradução de Denise R. Sales. Barueri: Manole, 2005.

ROSA, João Guimarães. Tutameia: terceiras estórias. Rio de Janeiro: José Olympio, 1967.

Primeiras estórias. 13. ed. Rio de Janeiro: Nova Fronteira, 1985.

Grande sertão: veredas. 19. ed. Rio de Janeiro: Nova Fronteira, 2001.

ROSÁRIO, António do. Frutas do Brasil: numa nova e ascética Monarquia, consagrada à Santíssima Senhora do Rosário. Lisboa: Biblioteca Nacional, 2002.

SAID ALI, Manoel. Versificação portuguesa. São Paulo: Edusp, 2006.

SALVINO, Romulo Valle. Catatau barroco. In: Catatau: as meditações da incerteza. São Paulo: Educ, 2000. p. 223-290.

SANT'ANNA, Affonso Romano de. Paródia, paráfrase \& cia. São Paulo: Ática, 1985.

. Barroco: do quadrado à elipse. Rio de Janeiro: Rocco, 2000.

Que fazer de Ezra Pound. Rio de Janeiro: Imago, 2003.

SANTOS, Jane Rodrigues. O (neo)barroco no fulgor da escrita de contos do Mal Errante. Revisa do Núcleo de Estudos de Literatura Portuguesa e Africana da UFF. Rio de Janeiro, v. 2, n. 3, p. 66-80, nov. 2009.

SARAIVA, Antonio J. História da literatura portuguesa. 11. ed. Lisboa: Europa-América, 1972. 
SARAIVA, Antonio J. O discurso engenhoso: o estudo sobre Vieira e outros autores barrocos. São Paulo: Perspectiva, 1980.

; LOPES, Oscar. História da literatura portuguesa. 6. ed. Porto: Porto Editora, 1966.

SARAIVA, F. R. dos Santos. Dicionário latino-português. 11. ed. Rio de Janeiro: Garnier, 2000.

SARBIEWSKI, Maciej Kazimierz. De acuto et arguto liber unicus sive Seneca et Martialis, ubi de epigrammatis, de coloribus declamatoriis, de epistolis argutis omnibus bono, quibus studium est acute et scribere, et loqui. In: SNYDER, Jon R. A estética do barroco. Lisboa: Editorial Estampa, 2007.

SARDUY, Severo. Escrito sobre um corpo. Organização de Haroldo de Campos. Tradução de Lígia Chiappini Moraes Leite e Lúcia Teixeira Wisnik. São Paulo: Perspectiva, 1979.

Barroco. Traduit par Jacques Henric et Severo Sarduy. Paris: Seuil, 1991.

. Obra completa. Edición crítica de Gustavo Guerrero e François Wahl. Madrid: Scipione Cultural, 1999. t. 1 e t. 2.

SAUSSURE, Ferdinand de. Curso de linguística geral. Tradução de Antônio Chelini, José Paulo Paes e Izidoro Blikstein. 19. ed. São Paulo: Cultrix, 1996.

Escritos de linguística geral. Tradução de Carlos Augusto Leuba Salum e Ana Lucia Franco.

12 ed. São Paulo: Cultrix, 2004.

Scritti inediti di linguistica generale. Traduzione di Tulio de Mauro. Roma: Editori Laterza, 2005.

Corso di linguistica generale. Introduzione, traduzione e commento di Tullio De Mauro.

25. ed. Bari: Editori Laterza, 2012.

SCHNAIDERMAN, Boris. A poética de Maiakóviski. São Paulo: Perspectiva, 1984.

(Org.). Semiótica russa. Tradução de Aurora Fornoni Bernardini, Boris Schnaiderman e Lucy Seki. 2. ed. São Paulo: Perspectiva, 2010.

SCHÜLER, Donaldo. Introdução. In: JOYCE, James. Finnegans Wake/Finnicius Revém. 2. ed. São Paulo: Ateliê, 2004, Livro 1, capítulo 1, p. 15-25.

SCHUMM, Petra. Barrocos y modernos: nuevos caminhos em la investigación del barroco iberoamericano. Madrid: Iberoamericana, 1998.

SCHWARTZ, Jorge. Vanguarda e cosmopolitismo na década de 20: Olivério Girondo e Oswald de Andrade. São Paulo: Perspectiva, 1983.

SEFAMÍ, Jacobo. Neobarrocos y neomodernistas em la poesia latinoamericana. Actas del XIII Congreso de la Asociación Internacional de Hispanistas, 1998, p. 420-427.

SILVA, Ignacio Assis. Corpo e sentido: a escuta do sensível. São Paulo: Unesp, 1996.

SILVEIRA, Francisco Maciel. Literatura barroca. São Paulo: Global, 1987.

; MONGELLI, Lênia M. M.; CUNHA, Maria H. R. A literatura portuguesa em perspectiva: classicismo, barroco e arcadismo. São Paulo: Atlas, 1993.

SILVEIRA, Regina. Anatomia do gol: Antonio Lizárraga. Revista USP, São Paulo, n. 22, p. 50-62, jun./ago. 1994.

SISCAR, Marcos. Estrelas extremas: a poesia de Haroldo de Campos. In: FERNANDES, Maria Lúcia Outeiro; LEITE, Guacira Marcondes Machado; BALDAN, Maria de Lourdes Ortiz Gandini. Estrelas extremas: ensaio sobre poesia e poetas. Araraquara: Laboratório Editorial Unesp: Cultura Acadêmica, 2006. p. 167-181. 
SISCAR, Marcos. Poesia e crise: ensaios sobre a "crise da poesia" como topos da modernidade. Campinas: Editora Unicamp, 2010.

SKRINE, Peter N. The baroque. Cambridge: Methuen, 1978.

SNYDER, Jon R. L'estetica del barocco. A cura di Remo Bodei. Bologna: II Mulino, 2005.

. Estética do barroco. Tradução de Isabel Teresa Santos. Lisboa: Editorial Estampa, 2007.

SOARES, Luis Eustáquio. José Lezama Lima: anacronia, lepra, barroco e utopia. Vitória: Edufes, 2007.

SODRÉ, Nelson Werneck. História da literatura brasileira. 4. ed. Rio de Janeiro: Editora Civilização Brasileira, 1964.

SOUSÂNDRADE, Joaquim de. O guesa. Prefácio de Augusto de Campos. São Paulo: Demônio Negro: Annablume, 2009.

SPINA, Segismundo. Gregório de Matos. Introdução, seleção e notas de Segismundo Spina. São Paulo: Assunção, [1946]. . Na madrugada das formas poéticas. 2. ed. São Paulo: Ateliê, 2002.

. Uma fotografia 3x4 de Gregório de Matos. In: Ensaios de crítica literária. São Paulo: Edusp, 2010. p. 165-171.

; SANTILLI, M. A. Apresentação da poesia barroca portuguesa. Assis: Unesp, 1967.

SPITZER, Leo. Três poemas sobre o êxtase. Tradução de Augusto de Campos, Carlito Azevedo, Haroldo de Campos. São Paulo: Cosac Naify, 2012.

STAROBINSKI, Jean. As palavras sob as palavras: os anagramas de Ferdinand de Saussure. Tradução de Carlos Vogt. São Paulo: Perspectiva, 1974.

SULLIVAN, Edward J. Brazil, body \& soul. New York: Guggenheim Museum, 2001.

TAPIÉ, Victor-L. O barroco. Tradução de Armando Ribeiro Pinto. São Paulo: Cultrix: Edusp, 1983.

TATIT, Luiz. Musicando a semiótica. São Paulo: Annablume, 1997.

Semiótica da canção. São Paulo: Escuta, 1999.

. Análise semiótica através das letras. São Paulo: Ateliê, 2001.

Hjelmslev e as bases tensivas do semissimbolismo. São Paulo: Editora CPS, 2007.

Semiótica à luz de Guimarães Rosa. São Paulo: Ateliê, 2010.

- Corpo na semiótica e nas artes. In: SILVA, Ignacio Assis. Corpo e sentido: a escuta do sensível. São Paulo: Editora da Universidade Estadual Paulista, 1996.

Adoração estética. In: LANDOWSKI, Eric; DORRA, Raúl; OLIVEIRA, Ana Claudia de. Semiótica, estesis, estética. São Paulo: Educ; Puebla: UAP, 1999. p. 195-212.

TEDESCO, Salvatore. La sirene del barocco. Il nuovo spazio dell'estetico nel dibattito barocco italiano su dialettica e retorica. Aesthetica Preprint, Università di Palermo, 68, ago. 2003.

TEIXEIRA, Ivan. Rosa e depois: o curso da agudeza na literatura contemporânea. Revista USP, São Paulo, n. 36, p. 100-115, dez./fev. 1997-1998.

. Retórica e literatura: fortuna crítica. Cult, São Paulo, p. 42-45, jul. 1998.

. Hermenêutica, retórica e poética nas letras da América Portuguesa. Revista USP, São Paulo,

n. 57, p. 138-159, março/maio 2003.

TELES, Gilberto Mendonça. Camões e a poesia brasileira. 2. ed. São Paulo: Edições Quíron, 1976. 
TELES, Gilberto Mendonça. Contramargem II: estudos de literatura. Goiânia: Editora da Universidade Católica de Goiás, 2009.

TESAURO, Emanuele. I/ cannochiale aristotélico. Savigliano: Editrice Artistica Piemontese, 2000.

TODOROV, Tzvetan. Poética. Tradução de António José Massano. Lisboa: Editorial Teorema, 1973. (Org.). I formalisti russi. Torino: Einaudi, 2003.

TOMACHEVSKI, B. Sobre o verso. In: EIKHENBAUM, B et al. Teoria da literatura: formalistas russos. Porto Alegre: Globo, 1978, p. 141-153.

TOMASI, Carolina. Pedro Xisto: entre o fazer sentir e o fazer saber. In: PORTELA, Jean et al. Semiótica: identidade e diálogos. São Paulo: Cultura Acadêmica, 2012. p. 135-151.

. Elementos de semiótica. São Paulo: Atlas, 2012.

TONETO, Diana Junkes Martha. Convergências em A máquina do mundo repensada: poesia e sincronia em Haroldo de Campos. Tese (Doutorado em Estudos Literários) - Faculdade de Ciências e Letras da Universidade Estadual Paulista Júlio de Mesquita Filho, Araraquara, 2008.

TORRINHA, Francisco. Novo dicionário da língua portuguesa. Porto: Editorial Domingos Barreira, 1946.

THÜRLEMANN, Felix. Como definir a arquitetura barroca? In: (Org.). Semiótica plástica. São Paulo: Hacker Editores, 2004.

VALÉRY, Paul. Oeuvres. Paris: Gallimard, 1957, t. 1.

. Oeuvres. Paris: Gallimard, 1960, t. 2.

. Cahiers. Paris: Gallimard: La Pléiade, 1973. t. I.

. Quaderni. 4. ed. Milano: Adelphi Edizioni, 1986.

. Cahiers. Paris: Gallimard, 1997. v. VI.

- Variedades. Organização de João Alexandre Barbosa. Tradução de Maiza Martins de Siqueira. São Paulo: lluminuras, 2007.

VERÍSSIMO, José. História da literatura brasileira. Prefácio de Alceu Amoroso Lima. 5. ed. Rio de Janeiro: José Olympio, 1969.

VIEIRA, Antonio. Sermões. Organização de Alcir Pécora. São Paulo: Hedra, 2000. v. 1.

VIOLA, Alan Flávio (Org.). Crítica literária contemporânea. Rio de Janeiro: Civilização Brasileira, 2013.

VIRGílIO. Eneida. Tradução de Odorico Mendes. 2. ed. São Paulo: Ateliê, 2010.

VITERBO, Frei Joaquim de Santa Rosa de. Elucidário das palavras, termos e frases. Porto: Lisboa [1798-1799]. 2. ed. [1865] 1962.

WELLEK, René. Conceitos de crítica. Tradução de Oscar Mendes. São Paulo: Cultrix, [197-].

; WARREN, Austin. Teoria da literatura. Tradução de José Palla e Carmo. 2. ed. Lisboa: Europa-América, 1971.

5. ed. Lisboa: Europa-América, [s.d].

WISNIK, Miguel (Org.). Poemas escolhidos de Gregório de Matos. São Paulo: Companhia das Letras, 2010.

WITTGENSTEIN, Ludwig. Investigações filosóficas. Tradução de José Carlos Bruni. São Paulo: Nova Cultural, 1999. 
WÖLFFLIN, Heinrich. Renascença e barroco. Tradução de Mary Amazonas Leite de Barros e Antonio Steffen. São Paulo: Perspectiva, 1989.

. A arte clássica. Tradução de Marion Fleischer. São Paulo: Martins Fontes, 1990.

Conceitos fundamentais da história da arte. Tradução de João Azenha Jr. 4. ed. São Paulo: Martins Fontes, 2006.

XISTO, Pedro; CAMPOS, Augusto de; CAMPOS, Haroldo de. Guimarães Rosa em três dimensões. São Paulo: Conselho Estadual de Cultural, 1970.

ZILBERBERG, Claude. L'essor du poème: information rythmique. Phoriques, Saint-Maurdes-Fossés, sept. 1985.

. Pour introduire le faire missif. Recherches Sémiotiques, v. 6, n. 3, p. 229-261, 1986.

. Présence de Wölfflin. Nouveaux Actes Semiotiques. Limoges: Pulim, 23-24, p. 1-110, 1992.

. L'affet comme clef cognitive? Eutopías, v. 49, 1994.

. As condições da mestiçagem. In: CAÑIZAL, Eduardo Peñuela; CAETANO, Kati Eliana (Org.). Olhar à deriva. São Paulo: Annablume, 2004.

. Eléments de grammaire tensive. Limoges: PULIM, 2006a.

Razão e poética do sentido. Tradução de Ivã Carlos Lopes, Luiz Tatit e Waldir Beividas. São Paulo: Edusp, 2006b.

p. 163-204.

Síntese da gramática tensiva. Revista brasileira de semiótica. Significação, n. 25, jun. 2006c, . Louvando o acontecimento. Revista Galáxia, São Paulo, n. 13, p. 13-28, jun. 2007.

Causerie sur la sémiotique tensive [2008]. Disponível em: <www.fflch.usp.br/dl/semiotica/.../zilberberg2008/cz-causerie.pdf> . Acesso em: abr. 2009.

Observações sobre a base tensiva do ritmo. Tradução de Lucia Teixeira e Ivã Carlos Lopes. Estudos Semióticos, v. 6, n. 2, p. 1-13, 2010.

Elementos de semiótica tensiva. Tradução de Ivã Carlos Lopes, Luiz Tatit e Waldir Beividas. São Paulo: Ateliê, 2011a.

. Des formes de vie aux valeurs. Paris: Puf, 2011b.

. La structure tensive: suivi de Note sur la structure des paradigmes et de Sur la dualité de la poétique. Liège: Presses Universitaires de Liège, 2012.

ZINGARELLI. Vocabolario della lingua italiana. Bologna: Zanichelli, 2001.

. Dizionario della lingua italiana compatto. Bologna: Zanichelli, 2003. 


\section{ÍNDICE REMISSIVO}

Abjeto, 303

\section{Accutezza, 61}

Aceleração, 152

Aceleração/desaceleração, 256, 260

Acentuação da re-forma, 419

Arcimboldo: escuro/claro estrutural, 142

Adjetivação do barroco: ampliação do campo temático-figurativo, 57

Agudeza, 61, 72, 313

Agudeza de expressão (PE)/agudeza de conteúdo (PC), 76, 79, 446

Agudeza de PE sonoro e visual, 93

Agudeza do final do século XX, 338

Agudeza do PE: Galáxias,426

Agudeza e fluidez, 308

Agudeza e maravilhamento, 65

Agudeza idiossincrônica, 66

Agudeza poética, 126

Agudeza seiscentista/agudeza do século XX

diferença de contrato enunciativo, 129

diversidade, 445

Agudeza visual, 279, 327, 348

Agudeza visual e sonora, 371

Agudeza: apoio em Aristóteles, 56

Agudeza: artifício/dissimulação, 129

Agudeza: atualização, 157
Agudeza: conceito segundo os tratadistas seiscentistas, 82-90

Agudeza: contrato de gênero, 80

Agudeza: decoro, 91

Agudeza: definições dicionarizadas, 78

Agudeza: desproporção fantástica, 75

Agudeza: dissimulação, 129

Agudeza: elementos preliminares, 94

Agudeza em Affonso Ávila, 374

Agudeza: especificidade das letras seiscentistas, 56

Agudeza: esquematização, 462

Agudeza: expressões equivalentes, 74

Agudeza: intensificação, 348

Agudeza: inventio, 87

Agudeza léxica, 180

Agudeza melopeica, 181

Agudeza: metáfora peregrina, 89

Agudeza: movimento tensivo dos objetos, 472

Agudeza: paradigmas do PE e do PC, 94

Agudeza: paralelismo com Zilberberg, 88

Agudeza: primeira propriedade, 128

Agudeza: propriedades estruturais, 125

Agudeza: recrudescimento, 459

Agudeza: retórica clássica, 66

Agudeza: saturação, 450 
Agudeza: segunda propriedade, 141, 142

Agudeza semântica, 180

Agudeza: sensível/inteligível, 149

Agudeza sintática, 180

Agudeza: síntese das propriedades, 149-151

Agudeza: terceira propriedade, 143, 145

Agudeza: tipos, 75-74, 288, 374-375

Agudeza: triângulo de Sarbiewski, 91

Agudeza: vivificação, 316

Ainda/já, 313

Alexandrinos, 375

Aliteração, 95, 413

Ambiguidade do barroco, 25, 46

Amplificação hiperbólica, 177

Amplitude conceitual de barroco, 48

Anagrama, 329, 442

Anagrama, 84

Anagrama: Saussure, 331

Andamento, 152

Anobjeto, 303

Antissujeito, 48, 52, 72

Antissujeito vívido, 40

Aproximação e distanciamento: Quintiliano, 160

Aproximação: simulacro de subjetividade, 160

Arbitrariedade e função poética, 451

Argúcia/agudo, 91

Arte/ciência, 160

Arte da contraconquista em Lezama Lima, 173

Artes combinatórias, 318

Artificialização de Sarduy, 166

Assonância, 98

Atração/repulsão: o sensível na semiótica, 250

Auctoritas: destinador, 77
Ausência/presença de recorte de barroco, 40,

$41 \mathrm{~s}$

Barbarismos e solecismos, 181

Barroco: acontecimento, 64

Barroco cíclico, 16

Barroco e o pensamento positivista, 29

Barroco e rótulo, 424

Barroco e sobrevir, 63

Barroco enigmático: Mario Perniola, 218

Barroco espanhol, 32

Barroco histórico, 39

Barroco inclusivo, 185

Barroco miltoniano, 31

Barroco rabelesiano, 31

Barroco sincrônico, 188

Barroco tênue, 175

Barroco vívido, 175

Barroco/neobarroco: rótulos, 224

Barroco: amplitude conceitual, 48

Barroco: análise filosófica/análise estética, 216

Barroco: campo figurativo, 62

Barroco: categoria formal, 47

Barroco: contemporaneidade, 228

Barroco: definições disfóricas, 60

Barroco: espírito do tempo em Eugenio D’Ors, 70

Barroco: exclusão, 14-15

Barroco: fenômeno europeu para Maravall, 70

Barroco: forma evolutiva wolffliniana, 38

Barroco: função poética, 244

Barroco: inclusão, 15

Barroco: inexistência de recorte, 36

Barroco: invenção neokantiana, 164 
Barroco: irradiação do termo, 30

Barroco: negação da euforia, 154

Barroco: noção de continuum, 230

Barroco: percurso, 175

Barroco: ponto de vista dos dicionaristas, 5760

Barroco: tradição criativa em Affonso Ávila, 214

Barroco: tradição inclusiva, 242

Barroco: Wölfflin, 36, 37

Barroquismo: aquém e além do tempo histórico, 180

Barroquismo: características, 205

Barroquismo de Haroldo de Campos: traços, 180-181

Barroquismo enigmático: Affonso Romano de Sant'Anna, 218

Barroquismo: obras, 206-208

Barroquismo sincrônico: Haroldo de Campos, 180

Barroquismo: traços segundo Haroldo, 349

Barroquismo verbal, 177

Berrueco, 51

Bizarrice e excessos na arquitetura, 51

Branco da página: expansão da linha, 426

Burckardt e a discussão do barroco, 44

Burckardt: começo da valorização eufórica do barroco, 52

Burlesco, 64

Cálculo semântico, 62

Campo de visão, 160

Campo fenomenal, 263

Cânone barroquista de Affonso Ávila, 216-217
Cânone barroquista de Affonso Romano de Sant'Anna, 218-221

Cânone barroquista de Horácio Costa, 231-241

Cânone barroquista de Ivan Teixeira, 241-242

Cânone barroquista: esquema, 209

Cânone barroquista: Haroldo de Campos, 190

Catálise, 82, 380, 442

Categoria formal: barroco, 47

Categorias aristotélicas, 126

Categorias de Wölfflin: Wellek, 471

Categorias dedutivas wolfflinianas, 26-27, 49

Categorias neokantianas, 65

Chinês: língua mais poética?, 450

Ciência/arte, 160

Cifra demais, 51

Cifra tensiva da agudeza, 450

Cifra tensiva do barroco: demais, 55

Claro/escuro estrutural, 142

Coerções de gênero, 130

Combinações anagramáticas, 308, 329

Comparativo: filosofia de Merleau-Ponty e estruturalismo de Saussure, 253-254

Competência discursiva, 132

Conceber/perceber, 282

Conceitismo e gongorismo, 30

Concentrado/difuso, 286

Concepção/percepção, 282

Conceptismo, 33

Concessão: conceito, 65

Concetto, 61

Condensação, 170, 459

Condensação aguda, 349

Conotação/denotação hjelmsleviana, 453

Conservação cognitiva, 303 
Conservação pragmática, 303

Constelação aguda, 364

Constelação poética, 365

Contemporaneidade barroquista: Ivan Teixeira, 228

Continuidade clássica, 24, 33

Contorno: esmaecimento e manutenção, 468

Contorno: esmaecimento e restabelecimento, 141

Contraconquista, 174

Contrarreforma, 46

Contrato de veridicção,35

Contrato enunciativo: agudeza do seiscentista e do século XX, 129

Contrato enuncivo, 35

Contrato fiduciário, 84, 129, 266

Corpo, 249, 254

Corpo como espaço/tempo, 260

Corpo: mediação, 259

Crátilo, 33

Crença atenuada, 268

Crença: cunho intersubjetivo, 267

Crença: cunho intrassubjetivo, 267

Crise de verso, 339, 341, 348

Cronopoiese/cronotrofia, 293

Culteranismo, 33, 36

Debreagem enunciva e enunciativa, 132

Definição de termos em definições lexemática de barroco, 63

Degeneração formal: Focillon, 165

Demais/pouco demais, 314

Demais: fórmula do barroco, 55

Demasiadamente mais, 52, 55, 462
Demasiadamente mais/basta, 314

Denotação/conotação hjelmsleviana, 453

Descontinuidade/continuidade, 255, 256

Descrição fantástica, 268

Descrição icástica, 268

Descrição sincrônica: Jakobson, 67

Desgaste da fórmula seiscentista, 55

Dessemantização do chamado barroco, 55

Destinador, 26

Destinador histórico, 49

Destinadores seiscentistas, 471

Diacronia e sincronia em Saussure, 68

Diferença: resultado de operação lógica, 285

Dimensão pragmática/dimensão cognitiva, 302

Direção, 256

Discreto, 83, 129

Dissimulação, 129

Distanciamento: simulacro de objetividade, 160

Dividendo/divisor: intensidade/extensidade, 286

Dobras, 308

Écfrase, 381

Eco, 95

Elipse, 333

Elipse e labirinto, 158

Elocução: doutrina aristotélica, 27

Enálage, 441

Enárgeia, 381

Energia: Deleuze, 284, 285

Enigma/segredo: conceito greimasiano, 329

Enjambement, 422-423 
Entimema, 84, 87

Entravamento: lentidão, 152

Entraves linguísticos, 125

Enumeração, 394-395

Enunciador poiético, 348

Enunciador/enunciatário néscio, 129

Enunciador/enunciatário discreto, 129

Enunciador: competência, 129

Epistemologia imanentista, 35

Escuro/claro estrutural, 142

Espacialidade e temporalidade: pintura e poesia, 386

Espanha barroca, 30

Espelho convexo, 155

Estados de barroco, 17

Estaticidade/movimento, 255, 257

Estaticidade/movimento, 467

Estático/acontecimento, 467

Estéticas: rótulos, 34

Estetização, 302

Estilo pictórico, 39

Estratégias poéticas de Mallarmé, 364

Estrutura barroquizante, 425

Etização, 304, 305, 307

Etização/antietização, 306

Etização/estetização, 308

Euforização barroquista: cenário, 210-213

Evolução e retrocesso, 39

Exclusão do barroco, 185

Experimentalismo do século XX, 222

Experimentalismo linguístico, 459

Experimentalismos: qualidades, 349

Experimentalistas portugueses/concretistas brasileiros, 228
Extensidade/difusão, 282

Extensidade/intensidade, 282

Extenso/intenso, 282

Fanopeia, 181, 422

Fantástico, 75, 425

Fantástico/icástico, 165, 222

Fazer icástico: regime de representação, 261

Fazer missivo, 293

Fé perceptiva, 262, 264, 265, 266, 270

Fé perceptiva/perobjeto, 292

Fé perceptiva: características noemáticas, 266

Fé perceptiva: características noéticas, 266

Fenomenologia merleau-pontiana, 251

Fídias e Alcmene: alegoria de Emanuele Tesauro, 383-384

Figuratividade/figural, 267

Filosofia: diálogo com a semiótica greimasiana, 249

Fingimento discursivo, 131

Fluidez aguda: acentuação, 355

Fluidez do acabamento, 54

Fluidez e a condensação aguda, 349

Fluidez/nitidez, 282, 333, 363-364, 375, 468

Fluidez/nitidez: esquema, 380

Fluidez/nitidez: vetor tensivo, 469

Fluidez: recrudescimento, 443

Fluido/nítido :: plástico/pictórico, 247

Forma aberta/forma fechada, 163

Forma barroca sincrônica, 186

Formas agudas: abertura e multiplicidade de combinações, 158

Formas agudas: Augusto de Campos e John Donne, 109 
Formas anagramáticas: Walter Benjamin, 339

Formas de arte em Platão: icástico/fantástico, 74-75

França do século XVII: antissujeito do barroco, 52

Frei Antônio Rosário: analogia com frutas brasileiras, 146

Fruição estética, 309

Fuga musical, 459

Função poética jakobsoniana, 244

Fusão de sofisticação e ingenuidade, 174

Galáxia de significantes, 428

Galáxias: simulacro de materialização, 419

Gêneros, 80

Gongorismo, 33

Gongorismo e conceitismo, 30

Gramática intensiva/gramática extensiva, 282

Greimas-Fontanille/Zilberberg/Merleau-Ponty: quadro comparativo, 257

Hipálage, 442

Hipotipose, 99, 381

História literária: implicação, 50

Hjelmslev/Deleuze/Zilberberg: quadro comparativo de intensidade/extensidade, 285-286

Homeoteleuto, 100

Icástico, 75, 178, 387, 425

Icástico/fantástico, 109, 165, 222

Idade neobarroca de Omar Calabrese, 164

Identificação enunciativa, 473

Idiossincronia nos Escritos de Saussure, 69
Ilusão: conceito greimasiano, 329

Ilusão: Huizinga, 329

Imanência e transcendência, 447

Imanência: hierarquia, 452-453

Implicação e história literária: 50

Implicação/concessão, 91

Implicado: conceito de Deleuze, 285

Implicado/explicado, 286

Inatistas/empiristas, 258

Inclusão: neobarroco, 243

Inteligível/sensível, 258

Intensidade/concentração, 282

Intensidade/extensidade, 282

Intenso/extenso, 282

Intertextualidade em Galáxias, 429-4437

Intertextualidade: neobarroco, 171

Invenção, 191

Inventio, 87

Irregularidade e inconstância,26

Já/ainda, 293, 313

Jogo de xadrez em Saussure, 463

Jogo linguístico em Wittgenstein, 461

Labirinto e elipse, 158

Labirinto linguístico, 181

Labirinto tensivo, 308, 316

Labirinto: múltiplas saídas (concessivo), 319

Labirinto: saída única (implicativo), 319

Labirintos poéticos, 225

Linearidade: princípio saussuriano, 311

Linearidade saussuriana, 310

Linguagem prodigiosa, 174

Literatos considerados neobarroquistas, 177 
Literatura seiscentista: valores disfóricos, 49

Logopeia, 181, 422

Ludus, 329

Malandro: tradição, 188

Manuais de história de literatura: ausência e presença de recorte de barroco 38

Manuais: discurso estereotipado sobre o barroco, 55

Mapeamento transistórico de Horácio Costa, 231-241

Maravilhamento: dois momentos, 127

Maravilhamento poético: Torquato Tasso, 73

Maravilhamento: primeiro momento/segundo momento, 108

Maravilhoso: neobarroco, 176-177

Marinismo, 32

Marsciani: diálogo com Husserl, 250

Marsciani: epoché semiótica, 252

Matéria, 448

Melhoração, 179

Melhoração/pejoração, 482

Melopeia, 181, 422

Metáfora acontecimento, 106

Metáfora aguda de Ovídio, 92

Metáfora aguda: metáfora acontecimento, 106

Metáfora aguda: posição absoluta, 108-109

Metáfora argumentativa, 105-106

Metáfora da intensidade: pérola irregular, 51

Metáforas epistemológicas, 155

Metaforização gongorina, 174

Metassemiótica, 453, 464

Método ideogrâmico de Pound, 39
Metonímia, 107

Milton barroco, 31

Mímica de Cummings, 339

Missividade, 293

Misticismo sincrético, 174

Mistura de línguas, 183

Mistura e triagem, 468, 469

Movimento silábico: poesia,345

Mudança semiótica:

aparecimento/desaparecimento de uma forma, 56

Multiplicidade semântica de barroco, 25, 56

Mundo percebido, 263

Negação da euforia barroca, 154

Neobarroco: Alejo Carpentier, 176

Neobarroco: características linguísticas, 166

Neobarroco: condensação, 170

Neobarroco: diversidade de pontos de vista, 161

Neobarroco do desperdício, 165

Neobarroco: inclusão, 243

Neobarroco: intertextualidade, 171

Neobarroco: Lezama Lima, 173

Neobarroco: Omar Calabrese, 164

Neobarroco: proliferação, 169

Neobarroco: Severo Sarduy, 165

Neobarroco: substituição de signos, 166

Neobarroco: tradição visual em Ana Hatherly, 222

Neobarroco: Umberto Eco, 161

Néscio, 129

Nitidez/fluidez, 363-364, 368, 375, 470

Nitidez/fluidez: esquema, 380 
Nitidez/fluidez: vetor tensivo, 469

Nítido/fluido :: plástico/pictórico, 247

Objeto estético agudo: fé perceptiva, 262

Objeto estético fluido: qualidades, 349

Objeto ético, 305

Objeto: novas perspectivas de observação, 157

Objeto poético fluido, 338

Objetos da tradição barroquista, segundo Haroldo de Campos, 192-205

Objetos seiscentistas: jogo especular, 155

Obscurecimento formal, 157

Ordens de crença, 267

Oxímoro e barroco, 425, 426

Paideuma, 188

Paideuma haroldiano, 205

Palavra-imagem, 225

Paradigma e sintagma, 310

Paradigmas do PC: comparações, 103

Paradigmas do PC: metáfora, 102-103

Paradigmas do PC: metáfora acontecimento, 106

Paradigmas do PC: metáfora aguda, 106

Paradigmas do PC: metáfora argumentativa, 105-106

Paradigmas do PC: metonímia, 107

Paradigmas do PE: aliteração, 95

Paradigmas do PE: assonância, 98

Paradigmas do PE: Eco, 95

Paradigmas do PE: hipotipose, 99

Paradigmas do PE: homeoteleuto, 100

Paradigmas do PE: igualdade sonora, 95
Paradigmas do PE: Paronomásia, 96

Paradigmas do PE: rima, 95

Paradoxos/oximoros, 92

Paragrama, 83

Paronomásia, 96, 147, 440, 442, 451

Paroxismo e sobrevir, 450

Paroxismo em Finnegans Wake, 446

Paroxismo: forte acentuação em Finnegans Wake, 456

Pejoração, 179

Pejoração/melhoração, 482

Perceber/conceber, 282

Percepção/concepção, 282

Periodicidade estética, $41 \mathrm{~s}$

Permutação lexemática, 336

Perobjeto, 302, 303, 304, 308

Pérola irregular, 34, 36, 51, 53, 54, 55

Pérola irregular: metáfora da intensidade, 51

Perspectiva e ponto de fuga, 156

Perspectiva: mudança, 337

Perspectiva: mudança nos objetos seiscentistas, 155, 158

Perspectiva: virada, 156

Pervir, 65

Pícaro, 188

Plasticidade da linguagem, 245

Plástico/pictórico, 470

Pli selon pli, 424

Poema vorticista, 241

Poesia aguda, 246

Poesia aguda como perobjeto, 292

Poesia aguda do século XX, 248

Poesia aguda: ênfase no conteúdo e/ou na expressão, 79 
Poesia aguda: fluida e nítida, 178

Poesia aguda: regência do significante, 331

Poesia brasileira no século XX: antes/depois da poesia concreta, 242

Poesia concreta, 242

Poesia da agudeza: visualidade, 154

Poesia do século XX e dos seiscentos, 465

Poesia do século XX: ut pictura poesis, 381

Poesia e pintura, 383

Poesia e prosa: ruptura com a retórica clássica, 420

Poesia fluida, 339, 348

Poesia nítida: potencialização, 339

Poesia seiscentista/poesia do final do século $X X, 327$

Poesia visual, 224

Poesia visual brasileira, 242

Poesia visual: Horácio Costa, 231-241

Poesia/pintura: "Anatomia do gol” de Haroldo de Campos, 402

Poesia: aproximação e distanciamento em "Klimt: tentativa de pintura", $391 \mathrm{~s}$

Poesia: sintético-ideogrâmica $\quad x$ analíticodiscursiva, 365

Poesis: efetividade, 348

Poetas e pintores: Horácio, 382

Poética engenhosa, 72

Poética idiossincrônica, 69

Poética sincrônica, 50

Ponto de fuga, 156, 337

Positivismo de Wolfflin, 29

Positivismo: sucessões melhorativas, 50

Pouco demais, 314

Práxis enunciativa, 56
Prodesse cum delectare, 80

Proliferação de signos: neobarroco, 169

Prosa, 343

Prosa e poesia, 419

Prosa e poesia: fronteira, 427

Quiasmo, 137

Rabelais barroco, 31

Racionalismo/mentalismo, 258

Real maravilhoso: neobarroco americanizado, 176

Recorte de barroco, 24, 28, 36, 37

Recorte do barroco na Alemanha, 28

Recortes da língua natural, 39

Recrudescimento da agudeza, 459

Reflexos do barroco na Europa, 30

Re-formatação, 157

Reiteração: desdobramento do signo,438

Reiteração: repetição de palavras, 438

Remissividade/emissividade, 294, 351

Renascimento: afirmação da ciência, 161

Renascimento/neoclassicismo: continuum sem recortes, 37

Retórica, 27

Retórica aristotélica, 126

Retórica clássica: ruptura, 420

Retóricas clássicas, 45

Revisão diacrônica, 8

Ritmo, 343-344

Ritmo: acento e modulação, 345

Ritmo: função, 345

Ritmo: noção, 351

Ritornello sonoro, 426 
Rótulo de barroco, 424

Rótulo de estéticas, 34, 35

Rótulos: barroco e neobarroco, 224

Rótulos de estéticas, 14

Saber insuficiente, 268

Saber onisciente, 270

Saber suficiente, 268,270

Saber/crer, 268

Sátira de Juvenal, 187

Sátira menipeia, 187

Saturação da agudeza, 450

Segredo/ilusão, 336

Seleção paradigmática/combinação sintagmática, 452

Semas e lexemas da arte barroca, 63

Semema barroco, 57

Semiocepção, 365

Semiocepção de Beividas, 277 ss

Semiose, 278

Semiótica da agudeza: rede de dependências, 471

Semiótica denotativa, 453

Semiótica do movimento/estaticidade do apoditismo, 257

Semiótica greimasiana: diálogo com a filosofia, 249

Semiótica lucreciana, 251

Semiótica tensiva: diálogo com a fenomenologia, 255

Semissimbolismo, 114-115, 139, 354, 359-360, 377,389

Sensível, 249

Sensível/inteligível, 337
Sequestro do barroco, 49, 184

Signo seiscentista, 77

Signo, 34

Signo: arbitrariedade, 37

Sílaba: breve e longa, 414

Simulacro de aproximação: subjetividade, 160

Simulacro de distanciamento: objetividade, 160

Simulacro discursivo, 129

Simultaneidade de Joyce, 339

Sincronia e diacronia em Edward Lopes, 69

Sincronia e diacronia em Saussure, 68

Sintaxe do refreamento, 313

Sintaxe solidária e reflexiva, 138

Sistema literário: Jakobson e Tynianov, 68

Sobrevir e barroco, 63

Sobrevir e paroxismo, 450

Sobrevir/pervir, 292

Sobrevir: semema barroco, 57

Sofista de Platão, 74

Subdivisão e dimensões: categoria hjelmsleviana, 421

Subdivisões prismáticas de Mallarmé, 339

Sublime em Longino, 452

Subobjeto, 302

Substituição de signos, 166

Suficiência, 314

Suficiência semiótica, 317

Sujeito da enunciação, 72

Sujeito suspenso, 310

Surpresa inteligível, 479

Surpresa sensível, 479

Suspensão retórica, 308, 309 
Teatralização da crise de verso, 339

Teatro shakespeariano: incômodo barroco, 64

Tectônico e atectônico, 465

Tela do parecer, 265

Temporalidade e espacialidade: pintura e poesia, 386

Tensão da semiótica da agudeza, 153

Tensão na sonoridade, 460

Tensão/relaxamento, 292

Tensividade das dobras agudas, 333

Tensividade: delectare e docere, 73

Tensividade fórica, 255

Teoria da perspectiva de Brunelleschi e Alberti, 156

Terza rima, 245

Timese, 441

Timia, 251

Tipos de agudeza: conceito, palavra, ação, 7576

Tradição barroca, 229-230

Tradição: conceito inclusivo, 230

Tradição inclusiva de barroco, 242

Tradição malandra, 188

Tradição/ruptura, 243

Transbarroco, 32, 40, 80, 179, 245, 420

Tratadistas seiscentistas, 72

Tratadistas seiscentistas: Baltazar Gracián, 86

Tratadistas seiscentistas: Emanuele Tesauro, 88

Tratadistas seiscentistas: Francisco Leitão Ferreira, 88

Tratadistas seiscentistas: Gracián, Peregrini, Pallavicino, Leitão Ferreira, 54, 61
Tratadistas seiscentistas: Matteo Peregrini, $82-84$

Tratadistas seiscentistas: Matteo Sarbiewski, 81

Tratadistas seiscentistas: obras, 81

Tratadistas seiscentistas: Sforza Pallavicino, 84

Trompe-I'oiel, 39

Ut pictura poesis, 90, 381

Ut pictura poesis: distância, claridade, número, 383

Ut pictura poesis: Lessing, 385

Valor de uso, 18

Valores clássicos e barrocos, 48

Valores disfóricos de barroco, 48

Valores em jogo, 18

Vanguarda, 230

Verdade/veridicção, 35

Verso, 342

Verso e prosa, 420, 421

Verso tradicional, 357

Verso vertical, 357

Verso: função de retardamento do reconhecimento, 374

Verso: função visual, 374

Verso: funções do corte, 347

Versos saturninos, 413

Vetores tensivos linearizados, 479

Vetorização gráfica de concentrado e difuso, 286

Visão disfórica do barroco, 46

Visualidade, 154

Visualidade barroca: Horácio Costa, 228 
Visualidade em Apollinaire, 389-390

Visualidade em Lewis Carroll, 388-389

Vívido e lento, 470

Vivificação aguda, 316

Vorticismo: conceito, 241
Wolfflin: barroco, 36

Zilberberg e os retóricos, 422 